U. S. GEOLOGICAL SURVEY. Field Library

Albuquerque, New Mexica

\title{
Geology of the Quartz Creek Pegmatite District, \\ Gunnison County, Colorado
}

\section{Trace Elements Investigations Report 138}

UNITED STATES DEPARTMENT OF THE INTERIOR GEOLOGICAL SURVEY 



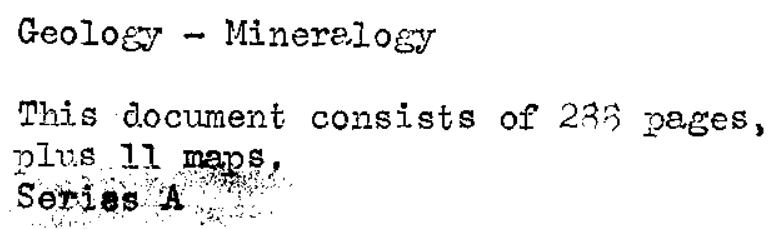

Mortimer H. Staatz and Albert F. Trites

Apriz 1952

Trace Ilenents Investigations Report 138

This preliminary report is distributed without editorial and technical review for conformity vith official standarods and nomenclature. It is not for public inspection or quotation.

* This report concerns work done on behalf of the Division of Raw Materials of the U.S. Atomic Inerey Commission

When separated from Part II, heincile Part I as UNCIASSIFI D D 
USGS - TII Report 138

GIOLOGY - MINERALOGY

Distrioution (Series A)

No, of copies

Anerican Cyanamid Company, Watertown .........., . . I

Argonne National Laboratory .................. 1

Atomic Inergy Commission, Washinston ..............2

Carbide and Carbon Chemicals Company, Y-12 Area . . . . . . I

Colorado Raw Materials Office (T.W. Oster) . . . . . . I

Division of Raw Materials, Denver ............ I

Division of Raw Materials, New York ........... 6

Division of Raw Materials, Salt Lake City. . . . . . . . . . I

Division of Raw Materials, Washington ............. 3

Dow Cherical Company, Pittsburg.............. I

Technical Information Service, Oalk Ridge ........... 6

U. S, Geological Survey:

Mineral Deposits Branch, Washington ....., . . . . . 2

Geochenistry and Petrology Branch, Washington ,....... I

Geophysics Branch, Washington ................ . I

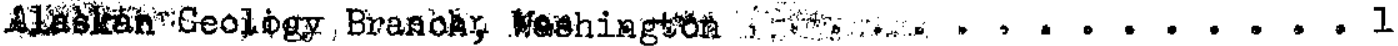

V, I. McKelvey, Washington ................ 1

I, R. Page, Denver ...................... 2

R. P. Fischer, Grand Junction ............... 1

A. I. Weissenborn, Spokane .................. I

A. H. Koschmann, Denver . . . . . . . . . . . . . I

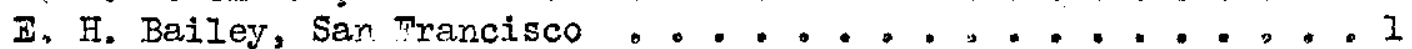

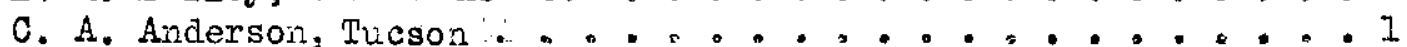

David Gallagher, Joplin ................. 1

Carl Driton, Macison................... 1

R. A. Laurence, Knoxville .................., I

R, J. Roberts, Salt Irake City . . . . . . . . . . . . I

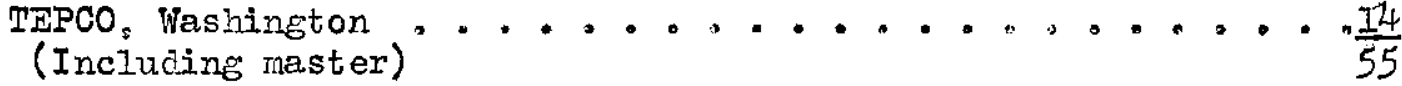




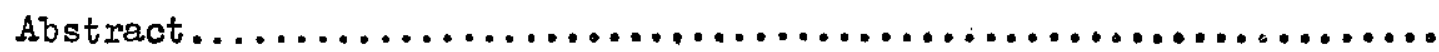

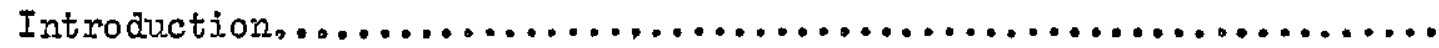

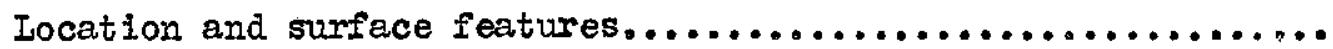

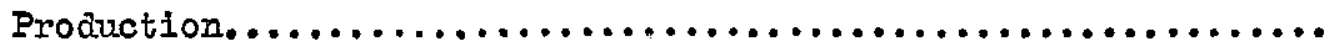

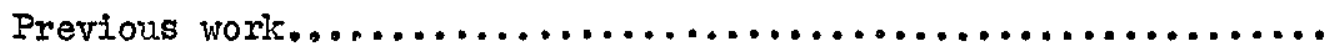

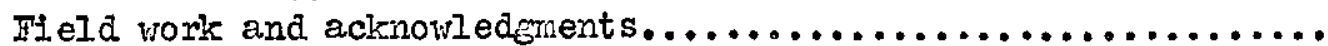

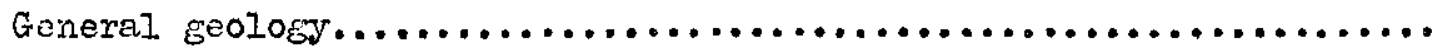

Pre-Cambrian rocks...................................

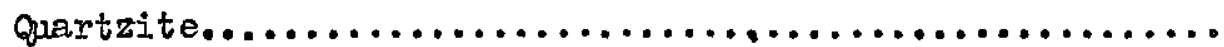

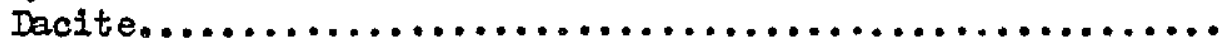

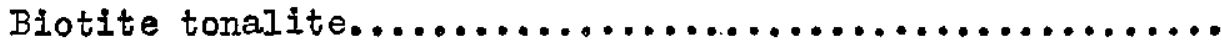

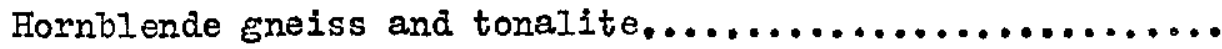

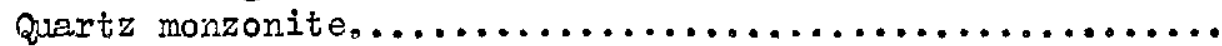

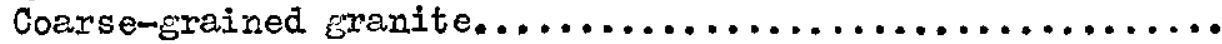

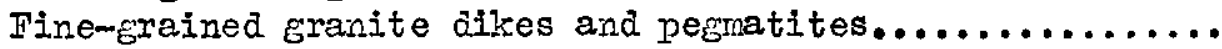

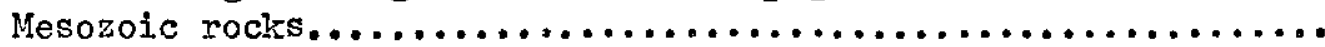

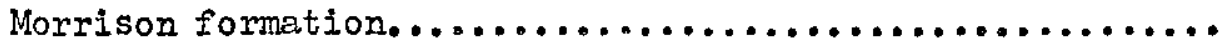

Daikota sandstone..................................

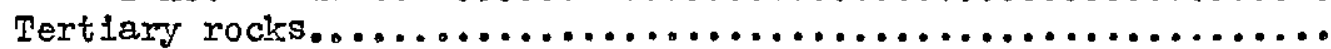

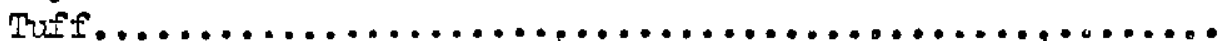

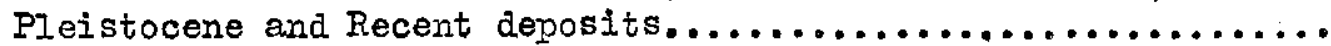

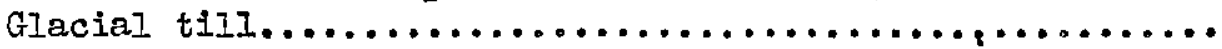

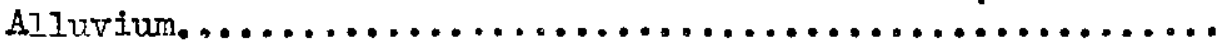

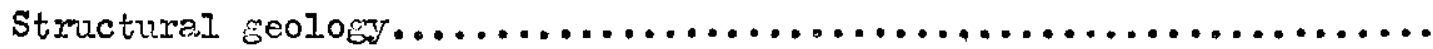

Pezmatites. $\ldots \ldots \ldots \ldots \ldots \ldots \ldots \ldots \ldots \ldots \ldots \ldots \ldots \ldots \ldots \ldots \ldots \ldots \ldots \ldots$

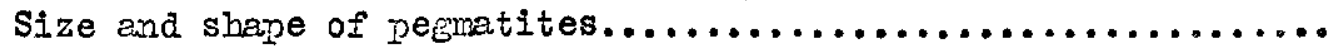

Internal structure................................

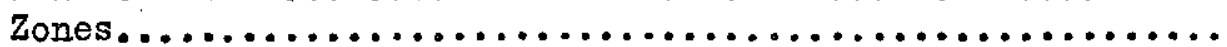

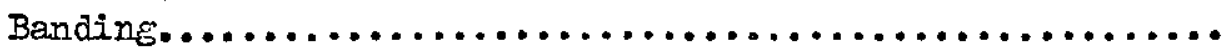

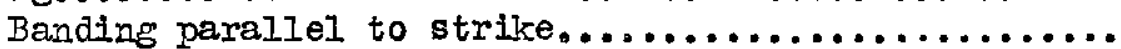

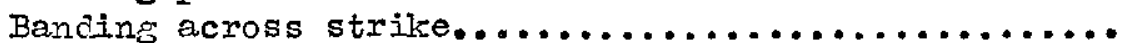

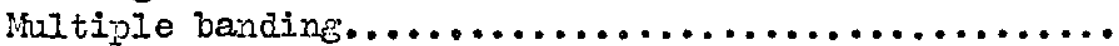

Fracture fillings.............................

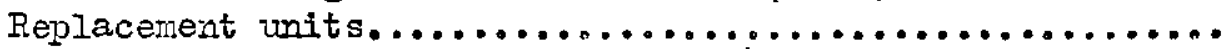

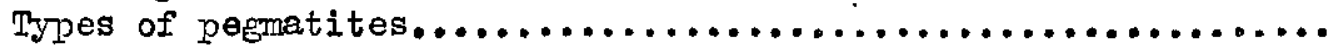

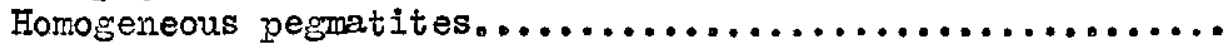

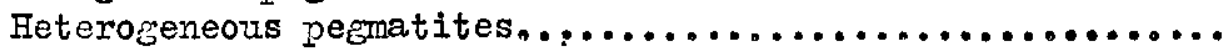

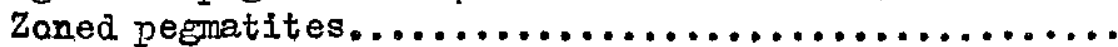

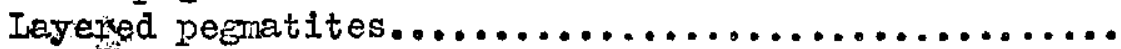

Pegmatites showing variation in composition along

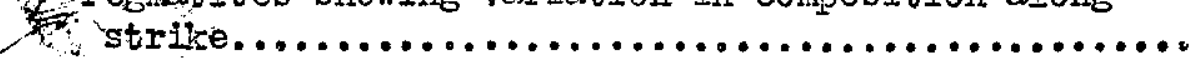

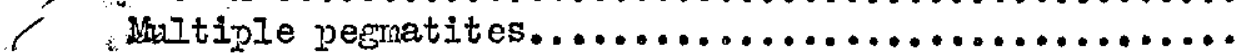

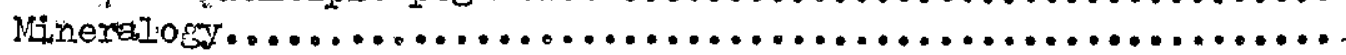

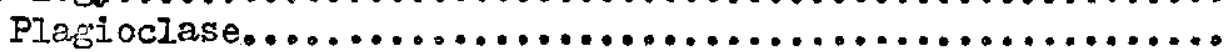

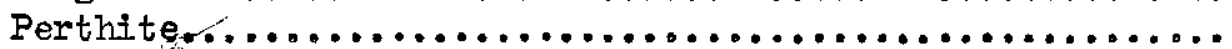

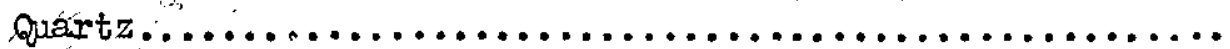

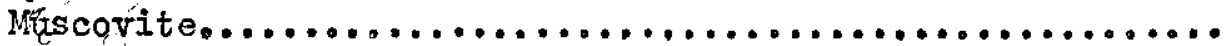

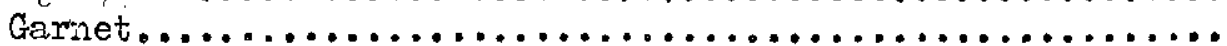

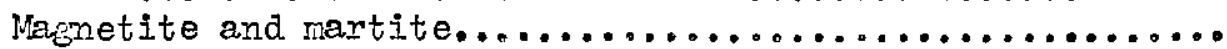

Biotite....................................

Beryl...................................... 
Pegmatites--Continued.

Mineralogy--Continued.

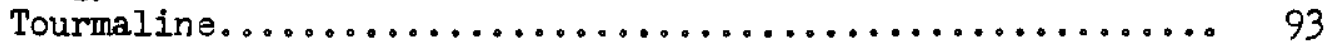

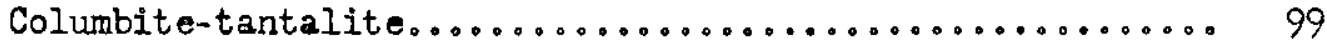

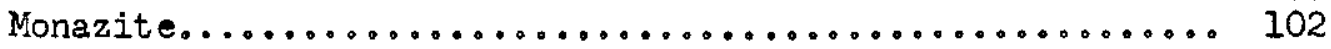

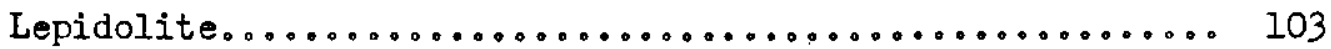

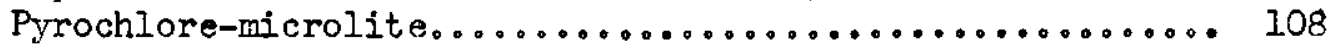

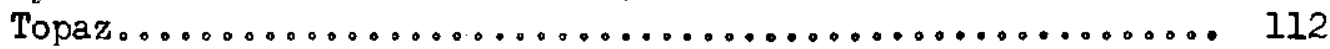

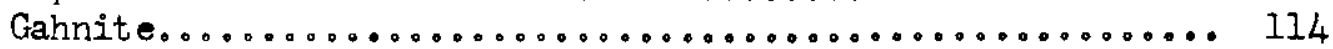

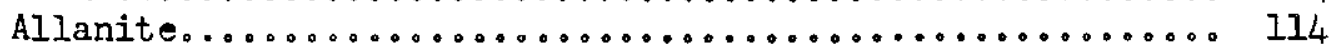

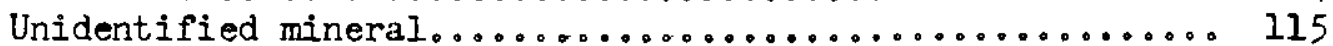

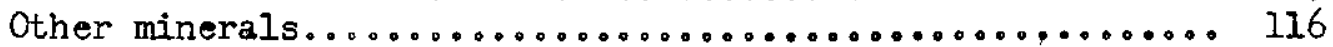

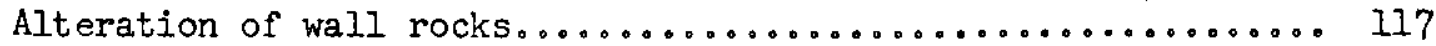

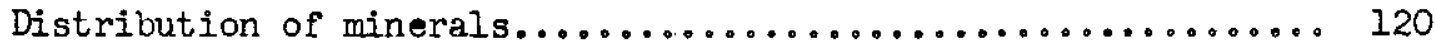

Relationship of the pegmatites to the country rock.......... 123

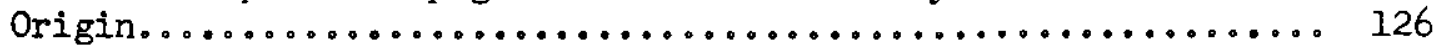

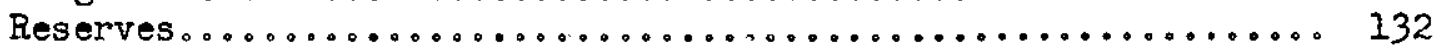

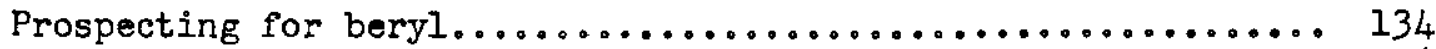

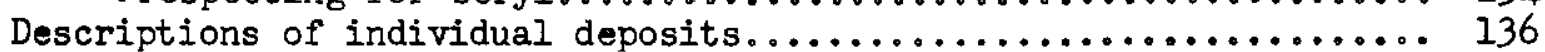

Opportunity No. 1 claim (pegmatite No. 215).............. 236

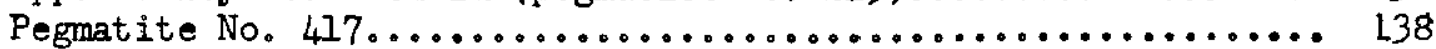

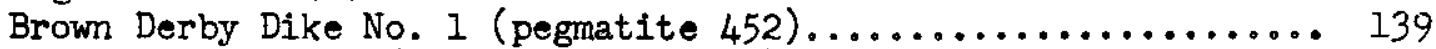

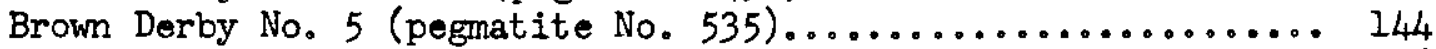

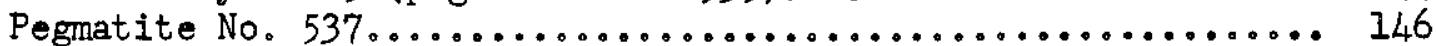

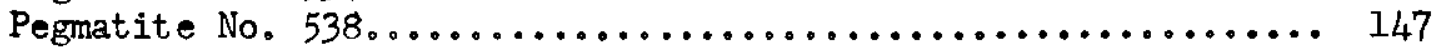

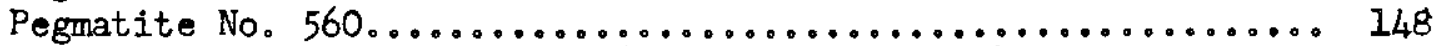

Beryl and Rare Minerals Lode (pegmatite No. 590)............ 149

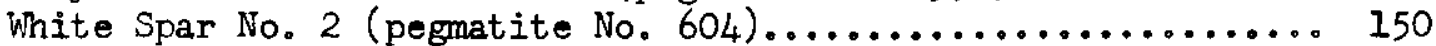

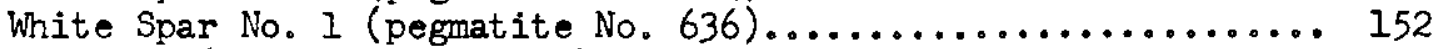

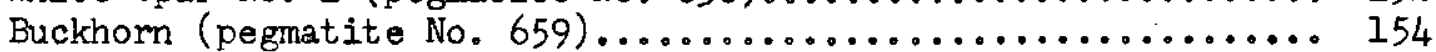

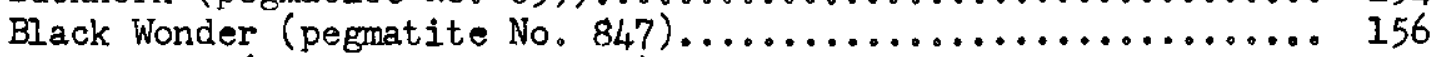

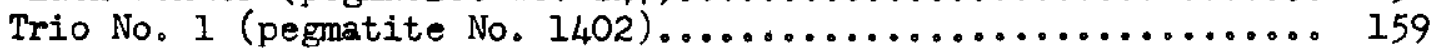

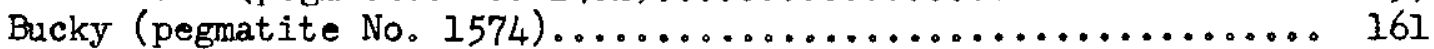

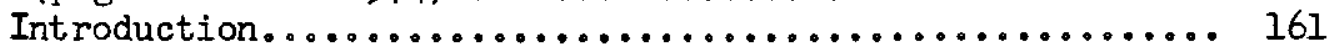

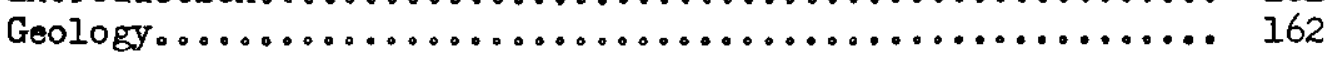




\section{IIIJSTRATIONS}

Page

Plate I A. Penorama sovthern end of Quartz Creek pegmatite district looling north. White areas in foreground are

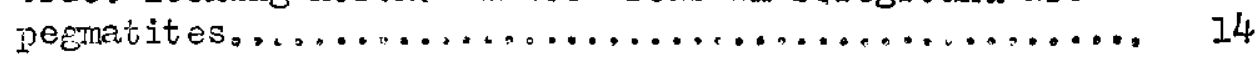

B: Panorama of the northerin end of the Quartz Creek pegmatite district looking west across Quartz Creek. outcrops in the backsround are the Black Wonder (No. 847) pegmatite.

II Geologic map and sections of the Quartz Creek pegmatite district, Gunison County, Colorado............. In envelope

III A. Tonalite outcrop on the northwest side of Wood Gulch... 21

B. Pillow lava showine ellipsoidal pillows on the north-

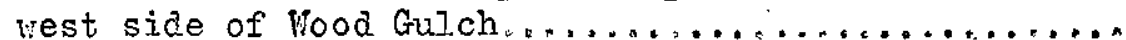

IV A. Coarse-erained sranite along the divide between Wood.

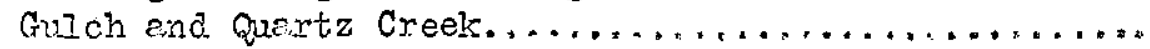

B. Coerse-grained Eranite vith two sets of joints at

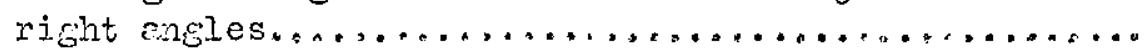

$V$ A. oliff of Delrota seindstone................... 34

B. Tuff with large volcanic fragment................ 34

VI A, Pegnatite showing regional trend. Brow Derby mine in

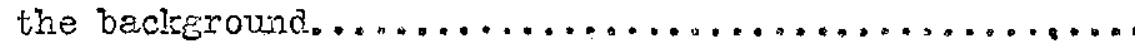

B, Anticline in center of picture is a downfaulted biock of Dalrota sancistoine...........................

VII A. Snall braiching pegmatite cutting fine-grained granite.

B. Large branching pegmatite (No. 250) cutting hornblende

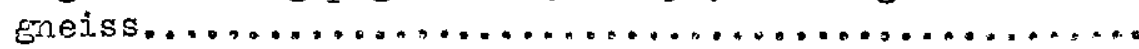

VIII Ao A thin zoned pesmatite with albite-quartz wall zone and a quartz core (gray).........................

B. Replacement of perthite by fine-grained muscovite (black). Note the unreplaced albite lamillae of the

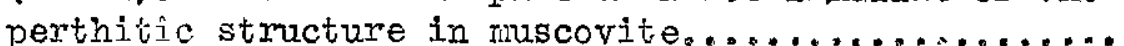

IX A. Iine rock in the low part of pegmatite No, 670. Fine dark layers are small brown gernets................

$\mathrm{B}_{3}$ Iine rock from pegmatite $\mathrm{No}_{3}$ 46I. Black layers are gernet and muscovite and. white layers are majinly al-

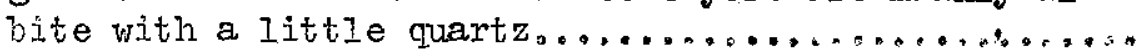




\section{ILLUSTRATIONS}

Page

Plate $X$ Lepidolite from left to right: fine-grained aggregate, curved plates, and large plates..... 105

XI Mouth of stope of Brown Derby No. 1 (pegmatite No. 452) showing contact of pegmatite with hormblende gneiss ................. 140

Figure 1. Index map, Quartz Creek pegmatite district, Colorado. - 255

2. Lenticular pegmatites, Quartz Creek pegmatite dis-

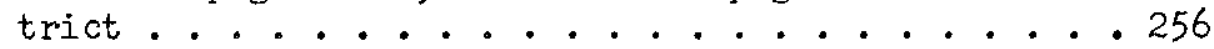

3. Lenticular and branching pegmatites, quartz Creek pegmatite district ........... . . 257

4. Shape of pegmatite No. 1294, Quartz Creek pegmatite district . . . . . . . . . 258

5. Oval pegmatites, Quartz Creek pegmatite district . . 259

6. Irregular pegmatites, Quartz Creek pegmatite district . 260

7. Pegmatite No. 297, Quartz Creek pegmatite district . 261

8. Angle between pegmatite contacts and foliation of country rock .................. 262

9. Contour diagram of joints in granite ...... In. envelope

10. Zoned pegmatites, Quartz Creek pegmatite district . . 263

11. Layered pegmatites, Quartz Creek pegmatite district . . 264

12. Pegmatites showing variation in composition along strike, Quartz Creek pegmatite district . . . . 265

13. Multiple pegmatites, Quartz Creek pegmatite district. . 266

14. Relation of banding to crystals or non-banded mineral aggregates, pegmatite No.70......... 267

15. Distribution of tourmaline, face of cut in pegmatite

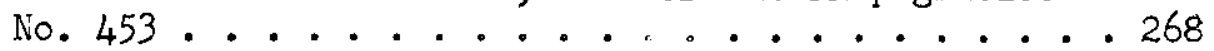

16. Distribution of beryl-bearing pegmatites .... In envelope

17. Distribution of tourmaline- and curved muscovitebearing pegmatites .......... In envelope 


\section{ILIUSTRATI ONS}

Figure 18. Distribution of magnetite- and biotite-bearing

Page

pegmatites .............. . . . . . envelope

19. Distribution of columbite-tantalite- and monazite-

bearing pegmatites . . . . . . . . . In envelope

20. Distribution of lepidolite-, cleavelandite-, topaz-, and mizrolite-bearing pegmatites..... In envelope

21. Geologic map, Opportunity No. 1. (No. 215) pegmatite ................. In envelope

22. Geologic map and sections of Brown Derby mine showing Bureau of Mines diamond drilling..... In envelope

23. Geologic map, Brown Derby No. 5 (No. 535)

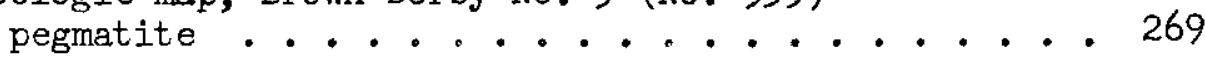

24. Geologic maps of pegmatite No. 537 and No. $538 . . .270$

25.' Geologic maps of pegmatite 560 and Beryl and Rare Mine rals Lode (No. 590) . . . . . . . 271

26. Geologic map, Buckhorn (No. 659) pegmatite . . . 272

27. Detailed map, Bucky (No. 1574) pegmatite...... In ervelope

28. Geologic sections, Bucky (No. 1574) pegmatite ... .In envelope

\section{TABLES}

Table 1. Ratio of pegmatite shapes to the oval type in different kinds of country rock ......... 44

2. Ratio of various pegmatite shapes to the oval type in hormblende gneiss and tonalite ....... 44

3. Occurrence of accessory minerals in the pegmatites of Quartz Creek pegmatite district........ 65

4. The range of refractive index ( $\left.\mathrm{N}_{2}\right)$ of plagioclase and cleavelandite from all types of pegmatite and pegmatite units in the Quartz Creek district and its relation to different types of country rock ... 67

5. Lower refractive index $\left(\mathrm{N}_{\alpha_{1}}\right)$ of plagioclase in zoned pegmatites............. 71

6. Lower refractive index $\left(\mathrm{No}_{1}\right)$ of plagioclase in layered pegmatites ............. 72 
Table 7. Chemical analysis of graphic granite from the Bucky

Fage mine, Guartz Creek district, Colorado........ 76

8. Number and distribution of median refractive indices

(i) found sil flat alla curved muscovite........ 80

9. Median refractive index ( $\mathrm{N}_{B}$ ) of muscovite from zoned pegmatites ................ 80

10. Median refractive index $\left(\mathrm{N}_{\beta}\right)$ of muscovite in layered

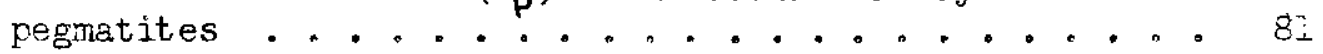

1. The nuwer of reprative index determinations of plagiolase and bery , their relation to different types of count ry rock, and types of pegmatites or units .... 90

12. Refractive indices of plagioclase and beryl from berylbearing units of zoned pegmatites.......... 92

13. Refractive indices of plagioclase and beryl from berylbearing layered pegmatites ..............

14. Refractive index (Nw) of tourmaline, Quartz Creek district ............... 96

15. Spectrographic determinations of minor elements in tourmaline from Maine.......... . 97

16. Measurements of specific gravity on columbite-tantalite. . 101'

17. Lower index of refraction $\left(N_{\alpha}\right)$ and the specific gravity of monazite ............... 103

18. Median refractive index ( $\mathrm{N}_{\beta}$ ) and description of lepidolite from quartz Creek district........ 107

19. Lower index of refraction ( $\mathrm{N}_{\alpha}$ ) of topaz from the Quartz

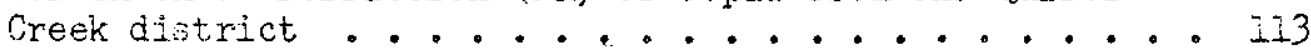

20. Mine ralogy of pegrnatites ............ 167 


\section{GBOLOGY OF THR QUARTZ CREDK PIGMATITA DISTRICT, GUNINISON COUNTY, COLORADO}

by

Mortimer H. Stantz and Albert F. Trites

\section{ABSTRACT}

The Quartz Creek jegmatite district includes an area about 29 square niles in the vicinity of Quartz Oreek in Gunisison County, Colo. This area contains, 1,803 pegmatites that are intruded into pre-Cambrian rocks.

The rocks exposed in the district range in age from pre-Cambrian to Recent. The oldest pre-Cambrian rocks are chiefly quartzites interbedded with a fev arkoses and conglomerates. These rocks are surrounded by rore abundant horablende gneiss and tonalite. A small body of biotite tonalite was intruded and two thin layers of dacitic pillow lava were extruded into this series. The hornblende gneiss and tonalite have the same corrposition and differ only in texture. The older naterial (hornblende gneiss) has a well-marked lineation, whereas the younger (tonalite) is equigranular. Subsequently, a large bocy of quartz nonzonite was intruded along the northern boundary of the mapped area. Latex, coarse-grained granite was intruded into the southern part of the area. Dikes of fine-grained granite cut the coarse-grained variety. The last period of intrusive activity in preCarbrian time is marked by a large number of pegmatites.

The pre-Cambrian rociss were tilted and eroded, and the flatlying Jurassic Morrison fornation was deposited on the irregular surface. This formation is conformably overlain by the Cretaceous Dakota sandstone. Faulting produced a vertical offset of 410 feet in the Mesozoic sediments along the only large fault in the area. At the end of Mesozoic time there 
was another period of erosion. Tertiary ( $($ ) tuff is exposed in small, scattered areas in the southern part of the district. It overlies both the Dakota sandstone and pre-Cambrian formations, Glacial till-occurs along the edses of Quartz Creek and Wood Gulch. Quaternary alluvium Iills the valley bottoms,

Although the composition of the country rock has little effect on the shaye of the pegmatites, the foliation imposed on this rock has a localizing effect and in part controls the ultimate shape of pegmatites, zoned and related internal structures are not well developed in the pegrnatites of this region. Many of the pegmatites are homogeneous and those that are zoned usually contain a large wall zone and small discontinuous cores. In addition to the more comnon homogeneous and zoned pegmatites, 7 percent of the pegmatites show a layered structure of textural and mineralogical units not repeated on the opposite side of the pegmatite. Other internal structural units include pegmatites which vary in composition along strike, multiple or "line-rock pegmatites", and fracture pillings。

The mineralogy of the pegmatites is described in detail. Specific attention was given to most of the 27 observed minerals. A study of the index of refraction of 439 specimens of plagioclase showed that the variation from zone to zone and layer to layer is minor and that there is no systematic variation in respect to the entire district. No correlation could be found between the refractive index of plagioclase in the pegrnatites and the type of country rock, or the presence of various accessory minerals.

Index of refraction determinations on 95 specimens of muscovite showed no constant variation from wall zone to core or from layer to layer. Curved. muscovite has identical optical properties with the flat variety. 
The incex of refraction wes determined for 183 beryl specimens. The beryl in pegnetites containing only a wall zone and a core showed no difference between zones, but in pegmatites that heve intermediate zones, the indices of refraction of the beryl showed an inward increese in the alkali content from the contact. Beryl occurs vith almost all of the pegmatite minerals and is not restricted in its mineral associations.

Tourmaline, except the black variety, is associated with lepidolite, Dark green and blue tourmaline is found in the outer zones of pegmatites containing lepicolite, and the pink and light green varieties are found in direct contect with lepiòolite.

Lepidolite occurs in aggregates of fine grains, in flat plates, ano in curved plates; the three varieties are optically identical. The lightercolored verieties have higher indices of refraction and contain less lithia than the darker varieties.

In eddition, the occurrence of the following ninerals is described in detail: perthite, quartz, nartite, biotite, garnet, coluribite-tantalite, nonazite, nicrolite, topaz, gahnite, allanite, and an unidentified mineral.

The lack of alteration in the wall rocks adjacent to the pegmatites is interpreted as indicating that the original pegmatite magma did not have an excess of materials such as $\mathrm{B}, \mathrm{OH}^{-}$, and $\mathrm{P}$ that are needed to form alteration minerals. Because of their low concentration, the above materials were available only in the pegmatitic macma during its crystallization. Pegmatites that contain the rare minerals such as beryl, tourmaline, curved. Inuscovite, biotite, masnetite, nonazite, columbite-tantalite, cleavelandite, topaz, lepidolite, and inicrolite show a grouping in clusters within the district.

Beryl-bearing pegnatites occur most abundantly in hornblencie gneiss and are only rarely found in either granite or quartz monzonite. 
The types of minerals that form in a pegmatite appear to be determined by the character of the material segregated from the original magma and the period in which it segregated. The elements escape at one period and may be from only a specific pocket in the magma. These liquids tend to form groups of pegmatites in which the later bodies contain a high proportion of volat1les.

Inferred reserves of the district are estimated for beryl, scrap mica, both hand-cobbing and milling feldspar, lepidolite, columbite-tantalite, topaz, monazite, and microlite, No sheet mica was found, Reserves are shall and transportation costs are high so substantial production of lowpriced feldspar and scrap mica will depend on the adoption of economical milling techniques for recovering the large quantities of feldspar available. Beryl is irfegulerly distributed and its recovery as a byproduct will depend on the establishment of a stable market for feldspar and scrap mica. Lepidolite reserves are small and low grade.

\section{INTRODUCTION}

Prior to World War II the Quartz Creek pegmatite district was well known for its fine specimen of colored tourmaline, books of lepidolite, topaz, and microlite. During and after World War II small quantities of beryl. feldspar, lepidolite, and tantalum minerals were produced from the district.

\section{Location and surface features}

The Quartz Creek pegmatite district is on the western slope of the Sawatch Range in Tps, 49 and 50 N., R. 3 I., New Mexico principal meridian, Gunnison County. Colo. (fig. 1)... It covers about 29 square miles in the 
vicinity of Quartz Creek. State Highway 162 follows Quartz Creek through the district, and joins U. S. Highway 50, 2 miles south of the southern boundary of the mapped area. A road branching from State Highray 162 crosses the southeastern corner of the area and connects with 0 . $s$. Highway 50 1 mile west of Doyleville. Unimproved roads follow several of the ralleys, and a mine-access road, made during World War II, connects State Highway 162 with the Brown Derby mine. The nearest railroad shipping point, Parlin, is on a narrow-gauge line of the Denver and Rio Grande Western Bailroad, which connects with standard-gauge lines at Salida (east-bound) or Montrose (west-bound). -

The topography is moderately steep and has a maximum relief of 2,200 feet (p1. I). The highest peak in the district is at the northern boundary and has an elevation of 10,238 feet. Quartz Creek, the main tributary draining the area, is in a flat cultivated valley, a quarter to half a mile wide. The hills rising from Quartz Creek are usually sage-covered, and the north-facing slopes of the higher hills are covered with aspen, or spruce and pine, quartz and Alder Creeks are the only parmanent stroams in the district, but water flows in Willow Creek and Wood crilch daring the spring and early summer.

\section{Production}

The recorded production of pegmatite minerals from the Quartz Creek district is about 51 tons of beryl, 283 tons of lepidolite, 140 tors of scrap mica, 5,000 pounds of tantalum and columbium minerals, and 15 pounds of monazite.

From September 1943 to the spring of 1945 the Brown Derby property was leased by the Fayden Mining Company. Prior to February 1945, 3,155.67 
UNTTED STATES

DEPARTMENT OF THE INTERIOR

GEOLOGICAL SURVEI
TRACE EILAMENTS INVESTIGATIONS

REPORT 138

Plate I

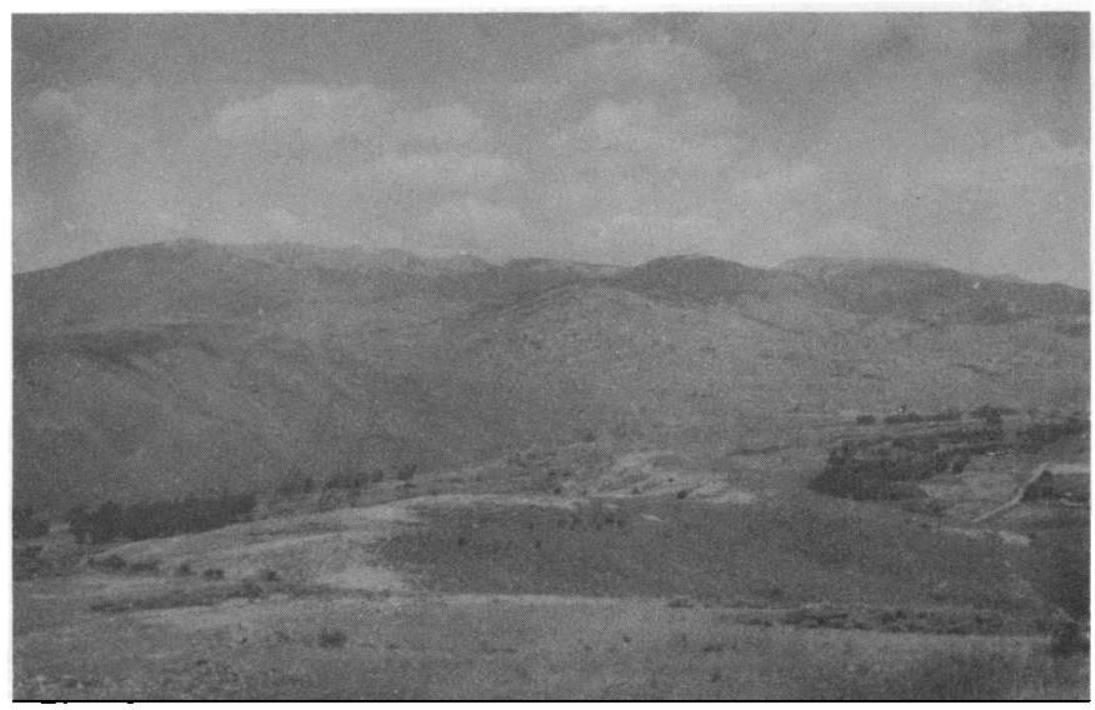

A. Panorama southern end of quartz Creak pegmatite district looking north. White areas in foreground are pegmatites.

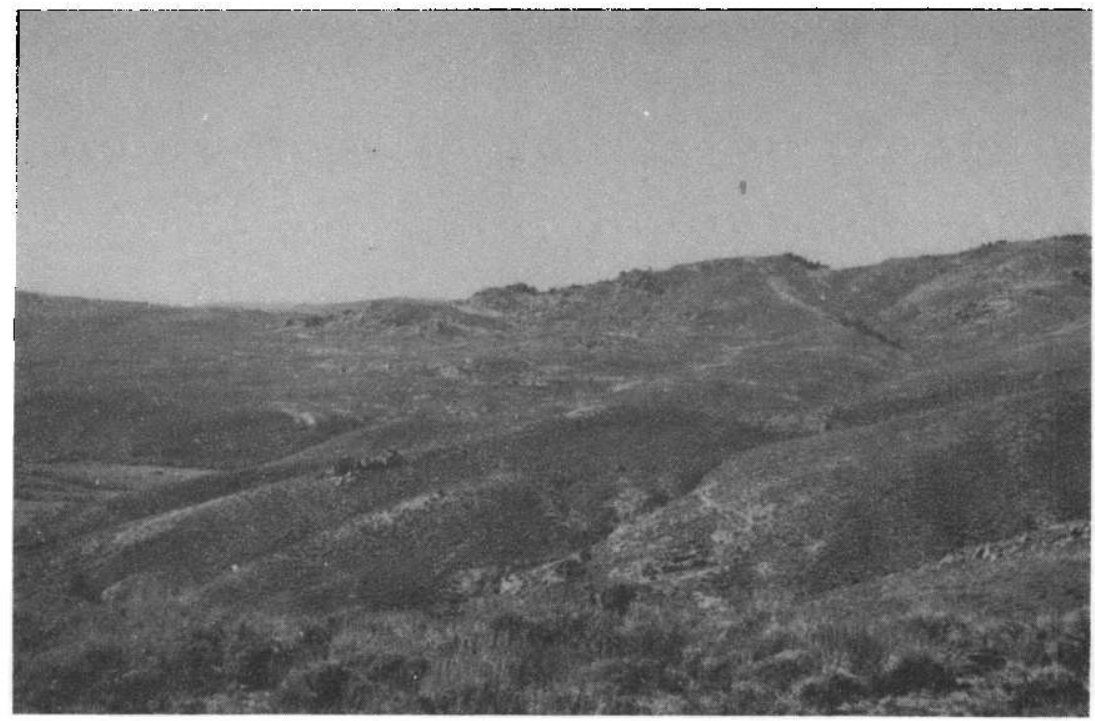

B. Panoram of the northern end of the quartz Creek pegmatite district looking west across quartz Creok. Outcrops in the background are the Bleck Wonder (No. 847) pegmatite. 
pounds $J$ of beryl were sold to Metals Reserve Company and 283 tons of

$J$ Hanley, J. B., unpublished notes.

lepidolite to Corning Glass Company. In addition, 4,000 pounds of microlite concentrate containing 52 percent microlite was stockpiled at the mill and later sold. Though the final production figures are not available, they do not greatly exceed these figures as mining stopped in the spring of 1945 .

The White Spar No, 1 and No, 2 pegmatites, which are 0.8 mile north of the Brown Derby mine, were mined for a short time during World War II by the Colorado Feldspar Company. The production of lepidolite and feldspar is not known, but was small.

There was no mining in the district from 1945 to 1947. Mr. Rod Fields located the Bucky claim on the east side of Willow Creek and started to mine beryl in the spring of 1948. Mr. Fields produced 17 tons of beryl, and in November 1948 sold the property to Beryllium Mining Company, Inc., which has produced 32.0 tons of beryl, 139.6 tons of scrap mica, 1,020 pounds of columbite-tantelite, 15 pounds of monazite, and 13 pounds of a sanarskite-like mineral to May 1950. The last two minerals were sold to Ward's Natural Science Istablishment, Inc.

\section{Previous work}

Tarly papers on the pegmatites of the Quartz Creek district have been concerned chiefly with the mineralogy of the Brown Derby pegmatites J.A

\footnotetext{
J Ickel, I. B., A new lepidolite deposit in Colorado: Am. Ceramic Soc. Jour., vol, 16, pp, 239-245, 1933. Iandes, K. K., Colorado pegmatites: Am. Mineralogist, vol。20, p. $333,1935$.

Eckel, . $_{\text {. }}$., and Lovering, T. S., Work of Ickel, Lovering, Fairchild-Microlite from Ohio City, Colorado: Report of the Committee on the Measurement of Geologic Time, pp.77-79, Apr. 1, 1935.
} 
Seaman, D. M., New pegmatite locality near Ohio City, Colorado: Oregon Mineralogist, vol. 2, p. 23, 1934.

map showing the regional feology of the Gold Brick district, on a scale of 1.5 inches equal one mile, was published by Crawford and Worcester $\rfloor$. The J Crawford, R. D., and Worcester, P. G., Geology and ore deposits of the Gold Brick district, Colorado: Colorado Geol. Survey Bul1. 10, 19161*

southwestern corner of their map, an area roughly 3.3 miles by 2 miles, overlaps the northern part of the present area mapped. No pegmatites are shown on their map and the area containing them is designated as "granite". The area around Tomichi Dome, several miles to the east of the Quartz Creek district, has been described by Stark and Behre _/.

Stark, J. T., and Behre, C. H., Jr., Tomichj dome flow: Geol. Soc. Anerica Bull., vol. 47, pp. 101-110, 1936.

Between September 1942 and December 1944 the Geological Survey had several field parties mapping in Colorado under $\mathbf{x}$. W. Heinrich in 1942 and John B. Fanley in 1942-1944 J. In the Quartz Creek district these parties

J Hanley, J. B., Heinrich, J. W., and Page, I. R., Pegmatite investigations in Colorado, Wyoming, and Utah 1942-1944: U. S. Geol. Survey Prof. Paper 227, pp. 63-80, 1950.

nappea in detail- on scales of 1 inch equals 20 feet to I inch equals 50 feet--the Opportunity No. I claim, the Brown Derby No. 1 claim, the Brown Derby Ridee pegmatites, Brown Derby No. 5, the White Spar No. 1, the White Spar No. 2, and the Bazooka pegmatites. A total of 25 pegmatites was mapped with plane table and telescopic alidade. Several other pegmatites were visited and described. 


\section{Field work and acknowledgments}

The investigations carried out by the Geological survey in the Quartz Creek pegmatite district during World War II were concerned primarily with pegmatites from which feldspar, muscovite, and minerals containing beryllium, tantalum, Iithium, and the rare earths were produced. Such pegmatites are in the minority, and time did not permit detailed study of the more numerous associated, but unproductive pegmatites, or of the broader relations of pegmatites to the regional geology. This study, started in 1948, was made not only to provide an economic appraisal of individual deposits, but also to determine the regional relationships of pegmatites and country rock.

The field work for this report was started on July 10, 1948. M. H. Staatz and P. T. Flawn began mapping on the east side of Quartz Creek and A. F. Trites and F. I. Klinger on the west side. Field work was recessed September 7, 1948. It was resumed on June 12,1949 and completed December 10, 1949. The writers were assisted during 1949 by F. I. Klinger for three months, and J. D. Vogel for two months. Mapping was done by pace and Brunton compass, using the Pitkin quadrangle topographic map enlarged to a

scale of one inch equals 1,000 feet as a base ( $p I$. In). Individual pace and compass maps also were made of each pegmatite on the scales of from one inch equals 40 feet to one inch equals 200 feet, depending upon the size of the pegmatite. Petrographic work was done during the spring of 1950. This investigation was made in part on behalf of the Division of Raw Materials of the U. S. Atomic Inergy Comission.

GENBRAI GEOLOGY

The rock units mapped in the Quartz Creek pegmatite district range in 
age from pre-Cambrian to Recent (pl. II). The age of the Brown Derby No. I pegmatite, as determined from uranium-bearing microlite by \$ckel and Lovering $J$, is 760 milition years. The oldest pre-Cambrian rocks consist of

\rfloor Eckel, I. B., and Lovering, T. S., op. cit., p. 79, 1935.

metasedimentary rocks, predominantly quartzites, that are surrounded by younger and more abundant tonalite and hornblende gneiss (a meta-tonalite). Included in this series are two small bands of dacitic pillow lava and one of biotite tonalite. A coarse-grained porphyritic granite, similar in appearance I to the Pikes Peak granite, intrudes the earlier pre-Cambrian

$J$ Eckel, I. B., op. cit., p. 240, 1933.

rocks in the south-central part of the district and a large quartz monzonite intrusive body occurs in the extreme northerm part. These rocks are intruded by numerous fine-grained pink granite dikes and by a large number of pegmatites.

An angular unconformity separates the pre-Cambrian rocks from the flatlying Jurassic Morrison formation and Cretaceous Dakota sandstone which crop out along the east and west sides of the area.

Flatlying Tertiary (?) tuff is exposed in three scattered patches overlying unconformably both the Dakota sandstone and pre-Cambrian formations. Small areas of glacial till border Quartz Creek and Wood Gulch, and Quaternary alluvium fills many of the valley bottoms.

In general, the pre-Cambrian formations dip steeply and have a northwesterly trend, which is brought out by the structure of both the metasedimentary rocks, the dacitic pillow lava, and the biotite tonalite. The pegmatites have a general northeast trend across all of the earlier structures. 
Only three faults with displacements of over 20 feet were found in the area. The largest of these trends northwest and separates the Dakota and Morrison formations from the pre-Cambrian in the southwestern corner of the district, Two other faults, which are terminated by this large fault, separate a block of Dakota sandstone from the pre-Cambrian and Morrison formations.

\title{
Pre-Cambrian rocks
}

\author{
Quartzite
}

Pre-Cambrian quartzite, interbedded partly with arkosic and conglomerate quartzite (pl. II), is best exposed on the northwestern slope of Wood Gulch where there are four mappable bodies. Two other bodies of arkosic quartzite, about half a mile long, crop out along the headwaters of Tollgate Gulch, a tributary of Quartz Creek, which is northwest of Wood Gulch. Narrow outcrops, a few tens or hundreds of feet long, are found at widely scattered localities on the northern side of Quartz Creek, These rocks have been highly metamorphosed and are part of a much larger area of sedimentary rocks that are separated by intrusive tonalite and hornblende gneiss.

The pre-Cambrian quartzites are generally dark gray but in places are white and brown, The original sediments ranged from siltstone to conglomerat but most were fine grained. Some of the quartzites are now slightly schistose. The northernmost band of metasedimentary rocks in Wood Gulch is a conglomerate containing pebbles from 0.1 to 2 inches long. Some of the pebbles are elongated; the ratio of width to length is from $1: 4$ to $1: 5$. Feldspar (orthoclase, microcline, and plagioclase) is present throughout the unit but the proportion varies widely. The rocks along Wood Gulch are 
Whation 20

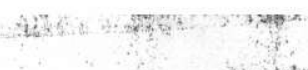

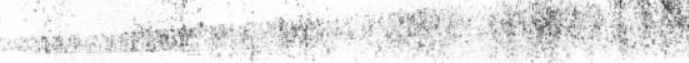

commonly quartzites with only a few percent of feldspar, but those on the north side of Quartz Greek contained 20 percent ox more of feldspar. The proportion of the dominant dark mineral, biotite, fanges from a trace to about 15 percent. Muscovite is common in amounts of one percent or less. In rocks rich in feldspar, epidote is prominent and may make up more than 50 percent of the rock. One specimen contains hornblende and clinozoisite as well as biotite. Apatite, zircon, and magnetite are common accessories.

Quartz-mica schists, composed chlefly of quarta, biotite, feldspar, and muscovite, are found in a few, scattered outcrops in the northern part of the area. Locally, these schists contain well-developed porphyroblasts of quartz and magnetite,

The thicknesses of the different exposures range from a few feet to a maximum of about 600 feet.

The quartzites are the oldest rocks in the district and are surrounded by younger hornblende gneiss, tonalite, and granite. One xenolith of conglomerate was found in the granite.

Dacite

Dacitic pillow lava (pl. II) occurs in two northwesterly-trending bands south of Quartz Creek, One of these is in sec. 11, T. 50 No, R. 3 I. on the northwestern slope of Wood Gulch, and the other is in secs. 3 and 34 . about 900 feet northwest of the Brown Derby mine.

The pillow lava is yellow green to dark green depending on the proportion of epidote. It is a fine-grained dense vesicular rock, with prominent flow lines. Some vesicles contain well-developed crystals of epidote and quartz; a few are completely filled with fine-grained quartz. Large ellipsoids or pillows ( $p I$. III, B), several feet long and about one 
UNITED STATES

DEPARTMENT OF THE INTERIOF

GEOLOGICAL SURVEY
21

TRACE EL.EMENTS INVESTIGATIONS

REPORT 138

Plate III

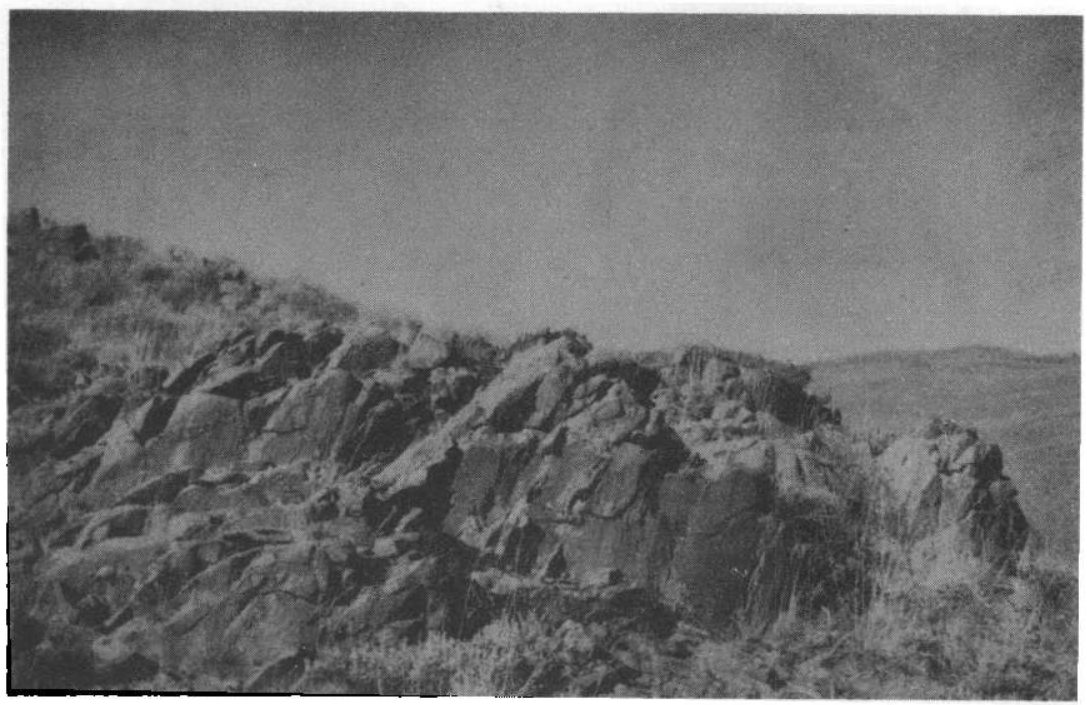

A. Tonalite outcrop on the northwest side of Wood Gulch.

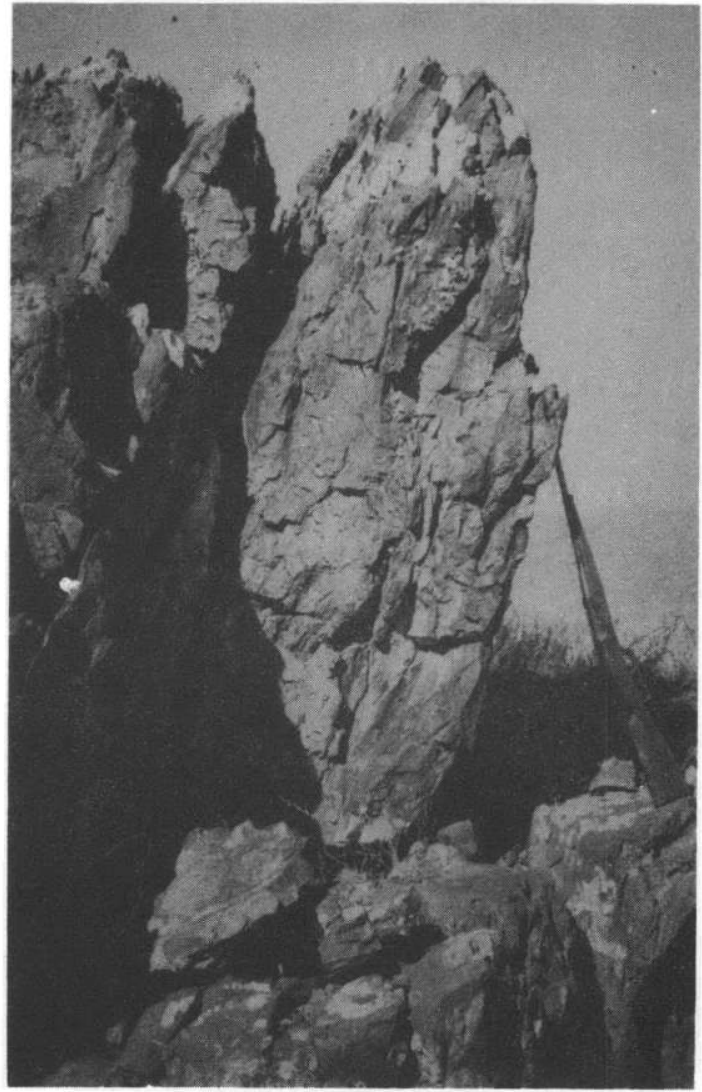

B. Pillow lava showing ellipsoidal pillows on the northwest side of Wood Gulch. 
foot wide, are common. Microscopically the unaltered rock consists of green prismatic homblende (50 percent), quartz (30 percent), and andesine (20 percent). Fipicote may be present almost to the exclusion of other minerals anò is veineả by calcite.

The band of pillow lava on the northwestern slope of Wood Gulch is 140 feet thick and is parallel in strike and dip to the enclosing preCambrian quartgite and conglomerate. This pillow lava was extmded under water onto a sand and was bojied by later sediments. A second band of pillow lava, 6,450 feet to the northwest, is enclosed in hornblende freiss. The two areas of pillow lava (pl. II) are almost alined on strike ana are probably remants of the same band. Both bands of pillow lava are younger than the pre-Cambrian quartzites on the northeast and older than the quartzites to the southwest.

\section{Biotite tonalite}

One small body of biotite tonalite, approximately 900 feet long and 110 feet wide, is exposed in sec. 1.1 on the northwestern slope of wood Gulch. It is bounded on the north by pre-Cambrian quartzite and on the south by hornblende gneiss, and is approximately 80 feet southwest of, and parallel to, a band of pillow lava.

The biotite tonalite is dark gray with prominent black hornblende crystals, 0.05 inch in diameter, in a black, speckled, fine-grained matrix. Plagioclase phenocrysts, the same size as the hornblende crystals, contain small included grains of biotite, epidote, and hornblende. Dark minerals make up about 50 percent of the rock. Hornblende, the chief dark mineral, constitutes 25 percent of the rock, and commonly forms ragged prismatic Erains, but locally it occurs as small included grains in the plagioclase 
and quartz. Biotite constitutes 22 percent of the rock and occurs with hornblende as aggregates and in the plagioclase as a moriad of fine grains. Ipidote ( 3 percent) and magnetite ( $<1$ percent) are the other dark minerals. Andesine ( 40 percent) forms large crystals clouded with many fine crystals of biotite, hormblende, and epidote. Quartz ( 10 percent) is interstitial to the andesine.

The biotite tonalite occurs near the southwest edge of the pre-Cambrian quartzite and has a trend parallel to the strike of the bedding. It is similar in composition to the pillow lava, except that it is not resicular and contains much less epidote and no calcite. It is also much coarser grained. The similarity in trend and composition suggests that the biotite tonalite and the pillow lave derived from the same magma about the same time, but one was intrusive and the other extrusive. The biotite tonalite is younger then the quartzite to the north and probably older than the hornblende gneiss to the south.

Hormbiende meiss and tonalite

The hormblende gneiss and tonalite are gradational-sometimes in the same outcrop. Tho difference between the two rocks fs one of texture, with the gneiss exhibiting a planar alinement of minerals. Though most of the hornblende gneiss and tonalite is clearly of intrusive orlgin, some unlts are lava flows. The hormblende gneiss and tonalite were maped separately only along the northwestem slope of Wood Gulch, where fine-gratned hormblende gneiss is very schiatose and is cut by the coarser, equigranular tonalite (pI. III, A). These two rocks are evidently of different ages, the tonam lite having been intruded after the older rodk had been motamomposed considerably. The intrusive tonalite bodies in foed olob howe a northwesterly trend, perallel to that of the pre-cambrian quartzites, 
The foliation of the hornblende gneiss south of Quartz Creek has a north to northwesterly strike and dips steeply in either direction. North of Quertz Greek the strike is between north-northicst and north-northeast. except where the foliation parallels the contact of the quartz monzontte

The hornblende gneiss and toralite have the wdest distribution of any rock type and occupy the central part of the dartr croek alstrict. These mafic rocks extend for a considerable distance to tho northeast boyond the area mapped, where they have been described by Crawford $J$. They

I Crawford, R, $D_{n}$, and Worcester, $P_{0} G_{*}$, Geology and ore deposits of the Gold Brick district, Colorado: Colorado Geol, Survey Bull, vol, 10 , $p p=27-28,1916$.

are the host rocks for a very large number of pegmatites, and numerous fine-grained grainte dikes.

The hornblende gneiss and tonalite range from fine-grained to coarsegrained; the maximum grain size is about 0.20 inch. Textures or structures commonly found are: (I) prominent, well banded gneissic structure, (2) diabasic texture, (3) porphyritic texture, and (4) equigranuar texture axposures of this rock are in general poor, and even where well exposed the textural changes are so great that in most places separation into mappable units was not feasible. Both rocks are dark gray to greenish black"where fresh, and weather greenish gray to reddish brown. The hornblende content rainges from 20 to 80 percent, but most of the rock contains 50 to 75 percent hornblende. Some facies are unusually rich in hornblende and the rock may then grade into a hornblendite or perknite.

The minerals in the hornblende gneiss and in the tonalite are essentially the sane, but the proportions of each vary widely. Hornblende, biotite, and feldspar are the only minerals that can be identified regascopical- 
1y. In places much of the hornblende has altered to biotite, Andesine is the dominant light-colored constituent, but quartz and microcline are present locally, The accessory minerals are apatite, zircon, sphene, magnetite, epidote, chlorite, and sericite.

Much of the hormblende is in distinct dark-green euhedral crystals, but part is in frayed, ragged, pale-green grains that are altered largely to biotite. In one place it is altered to chlorite. Biotite is not found in some areas, but in others it is abundant. It forms as much as 60 percent. of the rock, is comronly fresh, and occurs in brow prismatic crystals. Andesine $\left(\mathrm{Ari}_{30}-\mathrm{An}_{44}\right.$ ) is poorly twinned and commonly is clouded with fine kaolin and sericite. The andesine crystallized affer the hornblende in most places and fills the spaces between the hormblende crystals; in a few places the reverse is true. Quart is present in most specimens constituting a mazimun of 7 percent of the rock and occurs as small, clear grains with sutured borders. This mineral is interstitial to and cuts andesine; rarely they are micrographically intergrown. Because of the presence of a small amount of quartz, the rock is called a toilalite rather than a diorite, as used by Crawford $J$. Microcline is present in a few places, but in most of

J Crawford, R. D., and Worcester, P. G., op. cit., pp. 27-28, 1916.

the rock exanined, it was absent. A trace to several percent of apatite and zircon are almost universally present as well-formed euhedral crystals associated with biotite, Ipidote and sphene are found locally, usually where the hornblende is pale green and has been considerably altered, Magnetite occurs in irregular grains and is not common. Augite was noted in one specimen. 
Quartz monzonite

Quartz monzonite crops out along the northern boundary of the Quartz Creek district. Pegmatites, similar in size and shape to those in hornblende gneiss, are common near the outer edge of the intrusive. Farther into the mass the pegmatites are only a few inches thick and are very irregular in shape.

The quartz monzonite is a light- to dark-gray porphyritic rock that ranges in composition from quartz monzonite to Eranooiorite. Poor exposures make it difficult to map the variations of this rock in the field.

Mafic minerals ( 12 to 22 percent) are in clots and streaks composed of biotite, hornblende, zircon, sphene, magnetite, and apatite. Hornblende (0 to 15 percent), the dominant dark mineral, generally has been frayed and altered to biotite. Biotite ( $?$ to 14 percent) occurs in snall brown unaltered flakes and in clots or aggregates that appear megascopicaliy to be Iarge crystals. Apatite and magnetite ( 1 to 2 percent) commonly occur with biotite. Zircon, in trace quantities, is universally present as snall crystals. Wedge-shaped brown sphene crystals locally rake up as much as 5 percent of the rock. The leucocratic minerals are quartz, andesine, and microcline. Both andesine and microcline are in large phenocrysts and in fine grains in the groundnass. The feldspar content ranges from about 12 to 45 percent microcline and from about 30 to 65 percent andesine. The plagioclase has a composition of $\mathrm{An}_{31}-\mathrm{An}_{35^{\circ}}$. The microcline shows crosshatch twinning in most places. The andesine has some albite and pericline twinning and in some thin sections is covered by a thin film of taolin and Rericite. No quartz is observed megascopically, but in thin section small clear grains, interstitial to the feldspars, make up 4 to 15 percent of the rock. The quartz exhibits strain shadows and in many places has sutured 
borders.

The quartz monzonite was intruded into the hornblende gneiss and in turn was cut by pegmatites. It is thus intermediate in agre between pegmatite and hornblende gneiss. The age of the quartz monzonite in relation to the coarse-grained and fine-grained granite is not definitely known because the two rocks are not in contact. The following evidence, however, suggests that the quartz monzonite is older: (I) in many regions the differentiation of a batholith results in the early formation of mafic rocks. Subsequently, rocks of internediate and granitic composition are formed as in the Quartz Creek district where the quartz monzonite is intermediate in composition between the granite, and the earlier tonalite; (2) the gneissic texture in the hornblende gneiss parallels the contact on the quartz monzonite (p1. II). This inplies that the quartz monzonite was intruded during metanorphism; whereas the coarse-grained granite cuts across foliation in many places; (3) the pegmatites that cut the granite and quartz monzonite have a composition sinjlar to the granite and appear to have been derived from it rather than the quartz monzonite.

\section{Coarse-grained granite}

A large band of coarse-grained granite (pl. II) trends north-northwest across the district from the northeastern corner of sec. 22 to the northern border of sec. 33. This granite forms the prominent mountains on the southeast side of Quartz Creek. Another band of massive granite crops out a mile to the west and extends about one mile north of the southern boundary of the area mapped. These two granite masses converge several miles south of the Quartz Creek pegmatite district to form a large $\nabla_{0}$ In addition to these two large granite bodies, numerous small bodies with exposed areas of from a few feet square to 2,000 feet by 800 feet, are scattered throughout 
the hornblende gneiss and tonalite terrane. The area of nost abundant small scattered granite intrusives is west of the main granite mass and trends north-northwest.

The granite is a pinle porphyritic rock (pI. IV, A and B) that forms well-rounded outcrops. The phenocrysts are grains of pink microcline, 0.50 to 0.75 of an inch long, and grains of clear quartz, 0.25 to 0.50 of an inch long. In thin section the microcline phenocrysts show many small included crystals of diversely oriented microcline, quartz, biotite, and albite. The quartz phenocrysts are composed of several grains, commonly with sutured borders. The coarse-grained groundmass consists of interlocking grains of microcline, quartz, biotite, albite, magnetite, apatite, and zircon. Some specimens also contain sericite, epidote, and chlorite. The average corposition of this rock is estimated to be microcline (7I percent), quartz (20 percent), biotite ( 8 percent), albite ( 1 percent), and less than $I$ percent of magnetite, apatite, and zircon, and trace quantities of epidote, sericite, and chlorite. Apatite and zircon are nost abundant in the biotite. Epidote comonly occurs near the biotite and the chlorite is derived from the biotite.

There are two less common varieties of the coarse-grained granite. Granite gneiss occurs in a few isolated masses near the western edge of the district and is characterized by the parallel arrangement of elongate quartz and biotite crystals, granulation, and recrystallization of the quartz. Much of the biotite has been altered and only small wisps and discolored areas renain. The gneiss is believed to be a normal grenite that has been metamorphosed by shearing.

A red granite occurs in small patches within the two main granite masses. It has no large phenocrysts, has many small vugs, contalns only a 
UNITED STATES

DEPARTMENT OF THE INTERIOR

GEOLOGICAL SURVEY
29

TRACE ELENENTS INVESTIGATIONS

REPORT 138

Plate IV

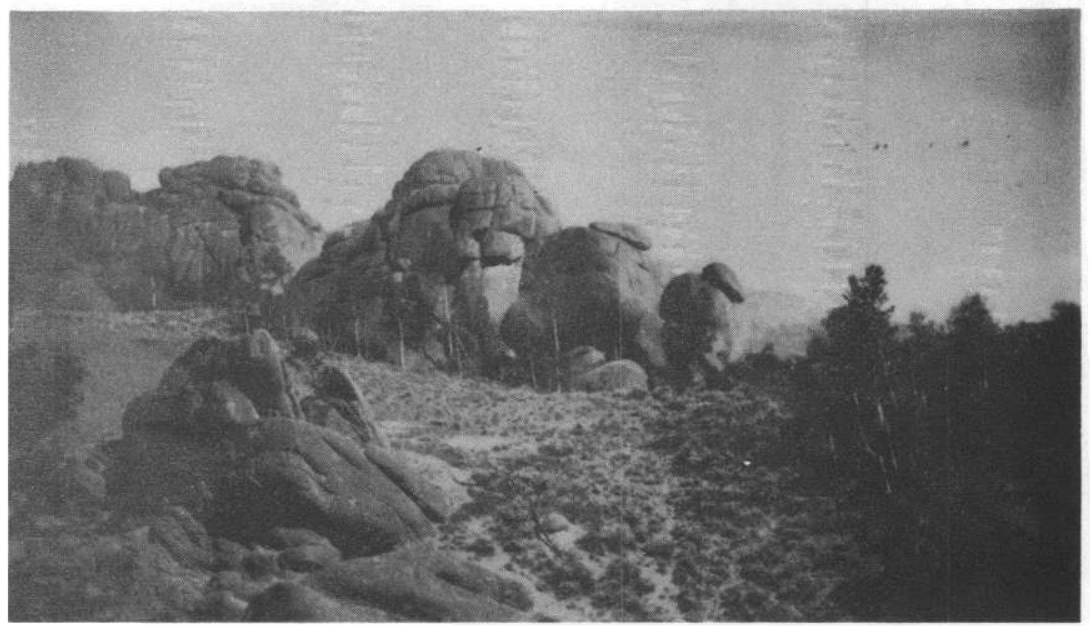

A. Coarse-grained grenite along the difide between Wood Gulch and Quartz Creek.

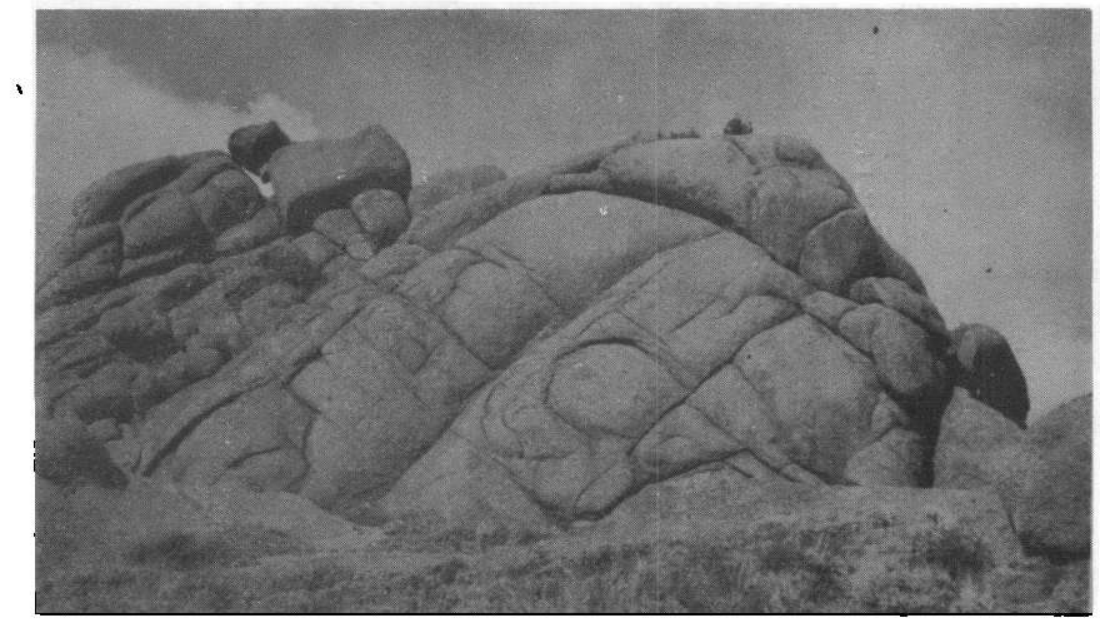

B. Coarse-grained granite with two sets of joints at right angles. 
few percent of quartz and a trace of biotite, and is high in albite, This rock is thought to be an albitized variety of the normal granite.

The granlte is younger than the hornblende gneiss, tonalite, and preCambrian quartzites because it cuts these rocks or contains partly assimilated inclusions of them. On Indian Head, a large granite mass jutting out into the valley of Quartz Creek (pi. II, sec. 4), numerous partly assimilated fragments have large microcline porphyroblasts, and one piece has well-rounded pebbles of conglonerate. The granite is in turn cut by dikes of finemgrained granite and by pegmatite. Its relation to the quartz monzonite is not clear, but the quartz monzonite is probably older than the granite.

\section{Fine-grained granite dikes and pegmatites}

Pegmatite and fine-grained granite ( 1 . II) are found together in many places and cut both hornblende gneiss and the coarse-grained granite. The fine-grained granite dikes are cut by the pegmatites, The pegmatites are found throughout the district, except in the central parts of the two main granite masses. The fine-greined granite is much more restricted in dism tribution, and occurs in dikes in a north-northwesterly trending zone west of the largest granite intmusion. The same zone contains many small intrusive bodies of coarse-grained granite. A few fine-grained granite dikes are found in hornblende gneiss 200 feet from the northeast edge of the largest granite body.

The structure in the earlier pre-Cambrian rocks is followed in part by the granite dikes on the north side of Quartz Creek, which have a general trend of from north to N. $20^{\circ} \mathrm{W}$. (pI. II). South of quartz Creek the dikes have a general northeasterly trend, but range from N, $20^{\circ}$ W. to N, $50^{\circ}$ I. 
The pegnatites form both long narrow dike-like bodies and irregular masses. The dikes trend, except in sec. 33, from $N_{0} 15^{\circ}-60^{\circ}$ s., cutting across the earlier structure. In the vicinity of the southeast corner of sec. 33, T. 50 N., R. 3 I. the pegmatites have an average trend of N. $35^{\circ} W$. and are described in detail in a succeeding part of this report.

The fine-grained granite is pink and has a grain size of about 0.015 of an inch. The dikes range in width from a few inches to 180 feet and in length from a few feet to 2,700 feet. The contacts with the surrounding rock are sharp, and the granite forms prominent outcrops, The rock is made up almost entirely of leucocratic microcline, quartz, and plagioclase. Microcline (20 to 60 percent) has crosshatch twinning. Clear quartz (I5 to 40 percent) forms irregular grains, many with sutured borders, and is interstitial to plagioclase and microcline. The plagioclase (20 to 40 percent) is albite ( $\mathrm{An}_{4}$ ) and occurs in crystals coated with kaolin and as inclusions in microcline crystals. Biotite is the dominant dark mineral ranging from a trace to about 5 percent; the average is less than 1 percent. Ragged. grains of muscovite, commonly on feldspar, is as mach as a few percent in some places. A few euhedral crystals of apatite and irregular-shaped grains of magnetite are present in some specimens.

A gray facies of this rock in secs. 8 and 17 differs from the average fine-grained granite in that it contains about 5 percent biotite and has andesine $\left(\mathrm{An}_{32}-\mathrm{An}_{34}\right)$ feldspar. It is poorly exposed and its relation to the other rocks is not known.

The fine-grained granite is related in age to the coarse-grained granite, and probably was derived from the same magma, but at a later date. This age relationship is indicated by their areal distribution. The small coarse-grained granite bodies and the fine-grained grante dikes crop out in the same north-northwesterly trending band west of the main granite mass and 
the fine-grained granite dikes also occur in a narrow zone along the northern contact of the largest granite mass. Both rocks are of the same mineral composition, but the fine-grained granite is commonly richer in plagioclase and poorer in microcline and may represent a more sodic fraction of the magma.

\section{Mesozoic rocks}

Morrison formation

The Morrison formation unconformably overlies the pre-Cambrian and is conformably overlain by the Dakota sandstone along the western and eastern edges of the Quartz Creek district. The Morrison formation is covered in nore than 90 percent of the area and the outcrops are commonly of the more resistant sandstone lenses.

This formation is composed of a basal and an upper sandstone that are separated by vari-colored shale. The basal sandstone rests on the preCambrian and closely resenbles the Dakata sandstone in appearance. It is white to $\tan$ and weathers buff to yellowish-brown. The quartz grains are subrounded, and a few beds are quaripitic. The middle unt of the formation rarely is exposed. It is composed of green, brow, and reddish shales with a few thin limestone and sandstone beds. Above the shales is a white finegrained sandstone flecked with iron oxide. This rock is prominently crossbedded, is usually friable, and the individual quartz grains are well rounded. This sandstone is conformable with the basal pebble conglomerate of the Dakota sandstone.

At no place in the area is a complete section of the Morrison formation exposed, but a thickness of 355 feet was. measured along the west side of Alder Creek, in sec. 36, T. $50 \mathrm{~N} ., \mathrm{R}, 2 \mathrm{~N}$. , from the top of the underlying 
pre-Cambrian (as determined by float) to the base of the Dakota formation. The thickness of this formation also was measured by Dings $J$ in the south-

J Dings, McClelland, Personal communication, 1949.

vestern corner of the adjacent Garfield quadrangle. His measurements, made under equally difficult conditions, with the exact position of the upper and lower limits inferred, indicate the thickness of the Morrison to be between 315 and 375 feet.

No fossils were found and the identification of the Morrison formation in the Quartz Creek district is based on its lithologic similarity to this formation in other areas.

Dakota sandstone

The Dakota sandstone is well exposed in a series of cliffs that border Alder Creek (pl. II). This nearly flatlying formation crops out in a series of orominent steplike cliffs. In plate $V$, A, it is shown capping the Morrison formation along the western border of the district; it also crops out east of the mapped area.

The Dakota is composed of a basal pebble conglomerate and an upper sandstone. The conglomerate is composed of subrounded to rounded pebbles averaging 0.25 of an inch in diameter. The pebbles are for the most part quartz, with subordinate amounts of black chert and red jasper. In part the conglomexete is arkosic though much of the feldspar has altered to clay. The upper part of this unit is quite friable and commonly cross-bedded, whereas the lower part locally is cemented with chalcedony and is very resistant.

The upper unit of the formation is composed almost entirely of sandstone, but in its upper part contains thin beds of fine-grained black to 
UNITED STATES

DEPARTIENT OF THE INTERIOR

GEOLOGICAL SURVEY
Plate V

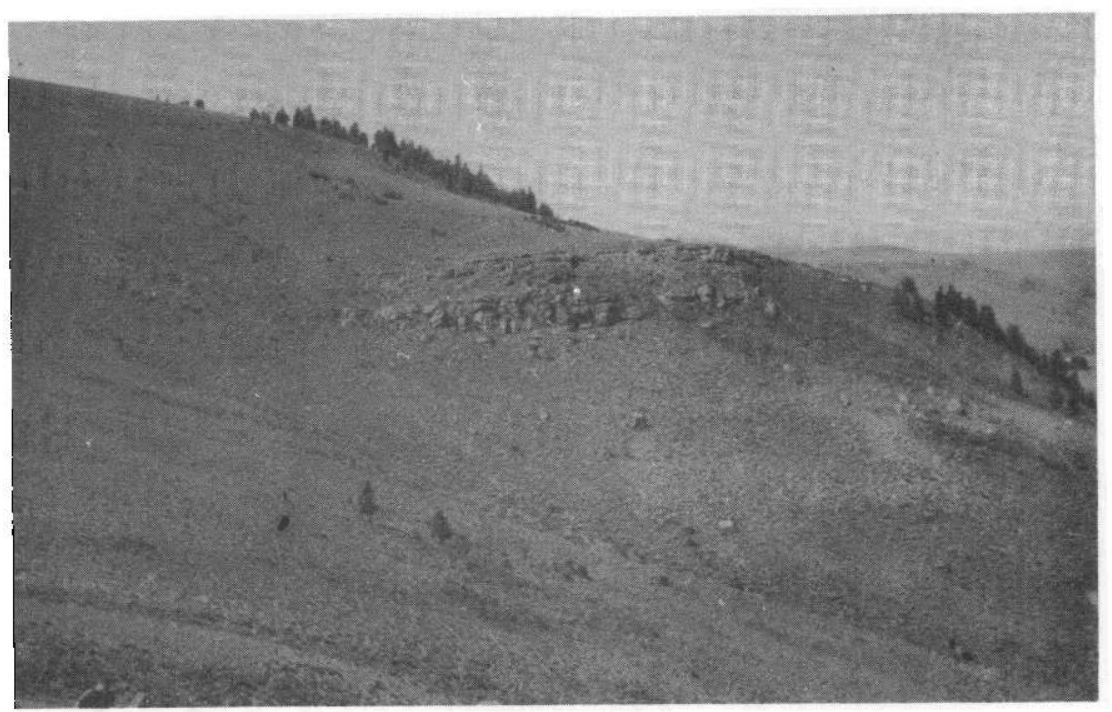

A. Cliff of Dakota sandstone.

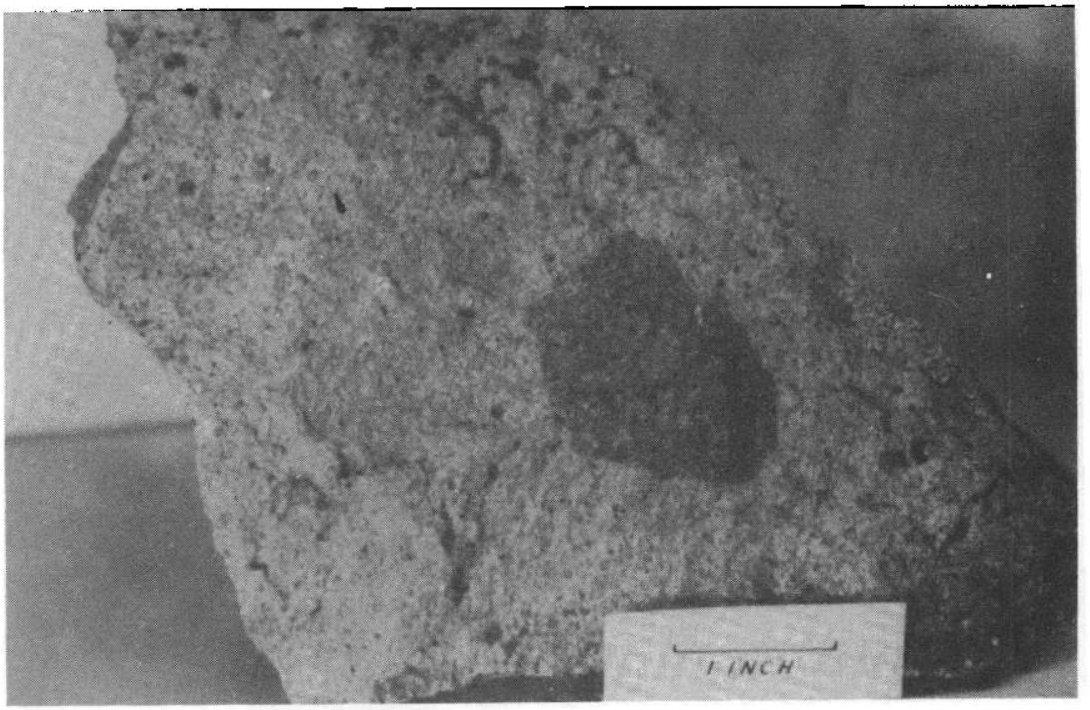

B. Tuff with large volcanic fragment. 
gray fissile shale a few inches to 1.5 feet thick. This sandstone is composed dominantly of subrounded grains of quartz, and subordinately of orthoclase. The rock ranges from a true arikose with about 25 percent feldspar to an almost pure quartz sandstone. The cliff-forming units are compact sandstone, but much of the unit is soft and friable. Locally it has been indurated to quartzite. The sandstone is white to gray and weathers buff or yellowish brown. Commonly it contains small spots of limonite, and one bed in the upper part contains radiating 1 -inch spheroids of limonite pseudomorphous after pyrite.

The Dakota sandstone is not completely exposed in the area mapped and the upper surface has been eroded. The maximam thickness obtained from the six sections measured is 183 feet; the basal conglomerate is 33 feet thick.

The only fossils found in this formation were a poorly preserved unidentifiable gastropod and a few fragmentary casts of plant stens,

\section{Tertiary rocks}

\section{Thuff}

A white tuff is well exposed on the south side of Quartz Creek, in the southeast corner of the Quartz Creek district (sec. 8), where it forms a small. cliff overlying the Dakota sandstone. At two other smaller areas of outcrop, in sec. I6 on the south side of Wood Gulch and in sec. 5 on the north side of Quartz Creek, the tuff overlies pre-Cambrian rocks.

The tuff is a porous, white flaggy rocis occurring in layers I to 2 inches thick. The layering dips from 4 to 23 degrees. A few subrounded fragments of darker volcanic rock ( $p l . V, B)$ are enclosed in an aphanitic matrix containing phenocrysts, one-thirty second of an inch long, of plagioclase and biotite. The orientation of the biotite in general is parallel to the layering: 
In thin section, the tuff has a clastic texture and shows many scattered phenocrysts in a brown cxyptocrystalline groundmass. The phenocrysts comprise about 35 percent of the rock, Andesine-labradorite (more than 30 percent) commonly occurring as angular fragments or rarely as euhedral crystals, is the most comnon phenocryst. Some of the plagioclase crystals show zoning. Long fibrous crystals of brown biotite ( 3 percent) is the chief dark mineral. Next in abundance is black anhedral magnetite ( 1 percent), Other minerals in the approximate order of their abundance are: hornblende, quartz, scapolite, sphene, apatite, and zircon.

The tuff outcrops are erosional remnants, a few tens of feet thick, of a thicker and more extensive tuff bed. The tuff that overlies the Dairota sandstone along the east side of Quartz Creek has a minimum thickness of 83 feet. The tuff is younger than the faulting which brought pre-Cambrian rocks against the Dakota sandstone, because the tuff is deposited across the fault line with no apparent displacement. It is overlain along Wood Gulch by glacial till, presumably of Pleistocene age. The tuff, therefore, has been tentatively designated as Tertiary.

\section{Pleistocene and Recent deposits}

Glacial till

Pleistocene ( $($ ) glacial till overlies the other formations along both sides of Quartz Creek and Wood Gulch, and fills the broad valley of Quartz Creek where it is covered by a foot or less of soil. On the south side of Quartz Creek the till is quite thin and pegmatite outcrops protrude through it. There is considerable difference in the altitude at which the till was deposited. The highest position is on the north side of Quartz Creek at 8,700 feet; on the south side the altitude is 8,250 feet. The till deposits on the north side are part of the lateral moraine whereas those on the south 
side are till ridges in the valley moraine. The till near the mouth of Wood Gulch appears as thin irregular patches which seem to be remnants of a broad valley moraine.

The till is composed of clay, fine sand, pebbles, and boulders as much as 3 feet in diameter. The boulders are a heterogeneas mixture of several rock types and differ from place to place. On the south side of Quartz Creek and along Wood Gulch, hornblende gneiss and tonalite are the dominant rock types in the till and in places form more than 80 percent of it. Near the mouth of Alder Creek on the north side of Quartz Creek the till consists of pegmatite (30 percent), Dakota and Morrison sandstone (30 percent), finegrained granite (20 percent), rhyolite porphyry (10 percent), and hornblende gneiss (10 percent). Other identifiable boulders include chert, preCambrian quartzite, Sawatch quartzite, epidote rock, quartz monzonite, basalt, massive quartz, and andesite.

\section{AlIuvium}

Alluvium forms a narrow strip in the bottom of most of the valleys in the Quartz Creek district. Along Quartz Creek this strip is $1 / 8$ to $3 / 4$ of a mile wide, and extends northeastward across the entire district. The alluvium is dominantly fine silt, 4 to 8 inches thick, and overlies glacial deposits along most of Quartz Creek.

\section{STRUCTURAL GEOLOGY}

The stmucture of the older pre-Cambrian rocks of the Quartz Creek district has a general northwest trend, which is cut by stocks and batholiths of younger pre-Cambrian granite and quartz monzonite. Mesozoic and later rocks are flatlying and are cut by several faults in the southern part of the district. 
The general trend of the pre-Cambrian metasedimentary rocks is northwest, with a steep dip southwest. The foliation of the pre-Cambrian hornblende gneiss strikes northwest to northeast and dips steeply. On the southeast side of Quartz Creek and along the western edge of the district the foliation trends northeast and dips from $70^{\circ} \mathrm{SE}$. to $59^{\circ} \mathrm{NW}$. Around the edge of the quartz monzonite intrusion the foliation parallels the contact and dips steeply away from it. In the northern part of the district, the foliation strikes northeast and dips from steeply southwest to vertical.

The large granite mass dips steeply to the northeast along its northeastern side. On the wott, however, the contact was not exposed, but due to the innumerable small stocks along this side (pl. II) it is believed that the granite underlies the schist at shallow depth. The contact of the quartz monzonite was not exposed but the strike of the foliation of the hornblende gneiss is oriented parallel to that of the contact, and it is probable that the dip is also parallel.

Most of the pegmatites trend northeast along joints and cut across the foliation of the older rocks. Groups of parallel lenticular pegmatites with this trend are common ( $p I . V I, A)$.

Faults are difficult to recognize in the pre-Cambrian rocks tyopt where pegmatites have been cut and offset. The displacement observed ranges from a few inches to 4 feet. Drag folds and local dismutions in the foliation also may have been the result of unrecognized fauting.

Two sheared and mineralized fractures were mapped in the hormblende gneiss. The larger of these is south of Quartz Creek, 250 feet east of the Buckhorm pegmatite (No. 659). The second shear zone is in the northwesterm part of the area mapped, where the southern part of pegmatite No. I199 has been displaced about 3 feet to the west. 
UNITED STATES

DEPARTMLENT OF THE INTERIOR

GEOLOGICAL SURVEY
TRACE ELEMENTS INVESTIGATIONS

39

REPORT 138

Plate VI

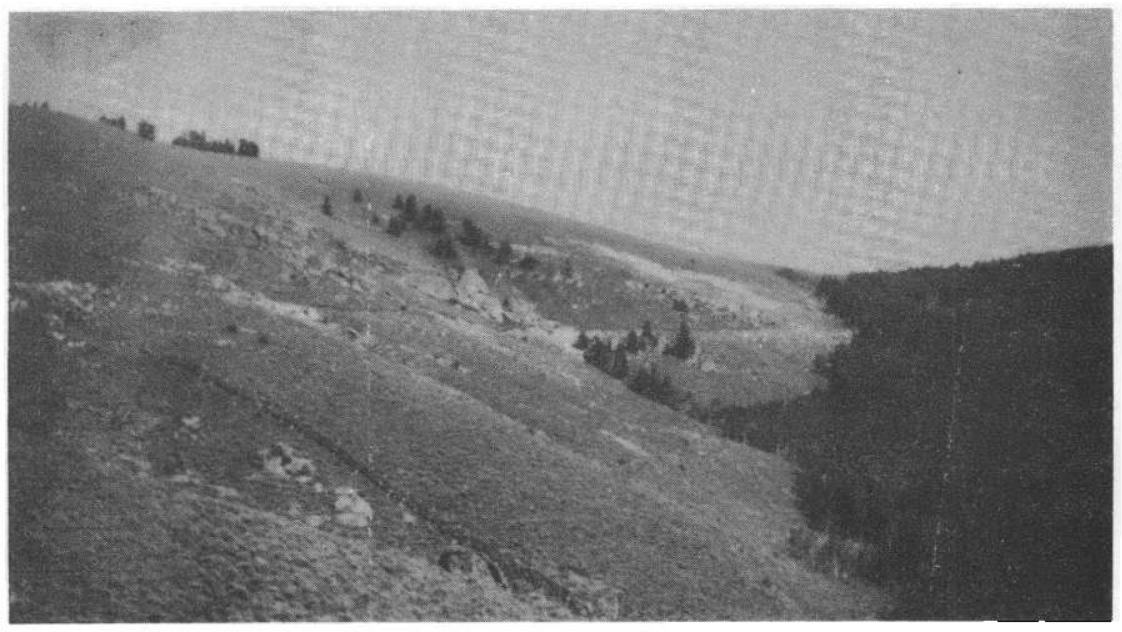

A. Pegmatites showing regional trend. Brown Derby mine in the background.

B. Anticline in center of plcture is a down faulted block of Dakota sandstone. 
In the Wesozoic sedinents faults are nore readily recognized. A najor fault separates Dakota sanostone from hornblende gneiss in the southwestern part of the district (pI. II) and trends $N .20^{\circ}-42^{\circ}$ W. A vertical displacement of 410 feet was measured on the west side of Alder Creek, the southern block having noved downward with respect to the northern block. On the west side of Alder Creek the Dakota sandstone has been sherply upturned by drag of the beds at the fault. In the southwestern part of the district, along State Highway 162, a small segment of Dakota sandstone has been downfaulted between the large fault and two smaller ones to the level of the highway and folded into a gentle anticline (pI. VI, B).

\section{PEGMATITES}

\section{Size aind shape of pegrnatites}

The pegmatites of the Quartz Creek district range in size from bodies a few inches wide and a few feet long to bodies like the Blacis Wonder pegmatite, 12,600 feet long by 6,700 feet in maximum vidt. Most pegmatites range from 100 to 400 feet in length, but 37 bodies are over 1,000 feet long. The two largest pecmatites are the Bucky deposit, 4,000 feet long by 2,600 feet in maximum width, and the Black Wonder, both of which are very irregular and have many small branches. The small pegmatites are comnoner in the Granite and quartz monzonite.

The pegmatites in the Quartz Creek district can be classified, on the basis of shape, as: (I) lenticular, (2) lenticular-branching, (3) oval, and (4) irregular. Dxarples of each are show in figures 2 to 6 and plate VII, $A$ and $B$, including both the extreme variations and the average shape in each type. Each of these examples represents many more pegmatites of similar shape. The lenticular pegmatites are 2.3 tines more common than ir- 
UNITED STATES

DEPARTMENT OF THE INTERIOR

GEOLOGICAL SURVEY

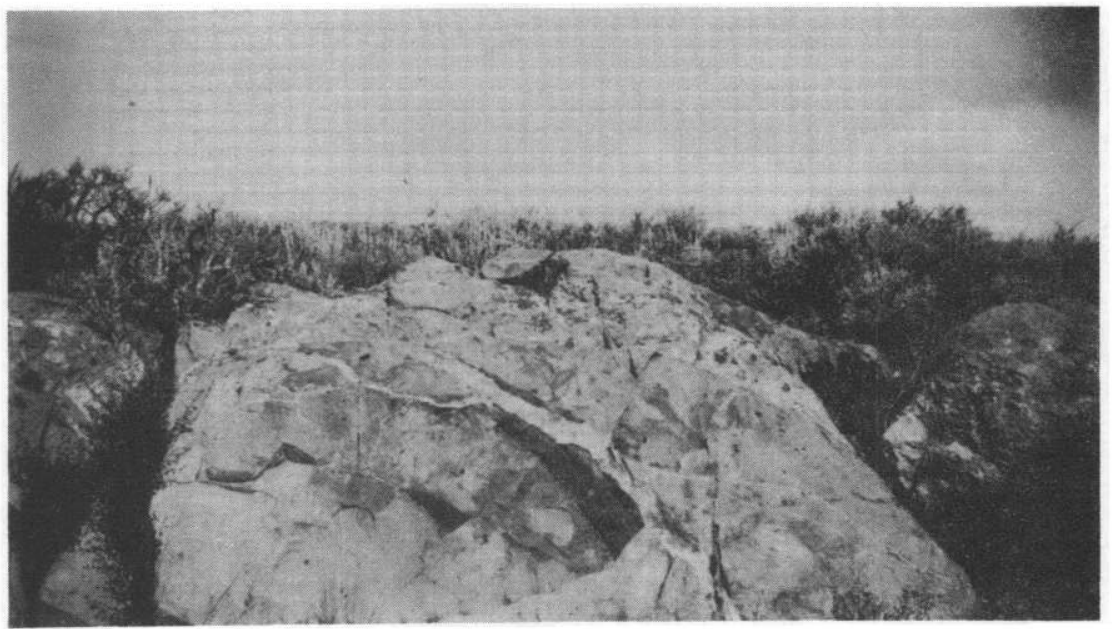

A. Small branching pegmatite cutting fine-grained granite.

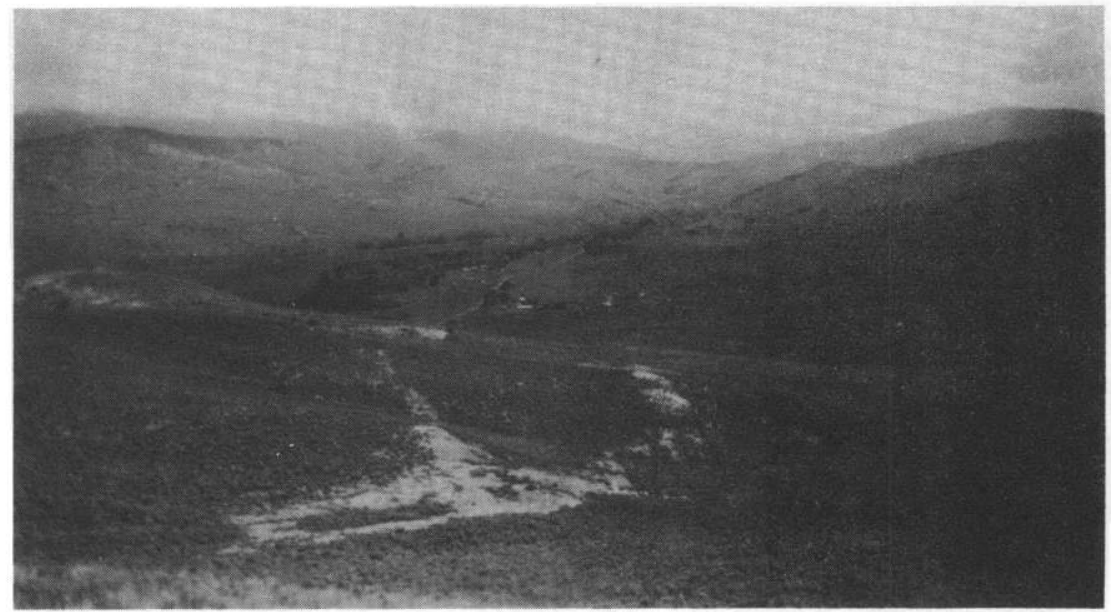

B. Large branching pegmatite (No. 250) cutting hornblende gneiss. 
regular pegnetites--the second most abundant type. The general order of frequency is one oval pegmatite to 2.3 lenticular-branching pegnatites, $2: 8$ irregular pegmatites, and 6.6 Ienticular pegmatites.

Comparison of pegmatite shapes in this district with shapes in the Black Hills / and other pegmatite districts has show that the shape of a J Page, I. R., et al, Pegmatite investigations 1942-1945, Black Hills,
South Deikota: U. S. Geol. Survey Prof. Paper (In preparation). granitic pegmatite is controlled primarily by the type and competency of country rock, and as the amount of material intmeded becomes large it controls the shape of the pegmatite to a greater degree.

The pegmatites in the Quartz Creek district for the most part are. intruded into granite, quartz monzonite, hornblende gneiss, and tonalite. The hornblende gneiss and tonalite have a similar conposition, but the hornblende gneiss is foliated and the tonalite is equigranular. Both rocks are conpetent and the pegmatites tend to follow fractures and joints that cut the poor to well-developed foliation in the hornblende gneiss. Though the pegmatites intruded into hornblende gneiss are usually well exposed, the adjacent gneiss is rarely seen. Wherever the foliation of the hornblende gneiss was exposed adjacent to the pegmatite the angle between the foliar tion plane and the side of the pegmatite was measured; the results are plotted in figure 8 on a bar graph. This graph indicates that there is no constant angle at which the pegmatites cut the foliation of the country rock; though it is most common up to 60 degrees. The irregularity of the pegmatites and their numerous changes in direction point to the emplacenent of the pegmatites along irregular fractures and joints. The hornblende gneiss and tonalite are too poorly exposed to allow measurement of any overall joint systems. The largest body of coarse-trained granjte is 
well exposed and 639 joints were measured (fig. 9). In local areas of several hundred square feet where 50 to 60 joints are exposed, they are related to 2 or 3 well-developed sets of joints. Over the entire granite body, however, 639 joints show a random orientation. The main granite body is cut by pegmatites only in its northwestern end, where the lenticular, and lenticular-branching pegmatites trend $\mathrm{N}_{0} 45^{\circ} \mathrm{W}$. In the hormblende gneiss and tonalite the pegmatites trend from north to N. $45^{\circ}$ F. (pl. II). The trend of the lenticular pegmatites in the mafic rocks is quite uniform over the whole district. This points to a district-wide joint system in the hornblende gneiss and tonalite, whereas the joint systems in the granite vary from one locality to the next. A probable explanation of this peculiar feature is that the joint system in the mafic rocks antedates the intrusion of the granite, and that the jointing in the granite was developed by local stresses at the time of the intrusion.

In comparing the various types of country rock to the shapes of pegmatites it was found that in areas of fractured competent rocks, lenticularbranching pegmatites predominate and are found along intersecting fractures; to a lesser extent irregular pegmatites and thin sinuous bodies characterize such terranes. The composition of the country rock has little to do with the shape of the pegmatite, provided the rocks being compared are of equal competency. Table I shows the frequency of occurrence of each shape compared to the oval shape in each of the three most common types of country rock, hornblende gneiss and tonalite, coarse-grained granite, and quartz monzonite. 
Table 1,--Ratio of pegmatite shapes to the oval" type in different kinds of country rock.

\begin{tabular}{l|c|c|c|c|}
\hline Rock tyoe & Ienticular & Ienticular-braiching & Irregular & Oval \\
\hline $\begin{array}{c}\text { Hornblende gneiss } \\
\text { and tonalite }\end{array}$ & 5.8 & 2.6 & 2.4 & 1.0 \\
$\begin{array}{l}\text { Coarse-grained } \\
\text { granite }\end{array}$ & 6.2 & 2.6 & 3.8 & 1.0 \\
guartz monzonite & 6.4 & 2.0 & 6.0 & 1.0 \\
\hline
\end{tabular}

All pegmatites that cut more than one rock type are omitted (fig. 7). Ixcept for the larger number of irregular pegnatites in the quartz nonzonite the ratios are renarkably sinilar. The higher natio of irreguar pegmatites in the quartz monuonite probably uan be correlated there wh the greater number of large pegmatites in this area. This is duscussed in more detail in a succeeding paragraph. The country rocks difrer greatiy in their mineralogy: texture, and chemical composition, and yet the shapes of the pegrna证 tites shov little variation. The rocks of this district have one importent characteristic, in comon: they are all tight, brittle, anc competent. The effect on the shape of the pegmatites where the host rock possesses even minor foliation is quite striking. Tabre 2 shows the frequency of occurrence of the different shapes as a ratio related to the oval shape in hornblende gnejss and tonalite.

Tajle $2_{n}-\cdots$ Ratio of various pegmatite shapes to the oval type in hornblende cheiss and tonalite.

\begin{tabular}{|l|c|c|c|c|}
\hline \multirow{2}{*}{ Rocis troe } & \multicolumn{3}{|c|}{ Pesmatite shapes } \\
\cline { 2 - 5 } Eornblende cheiss & Lenticular & Lenticular-branching & Irregular & Oral \\
Tonalite & 8.7 & 2.0 & 2.8 & 1.0 \\
\hline & 12.0 & 9.2 & 2.2 & 1.0 \\
\hline
\end{tabular}

Foliation has a profound effect in simplifying the shapes of the pegmatites 
by decreasing the number of branching types; the lenticular-branching type is 4.6 times more common in the tonalite than in the hornblende gneiss. Pegmatites in similarly competent rocks are found also in hornblende schist in the Bridger Mountains J, Wyoming, and in Pikes Peak granite in the

J McLaughlin, T, G., Pegmatite dikes of the Bridger Mountains, Wyoming: Am. Mineralogist, vol, 25, pl. 46-60, 1940.

Wight Mile Park, Colo._/

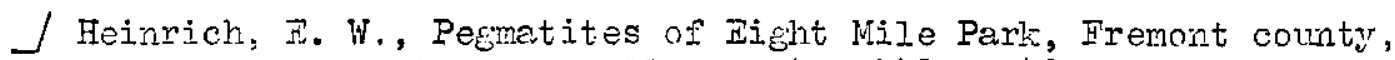
Colorado: Am. Mineralosist, vol. 33, pp. 420-448, 1948.

Pegmatites in incompetent rocis such as mica schist are in general concordant with the foliation and were intruded by shouldering apart the country rock. Pegmatites of this type are most commonly lenticular, but other common forms are troughlike, arcuate, and teerdrop. Ienticularbranching pegmatites are extremely rare. The schistosity of the wall rock is commonly conformable around the entire pegmatite.

The second factor influencing the shape of pegmatites is in the quantity of materlal intruded. With the intrusions of large quantities of pegnatite material the control of the stmuctures in the country rock on the shape is usually obscured and the body becomes an irregular stocklike mass. The directional control that fractures had on large pegmatites like the Black Wonder, Bucky, or Buckhorn was obliterated by the large quantity of material and is found only in the small stringers that extend outward from the main mass.

Whether pegmatites are in:competent or incompetent country rocks makes a great difference when it comes to predicting their position, shape, and attitude underground and in calculating ore reserves, Those in incompetent rocks may be projected with some confidence, whereas, pegmatites in gom- 
netent rociss such as in the quartz Creek district, can be predicted only if the attitudes of the controlline fractures are known.

\section{Internal structure}

The recognition of distinct lithologic and structural units within pegmatites dates back for many years. Hunt $J$, who noted a remarkable

I Front, T. S., Notes on granitic rocks: Am. Jour. Sci., 3d ser.,
vol. 1, pp. 89, 182-186, 1871. banded arrangement "formed by successive deposits of mineral matter" at Brunswick, Topshan, and Newry, Maine, appears to be the first American geologist to recognize a systematic internal structure in pegmatites. Many early authors of 25 to 40 years ago referred to segregations, veins, layers, bands, and streaks. An excellent historical review of these early writings is given by Cameron, Jahns, McNair, and Page $J$. Until about 1940

J Cemeron, I. H., Jahns, R. H., McNair, A. H., and Page, I. R., Internal structure of granitic pegmatites: Econ. Geology Mon. 2, pp. 10$13,1949$.

nost of the work on pegmatites was carried out by mineralogists and geologists who emphasized the mineralogy and theories of genesis of pegmatites $J$,

J See for example:

Fraser, H. J., Paragenesis of the Newry pegmatite, Maine: Am. Mineralogist, vol. 15, po. 349-364, 1930.

Hess, F. I., Pegmatites: Econ. Geology, vol. $28, \mathrm{pp} .447-462,1933$. Press, vol. 120, pp. 289-298, 1925. Irandes, K. K., Paragenesis of the granitic pegmatites of central Maine: Am. Mineralogist, vol. 10, pp. 355-411, 1925. - Sequence of mineralization in Keystone, South Dakota pegmatites: Am. Mineralogist, vol. 13, pp. 519-530, 537-558, 1923. vol. $\overline{27, p .211,1932 .}$ - Criteria of age relations of minerals: Icon. Geology, 
Iandes, K. K., Oricrin and classification of pegmatites: Am. Mineralogist, vol. 18, pp. 33-56, 95-103, 1933.

$319-3 \overline{33,1935 .}$ , Colorado pegmatites: Am. Mineralogist, vol. 20, pp.

Schaller, W. T., The genesis of Iithium pegmatites: An. Jour. Sci., 5th ser., vol. 10, pp. 269-279, 1925. , Mineral replacement in pegmatites: Am. Mineralogit st, vol. 12, pp. 59-63, 1927.

, Pegmatites: Ore deposits of the western states, pp. 144-1 51, Am. Inst. Min. Met. Ing, , New York, 1933.

and put little emphasis on their structure.

After 1940, because of the wartime need for pegmatite minerals, the U. S. Geological Survey made numerous studies of the internal mineralogic and structural units in pegmatites. As the economical concentrations of valuable minerals in pegmatites tend to be concentrated in rock units aistinct from the adjacent barren units, detailed mapping and interpretation of various pegmatite units have proved of much aid in exploration, development work, and minine $J$. Drilling on the basis of structural interpretar

\section{J For example see:}

Smith, W. C., and Page, I. R., Tin-bearing pegmatites of the Tintion district, Lawrence County, South Dakota: U. S. Geo1. Survey Bull. 922, pp. 595-630, 194I.

Olson, J. C., Mica-bearing pegmatites of New Hampshire: U. S. Geol. Survey Bull. 931-P, pp. 363-403, 1942 .

Bannernan, H. M., Structural and economic features of some New Hampshire pegmatites: New Hampshire Mineral Resources Survey, p1. 7, New Harroshire State Planning and Development Commission, Concord, pp. I-22, 1943.

Cameron, 天. N., Larrabee, D. M., McNair, A. H., Page, J. J., and Shainin, V. $\mathbb{E}_{0}$, Stmucture and economic characteristics of New England mica deposits: Econ. Geology, vol, 40, pp. 369-393, 1945.

Johnston, W. D., Jr., Beryl-tantalite pegmatites of northeastern Brazil: Geol. Soc. America Bull., vol. 56, pp. 1015-1070, 1945:

Jahns, R. H., Mica deposits of the Petaca district, Rio Arriba County, New Mexico: New Mexico Bur. Mines, Bull. 25, 293 pp., 1946.

Cameron, I. N., Jahns, R. H., McNair, A. H., and Page, I. R., Internal structure of granitic pegmatites: Icon. Geology Mon. 2, 115 pp., 1949.

Hanley, J. B., Heinrich, I. W., and Page, I. R., Pegmatite investigations in Colorado, Wyoming, and Utah: U. S. Geol. Survey Prof. Paper 227, 1950. 
tion of the internal units has given excellent results $J$.

J Page, I. R., Uranium in pegmatites: Econ. Geology, vol. 45, pp. Page, I. R., and Norton, J. J., Methods used to determine grade and reserves of pegmatites: (In preparation).

The internal units of pegmatites have been classified as (1) zones, (2) fracture fillings, and (3) replacement bodies $J$. Many of the pegmatites

J Cameron, I. N., Iarrabee, D. M., McNair, A. M., and Stewart, G. W., Characteristics of some New Ingland micambearing pegmatites (abstr.): Icon. Geology, vol. 39, p. 89, 1944.

Jahns, R. H., Mica deposits of the Petaca district, Rio Arriba

County, New Mexico: New Mexico Bur. Mines Bull. 25, pp. 39-51, 1946.

Heinrich, d. W., Pegmatites of Dight Mile Park, Fremont County, Colorado: Am. Mineralogist, vol. 33, pp. 436-442, 1948.

Cameron, I. N., Jahns, R. H., Mcllair, A. H., and Page, I. R., Internal structure of granitic pegmatites: Icon. Geology Mon. 2, pp. 1397, 1949.

of the Quartz Creek district differ from those in other pegmatite areas in that in adition to these three units they may contain the primary internal structure designated as banding in this paper.

\section{Zones}

The zones of a pegmatite in ideal development are concentric shells about an innermost zone or core; in many places they are incomplete, however, forming only along one end or in one part of the pegmatite. Zonal structure is formed during the primary consolidation of the pegmatite magma and may be cut by fracture fillings and replacement bodies. Zones have been classified $\perp$ as: (1) border zones, (2) wall zones, (3) intermediate zones,

J Jahns, R. H., op. cit., p. 42, 1946.

Cameron, R. N., Jahns, R. H., Mcirair, A. H., and Page, I. R., op. cit., p. 20, 1949.

and (4) cores. 
Border zones are fine-grained selvages that in most pegmatites are a rew inches or less in thiciness. Most are of little significance in the mining or quarryins of pegratites, and hence in the industry are not distinguished from the adjoining wall zones that are coarser grained and ruch thicker. Although they actvally are the second zones from the margins of pegmatite bodies, they are designated as wall zones in recognition of terminology firmly established in the pegmatite mining industry. The innermost zone or core occurs at or neer the center of the pegrnatite either as an elongate lens or a series of disconnected segments. Any zone between the core and the wall zone is an intermediate zone. Any number of intermeòiate zones can exist, but few pegmatites contain more than three. If the core is not exposed at any one level, the innermost exposed zone nay be identified erroneously as a core.

\section{Banding}

Banding is the name given to the layered stmatures forming pegmatite units that differ in mineralogy, texture, or both and tend to have a nonconcentric arrangenent within pegmatite bodies. Banding in a pegmatite nay divice the body either across or along the strike. Several distinct types of banding are recognized in the quartz Creek distriot.

Banding parallel to strike.-Pegmatites in which banding is parallel to the strike and dip of the body are called layered pegmatites (fig. II). The distinct bands or layers are mappable units of definite mineralogy or texture and are not repeated. The layered pegmatites commonly consist of several tabular units whose contacts are approximately parallel to the hanging-wall and footwall sides of the pegmatite. These layers differ from zones in that there is no repetition of units on the other side of 
the pegmatite. Pegmatites composed of two layers are by far the most common type in this district. These units commonly extend the entire length of the pegmatite and are from 1 to 30 feet thick. This type of banding is confined to narrow lenticular and lenticular-branching pegmatites or to a narrow lenticular part of irregular pegmatites. It is not found in thick parts of irregular pegmatites or oval pegmatites. The distinct upper and lower units in many of these layered pegmatites can be distinguished in only certain parts of the body and merge along strike into a single unit. Where two layers merge, or telescope, the unit formed has the bulk composition of the two combined layers and a texture intermediate between that of the upper and lower layers. In pegmatite No. 548, for example, an upper layer, consisting of perthite (50 percent), quartz (33 percent), albite (15 percent), and muscovite (2 percent), and a lower layer, consisting of albite (74 percent), quartz (20 percent), perthite ( 3 percent), and muscovite ( 3 percent), become progressively less distinct to the south and finally merge into a single unit, consisting of albite ( 63 percent), quartz, (20 percent), perthite ( 15 percent), and muscovite ( 2 percent). Banding across strike.--Many pegmatites are banded across the strike into two or more mappable units differing in mineralogy, texture, or both (fig. 12). These are designated as pegmatites showing variation in composition along strike. Banding across strike results in two or more pegmatite units that have their contact at an angle to, rather than parallel to, the strike of the pegmatite units. In such pegmatites the bands occupy the full width of the body, and are from 20 to several hundred feet across parallel to the strike of the pegmatite body. The units have the shape of whatever part of the pegmatite they occupy: thus, one unit may occupy the short, thin lenticular part and another long, irregular, bulbous part of a 
pegmatite. Banding across strike has been found only in lenticular and lenticular-branching pegmatites and all such bodies contain either two or three bands (fig. 12).

Multiple banding.-Some pegmatites in the Quartz Creek district are composed of innumerable very thin bands that differ in texture, mineralogy, or both. The bands are rarely mappable on ordinary scales. This type of banded rock has been described as "Iine rock" in the Pala district, Calif. I

J Schaller, W. T., Geilesis of lithium pegmatites: Am. Jour. Sci., 5 th ser., vol. 10, p. $273,1925$.

Iine rock in the Quartz Creek district is characterized by the repetition of bands of minerals from 0.01 inch to 0.4 foot thick; the average thickness is less than 0.5 inch. The banding in most places, as in pegmatite No. 670 , is parallel to the strike of the body, but in a few places it cuts across the strike. Iine rock is found commonly as patches in a small part of the pegmatite. No pegmatite with the exception of pegmatite No. 670 contains more than 15 percent of line rock, and most of them contain less than I percent. Iine-rock-bearing pegmatites, therefore, are not classified separately.

Iine rock is nost common in albite-rich pegmatites where the most obvious banding is caused by layers of garnet and muscovite as much as one-quarter of an inch thick (pl. IX, A and B). Layers of fine-grained albite-quartz pegmatite are interspersed with coarser layers of perthitequartz-albite pegmatite (a half inch to about 4 inches thick). The layers of perthite-quartz-albite pegmatite are lenticular and usually pinch out within short distances. Other layers may occur above or below to form an echelon pattern. Rarely the albite-quartz pegmatite forms the lenticular unts in line rock. The banding may end abmptly against large crystals or 
UNITED STATES

DEPARTMENT OF THE INTTERIOR

GEOLOGICAL SURVEY
TRACE EILAMENTS INVESTIGATIONS

52

REPORT 138

Plate IX

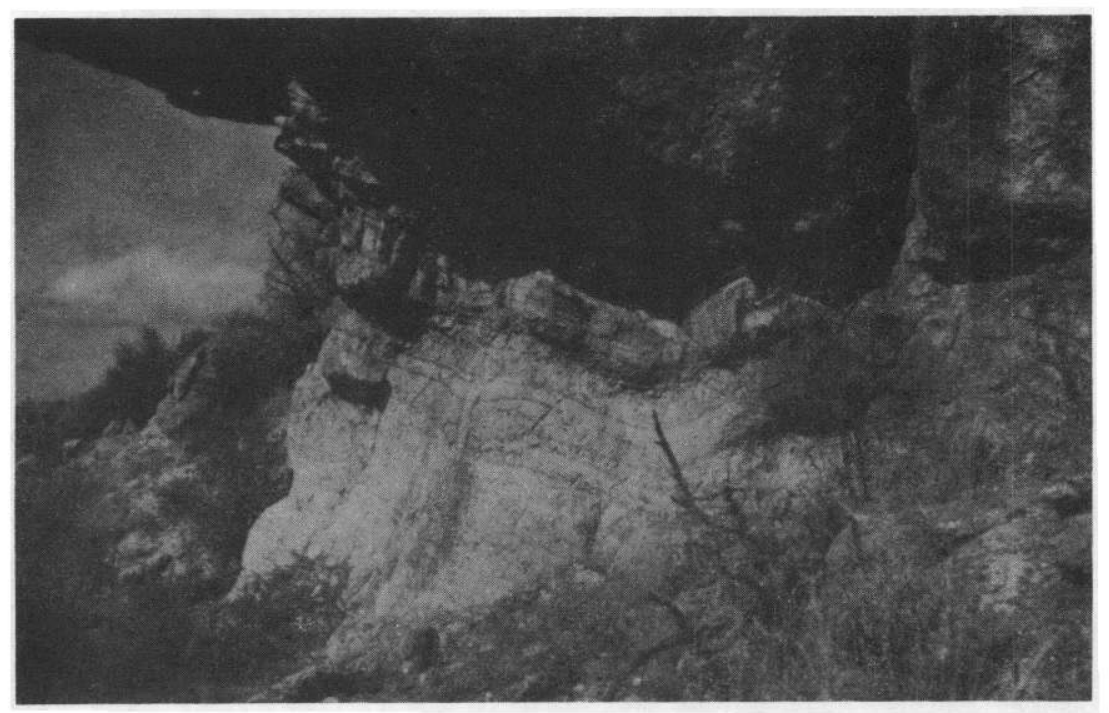

A. Ifne rock in the lower part of pegmatite No. 670 . Fine dark layers are small brown garnets.

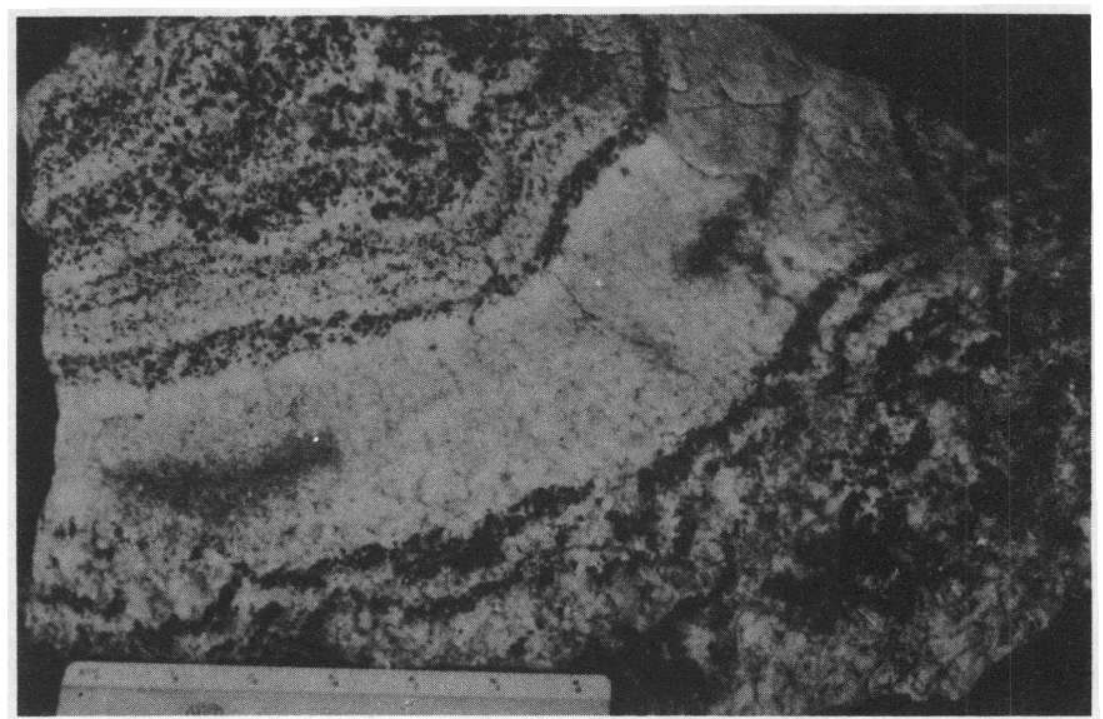

B. Iine rock from pegmatite No. 461. Black layers are garnet and muscovite and white layers are meinly albite with a little quartz. 
an aggregate of minerals ( $f i g .14$ ). Iine rock is most common adjacent to the walls of the pegmatite, especially on the footwall side. Thin layers of garnet and albite were noted terminating abmuptly against euhedral. perthite crystals in several places. The perthite is veined by albite along fractures and was either entirely crystallized or at least partly crystallized before all the albite was deposited. Thus, the perthite is not a late mineral which cut of the layering, but rather a buttress against which the layering stopped. The arrangement of garnets and micas in bands suggests at least local movement of the pegmatite magma with rapid minor changes in composition so that first one mineral would be crystallizing and then another. Thus a row of garnets might be formed in an area of movement up to a projecting perthite crystal, which would either turn the current or deposit a row up to its side and another along its top. This row on top might be swept off its more exposed position where narrowing of the channel caused the current to be swifter, or it might be incorporated into the perthite upon further growth. The alternating lenses of perthitequartz-albite pegmatite in fine-grained albite-quartz pegmatite suggests zoned multiple pegmatites. They might have been formed by crystalization from lenses of trapped liquid.

Line rock is common in many pegmatites in other areas: the Crystal Mountain district, Colo. J, the Middletow district, Conn, , the Pala distrita,

\section{J Thurston, W. R., Personal commurication.}

Calif.J, the Eight Mile Park district, Colo.J, and the Bridger Mountains:

J Schaller, w. T., op. cit, pp, 272-273.

J Heinrich, . W., Pegmatites of Bight Mile Park, Fremont County, Colorado: Am. Mineralogist, vol. 33, p. $448,1948$. 
district, Wyo. J

/ McLaughlin, T. G., Pegmatite dikes of the Bridger Mountains, Wyoming: Am. Mineralogist, vol, 25, pp. 62-63, 1940.

\section{Fracture fillings}

Fracture fillings are tabular bodies that extend from inner units into outer units of the pegmatite. In places they connect directly to the core.

Fracture filling units are common in pegmatites of the quartz Creek district but are usually small; many are only a few feet in length. Most of these units are only a minor part of a pegmatite, though there may be several in a single pegmatite. Discontinuous core segments and fracture fillings are difficult to distinguish in some irregular pegmatites.

Most of the fracture fillings are coarse-grained and consist predomiow a fracture filling of massive quartz extends from the core across the wall zone.

\section{Replacement units}

No mappable replacement units were found in the pegmatites of the Quartz Creek area, although there are several places where small areas were replaced alone fractures. Replacement units form by the replacement of pre-existing consolidated pegmatite with later material. The interaction of two minerals or of a mineral with the rest solution during the process of crystallization is not considered as replacement in this paper. The embayment of one mineral by another and the filling of small fractures have been given as criteria of replacement, but these textures also can be formed if an early-formed mineral is corroded by the rest solution and 
subsequently coated by a later mineral.

The criteria used to distinguish a replacement body are, therefore, the presence of relic textures or structures of the pre-existing rock that indicate essentially complete consolidation: Where a pegmatite is not zoned or where no pre-existing textures or structures remain it may be very difficult to recognize a replacement body.

The interaction of one mineral on another during the crystallization process is more pronounced in pegmatites than in other igneous rocks because of the large grain size of the crystals which magnifies the embaying of one mineral by another and the long crystallization period caused by the presence of volatiles. Thus, a crystal of one mineral may be partly or completely grown before the equilibrium in the solution will permit a second mineral to start crystallizing. This crystal may form around the first crystal, srow out from it or, in the new equilibrium, the first mineral may be soluble and may be replaced by the second. Evidence of this sort does not prove or disprove the presence of a replacement unit. An excellent example of muscovite selectively replacing perthite and leaving narrow albite stringers of the perthite intergrowth unreplaced, is illustrated in plate VIII, B. The pegmatite was essentially homogeneous and shows no evidence of a separate replacement body.

\section{Types of pegmatites}

Pegmatites may be divided into homogeneous and heterogeneous pegmatites. The homogeneous pegmatites are simple aggregates of feldspar, quartz, and accessory minerals which camot be divicled into contrasting units on the basis of mineralogy and texture. These pegmatites form the sreat bulk of pegmatites in mainy resions, such as the Quartz Creek district, Colo., Black Hills region, S. Dakt., Spruce Pine district, N. C.J, and the Crystal 
UNITED STATES

DEPARTMENT OF THE INTERIOR

GEOLOGICAL SURVEY
Efi

TRACE ELWMNTS INVESTIGATIONS

REPORT 138

Plate VIII

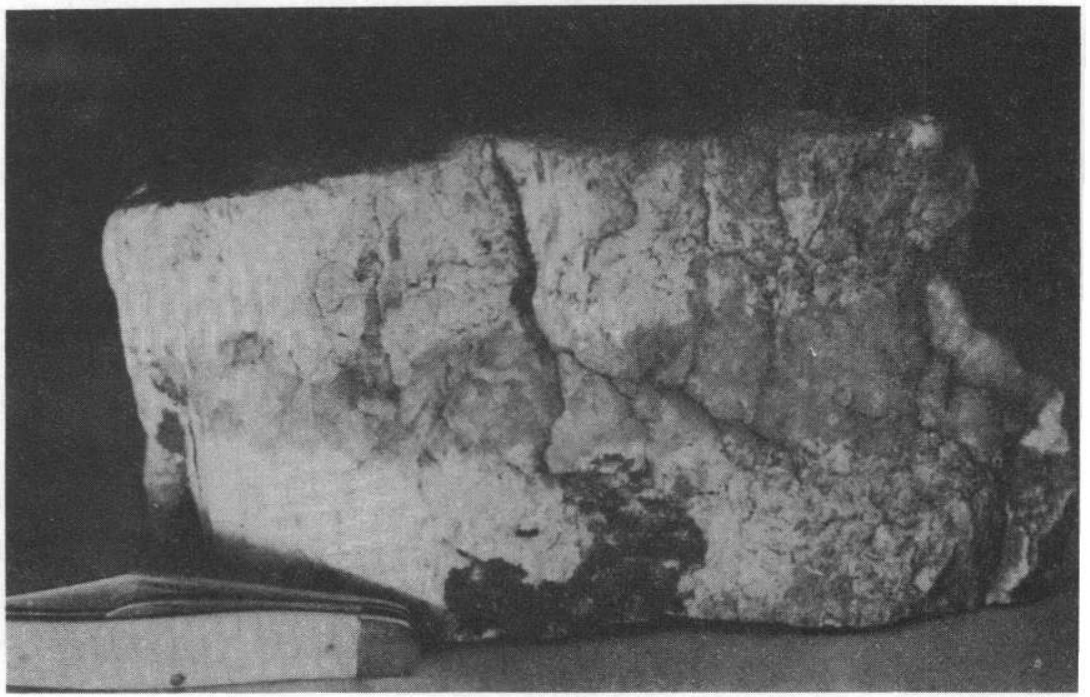

A. A thin zoned pegmatite with an albite-quartz wall zone and a quartz core (grey).

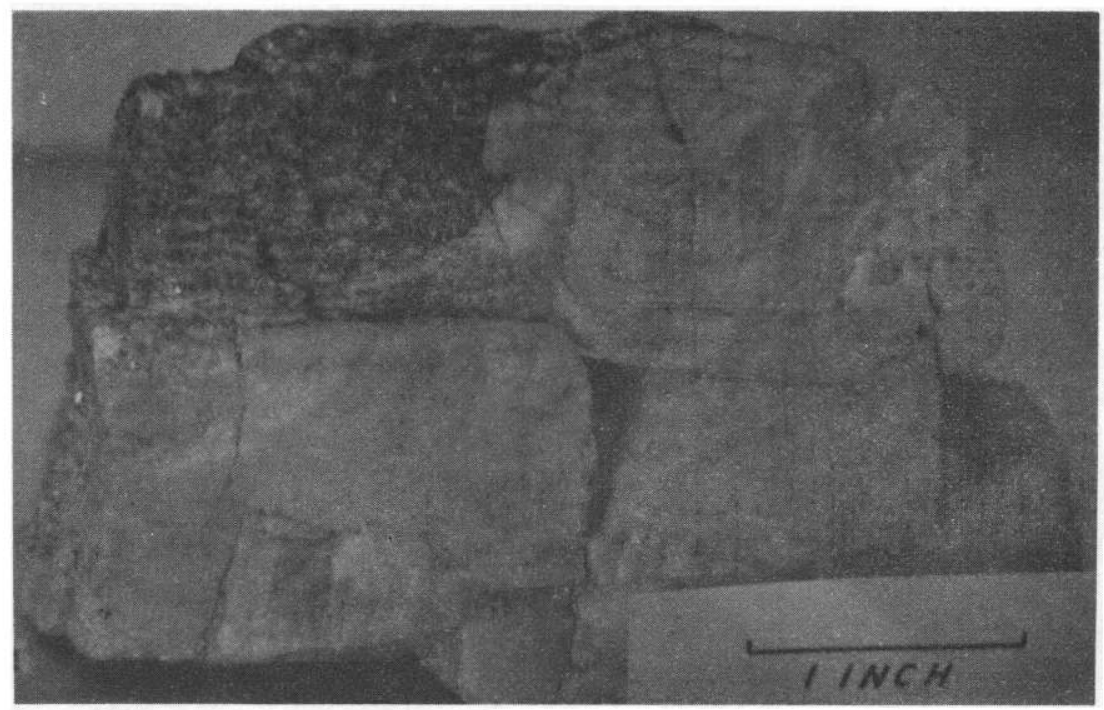

B. Replacement of perthite by fine-grained muscovite (black). Note the unreplaced albite lamillae of the perthitic structure In muscovite. 
J Brobst, D. A., Personal comnunication.

Mountain district, Colo. I Honogeneous pegmatites commonly form relative-

J Thurston, W. R., Personal comminication.

Iy small dikes and rarely contain minable concentrations of economic minerals. Because they lack the economic and rarer minerals, they have received in the past little consideration by mineralogists and geologists. Most of the pegmatite literature is devoted to descriptions of pegmetites containing the rarer minerals. Recently, however, the U. S. Geological Survey has unoertaken regional mapping of pegmatite districts in South Dakota, other parts of Colorado, North Carolina, and Connecticut--similar to that described in this report--that should result in obtaining a broad knowledge of the character and distribution of all types of pegmatites. This work may yield the much-needed data required to understand the relationships of homogeneous and heterogeneous pegmatites.

Heterogeneous pegmatites are those that can be divided into different rock units on the basis of mineralogy, texture, or both.

\section{Homogeneous pegmatites}

Homogeneous or one-unit pegmatites form the great bulk of the pegmatites in the Quartz Creek district. Out of more than 1,800 pegmatites, 78 percent are homogeneous or "unzoneo". Homogeneous pegnatites occur as lenticular, lenticular-branching, oval, and irregular bodies. Only a few of the larger irregular pegmatites are zoned; they contain one or more discontinuous cores. Ixamples of homogeneous pegmatites are shown in figures $2,3,4,5$, and 6 . The dominent minerals are plagioclase, quartz, and 
perthite. Most of the pegmatites contain as much as 2 percent of one or more of the following minerals: muscovite, garnet, biotite, and mametite. Beryl and tourmaline are present in some pegmatites but constitute only a small fraction of 1 percent.

\section{Heterogeneous pegmatites}

Zoned pegmatites.-Zoned pegmatites form roughly 14 percent of the pegmatites in the area (figs. ? and 10); most have only a core, a wall zone, and a narrow border zone. Most of the border zones in the Quartz Creek district are only a fraction of an inch thick and are cooling selvages. Owing to their thinness they were mapped with the wall zones.

The mineralogy and texture of the wall zone usually resembles the homogeneous pegmatites in the immediate vicinity. The core, except where the wall zone is predominantly graphic granite, is commonly coarser grained, and contains more perthite, or quartz, or both, than the surrounding wa11 zone. Cores consisting only of massive quartz are very common (pI. VIII, A) in the northwestern part of the district. Cores of perthite-quartz pegmatite also are common. There are 14 pegmatites consisting of a wall zone and a core, that have cores of cleavelandite-quartz, or cleavelanditeIepidolitemquartz pegmatite. These pegmatites include the Bazooka, White Spar No. 2, and the Brown Derby No. 2 and No. 3 pegmatites, that have been described previously by Hanley, Heinrich, and Page $J$. Not all the

J Hanley, J. B., Heinrich, I. W., and Page, I. R., Pegmatite investigations in Colorado, Wyoming, and Utah: U. S. Geol. Survey Prof. Paper 227, pp. 66-68, 71-74, 77-80, 1950.

lepidolite-bearing and cleavelandite-bearing pegmatites are zoned pegnam tites; these minerals are also found in small homogeneous pegmatites, 
layered pegnatites, and pegmatites which vary in composition along their Iength. The cores in small pegmatites may form a large proportion of the pegmatite (No. 267, fig. 10), but in large pegmatites they usually make up 1 percent or less of the total rock (fig. 7). Pegmatites having an intermediate zone as well as a core and a wall zone are rare. Only 7 pegnatites in the Quartz Creek district contain intermediate zones. In 5 pegmatites this zone consists of muscovite-albite pegmatite surrounding one or more small discontinuous cores.

The Quartz Creek district has few well-zoned pegmatites. Those which are zoned commonly consist of only a wall zone and a core. The core units are usually irregularly distributed, discontinuous segments, and constitute only a small part of the pegmatite. Judging from the sizes and distribution of the core segments only a small proportion of pegmatitic liquid remained after consolidation of the wall zone. This crystallized in scettered areas as core segments.

Layered pegmatites.--Iayered pegmatites make up approximately 7 percent of all pegmatites in the Quartz Creek district. Layering is most common in the thin dike-like lenticular and lenticular-branching types of pegmatites. Layering is not common in large irregular pegmatites, although a few of the thinner irregular bodies are layered.

Most of the lavered pegmatites contain a perthite-rich hanging-wall unit and an albite-rich footwall unit (fig. 1l). As an example, pegmatite No. 685 (pl. II) on the north side of Wood Gulch has a hanging-wall unit of albite ( 30 percent), quartz (20 percent), perthite ( 48 percent), and muscovite ( 2 percent) and a footwall unit of albite (65 percent), quartz (15 percent), perthite (19 percent), and muscovite ( 1 percent). In a few pegmatites the hanging-wall unit has more albite than perthite but this unit always contains more perthite than the footwall unit. Pegmatite No. 
1363 (fig. II and pl. II) is the only body that contains a higher proportion of perthite in what is believed to be the footwall unit; this pegmatite, hovever, is nearly vertical (81 degrees). The texture of the hanging-wall unit is coarser than that of the footwall unit, because perthite tends to form larger crystals than albite. Perthite forms in grains 0.5 to 3 inches in diameter and albite forms in grains 0.06 to 0.25 inch in diameter. In the albite-rich units the quartz grains are about the same size as the albite, but in the perthite-rich units they are nearly as large as the perthite.

Layered pegmatites with a perthite-rich hanging-wall layer and an albite-rich footwall layer have been described by Schaller $/$ in the Pala

Schaller, W. T., The genesis of lithium pegmatites: Am. Jour. Sci. 5th ser., vol. 10, pp. 271-274, 1925.

district, Calif.

The concentration of perthite as hoods in the upper part of zoned pegmatites is common in many districts, for example, the Keyes No. I pegmatite, Orange, N. H.; the W. T. Foster No. I pegmatite, Shelby, N. C., the Palermo No. 1, Grafton County, N. H., the Strickland-Cramer pegmatite, Portland, Conn.; the Beecher Ioce, Dyke Iode, Itta, Dan Patch, Hugo, and the Bob Ingersoll Dikes Nos 1 and 2 of the Black Hills, S. Dak. I The

J Cameron, R. N., Jahns, R. H., McNair, A. H., and Page, I. R., Internal structure of granitic pegmatites: Icon. Geology, Mon. 2, pp. $44-45$, $48,1950$.

perthite-rich hanging-wall layers in pegmatites of the Quartz Creek district appear to be the extrene development of perthite-rich hoods in thin Ienticular bodies. Two of the lepidolite-bearing pegmatites, pegmatite No. 306 (Opportunity No. $4^{\prime} \mathrm{claim}$ ) and pegmatite No. $452^{/ /}$(the Brown Derby 
No. 1) are layered. Pegmetite No, $306^{\prime}$ consists of en upper albite-quartzperthite unit and a lover cleavelancite-quartz-lepidolite unit. The Brown Derby No. $I^{\checkmark}$ pegnatite contains at least eight different units. Hot all of these are present throughout the pegmetite and some form lenticular pods. The Brown Derby is described by Hanley I as having a border zone, well $J$ Hanley, J. B., Heinrich, I. W., and Page, I. R., Pegmatite in-
vestigations in Colorado, Wroming and Utah: U. S. Geol. Survey Prof. Paper 227? pp. 69-71, 1950 .

zone, possible intermediate zone, and a compound core of three different units. The Brown Derby has nore mappable units than any other pegmatite in the region. Many of these layers are found in only certain parts of the dike and merge along strike vith other units. The central part of the unit has an albite-quartz wall zone on both hanging-wall and footwall sides, but to the north the wall zone on the hanging-wall side disappears and the pegmatite becomes a layered pegmatite. Other layered pegmatites probably are incompletely developed zoned pegmatites.

The layered pegmatites are most abundant in (1) along the ridge just south of Quartz Creek in the southwestern corner of the district, (2) in the vicinity of the Brown Derby mine, and (3) along the western side of Big Gulch. Iayered pegmatites are sparsely scattered among other types of pegnatites in the first two areas but are the dominant type in the third. 2rea. The layered type is almost absent in other areas. The distribution of the layered pegmatites suggests that their development is controlled by a particular set of conditions. The country rock in these areas is hornblende gneiss as in many areas that are void of layered pegmatites. The conditions under which these bodies cooled and crystallized probebly controlled their formation. The original composition of the pegmatite liquid 
may have been important, but probably was not the controling factor; because there are different mineral assemblages in layered pegmatites, and because many unlayered pegmatites are identical to layered ones in mineralogy. The possibility of the layers being formed by replacement of preexisting pegmatite rather than by difference in crystallization history hes been considered, but most of the perthite is in well-formed crystals, surrounded by later albite and quartz. The crystals are only slightly embayed and are not cut by veinlets of other minerals. The facts that the perthite layer, with only one possible exception, is on top, that the contact between the two layers is gradational, and that the layers may telescope gradually into a homogeneous unit do not seem to fit the picture of irregular replacement.

Pegmatites showing variation in composition along strike,-About $I$ percent of the pegmatites have nore than one unit, where the mineral composition of the unit changes along the length rather than across the pegmatite ( $f i_{G} .12$ ). In some lenticular-branching pegmatites, each branch has a different mineral assemblase. In lenticular pegmatites one end may be of one mineral composition and the opposite end the other, or the center of the pegmatite may be of one mineral composition and the ends a different mineral composition. In a few pegmatites one part may contain a core in adation to the layers across the pegmatite.

The dominant variation is from a unit rich in perthite to one in which perthite is less abundant or even absent; however, parts of some of the branching cleavelandite- and lepidolite-bearing pegmatites on the Opportunity No 1 claim (No. 209,-213, 214, 215, and 216) are of this type.

Pegmatites showing variation in composition along strike are in" lenticular, and lenticular-branching pegmatites and, in part, may represent mutiple injections of pegmatite liquid. 
Multiple pegmatites.--Multiple pegmatites are formed by multiple intrusions so that the walls of the pegmatite formed by the second injection are tangent to that of the first. Thus, the various units have strikes which trend within a few degrees of one another. Branching and irregular pegnatite bodies may be the result of multiple intrusion of two or more pegmatite liquids into the same spot. In general, adjacent pegmatites probably are derived from liquid fractions of the same granitic magma and may be expected to consist of the same minerals in approximately the same proportions. It may be difficult, therefore, to distinguish between a branching and a multiple pegmatite. There are in the Quartz Creek district two pegmatites that have been formed by two separate injections of pegmatitic liquids. Pegmatite No. 251 is a lenticular-branching body with a wall zone and a thin core in each branch (fig。13). The two branches join near the north end, and instead of the cores joining as cores do in a normal branching pegmatite, there are two parallel cores at the junction showing that it is a multiple pegmatite formed at slightly different times by two different injections. Pegmatite No. 216 on the Opportunity No。 1 claim is a north-trending albite-quartz-perthite pegmatite, which is cut by a northeasterly-trending body of perthite-quartz and cleavelanditequartz pegmatite (fig. 13). The north-trending part of the pegmatite mass is older than the northeasterly-trending branch. Though this pegmatite resembles a multiple pegmatite in that it is formed of two separate injections, the cross-cutting relationship proves it to be an earlier pegmatite cut by a later one.

\section{Mineralogy}

A total of 27 minerals has been found in the pegmatites of the Quartz Creek district. Perthite, plagioclase, and quartz are the essential min- 
erals and form from 95 to more than 99 percent of most pegmatites. Only a very few pegmatites have units rich in muscovite, and this mineral cannot be considered an essential mineral of the pegmatites of this district. The common accessory minerals are considered to be those found in more than 10 percent of the pegmatites, These minerals, in order of their frequency, are: muscovite, garnet, biotite, magnetite, and beryl. The quantity of these minerals in any particular pegmatite is small; muscovite commonly ranges from 0.5 to 3 percent, garnet, 0.5 to 1 percent, biotite and magnetite, less than 1 percent, and beryl, a few small crystals, The other 19 minerals are found in less than 3 percent of the pegmam tites of the district and are considered as rare accessory minerals. They also commonly amount to only a small fraction of a percent of the pegnatite. Table 3 lists all the, accessory minerals giving the number of pegmatites which contain these minerals and the percent of the total pegmam tites in which they are found. 
Table 3.--Occurrence of accessory minerals in the pegmatites of Quartz Creek district

\begin{tabular}{|l|c|c|}
\hline \multicolumn{1}{|c|}{ Mineral } & $\begin{array}{c}\text { Number of pegmatites } \\
\text { in which mineral } \\
\text { was observed }\end{array}$ & $\begin{array}{c}\text { Percentage of pegmatites } \\
\text { examined (1,803) in which } \\
\text { mineral was observed }\end{array}$ \\
\hline Wuscovite & 1,058 & 57.9 \\
Garnet & 965 & 52.9 \\
Magnetite or martite & 422 & 23.1 \\
Biotite & 357 & 19.6 \\
Beryl & 232 & 12.7 \\
Tourmaline & 48 & 2.6 \\
Columbite-tantalite & 29 & 1.6 \\
Monazite & 23 & 1.3 \\
Lepidolite & 17 & 0.9 \\
Microlite & 13 & 0.7 \\
Chlorite & 9 & 0.5 \\
Topaz & 8 & 0.4 \\
Gahnite & 8 & 0.4 \\
Samarskite & 7 & 0.4 \\
Epidote & 3 & 0.2 \\
Apatite & 3 & 0.2 \\
Fluorite & 2 & 0.1 \\
Spodumene & 1 & 0.06 \\
Amblygonite & 1 & 0.06 \\
Allanite & 1 & 0.06 \\
Lithiophilite-trithylite & 1 & 0.06 \\
Betafite & 1 & 0.06 \\
Chrysocolla & 1 & 0.06 \\
Unknown & 1 & 0.06 \\
L & & \\
\hline
\end{tabular}


Plagioclase

Plagioclase occurs in all pegmatites of the Quartz Creek district and is the dominant mineral in most of them. It may form as much as 90 percent of all types of structural or mineralogic units. The plagioclase occurs in fine-grained sugary aggregates of equigranular grains, and in coarse platy crystals (cleavelandite)。Cleavelandite has been found in 28 pegmatites in this district. Where used in this report, the term plagioclase refers only to the typical granular form, and the term cleavelandite refers to the platy form. Plagioclase commonly is abundant in (I) homogeneous pegmatites, (2) wall zones of zoned pegmatites, and (3) footwall layers of layered pegmatites. These units may contain more than: 98 percent plagioclase and quartz. Cleavelandite, on the other hand, is restricted for the most part to central parts of the pegmatites.

The plagioclase ranges in size from less than 0.003 inch to about 1.5 inches across; the average size is about 0.12 inch. Crystal shape is usually not discernible, but the cleavage surfaces commonly are curved or warped. Twinning is visible only on the large pieces. Plagioclase is found in graphic intergrowth with quartz in a few places. Most of the plagioclase is white, but cream-colored, brownish, and pinkish shades are common. The plagioclase locally resembles the perthite in color, but can usually be distinguished by the warped 
surfaces, twinning lamellae, lack of perthitic structure, and to a lesser extent by its occurrence in pine aggregates.

Cleavelandite is found in thin plates 0.003 to 0.006 inch thick and 0.5 to 4 inches in maximum dimension. The average plate is approximately 2 inches long, 1.5 inches wide, and 0.04 inch thick. The crystals are white and semi-transparent. The surface of the crystal is wavy and twin lamellae can be seen along the edges. The lowest index ( $\mathrm{K}_{\alpha}$ ) from the (010) cleavage flakes was determined on 439 specimens of plagioclase and on 17 specimens of cleavelandite from the Quartz Creek district. The index of the plagioclase ranged from $1.527\left(\mathrm{Ab}_{99} \mathrm{An}_{1}\right)$ to $1.541\left(\mathrm{Ab}_{74} \mathrm{An}_{26}\right)$ and of the cleavelandite from $1.528\left(\mathrm{Ab}_{97} \mathrm{An}_{3}\right)$ to $1.530\left(\mathrm{Ab}_{95} \mathrm{An}_{5}\right)$. The plagioclase has an average of $1.532\left(\mathrm{Ab}_{93} \mathrm{An}_{7}\right)$ and cleavelandite $1.529\left(\mathrm{Ab}_{96} \mathrm{An}_{4}\right)$. The plagioclase ranges from sodic albite to calcic oligoclase, and the cleavelandite is a sodic albite. Table 4 gives the results of these determinations, the type of country rock, and the type of pegmatite or pegmatite unit from which each specimen was taken. 
Table 4.- The range of refractive index $\left(\mathbb{N}_{\alpha 1}\right)$ of plagioclase and cleavelandite from all types of pegmatite units in the Quartz Creek district and its relation to different types of country rock.

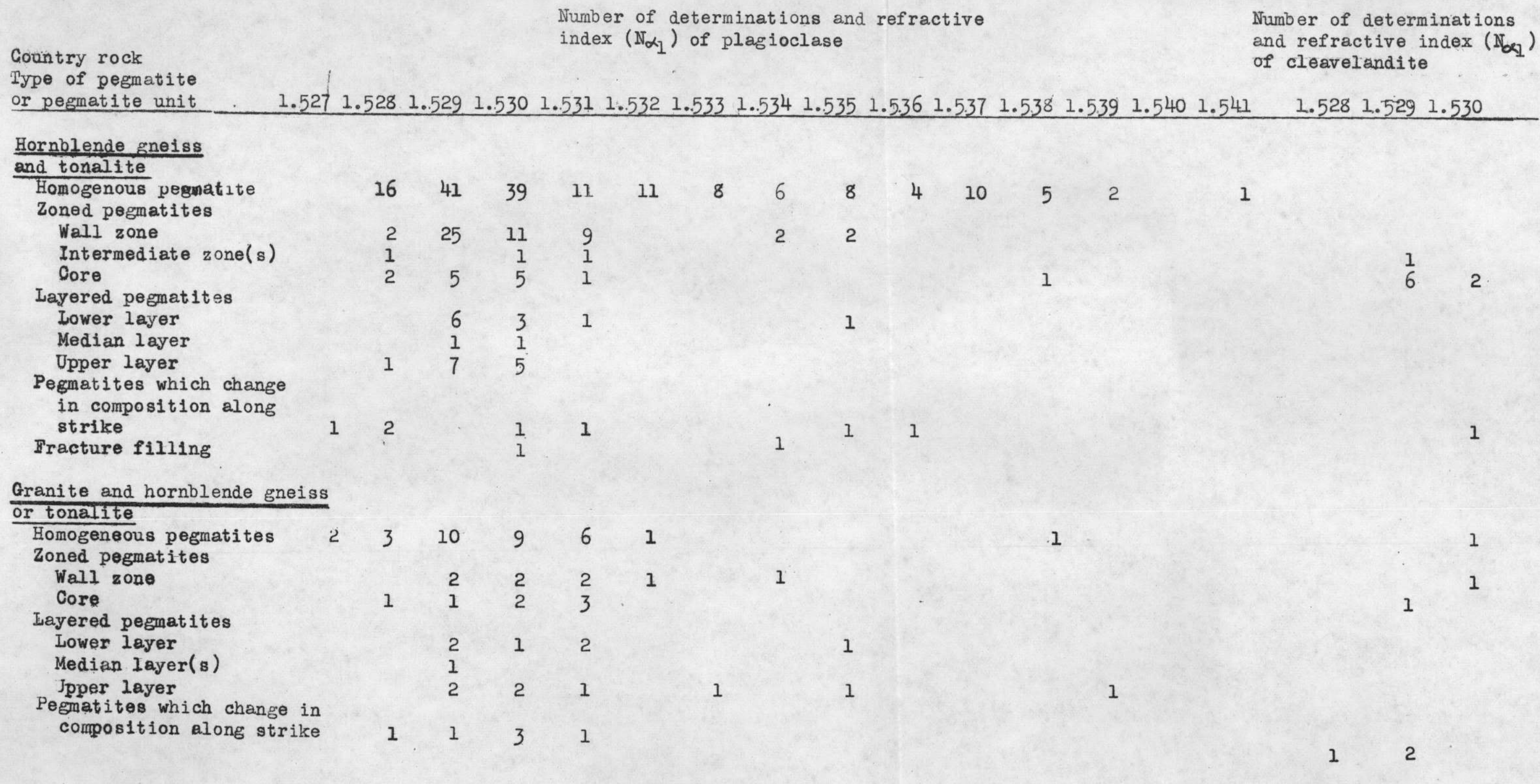


Table 4.--The range of refractive index $\left(\mathbb{N}_{\alpha_{1}}\right)$ of plagioclase and cleavelandite from all types of pegmatite units in the Quartz Creek district and its relation to different types of country rock.--Continued

Number of determinations and refractive

index $\left(\mathbb{N}_{\alpha_{1}}\right)$ of plagioclase
Number of determinations and refractive index $\left(\mathrm{N}_{\alpha_{1}}\right)$ velandite

Country rock

Type of pegmatite

or pegmatite unit

$\begin{array}{llllllllllllllllllllllllll}1.527 & 1.528 & 1.529 & 1.530 & 1.531 & 1.532 & 1.533 & 1.534 & 1.535 & 1.536 & 1.537 & 1.538 & 1.539 & 1.540 & 1.541 & 1.528 & 1.529 & 1.530\end{array}$

\section{Fine- and coarse-grained}
Homogeneous pegmatites
matites
wall zone

Core

$\begin{array}{ll}6 & 9 \\ 1 & 1 \\ 1 & \end{array}$

1

510

1

1

Quartz monzonite

Homogeneous pegmatite

Zoned pegmatites

Wall zones

Intermediate zone(s)

Layered pegmatite

Lower layer

2

1

1

Upper layer

\section{Country rock unknown}


The refractive indices of plagioclase were determined for all internal units in each beryl-bearing pegmatite and for a selected number of pegmatites in each type of country rock. The refractive indices of the plagioclase in pegmatites with the hornblende gneiss and tonalite wall rocks averagec 1.530 , and those in the quartz monzonite averaged 1.538 . Refractive indices of plagioclase in pegmatites from the hornblende gneiss near quartz monzonite are in the same range as those in the quartz monzonite. The refractive indices of plagioclase in pegmatites decrease from the quartz monzonite area southward; the difference appears to be controlled by the regional distribution rather than composition of the country rock. In the zoned pegmatites of the Black Hills J and other districts, J

\footnotetext{
$J$ Page, I. R., et al, Pegmatite investigations, 1942-1945, Black Hills, South Dakota: U. S. Geol. Survey Prof. Paper (in preparation). I Cameron, I. $\mathrm{N}_{*}$, et al, op. cit., p. 99, 1949.
}

a systematic variation in the plagioclase has been noted from zone to zone with the anorthite content decreasing toward the core. Most pegmatites in the Quartz Creek district do not have the well-developed zones but when zoned show a rather large wall zone with scattered core segments. Table 5 shows that there is not much change in the indices of the 17 pegmatites that are composed of just wall zone and core; eight showed no change of index, five decreased slightly in index $(0.001$ to 0.002$)$ from wall zone to core, while four increased in index $(0.001$ to 0.006$)$. In two well-segregated pegmatites with intermediate zones there is a decrease in refractive index of 0,005 towards the core, indicating a decrease in anorthite content, which is in accord with previous work. In a well-segregated pegmatite the plagioclase probably will tend to show a systematic change of anorthite content toward the center; but when the zoning is poor, the plagioclase 
will either have the same composition or have erratically distributed values.

Table 5.-Lower refractive index $\left(\mathbb{N}_{\alpha_{1}}\right)$ of plagioclase in zoned pegmatites.

\begin{tabular}{|c|c|c|c|}
\hline $\begin{array}{c}\text { Pegmatite No. } \\
\text { (pI. II) }\end{array}$ & $\begin{array}{c}\mathbb{N}_{\alpha I} \text { of plagioclase } \\
\text { in wal zone }\end{array}$ & $\begin{array}{c}N_{\alpha i} \text { of plagioclase } \\
\text { in intermediate zone }\end{array}$ & $\begin{array}{c}N_{\alpha I} \text { of plagioclase } \\
\text { in core }\end{array}$ \\
\hline 174 & 1.529 & & 1.528 \\
279 & 1.531 & & 1.529 \\
289 & 1.529 & & 1.530 \\
451 & 1.529 & & 1.529 \\
453 & 1.529 & & 1.529 \\
454 & 1.529 & & 1.529 \\
455 & 1.529 & 1.529 & 1.529 \\
456 & 1.529 & & 1.529 \\
535 & 1.535 & & 1.528 \\
536 & 1.528 & & 1.530 \\
674 & 1.531 & & 1.539 \\
847 & 1.533 & & 1.529 \\
989 & 1.530 & & 1.530 \\
1002 & 1.531 & & 1.531 \\
1028 & 1.529 & & 1.530 \\
1044 & 1.529 & & 1.529 \\
1202 & 1.530 & & \\
1402 & 1.537 & & \\
1666 & 1.529 & & \\
\hline
\end{tabular}

A comparison was also made between the refractive indices of plagioclase from the hanging-wall layer and the footwall layer of two layered pegmatites (table 6). As the hanging-wall layer is relatively rich in perthite and the footwall layer relatively poor, it was thought that this change in the alkali content might be reflected in the ratio of sodium to calcium in the plagioclase. Of the eleven pegmatites investigated, six showed no variation in index and five showed an increase of 0.001 to 0.002 in index from the hanging-wall layer to the footwall layer. As the limit of accuracy of the index determinations is approximately $0.001^{\text {t }}$, the results show a negligible change. The concentration of perthite and thus the potassium content in the upper layer seems to have little effect on the ratio of sodium to calcium in the plagioclase. 
Table 6.--Lover refractive index $\left(\mathbb{K}_{\alpha_{1}}\right)$ of plagioclase in layered pegmetites

\begin{tabular}{|c|c|c|}
\hline $\begin{array}{c}\text { Pegrnetite No. } \\
\text { (pl. II) }\end{array}$ & $\begin{array}{c}N_{\alpha} \text { of plagioclase in } \\
\text { hanjing-vall layer }\end{array}$ & $\begin{array}{c}N_{\alpha_{1}} \text { of plagioclase in } \\
\text { footwall laver }\end{array}$ \\
\hline & 1.528 & 1.530 \\
470 & 1.529 & 1.530 \\
432 & 1.530 & 1.530 \\
435 & 1.529 & 1.529 \\
462 & 1.529 & 1.529 \\
548 & 1.529 & 1.529 \\
778 & 1.535 & 1.535 \\
1004 & 1.529 & 1.529 \\
1043 & 1.530 & 1.531 \\
1105 & 1.530 & 1.531 \\
1172 & 1.529 & 1.531 \\
\hline
\end{tabular}

A comparison of the refractive indices of plagioclase in beryl-bearing anc non-beryl-bearing pegmatites (table 11) shows that both have a vide range and that the non-beryl-bearing pegmatites have more calcic plagioclase.

Cleevelandite occurs in crystals comonly nany times larger than the plagioclase, has a flat platy crystal habit compared to more equant grains of plegioclase, and is invariably white or bluish white whereas plagioclase is white, yellow, green or pink. These two varieties probably did not form under identical chemical and physical conditions. Cleavelandite occurs in 20 pegmeitites in the Quartz Creek district and has been noted in homogeneous, zoned, and layered pegnatites, and pegmatites which vary in composition along the strike. In zoned pernetites it is found in the intemediate zone in three places and in the core in sixteen. The tendency for cleaveIandite to form in the central part of pegmatites has been noted in other parts of Coloraco $J$ and in other districts in the United States $J$. $\int$ Hanley, J. B., et al, op. cit., p. 7, 1950. I Cameron, J. N., et al, op. cit., p. 58, 1949.

Cleavelanoite has distinctive mineral associations. In the Quartz Creek district it is associated with quartz, lepidolite, microlite, beryl, 
topaz, columbite-tantalite, perthite, muscovite, garnet, and tourmaline. Many of these minerals are normally found with cleavelandite though the reverse is not always true. Cleavelandite is associated with lepidolite in 14 of the 17 lepidolite-bearing pegmatites, with topaz in 8 of the 8 topazbearing pegmatites, and with mingiting 12 of the 13 microlite-bearing pegmatites. The association of cleavelandite with lithium minerals and some of the rare accessory minerals has been noted in other districts. In the Tin Mountain pegmatite, Custer County, S. Dak., cleavelandite occurs in the core associated with spodumene, lithium mica, beryl, amblysonite, cassiterite, columbite-tantalite, apatite, microlite, and pollucite. In the Harding mine near Dixon, N. Mex. I cleavelandite in fracture fillings

I Adams, J. W., Personal communication.

is associated with purple muscovite, microlite, and spodimene. In the Rutherford and Morefield pegmatites near Amelia, Va. J, cleavelandite is

$$
J \text { Glass, J. J., op. cit., pp. 76I-763, } 1935 .
$$

associated with cassiterite, manganotantalite, microlite, and zircon. The regional distribution of cleavelandite-bearing pegmatites (fig. 20) shows that with the exception of two bodies, all the deposits containing cleavelandite alșo contain lepidolite or are adjacent to pegmatites containing lepidolite. This suggests that some of the elements common to lepidolite and its associated minerals may be responsible for the formation of platy plagioclase. The elements that might promote the growth of cleavelandite are lithium (in lepidolite, zinnwaldite, amblygonite, and spodumene), rubidium or son (in lepidolite, muscovite, tourmaline, beryl, and pollucite), and fluorine (in lepidolite, fluorite, and topaz). Fluorine is rnore difficult to evaluate because it may be present as an essential 
constituent, as in fluorite, topaz, or lepidolite, or, it may occur undetected as a minor constituent in other minerals such as muscovite by substituting for the OH radical. Spectrographic analyses of both cleavelandite and albite from a number of pegmatites should be made to find whether small quantities of lithium, fluorine, or other elements are present in one type of plagioclase and not in another.

\section{Perthite}

AIl the potassium feldspar examined in pegmatites of the Quartz Creek district was white, cream-colored, or pink perthite; no orthoclase or microcline free of vein-like laminations of albite was noted. The albite laminae are thin, roughly parallel, and white. The albite is well twinned and the twinnins is parallel in all laminae. The twin planes parallel the lone dimension of the albite laminae and have the same orientation in a single perthite crystal.

Perthite occurs in most pegmatites and in some it is the predominant mineral. It is absent from some sodic-rich units, but forms as much as 93 percent of perthite cores. Sodic-rich pegmatites commonly contain less than I5 percent perthite; other pegmatites are in a large part graphic granite. Generally the perthite-rich pegmatites are most abundant in the northwest part of the district:

All pegmatite units contain perthite, but it is most abundant as graphic granite in homogeneous pegmatites, wall zones of zoned pegmatites, or as blocky perthite in cores of quartz-perthite pegmatite. The largest perthite-bearing pegmatites in the district contain graphic grenite whereas graphic granite is not common in the small cores of zoned pegmatites. The hanging-wall unit of layered pegmatites is commonly rich in perthite. 
The perthite is in crystals a quarter of an inch to 8 feet in maximurn dinension. The crystals are largest in cores where they average 1.5 feet. Perthite crystals in the wall zone or in layered and homogeneous pegmatites are 2 to 3 inches in size. In fine grained plagioclase-rich pegrnatites the perthite crystals are smaller than in pegmatites where perthite is the dominant mineral. Graphic granite crystals are from a half to 4 feet in length and average about 80 percent perthite and 20 percent quartz. About a ton of Eraphic granite was crushed, quartered, and analyzed J. This analysis (table 7) indicates that the soda is almost

I Ainalysis obtained through the courtesy of $\mathrm{C}$. A. Wemlinger, vice President in Charge of Operations, Beryllium Mining Co., Inc.

entirely in the albite laminae of the perthite. Normative minerals $J$,

1765, Washington, H. S., U. S. Geol. Survey Prof. Paper 99, pp. 1162$1165,1917$.

calculated from this analysis, verify that there is little present other than quartz and feldspar and that the microcline molecule is 4.5 times as abundant as that of plagioclase.

Perthite forms blocky equidimensional crystals that are surrounded and veined by an aggregate of quartz, albite, and muscovite. In most places perthite is the first essential mineral to crystallize, but rarely it appears to be later than some or all of the associated minerals, 
Table 7.--Chemical analysis I/ of graphic granite from the Bucky mine, Quartz Creek district, Colorado

\begin{tabular}{|l|c|}
\hline Oxide & Percerit \\
\hline $\mathrm{SiO}_{2}$ & 71.56 \\
$\mathrm{AI}_{2} \mathrm{O}_{3}$ & 14.82 \\
$\mathrm{~K}_{2} \mathrm{O}$ & 10.97 \\
$\mathrm{Na}_{2} \mathrm{O}$ & 1.69 \\
$\mathrm{CaO}$ & 0.08 \\
$\mathrm{Fe}_{2} \mathrm{O}_{3}$ & 0.01 \\
$\mathrm{MHO}_{5}$ & Trace \\
$\mathrm{Cr}_{2} \mathrm{O}_{3}$ & None \\
& 99.13 \\
\hline
\end{tabular}

If C. A. Parker, analyst.

Quartz

Quartz comprises 15 to 30 percent of all pegmatites in the district; the average is about 20 percent in homogeneous pegmatites, non-lepidolitebearing layered pegmatites, and wall zones of zoned pegmatites. Although the ratio of perthite to plagioclase varies widely in these types of rock, the quartz content is nearly everywhere 15 to 20 percent. Many cores and fracture fillings are made up solely of milky quartz, whereas other cores and fraeture fillings are mixtures of biocky perthite and quartz. The quartz in fracture fillings, intermediate zones, and cores is 10 to 100 percent of the unt,

The quartz is generally white to gray, although smoky varieties are found in a few pegmatites, usually as small oval blobs of from I to 10 feet. The smoky varieties are usually associated with radioactive minerals, for example, with microlite in pegmatites No, 215 , No 216 , and No. 452 , and with allanite in pegmatite No. 847 . Small patches of smoky quartz have been found without visible radioactive minerals.

Quartz in most places fills interstices and forms veins in perthite crystals, indicating that it crys tallized after the perthite. Rarely, 
however, the reverse is true. The quartz associated with blocky perthite is in crystals 2 to 18 inches in size and is commonly slightly finer grained than perthite. In graphic granite, the quartz forms crude cuniform-shaped rods 0.03 to 0.25 inch thick and as much as 1.5 feet long.

Albite is interstitial to quartz and in places appears to vein it. This relationship indicates that albite crystallized last, but in many places the mutual intergrowths suggest a contemporaneous age. Where quartz occurs solely with albite it forms crystals 0.03 to 0.5 inch in diameter; as the proportion of perthite increases in the unit the size generally increases. Muscovite and quartz in many places are intergrown and appear to have crystallized at about the same time.

\section{Muscovite}

Muscovite is found in about 60 percent of the pegnatites in the Quartz Creek district. On the east side of Quartz Creek it occurs in 85 percent of the pegmatites. On the west side the iron content of the pegmatites is higher, considerable magnetite is present, and biotite occurs in place of part of the muscovite. Muscovite is found in all types of internal units in the pegmatites and forms 0.5 to 3 percent of the rock; rare small pegmatites contain as much as 10 percent.

The muscovite is clear to green and individual sheets show black mineral staining. The larger pieces have reeves and "A" structure. Most of the muscovite, however, is about 0.25 inch in diameter, and commonly is intergrown with quartz. In only two pegmatites, the Buckhorn (No. 659) and the Bucky (No. 1574), are muscovite books more than 3 inches in size; books I foot in size occur in the Bucky pegmatite.

The miscovite is in both flat and curved forms. The flat variety is common in most rocks; the curved variety is found in 23 pegmatites, all on 
the northwestern slope of Wood Gulch, where it occurs in a series of concentric shells 0.12 to 0.5 inch thick.

The composition of muscovite is expressed in three constituent molecules $J$, the end nembers of a triangular composition diagram, and the 1947 - Winchell, A. N., Elements of optical mineralogy: pt. II, p. 268, Volk, G. W., Optical and chenical stuaies of muscovite: Am. Mineralogist, vol. 24, pp. 255-266, 1939.

composition of any sample of muscovite can be expressed in terms of these three end members. The end nembers are potassium muscovite $\left(\mathrm{H}_{4} \mathrm{~K}_{2} \mathrm{AI}_{6} \mathrm{Si}_{6} \mathrm{O}_{24}\right)$, phengite $\left(\mathrm{H}_{6} \mathrm{~K}_{2}\left(\mathrm{Fe}, \mathrm{Mg}_{2}\right)_{2} \mathrm{Al}_{4} \mathrm{Si}_{6} \mathrm{O}_{24}\right)$, and ferric iron muscovite $\left(\mathrm{H}_{4} \mathrm{I}_{2} \mathrm{Fe}_{2} \mathrm{Al}_{4} \mathrm{Si} 6\right.$ $0_{24}$ ). The refractive indices of mascovite increase with the proportion of the ferric iron muscovite in the mineral. The total amount of iron can not be ascertained by optical methods alone, however, as the iron may also be in the ferrous form in the phengite member. Specimens containing piengite and the potassium mascovite neraber have the same indices for equal amounts of the ferric iron muscovite. Information obtainable from refractive index determinations on the chemical composition of muscovite is therefore less useful than similar data on plagioclase and beryl. Volk / made

_ Volk, G. W., op. cit., pp. 257-259, 1939.

22 chemical analyses and obtained the optical data on muscovite from various pegmatites scattered throughout the world. These analyses are in an area on the diagram midway between potassium muscovite, phengite, and 0 to 38 percent ferric iron muscovite. The mecian refractive index $\left(N_{\beta}\right)$ was determined on 95 specimens of muscovite from the Quartz Creek district and ranged from $N_{\beta}=1.585$ to 1.606 (table 8), indicating from 0 to 28 percent of the ferric iron mascovite molecule. It was thought originally that a 
variation in the refractive indices, and thus in ferric iron content, misht be found between units or layers. Table 9 shows the median refractive indices $\left(\mathbb{N}_{\beta}\right)$ of muscovite from the wall zone and core of seven zoned pegmatites, There is a snall variation in the refractive indices but the variation is not constant, either in direction or amount. The median refractive indices of muscovite in layered pegmatites (table 10) show a smell but unsystematic variation between the hanging-wall to the footwall layers, A comparison of median refractive indices of muscovite from pegmatites in various types of country rock was made. The lack of sufficient samples from pegnatites in the granite and quartz monzonite made this work inconclusive, but the variations are in the seme range as those from pegmatites in the hornblende gneiss or tonalite. Cormerison was also made between the muscovite in various beryl-bearing and non-beryl-bearing units. The refractive indices of the muscovite in the beryl-bearing units were in the same range as those In the non-beryl-bearing units. 
Tejle 8.- Mhuber and distribution of median refractive indices (ii $\beta$ ) found in slat and curved muscovite

\begin{tabular}{|c|c|c|}
\hline \multirow{2}{*}{$\begin{array}{c}\text { Ifedian incex } \\
\text { (NB) }\end{array}$} & \multicolumn{2}{|c|}{ Nupber of specimens } \\
\hline & Flat imuscovite & Curved muscovite \\
\hline 1.585 & 1 & 1 \\
\hline 1.536 & 1 & 0 \\
\hline 1.587 & I & 0 \\
\hline 1.588 & 0 & 0 \\
\hline 1.589 & 0 & 2 \\
\hline 1.590 & 0 & 1 \\
\hline 1.591 & 0 & 0 \\
\hline 1.592 & 4 & 2 \\
\hline 1.593 & 1 & 0 \\
\hline 1.594 & 7 & 0 \\
\hline 1.595 & 4 & 2 \\
\hline 1.596 & 4 & 0 \\
\hline 1.597 & 12 & 1 \\
\hline 1.598 & 7 & 0 \\
\hline 1.599 & 4 & 3 \\
\hline 1.600 & 7 & 0 \\
\hline 1.601 & 8 & 1 \\
\hline 1.602 & 5 & $I$ \\
\hline 1.603 & 6 & 1 \\
\hline 1.604 & 1 & 0 \\
\hline 1.605 & 5 & 1 \\
\hline 1.606 & 1 & 0 \\
\hline
\end{tabular}

Table 9.-Median refractive index (Np) of muscovite from zoned pegmatites

\begin{tabular}{|c|c|c|}
\hline $\begin{array}{c}\text { Pegmatite } \\
\text { T.o. }\end{array}$ & $\begin{array}{c}\text { No of muscovite } \\
\text { in we.l zone }\end{array}$ & $\begin{array}{c}N_{\beta} \text { of muscovite } \\
\text { in core }\end{array}$ \\
\hline 174 & & 1.592 \\
208 & 1.599 & 1.578 (zinnwaldite) \\
213 & 1.592 & 1.599 \\
245 & 1.596 & 1.594 \\
266 & 1.597 & 1.595 \\
288 & 1.595 & - \\
\hline
\end{tabular}


Table 10.-mocien refractive incex (lip) of rascovite in layered pegmatites

\begin{tabular}{|c|c|c|}
\hline $\begin{array}{c}\text { Pesinetite } \\
\text { Iio }\end{array}$ & $\begin{array}{c}N_{\beta} \text { of muscovite in } \\
\text { hanging waIl }\end{array}$ & $\begin{array}{c}N_{\beta} \text { of min footwall } \\
\text { in fovite }\end{array}$ \\
\hline 913 & 1.597 & \\
927 & 1.604 & 1.600 \\
937 & 1.597 & $\mathbf{1 . 6 0 1}$ \\
944 & 1.601 & 1.602 \\
953 & 1.599 & 1.603 \\
954 & 1.605 & 1.598 \\
958 & 1.606 & 1.605 \\
959 & 1.605 & 1.603 \\
963 & 1.605 & 1.602 \\
969 & 1.605 & 1.601 \\
975 & 1.598 & 1.598 \\
997 & 1.603 & 1.601 \\
1132 & 1.601 & 1.594 \\
1172 & 1.595 & \\
\hline
\end{tabular}

It was thought that the curved miscovite in the quartz Creek district might also be a Iithium mice, but median indices (N/ $\beta$ ) determined for 16 specimens of curved muscovite show the sasne range of index and aproxinately the same distribution as the Ilat muscovite (table 8). Fharthermore, the ancle $2 \nabla$ of the curved mica. (40 desrees) is much too high for a lithium mice. Several Iithium nicas were found, however, in making refractive index deterninations on muscovite. These nicas are colorless, flat, and associated vith cleavelandite. Their median index ranges from 1.560 to 1.578 which is below that of the muscovite series. These specimens are in the zinnwlitie renge of the lepidolite series. There is no sure way to distinguish wite Iithium nice from muscovite in hand specimen. The lithium micas are more brittle, and the presence of cleavelanoite should lead one to consider the possibility of lithium micas being present. A simple test to distinguish the two involves the use of a blowpipe: the lithium micas can be fused but muscovite can not. 
Garnet

Approximately 55 percent of the pegmatites of the Quartz Creek district contain minor quantities of garnet. It is comnonly in crystals less than 0.03 inch in diameter and may be overlooked easily. Garnet ranges in size from less than 0.01 inch to 1 inch in diameter, but crystals over 0.15 inch are rare. This mineral occurs in all the pegmatite units, but has a decided preference for the fine-grained plagioclase-rich parts, such as found in the footwall units of layered pegmatites, the wall zones of zoned pegmeties, and homogeneous pegmatites. It is found in crystals 0.20 Inch and larger in the coarser-grained cares, but in most cores it is absent. Though garnet is widely distributed throughout the district, is constitutes only a trace to less than 1 percent of most pegmatites; in a few of the smaller ones it makes up as much as 1 percent of the rook. Garnet is exratic in distribution, and some parts of a pegmatite may contain several percent while others contain none. In the Bucky pegmatite (Fo. 1574) rocls exposed in two pits contains several percent garnet, whereas in the same unit in other pits the mineral is absent. Brown garnet is conspicuous. in "Iine rock", Forming long thin bands which contrast with the white plagioclase-rich bands.

The garnet occurs singly or in clusters as light-brown, reddish-brown, and black euhedral crystals. Some crystals are black on the outside due to manganese staining, but others are black throughout the crystal. The garnet in many pegmatites is clear reddish brown with no manganese staining. One of the larger crystals is an intergrowth of garnet and quartz.

The garnet group may be divided into six memberst almandite $\left(\mathrm{Fe}_{3} \mathrm{Al}_{2} \mathrm{Si}_{3} \mathrm{O}_{12}\right)$, spessartite $\left(\mathrm{Mn}_{3} \mathrm{Al}_{2} \mathrm{Si}_{3} \mathrm{O}_{12}\right)$, pyrope $\%\left(\mathrm{Mg}_{3} \mathrm{Al}_{2} \mathrm{Si}_{3} \mathrm{O}_{12}\right)$, grossularite $\left(\mathrm{Ca}_{3} \mathrm{Al}_{2} \mathrm{Si}_{3} \mathrm{O}_{12}\right)$, andradite $\left(\mathrm{Ca}_{3} \mathrm{Fe}_{2} \mathrm{Si}_{3} \mathrm{O}_{12}\right)$, and werovite $\left(\mathrm{Ca}_{3} \mathrm{Or}_{2} \mathrm{Si}_{3} \mathrm{O}_{12}\right)$. 
Ford _/, Fleischer J, and Wright / have shown that garnet specimens do

J Ford, W. I., A study of relationships existing between the chemical, optical and other physical properties of the members of the garnet group: Am. Jour. Sci., 4th ser., pp, 33-49, 1915.

$J$ Fleischer, Michael, The relation between chemical composition and physical properties in the garnet group: Am. Mineralogist, vol. 22, pp. 751-759, 1937,

J Wright, W. I., The composition and occurrence of garnets: Am. Mineralogist, vol. 23, pp. 436-449, 1938.

not correspond usually to any single chemical type, but contain two or more molecules in solid solution. It was shown first by Ford / that the index

\rfloor Ford, W. I., op, cit., pp. 33-49, 1915.

of refraction and specific gravity of a garnet depend in a simple and direct way on the chemical composition. He calculated the index of refraction and the specific gravity of 23 garnets from their chemical composition. These values agreed within less than 2 percent with those determined by direct measurement. The reverse process is not so simple, as a single determination of refractive index or specific gravity may correspond to several combinations of end members. It would be possible from a series composed of three different molecules to have a number of different combinations with the same index of refraction. The problem is somewhat simplified because all garnets are in one of two Eroups: the aluminum-bearing garnets (almandite, spessartite, and pyrope) and the calcium-bearing garnets (grossularite, andradite, and uvarovite). These two groups, as shown diagrammatically by Winchell $J$, are miscible with each other only in limited amounts. 1947.

/ Winchell, A. N., Blements of optical mineralogy: pt. 2, p. 175 , Wright $J$ compiled 35 analyses of garnets from pegmatites and 18 from 
J Wright, W. I., op, cit.,pp. 439, 446, 1938.

granites which he converted into weight percent of the five common members of the garnet group, namely: almandite, spessartite, pyrope, grossularite, and andradite. His conclusions from studies of garnet from pegmatites and other types of rock are: (1) that there is a remarkable constancy of one variety of garnet in each rock type, and (2) that spessartite and almandite constitute 85 to 90 percent of the molecules from pegmatites and granites. Thus, if one of the major constituents is known, the other can be estimated within a limit of error of 5 to 15 percent. Winchell / has compiled data

$J$ Winchell, A, N., op. cit. ,p?. 179-181, 1947.

by Ford and others into several diagrams from which, if the garmet group is known, and the specific gravity and index of refraction have been determined, a general composition in terms of the garnet molecules can be derived.

Indices of refraction were determined on garnet from 15 widely scattered pegnatites in the Quartz Creek district. Specific gravity was not determined, but all specimens were qualitatively tested and found to contain manganese. All the indices of refraction are between 1.810 and 1.820 with many specimens having refractive indices about 1.815 . The indices of refraction show small variations, but in general the garnet of this region is remarkably similar in index and composition. The proportion of almandite and spessartite can be roughly evaluated by neglecting the small percent pointed out by Wright to be taken up by the other garnet molecules and assuming that the mineral to be made up only of spessartite and almandite. In this case the garnet would range from 67 percent spessartite, 33 percent 
alnandite $(N=1.1810)$ to 33 percent spessartite, 67 percent almandite $(\mathbb{N}=1.820)$. Most of the values would be closer, however, to 50 percent spessartite and 50 percent almandite $(N=1.815)$.

Garnet is associated with all the comnon and almost all the rare pegnatite minerals. It does have, however, a tendency to occur more abundantIy with fine-grained plagioclase. In pegmatite units that are perthite-rich, garnet, if present, comonly will be associated with the plagioclase.

\section{Magnetite and martite}

Magnetite, comonly altered to martite, is videspread in minor quantities and is found in approximately 20 percent of the pegmatites. Most pegmatites contain only a few scattered crystals, but several of the snaller pegmatites have about 1 percent.

Magnetite and martite are dull to steely black in color and rarely form well-developed octahedra. Alnost all specimens, however, have Eood octahedral (111) parting which easily distinguishes this mineral from colurbite-tantalite. The mineral renges in size from grains less than 0.10 inch in size to round masses as much as 3 inches in diameter. Magnetite and nartite are found as an accessory mineral in the feldspathic pegmatites, but are not found in any of the lepidolite-bearing units. They are in both the perthite-rich and the albite-rich pegmatites, and are one of the few accessory minerals found in graphic granite. The distribution of magnetite and martite is usually erratic; a few small areas in the pegmatite may contain 1 or 2 percent and the rest of the pegmatite only a trace. They are associated commonly with perthite, albite, quartz, and biotite, end in a few places with garnet. Few beryl-bearing pegmatites contain either magnetite or nartite; the two minerals are nowhere adjacent to each other. Muscovite is nowhere associated closely with the 
magnetite although they may both be in the same pegmatite, whereas biotite is closely associated with magnetite or martite.

The association of magnetite with biotite but not with muscovite is easily explained. Those parts of the pegmatite with sufficient iron to form magnetite also had sufficient iron to form biotite; those parts free of iron would contain muscovite in place of biotite.

\section{Biotite}

Biotite is found in almost 20 percent of the pegmatites on the west side of Quartz Creek, but is found in only 6 percent of the pegmatites on the east side. In most of the pegmatites biotite forms considerably less than $I$ percent of the rock; in a few of the smaller pegmatites it forms several percent.

Biotite is dark to greenish black and occurs in widely scattered blades from a fraction of an inch to 8 inches in maximum dimension; in most pegmam tites the blades are 0.25 to 0.5 inch. The larger blades usually occur in small areas and may be either restricted to core segments or small patches in the otherwise uniform homogeneous pegmatite or the wall zone of a zoned pegmatite.

The median refractive index $\left(N_{\beta}\right)$ of seven specimens ranges from 1.636 to 1.671 . Not only do the refractive indices vary from specimen to specimen but also in different parts of the same book. Much of the biotite is partly altered to chlorite and the variation in refractive index depends on the extent to which the biotite has been altered. These median refractive indices indicate that the biotite approximates siderophyllite $J$ in 1947.

Winchell, A. N., Ilements of optical mineralogy: pt. II, p. 273, 
composition and is high-iron rather than high-magnesium biotite.

Biotite was found in part of the lepidolite-bearing pegmatites, but it is not in the same units as lepidolite. It is common in both perthite- and albite-rich pegmatite and is one of the few accessory minerals in graphic granite. Biotite is commonly associated with magnetite or martite; muscovite is found only in the magnetite-free part of these pegmatites.

\section{Beryl}

Beryl is found in 232 pegmatites and is widely distributed; in most pegInatites in the Quartz Creek district there are only a few small crystals. Beryl is found in all types of pegmatites and pegmatite units: homogeneous pegnatites; core, intermediate, and wall zones of zoned pegmatites; various layers of layered pegmatites; and units of pegmatites that differ in composition along strike.

Beryl may be brown, white, gray, greenish white, pale green, greenish gray, or pale blue green. The white, brown, and greenish white beryl is the most common, and it is difficult to distinguish from feldspar in many exposures. The beryl crystals range from 0.006 inch to 2 feet in diarneter. In fine-grained albite-rich pegmatites the beryl crystals are 0.10 to 0.25 inch in diameter, but larger crystals occur in the coarser-grained intermediate zones and cores. Although beryl was found in a higher percentage of the albite-rich units than in perthite-rich ones only the latter contained beryl in pieces large enough to be hand cobbed. The average beryl crystal is aporoximately twice the size of the albite and about half the size of the associated perthite grains.

Beryl occurs as subhedral to euhedral hexagonal crystals; tapered crystals are rare except at the Bucky pegmatite (No. 1574). Intergrowths 
of beryl with feldspar, quartz, tourraline, or other minerals are common in some regions, as in northeastern Brazil $J$, New Hampshire, Connecticut $J$,

\section{J Johnston, W. D., Jr., Beryl-tantalite pegmatites of northeastern Brazil: Geol. Soc. America Bull., vol. 56, pp. 1032-1034, 1945. \\ J Shaub, B. M., Contemporaneous crystallization of beryl and albite vs. replacement: Am. Mineralogist, vol. 22, pp. 1045-1051, 1937.}

and the Iight-Mile Park district, Colo. J, but in the Quartz Creek dis-

J Heinrich, I. W., Pegmatites of Iight Mile Park, Fremont County, Colorado: Am. Mineralogist, vol. 33, pp. 557-558, 1948.

trict only one mixed crystal was found. It was intergrown with garnet and quartz near the center of the crystal and with albite near the outer edges. Beryl may contain as much as the theoretical maximum of 14.0 percent Be0. In most beryl, however, substitutions involving $\mathrm{Cs}_{2} \mathrm{O}, \mathrm{Ii}_{2} \mathrm{O}, \mathrm{Na}_{2} \mathrm{O}$, and $\mathrm{Al}_{2} \mathrm{O}_{3}$ lower the $\mathrm{BeO}$ content and it commonly ranges from 11 to 13 percent J. Winchell J and later Schaller J have shown that the decrease

I Schaller, W. T., Unpublished chart. Adams, J. W., Beryllium deposits of the Mt. Antero region, Chaffee County, Colorado: U. S. Geol. Survey Bull., (in preparation). 1947.

$J$ Winchell, A. N., Ilements of optical mineralogy: part II, p. 213,

I Schaller, W. T., Unpublished chät.

in BeO content is accompanied by an increase in the refrective indices, and have compiled charts showing the alkali and Beo content for any particular refractive index. According to Schaller's chart, the refractive index of the slow ray $\left(N_{\omega}\right)$ of bery 1 containing 14 percent BeO is 2.566, whereas the refractive index of beryl containing 10 percent BeO is 1.600 .

The refractive index of the slow ray $\left(N_{\omega}\right)$, determined for 183 bery 1 specimens from various units, ranges from 1.573 to 1.585 and averages 1.578 . 
These determinations are compiled in table 11 together with the determinations of the minimum refractive index on cleavage plates of the associated plagioclase. The table is divided according to country-rock types and subdivided according to the type of pegmatite and internal structure. This table shows that the refractive index of beryl, and therefore the composition, varies irregularly in the different types of pegmatites and internal units. There appears to be no correlation between type of country rock and the refractive index of beryl. Only two specimens of beryl were obtained from pegmatites in the quartz monzonite and six from pegmatites in fine- and coarse-grained granite.

It has been noted in the Black Hills $J$ and other districts I that J Page, I. R., et al, Pegmatite investigations, 1942-1945, Black
Hills, South Dakota: U. S. Geol. Survey Prof. Paper (in preparation).
/ Cameron, I. N., , ot. al, op. cit., p. $99,1949$. there is a systematic increase in the alkali content of beryl from the wall zone inward toward the core. Similar data on beryl from zoned pegmatites from the Quartz Creek district is rather meager because a large part of the beryl found was from a single zone of a zoned pegmatite. The refractive indices of beryl from different units of zoned pegmatites are compiled in table 12 together with the minimum refractive index of albite for comparison. Most pegmatites have only small cores and are zoned poorly. A difference $\pi, 001$ is all that is noted from wall zone to core of the more simply zoned pegnatites. The refractive indices of the slow ray of beryl from three pegmatites that contain beryl in an intermediate zone as well as either a core or a wall zone differ as much as 0.003 between the intermediate zone and either the core or wall zone. This increase inward in alkali content is in accord with the findings of previous workers. 
Table 11... The number of refractive index determinations of plagioclase and beryl, their relation to different types of country rock, and types of pegmatites or units.

Country rock and

Lowest refractive index on cleavage

Highest refractive index on cleavage plates of beryl

type of unit

plates of plagioclase

$1.528^{2} 1.529 \quad 1.530 \quad 1.531$ Other $\begin{array}{llllllll}1.575 & 1.576 & 1.577 & 1.578 & 1.579 & 1.580 & 1.581 & \text { Other }\end{array}$

Hornblende gneiss and tonalite

Homogeneous pegmatite

$\begin{array}{llll}13 \quad 21 & 6 & 1.532-5 \\ 1 & 1.533-3\end{array}$

$1.533-3$
$1.534-1$

Zoned pe gmatites

Wal] zone

Intermediate zone(s)

Core

Layered pegmatites

Lower layer

Median layer(s)

Upper layer

Pegmatites which change

composition along strike

Fracture filling

1.534

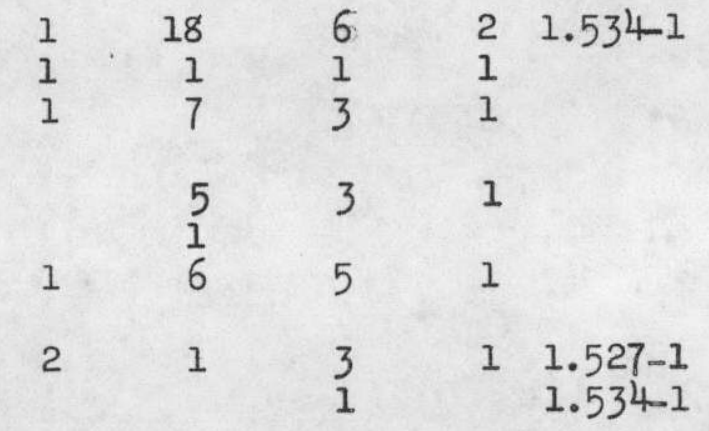

4

10

17

13

$3 \quad 1.573-1$

$1.582-2$

$1.583-1$

Granite, and hornblende gneiss

\section{and tonalite}

Homogeneous pegmatite

Zoned pegmatites

Wall zone

Intermediate zone(s)

Core

Layered pegmatite

Lower layer

Upper layer

Pegmatites which change

along strike

$6 \begin{aligned} & 1.527-2 \\ & 1.532-1\end{aligned}$

$\begin{array}{lllll} & 3 & 3 & 1 & 1 \\ 3 & 2 & 4 & 7 & 4\end{array}$

$1.582-2$

$\begin{array}{lllll} & 2 & 2 & 1 & \\ 1 & 1 & & & 1.533-1 \\ & 2 & 2 & 3 & 1.539-1 \\ & 2 & 2 & 2 & 1.535-1 \\ & 3 & 1 & 1 & 1.535-1 \\ & 3 & 3 & 2 & 1\end{array}$

1

$\begin{array}{ll}1 & 1 \\ 2 & 1 \\ & 2\end{array}$

6

4

$2 \quad 1.574-1$

$1.585-1$

1

1

$\begin{array}{llllll}1 & & & 1 & 1 \\ 1 & 1 & 3 & 3 & 2 & \\ 1 & 1 & 1 & & & \\ & 2 & 2 & 1 & 1.574-1\end{array}$


Table 11.--The number of refractive index determinations of plagioclase and beryl, their relation to different types of country rock, and types of pegmatites or units...continued

Country rock and

Lowest refractive index on cleavage

Highest refractive index on cleavage plates of beryl

type of unit

plates of plagioclase

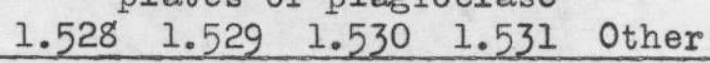

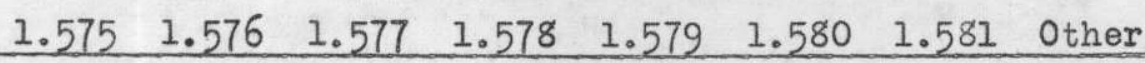

\section{Fine- and coarse-grained granite}

Homogeneous pegmatite

311

Quartz monzonite

Zoned pegmatites

Wall zone

1

1

1. $537-1$

$1.532-1$

1. $535-1$

\section{Country rock unknown}

Homogeneous pegmatites
$1.532-1$
11
1

$1 \quad 1.583-2$ 
Table 12.--Refractive indices of plagioclase and beryl from beryl-bearing units of zoned pegmatites

\begin{tabular}{|c|c|c|c|c|c|c|}
\hline & WaII $\mathrm{zc}$ & & Intermediat & zone & Core & \\
\hline $\begin{array}{c}\text { Pegmatite } \\
\text { No. }\end{array}$ & $\begin{array}{c}\pi_{\alpha} I^{2} \text { of } \\
\text { plagioclase }\end{array}$ & $\begin{array}{l}N_{\omega} \text { of } \\
\text { beryI }\end{array}$ & $\begin{array}{c}N_{\alpha I} \text { of } \\
\text { plagioclase }\end{array}$ & $\begin{array}{l}N_{\omega} \text { of } \\
\text { bervl }\end{array}$ & $\begin{array}{c}N_{\alpha I} \text { of } \\
p l a g i o c l a s e\end{array}$ & $\begin{array}{l}N_{\omega} \text { of } \\
\text { beryl }\end{array}$ \\
\hline $\begin{array}{r}174 \\
250 \\
279 \\
289 \\
436 \\
454 \\
455 \\
535 \\
847 \\
989 \\
1002 \\
1025 \\
1044 \\
1202 \\
1402\end{array}$ & $\begin{array}{l}1.529 \\
1.530 \\
1.531 \\
1.529 \\
1.529 \\
1.529 \\
1.529 \\
1.534 \\
1.533 \\
1.530 \\
1.531 \\
1.529 \\
1.529 \\
1.530 \\
1.537\end{array}$ & $\begin{array}{l}1.580 \\
1.576 \\
1.578\end{array}$ & $\begin{array}{l} \\
\text { (1) } 1.532 \\
\text { (2) } 1.535 \\
\text { (1) } 1.528 \\
\text { (2) } 1.530\end{array}$ & 1.578 & $\begin{array}{l}1.528 \\
1.529 \\
1.530 \\
1.529 \\
1.529 \\
1.539 \\
1.529 \\
1.530 \\
1.531 \\
1.530 \\
1.530\end{array}$ & $\begin{array}{l}1.580 \\
1.579 \\
1.578 \\
1.577 \\
1.578 \\
1.579 \\
1.580 \\
1.578 \\
1.578 \\
1.575 \\
1.578\end{array}$ \\
\hline
\end{tabular}

Refractive indices of beryz and plagioclase from layered pegmatites have not been published. Table 3 , gires the refractive indices of these two minerals in 12 two-layered pegnatites. These pegmatites contain an upper layer of perthite-rich rock and a lower layer of albite-rich rock. Most of the beryl is found in the coarser-grained upper layer; in two pegmatites it occurs in both layers. In these two pegmatites the beryl showed essentially no change in refractive index between units.

Beryl is associated with plagioclase, quartz, perthite, mascovite, garnet, lepidolite, tourmaline, topaz, microlite, tantalite, monazite, gahnite, and biotite. Beryl is not associated with any one of these pegmatite minerals to the exclusion of the others. It has not, however, been found in graphic granite pegmatite, Beryl usually is in clusters or groups of crystals; in many pegmatites only three or four closely spaced crystals 
are found. In pegmatite No. 279,35 crystals of beryl were found in an area about 2 feet square. This was the only beryl noted, although this brenching pegmatite exceeds 720 feet in length. Many other pegrnatites have a sinilarly spotty distribution of beryl.

Table 13.--Refractive inaices of plagioclase and beryl from beryl-bearing layered pegmatites

\begin{tabular}{|c|c|c|c|c|}
\hline \multirow{2}{*}{$\begin{array}{c}\text { Pegrnatite } \\
\text { No. }\end{array}$} & \multicolumn{2}{|c|}{ Lower Iayer } & \multicolumn{2}{|c|}{ Upper layer } \\
\cline { 2 - 5 } & $\begin{array}{c}N_{\alpha} \text { of } \\
\text { plagioclase }\end{array}$ & $\begin{array}{c}N_{\omega} \text { of } \\
\text { beryl }\end{array}$ & $\begin{array}{c}N_{\alpha} \text { of } \\
\text { plagioclase }\end{array}$ & $\begin{array}{c}N_{\omega} \text { of } \\
\text { bery } 1\end{array}$ \\
\hline 270 & 1.530 & & 1.528 & \\
417 & 1.529 & 1.577 & 1.530 & 1.577 \\
432 & 1.530 & & 1.529 & 1.576 \\
433 & 1.530 & & 1.530 & 1.577 \\
435 & 1.529 & & 1.529 & 1.575 \\
462 & 1.529 & & 1.529 & 1.578 \\
548 & 1.529 & & 1.529 & 1.576 \\
778 & 1.535 & & 1.535 & \\
985 & 1.530 & 1.578 & 1.530 & 1.577 \\
1004 & 1.529 & & 1.529 & \\
1105 & 1.530 & 1.579 & 1.531 & \\
1172 & & & 1.529 & \\
\hline
\end{tabular}

Tourmaline

Tourmaline is relatively rare in the Quartz Creek district, and has been found in only 48 of the 1,803 pegmatites studied. In many pegmatite areas tourmaline is present in nost pegmatites, but the Quartz Creek district is distinctive for its lack of tourmaline and the low boron content of its pegmatites. Ixcept in the lithium-bearing pegmatites, only a few grains occur in each pegmatite. Some units in the lithium-bearing pegmatites contain as much as 3 percent tourmaline.

The tourmaline is black, dark green, blue, light green, and pink. The green, blue, and pink varieties are found only in the lepidolite-bearing pesmatites; the black variety occurs in both lepidolite- and non-lepidolite- 
bearing pegmatites. Of the 48 tourmaline-bearing pegmatites 38 contain only the black variety. It occurs in subhedral to anhedral crystals; commonly the $\mathrm{m}(10 \overline{10})$ and $a(11 \overline{20})$ prism faces are the only faces developed. In many places it is in small pods of coarse-grained quartz or quartz-perthite pegrnatite in an otherwise homogeneous body. Blacir tourmaline has been found associated with quartz, perthite, albite, muscovite, beryl, garnet, cleavelandite, biotite, monazite, columbite-tantalite, and gahnite, but not with lepidolite and topaz.

The black tourmaline was found only in outer zones, completely free of lepidolite; in many zones it is restricted to the extreme hanging-wall or footwall part. Dark-green tourmaline was found either in zones containing lepidolite or the adjacent zones. It is common in the outer part of lepidolite-bearing units and the inner part of the adjacent unit. It is nowhere in contact with lepidolite, but occurs in the cleavelandite-quartz part of the zones. Pini and pale-green tourmaline occur adjacent to lepidolite in lepidolite-bearing units. These two varieties of tournaline commonly occur together; the pink variety is more abundant. In the Brown Derby No. I pegmatite (No. 452) these varieties are together as "watermelon" tournaline, in crystals which have a pink core and light-green rim. The dark blue variety of tourmaline is not present as individual crystals, but forms massive wavy bands in lepidolite-bearing pegmatites where it occurs in part with the black tourmaline and in part with the dark-green tourmaline. There is commonly a thin band of small garnets in the center of the blue bands. Figure 15, a sketch of part of pegmatite No. 453, shows the relation of various colored tourmalines to the pegmatite units.

The indices of refraction vary as well as the color. Table 14 gives the higher refractive index $\left(\mathrm{N}_{\omega}\right)$ of 19 tourmaline specimens; eleven are of 
black tourmaline and range from 1.652 to 1.664 . The two specimens with the lowest refractive indices are from the outer edges of lithium-bearing pegmatites. Three dark-green tourmaline specimens have refractive indices of 1.646 and 1.647 , all lower than black tourmaline. The black variety grades into the dark-green variety and it is to be expected that, if enough determinations of indices were made, a gradational series would be formed, with the green varieties having the lower refractive indices. Two pink tourmaline specimens from different pegmatites have refractive indices $\left(N_{\omega}\right)$ of 1.643 and 1.637 . A pale-green tourmaline and a pink tourmaIine from adjacent areas in pegmatite No. 452 have a refractive index for the slow ray of 1.637 ; the pink core and the pale-green rim of a "watermelon" tourmaline had a refractive index for the slow ray of 1.634 . The pale-green and pink varieties appear to vary in composition and variation can not be correlated with color. The different colors may be caused by either the presence of a minor element that does not affect the rePractive indices, oxidation or reduction of an element in different states of oxidation, or to a slight rearrangement of the molecular structure of tourmaline. The sequence from black tourmaline on the outer parts of lepidolite-bearing pegmatites to pale-green and pink tourmaline in the lepidolite-bearing part can be correlated with a progressive change in refractive indices, but the pale-green and pink crystals which grew together in the same environnent without detectable changes in index can not. 
Table I 4 --Refractive index $\left(\mathbb{N}_{\omega}\right)$ of toumaline, Quartz Creel district

\begin{tabular}{|c|c|c|c|}
\hline Pegnatite No. & Pefmetite Mame & Color & II \\
\hline 205 & & Black & 1.657 \\
\hline 215 & Opportunity No. 1 & Black & 1.652 \\
\hline 231 & & Black & 1.657 \\
\hline 251 & & Black & 1.657 \\
\hline 306 & Opportunity No. 4 & Black & 1.655 \\
\hline 311 & & Black & 1.663 \\
\hline 1238 & & Black & 1.657 \\
\hline 1238 & & Black & 1.659 \\
\hline 1278 & & Black & 1.6555 \\
\hline 1322 & & Black & 1.664 \\
\hline 1607 & & Black & 1.664 \\
\hline 215 & Opportunity No. I & Dark Green & 1.646 \\
\hline 306 & Opportunity No. 4 & Dark Green & 1.647 \\
\hline 306 & Opportunity No. 4 & Dark Green & 1.646 \\
\hline 306 & Opportunity No. 4 & Pink & 1.643 \\
\hline 452 & Brown Derby No. I & Pink & 1.637 \\
\hline 452 & Brown Derby No. I & Pale Green & 1.637 \\
\hline 452 & Brown Derby No. I & $\begin{array}{l}\text { (Pale Green } \\
\text { rim) } \\
\text { (Pink center) }\end{array}$ & 1.634 \\
\hline
\end{tabular}

Farly work has shown that change in color in tourmaline commonly varied with the density of the crystals $J$, the axial ratio a:c $/$, and the re-

I D'Achiardi, A., Mineralogia della Toscana, Pisa, 1872.

J D'Achiardi, $G_{\varphi}$, Ie tourmaline del graniteo elbano: Atti della soc. Toscana di Scienze Naturali, Memorii 15, 1896.

fractive indices. Color also was shown to vary with the chemical composition by more recent spectrographic work $/$; Carobbi and Pieruccini I con-

J Warner, T. W., Spectrographic analysis of tourmalines with correlar tion of color and composition: Am. Mineralogist, vol. 20, pp. 531-536, 1935.

J Carobii, G., and Piemccini, $R_{n}$, Spectrographic analysis of tourmam lines from the island of Ilba with correlation of color and composition: Am. Mineralogist, vol. 32, pp. 121-130 1947.

clude from their studies that the pink color is caused by manganese with lithiun and cesium. In the Quarti Creek district, manganese is present in most units but appears to be concentrated in the outer zones as indicated 
by the higher concentration of garnets. The presence of manganese it a unit does not insure that the tourmaline will be pink, though the pink variety usually is high in manganese. Shainin $J$ had spectrographic analyses made

J Shainin, V. I., Unpublished analyses of tourmaline from NewryRumford area, Maine.

of the minor base elements in four tourmaline specimens (table 15). These analyses show that the greatest amount of manganese ( 0.5 percent) occurs in a pink specimen and that all specimens contain manganese but that another pink specimen contains no more manganese than the green and blue specimens.

Table 15.-Spectrographic determination of minor elements in tourmaline from Maine I]

\begin{tabular}{|l|c|c|c|c|c|c|}
\hline Color & Mn & Ti & Ga & Sn & Pb & Zn \\
\hline Deep blue & .2 & .01 & .02 & .01 & $<.001$ & .5 \\
Green & .2 & .005 & .02 & .05 & .02 & .1 \\
Plnk & .5 & $<.001$ & .02 & .01 & -02 & .2 \\
Deep pink & .2 & $<.001$ & .01 & .05 & .05 & .02 \\
\hline
\end{tabular}

If Analysis made in the Investigations Section of the Geochenistry and Petrology Branch of the U, S. Geological Survey for Vincent Shainin. Janet Fletcher, Analyst.

Iithium and cesium are both more abundant in the lepidolite units, lithium is a major component ano cesium a minor component. Stevens $\perp$ in an $J$ Stevens, $R_{0} \vec{\Sigma}_{n}$, New analyses of lepidolites and their interpretam
tion: Am. Mineralogist, vol. 23, p. 615, 1938. article on lepidolites gives the analyses of 17 lepidolites from widely scattered districts in which $\mathrm{Cs}_{2} \mathrm{O}$ ranged from 0 to 0.67 percent; the average was 0.23 percent. These analyses show that cesium is concentrated in appreciable amounts with the Iithia, and that the two are comparatively abundant in those parts of the pegmatite where the pink and pale-green varieties of 
tournaline occur. The coloring elenents are difficult to deternine because of the large number that are present in minor amounts in tourmaline. Tourmaline acts as a scavenger and takes into its structure small quantities of a great variety of elements.

A list compiled from the spectrographic work of Shainin $J$, de Azcona $J$, Maine.

J Shainin, V. I., Unpublished analyses from Newry-Rumford area,

I de Azcona, J. M. I., Is there lead of radioactive origin in tourmaIine: Report of the Committee on the Measurement of Geologic Time 1943$1944-1945-1946, \mathrm{p} .61,1947$.

Carobbi and Piemccini $J$, and Warner $/$ includes the following 30 elements

$J$ Carobbi, G., and Pieruccini, R., op. cit., p. 123, 1947.

$\checkmark$ Warner, T. W., op. cit., p. 535, 1935 .

found in tourmaline: $\mathrm{B}, \mathrm{Si}, \mathrm{AI}, \mathrm{Ti}, \mathrm{Fe}, \mathrm{Ni}, \mathrm{Mg}, \mathrm{Mn}$, Cu, $\mathrm{Ca}, \mathrm{Na}, \mathrm{K}, \mathrm{Ba}, \mathrm{Ii}$, $\mathrm{Sr}_{\mathrm{r}} \mathrm{Cs}, \mathrm{Be}, \mathrm{V}, \mathrm{Ta}, \mathrm{Sc}, \mathrm{Sn}, \mathrm{Ce}, \mathrm{Ga}, \mathrm{Pb}, \mathrm{Zn}, \mathrm{Cr}, \mathrm{Co}, \mathrm{Se}, \mathrm{Ag}$, and $\mathrm{Sb}$. Some of these elements are reported in tourmaline from only one area, while others are almost universal. The presence of some of these elements depends on whether or not they were available in the pegmatitic liquid at the time the tourmaline was formed.

Many elements appear to have little or no effect on the color of tourmam line as they are present in some colored tourmalines and absent in others. Other elements may be responsible for a change in color only when found together with some other element:

In résumé, all tourmalines in the Quartz Creek district other than the black variety are in the lepidolite-bearing pegmatites. There is a gradual color change from black through blue and dark green to pink and light green paralleled by a change in refractive indices as the lepidolite-bearing parts of the pegmatite are approached. Changes in the concentration of a group 
of allelies, such as lithia, cesia, and probably others parallel the changes In color of the tourmalines. The enount of alkalies probably is responsible For the color change and these elenents probably have a greater aifinity For the tourneline structure then meny metallic elements. Iron and nengenese are usually equelly availeble in nost pemmatite units. When iron is ellowed into the stmucture it helps to darken the mineral to black or dark green, but the development of the lighter shades demands the presence of lithia and other allalies. The various shades of green and blue are probably cav.sed. by the presence of vorious other elements.

\section{Colurabite-tantalite}

Columbite-tantalite has been found in 29 pegmatites of the Quartz Creek district. It occurs in homogeneous pegnatites; wall zone, intermediate zone, and core of zoned pegmatites; layered pegnatites; and in parts of pegnetite which show variation along strike. These columbite-tantalitebearing pegmatites are widely scattered over the entire district. Columbite-tantalite is found in only a few crystals in most pegmatite: units except in pegmatites No. 1234 and No. 452 (Brow Derby No. 1). In the latter pegmatite it makes up 1.4 percent of the rock in a small unit about 20 feet long and I foot wicie.

In the Quartz Creek district the colunbite-tantalite is black with a duIl to Iustrous surface. It has a black to brown streak. The tabular crystals renge from the thiclmess of a sheet of paper to $I$ inch and are from a fraction of an inch to 4 inches lone. The crystals are usually subhedral to euhedral with the brachipinacoid, $b(010)$, forming the tabular faces present in most specimens. Other faces which were noted on sorne of the colunbite-tentalite crystals are: $a(100), d(110), g(130), \underline{r}(011)$, and. $u(I I I)$. 
The columbite-tantalite: $(\mathrm{Fe}, \mathrm{Mn})(\mathrm{Cb}, \mathrm{Ta})_{2} \mathrm{O}_{6}$, series is one of complete gradation between iron and manganese, and colurnium and tantalurn. Members of this series are divided on purely arbitrary standards with the columbite consisting of that part of the series where columbium exceeded tantalum in amount, and the tantalite part of the series where tantalum is in excess. A secondary division is made in these two main divisions by naming the mineral ferrocolumbite or ferrotantalite if the ratio of iron to manganese is greater than 3:1, and nanganocolumbite or manganotantalite if the ratio of manganese to iron is in excess of 3:1, The specific gravity, the streak $J$, and prob-

J De Almeida, S. C., Johnston, W. D., Leonardos, O. H., and Scorza, I. P., The beryl-tantalite-cassiterite pegmatites of Paraiba and Rio Grande do Norte, Northeastern Brazil: Icon. Geology, vol. 32, D. 218, 1944 .

ably certain other physical properties vary with the columbium and tantalum content. Because chenical analysis of these two elements is expensive, the epproximate composition is obtained by specific gravity determinations and reference to charts that related the specific gravity to the columbiumtantalum ratio. The retio of iron to manganese has only a minor effect on the change of gravity, and the higher the specific gravity the higher the tantalum content. Table 16 gives the specific gravity of 8 specimens from the Quartz Creek district as determined on a Jolly balance. These specimens range from an almost pure manganocolumbite (specific gravity 5.0 and 5.1 ) to a columbium-rich tentalite (specific gravity of 6,7). As only the latter specimen falls in the tantalite fields this district appears to be one that contains columbite alnost to the exclusion of tantalite. Fanley I gives the $\int$ Hanley, J, B., et als op. cito, $p_{n} 71,1950$ specific gravity of a piece of columbite-tantalite from pegmatite No. 452 (Brown Derby No. I claim) as 5.61 and the chemical composition of 72 percent $\mathrm{Cb}_{2} \mathrm{O}_{5}$ and 6 percent $\mathrm{Ta}_{2} \mathrm{O}_{5}$. 
The spgcimen on which the chemical work was done was collected by Ickel _/,

_ Icirel, I. B., op. cit., p. 244, 1933.

and was a different specimen from a different pegmatite unit from the Hanley specinen. Because the columbium-tantalum ratio commonly varies from zone to zone and evidently does on the two specimens used, the agreement is not good between the composition obtained from the specific gravity and that given by EckeI.

Table 16.-Measurements of specific gravity on columbite-tantalite

\begin{tabular}{|c|l|c|}
\hline Pegmatite Iuriber & Internal Unit & Specific gravity \\
\hline 205 & Core & 6.1 \\
205 & Core & 6.3 \\
245 & Core & 5.7 \\
452 & Layer & 5.8 \\
1234 & Wall zone & 5.0 \\
1234 & Wall zone & 5.1 \\
1557 & Core & 6.7 \\
1.574 & Intermediate & 6.0 \\
& zone & \\
\hline
\end{tabular}

Columbite-tantalite is found in direct contact with the following minerals in one or more pegmatites: quartz, albite, perthite, beryl, muscovite, monazite, biotite, tourmaline, and gahnite. It also has been found in the same zones, but not in direct contact with: garnet, topaz, microIite, martite, and lepidolite. Though it is associated vith almost all the pegmatite minerals, there are three associations which are most common in the Quartz Creek district: (1) with massive quartz...(2) with cleavelandite or cleavelandite and quartz, and (3) with feldspar (either perthite or plagioclase) and monazite. That its association with monazite is not pure happenstance can be seen in that 9 of the 24 monazite-bearing pegma- 
tites, or 37 percent, contain columbite-tantalite (fig. I9).

Monazite

Monazite, (Ce, Ia, $\mathbb{1 T d}, \mathrm{Pr}_{\mathrm{r}} \mathrm{PO}_{4}$, is found in 24 , or approximately 1.5 percent of the pegmatites. It occurs in homogeneous pegmatites; cores, pods, and. intermediate zones in zoned pesmatites; and in layered pegmatites. In three pegmatites, namely the Brown Dexby No. 1 (No. 452), the Black Woncer (No. 847), and the Bucky (No. 1574), monazite is found in more than a half-dozen crystals. A unit 20 feet long and I foot vide at the Brom Derby No. I, pegmatite No. 452, contains aporoximately 27 percent. of two localities in the Black Wonder pegmatite (No. 847), one is worth special attention in that it contains 0.05 percent monazite in an intermediate zone of plagioclase-mscovite-quartz pegmatite surrounding a quartz pod. This intermediate zone is about 4 feet thick, and the quertz pod.is approximately 15 feet long and 6 feet wide. In the Bucky pegmatite (No. 1574) the monazite occurs erratically in the mica zone around the quartz core.

Monazite occurs as euhedrel, darik-red to clove-brown crystals, that range in size from 0.25 inch long, 0.12 inch wide, and 0.03 inch thick to 2 inches Iong, 1.5 inches vide, and 0.5 inch thick. Most of the Iarger specimens come from the Brown Derby Mo. 1. Crystal forms identified include the $a(100), \mathrm{n}(110), \mathrm{n}(120), \mathrm{v}(111), \mathrm{r}(111), \mathrm{x}(101), \mathrm{c}(001)$, and $\mathrm{h}(305)$ faces. The crystals are usually flattened parallel to the a(100) face, end sone of them are also twinned parallel to this face.

The specific gravity of the monazite varies from 5.0 to 5.6 , as determined by the Jolly balance.

Optically, the monazite is colorless to yellow, with high bire- 
fringence. The lower index of refraction, $(\mathbb{N} \alpha)$, ranges from 1.78 to 1.80 , averaging about 1.79. Table 17 shows that the specific gravity and lower

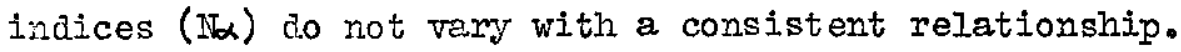

In the Quartz Creek district monazite is associated with quartz, albite, perthite, nuscovite, columbite-tantalite, gahnite, biotite, and garnet. It usually is found, however, in a feldspar-rich part of the pegmar tite, and comnonly produces a red stain in the feldspar imnediately adjacent to it. Of the 24 pegratites containing monazite, 9 also contain colurabite-tanteliten

Table 17.--Lower inaex of refraction $\left(\mathbb{N}_{\alpha}\right)$ and the specific gravity of monazite

\begin{tabular}{|c|c|c|c|}
\hline Pegriatite Inuber & Internal unit & $\begin{array}{c}\text { Index of refraction } \\
\left(N^{n} \times\right)\end{array}$ & $\begin{array}{l}\text { Specific } \\
\text { gravity }\end{array}$ \\
\hline $\begin{array}{l}452 \\
290 \\
347 \\
847 \\
997\end{array}$ & $\begin{array}{l}\text { Pod } \\
\text { Pod } \\
\text { Pod } \\
\text { Intermediate } \\
\quad \text { zone } \\
\text { Footwall layer }\end{array}$ & $\begin{array}{l}1.80 \\
1.79 \\
1.78 \\
1.78\end{array}$ & $\begin{array}{l}5.3 \\
5.1 \\
5.1 \\
5.6 \\
5.3\end{array}$ \\
\hline
\end{tabular}

Lepidolite

Lepidolite is found in 17 pegmatites, comprising homogeneous pegmatites, coro, and intemedinte zones of zoned pegnetites, interior layers of layered pegmatites and in parts of pegmatites which show variation in composition along strilse. Thus, no perticular type of pegrnatite seems to be favored. In the limited muver of zoned pegmatites it appears to be commonest in the central parts.

The lepidolite is white, lilac, or various shades of purple; Iilac to purple varieties are most common. It has three forms: (I) finegrained aggregates with individual sheets less than 0.25 inch in dianeter, 
(2) large platy books 2 to 10 inches in diameter, and (3) curved concentric books, 0.5 to 2 inches across (pl. X). The large-plate lepidolite is found in 5 of the 17 pegmatites and form a group between the Brown Derby No. 1 dike (No, 452) and the Brown Derby No. 5 dike (No, 535), a maximum distance of 2,200 feet. Only three pegmatites on the Brown Derby No.l claim (No. 452, 454, and 457) have curved lepidolite. The plate and curved lepido ite are either purple or lilac. An analysis is reported by Stevens $J$ on large

J Stevens, R. I., New analyses of lepidolites and their interpretation: Am. Mineralogist, vol. 23, p. 615, 1938.

tis

plates of pale-purple lepidolite from Ohio City. The sample probably came from either dikes No. 452, No. 453, or No. 454 (Brown Derby No. I claim), as these dikes were the only ones that had been developed at the time containing lepidolite in large plates. The analysis follows:

$\begin{array}{lclr}\mathrm{Ii}_{2} \mathrm{O} & 5.05 & \mathrm{MgO} & \text { None } \\ \mathrm{SiO}_{2} & 49.58 & \mathrm{MnO} & 2.78 \\ \mathrm{Al}_{2} \mathrm{O}_{3} & 23.87 & \mathrm{TiO}_{2} & 0.06 \\ \mathrm{~K}_{2} \mathrm{O} & 10.14 & \mathrm{~F}_{2} \mathrm{O} & 0.51 \\ \mathrm{NaO} & 0.57 & \mathrm{H}_{2} \mathrm{OH} & 1.22 \\ \mathrm{CaO} & \mathrm{None} & \mathrm{F} & \frac{7.49}{103.19} \\ \mathrm{Rb}_{2} \mathrm{O} & 1.62 & & \frac{3.15}{100.04} \\ \mathrm{Cs}_{20} & 0.09 & \text { Less } \mathrm{O}=\mathrm{F} & \end{array}$

1) Total iron reported as Feo.

The formula for this lepidolite as determined from the analysis is $\mathrm{K}_{4} \mathrm{II}_{7} \mathrm{AI}_{5} \cdot \mathrm{AI}_{2} \mathrm{Si}_{15} \mathrm{O}_{40}(\mathrm{~F}, \mathrm{OH})_{8}$. Hanley / reports that the physical and

Falley: J. B., Heinrich, $\boldsymbol{I}_{\text {. W. }}$, and Page, $I_{0} \mathrm{R}_{0}$, Pegnatite inves tigations in Colorado, Wyoming, and Utah: U. S. Geol. Survey Prof. Paper 227, p. 72, 1950.

optical properties of all the lepidolite from the Brown Derby claim (pegmatites No. 452, No. 453, and No. 454) are similar and the only chemical difference is that the manganese content of the large plates is slightly 
UNITESD STATES

DEPARTMENT OF THE INTERIOR

GEOLOGICAL SURVEY
105

TRACE FIWFIENTS INVESTIGATIONS

REPORT 138

Plate $\mathbf{X}$

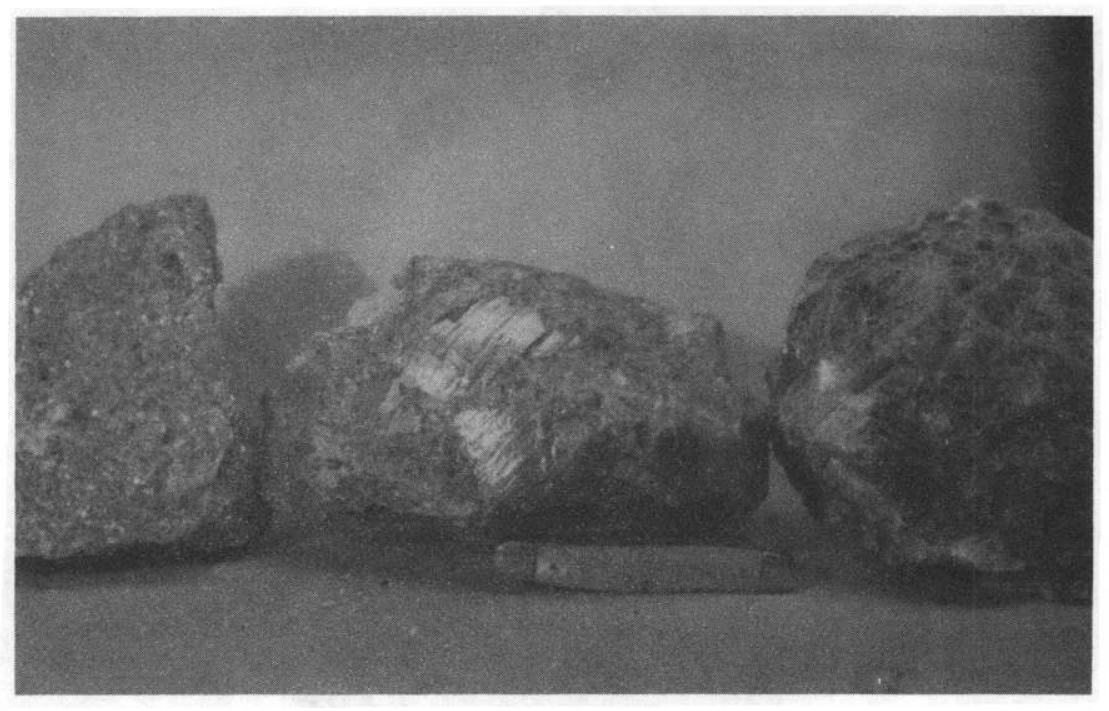

Lepidolite from left to right: fine-grained aggregate, curved plates, and large plates. 
higher. Winchell $J$ in a triangular diagram shows that the median index of J Winchell, A. N., Ilements of Optical Mineralogy: Part II, 3d ed., p. 27I, 1927.

the lepidolite group of mica increased from the poiythionite $\left(\mathrm{H}_{2} \mathrm{~K}_{2} \mathrm{Ii}_{3} \mathrm{Al}_{3} \mathrm{Si}_{8} \mathrm{O}_{24}\right)$ and lepidolite $\left(\mathrm{H}_{4} \mathrm{~K}_{2} \mathrm{Li}_{3} \mathrm{Al}_{5} \mathrm{Si}_{6} \mathrm{O}_{24}\right)$ end members to the protolithionite end member, $\left(\mathrm{H}_{4} \mathrm{~K}_{2} \mathrm{IiFe}_{4} \mathrm{Al}_{3} \mathrm{Si}_{6} \mathrm{O}_{24}\right)$. This increase of refractive index is in general paralleled by an increase of iron and a decrease of lithium and can be used to determine the approximate $\mathrm{Ii}_{2} \mathrm{O}$ content. The median index $\left(N_{\beta}\right)$ of 14 lepidolite specimens from six different pegmatites (table 18) ranged from 1.555 to 1.578 . Six specimens are white, or white with just a tinge of lilac, and these specimens have the highest indices $(1.560,1.564,1.564,1.565,1.575$, and 1.578). The two specimens with the 1.575 and the 1.578 median index give a strong qualitative test for iron, and fall well in the range of zinnwaldite rather than true lepidolite. The other four lepidolite specimens with high refractive indices are probably between lepidolite and zinnwaldite in composition. Three specimens of bool lepidolite had median indices of $1.557,1.559$, and 1.562 and one specimen of curved lepidolite had a median index of 1.560. These values average only a little higher than the purple lepidolite occurring in finegrained aggregates and show that the chemical corroosition of the different forms vary only to a minor extent. The shape and size of lepidolite gives no clue as to its chemical composition or optical properties. The best guide noted was color, with the paler and whiter forms having higher refractive indices and less lithia. 
Table 18.--Median refractive index $\left(\mathbb{N}_{\beta}\right)$ and description of lepidolite from Quartz Creek district

\begin{tabular}{|c|c|c|c|}
\hline Eegrnatite No. & Pegmatite Name & $N \beta$ & Description \\
\hline 208 & & 1.578 & White (1/4-1/8 inch sheets). \\
\hline 215 & Opportunity No. 1 & 1.565 & $\begin{array}{l}\text { White with lilac tinges } \\
\text { elongate ( } 3 / 4 \text { inch) blades } \\
\text { in a radial aggregate }\end{array}$ \\
\hline $\begin{array}{l}306 \\
306\end{array}$ & $\begin{array}{l}\text { Opportunity No. } 4 \\
\text { Opportunity No. } 4\end{array}$ & $\begin{array}{l}1.55 ? \\
1.558\end{array}$ & $\begin{array}{l}\text { Lilac, } 1 / 4-1 / 2 \text { inch sheets } \\
\text { Purple, fine-grained ag- } \\
\text { gregates ( } 1 / 32 \text { inch sheets) }\end{array}$ \\
\hline 306 & Opportunity No. 4 & 1.564 & $\begin{array}{l}\text { White with lilac tinge } \\
\text { (1/4 inch sheets) }\end{array}$ \\
\hline 452 & Brown Derby No. 1 & 1.557 & $\begin{array}{l}\text { Purple, fine-grained ag- } \\
\text { gregates ( } 1 / 16 \text { inch sheets) }\end{array}$ \\
\hline 452 & Brown Derby No. I & 1.555 & $\begin{array}{l}\text { Purple, fine-grained ag- } \\
\text { gregates ( } 1 / 8 \text { to } 1 / 4 \text { inch } \\
\text { sheets) }\end{array}$ \\
\hline 452 & Brown Derby No. 1 & 1.559 & $\begin{array}{l}\text { Lilac, book lepidolite } \\
\text { (6-inch sheets) }\end{array}$ \\
\hline & Brown Derby No. I & 1.560 & $\begin{array}{l}\text { Purple, curved lepidolite } \\
\text { (1 to } 2 \text { inch curved books) }\end{array}$ \\
\hline 461 & & 1.562 & $\begin{array}{l}\text { Furple, book lepidolite } \\
\text { ( } 2 \text { inch sheets) }\end{array}$ \\
\hline 535 & Brown Derby No. 5 & 1.560 & $\begin{array}{l}\text { Silvery white blades } \\
(1 / 4-1 / 2 \text { inch sheets })\end{array}$ \\
\hline 535 & Brown Derby No. 5 & 1.564 & $\begin{array}{l}\text { White, fine-grained } \\
\text { aggregate ( } 1 / 16 \text { inch sheets) }\end{array}$ \\
\hline 535 & Brown Derby No. 5 & 1.557 & $\begin{array}{l}\text { Lilac book lepidolite } \\
\text { ( } 5 \text { inch sheets) }\end{array}$ \\
\hline 637 & & 1.575 & $\begin{array}{l}\text { White (in aggregate with } \\
1 / 8-1 / 4 \text { inch sheets) }\end{array}$ \\
\hline
\end{tabular}

Lepidolite is found in anounts that range from a trace to 95 percent. Only the Brown Derby No. I (No. 452) has units containing lepidolite in excess of 10 percent of the rock, the White Spar No. 2(No. 602) has lepidoIite naking up 6 to 10 percent of the rock, and all others contained smaller proportions, The units, that contain lepidolite and are commonly lens shaped, are usually small; several are less than 15 feet. long. The Brown Derby No. 1 pegmatite (No. 452) contains by far the largest lepidolite body. This unit is 319 feet long.

Lepidolite was associated with the following minerals: cleavelandite, 
quartz, muscovite, perthite, topaz, beryl, microlite, albite, pink and green tourmaline, columbite-tantalite, and apatite. Cleavelandite, the usual form of albite found with lepidolite, is its cormonest associate. In two small pods the lepidolite is white and probably zinnwaldite. Topaz, microlite, and colored tourmaline characterize the lepidolite units and are rarely found outside of them.

Lepidolite in many places grows ir compact aggregates with cleavelandite or quartz; these minerals appear to have crystallized simultaneously. In other places, lepidolite veins and cuts cleavelandite, quartz, and perthite. Topaz commonly is surrounded by a rim of lepidolite that may be in part a product of reaction with the remaining liquid. Lepidolite appears to have been deposited late in the course of crystallization because in zoned pegmatites it is confined to the core where it is in part contemporaneous with the quartz and cleavelandite, and in part of later age.

\section{Pyrochlore-microlite}

Pyrochlore-microlite is found in 14 pegmatites, all on the east side of Quartz Creek. It does not oc cur in homogeneous pegmatites, wall zone of zoned pegmatites, or the hanging-wall layer of layered pegmatites; but it is found in the intermediate zone and cores of zoned pegmatites, interior and lower layer of layered pegmatites, and units of pegmatites which change in composition along strike. The most favorable place is the core of zoned pegmatites, as 7 of the 14 pegmatites that contain pyrochlore-microlite occur in this unit. Pyrochlore-microlite commonly occurs in a few scattered crystals, except in pegmatite No. 217 (Opportunity No. I claim) and pegmatite No. 452 (Brown Derby No. 1). In pegmatite No. 217 it occurs in concentrations of 10 or 12 crystals in cleavelandite and quartz, whereas 
pegmatite No. 452 contains 0.35 percent microlite $/$ in a central lepidolite 」 Hanley, J. B., et al., op. cit., p. 73, 1950.

unit.

Pyrochlore-microlite is light yellow, light greenish yellow, olive green, light brown, or dark brown. The crystals are from 0.01 to 0.4 inch in diameter. In massive fine-grained lepidolite the crystals are anhedral, but in quartz and cleavelandite they are euhedral with well-developed to distorted octahedrons, o(111), and modified dodecahedrons, d(110).

Fyrochlore is essentially $\mathrm{NaCaCb}_{2} \mathrm{O}_{6} \mathrm{~F}$, and microlite is essentially $(\mathrm{Na}, \mathrm{Ca})_{2} \mathrm{Ta}_{2} \mathrm{O}_{6}(\mathrm{O}, \mathrm{OH}, \mathrm{F})$. The two species form an isomorphous series with the columbium-rich members called pyrochlore and the tantalum-rich members microlite. Besides the elements given in the above formulas, oxides of some of the following elements may comprise several percent of the minerai: $\mathrm{K}, \mathrm{Mg}, \mathrm{Fe}, \mathrm{Mn}, \mathrm{Sb}, \mathrm{Ce}, \mathrm{La}, \mathrm{Di}, \mathrm{Er}, \mathrm{Y}, \mathrm{Th}, \mathrm{Zr}, \mathrm{U}, \mathrm{Ti}, \mathrm{Sn}$, and $\mathrm{W}$.

Considerable work has been done on the microlite from the Brown Derby No. I (pegmatite No. 452), especially during World War II, when it was mined along with the lepidolite. An analysis of microlite from this pegmatite by J. G. Fairchild has been previously reported $y$ and is given below:

/ Eckel, ‥ B., and Lovering, T. S., Work of Eckel, Lovering, Fairchild, Microlite from Ohio City, Colorado: Report of the Committee on the Measurement of Geologic Time, pp. 78-79, 1935. 


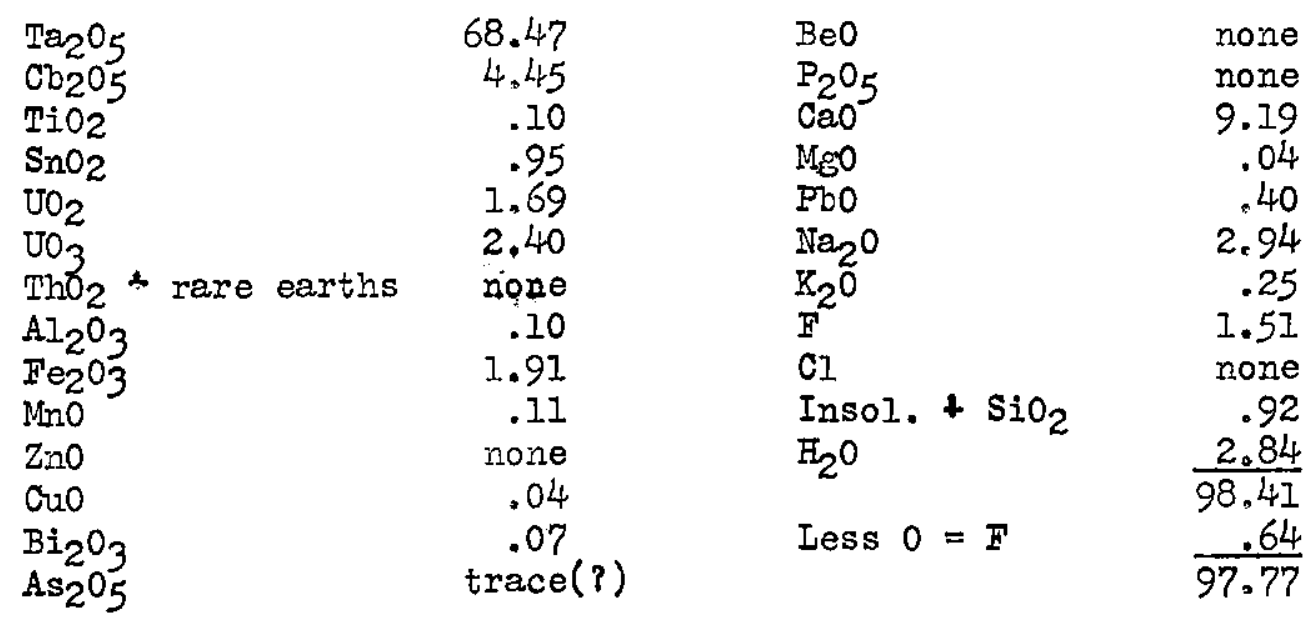

The specific gravity of this material is 5.604 , and its index of refraction, as determined by $J$. J. Glass of the Geological Survey, is close to 1.93. This analysis indicates that the mineral is microlite having a high ratio of tantalun to columbium. As would be suspected from the uranium content this mineral is highly radioactive and cain be easily detected with a Geiger-Muelier counter.

The material from the Brown Derby No. 1 pegmatite (No. 452) is dark brown to light brown. An olive-green specimen from the Brown Derby No. 5 pegnatite (No. 535) was analyzed spectrographically, and it was found that the tantalum was more abundant than the columbium. This specimen is also on the microlite side of the series. It gave a positive test with the Geiger-Mueller counter, but not as strong as that given by the dari-brown variety.

One light-greenish-yellow specimen from pegmatite No. 461 gives no reaction to the Geiger-Mueller counter. The dark color of the pyrochloremicrolite may be caused by the radioactivity of the uranium, as are the brown halos surrounding the dark pyrochlore-microlite in the lepidolite. Similar observations were made by Adams $I$ at the Harding mine near

\footnotetext{
J Adams, J. W., Personal communication.
} 
Dixon, $\mathbb{N}$, Mex., where he found that light microlite was not radioactive but dark microlite was.

Pyrochlore-microlite is associated in the Quartz Creek district, with: cleavelandite, lepidolite, quartz, and muscovite. The two types of occurrences are: (I) with massive fine-grained lepidolite, and (2) with cleavelandite and smoky quartz. In eight pegmatites it occurs in lepidolite and in six in cleavelandite and quartz. In most places, where it occurs in lepicolite, cleavelandite is present in minor amounts; where it occurs in cleavelandite, lepidolite is a minor constituent. Lepidolite is present in 12 out of the 14 pyrochlore-microlite-bearing units, and cleavelandite in 13. The occurrence of pyrochlore-microlite with either lepidolite, cleavelandite, or both, is common in pegmatites in other areas. It occurs with lepidolite and cleavelandite at the Bob Ingersoll mine, Penfield County, S. Dak, with cleavelandite and lepidolite at the Tin Mountain mine, Custer County, S. Dak., with cleavelandite and a lithium mica in the Harding mine, near Dixon, N. Mex. $J$, with cleavelandite at the

J Adams, J. W., Personal communication.

Rutherford and Morefield mines, near Amelia, Va. J, and with lepidolite J Glass, J. J., The pegmatite minerels from near Amelia, Virginia: An. Mineralogist, vol. 20, p. 753, 1935.

and albite (type not defined) from a pegmatite at Topsham, Maine $J$.

J Palache, C., and Gonyer, F. A., Microlite and stibiotantelite from Topsham, Maine: Am. Mineralogist, vol. 25, p. 412, 1940. 


\section{Topaz}

Topaz is relatively rare in pegmatites and the pegmatites of many districts do not contain this mineral. The Quartz Creek district contains eight topaz-bearing pegmatites, which is less than half of a percent of all pegmatites mapped.

The topaz is milky white, though some has a greenish stain on the outside. The crystals are subhedral to euhedral and are predominantly long tapering prismatic crystals. They are usually 4 to 8 inches in diameter and a foot or two in length, but specimens have been found which attained 12 inches in diameter and 4 feet in length. The prism faces, $m(110)$, and the pyramid faces, $i(223)$, are the best developed. The basal pinacoid, $0(001)$, was noted on a few specimens, and probably other faces could be found with continued study. Basal cleavage is well developed on most specimens. The lower index of refraction $\left(N_{\alpha}\right)$ was determined to range from 1.616 to 1.618 (table 19) on four topaz specimens from three different pegmatites. WinchelI I and Pardee, Glass, and Stevens I have shown that the indices

1947. $J$ Winchell, A. $\mathrm{N}_{\text {a. }}$ Ilements of Optical Mineralogy: Part II, p. I99. J Pardee, J. T., Glass, J. J., and Stevens, R. T., Mas sive low fluorine topaz from the Brewer mine, South Carolina: Am. Mineralogist, vol. 22, Pp. 1063-1064, 1937.

of topaz increase with the increase of water content and decrease of the fluorine content. The indices of topaz in the Quartz Creek district show that there is a uniform water and fluorine content, and by interpolating from a table given by winchell I that they contain between 17.0 and 18.5

J WinchelI, A. N., op, cit.., p. 199, 1947.

percent fluorine and 0.9 to 1.5 percent water. 
Table 19.--Iower index of refraction $\left(N_{\alpha}\right)$ of topaz from the quartz Creek district

\begin{tabular}{|c|c|c|}
\hline Pegmatite Number & Pegmatite Name & $\mathbb{N}_{\alpha}$ \\
\hline $\begin{array}{r}215 \\
452 \\
452 \\
1574\end{array}$ & $\begin{array}{l}\text { Opportunity No, I } \\
\text { Brown Derby No. I } \\
\text { Brown Derby No, I } \\
\text { Bucky }\end{array}$ & $\begin{array}{l}1.616 \\
1.617 \\
1.618 \\
1.616\end{array}$ \\
\hline
\end{tabular}

Topaz is found only in lepidolite-bearing pegmetites and is airectly as sociated with the folloving minerals in one or more pegmatites: lepidolite, cleavelandite, quartz, mascovite, beryl, perthite, and tourmaline. It is always found with the first three minerals. Purple lepidolite commonly forms a coating around topaz. Its association with lepidolite would be expected as this mineral also contains fluorine in its chemical composition. Stevens / made analyses on 17 different lepidolite specimens and

J Stevens, R, I., New analyses of lepicolites and their interpretation: Am. Mineralogist, vol. 23, p. 615, 1938.

found the fluorine content ranges from 4.09 to 9.19 percent, the average is 7.03 percent. On the Opportunity No. I claim, pegmatite No, 215, some of the topaz has a thin pale-green miccceous coating of polylithionite. This specimen of polylithionite is biaxial negative and has $\mathbb{N}_{\beta}=1.558$ and $\mathbb{N}_{\gamma}=$ 1.565. Both polylithionite and lepidolite appear to form as a procuct of reaction between the early-formed topaz crystals and the resioual liquid, and corrode the surface of the topaz crystals in some places. The topaz always occurs with the lepidolite, as the fluorine evidently comes off from the original magma at the same time as the lithium. Thus, in a pegmatite district in which both topaz and lithjum minerals are present they should be associated. Less than 0.5 percent of the pegmatites of the Quartz Creek 
district contain topaz, yet alnost 50 percent of the lepidolite-bearing pegnatites have topaz, and all of the topaz-bearing pegmatites contain lepidolite.

Gahinite

Gahnite, the zinc spinel, is a rare mineral found in only eight pegmatites. It occurs in homogeneous pegmatites, in intermediate zones and cores of zoned pegmatites, and in layered pegmatites.

Gahnite is greenish black to dark green, and occurs in anhedral masses. The crystals are from 0.03 to 0.75 inch in diameter. The mineral is green, isotropic, and has an index of refraction of $1.81 \pm 0.005$.

Gahnite does not appear to have any favored mineral association. In pegmatite Wo. $15: 0$ it is found with massive quartz, and muscovite, in pegmatite No. 1574 with albite, quartz, muscovite, and beryl, and in pegmatite No. 452 with albite columbite-tantalite, monazite, tourmaline, garnet, biotite, and quartz. The pegmatites containing this mineral are widely scattered and its presence depends upon the availability of zinc in the pegmatitic Iiquid.

Gahnite is rare or absent in most pegmatite districts, but has been reported from the Tims Hill deposit in Connecticut $J$.

J Foye, W. G., Mineral localities in the vicinity of Middletown, Connecticut: Am. Mineralogist, vol. 7, p. 9, 1922.

Allanite

Allanite is rare in the Quartz Creek district. In the Black Wonder (No. 847) it occurs in severe. pods, a few feet thick and about 10 feet long. This pegmatite is over 6,700 feet wide and 12,600 feet long and the 
pods represent only a minute fraction of the total pegmatite. The pocis are quartz (about 90 percent) and albite. A few scattered crystals of allanite occur in smoky quartz.

The allanite is in prismatic crystals, with a square cross section, as much as 0.5 inch across and 2 inches long. The mineral is black, has a shiny Iustre, and is ringed by a reddish-brow decomposition product. At least three different substances are observed under the microscope, One is isotropic, reddish brom $i$ in color, and has a refractive index a little less than 1.62; the second is anistropic and colorless; and the third is isotropic and grayish green. These observations are in agreement with those of Hitchens who describes the allanite from Fitchburg, Mass. I

J Hitchens, C. S., The pegmatites of Fitchburg, Massachusetts: Am. Mineralogist, vol. 20, p. I8, 1935.

\section{Unidentified mineral}

An unidentified shiny greenish-black mineral, believed to be a new species, was found at the Bucky pegmatite (No. 1574). This mineral occurs in scattered pockets in the mica zone. A total of 17 pounds was collected during the mining operation. This mineral is associated with muscovite, alterea feldspars, quartz, monazite, and columite-tantalite. It appears to be most closely associated and in places intergrown with columbitetantalite.

The ninerel has a conchoidal fracture, and superficially resembles samarskite, fergusonite, or euxenite. A powder $x$-ray film was compared With the files of known minerels in the X-ray libreries of the Geological Survey and Columbia University with negative results. A spectrographic analysis made by $A$. T. Meyers in the Geological Survey Trace Ilements 
Section Washington Laboratory indicates with the order of magnitude of concentration, the following components:

\begin{tabular}{|c|c|c|c|}
\hline $\begin{array}{l}\mathrm{Cb}_{2} \mathrm{O}_{5} \\
\mathrm{Ta}_{2} \mathrm{O}_{5} \\
\mathrm{U}_{3} \mathrm{O}_{8} \\
\mathrm{ThO}_{2} \\
\mathrm{MnO} \\
\mathrm{Fe}_{2} \mathrm{O}_{3} \\
\mathrm{CaO}_{3} \\
\mathrm{ZrO}_{2}\end{array}$ & $\begin{array}{r}X 0.0 \\
X .0 \\
X .0 \\
. X \\
. X \\
. X \\
. X \\
. X\end{array}$ & $\begin{array}{l}\mathrm{Y}_{2} \mathrm{O}_{3} \\
\mathrm{SnO}_{2} \\
\mathrm{Ia}_{2} \mathrm{O}_{3} \\
\mathrm{TiO}_{2} \\
\mathrm{PbO} \\
\mathrm{Sb}_{2} \mathrm{O}_{3} \\
\mathrm{MgO} \mathrm{M}^{2}\end{array}$ & $\begin{array}{l}. \mathrm{X} \\
. \mathrm{X} \\
\text { Traces } \\
. \mathrm{X} \\
. \mathrm{X} \\
. \mathrm{OX} \\
\text { Trace }\end{array}$ \\
\hline
\end{tabular}

Iooked for but not found: Wa, Bi, H, and $P$.

A determination of equivalent uraniun made by measuring the radiation from uranium and thorium, gave a value of 11 to 12 percent which would show that the $X_{,} O$ given for $\mathrm{U}_{3} \mathrm{O}_{8}$ would be nearly 10 percent. Iike many other radioactive columbo-tantalates this mineral 1s wetict.

This mineral, in thị section, is pale yellow, isotropic, and has an index of refraction of $1.80 \pm 0.05$

The mineral has a specific gravity of 3,8 , and some of it contains small cavities lined with a fine-grained yellow material.

\section{Other minerais}

Finely-grained chlorite occurs in nine small pegmatites in the quartz Greak district. It comprises several percent of these small pegmatites. grain size is from 0.03 to $0.06 \mathrm{inch}$. Chlorite is found in fine-grained. albite-rich pegmatites and is in part an alteration product of biotite,

Samarskite, or a similar mineral, such as euxenite, is present in. seven pegmatites. Only one or two crystals of this mineral, 0.03 to 0.5 inch long, are found in each pegmatite. It has refractive indices above 1.83 and in feldspar is surrounded by a reddish halo. This mineral is commonly as sociated with smoky quartz, and is strongly radioactive. Ipidote occurs in three pegmatites as fine-green veinlets, and was 
introduced into the pegmatite after its solidification.

Iight-blue epatite, as crystals 0.25 to 0.5 inch across, occurs in three pegmatites. In most pegmatite districts apatite is very comnon, but in the Quartz Creek district it is very rare.

Light purple fluorite is found in two pegmatites as grains about 0.06 inch in size. It is extremely rare.

Spodumene and amblygonite occur only in the Bazooka pegmatite (No. 424) in a circular core unit 20 feet in diameter. Spooupene in white lathlike crystals is frund on the smaly dump. No amblygonite was found by the writer, but was observed by Hanley $\perp$.

I Hanley, J. B., et al, op. cit., pp. 66-68, 1950.

Phosphates of the lithiophilite-triphylite series and their alteration products are found in the Bucky pegmatite (No. 1574). Two crystals were noted in the mica zone and one crystal was found in perthite-quartz pegmatite adjacent to a subsidiary core segment, approximately 2,500 feet to the southeast.

Betafite is reported by Fanley _/ associated with monazite, gahnite,

J Hanley, J. B., et al., op. cit., p, 71, 1950,

and. columite-tantalite in the Brown Deroy No. I pegmatite (No. 452). It was not observed by the writer and is probably very rare.

\section{Alteration of wall rocks}

The alteration of wall rock by the introduction of pegmatitic materials is common in many districts. Jahns $/$ describes impregnation of quartzite Jahns, R. H., Mica deposits of the Petaca district, Rio Arriba County, New Mexico: N. Mex。 Bur. Mines Bull. 25, pp. 52-54, 1946. . 
and mica schists in the Petaca district by muscovite, microcline, and plagioclase to the extent that the contact between some of the pegmatites and the country rock is gradational. The formation of muscovite and tourmaline in the country rock adjacent to the pegmatites in New Ingland has been briefly mentioned J. Numerous pegmatites in the Black Hills of South Dakota show

J Cameron, I. N., Iarrabee, D. M., Page, J. J., Stewart, G. W., and Shainin, V. I., Pegnatite investigations in Maine, New Hampsire, and Connecticut, 1942-1945: U. S. Geol. Survey Prof. Paper. (In preparation.)

abundant alteration at the wall rock-pegmatite contact $/$. The Helen

$J$ Page, I. R., et aln op. cit. (In preparation).

Beryl pegmatite in Custer County has patches of granulite along its sides from a few inches to 6 feet thick. The granulite varies in composition from place to place and consists of quartz (30 to 70 percent), muscovite ( 5 to 30 percent), biotite ( 2 to 15 percent), and minor quantities of tourmaIine and apatite. The Ilkhorn pegmatite, also in Custer County, has intensely tourmalized the quartz-mica schist on the hanging wall side of the pegmatite.

In the Quartz Creek district, however, there has been practically no alteration of the country rock adjacent to the pegmatite. The only noticeable alteration was of hornblende gneiss, which appeared slightly more friable adjacent to the contact. The three mein types of country rock, hornblende gneiss and tonalite, granite, and quartz monzonite, are equally free of alteration.

Alteration of the country rock might not be expected in the granite and quartz monzonite, as both rocks contain essentially the same minerals as the pegmatites. On the other hand, the hornblende gneiss and tonalite are 
markedy different in chemical composition from the permetites. Similar hornblende rocks in other districts heve been intensely altered. Jahns J

$J$ Jahns, R. H., op. cit,, p. 54, 1946.

in his description of the Petace district states, "vhere anphibole schist lies ageinst pegmatite, as in the Green Peal deposit, it has been converted to a cinse agrregate of biotite flakes". Mclaughlin / in a paper on the

/ Mclaughlin, T. G*, Pegratites of the Bridger Mountains, Wyoming: An. Mineralogist, vol. 25, p. 53, 1940.

pegmatites of the Bridger Mountains, Wyo., states that all the older pegma tite dikes are accompanied by alteration on the hanging-vall side of the dike, where the percentage of hornblende in the originel hornblende schist wes greatly reduced and quartz becane the predominant mineral.

The type of country rock may affect the kind or amount of alteration, but the type of country rock does not appear to be the prime controlining factor. The only difference between the pegmatites of the Quartz Creek district and those of many other districts that have widespread alteration along pegmatite contacts, is in the composition of the original pegmatite liquid. Tourmaline, apatite, and muscovite are some of the commonest minerals formed in the zone of alteration. Both tourmaline and apatite are anone the commoner minerels in most pegmatite districts and may occur in almost every pegmatite; but in the Quartz Creek district tournaline is a minor constituent of 48 out of 1,803 pegmatites and apatite is found in two. Tourmaline is the only boron minerel found; but phosphorous occurs in apam tite, in lithiophilite-triphylite in one pegmatite, in amblygonite in another, and in monezite in twenty-three. Muscovite, though common in the number of occurrences, is small in amount as compared to many other areas. 
These facts indicate that the original pegmatitic magma contained little B, $P$, and $O H$, and possibly other volatiles. Alteration of the wall rock is dependent upon solutions derived from the cooling pegatite; therefore, this deficiency of water and other volatiles is a determining factor in adding new minerals to wall rocks.

The lack of alteration in the Quartz Creek district appears to be caused by the Insufficlent concentrations of the elememts needed to form alteration minerals, though they were avallable in the pegutite magn to form rare minerals in the pegmatite during all stages of crystalliation.

\section{Distribution of minerais}

Some pegmatite districts are important as a source of lepidolito, sheat mca, celuibite-tentalite, beryl, or otber pegmatite minerals. The granitic pegnatites of most districts consist essentially of perthite, plagioclase, quartz, and muscorite, but not all pegatite districts have the sane assemblage of minor minerals. It is this ascenblage of minor minerals and variarts of common minerals, such as curved muscovite and colored tournaline, that indicat the differences in the overall composition in the original source gamas of each district.

Hot ind do the less camon minerals vary frem district to district, but from pegmatite to pegmatite. During World War II the $U_{0} \mathrm{~S}$. Coological Survey was studying pegmatites that produced cxitlcally needed naterials and peginatites: were grouped simply according to minerals of economic interest. It was recognized by many investigntors that a certain type of aineral vould oceur in certain groups of pegantites, that is, the lithim-bearing pegmatites of a district-wold not be scattered haphazardly throughout an area but would occur in a cluster or groups throughout a district. This grouping of mineralogically Bimilar pegmatites is 1llustrated in the Black Hills of South Dakota where such well-known lithium produeing pegatites as the 
Etta, Peerless, Hugo, and Idison, are all in one group; and the Helen Beryl, Helen BeryI No. 2, and Tin Mountain, in another.

The areal mapping on which this report is based afforded an excellent opportunity to study the distribution of minerals in a medium-sized pegmatite district. A series of maps, (figs, 16, 17, 18, 19, and 20), show the distribution of beryl, tourmaline, curved mascovite, biotite, magnetite, monazite, columbite-tantalite, cleavelandite, topaz, lepidolite, and micro Iite throughout the Quartz Creek district. Some minerals such as flat muscovite, and garnet are too widespread to be significant, whereas others like chlorite, amblygonite, and spodumene, are too rare to be of use statistically. Each pegmatite that contains at least one crystal of a particular mineral is indicated on the map as a bearer of that mineral. This scheme of representation has the serious defect in that large pegmatites appeer to have a greater quantity of the mineral than do the smaller pegmatites. For example, the Black Wonder pegmatite (12,600 feet long by 6,700 feet wide), contains only a few crystals of beryl in two small pockets, yet it appears on the map to be a large beryl-bearing area. Two facts are exphasized by these maps: (I) the relation of distribution of certain minerals to all the pegmatites in the district, and (2) the constant association of two or more minerals. The associated minerals are Erouped on the same figure.

Two hundred and thirty-two beryl-bearing pegmatites are shown in figure 16. The group of beryl-bearing pegmatites in the northwestern corner of the area mapped has a northeastwardly trend; a second group extends northeast from near Opportunity claims in the southwest part of the area mapped; a third group extends from Wood Gulch northwest to the Brown Derby mine; a fourth small group occurs in the vicinity of the Buckhorn mine on 
the eastern edge of the district; and a fifth small group is around the Bucky mine in the northeast corner of the district. There are scattered beryl-bearing pegmatites, including the Black Wonder, in the north-central part of the area mapped, which actually contain a little baryl. Figure 17 shows the location of the groups of tourmaline- and curved muscovite-bearing pegmatites. Tourmaline is most abundant in an area near the Opportunity claims on the southwestern edge of the district, in the vicinity of the Brown Derby No. I pegmatite, and adjacent to the quartz monzonite in a small area along the northern edge of the map. Curved muscovite is found only in the northwestern slope of Wood Gulch. It is surprising that these relatively rare minerals are grouped so closely in the hundreds of pegmatites mapped.

Magnetite and biotite are found in 422 and 357 pegmatites, respective1y. Almost every pegmatite in the northern part of the area (fig. 18) contains these two minerals, but in the southern part these minerals appear only in small clusters of pegmatites.

Figure 19 shows the distribution of columbite-tantalite-bearing and monazite-bearing pegmatites. Although they are not as abundant as the other minerals studied, the special association of pegmetites containine these minerals are clearly the same. Only one or two crystals of these minerals were formed in each pegmatite. They tend to occur in clusters of several pegmatites, as is apparent from the maps.

Figure 20 shows the grouping of lepidolite-, cleavelandite-, topaz-, and microlite-bearing pegmatites. The intimate association of these four minerals is clear. These minerals are abundant in four main groups of pegmatites: (1) in bouthyegtern part of the district around the Opportunity claims, (2) in the vicinity of the Brown Derby mine, (3) in the 
vicinity of the Wite Spar claims, and (4) in the vicinity of the Bucky property.

\section{Relationship of the pegmatites to the country rock}

One of the problems of pegmatites, as with many other igneous rocks, is the effect the country rock has on their occurrence and mineral composition. The pegmatites in the Quartz Creek district occur more commonly in hornblende gneiss and tonalite, and less frequently in granite and quartz monzonite. If the pegmatites were derived from the same magmas as either the granite or quartz monzonite, they would tend to occur along the outer edges of the parent igneous rock and in the adjacent country rock. In the Quartz Creek distilct, however, pegmatites are found on the edges of both the granite and the quartz monzonite. Also the pegmatites would not penetrate far into the granitic rocks, if they came from the outside.

An equally logical reason for the pegmatites distribution in this area is that the granite and quartz monzonite are less fractured and afford Iess easy passage to the pegmatite solutions. The pegmatites find zones of weakness to intrade only on the edges of these bodies, where cooling fractures are comnon. This does not preclude that the pegmatites were not derived from the original magma of either of these two rocks. It does seem, however, that the presence or absence of pegmatites in a particular rock or part of a rock may be the result of the ease of intrusion rather than the source from which they are derived.

A statistical count of the types of pegmatite minerals found in the various rock units was made on the pegmatites in the chief rock types, AlI pegmatites that occurred in two or more types of country rock were excluded. Certain minerals such as plagioclase, quartz, and perthite are omni- 
present and thus show no differences; whereas others like topez, gahnite, and spodumene are too rare to give a significant statistical count. Another problem is the distribution of minerals in groups which may appear to show concentrations of a mineral in one rock type, but which are related to the areal distribution rather then to the rock type. Some minerals such as lepidolite and cleavelandite are not found in pegmatites in either the granite or the quartz monzonite. The small number of pegmatites in which they are found, however, precludes any statement as to the effects of the country rock. Tourmaline, on the other hand, is fairly uniformly distributed in the three dominant types of country rock considering that it is found in only 48 pegmatites. The ratio of tourmaline-bearing to non-tourmaline-bearing pegmatites is 1:30 for hornblende gneiss and tonalite, of 1:21 for granite, and of 1:85 for quartz monzonite,

Beryl-bearing pegmatites show a marked preference for certain types of wall rock. Beryl occurs in 232 pegmatites and though irregularly distributed: it is believed, at least in the case of granite, which is also irregularly distributed in many areas of beryl-bearing pegmatites, that the distribution is wide enough to discount the general areal pattern of beryl occurrences. The ratio of beryl-bearing pegmatites to non-beryl-bearing pegmatites is $1: 6.4$ in hornblende gneiss and tonalite, 1:20 in grenite, and 1:189 in quartz monzonite. These figures show wide variance and suggest that the concentration of the beryl in pegmatites is influenced by the country rock. It was thought that the granite night absorb BeO from the pegmatite Iiquid, and, therefore, bulk samples were taiken from a graphic granite-rich pegmam tite (No. 512) and the adjoining coarse-grained granite. The pegmetite sample consisted of perthite (62 percent), quartz (20 percent), albite (15 percent), and muscovite (3 percent). A little more than half of this rock 
was graphic grenite. The granite was estimated to contain microcline (67 percent), albite (20 percent), quartz ( 8 percent), and biotite ( 5 percent). The pegmatite contained a trace of Beo and the granite contained an amount less than was detectable spectrographically (under 0.0001 percent). Bulk samples were taken also of the footwall layer of the Brown Derby No..1 pegnatite (No. 452) and of the hornblende gneiss, within 8 inches of the contact. Samples were split down from about 1,000 pounds of original material. The pegmatite was estimated to consist of albite ( 89 percent), quartz (10 percent), tourmaline (1-2 percent), muscovite (less than 1 percent), and garnet (trace). It had an average grain size of 0.12 inch and there was no visible beryl. The analysis showed this pegmatite to contain 0.030 percent BeO and the hornblende gneiss a trace. The results of these two sets of samples should be supplenented by much more data. Graphic granite pegmatites are commonly lean in beryl and the Brown Derby pegmatite had beryl in other units than the one sampled. This small amount of work seems to indicate that grainite does not absorb Beo from the pegmatite fluid and thereby cause the difference between the BeO content of pegmatites in granites and in hornblende gneiss. The possibility of the Beo being derived from the country rock has not been investigated. Samples of the hornblende gneiss away from the pegmatite are needed to see if it too contains a trace of Beo. More probably, however, the trace of BeO in the hornblende gneiss is derived from the pegrnetite, as BeO tends to be concentrated in the last stages of macmatic differentiation $/$ and is chiefly

$$
\text { J Rankama, K., and Sahama, T. G., Geochemistry, p. 443, } 1950 .
$$

found throughout the world in granites and nepheline syenites. 


\section{Origin}

The problem of the origin of peptratites is complex and involves not only the method by which they are demived from the original magma, but also their crystallization.: Pegnatites edpear in many areas to be related. areally to large bodies of intrusive fock. Most of these intrusive rocks crystallized from magmas of silicic composition and thus pegrnatites are comnonly associated with igneous rocks such as granites. Goranson J has

J Goranson, R., The solubjlity of water in granitic magmas: An. Jour. Sci., 5th ser., vol. 22, p. 481, 1931.

show that certain natural rhyolitic glasses may contain 8 to 10 percent water. Thus, from a granitic magma, containing only 1 to 2 percent water, the amounts of water released in the later stages by slov crystallization of such a magrna would be very large. In addition to water, the other volatile elements such as $F, C I, B$, and $P$, would be concentrated. The alralies, $\mathrm{Na}, \mathrm{K}, \mathrm{Ii}, \mathrm{Cs}$, and. $\mathrm{Rb}$, also tend to be concentrated in the later stages of crystallization.

Granitic pegratites have some of the properties of granites and some of various types of veins. They appear to be an intermediate type and have been correlated by various writers to both igneous rocks and veins. Beryl, a typical pegmatite mineral, is found in both granites and quartz veins as well as in pegmatites suggesting a continuous gradation between these rock types, Beryl, for example, is found in the granites on Mt. Antero, Colo. J $J$ Adarns, $J, W .$, Beryllium deposits of the Mt. Antero region, Chaffee
County, Colorado: $U, S, G e o l$, Survey Bull, (In preparation.) and in the Victorio Mouniains, N. Mex, $J$ and beryl-quartz veins are found helvite and beryl in the Tictorio Mountains, New Mexico. 
in the Victorio Mountains $J$, the California vein on Mt. Antero $J$, the

J Holser, W. T., op. cit.

Adens, J. W., op. cit.

Bormana vein, Arizona $J$, and Kazakhstan, Russian J.

$J$ Hobbs, S. W., Tungsten deposits in the Boreana district and the Aquarius Range, Mohave County, Arisona: U. S. Geol. Survey Bull. 940-I, p. 254,1944 .

J Sinegub, I. S., Bexill: Nemetallicheskiye 1skopayeny SSHR, Moscow-Ieningrad, vol. 2, pp. 129-157, 1943.

Most of the pegmatides in the Quartz Creek district are simple pegmatites composed of minerals typical of granites-perthite, quartz, plagioclase, muscovite, and garnet. The unusual "distinctive" minerals of pegmatites rarely are found, such minerals as cleavelandite, lepidolite, topaz, microlite, gahnite, and columbite-tantalite occur in less than 2 percent of the pegmatites in the Quartz Creek district. The predominant mineralogical difference between pegmatites in many districts and their associated granites is that the pegmatites are somewhat higher in muscovite, indicating a higher water content of the original liquid. In the Quartz Creek district, however, muscovite is a relatively minor mineral, suggesting that the original magma was water-poor. The fow pegmatites that have minerals containing other volatile elements are the result of a later stage of segregation and crystalization;

More than 90 percent of the pegmatites in the Quartz Creek district have an average grain size of less than 1 inch. This texture is commonly aplitic, and may resemble that of a fine- to coarse-grained granite. Many of the pegmatites in the Quartz Creek district resemble typical igneous rocks and have been mapped by Crawford and Worcester $J$ as granite in the 
I Crawford, R. D., and Worcester, $P_{0} G_{0}$, Geology and ore deposits of the Gold Brick district, Colorado: Colorado Geol. Survey Bull. 10, 1916.

northern part of the area. The lepidolite-bearing Brown Derby pegmatites, on the other hand, are much coarser textured and contain many minerals distinctive of pegmatites that have been described as showing "abundant evidence of hydrothermal replacement," by Iandes $J$. 333, Iandes, K. K., Colorado pegmatites: Am. Mineralogist, vol. $20, \mathrm{p}$.
1935.

The pegmatites of every district have distinctive characteristics that usually are reflected in the rare minerals, For example, the pegmatites of the Black Hills are in general rich in tournaline; muscovite, apatite, and other phosphate minerals. Very little topaz and lepidolite are found. in this large district. These minerals show that the original magma was comparatively rich in $P, B, O H$, and poor in $F$. The pegmatites of the quartz Creek district, on the other hand, differ from those in the South Dakota district and many others in that they are relatively lean in muscovite, biotite, tourmaline, and phosphate minerals, and are relatively rich in topaz, lepidolite, and columbite-tantalite. These minerals indicate that the original magma of the Quartz Creek district pegmatites was leen in OF, $B$, and $P$, and comparatively rich in $F, T a$, and $\mathrm{Cb}$. In the entire quartz Creek district, only three pegmatites contain enough muscovite to be considered as sources of scrap mica; the content is commonly 0.5 to 3 percent. Biotite is less than 1 percent. The lack of these two minerals in most pegmatites indicates that the pegmatites of this area contain relatively little OH. Tourmaline is found in only 48 pegmatites and the content is only a fraction of 1 percent. The dominant phosphorous mineral is mona- 
zite, which is present only as a few small crystals in 24 pegmatites. Other phosphate minerals are apatite, amblygonite, and lithiophilite-triphylite, which are found in only one or two pegmatites and are exceedingly rare. Fluorine is a constituent of topaz in 8 pegmatites, lepidolite in 17 pegmatites, microlite in 14 pegmatites, and in fluorite in 2 pegmatites. Colunbium and tantalum are present in columbite-tantalite in 29 pegmatites; in microlite in 14 pegmatites, and in samarskite ( $P$ ) in 7 pegmatites, and in an unidentified mineral in 1 pegmatite.

Within a particular district considerable variation is shown in the areal distribution of pegmatite minerals. As previously discussed, pegmatites of some of the rare elements occur in groups. Thus, beryl-bearing pegmatites are found in several clusters scattered over the area (fig. I6). This is also true for some of the other rare minerals as lepidolite, topaz, cleavelandite, microlite, columbite-tantalite, monazite, tourmaline, and curved muscovite (figs. 17, 18, 19, and 20). Pegmatite magma evidently escapes from a particular part of the chamber of its parent granitic magma In a speific direction dividing into separate units before final emplacement. This would account for the distribution of certain types of pegmatite minerals in one area. The distribution of these minerals in different groups is related to their origin. As the parent granite magma cools, pegmatite liquids are segregated in different parts of the magma and escape from various parts at different times. The pegmatite magma which is driven from the parent chamber earliest probably contains less volatile material, and forms the greater part of all pegmatites-those that most closely resemble other granitic rocks. The minerals found in any pegmatite depend on the original composition of the material segregated in a pocket, and on the stage of crystallization at which it was derived. The more highly volatile constituents are in the later derivations and form the few rare 
pegnatites. Many minerals are almost always found in close association with another mineral because these minerals may contain common ions which make their association imperative, or elements that are concentrated at the same stage in crystallization. M Minerals containing common ions include: lepidolite, topaz, and microlite-all of which contain F; and lepidolite, and colored toumaline which contain Li. Minerals which owe their association to elements segregated at approximately the same stage are columbitem tantalite and monazite. In places where these two minerals are not associated it probably reflects a lack of elements to form one or the other mineral.

The commoner minerals are segregated continuously or recurringly through the differentiation of the parent granite. In pegmatites that contain the rarer elements, minerals such as plagioclase, perthite, quartz, and muscovite are still the predominant minerals. The rarer elements such as $\mathrm{Ii}, \mathrm{Cs}, \mathrm{Rb}, \mathrm{F}, \mathrm{Cl}, \mathrm{Cb}$, and $\mathrm{Ta}$ are probably in the more soluble part of the pegmatite material and certainly are anong the last to crystallize.

The reaction of these late crystallizing rest solutions on the earlier crystallized material causes embayment and veining of the earlier crystallized minerals. This is given as proof of replacement by later solutions by some authors 1 . Whether the first magnatic part of a pegmatite was re-

$J$ Schalier, $W . \dot{T}_{0}$, The genesis of lithium pegmatites: Am. Jour. Sci., 5th ser., vol. 10, pp. 269-279, 1925. gist, vol. I2, pp. 59-63, 1927.
Landes, K. K., Paragenesis of the granite pegmatites of central Maine: Am. Mineralogist, vol. 10, pp. 355-411, 1925. alogist, vol. 20, pr. Origin and classification of pegmatites: Am. MinerHess, F. I., The natural history of the pegmatites: Ing. and Min. Jour.-Press, vol. 120, pp. 289-298, 1925. Gevers, T. W., Phases of mineralization in Namaqua land pegmatites: Trans. Geol. Soc. South Africa, vol. 39, pp. 331-377, 1936. 
Andersen, Olaf, Discussions of certain phases of the genesis of pegmatitest Norsk. geol. Tidsskr., Bd. 7, pp. 1-55, 1931.

Berry, D. R., The genetic relationships of pegmatites, aplites and tin veins: Geol. mas., vol. 68, pp. 454-475, 1931.

Jahns, R. H., Mica deposits of the Petaca district, Rio Arriba County, New Mexico: New Mexico Bur. Mines Bull. 25, pp. 72-75, 1946.

placed by hydrothermal solutions brought in after the first part of the pegmatite had solidified, or whether the earlier crystallized minerals were acted on by a rest solution that became unstable with the earlier crystallized minerals as the pressure and temperature changed the results would give identical textural relations with the earlier formed minerals being corroded and veined by the later. Ividence on whether pegmatites were formed in a closed system or by a series of hydrothermal replacements must depend on the mineralogical and structural relations rather than on a textural study. Studies of internal structure of the pegmatites and the order of sequence of mineral groups are markedly uniform and can be correlated from district to district as well as among pegmatites in the same district. The uniformity of sequence of mineral assemblages, and the relationship of the minerals themselves point to a similarity of conditions which would not be expected from hydrothermal replacement. A discussion of hydrothermal replacement versus forming in situ has been discussed thoroughly by Cameron, Jahns, Mcllair, and Page J; Stockwell $J$; Hanley $J$; and Page $J$, and will

\rfloor Cameron, I. N., et. al, op. cit., pp. 97-106, 1950.

J Stockwell, C. H., Genesis of a lithium pegmatite on the Bear Mineral claim, Southeast Manitoba: Royal Soc. Canada Proc. and Trans., $3 d$ ser., vol, $27, \mathrm{pp}, 27-36,1933$. - The genesis of pegmatites of southeast Manitoba: Royal Soc. Canada Proc and Trans., 3d ser., vol. 27, pp. 37-51, 1933. J Hanley, J. B., et. al, op. cit., pp. 7-9, 1950.

not be repeated here. 


\section{Reserves}

Reserves of pegmatite minerals are difficult to estimate because normal procedures of sempling cen not be used. The grade, however, can be obtained by measuring the areas of industrial minerals exposed on pegmatite surfaces and relating it to the total exposed area. The percent of mineral exposed nay be converted to a weicht percent of mineral by malcing proper corrections for specific gravity.

The tomage of rocls containine an industrial mineral can be calculated From a detailed map of the internal structure of pegmatite.

Reserve calculations have been made for all of the industrial minerals in pegmatites of the Quartz Creek district. The minerals that sustained mining operations in the past were lepidolite or scrap muscovite ano bery. Potash feldspar might sustain mining operetions, if trensportation were less costly.

The total reserves of clean $h$ nd-cobbaile feldspar are estimated to be 795,600 tons of potash feldspar and 9,740 tons of soda feldspar. These feldspar reserves are all in pegmatite units containing more than 25 percent feldspar, in grains greater than 12 inches in length. The minimu size of a unit included in these calculations was 200 feet 10 on and 40 feet thick.

In adition, there is considerable feldspar recoverable by milling. Most of this feldspar is in the form of graphic granite. A number of these pegmatites pose considerable transportation difficulties because they are several miles over mounteinous terrain from the nearest road. A total of 251,300,000 tons of milling grade feldspar are calculated in 40 pegmatites. This is an average of $6,028,000$ tons per pegmatite. The largest tonnage is in the Black Wonder (No. 847), which has 225,200,000 tons of milling 
felcspar,

There is no sheet mica and very little scrap mica in the Quartz Creek district. The total reserves of scrap muscovite is estimated to be 13,500 tons of which 1,400 tons is recoverable by hand methods. The scrap mica obtained is a byproduct of the mining of beryl-bearing pegmatites. There are only three pegmatites (the Bucky, the Buckhorn, and the Beryl and Rare Minerals Lode) which contain either enough muscovite or muscovite in large enough pieces to be considered recoverable as a byproduct of beryl mining. The muscovite reserves of these three pegmatites are calculated as 1,400 tons.

The total beryl reserve estimated for the Quartz Creek district is about 350 tons. The second largest pegmatite in the district was estimated to contain 160 tons of beryl as of November 1949. This deposit is twice as large a.s the reserves of any other pegmatite. Pegmatite No. 452 (Brown Derby No. I dike) contains 75 tons, the second largest beryI reserve in the area and pegmatite No. 538 is third with 40 tons of beryl. Thirty-eight of the pegmatites contain less than 10 tons of beryl. Of the total. 350 tons of beryl, probably 325 tons are hand cobbable.

Some of the pegmatites that have beryl reserves also contain lepidolite, microlite, topaz, columbite-tantalite, and monazite. The lepidolite reserves of the entire area amount to 3,560 tons. The largest deposit is the Brown Derby No. I dike (pegmatite No. 452) which has 1,600 tons of reserve. Only four lepidolite eposits have reserves over 100 tons. The topaz reserves are 900 tons, those of microlite 900 pounds, columbite-tantalite 4,000 pounds, and monazite 400 pounds. The reserves of the last three minerals, because they occur in such small widely distributed quantities, are very difficult to calculate. 
Prospecting for beryl

Of the 1,803 pegmatites found in the Quartz Creek district, 232 of them contein some beryl. Only one or two crystals of beryl, 0.10 to 0.25 inch in diameter, occur in most of these pegmatites. Of the 232 pegmatites, 42 have nore than 2 square inches of beryl exposed, and of these only a very few could be considered as possible sources of appreciable beryl production.

The finding of pegmatites that contain beryl in sufficient quantities to be of commercial value is very difficult. The beryl in this district is commonly white and approximates the physical appearance of feldspar or quartz. It is commonly overlooked by prospectors. Favorable beryl-bearing zones occur in covered areas in many places and diligent prospecting in these favorable areas might uncover worthwhile deposits.

Several broad statements can be made concerning the favorable and unfavorable areas for finding beryl in pegmatites in the Quartz Creek district. Granite and quartz monzonite appear definitely unfavorable as a host rock for beryl pegmatites. Only three pegmatites were found in Eranite that contained beryl and none of the exposures contained as much as 2 square inches of beryl. Only one pegmatite in quartz monzonite contained beryl. All pegmatites in the Quartz Creek district that contained as much e.s 2 square inches of beryl had homblende gneiss wall rocks. The hornblende gneiss covers a large area that is favorable for detailed prospecting.

Detailed studies also indicate that beryl is most comron in albiterich pegnatites. The albite-rich pegmatites are almost universally fine grained. The grain size of the beryl in these pegmatites ranges from 0.06 to 0.5 inch and no beryl has been recovered commercially from them. Perthiterich pegmatites, though less comnon as 2 source of beryl, have a large 
enough grain size so that nost of the beryl can be hand cobbed. The small grain size of the beryl-bearing albite-rich pegmatites precludes economic recovery of beryl under present technological conditions, though at some future date, such beryl-rich rock, if found in sufficient quantities, may be of economic importance and warrant the erection of a mill. Deposits of this type, therefore, cen not be expected to be of immediate concern to the prospector.

Some pegmatites have both albite- and perthite-rich parts. The perthite-rich parts may be a source of beryl at the present time but the albite-rich parts, though equally rich in beryl, will be too fine grained to mine. The beryl in pegmatites containing cleavelandite is coarse grained and may be recovered by hand methods, consequently cleavelanditebearing pegmatites should be prospected carefully.

Graphic granite pegmatites, one of the most common types of perthiterich pegmatites in the district, do not contain beryl and should be avoided in searching for beryl deposits. Beryl favors blocky perthite-quartz pegmatite units or perthite-muscovite-rich units, though the very irregular distribution of beryl may cause one part of a unit to be completely barren of beryl, whereas in other parts it may be abundant. Prospecting for beryl should be nost intense in perthite-quartz units, and the edge of quartz cores especially where a feldspar-rich muscovite-bearing unit may be covered by float. Much beryl is found in lepidolite-bearing pegmatites and lepidolite is considered one of the more favorable indicators of beryl in prospecting.

In general, the Quartz Creek district is not too favorable a district to prospect for beryl, because the sood mica and feldspar deposits are of small size and production of beryl in the past has been as a byproduct of mining for one or the other of these minerals. There are no sheet mica 
deposits in the district, the scrap mica deposits are not large, feldspar in Iarge quantities must be recovered by milling of graphic granite, and deposits of hand cobbable feldspar are smell. The size of the deposits of these minerals added to the high cost of transportation almost preclude profitable mining operations in this district at 1951 prices. Iittle feldspar has been sold by local producers, and the high cost of transportation End the small size of the perthite units are not encouraging for the production of feldspar. Because of these factors that concern muscovite and feldspar, the future of this district as a source of beryl is not too bright.

\section{DRSCRIPTIONS OF INDIVIDUAI, DFPOSITS}

\section{Opportunity No. I claim (pegmatite No. 215)}

The Opportunity No. 1 claim is in the $\sqrt{P^{\frac{3}{4}}}$ sec. 17, T. $49 \mathrm{~N} ., \mathrm{R} .3 \mathrm{I}$, New Wexico principal meridian. This prospect is claimed by Iarl A. Serry, and is south of the Doyleville road on the eastern slope of a north-trending ridge. The claim covers more than 10 pegmatites, but the main workings are on the largest one, No. 215. This pegmatite is exposed by five small cuts, the largest of which is 37 feet lone, 10 feet wide, and 10 feet deep; the other four are each about 8 feet long, 4 feet wide, and 5 feet deep. No minerals have been producedifnom thi propect.

The pegnatite is a lenticular-branching pegratite 730 feet in maximum Iength and $1: 0$ feet in maximum thickness. Much of the pegmatite, however, has a thickness of less than 5 feet. It dips $45^{\circ}$ to $80^{\circ} \mathrm{SI}$., and cuts both fine-grained granite and hornblende gneiss.

The pegmatite is divided into four units along the strike of the body (fig. 21). Albite-quartz-perthite pegmatite forms a unit in the stringers 
atonding from the northeast, the southwest, and the centrel part of the pegnetite. This uit has an avorage grain size of 0.25 inch and is estimated to consist of albite ( 65 percent), quartz (20 percent), perthite (15 percent), muscovite (less than 1 percent), and one small--0.25 inch-palegreen beryl crystal. Neer the south end of the pegmatite, the body widens considerably at the junction of a small northward-trending branch with the main boo.y of the pegmatite. This wide area contains several units. Along the vestern side is a unit of quartz-albite pegmatite that has an average grain size of 3 to 4 inches, and is estimated to contain quartz (75 percent), albite (20 percent), muscovite ( 3 percent), perthite ( 2 percent), and tournaline (less than 1 percent). The eastern side of this bulge area is dominantly perthite-cleavelandite-quartz pegmatite, has an average grain size of about 2 to 3 inches, and is estimated to consist of pink perthite (60 percent), white cleavelandite (20 percent), quartz (20 percent), m.scovite (Iess than 1 percent), black tourmaline (Iess than I percent), and Gernet (trace). The perthite occurs in crystals as much as 12 inches long. The central part of this bulge, and the remainder of the pegmatite to the north, is cleavelandite-quartz pegmatite. This pegmatite has an average grain size of 1,5 inches and is estimated to consist of white cleevelandite (69 percent), quartz (20 percent), perthite ( 8 percent), muscovite (2 percent), black anc derk sreen toumaline ( 1 percent), lepicom Iite (Iess then 1 percent), topaz (Iess than 0.5 percent), beryl ( 0.1 percent), and gernet (trace), nicrolite (trace), columbite-tantalite (trece), and monazite (trace). Iocally clots of varying lepicalite content are prosent. In one 3-foot area lepidolite constitutes as much as 5 percent of the rock. It occurs as fine-grained aggregates and in larger plates 0.25 to 1 inch in diander. The topaz is milly white, has a good 
cleavage and comnonly occurs with white beryl. Beryl and topaz have an irregular distribution. Microlite is found in the southern part of this unit with sioly quartz and platy cleavelandite as clusters of distorted oftehedrons, nodified by dodecahedrons as much as 0.25 inch in diameter. Probably the microlite content of this small part of the pegmatite is a few pounds per ton. Colurbite-tantalite is less connon than the microlite. and only a few small crystals, the largest an inch across, were found. Monazite was noted in four crystals and is associated with columbitetantalite.

\section{Pegratite INo, 417}

Pegmatite No. 417 (pl. II) is on the western side of the vestern, branch of Wood Gulch, near the western edge of sec. $2, T .49 N_{0}, R_{2}, 3$, , New Mexico principal meridian. It is a few feet above the cenvon botton and can be reached by the secondary road mning up Wood Gulch. It is opened by one small pit 18 feet long, 4 feet vide, and 4 feet deep at its western face.

The pegratite is irregular, and is approxinately 370 feet long and. 105 feet in maximun width. Part of the irregularity is the result of its exposure on a dip slope. The pit, which is near the center of the pegmatite, cuts completely through the body, and at this point the pegnatite is 6 feet thicl. The pegrnatite intrudes hornolende gneiss, and has a wall zone and a core. The wall zone is the greater part of the body and has an average grain size of 0.12 inch. It consists of albite ( 55 percent), quartz ( 35 percent), perthite ( 5 percent), muscovite ( 5 percent), and bery1 ( 0.75 inch crystal). The core has an average grain size of 3 inches and consists of perthite ( 45 percent), albite ( 42 percent), quartz ( 8 percent), 
muscovite ( 5 percent), beryl ( 0.2 percent), and one small piece of samarslite. The beryl forms pale freen, euhedral crystals that range in size from 0.25 inch by 0.25 inch to 2 inches by 4 inches. A grain count of 101 square feet of the core contained 0.2 percent beryl in.33 crystals. The beryl reserves of this unit are calculated as 3.8 tons.

\section{Brown Derby Dike No. I (pegmatite No. 452)}

The Brow Derby Dike Iio, 1 is the easternmost of the Brown Derby Eroup of dikes, in sec. 3, T. 49 N., R. 3 …, New Mexico principal meridian, This dike is a few hundred feet below the crest of a long ridge at 9,300 feet on the east side of Quartz Creek. An access road was built by the Federal Government from Colorado State Highway 162 to the workings, a distance of approximately 2 miles.

The pegmatite has been described by $J: B$. Hanley J. Since this mapping

J Hanley, J. B., Heinrich, I. W., and Page, I. R., Pegmatite investigations in Colorado, Wyoming, and Utah, 1942-1944: U. S. Geot Survey Prof. Paper 227, pp. 68-71, 1950.

was finished (December 1944), the high-grade pod-shaped concentration of lepidolite in the lepidolite-quartzacleavelandite core has been completely mined out ( $\mathrm{pl} . \mathrm{XI}$ ), In addition, the lepidolite-quartz-cleavelandite core in tunnel 2 has been mined approximately 30 feet east of the former face to a width of 20 feet. This additional work was completed by the Fayden Mining Company before it ceased mining in 1945.

In May and June, 1950, the U. S. Bureau of Mines drilled two core holes. Diesnond-drill hole No. I (fig. 22) is inclined 60 degrees, has a bearing of N. $77^{\circ} \mathrm{W}$, and was drilled from the dump of dike No, l. The hole has a Iength of 208.5 feet, and cut both dikes No. 2 and No. 3. Diamond-drill 
UNITED STATES

DEPARTMENT OF THE INTERIOR

GEOLOGICAL SURVEY
140

TRACE ELEMENTS INVESTIGATIONS

REPORT 138

Plate XI

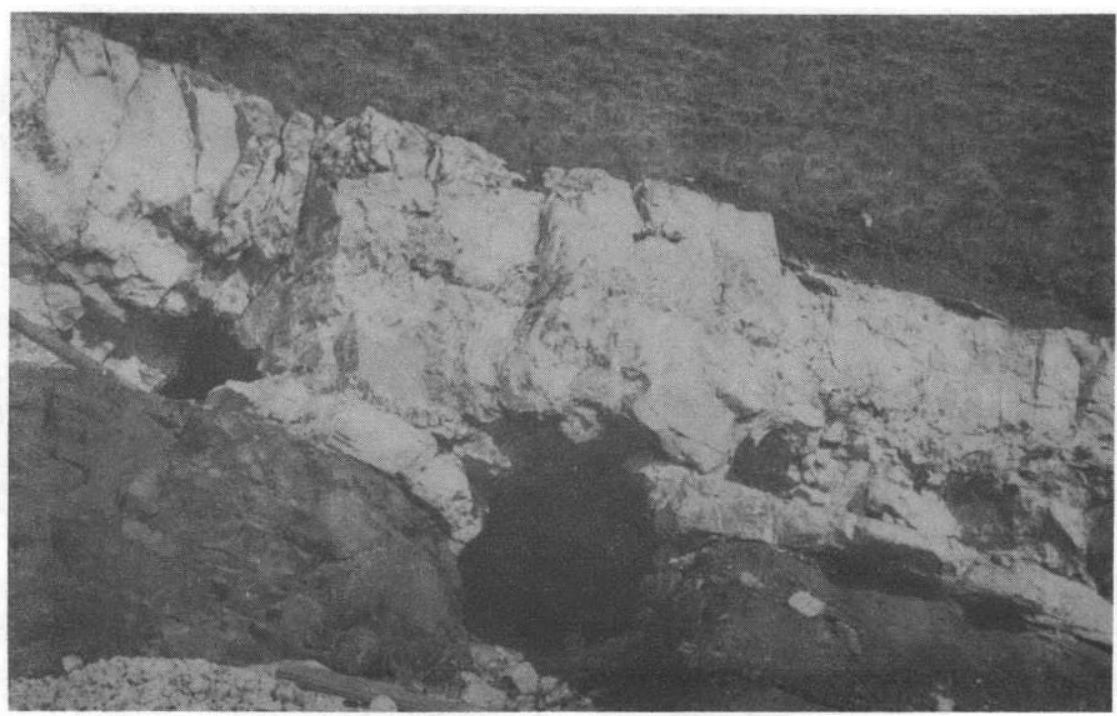

Mouth of stope of the Brown Derby No. 1 pegmatite (No. 452) showing contact of pegmatite with hornblende gneiss. 
hole Io. 2 was arilled from the hillside above tunel 3 and cut cikes lios. 1, 2, and 3. The bearing of the hole is $\mathrm{N}^{\circ} 88^{\circ} \mathrm{W}$, and the inclination is a minus 65 degrees.

The Brown Derby No. 1 dike is a lenticular and branching pesmatite, with two brenches at its southern end. It is exposed for a total length of 913 feet.

The vest branch is exposed in a series of six prospect pits. It is made up of a wall zone of albite-quartz pegmatite and a core of albitequartz-biotite permetite.

The albite-quartz pegmatite forms nearly all of the west branch of the dike. It has a grain size of 4 to 6 inches and is estimated to contain quartz ( 52 percent), cleavelandite ( 45 percent), muscovite ( 3 percent), and less then 1 percent of garnet, tourmaline, and lepidolite.

The albite-quartz-biotite pegmatite of the core is exposed in pit ITo. 11, and is 20 feet long by 1.5 feet wide. The grain size of the core ranges fron 0.12 to $0.25 \mathrm{inch}$. The unit conteins albite (86 percent), quartz (5 percent), biotite ( 4 percent), monzonite ( 2.2 percent), columbite-tantalite ( 1.4 percent), gellnite, the zinc spinel. ( 1 percent), and less than I percent garnet, tourmaline, and trace quantities of fluorite and betafite. Monazite forms well developed enhedral crystals, 0.25 to 1.5 inches across, ano colunite-tantalite are tabular crystals, 0.25 to I inch across.

The main part of the pegmatite is composed of six different units, identified from hanging vall to footwall as follows: pertitite-albitequartz pegnatite (hanging-wall laver), hanging-vall quartz pod, curved lepicolite layer, lepidolite-microlite poâ, quartz-cleavelandite-lepióolitetopaz layer, and a.lbite pecmatite (rootwall layer).

The perthite-albite-quartz pegmatite makes up the entire width of the 
northern pert of the dile and the eastern branch of the southern part of the dike. Ilsewhere, in the lepidolite-bearing part of the dike, it occurs as the hanging-wall layer, with the exception of the vicinity of the inclined shaft where it is missing. At this point the quartz pod takes the place of the perthite-albite-quartz pegmatite. This pegmatite has an average thickness of about 8 feet. In the lepidolite-bearing part of the pegmatite it does not exceed 4 feet. The grain size of the unit is about 12 inches, and the composition is estinated to be perthite ( 40 percent), albite ( 30 percent), quartz (20 percent), muscovite (10 percent), beryl ( $0: 1$ percent), and trace of tourmaline. Beryl crystals range from 0.25 to 2 inches in diameter.

The hanging-wall quartz pod is approximately 84 feet long and 2 feet thick. Its grain size is 24 inches, and the constituents are estimated as quartz (70 percent), cleavelandite (25 percent), and lepidolite (5 percent). The lepidolite is in sheets from 3 to 4 inches across.

The curved lepidolite layer is the uppermost of the lepidolite-bearing units; it is 190 feet long and averages 2 feet thick. This unit forms the back of the extension of tunnel 2 and much of the back of the stoped area in the inclined shaft. The grain size of the curved lepidolite layer is 4 to 5 inches and the composition is cleavelandite ( 44 percent), quartz ( 40 percent), curved lepidolite ( 15 percent), topaz ( 1 percent), less than one percent muscovite and tourmaline, and a trace of apatite. The curved. lepidolite ranges from 0.25 to 2 inches across, and the topaz ranges from 4 to 8 inches across.

Two principal lepicolite-microlite pods are known. In addition; smaller pods have been exposed in pits and trenches. The largest pod was mined in the inclined shaft and the other was discovered underground and 
mined by tunnel 2. The pod at the inclined shaft was approximately 60 feet Iong with a maximum width of 8 feet. It was mined from the inclined shaft for a total length of about 170 feet down the dip. The pod exposed in tunnel 2 is approximately 30 feet wide by $6 \frac{1}{2}$ feet thick, and is present in the face of the tuninel. The mined length is approximately 40 feet. The average grain size of the unit is 1 inch, and the average composition is cleavelandite ( 43 percent), lepidolite ( 40 percent), quartz ( 15 percent), topaz ( 2 percent), microlite ( 0.35 percent), and a trace of beryl. The lepidolite is in crystals 0.03 to 0.12 inch across, and is irregularly distributed within the pods. Microlite crystals range from less than 0.01 inch to 0.25 inch in diameter and are in shoots within the pods. This unit in tunnel 2 is extremely low in microlite, and has also a low lepidolite content. The pod has been nearly mined out in the incline; the remainder show in the bottom is pinching to the southeast.

The quartz-cleavelandite-lepidolite-topaz layer is the footwall part of the lepidolite-bearing units of the pegmatite. It is exposed on the surface for 319 feet and has an average thickness of 2 feet. The unit has an average grain size of 4 to 6 inches and consists of quartz ( 55 percent), cleavelandite (25 percent), lepidolite ( 10 percent), topaz ( 10 percent), less than 1 percent muscovite, and less then 0.1 percent bery. LepidoIite is in flat bools ranging from 1 to 7 inches across and topaz crystals are as much as 42 inches 1ong. Beryl is in crystals ranging from 1 to 4 inches in dianeter.

The aloite pegmatite (footwall layer) has an average thickness of 1.5 feet. It occurs discontinuously along the lepicolite-bearing part of the pegmatite. It has a grain size of $0.25 \mathrm{inch}$, and composition estimated to be albite ( 90 percent), quartz ( 8 percent), tourmaline ( 2 percent), less 
than 1 percent garnet, and a trace of biotite.

Reserves estinated for the entire dike total 30,500 tons of perthite, 7,600 tons of scrap mica, 3,980 tons of soda feldspar, 1,571 tons of lepidolite, 823 tons of topaz, 76 tons of beryl, 282 pounds of monazite, 179 pounds of colurnbite-tantalite, and 57 pounds of microlite.

\section{Brown Derby No. 5 (pegmatite No. 535)}

The Brown Derby No. 5 (pegmatite No. 535) (pl. II) is in a small gulch on the west side of the Brown Derby ridge at an elevation of 8,900 feet. It is in the south-central part of sec. 34 , T. 50 N., R. 3 I., New Mexico principal meridian.

This claim is reached by a short spur road from the main Brown Derby road and is omed by Mrs. Marie Disberger. The working's consist of two small open cuts and an adit. The larger cut has a main part, 32 feet lons, 15 feet vide, and 18 feet deep at the eastern face. The southern branch of this cut is 12 feet long, 6 feet wide, and 6 feet deep at the northeast face. An adit, approximately 10 feet long, was driven from the eastern end of this cut. A second shallow cut, 10 feet long and 8 feet wide, is northeast of the main cut. This pegmatite was originally napped by $\mathrm{J} . \mathrm{B}$. Hanley and R. Miller III, on September 3, 1943, with plane table and telescopic alidade. The internal structure of the pegnatite was revised by the writer in September 1949 (i.g. 23).

The Brom Derby No. 5 pegmatite intrudes greenish-black tonalite. The pegmatite is irreguler in shape, has a length of 210 feet, and a maximun wiath of 50 feet. It consists of three zones: wall zone, intermediate zone, and core. The wall zone is 2.5 feet thick where it is exposed in the large open cut, has a range in grain size of 0.12 inch to 0.25 inch, and 
consists of albite ( 61 percent), quartz (25 percent), perthite (10 percent), muscovite ( 4 percent), bleck to greenish-black tourmaline (<1 percent), lepidolite (trace), garnet (trace), and beryl ( $<0.1$ percent). One exposed area of the vall zone, about 3 feet square, contains 17 beryl crystals raneinf in size from 0.5 inch by 0.5 inch to 1 inch by 1.3 inches. This unusually rich area avereged 1.13 percent beryl, but contained only three cobvable crystals, The bexyl is in blue-green evheriral crystels,

Inside the wall zone a small intermediate zone is found in the sontheastem part of the pegmatite. This zone is approximately 50 feet long and 14 feet thicl. It has an average grain size of 4 inches and consists of quartz (55 percent), white cleavelandite (35 percent), lepidolite ( 5 percent), white blocigy perthite ( 4 percent), muscovite ( $I$ percent), beryI ( 0.1 percent), topaz $(<1$ percent), garnet $(<I$ percent), greenish-blacl: tournaline (<I percent), apatite (trace), microlite (trace), eind columbitetantelite (trace). Lepicolite occurs as fine-grained asgregates anc. as large flat sheets that are 4 to 6 inches in diameter. The vorings are on this zone, ano mining was directea toward the recovery of the fine-grained lepicolite; most of the large sheets were thrown onto the cump. The beryl is in blue-green euhedral crystels from 0.5 to 3.5 inches in diameter. The beryl content increases in the northern part of the zone and appears richest in the small northerm pit. A bergl count made on an area 4 feet by 5 feet in this upper pit contained 0.43 percent beryl. $\Lambda$ bout 15 pounds of beryl were also found. Iying on the dump from this pit. The topaz is milky white end forms ouhedral crystals 4 to 6 inches lons adjacent to the lepicolite. The gernet forms crystals as much as 1.5 inches in diameter, and comnonly is surrounced by coronas of muscovite. It is most common near the contect 
with the underlying wall zone. The apatite is in widely scattered lightblue 0.5 inch crystals. Microlite was not seen in place, but was found on the dump in distorted octahedrons 0.12 to 0.25 inch in diameter. The olive green microlite is faintly radioactive and is found between plates of cleavelandite. One crystal of columbite-tantalite, 0.06 inch thick by 0.75 inch wide, was found between plates of cleavelandite.

The core at its southeastern end has a gradational contact with the intermediate zone. The minerals of the core have an average grain size of 6 inches. It consists of white massive quartz ( 40 percent), white blocky perthite ( 39 percent), albite (20 percent), muscovite ( 1 percent), lefioclite (srace), blue-green beryl ( 1 crystal, 4 by 6 inches), and columbite-tantalite (two thin pieces, 0.5 inch long by 0.06 inch thick).

The reserves of the intermediate zone are estimated to be 0.75 tons of beryl, 30 tons of perthite, 7.5 tons of scrap mica, 260 tons of cleavelandite, and 37 tons of lepidolite.

\section{Pegmatite No. 537}

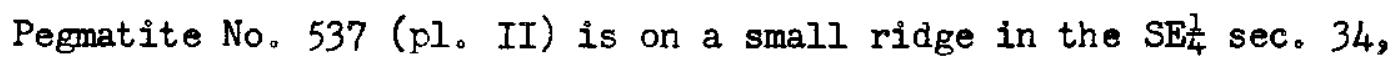
T。 $50 \mathrm{~N}_{0}, \mathrm{R}_{0} 3 \mathrm{E}$, New Mexico principal meridian. It contains one small adit approximately 4 feet wide and 6 feet long. This working is several hundred feet above and 600 feet to the northeast of the Brown Derby mine road. An old unidentified location marker is found near the adit.

Pegmatite No. 537 is an irregular dumbbell-shaped body (fig.24) 530 feet long and 84 feet in maximum width. The pegmatite intrudes hornblende gneiss, has a fine-grained wall zone, and has three small discontinuous core segments. The wall zone is more than 90 percent of the pegmatite and has an average grain size of 0.25 inch. It consists of albite ( 60 percent), quartz (25 percent), perthite (10 percent)\& muscovite ( 5 percent), and 
garnet (Iess than 1 percent).

The northern and southern core segments of this pegmatite have an average grain size of 6 inches and consist of perthite ( 66 percent), quartz (20 percent), albite (10 percent), and muscovite ( 4 percent). The perthite ranges in size from 3 to 12 inches. Beryl is found in only the northern core segment. A grain count on the sides of the small adit in this core showed 0.31 percent beryl. The beryI is present as 22 pale green euhedral crystals that range in size from 0.250 .12 inch to 2.5 by 4 inches. The core segment containing beryl is 52 feet long and 10 feet wide, and is estimated to contain 3.4 tons of beryl. The central core segment is a few feet wide, has an average grain size of 6 inches, and contains quartz ( 85 percent), perthite ( 10 percent), albite ( 5 percent), and muscovite (Iess than I percent). No beryl was noted in this pod.

\section{Pesmatite No. 538}

Pegmatite No. 538 (pI. II) caps the top of a small ridge in the $5 \mathrm{~N} \frac{1}{4}$ sec. 34, T. 50 N., R. 3 I., New Mexico principal meridian. One small cut, 6 feet square by I foot deep, exposes the southern end of this pegmatite, This cut is approximately 650 feet northeast of the Brown Derby road and several hundred feet above it. Pegmatite No. 538 is an elongate lenticularbranching pegmatite, approximately 550 feet long and 60 feet in maximum, width (fig. 24). The pegmatite intrudes hornblende gneiss, and consists of wall zone and three small discontinuous core segments located in the thicker parts of the pegmatite. The wall zone comprises more than 60 percent of the pegmatite, has an average grein size of 0.25 inch, and consists of albite ( 57 percent), quartz (25 percent), perthite (10 percent), and muscovite ( 8 percent). The core segments have an average grain size of 4 inches and consist of quartz (50 percent), perthite (32 percent), 
albite ( 15 percent), anä muscovite ( 3 percent). Perthite occurs in crsvis 6 to 3 inches in oianeter, Pale-freen beryl was noted only in the southernnost core segment, where it was estinated, from several beryl counts, to be 0.95 percent of the rock. The beryl crystals range from 0.12 inch by 0.12 inch to 6 inches by 6 inches in area. The southern pod is ' 128 feet long and has a maximum width of 35 feet. It was calculated to contain 42 tons of beryl to a depth of 24 feet.

\section{Pegmatite No. 560}

Pegmatite No. 560 (pl. II) is an unclaimed pegmatite at the foot of the mountains on the east side of Quartz Creek in the west central part of sec. 34, T. 50 N., R. 3 I., New Mexico principal meridian. This pegmatite is $I, 500$ feet south of State Highway $I 62$ and lies directly across a meadow. It is extremely irregular (fig. 25) and has a maximum length of 430 feet and a maximum width of 200 feet. It cuts across the hornblende gneissgranite contact. This pegmatite consists of a narrow wall zone, a large core, and a small pod on the south end. The wall zone has an average grain size of 0.12 inch and is estimated to consist of albite ( 60 percent), quartz (36 percent), perthite ( 4 percent), muscovite (less than I percent), and garnet (trace). The core comprises the greater part of the pegmatite and has an average grain size of 4 inches. It consists of perthite (50 percent), quartz (30 percent), albite (20 percent), and muscovite (trace). On the south end of the pegmatite there is a lenticular pod, 78 feet long and 18 feet wide. This pod has an average grain size of $I$ to 2 feet, and contains perthite (75 percent), quartz (20 percent), albite ( 5 percent), and bery $1(0.45$ percent). The beryl is pale green and ranges in size from I by 2 inches to 4 by 8 inches. This pod. contains the only beryl that was 
noted in the pegmatite. Reserves of beryl. are calculated to be 9.5 tons to a depth of 20 feet.

\section{Beryl and are Minerals Lode (permatite No, 590)}

The Beryl and Rare Minerals Lode (No. 590, pl. II) is a small lenticular pegmatite on the north-facing slope of Tollgate Gulch, in the SII sec. 34, T. 50 N., R. 3 I., Nev Mexico principal meridian, This lenticular pegmatite is 154 feet long and 55 feet wide: and dips gently to the south a.t the antle of 5 to 10 defrees (fig, 25).

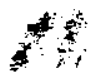

The property is about a quarter of a mile south of a smizing private roa in the bottom of Tollgate Gulch, and is reached by a narrow path vinoing up the hillside.

The claim on this pegmatite was located by Jesse Fleld on November 27, 1949. Mr. Field has opened at least six small pits ranfing from a fev feet square by 1 foot deep, to 22 feet long, 10 feet wide, and 2 feet deep. These pits are on local concentrations of beryl and thus expose the richest parts of the bexyl-bearing pegmatite. To date Mr. Field has recovered approximateIy 480 pounds of berrl, 2 pounos of columbite-tantalite, and approximately 800 pounds of muscovite. The Beryl and Rare Minerals pegmatite intrudes hornblende gneiss and may be divided into three zones: wall zone, intermediate zone, and core. The top of the pegmatite has been eroded, exposing the flatlying central units. The wall zone is thin and irregular, and is exposed in only a few places along the edge of the pegrnatite. It has an average grain size of 0.25 inch and consists of albite (55 fercent), perthite (20 percent), quartz (25 percent), and muscovite (<I percent).

The intermediate zone is well exposed by the workings. It has an average grain size of approximately 3 feet and is estimated to consist of 
perthite (50 percent), muscovite (30 percent), quartz (20 percent), albite ( $<$ I percent), beryl ( 0.1 percent), columbite-tantalite $<0.05$ percent), gahnite (traces), and an unidentified mineral which resembles the samarskite, fergusonite, or euxenite group of minerals. The perthite occurs in crystals from $I$ to 5 feet in diameter. The muscovite is abundant in the outer part of this zone and occurs in books as much as 8 inches across. It is reeved: soft, and heavily stained and is all scrap mica. It closely resernbles the mica obtained at the Bucky and Buckhorn properties. Beryl ranges from 0.5 to 8 inches in diameter and is white. The percentage of beryl obtained in the pits is estimated from the amount of beryl recovered and the size of the worlcines to be 0.4 percent. Because the pits were in the beryl-rich parts of the pegmatite and as many parts of this zone are completely barren of beryl, the overall content in this zone is approximateIy 0.1 percent. Columbite-tantalite was found intergrown with perthite in one pit. These crystals are from 0.01 to 0.12 inch thick and as much as 2 inches across, but no columbite-tantalite is exposed in the rest of the pegmatite. Gahnite is intergrown with fine muscovite in one small area. This mineral crystallizes as dark-green octahedrons 0.01 inch in diameter. Inside the intermediate zone is a core made up entirely of quartz, that extends the length of the pegmatite.

\section{White Spar No. 2 (pegmatite No. 604)}

The White Spar No. 2 pegmatite is in sec. 35, T. 50 N., R, 3 I., New Mexico principal meridian. It is on the north side of Tollgate Gulch, 0.9 mile from State Highway 162 , and is reached by a mine road that follows the gulch. The pegmatite is now being mined for lepidolite by Coinsolidated Feldspar Company. It was located in August 1942 and is owned by the Colorado Feldspar Company. 
The pegmatite was examined and mapped with plane table and telescopic alidade by $\boldsymbol{I}_{n}$ W. Heinrich and RoswelI Miller IIJ; on July 28, $1943 \mathrm{~J}$

$J$ Hanley, J. B.: Heinrich, $I_{0} W_{0}$ a and Page, $I_{0} B_{n}$, Pegmatite investigations in Colorado: Wyoming, and Utah, 1942-1944: U. S. Geol. Survey Prof. Paper 227, pp. 77-80, 1950.

Two prospect pits have been made in the pegmatite: one about 40 feet long and 10 feet wide at the north end of the dike and one approximately 60 feet long and 25 feet wide at the south end.

The pegmatite is about 260 feet long and ranges in width from 6 feet near tho center to nearly 50 feet at the north end. The trend is north, but the southern contact of the pegmatite strikes $\mathrm{N}_{0} 15^{\circ} \mathrm{We}$, and dips $70^{\circ}$ II. The pegmatite cuts hornblende gneiss, whose foliation strikes N. $25^{\circ}$ $\boldsymbol{Y}_{n}$ and dips $70^{\circ}$ to $80^{\circ}$ NW. The pegmatite consists of a core of fine-grained albite-quartz-perthite-lepidolite pegmatite surrounded by a discontinuous val1. zone of albite-perthite-quartz-muscovite pegmatite, The wall zone is discontinuous over the length of the pegmatite, and has a maximum width of 5 feet. Its grain size averages 0.25 inch, and the composition is estimated to be 45 percent albite, 30 percent perthite, 20 percent quartos; 5 percent mansortte, and less than I percent lepidolite. The lepidolite has an average grain size of 0.12 inch, but occurs in books as much as I inch across, The core ranges from 6 to 32 feet wide. It has a finer grain size then the wall zone, averaging 0.02 inch, and conteins 45 percent plagioclase, 35 percent quartz, 10 percent perthite, 10 percent lepidolite. less than $I$ percent garnet, and traces of beryl, microlite, fluorite, and chrysocolla. The lepidolite has an average grain size of 0.03 inch and occurs in lenses and stringers up to 4 inches wide. The lepidolite ex- 
posed in the northern pit is banded with coarser-grained albite and quartz.

$1 \mathrm{grab}$ sarmle of the core taken by Heinrich J from the southern pit

\rfloor Hanzey, J. B., et al, op. cit., p, 80, 1950.

and analyzed spectrographicelly by the Geological Survey contained 0.7 percent $\mathrm{Li}_{2} \mathrm{O}$, or about 17 percent lepidolite, 0.05 percent $\mathrm{BeO}$, and no $\mathrm{Cb}$ or Ta.

White Spar No. I (pesmatite No. 636)

The White Spar No, I pesmatite is in sec. 35 , T. 50 N., R. 3 I., New Mexico principal meridian. It is on the north side of Tollgate Ginch and is comnected to State Filohway 162 by a mine road 0.7 mile long running up the bottom of the gulch. A claim was located on this pegmatite in 1942 by the Colorado Feldspar Company. T. W. Heinrich and Roswell Miller III of the Survey examined and mapped this property with plane table and telescopic aIidade on July 29, 1942. J

\footnotetext{
J Hanley, J. B., Heinrich, …W., and Page, I. R., Pegmatite investigations in Coloredo, Wyoming, and Utah, 1942-194L: U. S. Geol. Survey Prof. Paper 227, pp. 77-80, 1950.
}

The mine workings consist of five prospect pits, the largest of which is 50 feet long and has a narimum vidth of 25 feet.

The pegnatite crops out on the top and on the south-facing slope of a narrov ridge paralleling and separating Tollgate Gulch from a gulch to the north. The pesmatite is intruced into hornblende gneiss, but none of the contacts are exposed.

The pegmatite trends $\mathbb{N} .20^{\circ}$ I, and dips $30^{\circ}-35^{\circ} \mathrm{SI}$. It has a leigth of 200 feet and a meminum vidth of 85 feet. 
Four zones are well developed within the pegmatite. A wall zone of fine-grained albite-perthite-quartz-muscovite pegmatite completely surrounds an intermediate zone of fine-grained cleavelandite-quartz-perthitelepidolite pegmatite and cores of lepidolite-quartz pegmatite and quartz pegmatite. The wall zone is 9 feet thick on the hanging-wall side and 33 feet on the footwall side $J$, and has an average grain size of 2 inches, 1950, J Hanley, J, B, Heinrich, I. W, and Page, I, R., op cit, p. 77.

The composition is estimated to be 45 percent albite, 32 percent perthite, 20 percent quartz, and 3 percent muscovite. Perthite is in crystals as much as 24 inches long and 15 inches wide, and macovite booke srerago 1.5 inches across and 1 inch thick.

The cleavelandite-quartz-perthite-lepidolite intermediate zone on the western and southern edges of the quartz core, is 90 feet long and ranges in width from 1 to 18 feet. The grain size is 1 inch, and the zone is estimated to contain 55 percent cleavelandite, 25 percent quartz, 15 percent perthite, 5 percent lepidolite, 0.01 percent beryl, 0.003 percent topaz, and 0,0003 percent columbite-tantalite, and a trace of microlite. Perthite crystals average 12 inches in length and 8 inches in width. The lepidolite is in books 3 inches across and 0.5 inch thick. The beryl is yellow to pale bluegreen and occurs in orystals from 0.5 to 1.75 inches in diemeter. Topaz crystals are small, ranging in size from 0.06 to 1 inch. The columbitemtantalite crytals are as much as 0.4 inch long and 0.25 inch wìde.

The pegmatite cores are of two types: white massive quarti pegmatite and lepidolite-quartz-microlite pegmatites The quartz pogmatite occurs as: one large irregular moss 80 feet long and 3 to 13 feet wlde, and seren 
smaller Ienses.

The core of the lepidolite-quartz-microlite pegmatite is on the west side of the quartz pegmatite, between the core and the intermediate zone of cleavelandite-quartz-perthite-lepidolite pegmatite. This core is 20 feet long and from $I$ to 8 feet wide, and has a grain size of 0.03 inch, and contains approximately 90 percent lepidolite, 10 percent quartz, and 0.1 percent microlite.

\section{Buckhorn (pegmatite No. 659)}

The Buckhorn (pegmatite No. 659, pl. II) caps the top of a ridge on

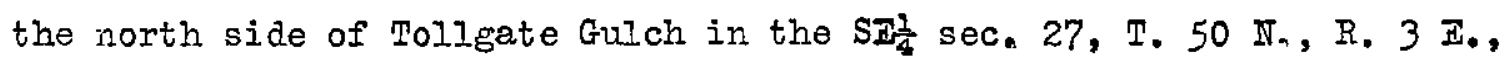
New Mexico principal meridian. This irregular pegmatite (fig. 26) has a maximum length of 1,750 feet and a maximum width of 1,360 feet. It is between 8,900 and 9,400 feet above sea level and 350 to 850 feet above Tollgate Gulch, The nearest road is State Highway 162, 0.4 mile to the west.

At least three claims have been located on this pegmatite. Claim notices show two of these to be: the Buckhorn, which is on the northwestern part of the pegmatite and the Feldspar claim in the northeastern part of the pegmatite, both located by Bert and Florence Tucker. On the Buckhorn claim there are several small trenches, the largest is 30 feet long and 5 feet wide, and the smallest is about 4 feet long, 3 feet wide, and 2 feet deep. The Feldspar claim has a trench 15 feet long, 3 feet wide, and 2 feet deep. Several hundred feet to the east of the Feldspar claim is an unnaned claim which has a small shaft, 4 feet square and 8 feet deep, and a trench 15 feet long and 3 feet wide. No mining has been done on these claims. 
The Buckhorn pegrnatite (fig, 26) intrudes hornblende gneiss and tonalite, The greater part of this pegmatite has only one zone, but it contains several small disconnected core segments in its upper part along the ridge. Around one of these cores is a small intermediate zone. The small cuts in the Buckhorn claim are made on this intermediate zone. The wall zone, which forms more than 90 percent of the pegmatite, has an average grain size of 0.25 to $0.5 \mathrm{inch}$. It is estimated to contain albite ( 59 percent). quartz (20 percent), white to pink perthite (20 percent), fine-grained graygreen muscovite ( 1 percent), garnet (trace), and biotite (trace). Though nost of these minerals are fine grained, the perthite occurs in blocky crystals 1 to 3 inches in diameter.

The intermediate zone is 1.5 to 2 feet thick. It has an average grain size of approximately 1 foot, and consists of perthite (50 percent), muscovite ( 40 percent), and quartz (10 percent), A few greenish crystals of beryl, approximately 1 inch in diameter, were noted. Adjacent to the core in a feldspar-rich part of this zone three or four crystals of columbite-tantalite and monazite, about 0.5 inch long, were found. The muscovite in the intermediate zone occurs in books as large as 10 by 18 inches. It is greenish-gray, and has a strong "A" structure. It crumbles easily between the fingers. It closely resembles the scrap mica from the Bucky nine, which is prized as a grinding mica. The intermediate zone is about 150 feet long, and dininishes in grade to the south. The amount of scrap mica available, therefore, is small.

The core segment inside the intermediate zone is south of the other core segments and differs considerably from them in composition and texture. This core has an average grein size of 2 feet and consists of perthite ( 91 percent), quartz ( 7 percent), muscovite ( $I$ percent), and 
beryl ( 0.7 percent) as determined by a beryl count along the sides of the largest cut. The beryl is pale green and ranges in size from 0.017 by 0.058 foot to 0.27 by 0.45 foot:

The other cores lying alons the top of an east-west trending ridge are only 10 to 20 feet thick. They may be the eroded remnants of a once much larger and continuous core, The average grain size of the minerals in these core segments is 8 to 12 inches, and though they vary in the percentage of minerals, they are estimated to contain perthite (53 percent), quartz ( 45 percent), a. bite ( $I$ percent), anò muscovite ( $I$ percent).

The small shaft to the east of the Feldspar claim was sunk in a quartz-rich part of this pegmatite. It yielded approximately 75 pounds of beryl. These beryl crystals are 1 to 2 inches across, are white, end closely resemble quart $z$, This appears to be a beryl-rich pocket and others night be found on further exploration. The amount of beryl is not likely to be large, as the core segments are extremely thin, A limited amount of feldspar could be obtained from these core segments, but as the cost of feldspar is low and transportation costs are high, the econornic feasibility of this is questionable,

\section{Black Wonder (pegmatite No. 847)}

The Black Wonder pegmatite is the largest pegmatite in the district. covering parts of secs. $20,21,22,27,28,29,32$, and $33, T_{0}, 50 \mathrm{~N}_{\mathrm{s}}$, R, $3 \vec{B}_{n}$, New Mexico principal meridian, It is 12,600 feet 1 bng and has a maximum width of 6,700 feet. The northeast end is less then 200 feet from Willow Creek and the southwest end is at Big GuIch. A road from Big GuIch to the State Highway 162 traverses the pegmatite for 1.5 miles. Much of the eastern edge is within a quarter of a mile of the highway. The western part 
of the pecmetite forms the southern extension of a prominent north-trending ridge. This ridge rises to the north, and the highest point on the pegmatite is over 9,700 feet. The southern and eastern edges of the pegmatite are at an altituce of slightly above 8,500 feet.

The Black Wonder is extremely irregular, consisting of a large number of intersecting dikes of uneven spacing and size.

Most of the pegmatite intmudes hormblence gneiss, but part of it cuts coarse-greined grenite at the southeast and pre-Cambrian sediments in a snell area at the northeast.

The pegrnetite has arousec little mining interest. Tvo clains heve been filed on different parts of the pegmatite: the Black Wonder end the Beryl claim. The Black Wonder prospect, in the eastern part of sec. 29, was located in Mey 1948 on a marnetite-rich area in the pesnatite, and consists of one smell pit. The Beryl claim, located in June $19 ! 18$ by Bert Tucker, is in sec. 27 and consists of three pits on a beryl-bearing unit and a fourth on a monazite-bearing unit.

The pecrmatite consists of a tlick wall zone enclosing small vicely scattered. cores and cut by occasional fracture fillings. OnIy a fev of the cores heve an intermediate zone between them and the wall zone. The vell zone, constituting over 95 percent of the pegmatite, varies in texture and composition. In the southern and western parts of the pegmatite it is a graphic granite unit, grading to the north and northeast into a unit with only a few crystals of graphic Grenite in a matrix of albite and guartz. The wall zone at the south and west end has an average grein size of 3 inches and is estinated to contain 60 percent perthite, 24 percent albite, 15 percent quartz, I percent martite, less then 1 percent biotite, and a trece of garnet. Grephic granite crystals, as moch as 5 feet across, 
constitute 50 percent of this part of the wall zone. Small locel concentrations of martite are common, such as the one upon which the Black Wonoer claim was macie. Martite corrprises 10 percent of the wall zone at the prospect pit and to the northeast for 50 feet, in crystals as much as 4 inches across. The wall zone to the north and east has an average grain size of 1.5 inches and is estimated to contain 55 percent albite, 30 percent perthite, 15 percent quartz, less than 1 percent garnet, and a trace of martite. Graphic Eranite constitutes Iess than 10 percent of this pert of the wall zone in crystals less than 6 inches across.

At the Beryl claim, two different types of intermediate zone surround quartz cores. One intermediate zone contains monazite and columbitetantalite, and the other beryl crystals. The intermediate zone that contains beryl is between two small quartz pegmatite cores, 7 feet apart, the larger of which is 25 feet long by 10 feet vide. Two prospect pits, the larger of which is 9 feet long by 6 feet wide, are along the east sice of the larger quartz pegmatite core. Another pit, 15 feet long and 4 feet vice, is on the east edge of the smaller quartz pegmatite core. The internediate zone is not exposed completely around the larger core, but lies east of it, surrounding the smaller one. This zone has a maximum size of 30 feet long and 15 feet wide. The grain size averages 2 inches, and the zone is estinated to contein 79 percent albite, 10 percent quartz, 5 percent perthite, 5 percent muscovite, 1 percent garnet, and 0.2 percent beryl. The muscovite is in books from 0.25 to 5 inches across. Garnet crystals range in size from 0.25 to 2 inches. Beryl is concentrated alone the eastern edge of the larger quartz pegmatite core in semitransparent yellowishgreen crystals from 0.5 to 1.25 inches in dianeter. The monazite-bearing interneoiate zone is approximately 400 feet north- 
east from the beryl-bearing zone, and is exposed by a prospect pit 4 feet Ione and 3 feet wide, on the east side of a quartz pegmatite core. The core is 15 feet long, 6 feet wide, and 1s 2 feet thick at its edge in the pit. This intermediate zone is estimated to be 15 feet long and 4 feet wide. Its grain size is 6 inches and the composition is estimated to be 55 percent albite, 30 percent muscovite, 15 percent quartz, and traces of monazite and columbite-tantalite. Muscovite books are as much as 8 inches across, and monaztte crystals average 0.75 inch long by 0.12 inch wide, The columbite-tantalite averages 0.12 inch by 0.06 inch.

The cores are nearly all small, measured in tens of feet long and less than 10 feet wide. They range from 100 percent quartz to 10 percent quartz and 90 percent perthite. In the northeast part of the pegmatite muscovite books form as much as 30 percent of the cores in crystals as much as 5 inches across. In some of the cores the quartz is smoky, suggesting the presence of radioactive minerals. Several small crystals of allanite were found in one core.

In various places the wall zone is cut by fracture fillings of white quartz. These fracture fillings range from a fraction of an inch to 6 inches in width.

Trio No. 1 (pegmatite No. 1402)

The Trio No. 1 pegmatite is on the ridge west of Willow Creek at an altitude of 10,000 feet, in secs. 16 and $21, T, 50 \mathrm{~N}, \mathrm{R}, 3$ s., New Mexico principal meridian. The nearest road is along Willow Creek 1 mile northeast of the claim. This road joins State Highway 162,2,5 miles to the southeast. The clain was Iocated on May 2, 1949 by Bert Tucker, George Tucker, and A. T. Pearson. Discovery workings consist of four small prospect pits, 
the Iargest of thich is 13 feet long, 10 feet wide, and 4 feet deep.

The pegmatite is 644 feet lone and has a maximum width of 152 feet. It is irregular in shape and is intruded into quartz monzonite. The pegmatite is made up of four zones: a large thick wall zone constituting over 90 percent of the pegmatite, two small intermediate zones, and several small discontinuous cores. The vall zone has an average grain size of 0.75 inch and is made up of albite ( 45 percent)s perthite ( 1.0 percent), quertz ( 15 percent), biotite (less than 1 percent), and nartite (less then I percent)。 The intermediate zones are of two types: a quartzalbite-perthite pegmatite and a quartz-albite-muscovite pegmatite, both found around one core. The quartz-albite-perthite pegmatite intermediate zone, 20 feet lone by 15 feet vide, is east of the quartz-albite-miscovite pegmatite intermediate zone and separetes it from the wall zone. This quartz-albite-perthite pegmatite has an average grain size of 6 inches and is estimated to contain quartz ( 35 percent), albite ( 34 percent), perthite (30 percent): garnet $(0.5$ percent), and biotite $(0.5$ percent). Six beryl crystals from this zone were found on the stockpile, ranging from 1 to 8 inches in diameter and from 1 to 6 inches in length. The quartz-albitemuscovite pegmatite is 3.5 feet thick and surrounds the core of quartz pegmatite. This zone has an average grain size of 1 inch and is made up of quartz ( 60 percent), albite (25 percent), muscovite ( 15 percent), and garnet (Iess than I percent). Muscovite crystals average I inch across and 1,5 inches thick.

Cores of quartz pegmatite occur in several places and are as much as 15 feet long by 12 feet wide. The core on which the workings are Iocated is 20 feet long by 5 feet wide and consists entirely of quartz. 
Bucky (pesmatite No. 1574)

\section{Introcuction}

The Bucty pegmatite is an irregular pegmatite on the riofe between Willow and Illinois Creeks. Nunerous claims are loceted on this pegmatite in the $\mathbb{P}_{\mathrm{Z}}^{\mathrm{T}}$ sec. 22, T. 50 N., R. 3 E., New Mexico principal meriòias. The Bucly clain on which the min workings are founo is on its northern end, covering a quartz pod 100 feet long and 60 feet wide. This clain was orifinally omed by Roo Fields, who has driven several smell adits alone: the southern side of the pod and has produced approxinetely 17 tons of bery 1, 100 pouncs of colurabite-tantalite, 25 pouno.s of an unidentified sanerskite-lilte mineral, endi 15 pounảs of monezite. Scrap mica was at first discerdec but approximately 20 tons were stockpiled in Septernber 1948. In the fell of $1948, \mathrm{Mr}$. Fields sold the property to the Beryllium Minine Corrpany, Inc., which has operated from open pits excevated by blasting and bulldozing. A road was constmeted to the mine worlings approximetely 400 feet above the valley bottom by the Beryllium Minine Company, Inc. In May 1950 a snall mill for separating the scrap mica built aloneside the mine road. Prior to Moy 15, 1950, the Beryllium Minine Company, Inc. had produced 32 tons of beryl, 139.6 tons of scrap mice, 1,020 pounds of colurbite-tantalite, 15 pounds of monazite, anci 13 pouncis of a samarskite-like mineral.

The beryl was sold to various buyers in Coloracio, and was trucked to Ioncrnont or sold on the property. The scrap mica is sold to Vestern INonmetallics in Preblo, Colo., at $\$ 25.00$ a ton, delivered in Pueblo. ITo colunite-tantalite has been sold, and the monazite and the sararskite-like mineral have been sold to Waro'.'s Natural Sclence Istablishment for resale as ninerel specinens. 
The Buclsy mine workinds were mappec by Staatz and Flawn betreen September 28 ano. 31 in 1943, vith plane table and telescopic alicicie. This nep (fics. 27 end 28) covered an area from the northern contact of : the pesmatite with the schist to a point 180 feet south of the main quartz poc. A beryl count was nace in the mine workings. On November $22,1949$. the map was revised. by Staatz and Trites to show the new vorines. The outline of the thole pegmatite was mapped by Staatz (pl. II) in the course of resionel moping in September 1849.

\section{Geolo: $3 y$}

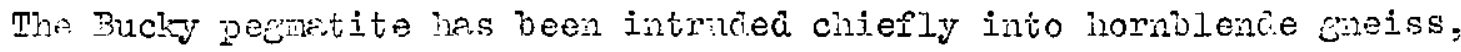
unt it Iso cuts severk smell banos nf quartzite. The pegmetite is extrenely inregular anc. conteins nany snell inclusions or pendents of country rock. The nein bulle the pegnatite is a fine-greined discontinuous vell zone and a coarse-grineo graphic sranite intermediate zone. Inside this are scotteren 36 cores of quartz pectetite segments at least 10 feet Iong. Sone of these core secuents are surmo uned by one to three internediate zones. The core segnents have a peripherel arrangenent in the pegratite (fic. 27) and sone nay be fracture fillings rather than true core segments. The wall zone is discontinuous; it is absent in sone parts and severel muncred feet thick in others. It has an avcrase errain size of 0.25 inch, and consists of aloite (60 percent), perthite (20 percent), quartz (1o percent), muscovite (4 percent), and a trace of garnet.

Insice the wal zone is a thick interinedinte zone nece up chierly of graphic grinite. The srephic granite ascregates range fron 2 inches to I foot in dieneter, snd rverace about 5 inches. Besides fraphic grenite, this peghetite wit conteins 3 to 4 percent of cream-colored blocky 
gortite, 1 percent of rinte cuentz cirsters, 3 percent of tine-bined.

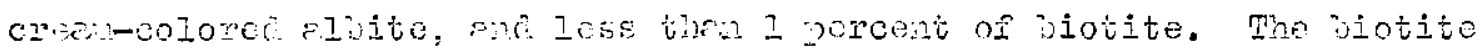
occus in thin, 6-inch bleces thet rre locelized in smell areas in this rool. The aluite is dificult to distingish from the pertinte but is nost abuidnt alons the contect of the quertz-aloite perthite pegrnetite. The albite has a rinimun incex of refraction $\left(I_{\alpha_{1}}\right)$ of $1.530 \pm 0.002$. The estimeted bulk composition of this rock is perthite (77 percent), quartz (20 percent), albite ( 3 percent), biotite ( 1 percent). Quartz albite pegnatite is the nost common type of pezmetite adjacent to and encircling quartz pods. Some quartz pois heve no other intermediate zones separating them from the graphic granite pegmatite, while others have as many as three. Good exposures of this zone are found around the large poo on the Bucly clain. The quartz-albite peometite has an average grain size of $0.5 \mathrm{inch}$, and usually contains equidinensional quarta grains surrounced by aIbite. The estineted composition of this rocle is quartz (55 percent), albite (40 percent), perthite (3 jercent), ruscovite ( 1 percent), and garnet (I percent). The aluite is crean-colored and usualy fills around the quartz crystals. It has a minimum inciex of refraction (Ital) of 1.532. \pm 0.002 . The perthite is com 10 nest near the perthite-quartz pegrnatite zone where it occurs as grajhic srewite, and neer the muscovitefelospar-quartz-beryl zone there it occurs as crean-coloreo blocky crystals about 4 inches across. The mascovite is in light-colored irregular books 0.25 to 0.75 inch long. It occurs in local aggregates, comprisins as nuch as 10 percent of the rock. Adjacent to the core of the Bucky mine the feldspar is considerably isaolinized.

Muscovite-feldspar-quartz-beryl pegmatite predoninates around the lerge Brolgy core secment (fics. 27 and 28) but is also vell developeo 
around at lerst two other core sognents and nay be present to a minor extent around several more. This zone veethers easily and is usually concealed by quartz float. It has been well exposed along the southern and eastern sicle of the Bucky claim, where mine faces are over 20 feet high. This zone extends around three-fourths of the Bucky core segment but pinches out in the northwest quarter and is from $I$ to 10 feet thick. The muscovite-feldspar-quartz-beryl pegmatite zone has a grain size which ranges from 3 inches to over 8 feet and has an average of about 2 feet. It has an estinated composition of muscovite (40 percent), felespar (31. percent), quartz (20 percent), bery1 (8.9 percent), colunite-tantalite (0.11 percent), samarskite-like widentified mineral (6,003 percent), and monazite ( 0.003 percent), topaz ( 1 percent), gahite ( $<$ I percent), phosm phates (trace), and lepidolite (trace). Muscovite makes up from 10 to 80 percent of the rock and is found in books as much as I foot across; the everage is 6 inches. The books are heavily lined, have irregular surfaces, contein minute croolred Eractures, and have a prominent "Al structure. Both red and black nineral staining is common. This mica is also scrap and is quite soit, which makes it an excellent grinding mice. The feldspar occurs chiê̂ly as cream-colored blocky perthite and as cream-colored fineBrained albite, The albite is comonest in heavy muscovite concentrations and has a minimum index of refraction $\left(\mathbb{N}_{\alpha}\right)$ of $1.531 \div 0.002$. Because of the heavy lsaolinization of both felaspars, the relative proportions of pertinite to albite could not be readily determined, Quartz occurs as Iarge white crystals several. feet in diameter. Beryl is found in large white to pale-green euhedral crystals. A total of 64 beryl crystals was noted in 344.5 square feet of muscovite-felospar-quartz-beryl pegmatite measured along the mine walls. The crystals ranged in area across their 
bescs from 0.007 to 5.0 squere feet, and averaged. 0.70 squere feet. Beryl is more comon enc occurs in lerger crystels in the perthite-quartz-rich pert then in the mscovitemich part. A beryl count made in Fields oarly workings, which were driven on a beryl-rich concentration, gave an everace of 13 percent beryl. Since thet tine nost of this zone has contained much less benyl. A second pocket wes opened in April 1950, from which epproxinetely 9 tons of beryl hed been taken prior to June of the sene year. The beryl in this, as in all zones, is concentrated in pockets separated by amost barren rocks. The beryl has a naximum index of reiraction $\left(N_{\omega}\right)$ of $1.578 \pm 0.002$, which corresponds to approxinetely 13.2 percent $B e 0$. A small part of the beryl has been kaolinized. The columbite-tantalite, monezite, and an unidentified sanarskite-like mineral usually occur together in erratic pockets. They were found in sone of the early vorkings adjacent to the core segment. The columbite-tantalite occurs in black tabular crystals as much as 6 inches across. Monezite occurs in 0.25 to 1 inch Iong redish-brow enhedral crystels and the aijacent felcsper is frequently stained red. The semerskite-like whichtified nineral has been found in nasses as moh as 5 inches across. It is derk creenish-bleck in color, hes conchoidel fracture, a sreasy luster, and no aperent crytur corn. This ninerel is netemict and its $x$-rey pettern coes not egree with thet of semarsitite, fergusonite, euxenite, ellenite, or ureninite. A nore complete discussion of this mineral is given in the section on mineralogy. Topez has been reported from the Bucly core segment but is found in oreeter abundence arovnd a snall pod on the southwestem pert of the pegmetite. The zone in this area ney contein as much as 1 percent of topez in crystals I to 4 inches across. Iepidolite has been found adjacent to the topez but is quite rare and in very fine-greined aggregates. 
Iithiophilito-triphylite has been found in a fev rare crystals aojacent to the Bucly core sesment end another small pod in the extrene northeesterin end of the pegnatite*

In adition to the macovite-relospar-beryl pesmatite, there is a coarse-grained perthite pecrnatite around the Bucky core segment. This rock has an average grain size of 6 feet and is estinated to consist of 93 percent of crean-colored blocky perthite, 7 percent of quartz, and less than 1 percent of albite and muscovite. The perthite is slightly kaolinized. About 30 tons of creasl-colored perthite has been stoclpiled at the mine, but none had been sold prior to June 1950 .

Quartz core segments are found scattered throughout the pesmatite fac renge from a few feet long and less than I foot wide to the one 100 feet lons and 80 feet wide on which the Bucly claim is located. The quertz pegmatite is made up of 100 percent white massive quartz. As this rock is resistent to erosion, it forns proninent knojs, end joint blocirs commin cover the adjoining pegmetite.

A unit which is believed to be a fracture filling was found in two places along the outer edge of the pegmatite. This unit has an average grain size of 3 feet and is estimated to consist of 50 percent quartz and 50 percent perthite. 
Table $0^{20}$. -Mineralogy of pepatites

\begin{tabular}{|c|c|c|c|c|c|c|c|c|c|c|c|c|c|c|c|c|c|c|c|c|c|c|c|c|c|}
\hline \multirow{4}{*}{ 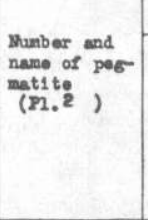 } & \multicolumn{2}{|c|}{ Mall rock } & \multicolumn{23}{|c|}{ Pegat to } \\
\hline & \multirow{3}{*}{$\begin{array}{l}\text { Type and } \\
\text { formation }\end{array}$} & \multirow[t]{3}{*}{ Nlteration } & \multirow{3}{*}{$\begin{array}{c}\text { Relation to } \\
\text { val1 rock }\end{array}$} & \multirow[t]{3}{*}{ Shape } & \multirow{3}{*}{$\begin{array}{l}\text { Internal } \\
\text { strueture }\end{array}$} & \multirow{3}{*}{ Pexture } & \multicolumn{19}{|c|}{ Mineralogy } \\
\hline & & & & & & & \multicolumn{2}{|c|}{ Plaglociaso } & \multicolumn{2}{|c|}{ Perth1te } & $\begin{array}{l}\text { Graph10 } \\
\text { gran1 to }\end{array}$ & \multicolumn{2}{|c|}{ Quartz } & \multicolumn{2}{|c|}{ Muscovit to } & \multicolumn{2}{|c|}{ Garnet } & \multicolumn{2}{|c|}{ Tourmal ino } & \multicolumn{3}{|c|}{ IS thium minerals } & \multicolumn{3}{|c|}{ Othor minerals } \\
\hline & & & & & & & $\begin{array}{l}\text { Par- } \\
\text { cont }\end{array}$ & (1noho & Poont & 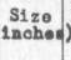 & Per $\begin{array}{c}\text { S1ze } \\
\text { Peent (1ncheo })\end{array}$ & Par- & $\begin{array}{c}\text { S1zo } \\
\text { (necheos) }\end{array}$ & $\begin{array}{l}\text { Per- } \\
\text { Peent }\end{array}$ & 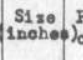 & Per- & $\begin{array}{l}\text { S1za } \\
\text { 1nchoo: }\end{array}$ & Q) Per- & S1zo & Mineral & $\begin{array}{l}\text { Por- } \\
\text { cent }\end{array}$ & $51=0$ & Minoral & $\begin{array}{l}\text { Por- } \\
\text { cent }\end{array}$ & (1ndzog) \\
\hline 1 & Tonal1to. & & Mot expesed. & Lentievera & One unst. & $3 / 4$ & 45 & & 35 & & & 25 & & $<1$ & & & & & & & & & & & \\
\hline 2 & Do. & & Do. & Do. & Do. & $2-3$ & 15 & & 49 & & & 35 & & 1 & & & & & & & & & & & \\
\hline 3 & Do. & & Do. & oral. & Do. & $1 / 4-1 / 2$ & 47 & & 25 & & & 25 & & 3 & & $<1$ & & & & & & & & & \\
\hline 4 & Do. & & Do. & Lent1 evlar. & Do. & $3 / 4-1$ & 53 & $1 / 16$ & 15 & & & 30 & 12 & 1 & & 1 & $1 / 8$ & & & & & & $\begin{array}{l}\text { B1ot1 te. } \\
\text { Gahns to. } \\
\text { Beryl. }\end{array}$ & $\begin{array}{l}\text { Trace. } \\
\text { Frace. } \\
\text { 4rergetalo. }\end{array}$ & $\begin{array}{l}1 / 32 \\
1 / 8-3\end{array}$ \\
\hline 5 & 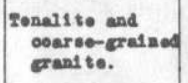 & Mone. & Cross-enttiac & branobinge & D. & $1 / 4$ & 54 & & $\infty$ & & & 25 & & 1 & & $<2$ & & & & & & & & & \\
\hline 6 & eranito. & Do. & & Loust oular. & Do. & $\mid 1 / 8-1 / 4$ & 65 & & 15 & & & $\infty$ & & $<1$ & & trace. & & & & & & & & & \\
\hline 7 & $\begin{array}{l}\text { Tonalite } \\
\text { Cranite. }\end{array}$ & & lot exposed. & $\begin{array}{l}\text { Lenticular } \\
\text { brenching. }\end{array}$ & Do. & $|1 / 8-1 / 4|$ & 58 & & 20 & & & 20 & & 2 & & $<2$ & & & & & & & & & \\
\hline 8 & M10t1 to enot as & עose. & Conforsablo. & $\begin{array}{l}\text { Lontioular- } \\
\text { brasolinge. }\end{array}$ & Do. & $1 / 4$ & 60 & & 20 & & & 20 & & $<1$ & & traoe. & & & & & & & & & \\
\hline 9 & $\begin{array}{l}\text { Tonal1to and } \\
\text { exael to. }\end{array}$ & Do. & Orese-outting & elentioulax. & Do. & $2 / 4-1 / 2$ & 62 & & 18 & & & 20 & & $<1$ & & $<1$ & & & & & & & & & \\
\hline 10 & Duknows. & & & Do. & Do. & \begin{tabular}{|l|l}
$1 / 26$ & 1
\end{tabular} & 69 & & 10 & & & $\infty$ & & Erace. & & $<1$ & & & & & & & & & \\
\hline u2 & Tonell to. & Mono. & Oroes-outting & 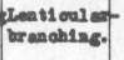 & Do. & $1 / 4$ & 60 & & $\infty$ & & & 20 & & $<1$ & & $<1$ & & & & & & & & & \\
\hline 12 & 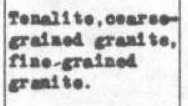 & Do. & Do. & Do. & Do. & $1 / 4-1 / 2$ & 4 & & 35 & & & 20 & & $<1$ & & $<1$ & & & & & & & & & \\
\hline 23 & $\begin{array}{l}\text { ooarne- erainod } \\
\text { erand to. }\end{array}$ & & & Lentioulex. & Do. & $\mid 2 / 8-1 / 4$ & 65 & & 15 & & & 20 & & $<1$ & & Treoe. & & & & & & & & & \\
\hline 14 & soaelit te. & & Crose-cutting & zeationlar. & Do. & $\mid 1 / 8-1 / 4$ & 65 & & 15 & & & 20 & & $<1$ & & $<1$ & & traee. & & & & & & & \\
\hline 15 & $\begin{array}{l}\text { Maco-gralaned } \\
\text { Crailito. }\end{array}$ & & & Do. & Do. & $1:$ & 30 & & 35 & & & 35 & & 2 & & $<1$ & & & & & & & & & \\
\hline 16 & somall te. & & Wot expoeed. & Leat1 oular & Do. & $2 / 2-3 / 4$ & 50 & & 15 & & & 35 & & $<1$ & & $\angle 1$ & & & & & & & & & \\
\hline 27 & Onimonan. & & Do. & $\begin{array}{l}\text { Leatioulart } \\
\text { branohing. }\end{array}$ & Do. & $\mid 2 / 2-3 / 4$ & 55 & $1 / 8$ & 25 & 46 & & 20 & 46 & $<1$ & & 21 & & & & & & & & & \\
\hline 28 & 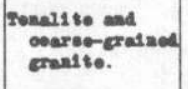 & Moso. & as so-outting & D. & Do. & 34 & 25 & $1 / 8$ & 59 & -10 & & 25 & $8-10$ & 13 & $3-4$ & $<1$ & & & & & & & & & \\
\hline 29 & Toasel1to. & & Hot exposed. & Lent1 owlar. & Do. & 4 & 25 & & 50 & & & 25 & & & & Fraece. & & & & & & & & & \\
\hline$\infty$ & Do. & soan. & Groso-outing & . Irrocalar & Do. & $1 / 8$ & 72 & & 7 & & & 20 & & $<1$ & & $<1$ & & & & & & & & & \\
\hline 21 & Do. & & sot axpoeced. & Lant1 ouler. & Do. & $1 / 2$ & 55 & & 25 & & & 20 & & $<1$ & & $<1$ & & & & & & & 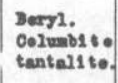 & $\begin{array}{l}1 \text { cryotal } \\
3 \text { cryotal }\end{array}$ & a. $1 / 4$ \\
\hline
\end{tabular}


Tab10 20 .--Mineralogy of pepatitos -(Cont1nuod)

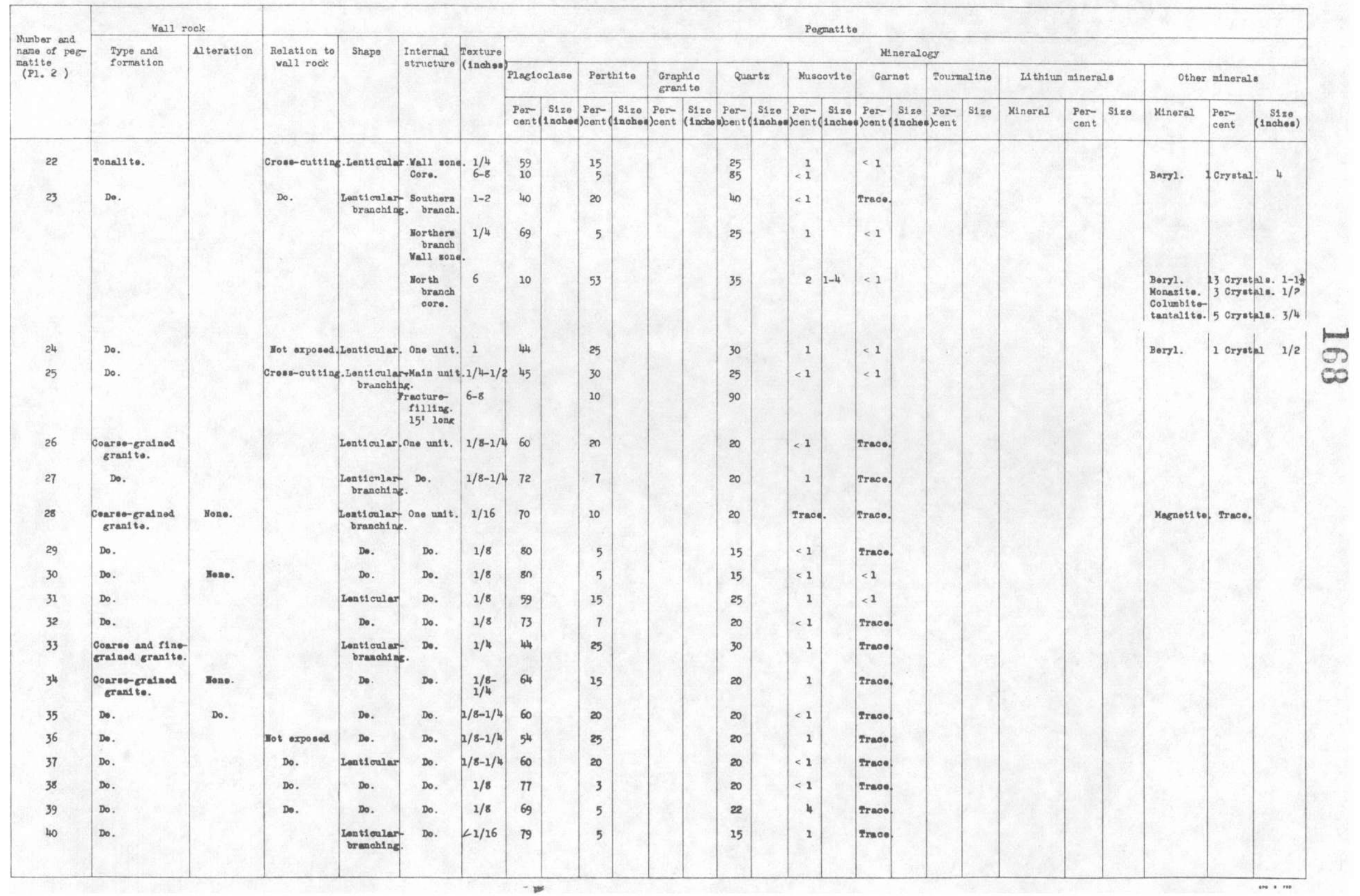




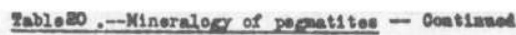

\begin{tabular}{|c|c|c|c|c|c|c|c|c|c|c|c|c|c|c|c|c|c|c|c|c|c|c|c|c|c|c|}
\hline \multirow{4}{*}{ 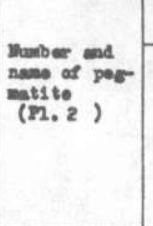 } & \multicolumn{2}{|c|}{ Voul rook } & \multicolumn{24}{|c|}{ Popont1to } \\
\hline & \multirow{3}{*}{$\begin{array}{l}\text { sype and } \\
\text { Sormation }\end{array}$} & \multirow[t]{3}{*}{ Nuteration } & \multirow{3}{*}{$\begin{array}{l}\text { Rolation to } \\
\text { vall rookt }\end{array}$} & \multirow[t]{3}{*}{ Shepe } & \multirow{3}{*}{$\begin{array}{l}\text { Internal } \\
\text { itrueture of }\end{array}$} & \multirow{3}{*}{ Rexture } & \multicolumn{20}{|c|}{ Minoralogy } \\
\hline & & & & & & & \multicolumn{2}{|c|}{ Plagloclase } & \multicolumn{2}{|c|}{ Perth1to } & \multicolumn{2}{|c|}{$\begin{array}{l}\text { Graphse } \\
\text { grent to }\end{array}$} & \multicolumn{2}{|c|}{ Quarts } & \multicolumn{2}{|c|}{ Husoort to } & \multicolumn{2}{|c|}{ Garnot } & \multicolumn{2}{|c|}{ Tourneal ine } & \multicolumn{3}{|c|}{ LS th1um minorals } & \multicolumn{3}{|c|}{ Other mineral. } \\
\hline & & & & & & & Por- & $\begin{array}{l}8180 \\
1 \text { 1nehood }\end{array}$ & $\begin{array}{l}\text { Por- } \\
\text { Doent }\end{array}$ & $\begin{array}{l}\text { S1zo } \\
\text { (112ohoed }\end{array}$ & $\begin{array}{l}\text { Por } \\
\text { Poont }\end{array}$ & $\begin{array}{l}81=0 \\
\text { (1nahoded }\end{array}$ & $\begin{array}{l}\text { Parr- } \\
\text { Soents }\end{array}$ & 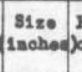 & $\begin{array}{l}\text { Porn } \\
\text { Doont (1: }\end{array}$ & 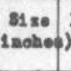 & $\begin{array}{l}\text { Por- } \\
\text { Soent }\end{array}$ & 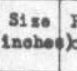 & $\begin{array}{l}\text { Per } \\
\text { Seent }\end{array}$ & $81 \mathrm{so}$ & Minaral & \begin{tabular}{l|} 
Porr \\
cont
\end{tabular} & $81 \mathrm{se}$ & Minoral & $\left.\right|_{\text {Per- }}$ & 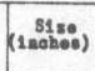 \\
\hline 42 & 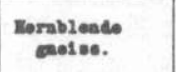 & & sot exposed & Leationaly & to. oesond & $1 / 8$ & $n$ & & 8 & & & & 20 & & 2 & & Iraoe. & & & & & & & & & \\
\hline 42 & D. & & Do. & Irragelar. & Do. & $1 / 16-1 / 6$ & 74 & & 10 & & & & 25 & & 1 & & 2 & & & & & & & & & \\
\hline 43 & $\begin{array}{l}\text { Coovere- errained } \\
\text { erand to. }\end{array}$ & Mane. & & D. & $\infty$. & $1 / 6-1 / 4$ & 4 & & 30 & & & & $\infty$ & & 2 & & 1 & & & & & & & & & \\
\hline th & Do. & & & zoentioalax. & $\infty$. & $1 / 8$ & 7 & & 5 & & & & $\approx$ & & 1 & & 1 & & & & & & & & & \\
\hline 45 & $\begin{array}{c}\text { Iomblande } \\
\text { moles. }\end{array}$ & & Hot exposod. & Do. & Do. & $1 / 4$ & 63 & & 25 & & & & 19 & & 1 & & & & & & & & & & & \\
\hline 46 & Do. & & Oroseontis & 6. Lentiones & D. & $1 / 8$ & 74 & & 5 & & & & 20 & & 1 & & 1 & & & & & & & & & \\
\hline 47 & $\begin{array}{l}\text { Homblendo } \\
\text { gavise and } \\
\text { erent to. }\end{array}$ & & D. & Do. & Do. & $2 / 8-1 / 4$ & 65 & & 15 & & & & 20 & & $<1$ & & treoe. & & & & & & & & & \\
\hline 48 & $\begin{array}{c}\text { Hornbleade } \\
\text { nosios. }\end{array}$ & & Do. & Do. & Do. & $1 / 8-1 / 4$ & 6 & & 20 & & & & $\boldsymbol{\infty}$ & & 1 & & $<1$ & & & & & & & & & \\
\hline 49 & Do. & & Do. & Do. & Do. & $1 / 26-1 / 4$ & 64 & & 10 & & & & 25 & & 1 & & $<1$ & & & & & & & & & \\
\hline 50 & Do. & & Mot exposed. & Lantioule & D. $D$. & $1 / 4$ & 65 & & 15 & & & & 20 & & $<1$ & & 2raos. & & & & & & & & & \\
\hline 51 & Do. & & Do. & Irragaler. & Do. & $1 / 4$ & 65 & & 25 & & & & $\approx$ & & sraoo. & & traee. & & & & & & & & & \\
\hline 52 & Tonal140 & & Oroseoutting & Ireatioulare & Do. & $1 / 8-1 / 4$ & 70 & & 7 & & & & 23 & & Traoes. & & & & & & & & & & & \\
\hline 53 & Morablones & & & Lent1oular & D. & $1 / 32$ & 80 & & 5 & & & & 15 & & traoos. & & $<1$ & & & & & & & & & \\
\hline 5h & Do. & & Tot exposed. & Do. & Do. & $1 / 4$ & 5 & & $\infty$ & & & & 25 & & $<2$ & & $<1$ & & & & & & & & & \\
\hline 55 & Fonel110 & & Oroesoutting & Irragalar. & South ad. & $1 / 4$ & 59 & & 207 & & & & $\begin{array}{l}20 \\
45\end{array}$ & & $<\frac{1}{1}$ & & straeo. & & & & & & & Berst. & 1 & $1-1 / 2$ \\
\hline$\%$ & Do. & & mot axposed. & Lentioverar & Ono unit. & $1 / 8$ & 75 & & 5 & & & & 20 & & $<1$ & & $<1$ & & & & & & & & 0ryetal & \\
\hline 57 & 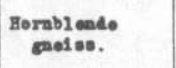 & & Do. & D. & $\begin{array}{l}\text { Yell soas } \\
\text { Cores }\end{array}$ & $\frac{2 / 8-1 / 4}{1}$ & $\begin{array}{l}70 \\
25\end{array}$ & & $\begin{array}{l}15 \\
35\end{array}$ & & & & $\frac{15}{40}$ & & $\prod_{<1}^{2 r a 00}$. & & traoe. & & & & & & & & & \\
\hline 58 & Tonalito & & Do. & $\infty$. & Dao units. & $1 / 16-1 / 8$ & $\pi$ & & 3 & & & & 20 & & Iraoe. & & treos. & & & & & & & & & \\
\hline 59 & Do. & & Do. & D. & Do. & $1 / 8$ & so & & 5 & & & & 25 & & & & treeo. & & & & & & & & & \\
\hline 60 & Do. & & Do. & Irragaler. & D. & $1 / 8$ & $n$ & & 8 & & & & $\approx$ & & 1 & & 1 & & & & & & & & & \\
\hline 61 & Do. & & Do. & tontiouler & Do. & $1-2$ & 35 & & 30 & & & & 35 & & 1 & & & & & & & & & & & \\
\hline 62 & Do. & & Do. & Do. & $\begin{array}{l}\text { Yal1 sone } \\
\text { Oore }\end{array}$ & $\begin{array}{l}1 / 8 \\
20-12\end{array}$ & $\begin{array}{c}70 \\
5\end{array}$ & & $\begin{array}{l}15 \\
10\end{array}$ & & & & $\begin{array}{l}15 \\
85\end{array}$ & & 1 & & 2 & & & & & & & & & \\
\hline 63 & Do. & & prosocutting & 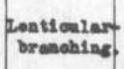 & - ono unis & 1 & sh & & $\infty$ & & & & 25 & & 1 & & Preae. & & & & & & & & & \\
\hline
\end{tabular}


Teb120. - Mineralory of peretitos - continued

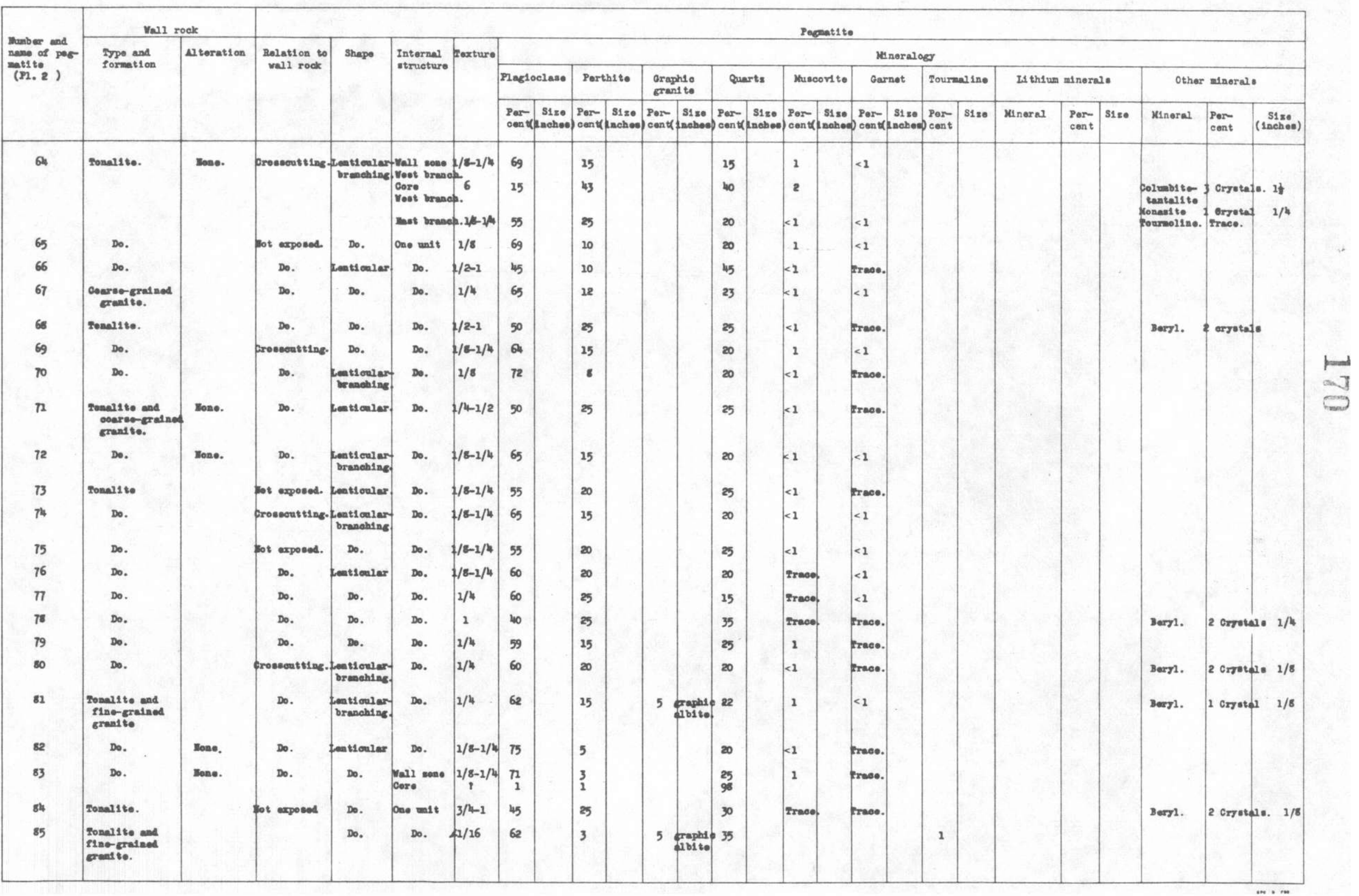


Fab1e 20. - Mineralogy of pepatitos - Cont1nued.

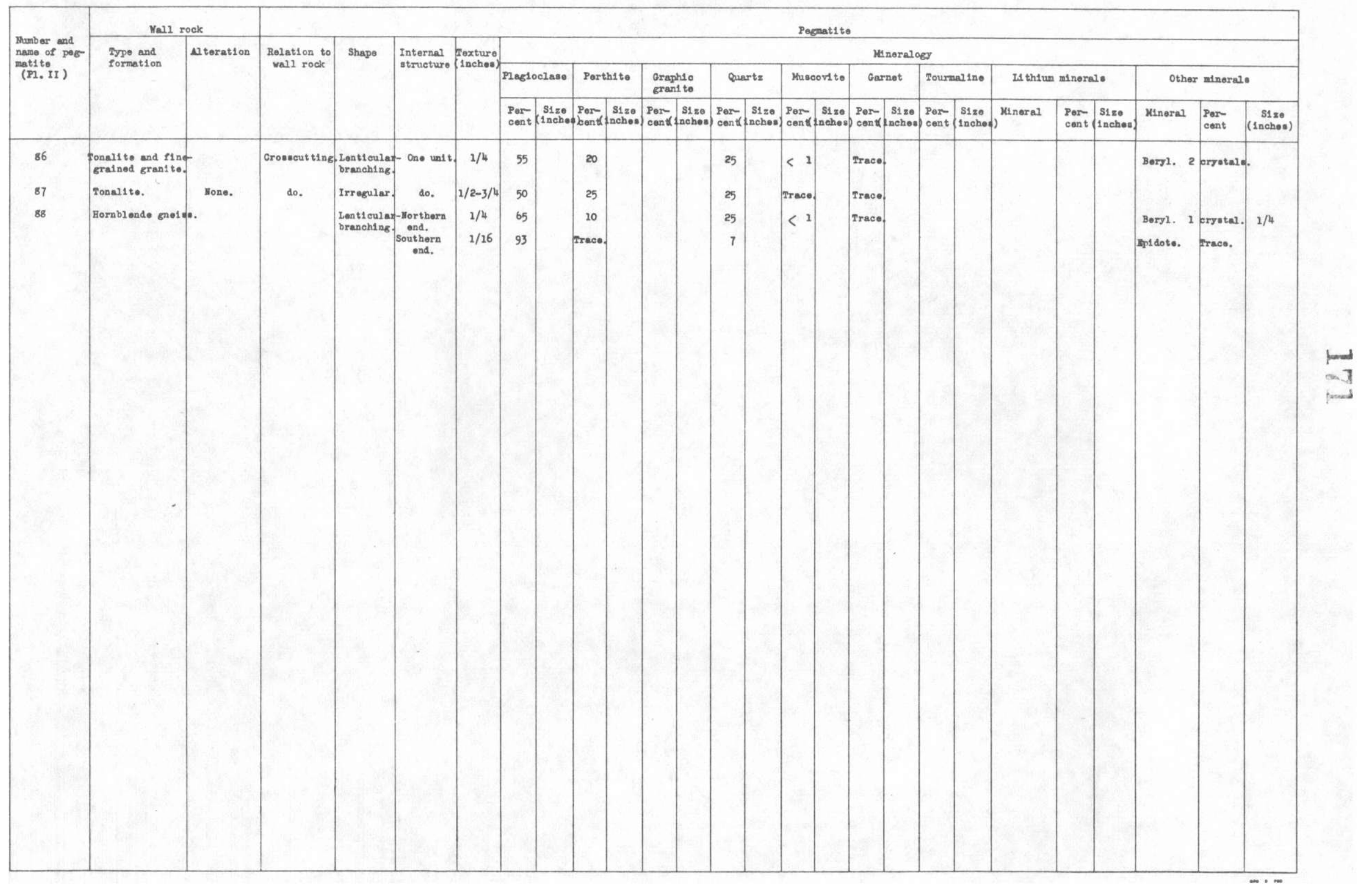


Tab1o 20.--Mineralogy of peratit tes--Cont1 nued.

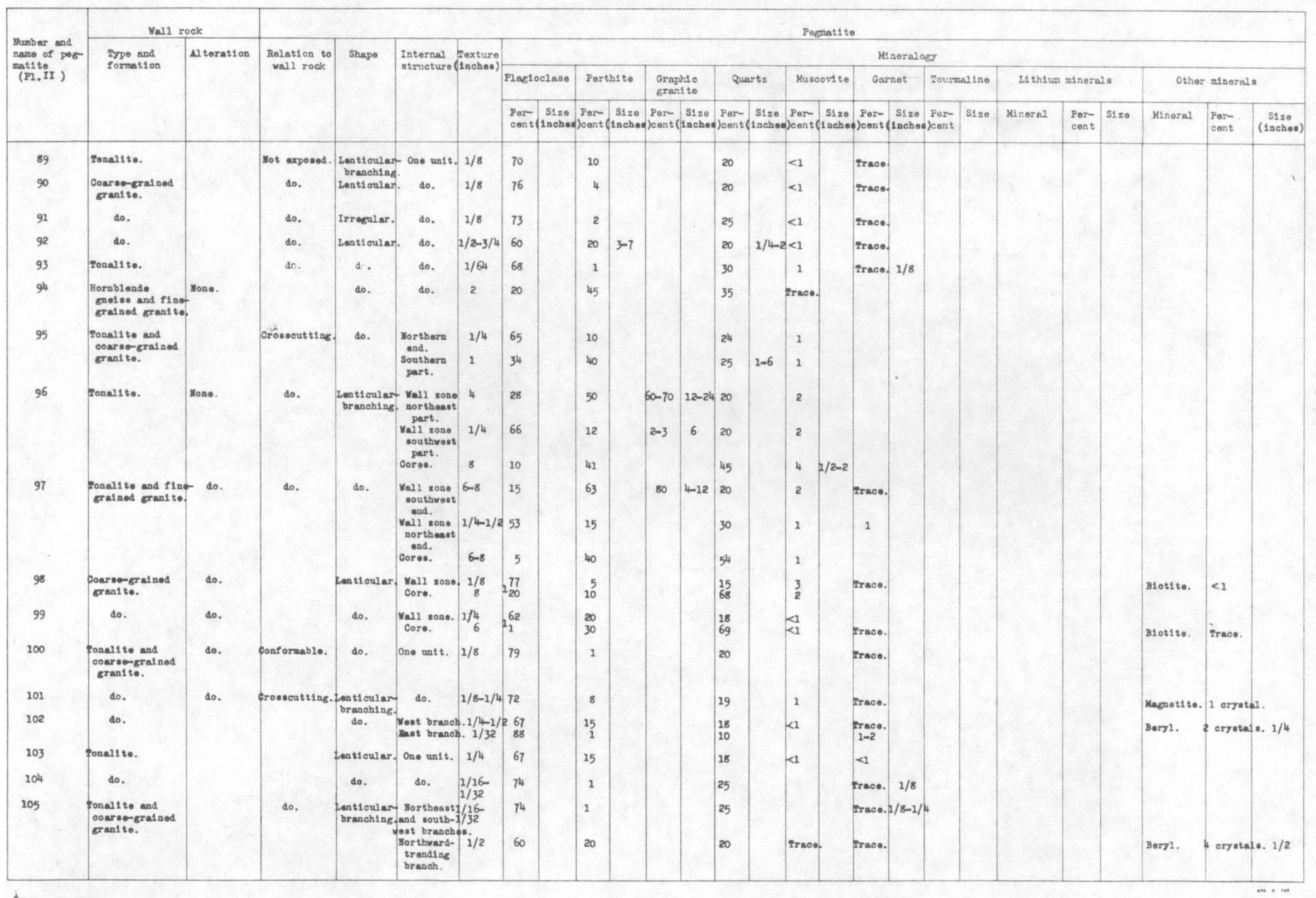




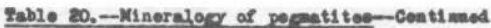

\begin{tabular}{|c|c|c|c|c|c|c|c|c|c|c|c|c|c|c|c|c|c|c|c|c|c|c|c|c|c|c|}
\hline \multirow{4}{*}{$\begin{array}{l}\text { number ond } \\
\text { netito of } \\
\text { (II. II) }\end{array}$} & \multicolumn{2}{|c|}{ Vall roak } & \multicolumn{24}{|c|}{ Peonat 10 } \\
\hline & \multirow{3}{*}{$\begin{array}{l}\text { Ispe and } \\
\text { formation }\end{array}$} & \multirow[t]{3}{*}{ Altaration } & \multirow{3}{*}{$\begin{array}{l}\text { Rolation to } \\
\text { vall rook }\end{array}$} & \multirow[t]{3}{*}{ Shappo } & \multirow{3}{*}{$\begin{array}{l}\text { Interneal } \\
\text { itruetures }\end{array}$} & \multirow{3}{*}{ (2exture } & \multicolumn{20}{|c|}{ Menoraloes } \\
\hline & & & & & & & \multicolumn{2}{|c|}{ Praslociase } & \multicolumn{2}{|c|}{ Parth1to } & \multicolumn{2}{|c|}{$\begin{array}{l}\text { Graphs. } \\
\text { crant to }\end{array}$} & \multicolumn{2}{|c|}{ Sharts: } & \multicolumn{2}{|c|}{ Muscorl to } & \multicolumn{2}{|c|}{ Garnot } & \multicolumn{2}{|c|}{ Tournaline } & \multicolumn{3}{|c|}{ IS th1um minerale } & \multicolumn{3}{|c|}{ Other manaralo } \\
\hline & & & & & & & $\begin{array}{l}\text { Porr } \\
\text { oont }\end{array}$ & s1so & $\begin{array}{l}\text { Porr } \\
\text { oent }\end{array}$ & size & Por- & $\begin{array}{l}3180 \\
\text { incheo }\end{array}$ & Par- & $\left.\begin{array}{c}\text { s1so } \\
\text { 1mation }\end{array}\right)$ & Pers & $\begin{array}{l}\text { si so } \\
\text { netseo }\end{array}$ & Por- & 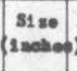 & Per- & 81 so & vineral & $\begin{array}{l}\text { Par } \\
\text { Cont }\end{array}$ & s1so & Mineral & $\begin{array}{l}\text { Pern- } \\
\text { cont }\end{array}$ & $\begin{array}{l}\text { S130 } \\
\text { (1 10ohode) }\end{array}$ \\
\hline 106 & Toeall to. & & Cronecattine & Leatiould & $-\infty=00$ & $1 / 4$ & 72 & & 8 & & & & $\infty$ & & $<1$ & & traee. & & & & & & & Borns. & Perpotal & 1. $\frac{1 / 8}{1 / 4}$ \\
\hline 107 & هo. & & & ه. & a. & $2 / 8$ & 67 & & 8 & & & & 25 & & treese. & & & & & & & & & monotite. & e eryataf. & 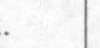 \\
\hline 108 & cos. & & & Lentioular. & ه. & $\begin{array}{l}2 / 16 \\
2 / 8\end{array}$ & $n$ & & 3 & & & & 5 & & treee. & & & & & & & & & aniertto. & 2 & \\
\hline 109 & هo. & & & o. & a. & $2 / 4$ & 70 & & 20 & & & & $\infty$ & & $<1$ & & Freece. & & & & & & & & & \\
\hline 110 & e. & & Hot expoest. & Lentionelax & «o. & $2 / 8$ & $n$ & & 4 & . & & & 25 & & $<1$ & & Eraoe. & & treoes. & & & & & & & \\
\hline in & (o. & & do. & Lentioular. & هo. & $2 / 8-1 / 4$ & 70 & & 5 & & & & 25 & & $<1$ & & Treoe. & & & & & & & & & \\
\hline 112 & Hornblende cnelap. & & هo. & Lamentart & هo. & $\mid 1 / 6-1 / 4$ & 75 & & 5 & & & & 20 & & $<1$ & & $<1$ & & & & & & & Marn. & 13 arrete & 1. $1 / 8$ \\
\hline 113 & 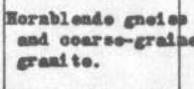 & & ه. & do. & هo. & $1 / 8-1 / 4$ & 74 & & 8 & & & & 18 & & $<1$ & & Fraoe. & & & & & & & & & \\
\hline 114 & Roernblendo enoles. & & ه. & Lentioviar. & ه. & $2 / 8-1 / 4$ & 70 & & 10 & & & & 20 & & $<1$ & & $<1$ & & . & & & & & Bespl. & 2 eryotad & 10. $1 / 8$ \\
\hline 2125 & 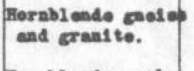 & & مه. & Intionelaty & هo. & $1 / 8$ & 73 & & 5 & & & & 22 & & $<1$ & & traoe. & & & & & & & & & \\
\hline 116 & Rornblendo cont of. & & Crossontting. & Irregalar. & do. & $2 / 8-1 / 4$ & 65 & & 15 & & & & $\infty$ & & $<1$ & & treece. & & & & & & & Marr1. & 2 orgutep & . $1 / 4 / 4$ \\
\hline 117 & 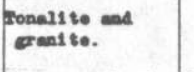 & & Pot axposod. & Pentioulax. & هo. & $1 / 4-1 / 2$ & 65 & & 15 & & & & $\infty$ & & $<1$ & & Traoe. & & & & & & & c. & 3 oryotad & c. $1 / 8$ \\
\hline 128 & $\begin{array}{l}\text { coareo-eralned } \\
\text { cremito. }\end{array}$ & Mone. & & Treatioulent & do. & $1 / 26$ & 2 & & 4 & & & & 15 & & $<1$ & & trace. & & & & & & & & & \\
\hline 119 & do. & & pot exposed. & do. & do. & $1 / 8-1 / 4$ & 67 & & 8 & & & & 25 & & trace. & & Treoo. & & & & & & & & & \\
\hline 220 & Ponell1te. & & proesouttias. & a. & a. & $\begin{array}{l}1 / 32 \\
1 / 16\end{array}$ & 80 & & 2 & & & & 28 & & rraoe. & & Traoe. & & & & & & & & & \\
\hline 121 & do. & & هo. & do. & ه. & $1 / 16-1 / 8$ & 76 & & 4 & & & & 20 & & trace. & & Ireoe. & & & & & & & Bergl. & 5 orgotad & .. $\begin{array}{l}1 / 8-2 \\
1 / 2\end{array}$ \\
\hline 122 & Pot expoend. & & pot exposed. & Irracular. & ه. & $\mid / 6-1 / 4$ & 65 & & 15 & & 5 & & 20 & & $<1$ & & traece. & & & & & & & & & \\
\hline 123 & do. & & do. & do. & ه. & $\mid / 8-1 / 4$ & 62 & & 28 & & & & 20 & & $<1$ & & $<1$ & & & & & & & & & \\
\hline 124 & $\begin{array}{l}\text { Proe-gralnod } \\
\text { cranit to. }\end{array}$ & & هo. & benticular & do. & $1 / 6-1 / 4$ & 70 & & 10 & & 2 & & $\infty$ & & $<1$ & & traoen. & & & & & & & & & \\
\hline 125 & monalite. & & & pontsouler. & هo. & $1 / 8$ & 75 & & 5 & & & & 20 & & kreos. & & Trace. & & & & & & & Berry. & A ergotea & . $5 / 8$ \\
\hline 126 & do. & & pot exposed. & & 4. & $2 / 6-1 / 4$ & 75 & & 10 & & & & 15 & & traoe. & & Treos. & & & & & & & do. & 2 ergetea & $1 / 8$ \\
\hline 127 & fornblendo cont ad. & & do. & & هo. & $1 / 8-1 / 4$ & 70 & & 20 & & & & 20 & & $<$ & & Irace. & & & & & & & & & \\
\hline 128 & do. & & do. & & do. & $2 / 8-1 / 4$ & 73 & & 7 & & & & 20 & & $<1$ & & Treoe. & & & & & & & Bargl. & 2 ergotal & a. $1 / 8$ \\
\hline 129 & ponalite. & & crosecuttins. & brantiovilant & ه. & $1 / 8$ & 76 & & 4 & & & & 20 & & trace. & & trace. & & & & & & & 4. & 2 eryotad & . $1 / 8$ \\
\hline
\end{tabular}




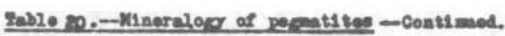

\begin{tabular}{|c|c|c|c|c|c|c|c|c|c|c|c|c|c|c|c|c|c|c|c|c|c|c|c|c|c|c|}
\hline \multirow{4}{*}{ 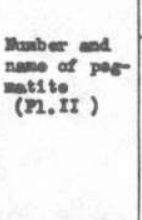 } & \multicolumn{2}{|c|}{ Well rook } & \multicolumn{24}{|c|}{ Peopetite } \\
\hline & \multirow{3}{*}{$\begin{array}{l}\text { Sppe and } \\
\text { formention }\end{array}$} & \multirow[t]{3}{*}{ Ml teration } & \multirow{3}{*}{$\begin{array}{l}\text { Rolation } \\
\text { vall rook }\end{array}$} & \multirow[t]{3}{*}{ shepo } & \multirow{3}{*}{$\begin{array}{l}\text { Internal } \\
\text { strueture o }\end{array}$} & \multirow{3}{*}{ Eaxture: } & \multicolumn{20}{|c|}{ Nenoralagr } \\
\hline & & & & & & & \multicolumn{2}{|c|}{ meclociaso } & \multicolumn{2}{|c|}{ Porth1 to } & \multicolumn{2}{|c|}{$\begin{array}{l}\text { arephse } \\
\text { arount to }\end{array}$} & \multicolumn{2}{|c|}{ Querts } & \multicolumn{2}{|c|}{ Theoovite } & \multicolumn{2}{|c|}{ Garnat } & \multicolumn{2}{|c|}{ Tournaal ino } & \multicolumn{3}{|c|}{ IS th1um minerale } & \multicolumn{3}{|c|}{ Other minerele } \\
\hline & & & & & & & Porr & s1so & $\begin{array}{l}\text { Par- } \\
\text { oent } 19\end{array}$ & sise & Poorr & $\begin{array}{l}\text { sines } \\
\text { ineheos) }\end{array}$ & $\begin{array}{l}\text { Par } \\
\text { Doont }\end{array}$ & $\begin{array}{l}8180 \\
1 \text { incteod }\end{array}$ & Poent & 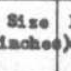 & Por- & $\begin{array}{c}8120 \\
\text { 1nothod }\end{array}$ & $\begin{array}{l}\text { Par } \\
\operatorname{cont}\end{array}$ & $81 \leq 0$ & Meneral & $\begin{array}{l}\text { Par } \\
\text { cont } t\end{array}$ & $31=0$ & Xinoral & Poor- & $\begin{array}{c}\text { S1ze } \\
\text { (1 inothos) }\end{array}$ \\
\hline 130 & remal1 to. & & arosecut ting & Lantloviart & - ono und t & $2 / 8-1 / 4$ & 75 & & 5 & & & & $\approx$ & & $<1$ & & Treoe. & & & & & & & Mern. & y) orgotal & $2 / 8$ \\
\hline 131 & a. & & هo. & a. & do. & $2 / 4$ & 65 & & - & & & & 27 & & traceo. & & Ireee. & & & & & & & ه. & \& argotial. & $2 / 8$ \\
\hline 132 & a. & & ه. & ه. & هo. & $1 / 8$ & $n$ & & 5 & & & & 18 & & $\Leftrightarrow 2$ & & Irece. & & & & & & & s. & 2 orgotal. & 6. $3 / 4$ \\
\hline 233 & Barabloode coel of. & & Tot exposed. & do. & هo. & $2 / 4-1 / 2$ & 56 & & 4 & & & & no & & $<1$ & & treoes. & & & & & & & ه. & 2 ergotal & . $1 / 4$ \\
\hline $13 \mathrm{~h}$ & do. & & e. & Irragular. & so. & $\mid 2 / 8-1 / 4$ & 73 & & 2 & & & & 25 & & $<1$ & & trece. & & & & & & & هo. & 2 orrotale. & $1 / 4$ \\
\hline 135 & e. & & \&. & Lentioular. & هo. & $2 / 6-1 / 4$ & 70 & & 20 & & & & $\approx$ & & $<1$ & & treoe. & & & & & & & ه. & 2 orgotal & $1 / 8$ \\
\hline 136 & Poneal1 to. & Moan. & & Irrogeler. & هo. & $2 / 2-3 / 4$ & 70 & & 8 & & & & $\boldsymbol{2}$ & & $<1$ & & Irace. & & & & & & & 1. 12 & 12 orgotan & 2. $1 / 4$ \\
\hline 137 & Pornblede onel al. & & & Lentioviart & $\infty$ co. & $1 / 4$ & 75 & & 20 & & & & 25 & & $<$ & & Traoe. & & & & & & & ఉ. & 4 argoteas & $1 / 4$ \\
\hline 136 & $\begin{array}{l}\text { Fornbleade gnoled } \\
\text { and eranito. }\end{array}$ & Mone. & & \&. & ه.. & $1 / 8$ & 72 & & 8 & & & & 20 & & $<1$ & & treoe. & & & & & & & & & \\
\hline 139 & pornbleade coes an. & do. & & Lentieular. & هo. & $1 / 4$ & 65 & & 15 & & & & $\infty$ & & $<1$ & & treoes. & & Traoo. & & & & & Maryl. & 1 argoteal. & $1 / 2$ \\
\hline 140 & $\begin{array}{l}\text { Coareo-gralned } \\
\text { crent to. }\end{array}$ & so. & & Prentioulant. & هo. & $2 / 2-3 / 4$ & 60 & & 30 & & & & 20 & & $<1$ & & traee. & & & & & & & & & \\
\hline 162 & 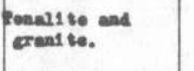 & ه. & Frosecuttine. & do. & do. & $2 / 4$ & 72 & & 20 & & & & 28 & & & & treoee. & & & & & & & & & \\
\hline 142 & poeallsto. & & & Heatioular. & do. & $1 / 4$ & 72 & & 3 & & & & 25 & & & & Treeo. & & & & & & & & & \\
\hline 243 & 4. & & & trregular. & هo. & $1 / 8$ & 73 & & 2 & & & & 25 & & traoe. & & treece. & & & & & & & Doens. 1 & argetal, & $3 / 16$ \\
\hline 144 & Plornblendo enolod. & & pot expoest. & reatiecular. & هo. & $2 / 2$ & 40 & & 35 & & & & $\infty$ & & & & & & & & & & & & & \\
\hline 145 & هo. & & so. & do. & w. & $2 / 16-$ & 81 & & 4 & & & & 15 & & & & traee. & & & & & & & & & \\
\hline 146 & & Mone. & proseout tine. & 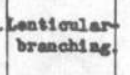 & do. & $1 / 2$ & 55 & & 25 & & & & 20 & & $<1$ & & traece. & & & & & & & & & \\
\hline 247 & pooal 1 te. & Mone. & & pentioular & do. & $1 / n$ & 70 & & treces. & & & & 30 & & & & & & & & & & & 2eryl. & 3 argotal & . $1 / 8$ \\
\hline 148 & مه (م) & do. & & do. & do. & $1 / 8-1 / 4$ & 73 & & 2 & & & & 25 & & $k_{1}$ & & traee. & & & & & & & d. 1 & argeter. & $1 / 8$ \\
\hline $\begin{array}{l}149 \\
150\end{array}$ & 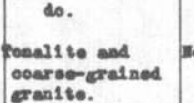 & Mono. & & $\begin{array}{l}\text { do. } \\
\text { ometicular- } \\
\text { oranching. }\end{array}$ & $\begin{array}{l}\text { so. } \\
\text { s. }\end{array}$ & $\left|\begin{array}{c}1 / 8 \\
1 / 8-1 / 4\end{array}\right|$ & $\begin{array}{l}72 \\
65\end{array}$ & & $\begin{array}{c}3 \\
15\end{array}$ & & & & 25 & & traoe. & & $\begin{array}{l}\text { traee. } \\
<1\end{array}$ & & & & & & & norn1. 2 & aryotal & $1 / n$ \\
\hline 151 & هo. & & & fentioular. & هo. & $1 / 4$ & 70 & & 15 & & & & 15 & & & & & & & & & & & & & \\
\hline 152 & $\begin{array}{l}\text { coarcoetrateded } \\
\text { cranito. }\end{array}$ & & pot exposed. & do. & do. & $1 / 8$ & 70 & & 25 & & & & 15 & & & & Fraoo. & & & & & & & & & \\
\hline 153 & 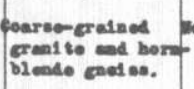 & Pose. & proecoutting. & branching. & do. & $1 / 4-1 / 2$ & 63 & & 15 & & & & 22 & & $k_{1}$ & & Freoe. & & & & & & & & & \\
\hline
\end{tabular}


Tab1e 20-Mineralogy of pepatites-Cont1nued.

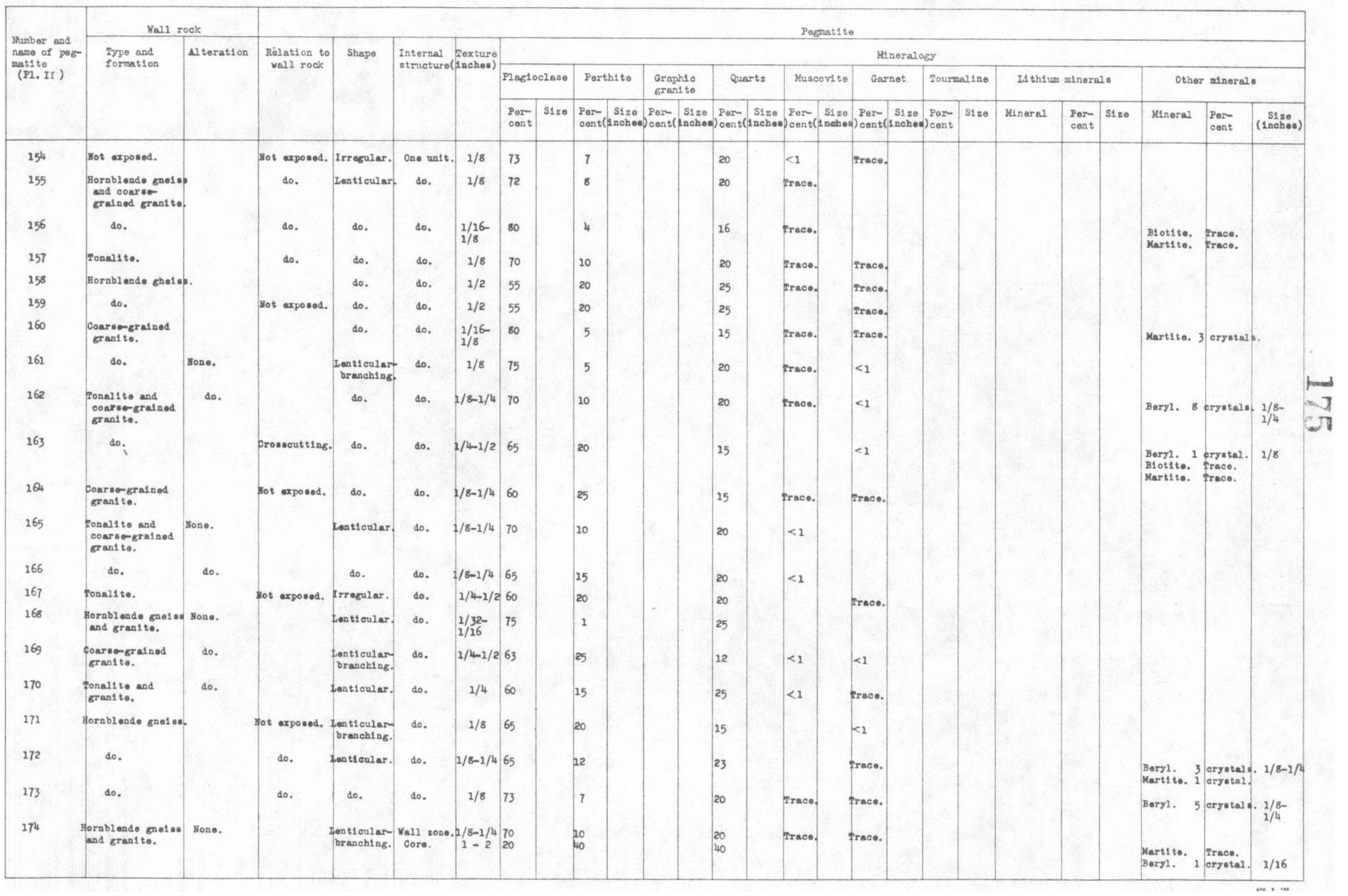




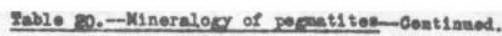

\begin{tabular}{|c|c|c|c|c|c|c|c|c|c|c|c|c|c|c|c|c|c|c|c|c|c|c|c|c|c|c|}
\hline \multirow{4}{*}{ 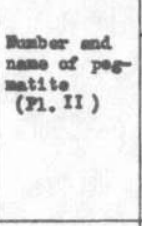 } & \multicolumn{2}{|c|}{ Wall rook } & \multicolumn{24}{|c|}{ Pogatito } \\
\hline & \multirow{3}{*}{$\begin{array}{l}\text { Sppe and } \\
\text { formetion }\end{array}$} & \multirow[t]{3}{*}{ Neteration } & \multirow{3}{*}{$\begin{array}{l}\text { Rolati on to } \\
\text { vall rocke }\end{array}$} & \multirow[t]{3}{*}{ Shape } & \multirow{3}{*}{$\begin{array}{l}\text { Internal } \\
\text { atruetur o }\end{array}$} & \multirow{3}{*}{ 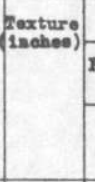 } & \multicolumn{20}{|c|}{ Weneralogy } \\
\hline & & & & & & & \multicolumn{2}{|c|}{ Maglociase } & \multicolumn{2}{|c|}{ Porth1to } & \multicolumn{2}{|c|}{$\begin{array}{l}\text { Graphs: } \\
\text { Eran1 to }\end{array}$} & \multicolumn{2}{|c|}{ Quart: } & \multicolumn{2}{|c|}{ Mucoort to } & \multicolumn{2}{|c|}{ Garnot } & \multicolumn{2}{|c|}{\begin{tabular}{|c|} 
Tournal ino \\
\end{tabular}} & \multicolumn{3}{|c|}{ IS thlum minoral. } & \multicolumn{3}{|c|}{ Other manerals } \\
\hline & & & & & & & $\begin{array}{l}\text { Por- } \\
\text { Oont }\end{array}$ & 3180 & $\begin{array}{l}\text { Per- } \\
\text { oent }\end{array}$ & $\begin{array}{l}3180 \\
\text { natoos: }\end{array}$ & $\begin{array}{l}\text { Por- } \\
\text { oentin }\end{array}$ & $\begin{array}{l}\text { s1s:o } \\
\text { nehoos: }\end{array}$ & $\begin{array}{l}\text { Par- } \\
\text { cont } 1 .\end{array}$ & $\begin{array}{c}\text { S1zo: } \\
\text { nohoo: }\end{array}$ & $\begin{array}{l}\text { Por } \\
\text { cont? }\end{array}$ & $\begin{array}{c}\text { s1 se } \\
\text { nohea }\end{array}$ & $\begin{array}{l}\text { Por } \\
\text { cont }\end{array}$ & $\begin{array}{l}5180 \\
\text { noheos }\end{array}$ & \begin{tabular}{l|} 
Por \\
cent
\end{tabular} & s1so & Neneral & $\begin{array}{l}\text { Por- } \\
\text { cont } t\end{array}$ & $31 \leq 0$ & kinoral & \begin{tabular}{|l|} 
Per \\
cent
\end{tabular} & $\begin{array}{c}\text { S1so } \\
\text { (1 1 nohoo) }\end{array}$ \\
\hline 275 & $\begin{array}{l}\text { Poarcoogral and } \\
\text { eranito. }\end{array}$ & Hono. & & Lant1oulare & Wall sone. & $1 / 4$ & 6 & & 25 & & & & $\begin{array}{r}20 \\
100\end{array}$ & & trace. & & & & & & & & & & & \\
\hline 176 & 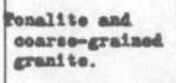 & So. & & Lent1oular. & $\begin{array}{l}\text { Vall soase. } \\
\text { Core. }\end{array}$ & $\mid \begin{array}{l}1 / 16- \\
1 / 8 \\
6\end{array}$ & $\begin{array}{l}83 \\
10\end{array}$ & & 20 & & & & $\begin{array}{l}15 \\
70\end{array}$ & & traeen & & & & & & & & & & & \\
\hline $2 \pi$ & $\begin{array}{l}\text { Ponal1te. and } \\
\text { carant to. }\end{array}$ & & Mot expoesch. & Lentievelar. & Oeo unit. & $1 / 8-1 / 4$ & 65 & & 15 & & & & 20 & & & & $<1$ & & & & & & & & & \\
\hline 278 & $\begin{array}{l}\text { Coareo-grainod } \\
\text { crenite. }\end{array}$ & Hose. & & do. & do. & $1 / 8$ & 75 & & 5 & & & & 20 & & & & treees. & & & & & & & Marti to. & Traoe. & \\
\hline 279 & fonal1 to. & & Wot exposed. & o. & ه. & $1 / 8$ & 73 & & 7 & & & & 20 & & & & treoes. & & & & & & & Magnotito. & trace. & \\
\hline 280 & do. & & & $\begin{array}{l}\text { Lantioulary } \\
\text { branchinge. }\end{array}$ & هo. & $1 / 2$ & 45 & & 25 & & & & 30 & & & & rrace. & & & & & & & & & \\
\hline 181 & ponelite and & Mono. & Crosecutinge. & ه. & هo. & $1 / 4$ & 72 & & 20 & & & & 8 & & trace. & & trease. & & & & & & & Magnet 1 to. & Trace. & \\
\hline 182 & ه. & ه. & ه. & Leatiouler. & e. & $1 / 16$ & 66 & & 25 & & & & 8 & & Treoo. & & $<1$ & & & & & & & & & \\
\hline 183 & 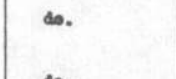 & ه.. & do. & do. & ه. & $1 / 16-$ & 70 & & 5 & & & & 20 & & Trace. & & $<1$ & & & & & & & & & \\
\hline 104 & $\infty$. & & mot exposed. & so. & ه. & $1 / 8$ & 70 & & 20 & & & & 10 & & & & traee. & & & & & & & Born1. 2 & ergetalo. & d. $1 / 16$ \\
\hline 185 & ه. & Mono. & Crosocut t1ne & o. & a. & $1 / 2$ & 65 & & 25 & & & & 15 & & traoe. & & raseo. & & & & & & & 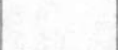 & $1=$ & \\
\hline 186 & ه. & هo. & do. & branchinger & do. & $1 / 4$ & $n$ & & 20 & & & & 8 & & 1 & & traoo. & & & & & & & Martito. & $\begin{array}{l}\text { Iraco. } \\
\text { oryotal. }\end{array}$ & $1 / 8$ \\
\hline $\begin{array}{l}187 \\
188\end{array}$ & $\begin{array}{l}\text { do. } \\
\text { do. }\end{array}$ & do. & Crosseutting & $\begin{array}{l}\text { pentiouler. } \\
\text { Lanticular } \\
\text { brenchling. }\end{array}$ & do. & $\left|\begin{array}{l}1 / 4-1 / 2 \\
1 / 6-1 / 4\end{array}\right|$ & $\begin{array}{l}50 \\
73\end{array}$ & & $\begin{array}{l}32 \\
22\end{array}$ & & & & $\begin{array}{r}18 \\
5\end{array}$ & & 1 & & $<1$ & & & & & & & $\begin{array}{l}\text { Magnotit to. } \\
\text { Borry. 2. }\end{array}$ & Traose. & 1/8 \\
\hline 189 & do. & هo. & do. & do. & \&. & $1 / 4-1 / 2$ & 45 & & 30 & & & & 25 & & & & Trace. & & & & & & & & & $T-10$ \\
\hline 190 & Tonal1 te. & ه. & do. & هo. & هo. & $\begin{array}{l}1 / 16 \\
1 / 8\end{array}$ & 69 & & 6 & & & & 25 & & & & & & & & & & & Boryl. 2 & oryotelas. & $1 / 8$ \\
\hline 191 & do. & & do. & ه. & A. & $1 / 16$ & 75 & & 5 & & & & 20 & & & & Trace. & & & & & & & & & \\
\hline 192 & $\begin{array}{l}\text { Tonalt te and } \\
\text { Crantite. }\end{array}$ & Hono. & & Lentioular. & $\begin{array}{l}\text { Voll sone } \\
\text { Core. }\end{array}$ & $1 / 32$ & 83 & & 2 & & & & $\begin{array}{l}15 \\
60\end{array}$ & & & & & & & & & & & & & \\
\hline 193 & Tonal 1 te. & Ao. & & $\begin{array}{l}\text { Lantioulary } \\
\text { branohine }\end{array}$ & - One unit. & $1 / 16$ & 76 & & 4 & & & & $\approx$ & & & & $<1$ & & & & & & & Magnotite. & Trace. & \\
\hline 194 & do. & هo. & & Lentioular. & do. & $1 / 16$ & 78 & & 2 & & & & 20 & & & & Trece. & & & & & & & do. & Traos. & \\
\hline 195 & $\begin{array}{l}\text { Tonal1te and } \\
\text { Grant to. }\end{array}$ & & mot expoesed. & $\begin{array}{l}\text { Lentioulare } \\
\text { branohitace }\end{array}$ & do. & 1 & 33 & & 45 & & & & 22 & & $<1$ & & $<1$ & & & & & & & & & \\
\hline 196 & هo. & & & do. & do. & $1 / 4$ & 70 & & 20 & & & & $\approx$ & & trace. & & Treoo. & & & & & & & Beryl. & a oryotea & - $\begin{array}{l}2 / 16- \\
3 / 4\end{array}$ \\
\hline 197 & Fonal1 to. & Mono. & & Lent1ouler & do. & $1 / 8$ & 67 & & 8 & & & & 25 & & $<1$ & & & & & & & & & A. 5 & ergetald. & d. $1 / 4$ \\
\hline
\end{tabular}




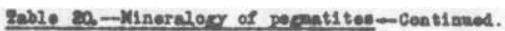

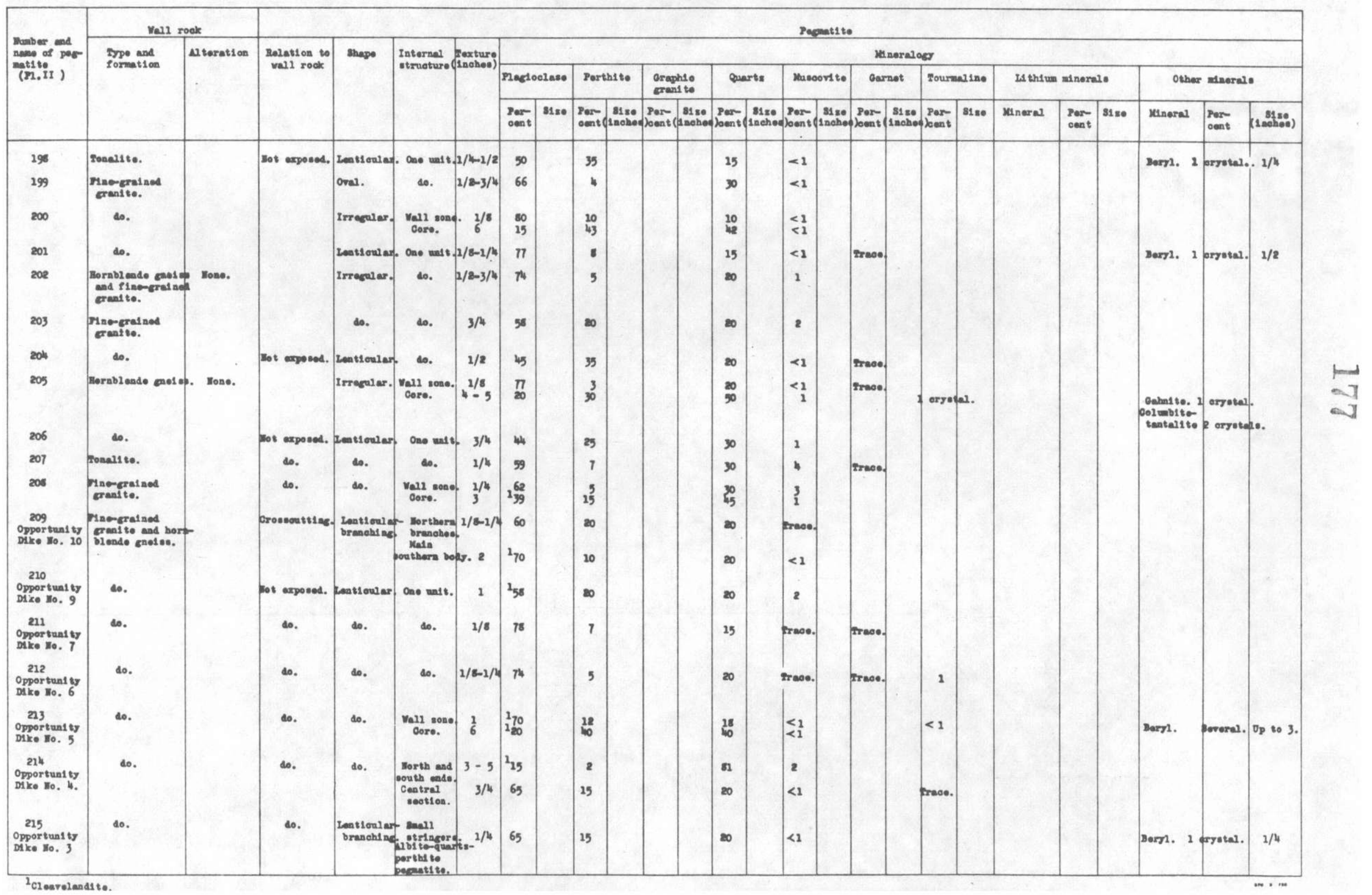




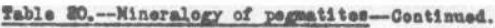

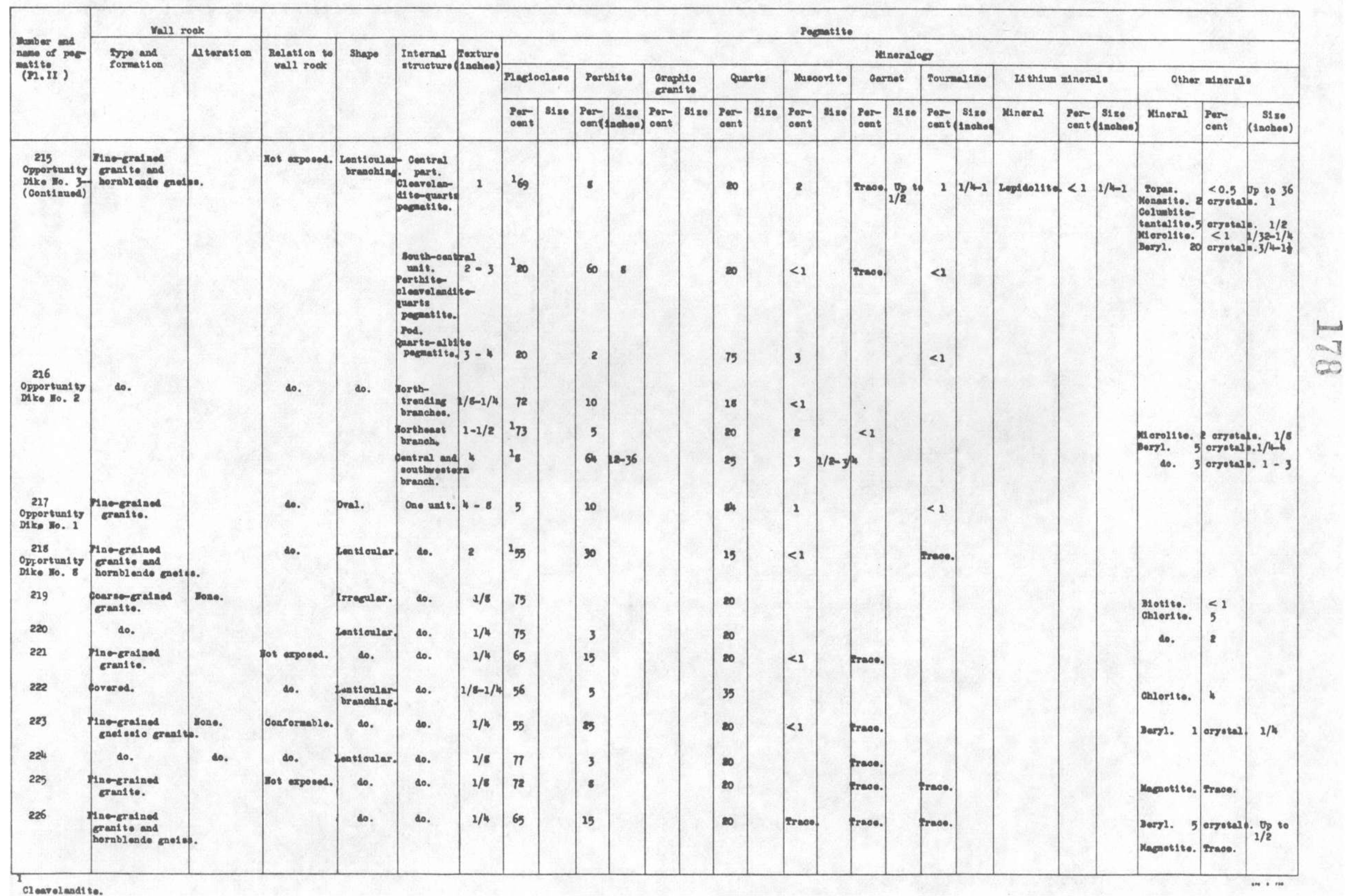


7eble as-Kinorelogy of pereat1tos-Contimed.

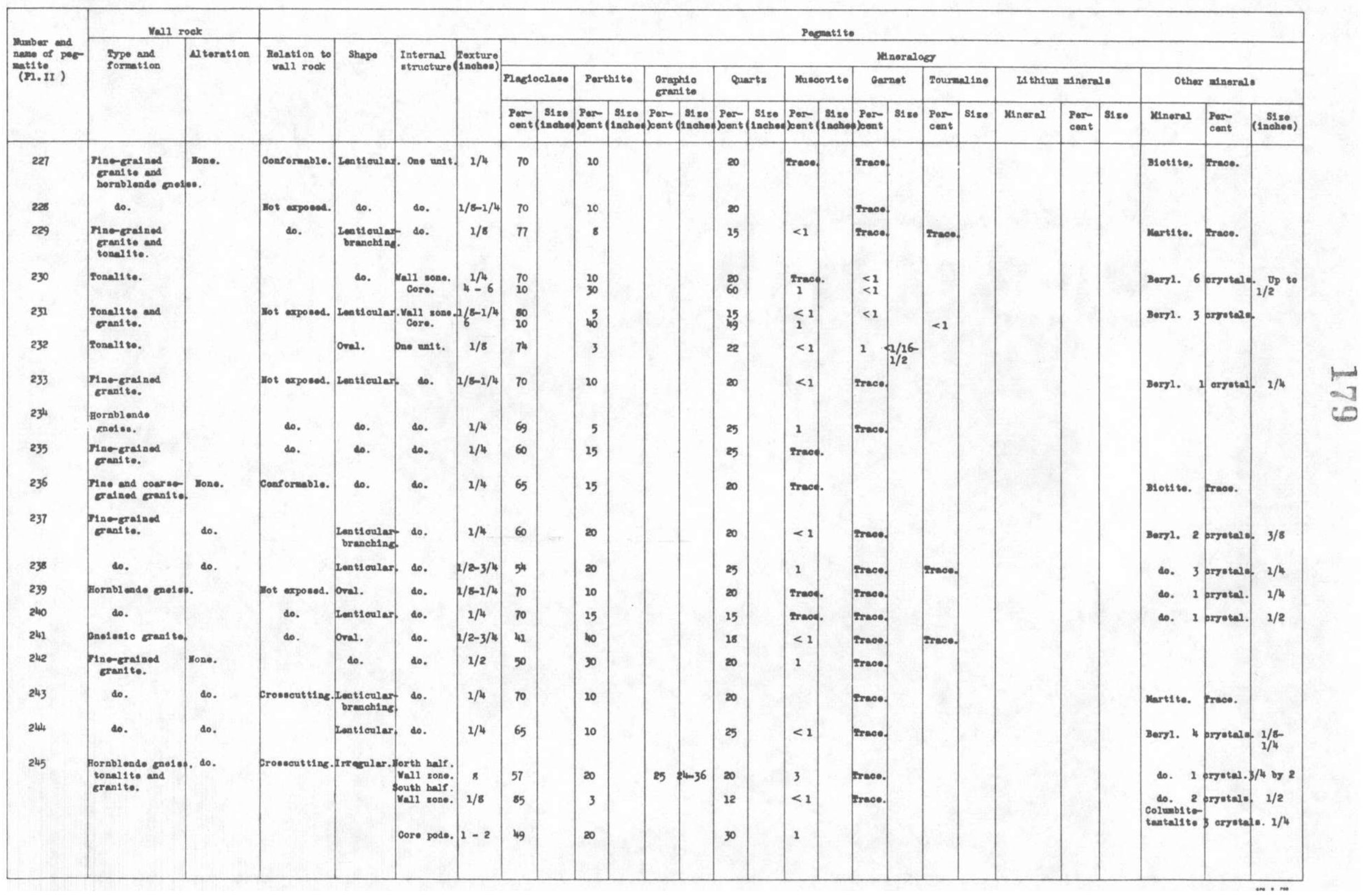


Fable 20.--Mineralogy of pepat1 tor-Cont1 nued.

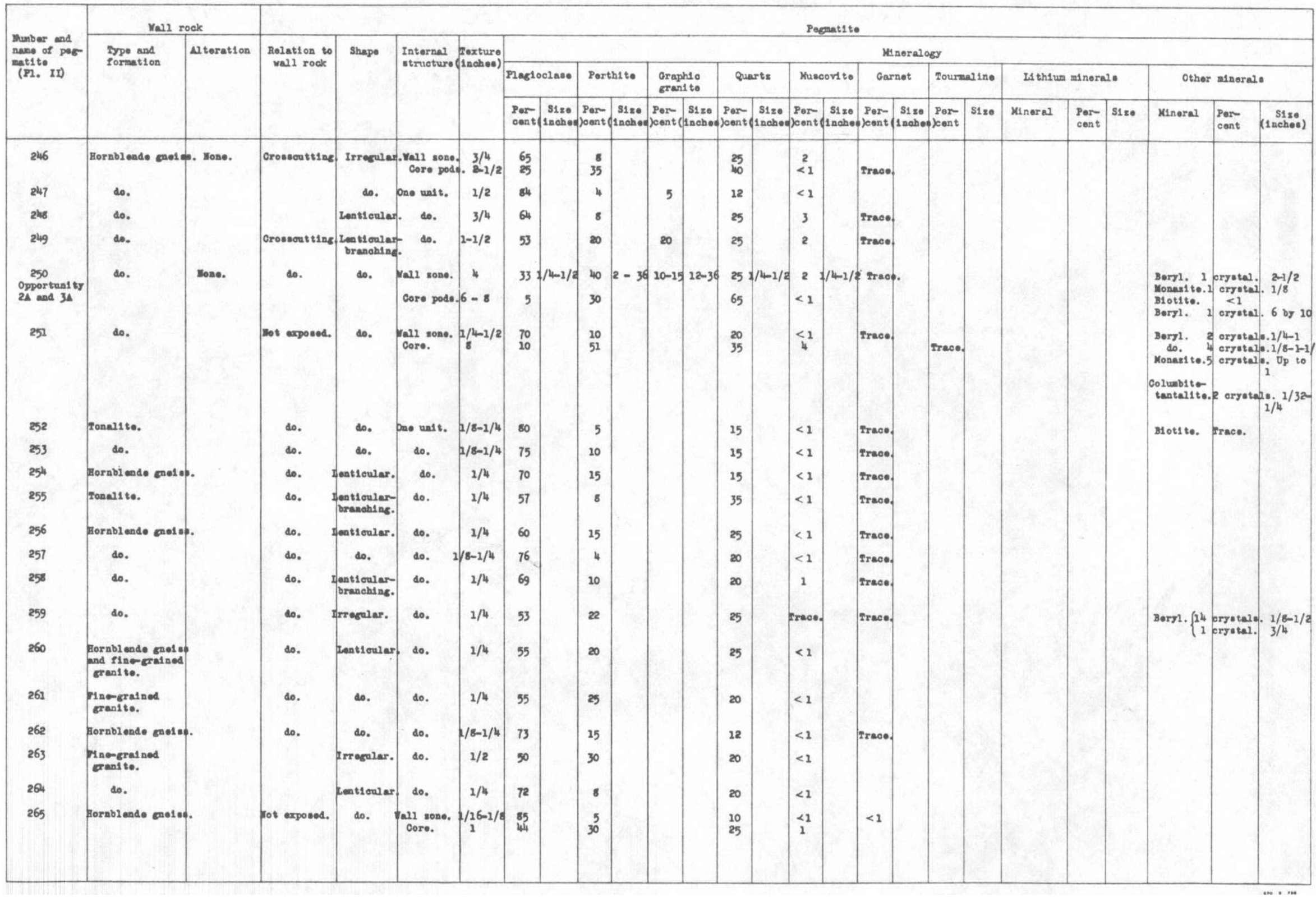


Trob10 20.--Mineralopy of peenat1 tog-Cont1 mued.

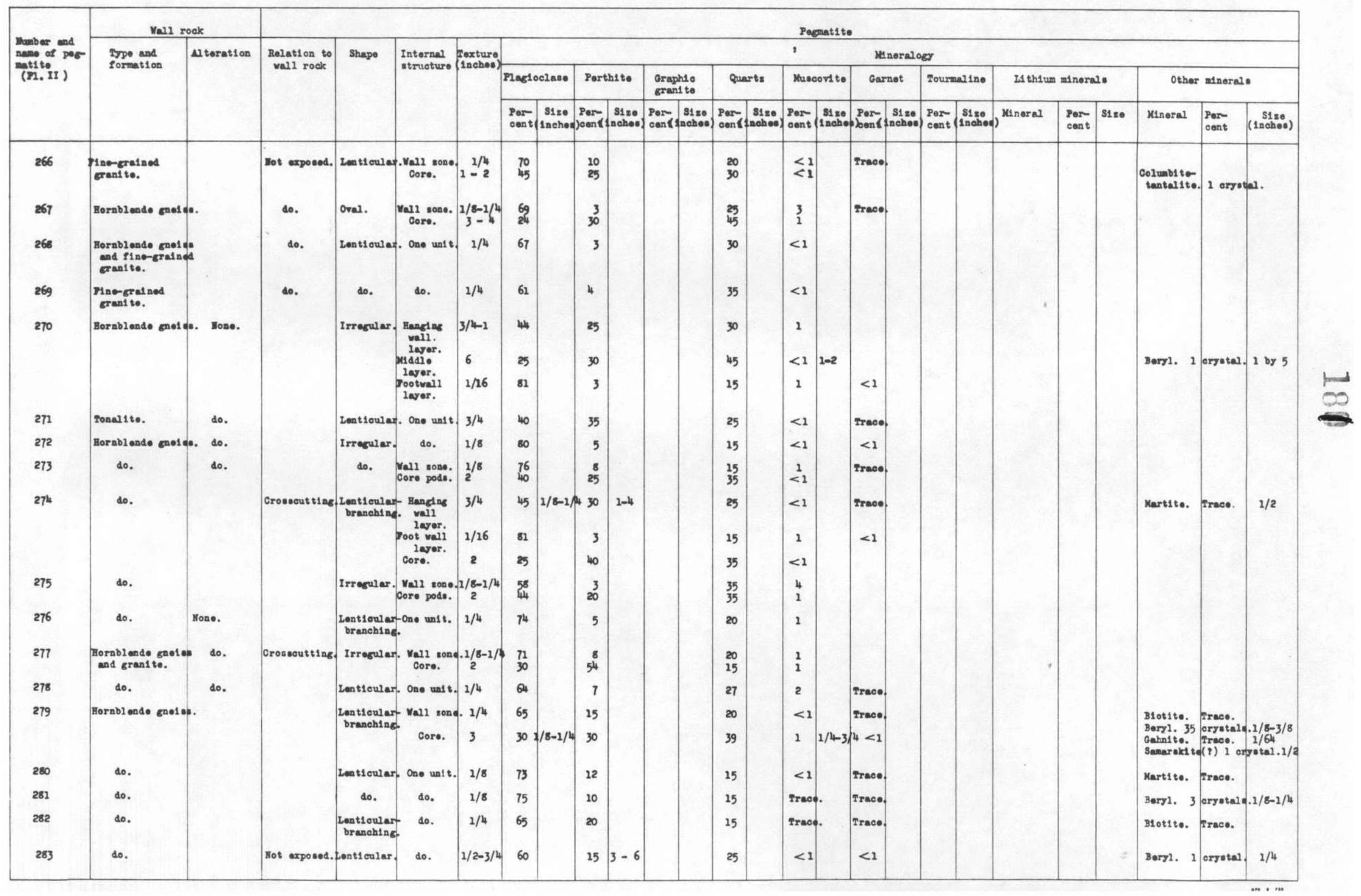


Table 20.--Mineralogy of pereatites --Cont1 nued.

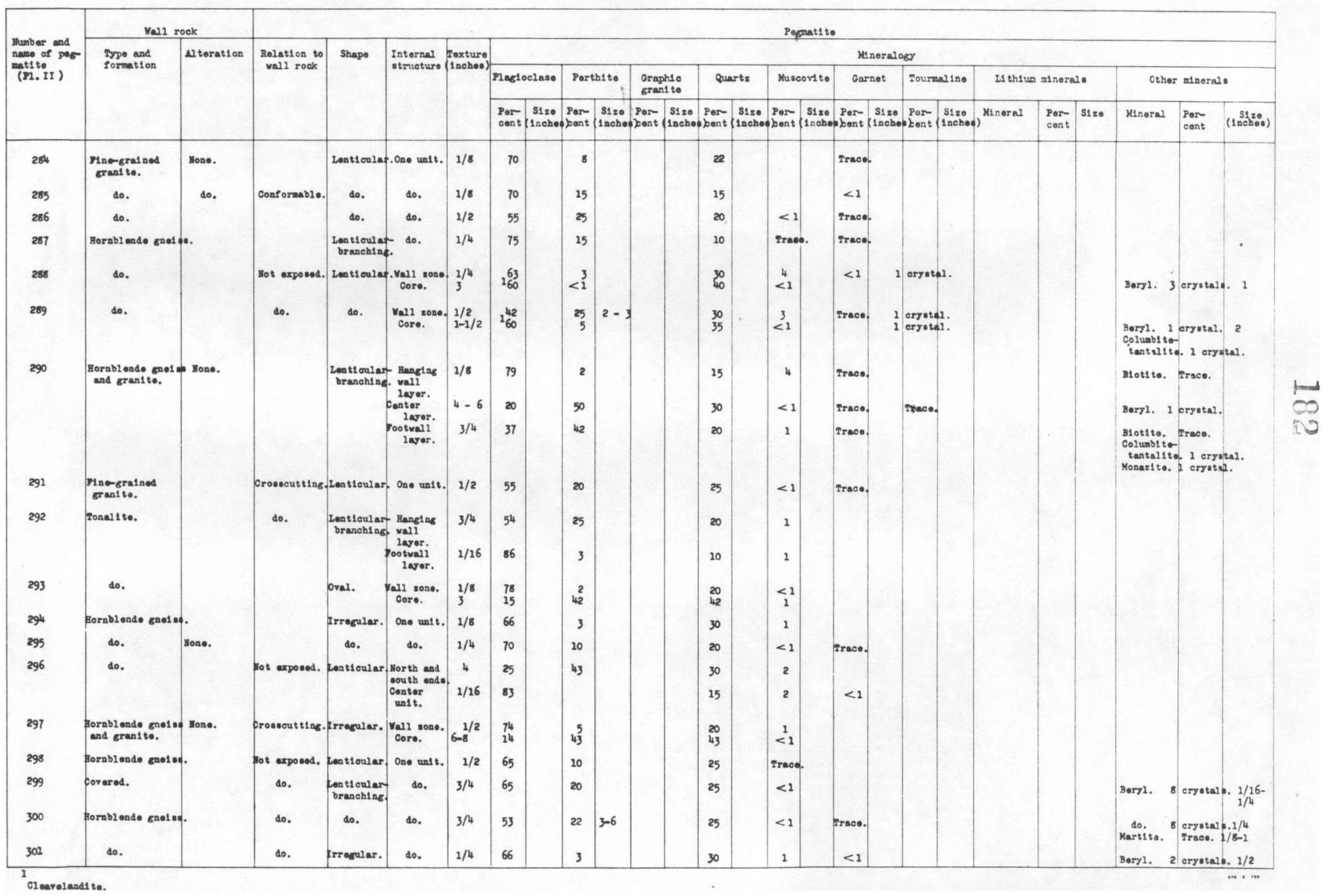




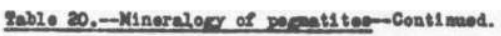

\begin{tabular}{|c|c|c|c|c|c|c|c|c|c|c|c|c|c|c|c|c|c|c|c|c|c|c|c|c|c|c|}
\hline \multirow{4}{*}{$\begin{array}{l}\text { number ond } \\
\text { nevor of por } \\
\text { (II.II) }\end{array}$} & \multicolumn{2}{|c|}{ Vall rook } & \multicolumn{24}{|c|}{, Peonatito } \\
\hline & \multirow{3}{*}{$\begin{array}{l}\text { Sypo and } \\
\text { formation }\end{array}$} & \multirow[t]{3}{*}{ N teration } & \multirow{3}{*}{$\begin{array}{l}\text { Ralation to } \\
\text { vall rook }\end{array}$} & \multirow[t]{3}{*}{ Shape } & \multirow{3}{*}{$\begin{array}{l}\text { Interneal } \\
\text { struetured }\end{array}$} & \multirow{3}{*}{ Sexture } & \multicolumn{20}{|c|}{ Mnoreloger } \\
\hline & & & & & & & \multicolumn{2}{|c|}{ Profloolaeo } & \multicolumn{2}{|c|}{ Porth1to } & \multicolumn{2}{|c|}{$\begin{array}{l}\text { Graphse } \\
\text { cranl to }\end{array}$} & \multicolumn{2}{|c|}{ Guarts } & \multicolumn{2}{|c|}{ Musoord to } & \multicolumn{2}{|c|}{ Garnot } & \multicolumn{2}{|c|}{ Tournealino } & \multicolumn{3}{|c|}{ If thium alinorals } & \multicolumn{3}{|c|}{ Other minorals } \\
\hline & & & & & & & Paent & 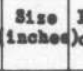 & $\begin{array}{l}\text { Parr } \\
\text { Doent } 12\end{array}$ & $\begin{array}{l}\text { 81zo: } \\
\text { 1noheodx }\end{array}$ & $\begin{array}{l}\text { Por- } 8 \\
\text { Deant }(12\end{array}$ & 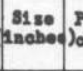 & Part & $\begin{array}{l}8180 \\
\text { ineheod to. }\end{array}$ & $\begin{array}{l}\text { Por- } \\
\text { eent }\end{array}$ & 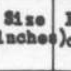 & $\begin{array}{l}\text { Por- } \\
\text { Poont } \\
\text { 1n }\end{array}$ & 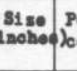 & Ceant Pal $_{1}$ & 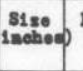 & xinaral & $\begin{array}{l}\text { Par- } \\
\text { cont }\end{array}$ & $31 \mathbf{s 0}$ & Winoral & $\begin{array}{l}\text { Per- } \\
\text { cont }\end{array}$ & (1513060) \\
\hline 302 & Horableado canel & & Wot expoesed. & Inentioulas & - Mell sone. & $\begin{array}{r}1 / 2 \\
2+1 / 2\end{array}$ & $\begin{array}{l}70 \\
15\end{array}$ & & 10 & & & & $\begin{array}{c}20 \\
45\end{array}$ & & $<1$ & & Treoe. & & & & & & & Bergl. & 2 ergotalo. & $.1 / 2-1$ \\
\hline 303 & هo. & & do. & Leatioveras. & . Ono units. & $1 / 8$ & $\infty$ & & 8 & & & & 12 & & $<1$ & & $<1$ & & & & & & & & & \\
\hline 3014 & هo. & & هo. & over. & \&. & $2 / 2$ & 54 & & $\infty$ & & & & 25 & & 2 & & $<1$ & & & & & & & & & \\
\hline 305 & 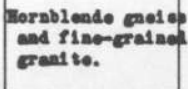 & Hose. & & Irragaler. & $\begin{array}{l}\text { Vall sose. } \\
\text { Coro. }\end{array}$ & $1 / 8$ & 80 & & $\begin{array}{l}5 \\
7\end{array}$ & & 1 & & $\begin{array}{l}15 \\
\checkmark\end{array}$ & & $<1$ & & $<1$ & & & & & & & $\begin{array}{l}\text { Bargl. } \\
\text { Calorito. }\end{array}$ & 3 eryotal. & $1 / 16$ \\
\hline Opportunity & Porablosedo cous op & & Hot exposed. & Inetioular. & Moot 1aver & $1 / 4$ & 179 & $2-3$ & 10 & 3 & 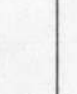 & & $\begin{array}{l}22 \\
25\end{array}$ & & $\begin{array}{l}3 \\
1\end{array}$ & & Fraoo. & & $<1$ & & Lepidolito. & $4-5$ & $\begin{array}{c}<1 / 16- \\
1 / 2\end{array}$ & Mierolito. & 2 argotha & 1.. $1 / 10$ \\
\hline $\begin{array}{c}307 \\
\text { Opportuan ty } \\
\text { Wo. }\end{array}$ & do. & & ه. & Irregalar. & One unit. & $1 / 2$ & 47 & & 30 & & $5-10$ & & 20 & & 3 & & $<1$ & & treoes. & & & & & & & \\
\hline 308 & هo. & & هo. & Pantioulas. & $\begin{array}{l}\text { Voll sono. } \\
\text { Cors. }\end{array}$ & $3 / 2$ & 59 & & 25 & & $=020$ & & 25 & & 2 & & traoo. & & & & & & - & Borg1. & 1 ergotal. & \\
\hline 309 & $\infty$. & & هo. & Irracular. & 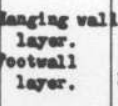 & $\int_{46}^{1 / 4}$ & 5 & & 20 & & $>50$ & & $\begin{array}{l}15 \\
20\end{array}$ & & $\begin{array}{l}1 \\
<1\end{array}$ & & $<1$ & & & & & & & & & \\
\hline 310 & هo. & & ه. & do. & Ono ents. & $1 / 4$ & 35 & & 45 & & $5-10$ & & $\infty$ & & 2 & & & & & & & & & & & \\
\hline 311 & \&.. & & ه. & pentioular. & \&. & $3 / 4$ & 4 & & 35 & & 30 & & $\infty$ & & 1 & & $<1$ & & traoes. & & & & & Bergl. 2 & exyotale. & $1 / 4$ \\
\hline 312 & ه. & & هo. & Irragular. & «.. & $2-3$ & 25 & & 54 & & 75 & & 20 & & 1 & & trace. & & traces. & & & & & & & \\
\hline 313 & Gran1 to mol os. & & «o. & pras. & do. & & 15 & & Q4 & & 75 & & 20 & & 1 & & & & & & & & & & & \\
\hline 324 & 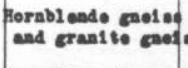 & & ه. & Pentioular. & L. & 1 & 38 & & 40 & & 50 & & 20 & & 2 & & & & & & & & & z & & \\
\hline 315 & Ponall to and crovs & 18. Wose. & grossouttine. & $\begin{array}{l}\text { Pentioulary } \\
\text { Oranobinge. }\end{array}$ & \&. & $1 / 2-3 / 4$ & 75 & & 5 & & & & 20 & & $<1$ & & & & & & & & & & & \\
\hline 316 & ponal1 to. & هo. & ه. & Irragular. & $\begin{array}{l}\text { Yall sone. } \\
\text { Core. }\end{array}$ & $8^{1 / 4}$ & \begin{tabular}{|l}
66 \\
10
\end{tabular} & & 25 & & 5 & & 6\% & & 1 & 2 & 4 & & & & & & & 3oryl. & 1 orgotal. & $3 / 4$ \\
\hline 317 & هo. & & tot axposod. & bentioular & $\begin{array}{l}\text { Vell sone } \\
\text { Core. }\end{array}$ & $1 / 4-1 / 2$ & $\begin{array}{l}58 \\
15\end{array}$ & & $\frac{15}{35}$ & & & & 25 & & $\frac{2}{2}$ & & treoe. & & & & & & & & & \\
\hline 318 & do. & & ه. & Sentioular. & ono unit. & $1 / 4$ & 6 & & 1 & & & & 30 & & $<1$ & & & & & & & & & & & \\
\hline 319 & fornblendo onol ead. & & ه. & ه. & ه. & $3 / 4$ & 4 & & 30 & & & & 20 & & 6 & & & & & & & & & & & \\
\hline 320 & ه.. & & هo. & $\begin{array}{l}\text { Pentioular. } \\
\text { branohinac. }\end{array}$ & do. & $1 / 2$ & 61 & & 1 & & & & 35 & & 3 & & & & & & & & & & & \\
\hline 323 & Tonal1 to. & Mono. & donf arnable. & fenticular. & 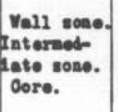 & $1 / 8$ & $\begin{array}{l}70 \\
4\end{array}$ & & 2 & & & & $\begin{array}{l}30 \\
10 \\
100\end{array}$ & & 4 & & & & & & & & & & & \\
\hline
\end{tabular}


Iab1e 2a--Mineralogy of pepat1 tes--Cont1auod.

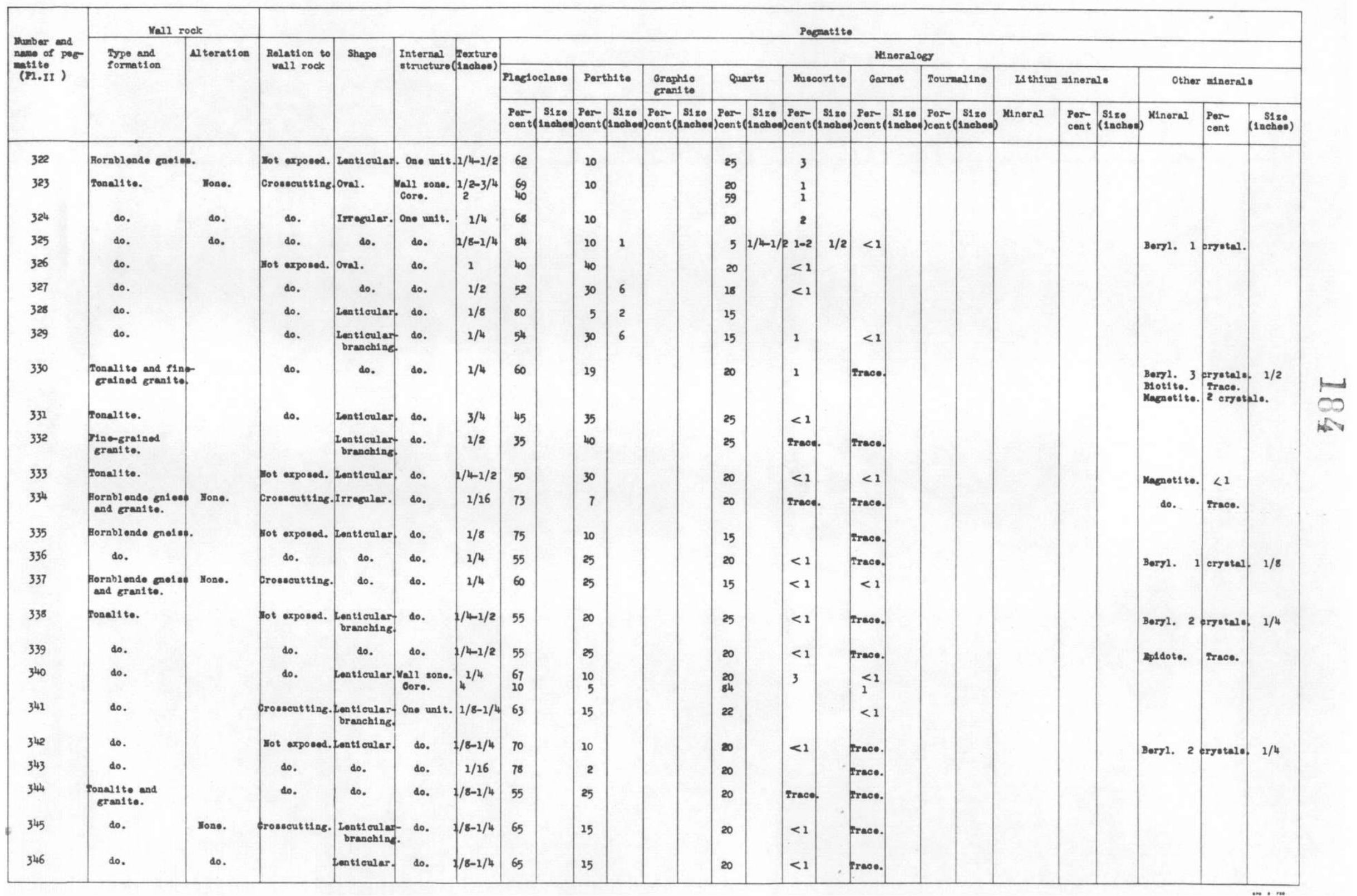


Ieb10 20.--Minoralogy of pepeat1 tes -Continued.

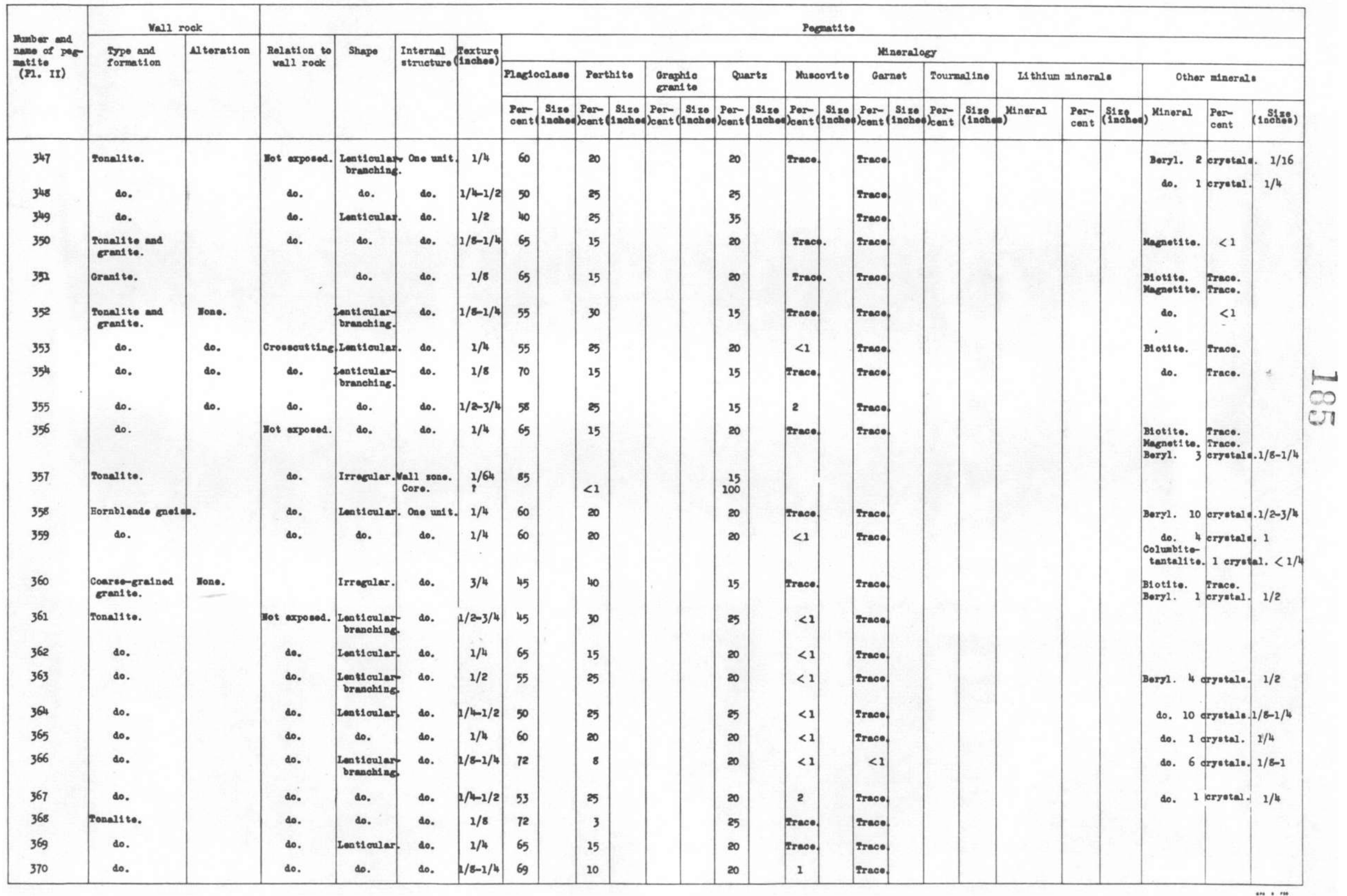


Feb10 20. -Minorelore of pereat1tee-Cont1nuod.

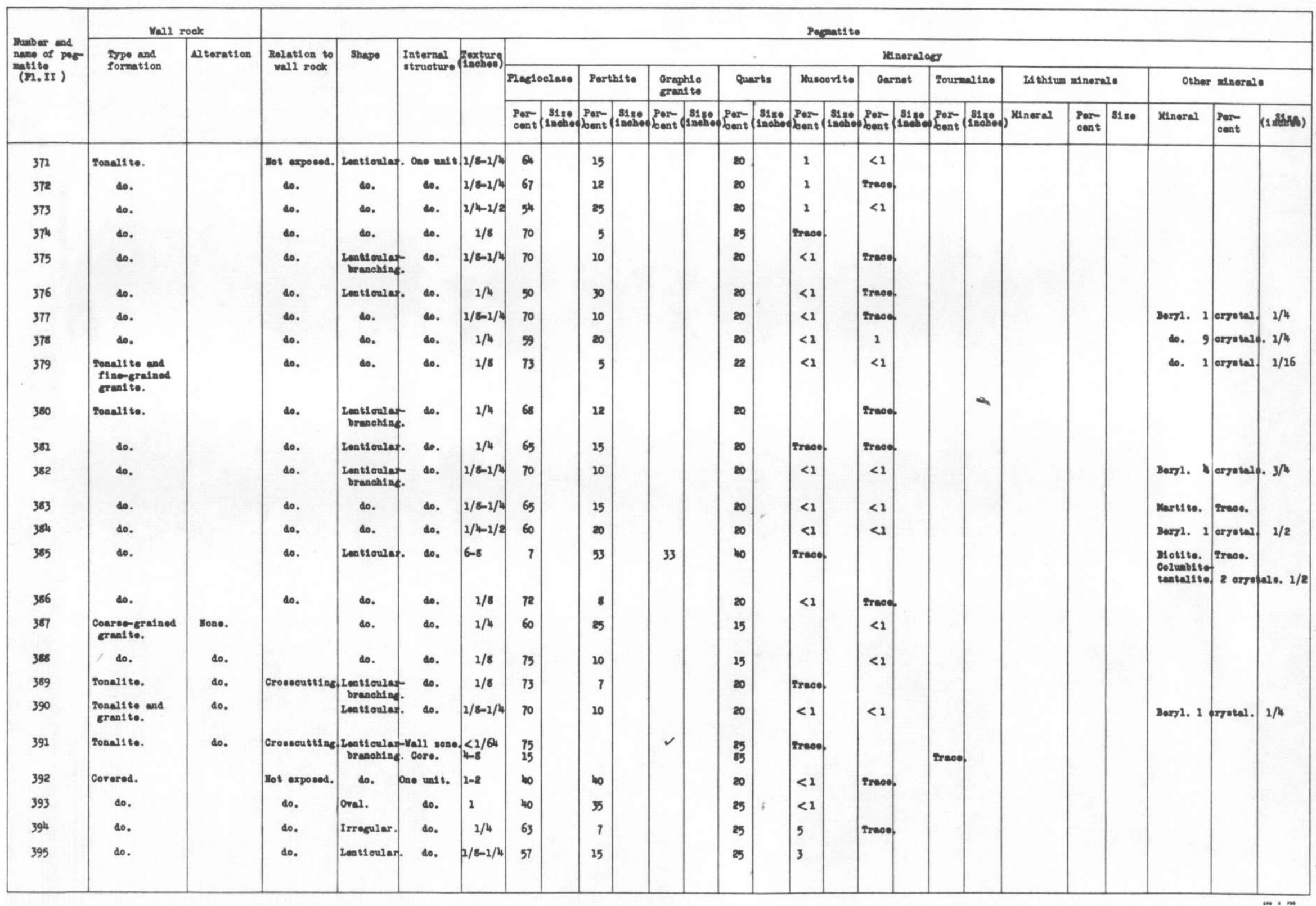




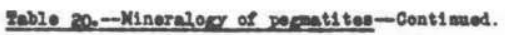

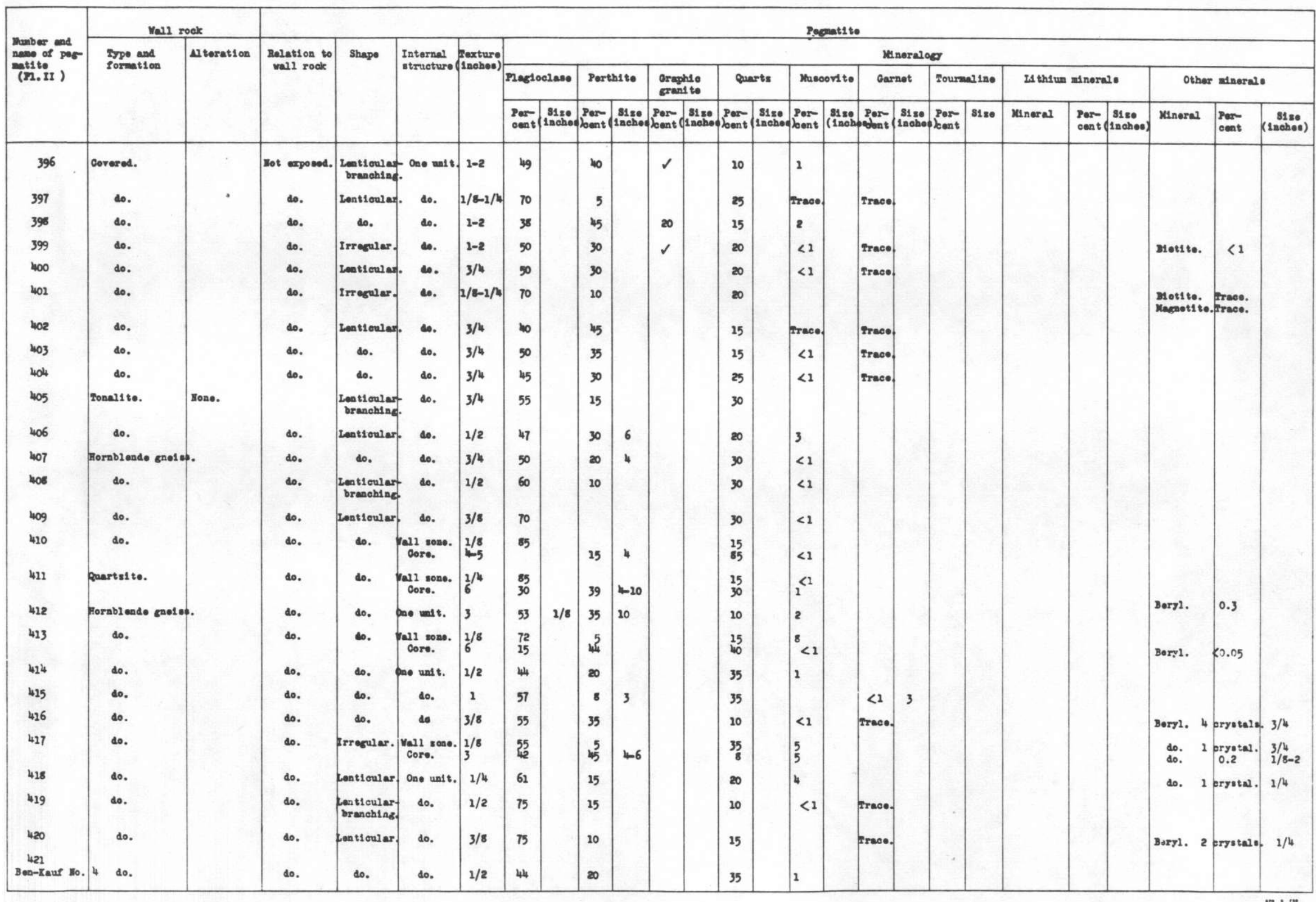


Tab10 20.--Mineralogy of pepat1 tor-Cont I nued.

\begin{tabular}{|c|c|c|c|c|c|c|c|c|c|c|c|c|c|c|c|c|c|c|c|c|c|c|c|c|c|}
\hline \multirow{4}{*}{ 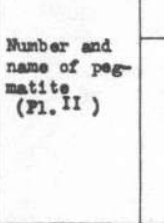 } & \multicolumn{2}{|c|}{ Mall roak } & \multicolumn{23}{|c|}{ Pegmat 1 to } \\
\hline & \multirow{3}{*}{$\begin{array}{l}\text { Type and } \\
\text { formation }\end{array}$} & \multirow{3}{*}{ N teration } & \multirow{3}{*}{$\begin{array}{l}\text { Rolation to } \\
\text { vall rock }\end{array}$} & \multirow[t]{3}{*}{ Shape } & \multirow{3}{*}{$\begin{array}{l}\text { Internal } \\
\text { structure }\end{array}$} & \multirow{3}{*}{$\begin{array}{l}\text { Toxture } \\
\text { 1nchoos) }\end{array}$} & \multicolumn{19}{|c|}{ Mineralogy } \\
\hline & & & & & & & \multicolumn{2}{|c|}{ Plagioclaso } & \multicolumn{2}{|c|}{ Porth1 to } & $\begin{array}{l}\text { Graph10 } \\
\text { gran1 to }\end{array}$ & \multicolumn{2}{|c|}{ Quartz } & \multicolumn{2}{|c|}{ Muscovit to } & \multicolumn{2}{|c|}{ Garnot } & \multicolumn{2}{|c|}{ Tournaline } & \multicolumn{3}{|c|}{ I1 th1un minorals } & \multicolumn{3}{|c|}{ Othor minorals } \\
\hline & & & & & & & $\begin{array}{l}\text { Par- } \\
\text { cont }\end{array}$ & $\begin{array}{l}\text { S1zo } \\
\text { (1nohod }\end{array}$ & $\begin{array}{l}\text { Por } \\
\text { Sunt }\end{array}$ & $\begin{array}{l}\text { S1zo } \\
\text { 1nehoof }\end{array}$ & $\begin{array}{l}\text { Per } \$ 1 z e \\
\text { bent (1nehoo) }\end{array}$ & $\begin{array}{l}\text { Par } \\
\text { Xent (1 }\end{array}$ & $\begin{array}{l}\text { S1ze } \\
(1 \mathrm{neheo})^{P}\end{array}$ & $\begin{array}{l}\text { Perr } \\
\text { bent (1 }\end{array}$ & $\begin{array}{l}S 120 \quad \\
\text { incheos } x\end{array}$ & $\begin{array}{l}\text { Per- } \\
\text { bent (1 }\end{array}$ & $\begin{array}{l}\text { S1zo } \\
1 \text { 1ncheo }\end{array}$ & $\begin{array}{l}\text { Por } \\
\text { oent }\end{array}$ & 5120 & Mineral & $\begin{array}{l}\text { Por } \\
\text { cont }\end{array}$ & \begin{tabular}{|l|} 
S1ze日 \\
1ncheos)
\end{tabular} & Kinoral & $\begin{array}{l}\text { Por- } \\
\text { cont }\end{array}$ & (1 1 sethos) \\
\hline $\begin{array}{l}422 \\
\text { Bon-Keuf } \\
\text { Ho., } 1\end{array}$ & Tonalit to. & & Mot exposed. & branching. & $\begin{array}{l}\text { Hang1ng } \\
\text { veall } \\
\text { lavor. } \\
\text { contrai } \\
\text { untt. } \\
\text { poott. } \\
\text { lever. } \\
\text { lever. }\end{array}$ & $\begin{array}{c}3 \\
1 / 2 \\
1 / 4\end{array}$ & $\begin{array}{r}22 \\
181 \\
50\end{array}$ & & $\begin{array}{r}35 \\
15 \\
2\end{array}$ & & & $\begin{array}{l}35 \\
2 \\
40\end{array}$ & & 8 & & & & & & Lep1dollte. & . 2 & & $\begin{array}{l}\text { M1 orol1 to. } \\
\text { Apat1 to. }\end{array}$ & i. 0.01 oryotal. & 2. $1 / 4$ \\
\hline 423 & Hornb1oade conol. & o. & do. & Lonticular. & One unit & $1 / 2$ & 49 & & 35 & & & 15 & & 1 & & & & & & & & & & & \\
\hline $\begin{array}{c}424 \\
\text { Bazooka }\end{array}$ & Ponall to. & & do. & do. & $\begin{array}{c}\text { Mall sono. } \\
\text { Corro. } \\
\text { do. }\end{array}$ & $\begin{array}{l}1 / 2 \\
1-2 \\
4\end{array}$ & $\begin{array}{l}282 \\
115 \\
120\end{array}$ & & & & & $\begin{array}{l}10 \\
85 \\
60\end{array}$ & & & & & & & & $\begin{array}{l}\text { Lopldollte. } \\
\text { Lopidolit te. } \\
\text { Spodumene. } \\
\text { Lmblygonito. }\end{array}$ & $\begin{array}{r}8 \\
2 \\
12 \\
6.6\end{array}$ & & Miorolite. & 1 oryotal & cal. \\
\hline 425 & Bornblande gne1 & o. & do. & do. & One unit. & $1 / 4$ & 60 & & 15 & & & 25 & & & & & & & & & & & Bory1. 3 & ergotale. & $3 / 4$ \\
\hline 426 & do. & & do. & do. & do. & $3 / 8$ & 54 & $1 / 8$ & 10 & 4 & & 35 & & 1 & & & & & & & & & & & \\
\hline 427 & do. & & do. & do. & đo. & 1 & 30 & & 40 & & & 30 & & & & & & & & & & & & & \\
\hline 428 & do. & & do. & do. & do. & 1 & 30 & & 40 & & & 30 & & $<1$ & & & & & & & & & Boryl. 2 & ergotale. & $1 / 2$ \\
\hline 429 & đo. & & do. & do. & do. & $1 / 2$ & 70 & & 15 & 8 & & 15 & & $<1$ & & & & & & & & & & & \\
\hline 430 & Gornblende gnold & b. & do. & oral. & One unit. & $1 / 2$ & 55 & $<1 / 8$ & 20 & 2 & & 25 & & Trace. & & & & & & & & & & & \\
\hline 431 & do. & & do. & $\begin{array}{l}\text { Lon t1 cular } \\
\text { branching. }\end{array}$ & $\begin{array}{l}\text { Ranging } \\
\text { vall } \\
\text { laver. } \\
\text { Pootwali } \\
\text { layer. }\end{array}$ & $1 / 4-1 / 2$ & $\begin{array}{l}30 \\
65\end{array}$ & & $\begin{array}{l}45 \\
20\end{array}$ & & & $\begin{array}{l}25 \\
15\end{array}$ & & $<1$ & & & & & & & & & Boryl. & $<0.05$ & 1 \\
\hline 432 & do. & & do. & do. & 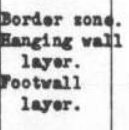 & $\begin{array}{c}1 / 1 / 8 \\
2 \\
1 / 4\end{array}$ & $\begin{array}{l}92 \\
46 \\
62\end{array}$ & $1 / 8$ & $\begin{array}{l}5 \\
30 \\
2\end{array}$ & & & $\begin{array}{l}3 \\
20 \\
35\end{array}$ & & 4 & & trace. & & & & & & & $\begin{array}{l}\text { Beryl. } \\
\text { do. } \\
\text { do. } 1\end{array}$ & $\begin{array}{l}0.1 \\
0.05 \\
\text { eryetal. }\end{array}$ & $\begin{array}{l}1 / 4-3 / 4 \\
1 / 4-3 / 4\end{array}$ \\
\hline 433 & do. & Mono. & Conf ornablo. I & Lont1 foular. & $\begin{array}{l}\text { Rengling } \\
\text { vall } \\
\text { lavor. } \\
\text { Pootwail } \\
\text { lavor. }\end{array}$ & $\begin{array}{l}1 / 2 \\
1 / 8\end{array}$ & 44 & & 20 & 4 & & $\begin{array}{l}35 \\
35\end{array}$ & & 1 & & Traced & & & & & & & do. & $<0.05$ & $1-1 / 2$ \\
\hline 434 & do. & & lot exposed. & do. & One unit. & $1 / 4$ & 54 & & 8 & & & 35 & & 3 & $1 / 4$ & & & & & & & & Boryl. 1 & ergotal. & 6 \\
\hline 435 & do. & & do. & do. & $\begin{array}{l}\text { Rangling valu } \\
\text { laver. } \\
\text { rotwail } \\
\text { laver. }\end{array}$ & $\begin{array}{c}1 \\
1 / 8\end{array}$ & $\begin{array}{l}40 \\
65\end{array}$ & & 35 & & & $\begin{array}{l}15 \\
35\end{array}$ & & $\begin{array}{c}2 \\
<1\end{array}$ & & & & & & & & & do. 4 & ergotale. & \\
\hline 436 & do. & & do. & do. & $\begin{array}{l}\text { rall sone. } \\
\text { Core. }\end{array}$ & $4^{1 / 4}$ & $\begin{array}{r}65 \\
5\end{array}$ & $1 / 8$ & $8^{5}$ & 3 & & $\begin{array}{l}30 \\
15\end{array}$ & & $\begin{array}{l}<1 \\
<1\end{array}$ & & & & & & & & & Berzl. 1 & eryotal. & 1 \\
\hline 437 & do. & & do. & do. & One unit. & $1 / 4$ & 46 & $1 / 8$ & $\infty$ & 8 & & 32 & & 2 & & & & & & & & & do. 1 & ergotal & $1 / 2$ \\
\hline 438 & do. & & do. & do. & do. & $1 / 4$ & 55 & $1 / 8$ & 15 & 6 & & 30 & & $<1$ & & & & & & & & & do. 1 & ergotal. & $3 / 4$ \\
\hline
\end{tabular}


Frob10 20,-Mineralory of perpatis toe--Cont1 nuod.

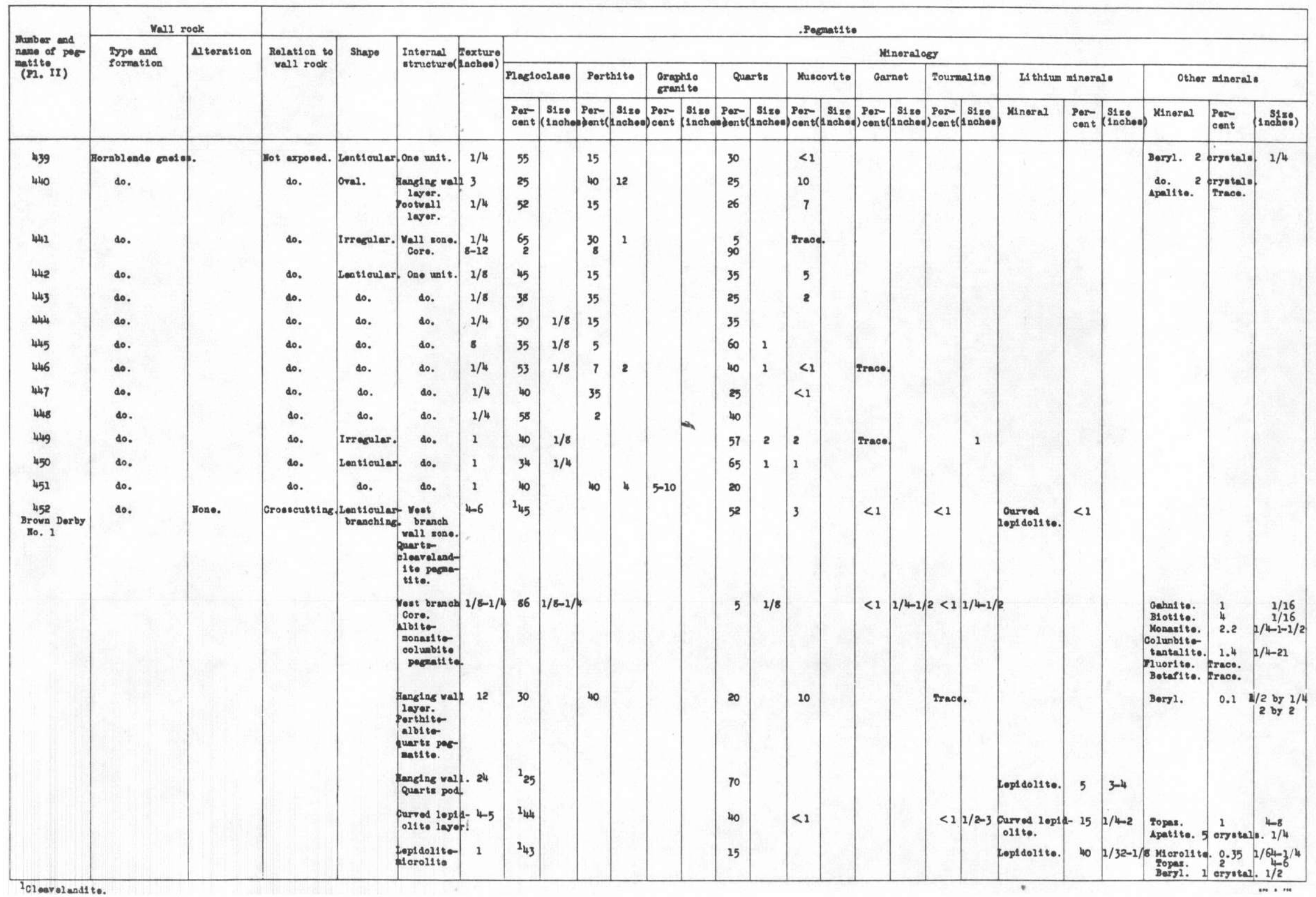


Feb1e 20,-Minerelory of peent1 ted--Cont1 nuod.

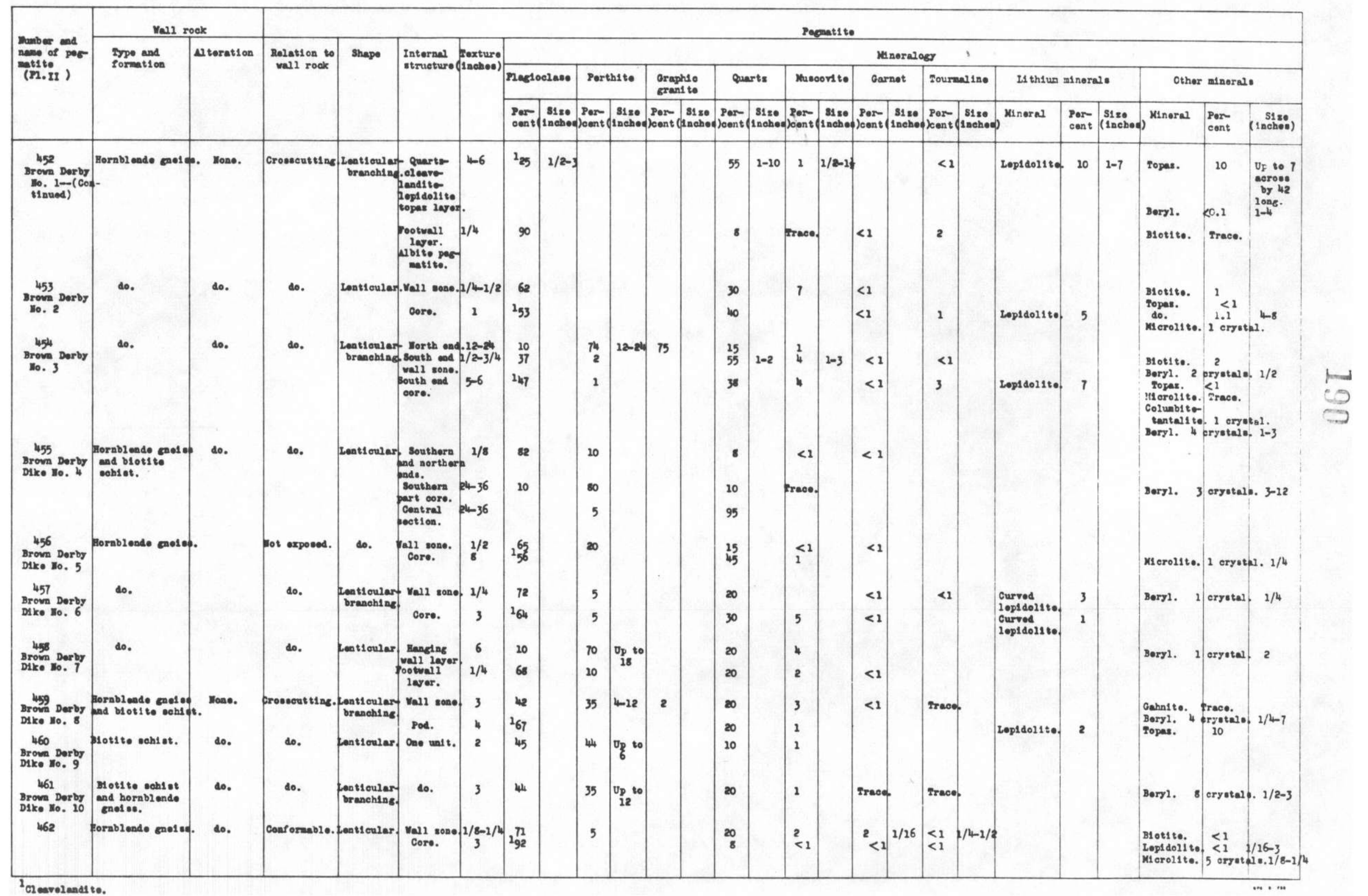


Teble 20,-Mineralogy of peet1 tes-Cont1 nued.

\begin{tabular}{|c|c|c|c|c|c|c|c|c|c|c|c|c|c|c|c|c|c|c|c|c|c|c|c|c|c|c|}
\hline \multirow{4}{*}{$\begin{array}{l}\text { Mumber and } \\
\text { nowe of peg- } \\
\text { mat1 to } \\
\text { (P1. II) }\end{array}$} & \multicolumn{2}{|c|}{ Wall rock } & \multicolumn{24}{|c|}{ Pogmat1 10 } \\
\hline & \multirow{3}{*}{$\begin{array}{l}\text { Type and } \\
\text { formation }\end{array}$} & \multirow[t]{3}{*}{ N teration } & \multirow{3}{*}{$\begin{array}{l}\text { Rolatstion to } \\
\text { vall rock }\end{array}$} & \multirow[t]{3}{*}{ Shape } & \multirow{3}{*}{$\begin{array}{l}\text { Internal } \\
\text { structure }\end{array}$} & \multirow{3}{*}{ Poxture } & \multicolumn{20}{|c|}{ Nineralogy } \\
\hline & & & & & & & \multicolumn{2}{|c|}{ Plagiociaso } & \multicolumn{2}{|c|}{ Perth1te } & \multicolumn{2}{|c|}{$\begin{array}{l}\text { Graph10 } \\
\text { gran1 to }\end{array}$} & \multicolumn{2}{|c|}{ Quartz } & \multicolumn{2}{|c|}{ Musoovit to } & \multicolumn{2}{|c|}{ Garnot } & \multicolumn{2}{|c|}{ zournaline } & \multicolumn{3}{|c|}{ Li thium mineral. } & \multicolumn{3}{|c|}{ Other minerals. } \\
\hline & & & & & & & $\begin{array}{l}\text { Par- } \\
\text { cont }\end{array}$ & \begin{tabular}{|l|}
$51 z e$ \\
1 1nchod
\end{tabular} & $\begin{array}{c}\text { Per } \\
\text { Doent }\end{array}$ & 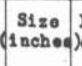 & $\begin{array}{l}\text { Per- } S \\
\text { cent }(1 x\end{array}$ & $\begin{array}{l}\text { s1ze } \\
\text { lnohes) }\end{array}$ & $\begin{array}{l}\text { Por- } \\
\text { Deont }\end{array}$ & $\begin{array}{l}\text { S1ze } \\
\text { 1ncheof) }\end{array}$ & $\begin{array}{l}\text { Per } \\
\text { Peont }(1:\end{array}$ & $\begin{array}{l}\text { s1 ze } \\
\text { 1ncheof }\end{array}$ & $\begin{array}{l}\text { Per- } \\
\text { Poont }(1\end{array}$ & $\begin{array}{c}\text { S1 ze } \\
\text { 1nehoot) }\end{array}$ & $\begin{array}{l}\text { Per } \\
\text { xent }\end{array}$ & $\begin{array}{l}\text { s1ze } \\
\text { lnohoga) }\end{array}$ & Mineral & $\begin{array}{l}\text { Por } \\
\text { cont }(1\end{array}$ & $\begin{array}{l}\begin{array}{l}\text { S1zo } \\
\text { 1nchoo: }\end{array} \\
\end{array}$ & Xinoral & \begin{tabular}{|l|}
$\begin{array}{l}\text { Porr } \\
\text { cent }\end{array}$ \\
\end{tabular} & $\begin{array}{l}\text { S180 } \\
(1 \text { inches) }\end{array}$ \\
\hline 463 & Hornblende ene1. & . & Not exposed. I & Lont1cular. & $\begin{array}{l}\text { Bangling } \\
\text { rall layor. } \\
\text { Tootvall } \\
\text { laver. }\end{array}$ & $\begin{array}{l}3 \\
1 / 4\end{array}$ & $\begin{array}{l}25 \\
71\end{array}$ & & $\begin{array}{l}52 \\
8\end{array}$ & & & & $\begin{array}{l}20 \\
20\end{array}$ & & $\begin{array}{l}3 \\
1\end{array}$ & & $\begin{array}{l}<1 \\
<1\end{array}$ & & & & & & & Bergl. 1 & eryotal. & $1 / 4$ \\
\hline 404 & do. & & ه.. & ه.. & $\begin{array}{l}\text { Yall sono. } \\
\text { Core. }\end{array}$ & $\frac{1 / 4-1 / 2}{2}$ & $\begin{array}{l}45 \\
10\end{array}$ & & $\begin{array}{l}10 \\
55\end{array}$ & & & & $\begin{array}{l}40 \\
25\end{array}$ & & $\begin{array}{l}5 \\
5\end{array}$ & & & & & & & & & B1ot1 to. & $<1$ & \\
\hline 465 & do. & & do. & do. & $\begin{array}{l}\text { rall sone. } \\
\text { Core. }\end{array}$ & $\begin{array}{l}1 / 4 \\
12\end{array}$ & $\begin{array}{r}70 \\
5\end{array}$ & & $\begin{array}{l}15 \\
20\end{array}$ & $\mathrm{DP}_{3}$ to & & & $\begin{array}{l}15 \\
75\end{array}$ & & $<1$ & & & & & & & & & do. & Trace. & \\
\hline 466 & do. & & do. & do. & One unit. & $1 / 2$ & 65 & & 20 & & & & 15 & & & & & & & & & & & & & \\
\hline 467 & do. & Mone. & & do. & $\begin{array}{l}\text { Hanging } \\
\text { pall laver. } \\
\text { Pootwall } \\
\text { 1 a por. } \\
\text { ractur: } \\
\text { f1111ng. }\end{array}$ & $\begin{array}{c}4 \\
1 / 4\end{array}$ & $\begin{array}{l}30 \\
65\end{array}$ & & $\begin{array}{l}40 \\
15\end{array}$ & & & & $\begin{array}{r}30 \\
20 \\
100\end{array}$ & & $<1$ & & trace. & & & & & & & & & \\
\hline 468 & $\begin{array}{l}\text { Coarco-gralnod } \\
\text { gran1to. }\end{array}$ & do. & & do. & $\begin{array}{l}\text { vall sono. } \\
\text { Coro. }\end{array}$ & $3 / 4-1$ & 3 & & $\begin{array}{l}77 \\
60\end{array}$ & & 30 & & $\begin{array}{l}20 \\
40\end{array}$ & & $<1$ & & & & & & & & & & & \\
\hline 469 & do. & do. & & do. & one un1 t. & $3 / 4=1$ & 3 & & 72 & & & & 25 & & Trace. & & Trace. & & & & & & & B1ot1to. & Treace. & \\
\hline $\begin{array}{l}470 \\
471\end{array}$ & $\begin{array}{l}\text { do. } \\
\text { do. }\end{array}$ & & & $\begin{array}{c}\text { do. } \\
\text { Lent1 cular- }\end{array}$ & $\begin{array}{l}\text { do. } \\
\text { do. }\end{array}$ & $\begin{array}{c}1-2 \\
1 / 4-1 / 2\end{array}$ & $\begin{array}{c}5 \\
25\end{array}$ & & $\begin{array}{l}75 \\
49\end{array}$ & & $10-15$ & & $\begin{array}{l}20 \\
25\end{array}$ & & $\begin{array}{c}<1 \\
1\end{array}$ & & & & & & & & & & & \\
\hline 472 & do. & None & & $\begin{array}{c}\text { branching } \\
\text { do. }\end{array}$ & do. & $2-3$ & 4 & & 69 & & 30 & & 25 & & 2 & & Trace. & & & & & & & & & \\
\hline 473 & do. & & & Lonticular. & do. & $3 / 4$ & 30 & & 4 & & 25 & & 25 & & 1 & & Trace. & & & & & & & & & \\
\hline 474 & do. & None. & & $\begin{array}{l}\text { Lonticular } \\
\text { branch1ng. }\end{array}$ & do. & $3 / 4$ & 3 & & 77 & & 30 & & 20 & & $<1$ & & arece. & & & & & & & & & \\
\hline 475 & do. & do. & & Lantieular. & do. & $1-2$ & 1 & & 78 & & 20 & & 20 & & 1 & & & & & & & & & & & \\
\hline 476 & do. & do. & & $\begin{array}{l}\text { Lenticular- } \\
\text { branching. }\end{array}$ & do. & $1-1 / 2$ & 2 & & 78 & & 30 & & 20 & & Trace. & & Trace. & & & & & & & & Traco. & \\
\hline 477 & do. & do. & & do. & do. & $1 / 4-1 / 25$ & 50 & & 25 & & & & 25 & & $<1$ & & race. & & & & & & & Boryl. 21 & $\underset{<1}{\text { eryotal }}$ & $.1 / 8-1 / 2$ \\
\hline 478 & do. & do. & & Lont1oular. & do. & $3-4$ & 1 & & 73 & & 90 & & 25 & & 1 & & & & & & & & & & & \\
\hline 479 & do. & & & $\begin{array}{l}\text { Lonticular } \\
\text { branching. }\end{array}$ & do. & 1 & 2 & & 77 & & 50 & & 20 & & 1 & & rrace. & & & & & & & & & \\
\hline 480 & do. & & & Lont1 oular. & do. & $1-2$ & 5 & & 75 & & 70 & & 20 & & & & Irace & & & & & & & Magnet1 to. & Traco. & \\
\hline 481 & do. & & & do. & do. & $1-2$ & 2 & & 78 & & 60 & & 20 & & $<1$ & & Trace. & & & & & & & & & \\
\hline 482 & do. & & & do. & do. & $1-2$ & 1 & & 79 & & 75 & & 20 & & $<1$ & & & & & & & & & & & \\
\hline 483 & do. & & & do. & do. & $1 / 2-3 / 4 \mid 1$ & 15 & & 65 & & 30 & & 20 & & Traoe. & & & & & & & & & $\begin{array}{l}\text { Boryl. } \\
\text { B1ot1 to. }\end{array}$ & $\begin{array}{c}\text { cryotal. } \\
\text { Trace. }\end{array}$ & $1 / 4$ \\
\hline 484 & do. & None. & & do. & $\begin{array}{l}\text { Yall zone. } \\
\text { Core. }\end{array}$ & $\begin{array}{c}1-2 \\
3\end{array}$ & 2 & & $\begin{array}{l}78 \\
30\end{array}$ & & 90 & 4 & $\begin{array}{l}20 \\
70\end{array}$ & $1 / 8$ & & & & & & & & & & Magnet 1 to. & Trace. & \\
\hline
\end{tabular}


Fab10 20,--Mineralecy of perpat1 tog--Cont1 nued.

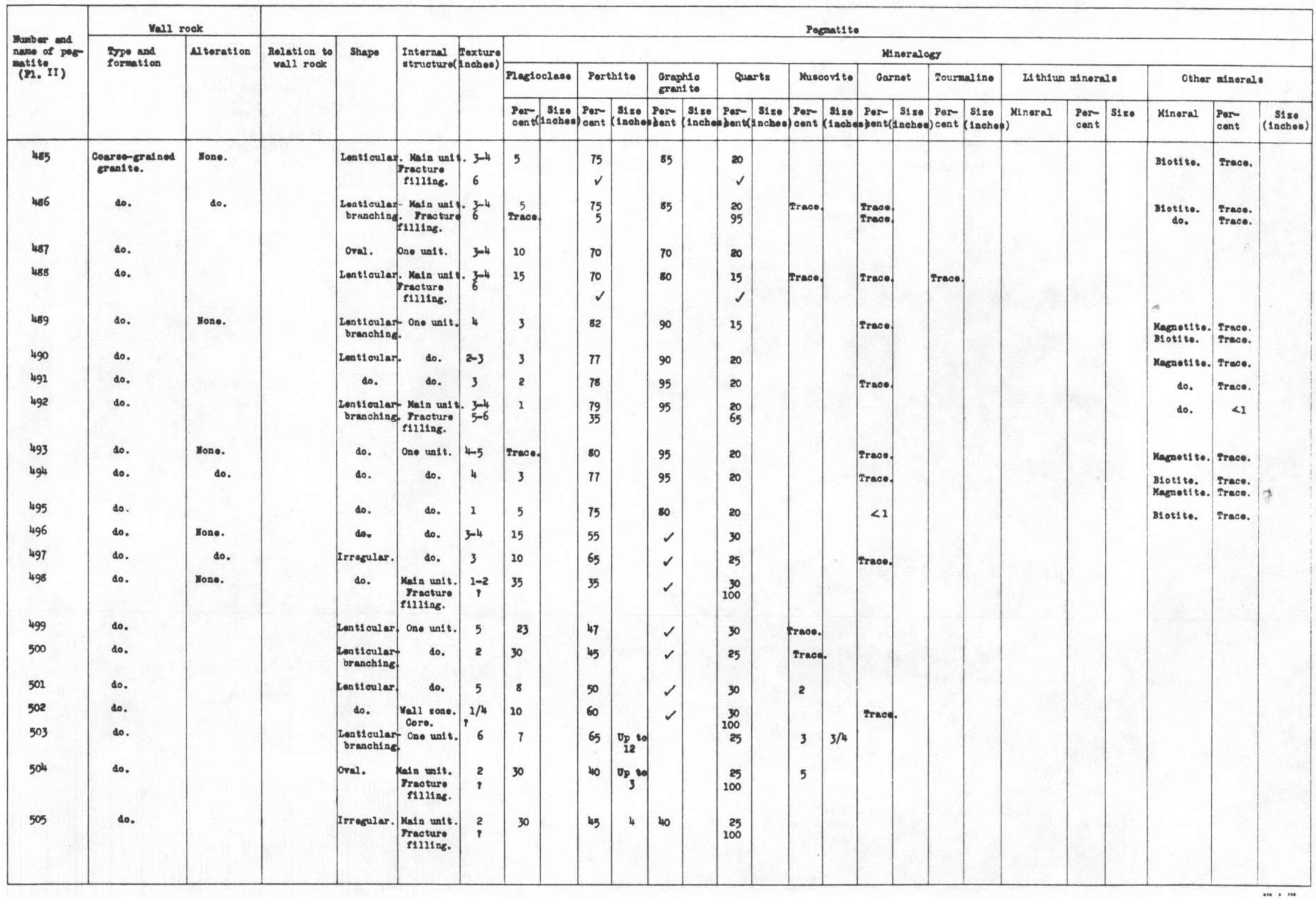




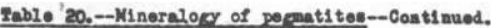

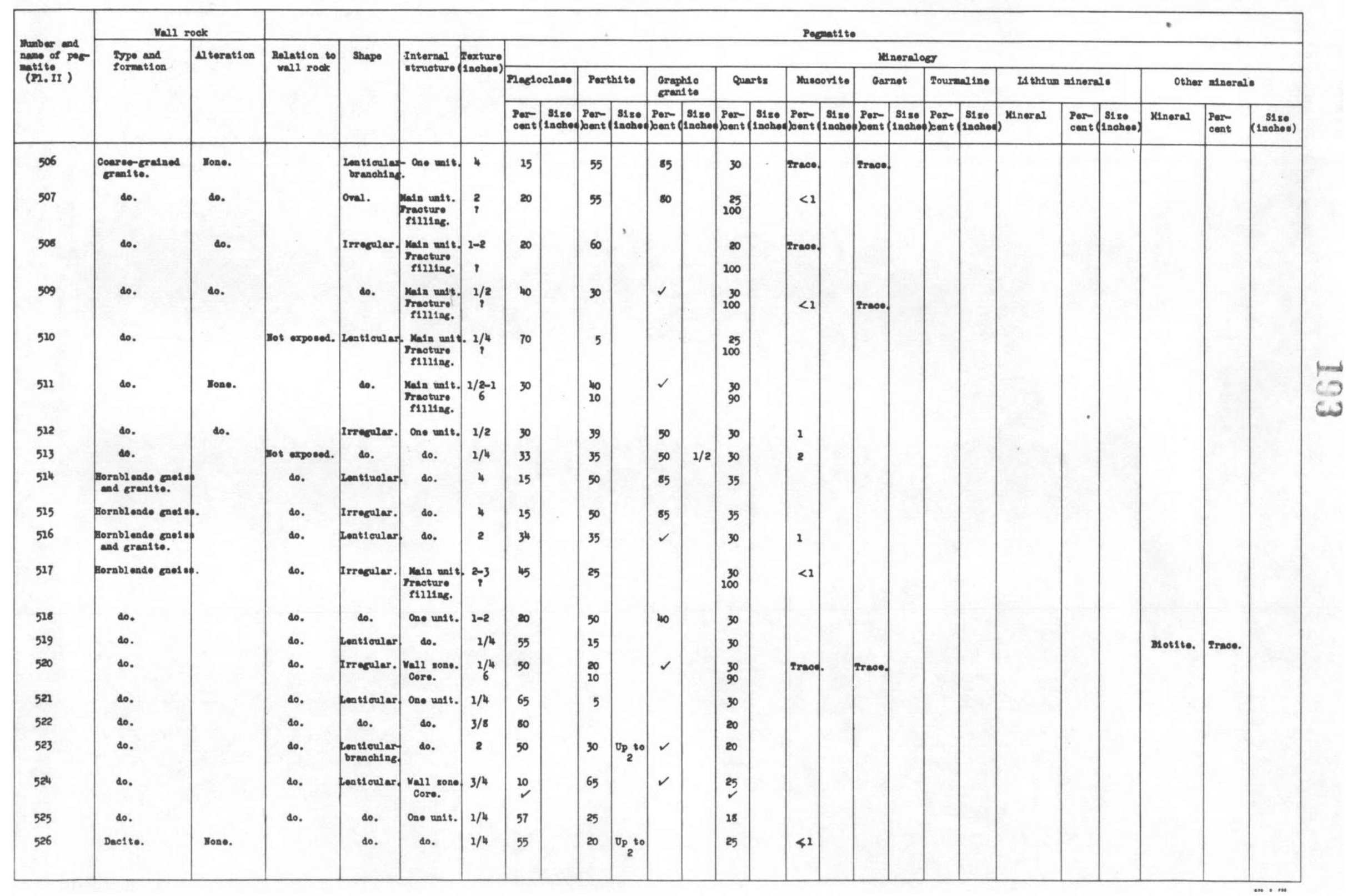


Feb10 20,--Mineralogy of pepent1 tes --Cont1 mued.

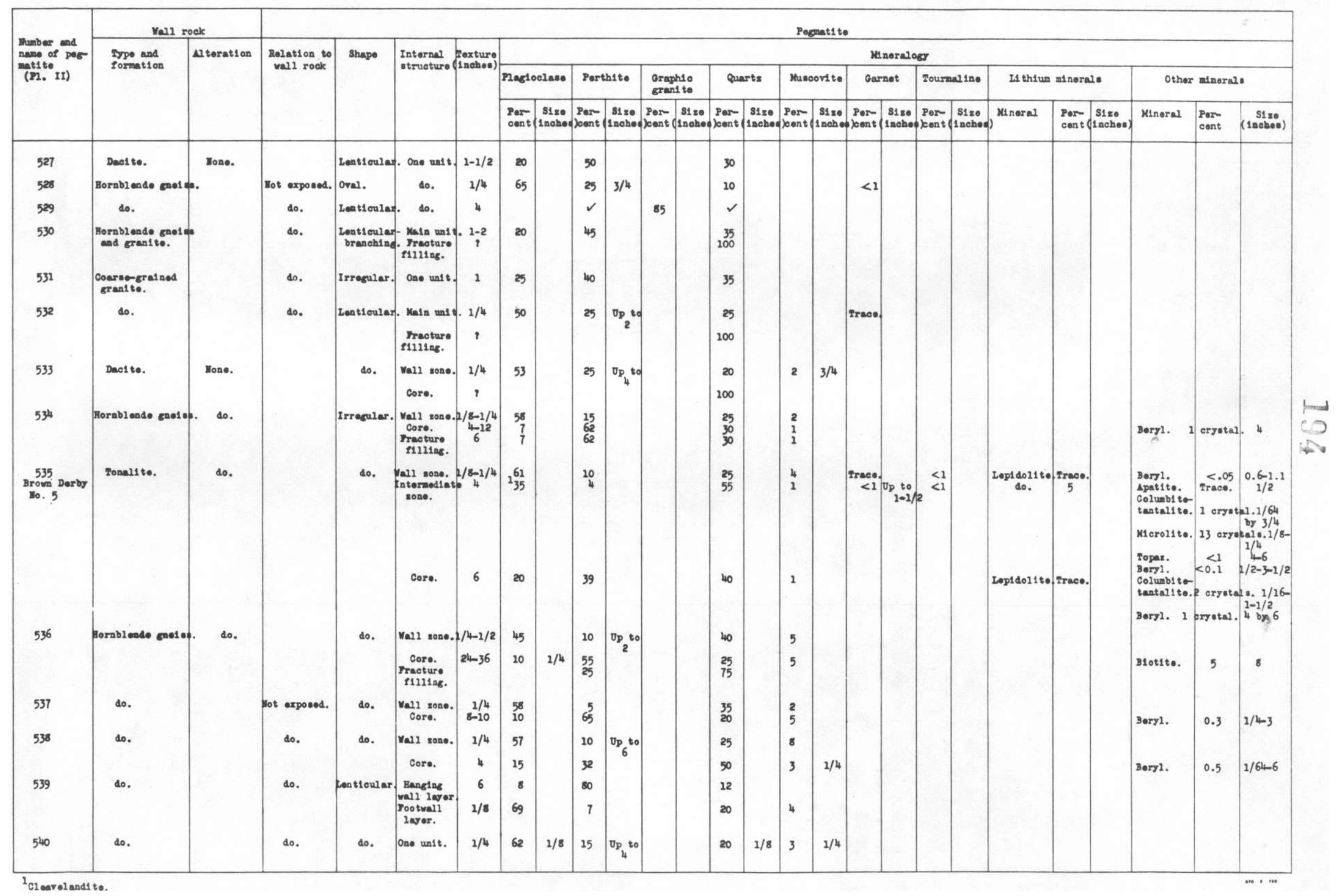


Feble 20--Mineralory of peentitos-Continuod.

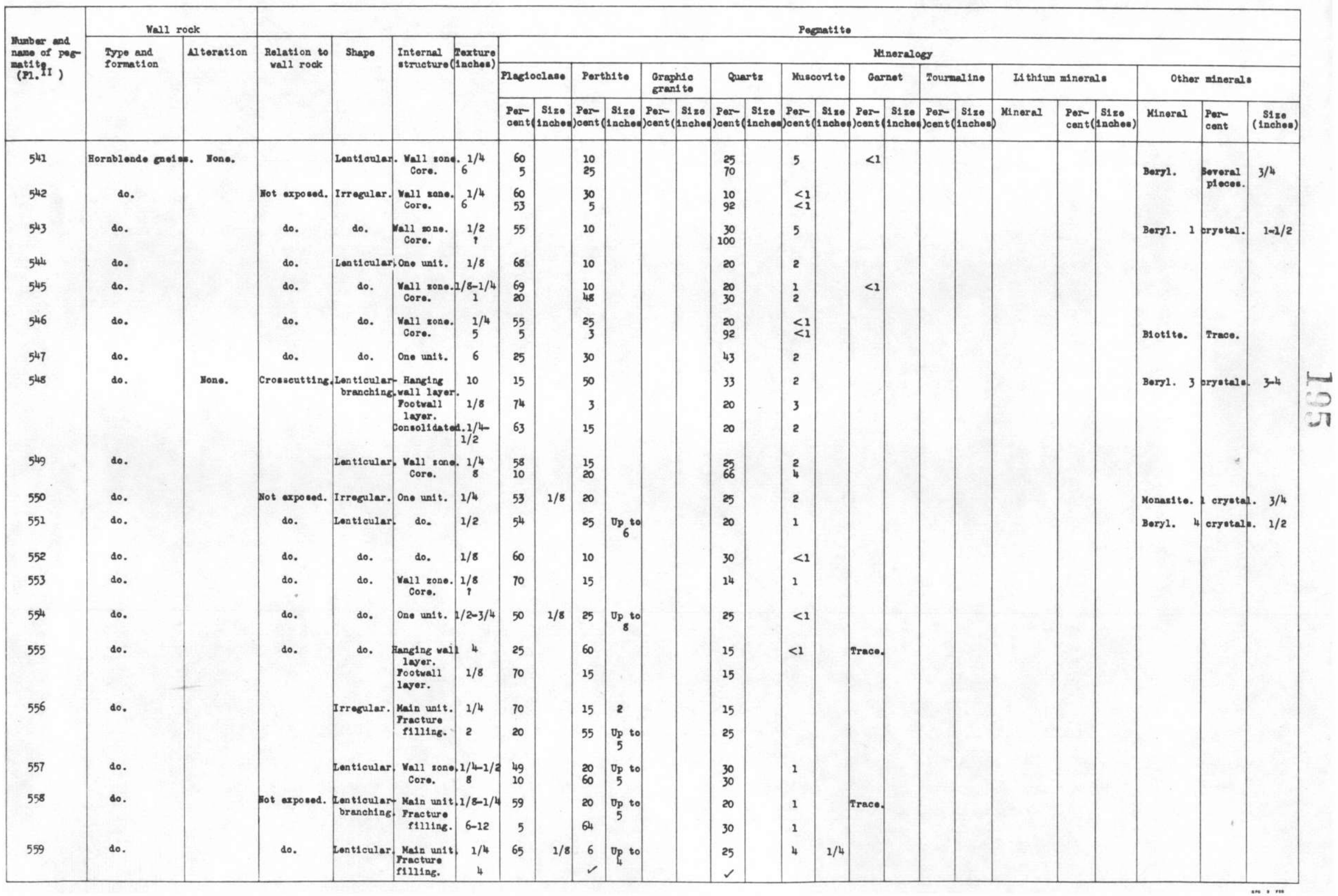


Fable 20.-Mineraloey of peoat1 tes--Cont1 nued.

\begin{tabular}{|c|c|c|c|c|c|c|c|c|c|c|c|c|c|c|c|c|c|c|c|c|c|c|c|c|c|c|}
\hline \multirow{4}{*}{$\begin{array}{l}\text { Mumber and } \\
\text { neve of per } \\
\text { matite } \\
\text { (PI. II) }\end{array}$} & \multicolumn{2}{|c|}{ Mell roak } & \multicolumn{24}{|c|}{ Pogmat1 to } \\
\hline & \multirow{3}{*}{$\begin{array}{l}\text { Type and } \\
\text { format1 on }\end{array}$} & \multirow{3}{*}{ Llteration } & \multirow{3}{*}{$\begin{array}{l}\text { Rolation to } \\
\text { vall rook }\end{array}$} & \multirow[t]{3}{*}{ Shape } & \multirow{3}{*}{$\begin{array}{l}\text { Internel } \\
\text { structure }\end{array}$} & \multirow{3}{*}{$\begin{array}{l}\text { Yexture } \\
\text { (nehoo) }\end{array}$} & \multicolumn{20}{|c|}{ Weneralogy } \\
\hline & & & & & & & \multicolumn{2}{|c|}{ Plagloclaso } & \multicolumn{2}{|c|}{ Porth1to } & \multicolumn{2}{|c|}{$\begin{array}{l}\text { Graph10 } \\
\text { Grant to }\end{array}$} & \multicolumn{2}{|c|}{ Quarts } & \multicolumn{2}{|c|}{ Nuscorlt te } & \multicolumn{2}{|c|}{ Garnot } & \multicolumn{2}{|c|}{ Tournaline } & \multicolumn{3}{|c|}{ Li thiun mineral. } & \multicolumn{3}{|c|}{ Other mineralo } \\
\hline & & & & & & & $\begin{array}{l}\text { Par } \\
\text { cont }\end{array}$ & $\begin{array}{l}\text { S1ze } \\
\text { (1nchoo }\end{array}$ & $\begin{array}{l}\text { Per- } \\
\text { Poent }\end{array}$ & $\begin{array}{l}\text { S1zo } \\
\text { 1nchoo: }\end{array}$ & $\begin{array}{l}\text { Per- } \\
\text { Peont }\end{array}$ & $\begin{array}{l}\text { S1zo } \\
\text { 1nehoo }\end{array}$ & $\begin{array}{l}\text { Por- } \\
\text { bentin }\end{array}$ & $\begin{array}{c}\text { S1zo } \\
\text { inchood }\end{array}$ & $\left\{\begin{array}{l}\text { Per } \\
\text { cent }\end{array}\right.$ & $\begin{array}{l}\text { S1ze } \\
\text { ncheos }\end{array}$ & $\begin{array}{l}\text { Per- } \\
\text { conth }\end{array}$ & $\begin{array}{r}\text { S1ze } \\
\text { anchos: }\end{array}$ & $\begin{array}{l}\text { Par } \\
\text { cont }\end{array}$ & $\begin{array}{l}51 z \theta \\
\text { scheos }\end{array}$ & Mineral & $\begin{array}{l}\text { Por- } \\
\text { cont }\end{array}$ & $\left(\begin{array}{c}51 z 0 \\
\text { 1nchoos) }\end{array}\right)$ & K1naral & $\begin{array}{l}\text { Por- } \\
\text { cont }\end{array}$ & (1 51 nckes) \\
\hline 560 & $\begin{array}{l}\text { Horablende gnoldet } \\
\text { and granito. }\end{array}$ & Yone. & & Irragular. & $\begin{array}{l}\text { Yall sone. } \\
\text { Yasta coro. } \\
\text { small pod. }\end{array}$ & $\begin{array}{r}1 / 8 \\
42-24\end{array}$ & $\begin{array}{l}60 \\
20 \\
5\end{array}$ & 1/8 & $\begin{array}{r}4 \\
50 \\
75\end{array}$ & & & & $\begin{array}{l}36 \\
30 \\
20\end{array}$ & & Trace. & & Trace. & & & & & & & Bory1. & 0.45 & $1-1 / 2-5$ \\
\hline 561 & Bornbl ende cnelde & e. & & Lon t1 oules: & $\begin{array}{l}\text { Morth ond } \\
\text { South ond. }\end{array}$ & d. $1 / 4$ & $\begin{array}{l}60 \\
30\end{array}$ & & $\begin{array}{l}20 \\
45\end{array}$ & & & & $\begin{array}{l}20 \\
25\end{array}$ & & Trace. & & $.7 \mathrm{rac} 0$. & & & & & & & & & \\
\hline 562 & $\begin{array}{l}\text { Coaracergral nod } \\
\text { granit to. }\end{array}$ & & Ilot exposed. & Irragular. & $\begin{array}{l}\text { Yell sono. } \\
\text { Core. }\end{array}$ & $\frac{1 / 8}{1}$ & $\begin{array}{l}93 \\
20\end{array}$ & & $\begin{array}{l}1 \\
35\end{array}$ & op to & & & $\begin{array}{r}6 \\
45\end{array}$ & & $<1$ & & Irece. & & & & & & & & & \\
\hline 563 & Hornblende coselo & o. & & Lenticular. & 1. One unit. & $3 / 4$ & 45 & & 40 & $\mathrm{Opp}_{3}^{\circ}$ to & & & 25 & & & & & & & & & & & & & \\
\hline 504 & do. & & Mot exposed. & Irrogular. & $\begin{array}{c}\text { Main unit } \\
\text { Practure } \\
\text { f111119. } \\
\text { do. }\end{array}$ & $1 / 4$ & 60 & & $\begin{array}{l}20 \\
50\end{array}$ & $\mathrm{OP}_{8}$ to & $\checkmark$ & & $\begin{array}{r}19 \\
50 \\
100\end{array}$ & & 1 & & Trace. & & & & & & & & & \\
\hline 565 & do. & & do. & $\begin{array}{l}\text { Lent1oular } \\
\text { branchlnge. }\end{array}$ & $\begin{array}{l}\text { Nall sone } \\
\text { Core. }\end{array}$ & $1 / 8$ & $\begin{array}{l}70 \\
35\end{array}$ & & 35 & & & & $\begin{array}{l}25 \\
30\end{array}$ & & Irace. & & Trace. & & & & & & & & & \\
\hline 566 & do. & & do. & Irrogular. & $\begin{array}{l}\text { Malin unit } \\
\text { Practuro } \\
\text { f1111ing. }\end{array}$ & $1 / 4$ & 50 & & 20 & & $\checkmark$ & & $\begin{array}{r}30 \\
100\end{array}$ & & & & & & & & & & & & & \\
\hline 567 & do. & Yono. & & do. & $\begin{array}{l}\text { Yall sono. } \\
\text { Fod. }\end{array}$ & $1 / 8$ & 78 & & 2 & & & & $\begin{array}{r}20 \\
100\end{array}$ & & Trace. & & & & & & & & & & & \\
\hline 568 & do. & do. & & do. & $\begin{array}{l}\text { Mant un unt. } \\
\text { Practure } \\
\text { F1111ng. }\end{array}$ & $\begin{array}{c}1 / 8 \\
2-8\end{array}$ & 67 & & $\begin{array}{l}7 \\
50\end{array}$ & $1 / 2-4$ & & & $\begin{array}{l}25 \\
50\end{array}$ & & $<1$ & & 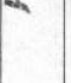 & & & & & & & & & \\
\hline 569 & do. & & Hot exposod. & Oral. & Ono unit. & $1 / 8$ & 50 & & 20 & & & & 30 & & Trace. & & & & & & & & & & & \\
\hline 570 & do. & Mone. & & Lontievias. & d. do. & 2/8 & 67 & & 8 & $\mathrm{Dp}_{6} \mathrm{to}^{\circ}$ & & & 25 & & $<1$ & & Traco. & & & & & & & & & \\
\hline 571 & do. & & mot axposed. & Irregular. & do. & $1 / 8-1 / 4$ & 73 & & 5 & & & & 20 & & 1 & & 1 & & & & & & & & & \\
\hline 572 & do. & & do. & do. & $\begin{array}{l}\text { vel1 sone. } \\
\text { Coro. }\end{array}$ & $12^{1 / 4}$ & 65 & & $\begin{array}{r}10 \\
9\end{array}$ & & & & $\begin{array}{l}25 \\
90\end{array}$ & & $i_{1}^{<1}$ & & $<1$ & & & & & & & & & \\
\hline 573 & do. & Yone. & & do. & $\begin{array}{c}\text { Masin unit. } \\
\text { Traoture } \\
\text { F11119. }\end{array}$ & $1 / 4$ & 64 & & $\begin{array}{l}15 \\
50\end{array}$ & & & & $\begin{array}{l}20 \\
50\end{array}$ & & 1 & & Trace. & & & & & & & & & \\
\hline 574 & do. & do. & & do. & $\begin{array}{c}\text { Maln unit. } \\
\text { Fracture } \\
\text { fill11ng. } \\
\text { do. }\end{array}$ & $\begin{array}{c}1 / 8-1 / 4 \\
1\end{array}$ & 54 & & $\begin{array}{l}15 \\
50\end{array}$ & & & & $\begin{array}{r}30 \\
50 \\
100\end{array}$ & & 1 & & $<1$ & & & & & & & & & \\
\hline 575 & do. & & Mot exposed. & Lenticular. & $\begin{array}{l}\text { 7. Mall son } \\
\text { Core. }\end{array}$ & $1 / 8$ & 60 & & 15 & & & & $\begin{array}{r}25 \\
100\end{array}$ & & $<1$ & & & & & & & & & & & \\
\hline 576 & هo. & & do. & oval. & $\begin{array}{l}\text { vall sone. } \\
\text { Core. }\end{array}$ & $\sum_{5-6}^{1 / 8}$ & $\begin{array}{l}73 \\
20\end{array}$ & & $\begin{array}{l}2 \\
45\end{array}$ & & & & $\begin{array}{l}25 \\
35\end{array}$ & & $\begin{array}{l}\text { Trace. } \\
<1\end{array}$ & & $<1$ & & & & & & & & & \\
\hline 577 & do. & & do. & do. & $\begin{array}{l}\text { Maln unit t. } \\
\text { Fracture } \\
\text { F11119g. } \\
\text { do. }\end{array}$ & $\begin{array}{c}1 / 8-1 / 4 \\
?\end{array}$ & 66 & & $\begin{array}{r}5 \\
50\end{array}$ & & & & $\begin{array}{r}25 \\
50 \\
100\end{array}$ & & 3 & & 1 & & & & & & & & & \\
\hline
\end{tabular}


Tab10 20,-Mineralory of pereatites--Cont1 mued.

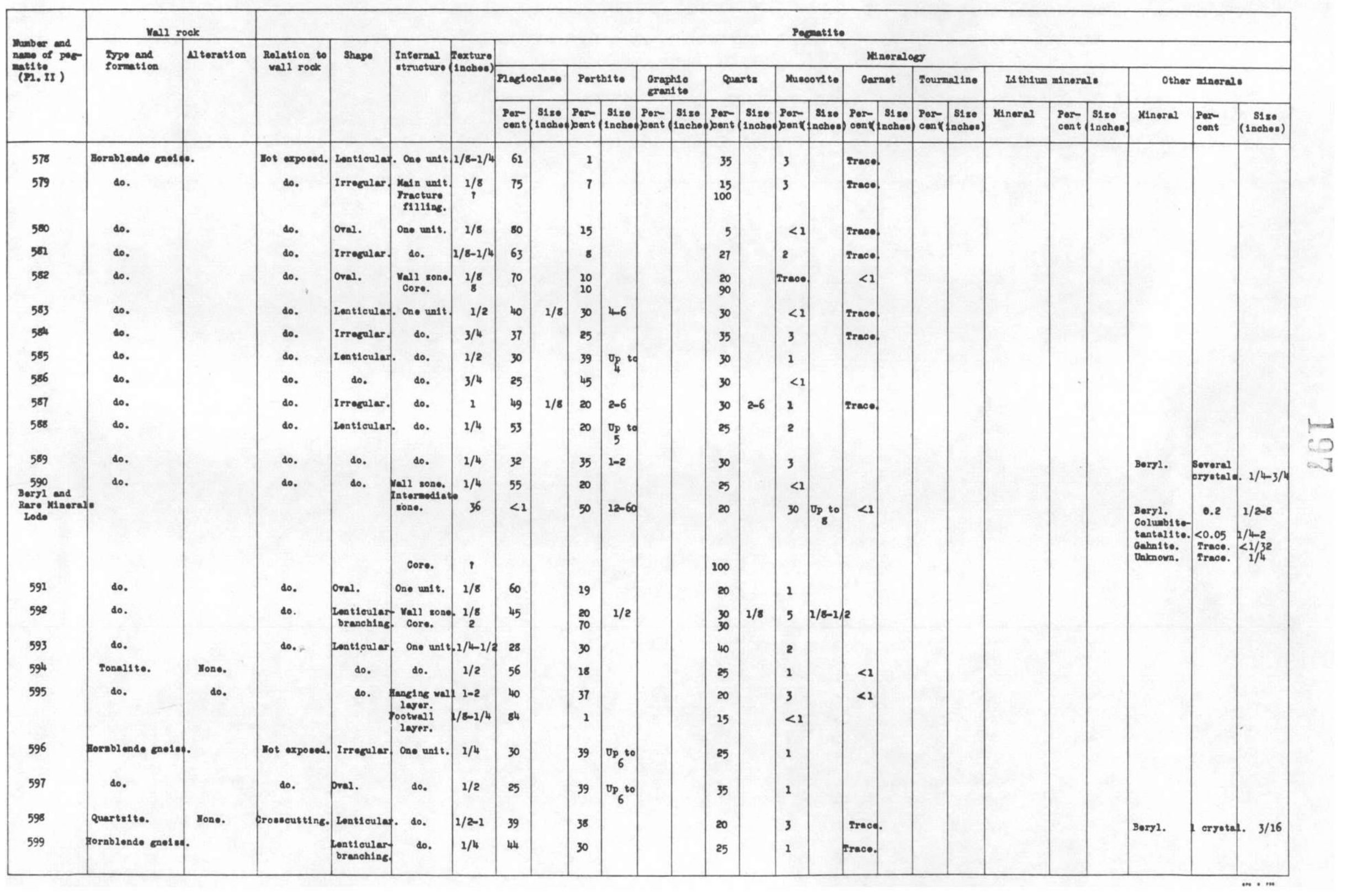


Fab10 20.-Mineralopy of pepant1 tes--Cont1 nued.

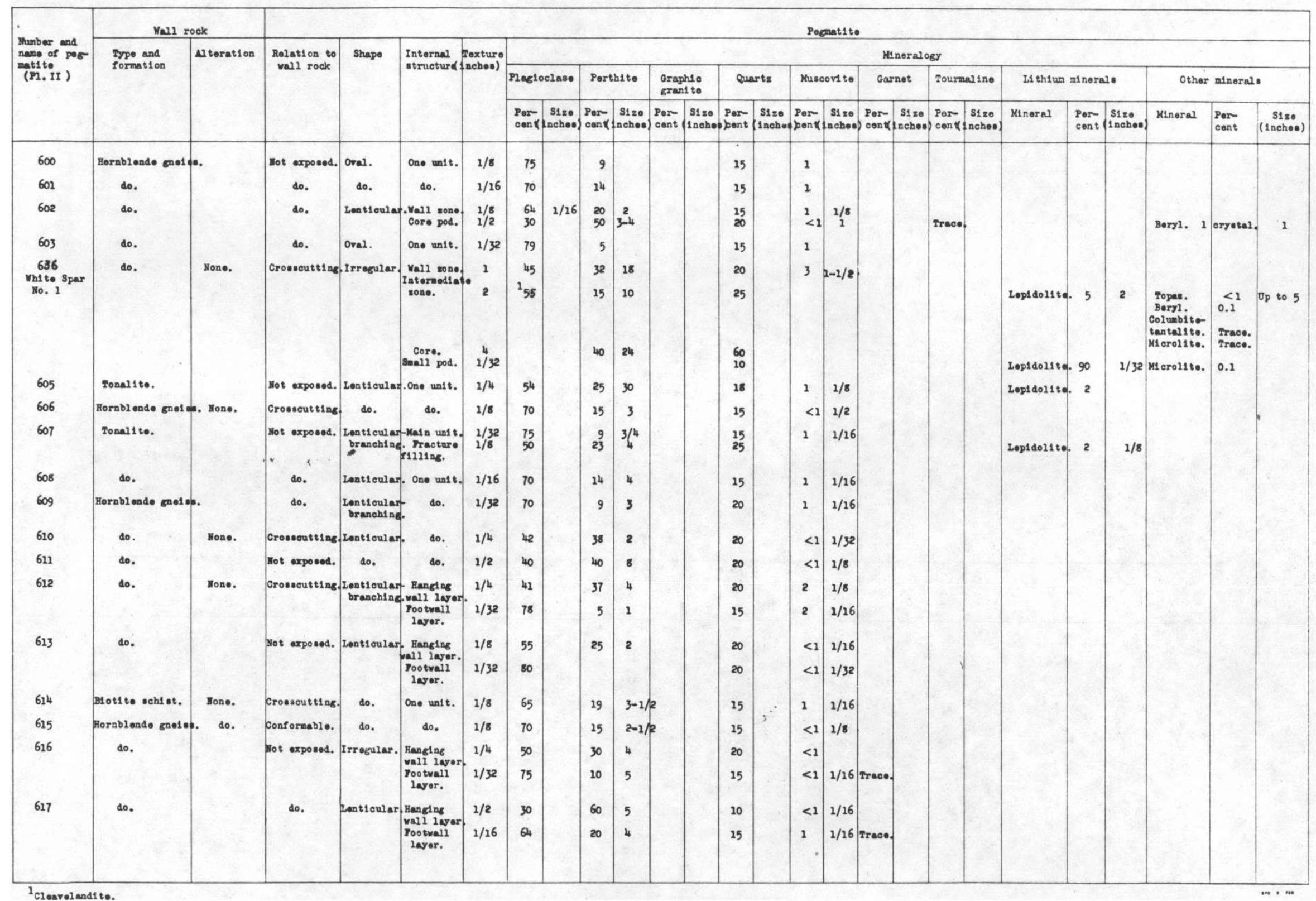


2ab10 20,-Mineralocy of pe mat1 tes--Cont1 nued.

\begin{tabular}{|c|c|c|c|c|c|c|c|c|c|c|c|c|c|c|c|c|c|c|c|c|c|c|c|c|c|c|}
\hline \multirow{4}{*}{$\begin{array}{l}\text { Mumber and } \\
\text { nave of por } \\
\text { matitito } \\
\text { (II.II) }\end{array}$} & \multicolumn{2}{|c|}{ Nall rock } & \multicolumn{24}{|c|}{ Ponat 1 to } \\
\hline & \multirow{3}{*}{$\begin{array}{l}\text { Type and } \\
\text { formation }\end{array}$} & \multirow{3}{*}{ Al teration } & \multirow{3}{*}{$\begin{array}{l}\text { Rolation to } \\
\text { vall rock }\end{array}$} & \multirow[t]{3}{*}{ Shape } & \multirow{3}{*}{$\begin{array}{l}\text { Internal } \\
\text { strueture }\end{array}$} & \multirow{3}{*}{$\begin{array}{l}\text { Toxture } \\
\text { 1nchoos) }\end{array}$} & \multicolumn{20}{|c|}{ Nineralogy } \\
\hline & & & & & & & \multicolumn{2}{|c|}{ Plaglociaso } & \multicolumn{2}{|c|}{ Porthite } & \multicolumn{2}{|c|}{$\begin{array}{l}\text { Graphse } \\
\text { grant to }\end{array}$} & \multicolumn{2}{|c|}{ Querts } & \multicolumn{2}{|c|}{ Muscorl to } & \multicolumn{2}{|c|}{ Garnet } & \multicolumn{2}{|c|}{ Tournaline } & \multicolumn{3}{|c|}{ Li thium minerals } & \multicolumn{3}{|c|}{ Othor minoral. } \\
\hline & & & & & & & $\begin{array}{l}\text { Per- } \\
\text { cont }\end{array}$ & $\begin{array}{l}31 \text { seo } \\
\text { (1nchoo })\end{array}$ & $\begin{array}{l}\text { Por- } \\
\text { bent }\end{array}$ & 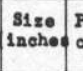 & $\begin{array}{l}\text { Perr } \\
\text { cent }(1\end{array}$ & $\begin{array}{l}\text { S180 } \\
\text { 1nohoe }\end{array}$ & $\begin{array}{l}\text { Par- } \\
\text { bent }\end{array}$ & $\left.\begin{array}{l}\text { S1zo } \\
\text { (1noho of }\end{array}\right)$ & Por & $\begin{array}{l}\text { S1zo: } \\
\text { 1neho. }\end{array}$ & $\begin{array}{l}\text { Por- } \\
\text { boont }\end{array}$ & \begin{tabular}{|l} 
S1zo \\
inchoo
\end{tabular} & $\begin{array}{l}\text { Per } \\
\text { peant }\end{array}$ & $\begin{array}{l}\text { S1zo } \\
\text { 1neheo }\end{array}$ & ) $)^{\text {xineral }}$ & $\begin{array}{l}\text { Porm } \\
\text { cont } t=1\end{array}$ & $\begin{array}{l}\text { S1zeo } \\
\text { 10acos: }\end{array}$ & Nineral & $\begin{array}{l}\text { Por- } \\
\text { cont }\end{array}$ & (1 nacheo) \\
\hline 618 & Hornb1 ande ganel & e. Sono. & Crosscutting. & Irrogular. & $\begin{array}{l}\text { Heanging } \\
\text { vall lavor. } \\
\text { Pootvall } \\
\text { layor. }\end{array}$ & $\begin{array}{l}1 / 2 \\
1 / 16\end{array}$ & $\begin{array}{l}54 \\
74\end{array}$ & & $\begin{array}{l}25 \\
10\end{array}$ & $\begin{array}{l}5 \\
3\end{array}$ & & & $\begin{array}{l}20 \\
15\end{array}$ & & 1 & $\begin{array}{l}1 / 16 \\
1 / 16\end{array}$ & Trace. & & & & & & & & & \\
\hline 619 & do. & & Mot exposed. I & Ient1 culas. & one unit t. & $1 / 8$ & 65 & & 20 & 4 & & & 15 & & & & & & & & & & & & & \\
\hline 620 & do. & & do. & do. & do. & $1 / 8$ & 70 & & 15 & 1 & & & 15 & & $<1$ & $1 / 26$ & & & & & & & & & & \\
\hline 621 & do. & & do. & do. & do. & $1 / 4$ & 60 & & 25 & 3 & & & 15 & & $<1$ & $1 / 16$ & & & & & & & & & & \\
\hline 622 & do. & & do. & do. & do. & $1 / 8$ & 65 & & 25 & 2 & & & 10 & & $<1$ & $1 / 16$ & & & & & & & & & & \\
\hline 623 & do. & & do. & do. & do. & $1 / 4$ & 40 & & 40 & 2 & & & 20 & & $<1$ & $1 / 8$ & & & & & & & & & & \\
\hline 624 & do. & Yono. & & Irrogular. & do. & $1 / 16$ & 60 & & 15 & 2 & & & 24 & & 1 & $1 / 32$ & & & & & & & & & & \\
\hline 625 & do. & do. & & Lonticular. & do. & $1 / 16$ & 65 & & 9 & $2-5$ & & & 25 & & 1 & $2 / 26$ & & & & & & & & & & \\
\hline 626 & do. & & Crosscutting. & do. & do. & $1 / 16$ & 70 & & 15 & $3-9$ & & & 15 & & $<1$ & $1 / 16$ & & & & & & & & & & \\
\hline 627 & do. & & do. & do. & $\begin{array}{l}\text { Vall sone. } \\
\text { Core. }\end{array}$ & $\begin{array}{l}1 / 16 \\
1 / 4\end{array}$ & $\begin{array}{l}60 \\
30\end{array}$ & & $\begin{array}{l}20 \\
50\end{array}$ & $\begin{array}{l}1-2 \\
2-4\end{array}$ & & & $\underset{20}{20}$ & & $<1$ & $1 / 16$ & & & & & & & & & & \\
\hline 628 & do. & & do. & do. & $\begin{array}{l}\text { Iangling } \\
\text { rall Layor. } \\
\text { Trootwail } \\
\text { 1avor. }\end{array}$ & $\begin{array}{l}1 \\
1 / 32\end{array}$ & $\begin{array}{l}44 \\
70\end{array}$ & & $\begin{array}{l}35 \\
10\end{array}$ & $\begin{array}{l}4-7 \\
1-2\end{array}$ & & & $\begin{array}{l}20 \\
19\end{array}$ & & $\begin{array}{l}1 \\
1\end{array}$ & \begin{tabular}{r|}
$1 / 4$ \\
$1 / 26$
\end{tabular} & & & & & & & & & & \\
\hline 629 & do. & & Mot expoeod. & do. & One unit. & $1 / 4$ & 50 & & 29. & $2-4$ & & & 20 & & 1 & $1 / 8$ & & & & & & & & & & \\
\hline 630 & do. & Hone. & Crosscutting. & do. & do. & $1 / 4$ & Q4 & & $\infty$ & $3-6$ & & & 15 & & 1 & $1 / 16$ & & & & & & & & & & \\
\hline 631 & do. & & Hot exposed. & do. & do. & $1 / 16$ & 69 & & 15 & $3-6$ & & & 15 & & 1 & $1 / 16$ & Trace. & & & & & & & & & \\
\hline 632 & do. & & do. & do. & do. & $1 / 4$ & 45 & & 35 & $2-4$ & & & 20 & & $<1$ & $1 / 16$ & & & & & & & & & & \\
\hline 633 & do. & & do. & do. & do. & $1 / 32$ & 65 & & 20 & & & & 14 & & 1 & & Trace. & & & & & & & & & \\
\hline 634 & do. & & do. & do. & do. & $1 / 64$ & 65 & & 20 & & & & 13 & & 2 & & & & & & & & & & & \\
\hline 635 & Tonal1to. & & do. & do. & do. & $1 / 16$ & 60 & & 19 & & & & 20 & & 1 & & & & & & & & & & & \\
\hline $\begin{array}{l}\text { 6014 } \\
\text { mal to 3par } \\
\text { \$o. } 2\end{array}$ & Hornblende gnel & 1.. Mono. & crosscuttins. & do. & $\begin{array}{l}\text { Yall sono. } \\
\text { Coro. }\end{array}$ & $\begin{array}{l}1 / 4 \\
1 / 32\end{array}$ & $\begin{array}{l}45 \\
45\end{array}$ & & ${ }_{10}^{30} 1-$ & $-1 / 2-2-2$ & & & $\begin{array}{l}20 \\
35\end{array}$ & & 5 & & $<1$ & & & & $\begin{array}{l}\text { Lopldolit to. } \\
\text { Lop1dolite. }\end{array}$ & $10^{<1}$ & $\begin{array}{l}1 / 8 \\
1 / 32\end{array}$ & $\begin{array}{l}\text { Muor1 to. } \\
\text { Mierollto. } \\
\text { Boryl. 2 } \\
\text { Chrysecoll }\end{array}$ & $\begin{array}{l}\text { Trace. } \\
\text { <o o.oi } \\
\text { oryetal. } \\
\text { 2. Erace. }\end{array}$ & $.5 / 8$ \\
\hline 637 & do. & do. & & do. & $\begin{array}{l}\text { rall sone. } \\
\text { Core pod. } \\
\text { rracture } \\
\text { f1111ng. }\end{array}$ & $\begin{array}{c}1 / 4 \\
1 \\
1 / 4\end{array}$ & $\begin{array}{l}140 \\
120 \\
150\end{array}$ & & $\begin{array}{r}38 \\
35 \\
5\end{array}$ & $\begin{array}{l}8-12 \\
4-10\end{array}$ & & & $\begin{array}{l}20 \\
40 \\
30\end{array}$ & & $\begin{array}{r}2 \\
5 \\
15\end{array}$ & & Trace. & & & & $\begin{array}{l}\text { Lopidolit te. } \\
\text { Lopidolite. }\end{array}$ & $\begin{array}{l}\text { Trace. } \\
\text { traces. }\end{array}$ & & $\begin{array}{l}\text { Columb1 to } \\
\text { tantall to. } \\
\text { Borgl. i } \\
\text { M1croilto. }\end{array}$ & $\begin{array}{l}\text { oryotan. } \\
\text { cryetal. } \\
.01\end{array}$ & 2 \\
\hline 638 & do. & & Mot axposed. & do. & 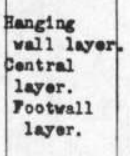 & $\begin{array}{l}1 / 4 \\
3 \\
1 / 8\end{array}$ & $\begin{array}{l}30 \\
70 \\
04\end{array}$ & & $\begin{array}{l}5 \\
5\end{array}$ & & & & $\begin{array}{l}50 \\
30 \\
30\end{array}$ & & ${ }_{1}^{15}$ & & & & & & & & & & & \\
\hline
\end{tabular}


Feb10 20.-Mineralogy of peeat1 top-Cont1 nued.

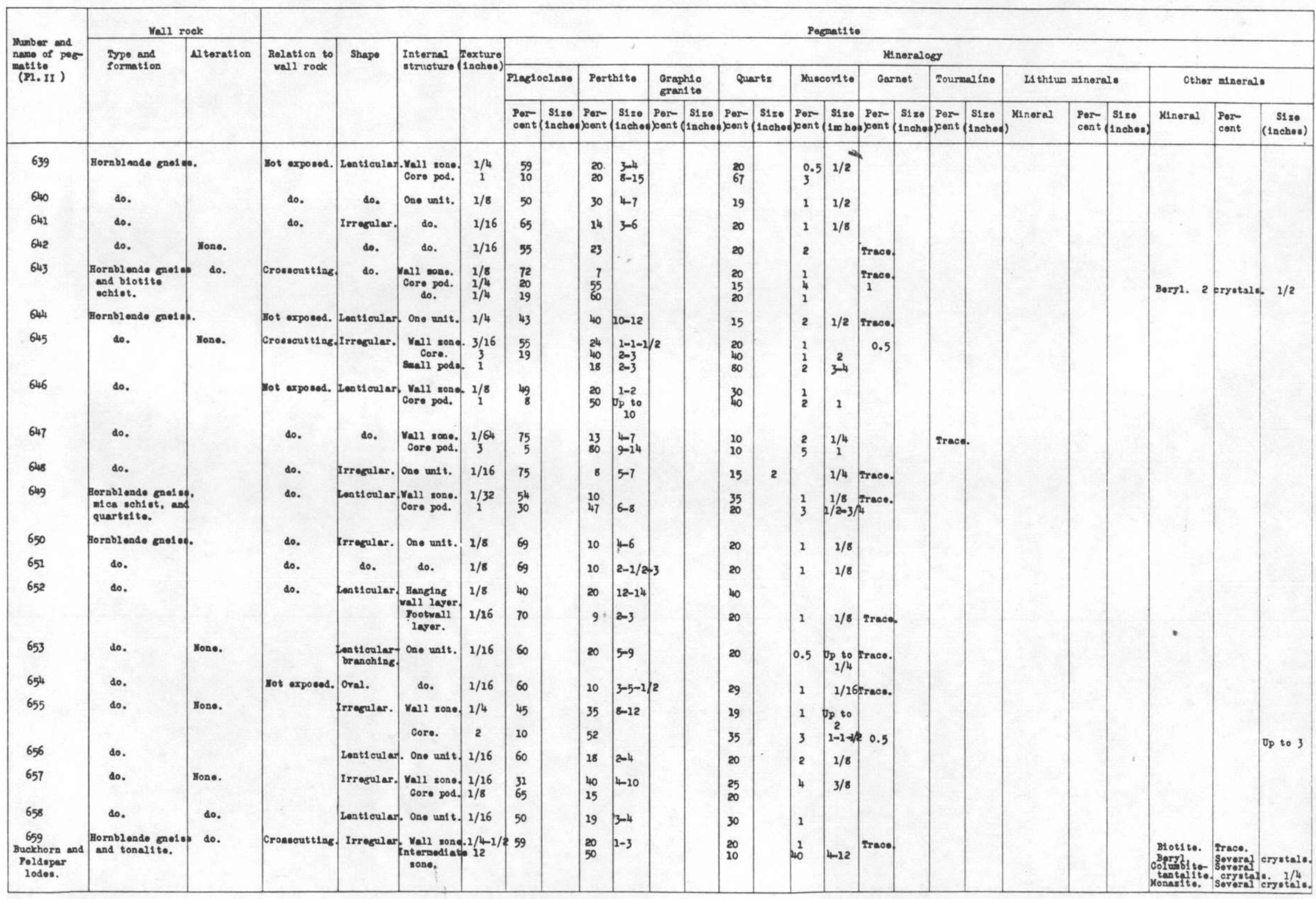


Frbie 20.--Minoralory of peratit ter-Cont1 nued.

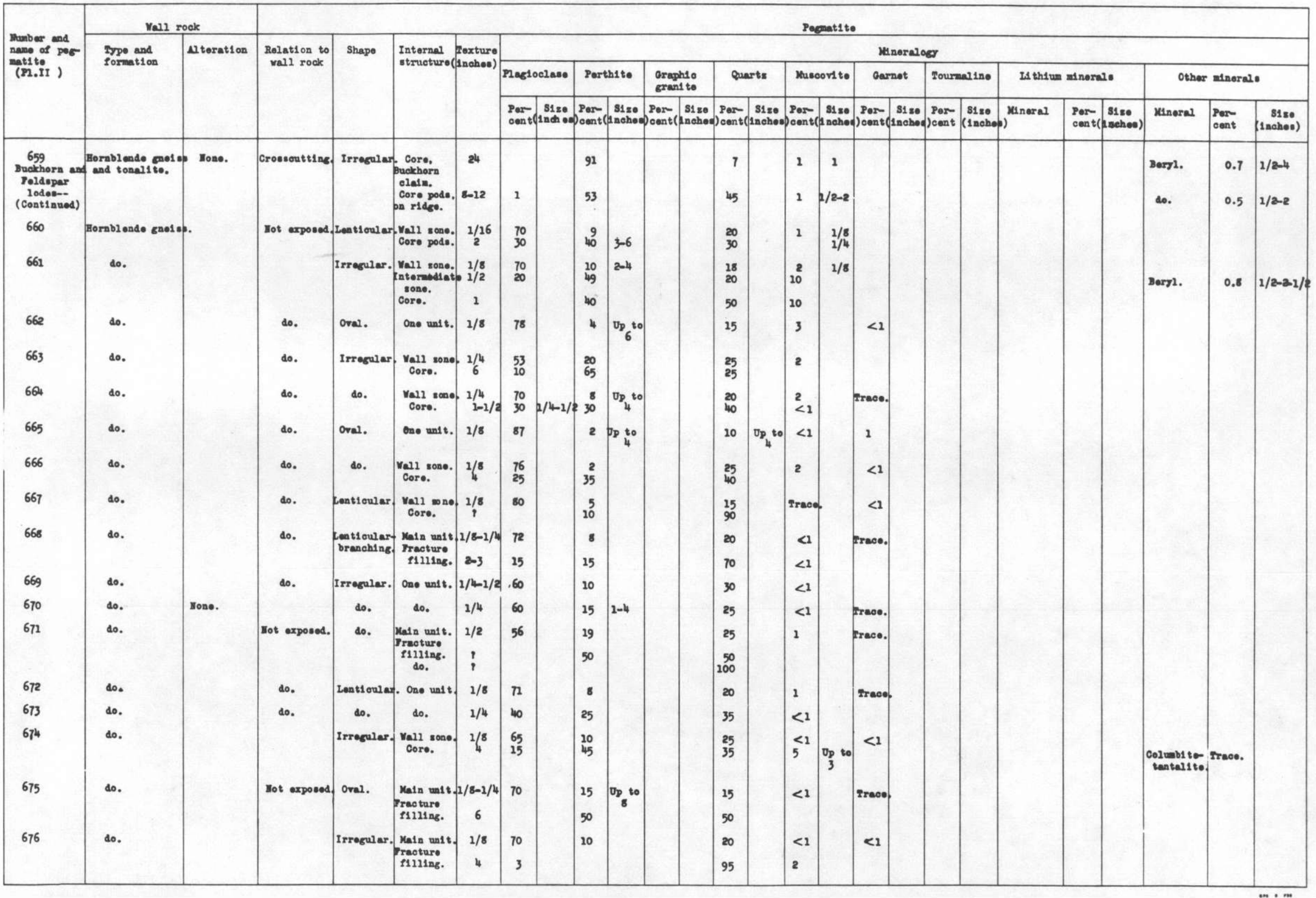


Teb10 20.-Mineralory of perestiteo-Cont1nuod.

\begin{tabular}{|c|c|c|c|c|c|c|c|c|c|c|c|c|c|c|c|c|c|c|c|c|c|c|c|c|c|c|}
\hline \multirow{4}{*}{ 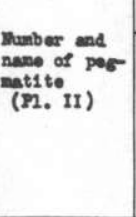 } & \multicolumn{2}{|c|}{ Voll roak } & \multicolumn{24}{|c|}{ Peout 1to } \\
\hline & \multirow{3}{*}{$\begin{array}{l}\text { Type and } \\
\text { formation }\end{array}$} & \multirow{3}{*}{ Neteration } & \multirow{3}{*}{$\begin{array}{l}\text { Rolation to } \\
\text { vall rookk }\end{array}$} & \multirow[t]{3}{*}{ Shapo } & \multirow{3}{*}{$\begin{array}{l}\text { Internal } \\
\text { struetures }(12\end{array}$} & \multirow{3}{*}{ Rexture } & \multicolumn{20}{|c|}{ Mineralogy } \\
\hline & & & & & & & \multicolumn{2}{|c|}{ Pragloclase } & \multicolumn{2}{|c|}{ Porth1 te } & \multicolumn{2}{|c|}{$\begin{array}{l}\text { Oraph10 } \\
\text { gran1 to }\end{array}$} & \multicolumn{2}{|c|}{ quarts } & \multicolumn{2}{|c|}{ Muscovit to } & \multicolumn{2}{|c|}{ Garnet } & \multicolumn{2}{|c|}{ Tournaline } & \multicolumn{3}{|c|}{ Lith1um minerale } & \multicolumn{3}{|c|}{ Othar minerale } \\
\hline & & & & & & & $\begin{array}{l}\text { Per- } \\
\text { Cont }(1\end{array}$ & $\begin{array}{l}\text { size } \\
\text { 1nchood }\end{array}$ & $\begin{array}{l}\text { Porr } \\
\text { Poent(1 }\end{array}$ & 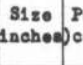 & $\begin{array}{l}\text { Por- } \\
\text { Peont (1) }\end{array}$ & $\begin{array}{l}31 \text { zo } \\
\text { natoed) }\end{array}$ & $\begin{array}{l}\text { Por } \\
\text { cont }(12\end{array}$ & $\begin{array}{c}\text { s1zo } \\
\text { 1nohoopj }\end{array}$ & $\begin{array}{l}\text { Per } \\
\text { cent }(12 x\end{array}$ & $\begin{array}{c}8130 \\
\text { (nncheof) }\end{array}$ & $\begin{array}{l}\text { Por- } s \\
\text { cont }(1 n\end{array}$ & $\begin{array}{l}3180 \\
\text { lnches) }\end{array}$ & $\begin{array}{l}\text { Per- } \\
\text { cont }(1\end{array}$ & $\begin{array}{l}\text { S1ze } \\
\text { Inchoos }\end{array}$ & Kineral & $\begin{array}{l}\text { Por- } \\
\text { cont(1) }\end{array}$ & $\begin{array}{l}\text { S18e } \\
\text { ancheo) }\end{array}$ & Kineral & $\begin{array}{l}\text { Por- } \\
\text { cont }\end{array}$ & $\begin{array}{c}\text { S1zes } \\
\text { (1nches) }\end{array}$ \\
\hline 677 & Hornblende cols & e. & Mot exposed. & Oral. & Main unit 1 & $1 / 8-1 / 4$ & 60 & & 15 & $\mathrm{Op}_{2}{ }^{\mathrm{to}}$ & & & 25 & & $<1$ & & & & & & & & & B10t1 to. & Traeo. & \\
\hline & & & & & $\underset{\text { Practurs }}{\text { P1111ng. }}$ & , & & & & & & & 100 & & & & & & & & & & & & & \\
\hline 678 & do. & & هo. & Irragular. & 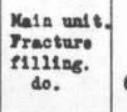 & $\cos _{6-8}^{2-1 / 2}$ & $\begin{array}{l}40 \\
15\end{array}$ & $1 / 4$ & $\begin{array}{l}35 \\
55\end{array}$ & $3-4$ & & & $\begin{array}{r}25 \\
100 \\
30\end{array}$ & $3-4$ & $<1$ & & Frace. & & & & & & & & & \\
\hline 679 & do. & & & $\begin{array}{l}\text { Len t1 oulary } \\
\text { bresebinge. }\end{array}$ & $\begin{array}{l}\text { Mall sone. } \\
\text { Core. }\end{array}$ & $\cdot \int_{4-8}^{1 / 8}$ & $\begin{array}{l}72 \\
15\end{array}$ & & $\begin{array}{l}12 \\
40\end{array}$ & & & & $\begin{array}{l}15 \\
45\end{array}$ & & $\begin{array}{l}1 \\
<1\end{array}$ & & Traed. & & & & & & & & & \\
\hline 680 & do. & & Crosseutt1nes & 1rraguler. & $\begin{array}{l}\text { Meln unit. } \\
\text { Mracture } \\
\text { f111128. }\end{array}$ & $\begin{array}{c}1 / 8 \\
1\end{array}$ & 74 & & 5 & & & & $\begin{array}{r}20 \\
100\end{array}$ & & 1 & & $<1$ & & & & & & & & & \\
\hline 682 & do. & & & do. 0 & One unst. & $1 / 16$ & 70 & & 9 & & & & 20 & & 1 & & Erace. & & & & & & & & & \\
\hline 682 & do. & & crosscutting. & Irregular. & $\begin{array}{l}\text { Yell sone. } \\
\text { core pod. }\end{array}$ & $\begin{array}{l}1 / 32 \\
3 / 4\end{array}$ & $\begin{array}{l}70 \\
15\end{array}$ & & $\frac{14}{54}$ & $b_{6-10}^{3-5}$ & & & $\begin{array}{l}15 \\
30\end{array}$ & & 1 & $\begin{array}{l}1 / 4 \\
1 / 2\end{array}$ & rrace. & & & & & & & & & \\
\hline 663 & do. & & llot exposed. & Lent1oulat. & . One unte. & $1 / 16$ & 70 & & 9 & $4-5$ & & & 20 & & 1 & $1 / 32$ & & & & & & & & & & \\
\hline 604 & هo. & Mono. & Confornable. & Irragular. & $\begin{array}{l}\text { Hanglag } \\
\text { vall layer. } \\
\text { Pootwall } \\
\text { layor. }\end{array}$ & $\frac{1}{1 / 32}$ & $\begin{array}{l}45 \\
75\end{array}$ & & $\begin{array}{l}38 \\
14\end{array}$ & 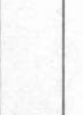 & & & $\begin{array}{l}15 \\
15\end{array}$ & & $\begin{array}{l}2 \\
1\end{array}$ & & tracoo. & & & & & & & & & \\
\hline 685 & do. & & & Lenti cular. & $\begin{array}{l}\text { Hangling } \\
\text { vall layer. } \\
\text { Pootvall } \\
\text { layer. }\end{array}$ & $\begin{array}{l}1 / 2 \\
1 / 32\end{array}$ & $\begin{array}{l}30 \\
65\end{array}$ & & $\begin{array}{l}48 \\
19\end{array}$ & $\begin{array}{l}4-6 \\
2-3\end{array}$ & & & $\begin{array}{l}20 \\
15\end{array}$ & & $\begin{array}{l}2 \\
1\end{array}$ & \begin{tabular}{l|l}
$1 / 2$ & \\
$1 / 8$ & $\mathrm{Tr}$
\end{tabular} & irace. & & & & & & & & & ( \\
\hline 686 & do. & & Iot exposod. & oral. or & One unit. & $1 / 4$ & 60 & & 20 & $5-7$ & & & 19 & & 1 & $1-1 / 2^{2} x_{x}$ & irace. & & & & . & & & & & \\
\hline 687 & do. & & do. & Lenticular. & do. & $1 / 4$ & 50 & & 39 & & & & 10 & & 1 & & & & & & & & & & & \\
\hline 688 & do. & & do. & Irragular. & do. & $1 / 32$ & 70 & & 14 & $2-4$ & & & 15 & & 13 & $3 / 4$ & & & & & & & & & & \\
\hline 689 & do. & & do. & Oval. & $\begin{array}{l}\text { Rengling } \\
\text { vall levor. } \\
\text { Yoottrall } \\
\text { 1evor. }\end{array}$ & $\begin{array}{l}1 / 2 \\
1 / 16\end{array}$ & $\begin{array}{l}30 \\
45\end{array}$ & & $\begin{array}{l}55 \\
33\end{array}$ & $\begin{array}{l}6-12 \\
2-3\end{array}$ & & & $\begin{array}{l}15 \\
20\end{array}$ & & \begin{tabular}{l|l}
$<1$ & 2 \\
2 & 1
\end{tabular} & $\begin{array}{l}1 / 2 \\
1 / 2\end{array}$ & & & & & & & & & & \\
\hline 690 & do. & & do. & do. & Ore unit. & $1 / 32$ & 60 & & 23 & $5-7$ & & & 15 & & 21 & $1 / 4$ & & & & & & & & & & \\
\hline 691 & do. & & do. & do. & do. & $1 / 4$ & 65 & & 20 & $3-4$ & & & 13 & & 2 & $1 / 2$ & & & & & & & & & & \\
\hline 698 & هo. & & do. & هo. & do. 1 & $1 / 4$ & 40 & & 40 & & & & 19 & & 1 & & & & & & & & & & & \\
\hline 693 & do. & & & & $\begin{array}{l}\text { Mall zone. } \\
\text { Core. }\end{array}$ & $\begin{array}{l}1 / 16 \\
1 / 2\end{array}$ & $\begin{array}{l}60 \\
20\end{array}$ & & $\begin{array}{l}24 \\
19\end{array}$ & & & & $\begin{array}{l}15 \\
60 .\end{array}$ & & $\begin{array}{l}1 \\
1\end{array}$ & & & & & & & & & & & \\
\hline 694 & do. & & & Irregular. 0 & One unit. & $1 / 64$ & 74 & & 10 & & $\checkmark$ & & 15 & & 1 & & & & & & & & & & & \\
\hline 695 & do. & & Not exposed. & Lentioular. & One unit & $1 / 4$ & 50 & & 30 & & & & 20 & & & & & & & & & & & & & \\
\hline $\begin{array}{l}696 \\
697\end{array}$ & $\begin{array}{l}\text { do. } \\
\text { do. }\end{array}$ & & $\begin{array}{l}\text { do. } \\
\text { do. }\end{array}$ & do. & $\begin{array}{l}\text { do. } \\
\text { do. }\end{array}$ & $\begin{array}{l}1 / 8 \\
1 / 8\end{array}$ & $\begin{array}{l}60 \\
30\end{array}$ & & $\begin{array}{l}20 \\
54\end{array}$ & & & & $\begin{array}{l}20 \\
15\end{array}$ & & 1 & & & & & & & & & & & \\
\hline
\end{tabular}


Feb10 20.-Minerelen of pereatites --Cont1 nued.

\begin{tabular}{|c|c|c|c|c|c|c|c|c|c|c|c|c|c|c|c|c|c|c|c|c|c|c|c|c|c|c|}
\hline \multirow{4}{*}{ 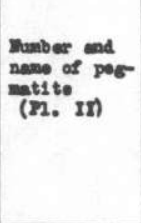 } & \multicolumn{2}{|c|}{ Mall rook } & \multicolumn{24}{|c|}{ Peopetito } \\
\hline & \multirow{3}{*}{$\begin{array}{l}\text { Sppo and } \\
\text { formation }\end{array}$} & \multirow[t]{3}{*}{ Nlterat1 on } & \multirow{3}{*}{$\begin{array}{l}\text { Rolatid on to } \\
\text { vall rookk }\end{array}$} & \multirow[t]{3}{*}{ Shapo } & \multirow{3}{*}{$\begin{array}{l}\text { Internal } \\
\text { strueturo }\end{array}$} & \multirow{3}{*}{$\begin{array}{l}\text { Cexture } \\
\text { inohoos) }\end{array}$} & \multicolumn{20}{|c|}{ Nenoraloger } \\
\hline & & & & & & & \multicolumn{2}{|c|}{ Miagloclase } & \multicolumn{2}{|c|}{ Perth1to } & \multicolumn{2}{|c|}{$\begin{array}{l}\text { Graphse } \\
\text { Exant to }\end{array}$} & \multicolumn{2}{|c|}{ Quarts } & \multicolumn{2}{|c|}{ Musoort to } & \multicolumn{2}{|c|}{ Garnot } & \multicolumn{2}{|c|}{ Tournaline } & \multicolumn{3}{|c|}{ II th1um minorals } & \multicolumn{3}{|c|}{ Other minerale } \\
\hline & & & & & & & Par- & $\begin{array}{l}81 \text { so: } \\
\text { Anohoes }\end{array}$ & $\left\{\begin{array}{l}\text { Por } \\
\text { oent }\end{array}\right.$ & $\begin{array}{l}\text { s1seo } \\
\text { neheos: }\end{array}$ & $\begin{array}{l}\text { Por- } \\
\text { cont }\end{array}$ & $\begin{array}{l}31 \text { s so } \\
\text { 1nabo. }\end{array}$ & $\begin{array}{l}\text { Par- } \\
\text { boent. }\end{array}$ & $\begin{array}{l}81 z 0 \\
\text { tnctioes }\end{array}$ & $\begin{array}{l}\text { Por } \\
\text { Cont }\end{array}$ & $\begin{array}{l}\mathbf{s 1} \mathbf{s 0} \\
\text { nathes. }\end{array}$ & $\begin{array}{l}\text { Par- } \\
\text { oent } 1 \text {. }\end{array}$ & $\begin{array}{c}\text { S1 so } \\
\text { Incheos }\end{array}$ & $\begin{array}{l}\text { Per- } \\
\text { cont }\end{array}$ & $\begin{array}{l}\text { 81130 } \\
\text { (1noboed) }\end{array}$ & )$^{\text {Mnaral }}$ & $\begin{array}{l}\text { Porr- } \\
\text { cont }\end{array}$ & \begin{tabular}{|l|} 
s1z: \\
1nehioes:
\end{tabular} & Ninaral & Porn & $\begin{array}{c}8180 \\
\text { (1 1 noheos) }\end{array}$ \\
\hline 698 & Hornblendo enolde & & Mot axposod. & Irragalar. 0 & one unit. & $1 / 26$ & 60 & & 19.5 & & & & 20 & & 0.5 & & & & & & & & & & & \\
\hline 699 & do. & & do. & d. & do. & $1 / 8$ & 50 & & 30 & & 30 & 8 & 20 & & Irace. & & Traoo. & $1 / 16$ & & & & & & Bot1to. & treece. & $1 / 8$ \\
\hline 700 & Ao. & & هo. & do. & do. & $1 / 4$ & 55 & & 30 & & 30 & 5 & 15 & & & & & & & & & & & $\begin{array}{l}\text { Marnet1 to. } \\
\text { B10t1 to. }\end{array}$ & Traoe. & $\begin{array}{l}1 / 16 \\
1 / 16\end{array}$ \\
\hline 701 & do. & & do. & do. & do. & 1 & 20 & & 50 & & $\checkmark$ & 10 & 30 & & & & Trace. & $1 / 16$ & & & & & & ه. & Irece. & $1 / 4$ \\
\hline 702 & do. & & ه. & Lantioulas. & do. & 2 & 35 & & 50 & & 40 & 10 & 15 & & & & Erace. & $1 / 32$ & & & & & & Magnotito. & Trace. & $1 / 16$ \\
\hline 703 & هo. & & هo. & oral. & ه.. & $1 / 4$ & 50 & & 30 & & $\checkmark$ & & 20 & & & & Treoo. & & & & & & & M10t1to. & Treos. & \\
\hline 704 & ه. & & do. & Irrogular. & do. & $1 / 8$ & 50 & & 35 & & 30 & & 15 & & & & & & & & & & & & & \\
\hline 705 & Ao. & & do. & Lonti oular. & do. & $1 / 16$ & 65 & & 15 & & & & 20 & & & & & & & & & & & Motito. & Trace. & \\
\hline 706 & do. & & do. & do. & do. & $1 / 8$ & 40 & & 30 & & & & 30 & & & & & & & & & & & & & \\
\hline 707 & do. & & do. & oval. & do. & $1 / 16$ & 70 & & 5 & & & & 25 & & & & & & & & & & & & & \\
\hline 708 & do. & & do. & Lont1eular. & do. , & 2 & 10 & & 65 & & 80 & & 25 & & & & & & & & & & & & & \\
\hline 709 & do. & & do. & do. & do. & 2 & 10 & & 65 & & 80 & & 25 & & & & & & & & & & & & & \\
\hline no & do. & & do. & do. & do. & 1 & 30 & & 40 & & & & 30 & & & & & & & & & & & & & \\
\hline 721 & هo. & & do. & do. & do. & 3 & 10 & & 70 & & 80 & & 20 & & & & & & & & & & & & & \\
\hline$n 2$ & do. & & do. & Oral. & do. & 3 & 10 & & 60 & & $\checkmark$ & & 30 & & & & & & & & & & & & & \\
\hline 723 & do. & & do. & Irragular. & do. & 3 & 10 & & 60 & & & & 30 & & & & & & & & & & & & & \\
\hline 724 & do. & & do. & Lent1 oular. & do. & 3 & 10 & & 60 & & 80 & & 30 & & & & & & & & & & & & & \\
\hline 715 & do. & & do. & Irregular. & $\begin{array}{l}\text { Vall zone. } \\
\text { internedilact } \\
\text { sono. } \\
\text { Core. }\end{array}$ & ${ }^{2}$ & 10 & & 60 & & & & $\begin{array}{r}30 \\
50 \\
100\end{array}$ & & 50 & $3 / 4$ & & . & 8 & & & & & & & \\
\hline 726 & do. & & do. & Lant1eular. & Ono unit. & 3 & 10 & & 70 & & & & 20 & & & . & Treoe. & & & & & & & & & \\
\hline 717 & do. & & do. & do. & do. & 2 & 10 & & 70 & & & & 20 & & & & & & & & & & & & & \\
\hline 728 & do. & & do. & do. & do. & 3 & 10 & & 70 & & 80 & & 20 & & & & & & & & & & & & & \\
\hline 719 & do. & & do. & oval. & do. & $1 / 2$ & 60 & & 10 & 8 & & & 30 & & & & Traeo. & & & & & & & & & \\
\hline 720 & do. & & do. & Ientioular. & do. & $1 / 4$ & 70 & & 10 & & & & 20 & & & & & & & & & & & & & \\
\hline 721 & هo. & & do. & Oral. & do. & 1 & 10 & & 60 & & & & 30 & & & & Trace. & & & & & & & & & \\
\hline 722 & do. & & do. & Len t1 eular. & do. & $1 / 8$ & 70 & & 10 & & & & 20 & & & & & & & & & & & & & \\
\hline 723 & 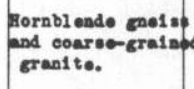 & & ه. & so. & do. & $1 / 4$ & 50 & & 30 & & & & 20 & & & & Trace. & & & & & & & B1ot1 to. & Frace. & \\
\hline 724 & 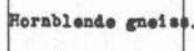 & & do. & do. & do. & $1 / 4$ & 60 & & 10 & & & & 30 & & & & & & & & & & & & & \\
\hline 725 & do. & & هo. & do. & do. & $1 / 4$ & 50 & & 20 & & & & 30 & & & & & & & & & & & & & \\
\hline
\end{tabular}


Fab10 20,-Minoralory of peratit tog--Cont1 mued.

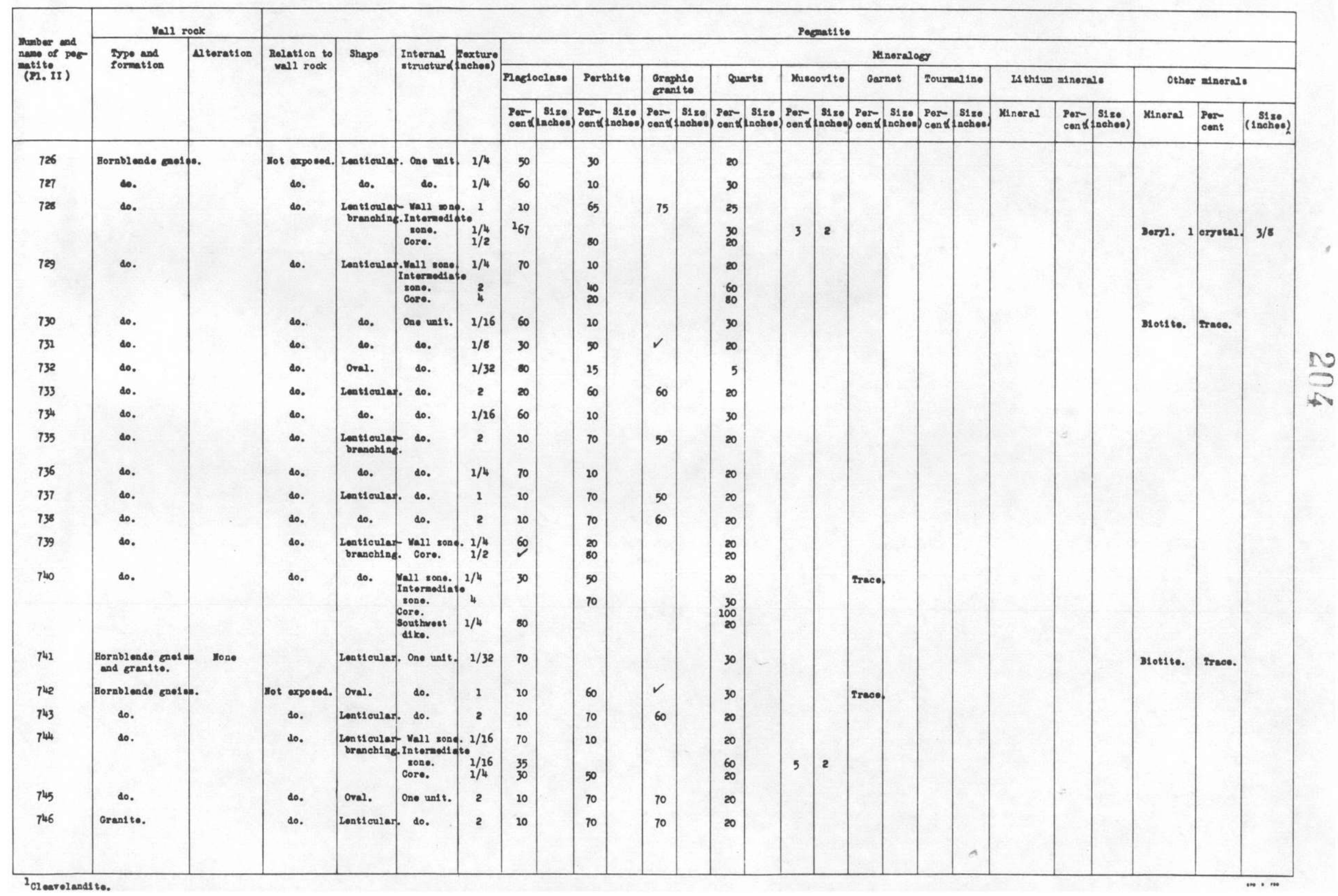


2eb10. 2Q-Minerelory of pereatiteg--Cont1nued.

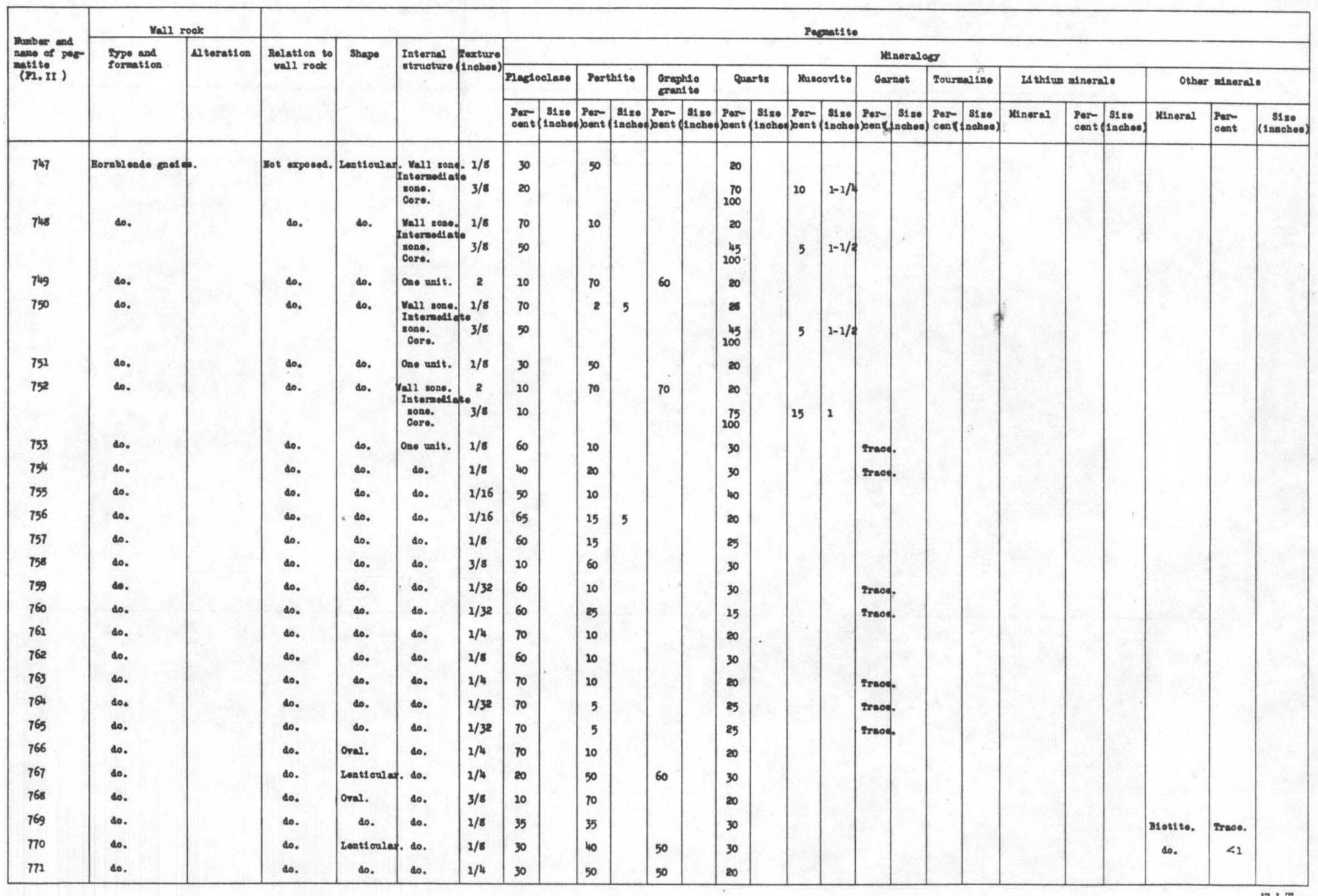




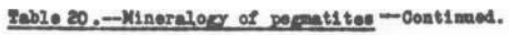

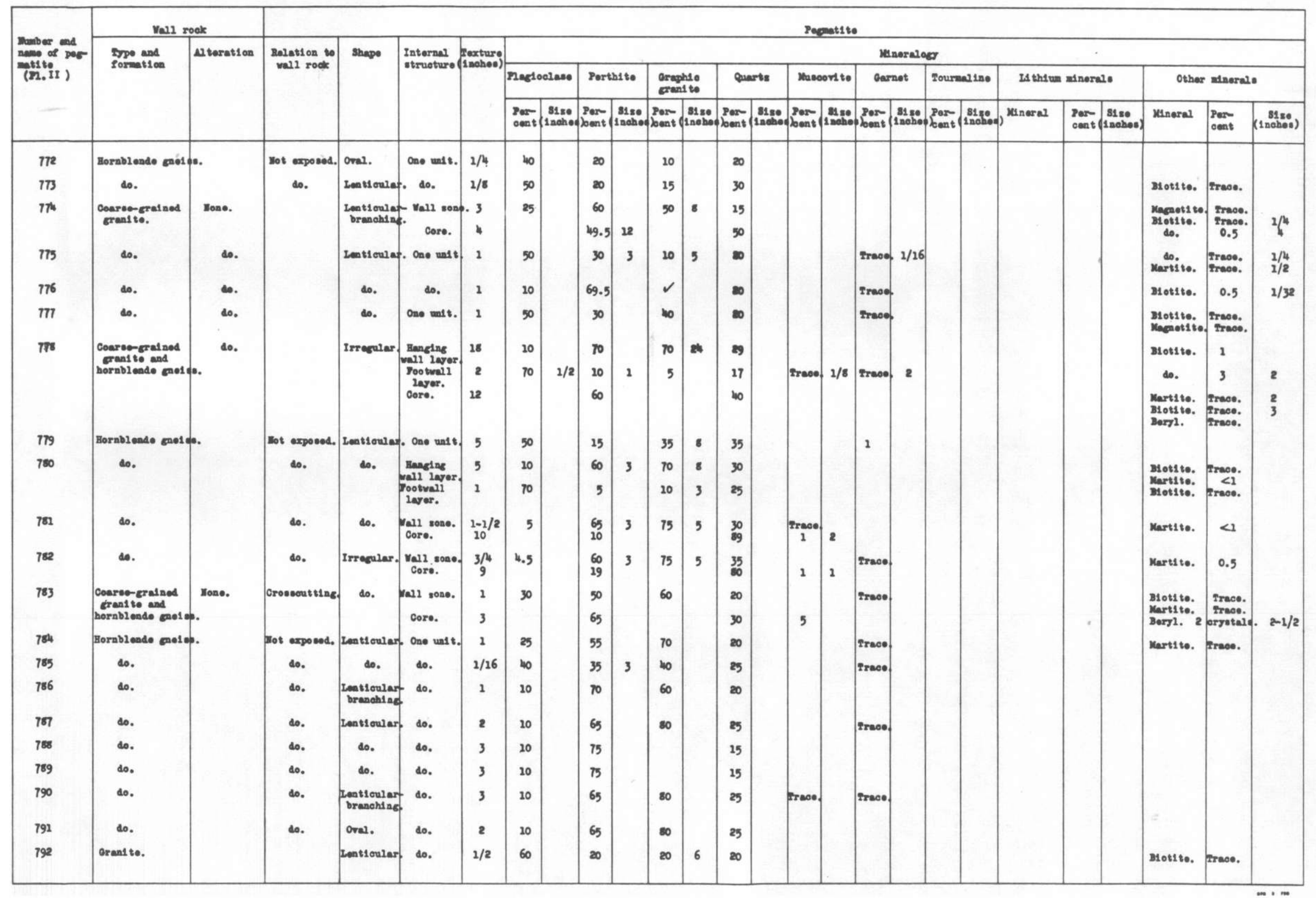


Fab10 20.--Mineralory of peopat1 tor-Cont1nued.

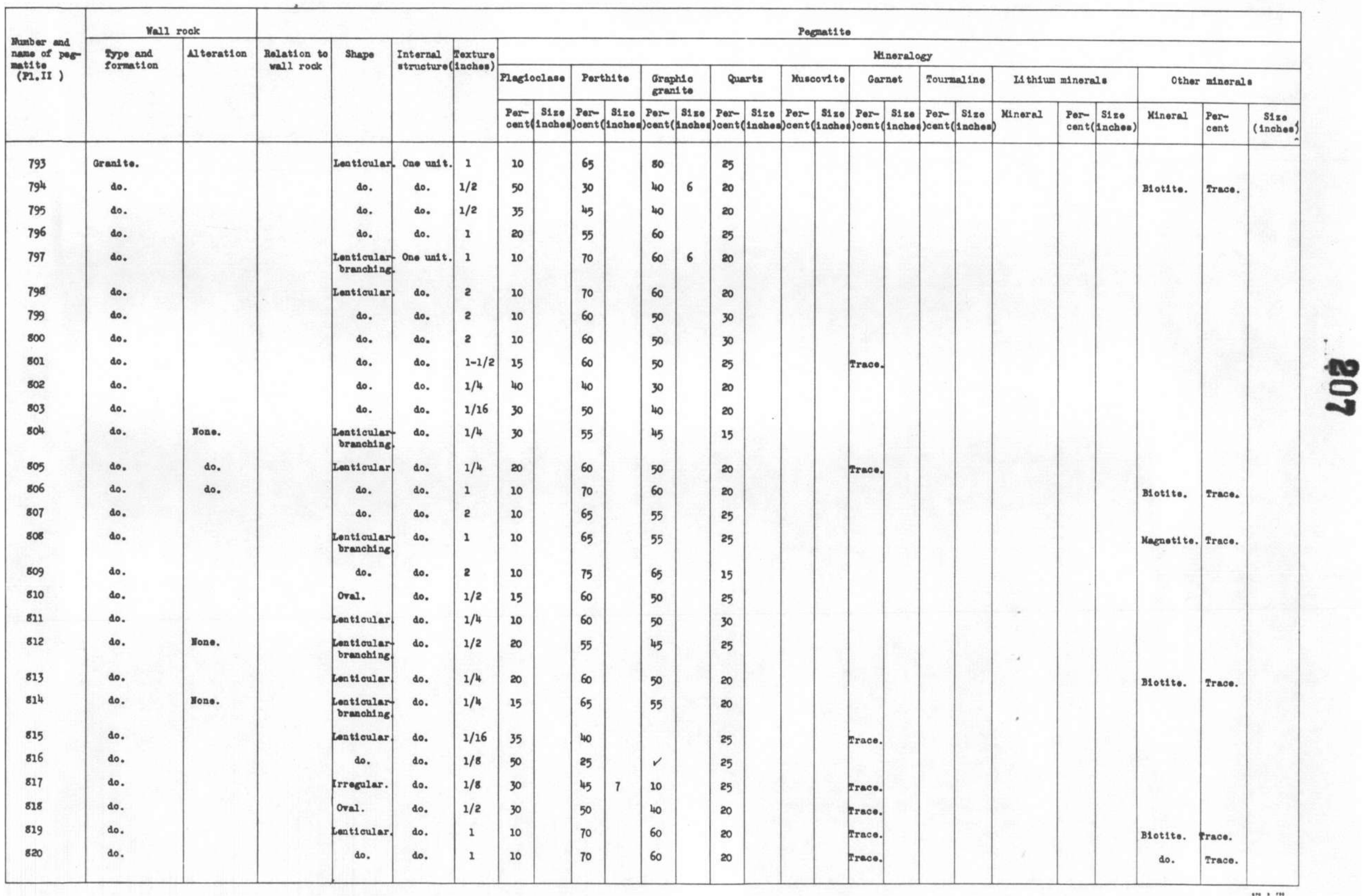


Thb10 20.-Mineralogy of pereatiten--Cont1mued.

\begin{tabular}{|c|c|c|c|c|c|c|c|c|c|c|c|c|c|c|c|c|c|c|c|c|c|c|c|c|c|c|}
\hline \multirow{4}{*}{$\begin{array}{l}\text { Muanber and } \\
\text { nane of peg } \\
\text { matitito } \\
\text { (II.II) }\end{array}$} & \multicolumn{2}{|c|}{ Mall rook } & \multirow{4}{*}{$\begin{array}{l}\text { Rolati on to } \\
\text { vall rook }\end{array}$} & \multicolumn{23}{|c|}{ Peont 1to } \\
\hline & \multirow{3}{*}{$\begin{array}{l}\text { Type and } \\
\text { formation }\end{array}$} & \multirow[t]{3}{*}{ N- teration } & & \multirow[t]{3}{*}{ Shapo } & \multirow{3}{*}{$\begin{array}{l}\text { Internal } \\
\text { itrueture (19 }\end{array}$} & \multirow{3}{*}{$\begin{array}{l}\text { Mexture } \\
(\text { Inchoos) }\end{array}$} & \multicolumn{20}{|c|}{ Mtneralogy } \\
\hline & & & & & & & \multicolumn{2}{|c|}{ PIaglociaso } & \multicolumn{2}{|c|}{ Perth1te } & \multicolumn{2}{|c|}{$\begin{array}{l}\text { araph10 } \\
\text { gran1 to }\end{array}$} & \multicolumn{2}{|c|}{ Quarts } & \multicolumn{2}{|c|}{ Musoovit te } & \multicolumn{2}{|c|}{ Garnot } & \multicolumn{2}{|c|}{ Tournaline } & \multicolumn{3}{|c|}{ Is thium minorals } & \multicolumn{3}{|c|}{ Other mineral. } \\
\hline & & & & & & & Par- & $\begin{array}{c}\text { 81zo } \\
\text { inceopd }\end{array}$ & $\begin{array}{l}\text { Por- } \\
\text { Doent }(1\end{array}$ & $\begin{array}{c}31 \text { so } \\
\text { Inchood }\end{array}$ & $\begin{array}{l}\text { Pore } \\
\text { d) Cont (at }\end{array}$ & \begin{tabular}{|l|} 
s1so \\
anohead)
\end{tabular} & $\begin{array}{l}\text { Par- } \\
\text { joente: }\end{array}$ & $\begin{array}{c}31 \text { s10 } \\
\text { (1nahood }\end{array}$ & $\begin{array}{l}\text { Por- } \\
\text { poent }(1\end{array}$ & $\begin{array}{c}81 \text { so } \\
\text { 1nohoed) }\end{array}$ & $\begin{array}{l}\text { Per- } \\
\text { joent }(1\end{array}$ & $\begin{array}{c}\text { S1 } 180 \\
\text { lnohoof) }\end{array}$ & $\begin{array}{l}\text { Per- } \\
\text { feent }\end{array}$ & $\begin{array}{l}\text { S1so } \\
\text { 1noboed }\end{array}$ & Winaral & $\begin{array}{l}\text { Por- } s \\
\text { cont }(12 x\end{array}$ & $\begin{array}{l}\text { s1:e } \\
\text { 1ncheos) }\end{array}$ & Xinoral & $\begin{array}{l}\text { Por- } \\
\text { oent }\end{array}$ & $\begin{array}{c}5180 \\
\text { (1nchoo) }\end{array}$ \\
\hline 821 & Granito. & & & Lent1 cular. & One unit. & $1 / 4$ & 25 & & 55 & & & & 20 & & & & & & & & & & & & & \\
\hline 822 & đo. & & & oral. & do. & $1 / 32$ & 50 & & 30 & & & & 20 & & & & & & & & & & & & & \\
\hline 823 & do. & & & Irrogular. & do. & $1 / 4$ & 45 & & 35 & 1 & 25 & 7 & 20 & & & & & & & & & & & & & \\
\hline 824 & do. & & & oval. & do. & 2 & 10 & & 60 & & 50 & & 30 & & & & & & & & & & & & & \\
\hline 825 & do. & Mono. & & Ion t1 eular. & do. & 1 & 10 & & 65 & & 55 & & 25 & & & & & & & & & & & & & \\
\hline 826 & do. & do. & & do. & $\begin{array}{l}\text { Yall sone. } \\
\text { Core. }\end{array}$ & $\frac{1 / 4}{3}$ & $\begin{array}{l}30 \\
10\end{array}$ & $1 / 16$ & $\begin{array}{l}50 \\
55\end{array}$ & $\begin{array}{l}2 \\
2\end{array}$ & 40 & $\begin{array}{r}6 \\
12\end{array}$ & $\underset{20}{20}$ & & $\begin{array}{l}<1 \\
15\end{array}$ & $1 / 2$ & & & & & & & & Monasite. & Trace. & $1 / 2$ \\
\hline $8 x$ & do. & do. & & do. & One unt t. & $1 / 2$ & 35 & $1 / 4$ & 45 & 5 & 20 & 5 & 20 & & $<1$ & $1 / 8=2$ & Traos. & & & & & & & Monani to. & trace. & $1 / 4$ \\
\hline 828 & do. & do. & & do. & do. & $1 / 4$ & 50 & & 30 & & 20 & 6 & 20 & & & & & & & & & & & ๑. & Trace. & $1 / 4$ \\
\hline 829 & هo. & do. & & Irrogular. & do. & $1 / 4$ & 50 & & 30 & 5 & 20 & 8 & 20 & & & & Trace. & & & & & & & B1ot1 to. & Traco. & \\
\hline 830 & do. & do. & & Lont1 eular. & do. & $1 / 2$ & 25 & & 55 & & 10 & & 20 & & & & & & & & & & & & & \\
\hline 831 & do. & do. & & do. & do. & $3 / 4$ & 35 & $1 / 16$ & 45 & 3 & & 8 & 20 & & Trace. & & Trace. & & & & & & & & & \\
\hline 832 & do. & هo. & & Oral. & do. & $3 / 4$ & 10 & & 65 & 2 & 40 & 6 & 25 & & & & Trece. & & & & & & & $\begin{array}{l}\text { B1otite. } \\
\text { Magnet1 to. }\end{array}$ & $\begin{array}{l}\text { Trace. } \\
\text { Trace. }\end{array}$ & \\
\hline 833 & do. & & & do. & do. & $1 / 16$ & 60 & & 24 & 5 & & & 15 & & 1 & 2 & & & & & & & & & & \\
\hline 834 & do. & Mone. & & $\begin{array}{l}\text { Cont1 eulary } \\
\text { branching. }\end{array}$ & do. & $1 / 2$ & 30 & & 55 & & 40 & & 15 & & Iraoee & & Frace. & & & & & & & Bot1 to. & Traco. & \\
\hline 835 & do. & a.. & & do. & do. & $1 / 2$ & 30 & & 50 & 4 & 40 & 4 & 20 & & & & Traco. & & & & & & & do. & trace. & \\
\hline 836 & do. & do. & & do. & do. & $1 / 4$ & 50 & & 30 & & & & 20 & & & & Fraoos. & & & & & & & & & \\
\hline 837 & do. & & & Irragular. & do. & $1 / 4$ & 20 & & 65 & & 55 & 16 & 15 & & & & & & & & & & & & & \\
\hline 838 & do. & Mono. & & font1 cular. & do. & $1 / 8$ & 45 & & 40 & & 30 & 8 & 15 & & & & & & & & & & & & & \\
\hline 839 & do. & do. & & $\begin{array}{l}\text { fent1 oular } \\
\text { branching. }\end{array}$ & do. & $1 / 8$ & 65 & & 20 & & 10 & 10 & 15 & & & & & & & & & & & & & \\
\hline 840 & do. & & & font1 cular. & do. & 2 & 10 & & 70 & & 60 & 6 & 20 & & & & & & & & & & & & & \\
\hline 841 & do. & & & oval. & do. & $1 / 8$ & 65 & & 20 & 1 & & & 15 & & Trace. & & & & & & & & & Martito. & Irace. & \\
\hline 842 & do. & & & do. & do. & $1 / 4$ & 65 & & 15 & & & & 20 & & Trace. & & & & & & & & & & & \\
\hline 843 & do. & & & do. & do. & $1 / 8$ & 35 & & 50 & & 40 & & 15 & & & & & & & & & & & B1ot1 te. & Trace. & \\
\hline $\begin{array}{l}844 \\
845\end{array}$ & $\begin{array}{l}\text { do. } \\
\text { Covered with }\end{array}$ & & & $\begin{array}{c}\text { Irrogular. } \\
\text { do. }\end{array}$ & do. & $\begin{array}{c}1 / 8 \\
2\end{array}$ & $\begin{array}{l}70 \\
30\end{array}$ & & 15 & 2 & 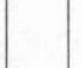 & & 15 & & & & & & & & & & & & & \\
\hline 846 & Glactal tili. & & & do. & do. & ${ }^{2}$ & 30 & & 4 & & & & 20 & & 0.5 & 1 & 0.5 & $1 / 32$ & & & & & & & & \\
\hline 846 & do. & & & do. & do. & 1 & 33.5 & & 45 & & 35 & 8 & 20 & & 0.53 & $3 / 4$ & 1 & $1 / 16$ & & & & & & & & \\
\hline
\end{tabular}


Feb10 20-Mineralogy of peematiteg--Cont1nued.

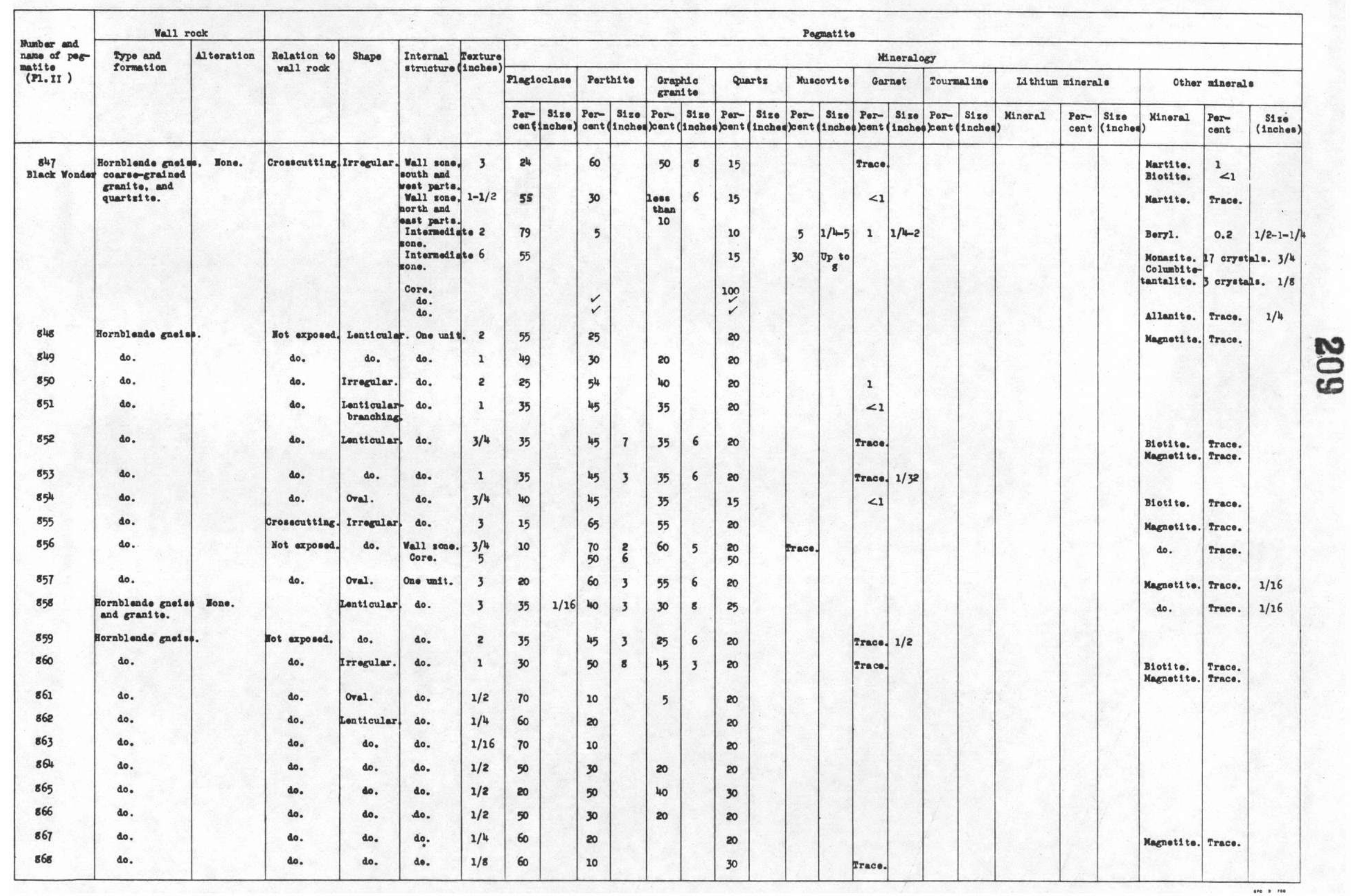




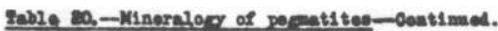

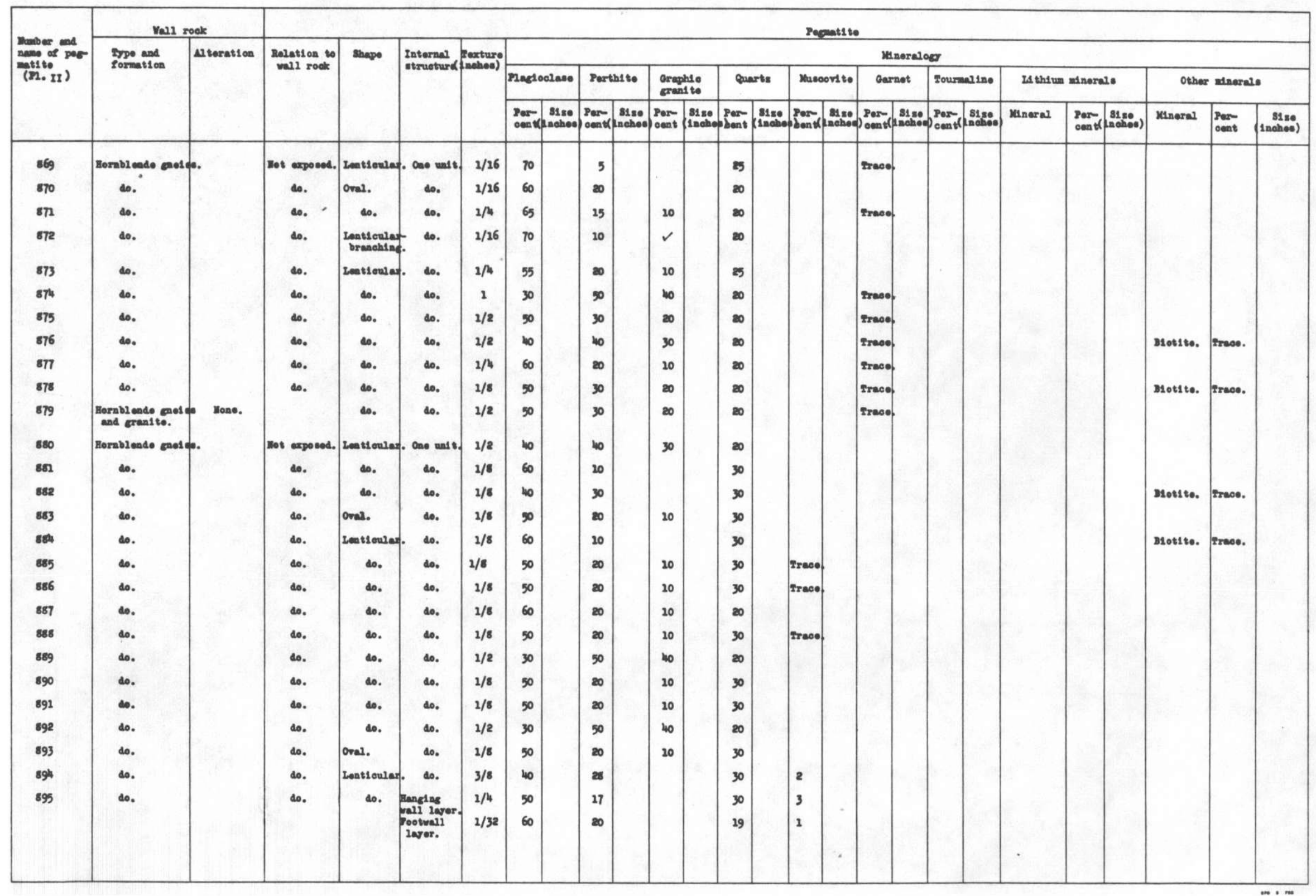




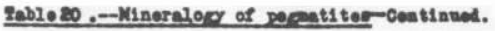

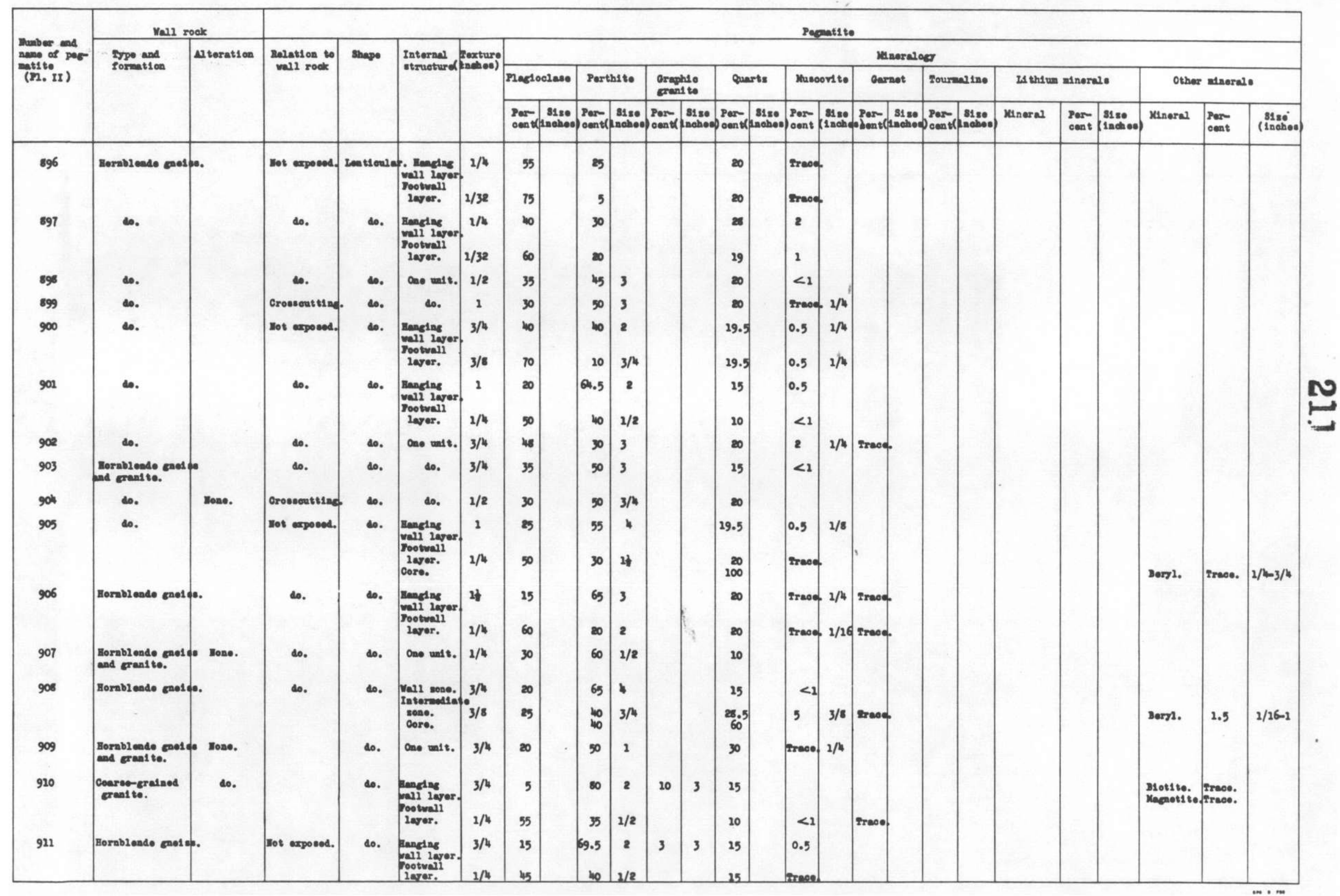




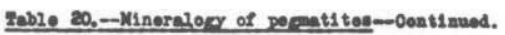

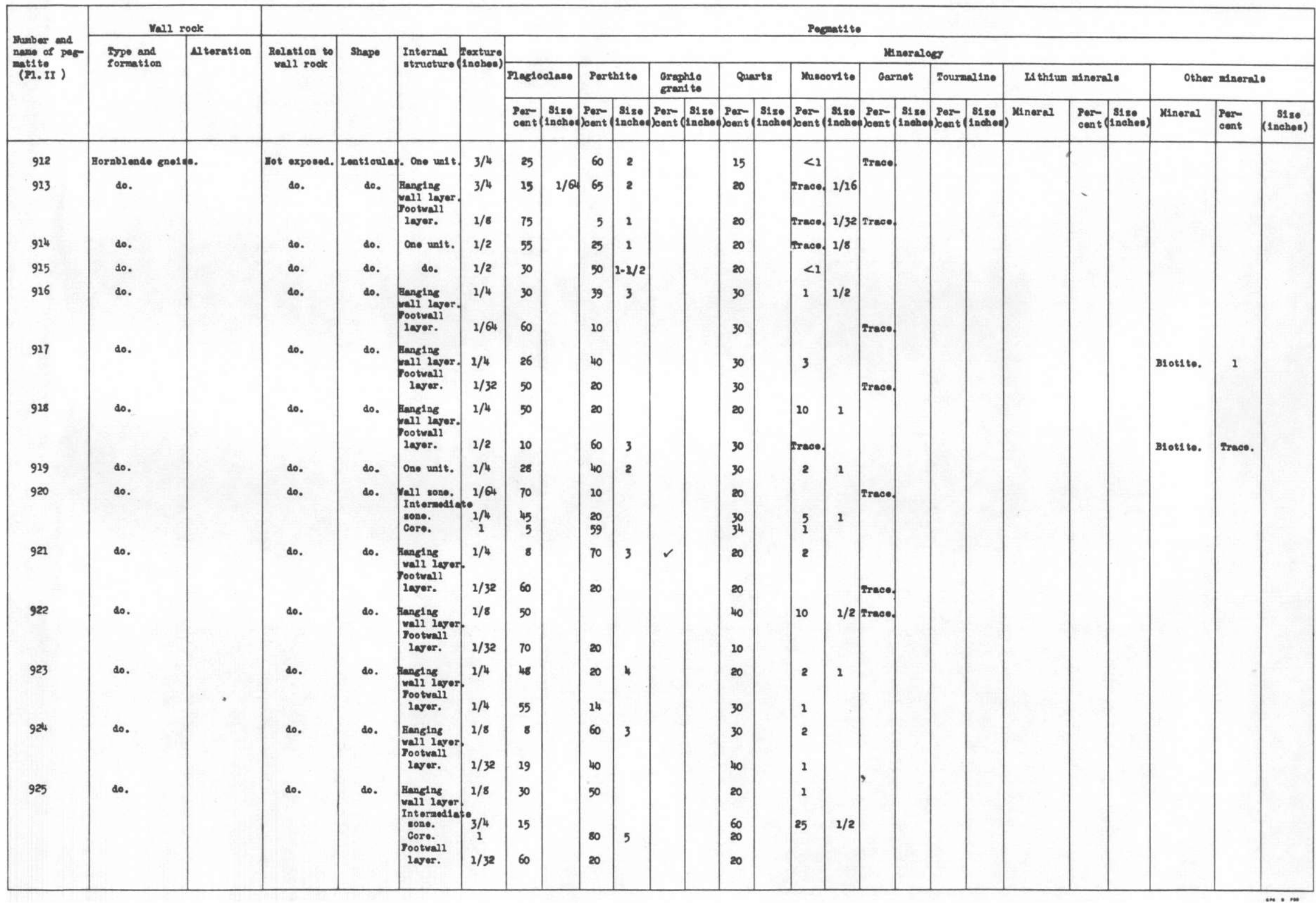




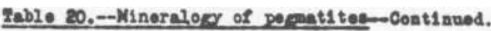

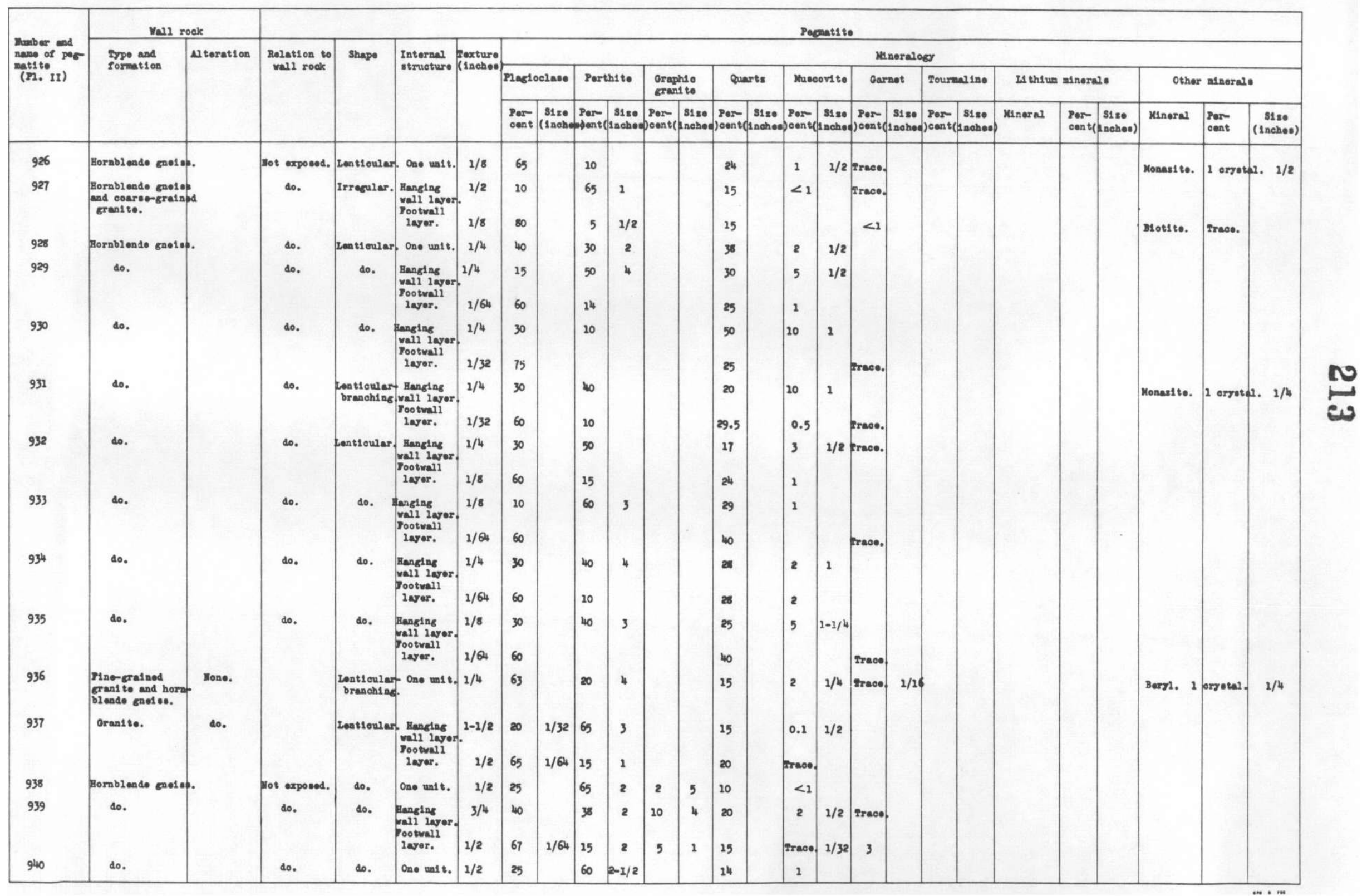




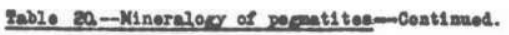

\begin{tabular}{|c|c|c|c|c|c|c|c|c|c|c|c|c|c|c|c|c|c|c|c|c|c|c|c|c|c|c|}
\hline \multirow{4}{*}{$\begin{array}{l}\text { Munbor and } \\
\text { nane of peo } \\
\text { metite. II) } \\
\text { (II. ID) }\end{array}$} & \multicolumn{2}{|c|}{ Mall rook } & \multicolumn{24}{|c|}{ Peonat 1 to } \\
\hline & \multirow{3}{*}{$\begin{array}{l}\text { Type and } \\
\text { formation }\end{array}$} & \multirow[t]{3}{*}{ Dlteration } & \multirow{3}{*}{$\begin{array}{l}\text { Rolation to } \\
\text { wall rook }\end{array}$} & \multirow[t]{3}{*}{ Shape } & \multirow{3}{*}{$\begin{array}{l}\text { Internal } \\
\text { itrueturo }\end{array}$} & \multirow{3}{*}{$\begin{array}{l}\text { Soxture } \\
\text { 100hoos) }\end{array}$} & \multicolumn{20}{|c|}{ Herealoeg } \\
\hline & & & & & & & \multicolumn{2}{|c|}{ Placlociase } & \multicolumn{2}{|c|}{ Porth1to } & \multicolumn{2}{|c|}{$\begin{array}{l}\text { Graphse } \\
\text { eran1 to }\end{array}$} & \multicolumn{2}{|c|}{ Sharts } & \multicolumn{2}{|c|}{ Musoovit to } & \multicolumn{2}{|c|}{ Garnot } & \multicolumn{2}{|c|}{ Tournalino } & \multicolumn{3}{|c|}{ IS thium mineral. } & \multicolumn{3}{|c|}{ Other minerals. } \\
\hline & & & & & & & $\begin{array}{l}\text { Por- } \\
\text { oent }\end{array}$ & 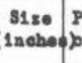 & $\begin{array}{l}\text { Par- } \\
\text { bent }\end{array}$ & $\begin{array}{l}\text { siso } \\
\text { 1neted }\end{array}$ & $\begin{array}{l}\text { Por- } \\
\text { poent }\end{array}$ & $\begin{array}{c}81 \text { se } \\
\text { Ineheop? }\end{array}$ & $\begin{array}{l}\text { Par- } \\
\text { pent }\end{array}$ & $\begin{array}{l}\text { s1ze } \\
\text { 1nehoodx }\end{array}$ & $\begin{array}{l}\text { Por- } \\
\text { pont }\end{array}$ & $\begin{array}{l}8120 \\
1 \text { 120hop }\end{array}$ & $\begin{array}{l}\text { Por- } \\
\text { poont }\end{array}$ & $\begin{array}{l}\mathbf{s 1} \mathbf{s e} \\
\text { 1sebop })\end{array}$ & $\begin{array}{l}\text { Peer } \\
\text { Jent }\end{array}$ & $\begin{array}{l}81 \text { so } \\
\text { 1nchoof) }\end{array}$ & )$^{\text {Xineral }}$ & Coent $(2$ & $\begin{array}{l}3180 \\
\text { 1nebeos }\end{array}$ & Xinoral & $\begin{array}{l}\text { Por- } \\
\text { cont }\end{array}$ & 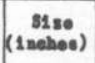 \\
\hline 941 & $\begin{array}{l}\text { Gran1 to and } \\
\text { pornblendo gnot on }\end{array}$ & Mono. & & Len tioulat & f. One ount 2 . & 1 & 15 & & 55 & & 5 & 5 & 30 & & traco. & & traoe. & & & & & & & & & \\
\hline 942 & do. & do. & & هo. & do. & $3 / 4$ & 10 & & 65 & 3 & & & 25 & & & & & & & & & & & & & \\
\hline 943 & Gnolsolo cranlito. & do. & Croseouttine. & do. & do. & $1 / 2$ & 30 & $1 / 39$ & 50 & 2 & & & 28 & & 2 & $1 / 4$ & & & & & & & & & & \\
\hline 944 & $\begin{array}{l}\text { Granit to and horn } \\
\text { blendo gneles. }\end{array}$ & & Mot exposod. & do. & $\begin{array}{l}\text { Ranglage } \\
\text { val1 1ayor } \\
\text { prootwal1 } \\
\text { layor. }\end{array}$ & $\left\{\begin{array}{l}3 / 4 \\
1 / 4\end{array}\right.$ & $\begin{array}{l}20 \\
50\end{array}$ & $1 / 32$ & $\begin{array}{l}15 \\
10\end{array}$ & 4 & & & 20 & $1 / 4$ & $\approx$ & $\begin{array}{l}2 / 8 \\
1 / 4\end{array}$ & 0.1 & & & & & & & & & \\
\hline 945 & do. & Mono. & & do. & $\begin{array}{l}\text { Manging } \\
\text { vall 1eves. } \\
\text { Proturall } \\
\text { 1ever. }\end{array}$ & $\begin{array}{l}1-1 / 2 \\
1 / 8\end{array}$ & $\begin{array}{l}15 \\
50\end{array}$ & $1 / 32$ & $\begin{array}{l}60 \\
10\end{array}$ & 3 & & & $\begin{array}{l}15 \\
20\end{array}$ & & 20 & $1 / 2$ & & & & & & & & & & \\
\hline 946 & Borablende gno1 C & o. & Wot exposed. I & $\begin{array}{l}\text { Lenticular } \\
\text { branohinge }\end{array}$ & 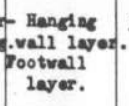 & $\underbrace{3 / 4} 1 / 2$ & $\begin{array}{l}30 \\
50\end{array}$ & & $\begin{array}{l}20 \\
40\end{array}$ & $2-1 / 2$ & & & $\begin{array}{l}50 \\
10\end{array}$ & & $\begin{array}{l}2 r \infty 00 . \\
<1\end{array}$ & & Irace. & & & & & & & & & \\
\hline 947 & Gran1 to. & Bono. & & Len t1oular & 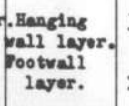 & $\begin{array}{l}3 / 4 \\
1 / 2\end{array}$ & $\begin{array}{l}30 \\
60\end{array}$ & $1 / 32$ & $\begin{array}{l}50 \\
20\end{array}$ & 2 & & & $\begin{array}{l}20 \\
20\end{array}$ & & treoen. & & & & & & & & & & & \\
\hline 948 & Hornblende gnolep & & Mot expoeod. & do. & 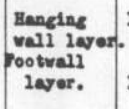 & $\int^{1 / 4}$ & $\begin{array}{l}55 \\
60\end{array}$ & & $\begin{array}{l}15 \\
10\end{array}$ & & & & 30 & & 2 & & & & & & & & & & & \\
\hline 949 & do. & & do. & do. & 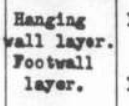 & $\begin{array}{l}1 / 16 \\
1 / 32\end{array}$ & $\begin{array}{l}35 \\
60\end{array}$ & & $\begin{array}{l}35 \\
9\end{array}$ & & & & $\begin{array}{l}28 \\
30\end{array}$ & & 1 & & & & & & & & & & & \\
\hline 950 & do. & & do. & do. & $\begin{array}{l}\text { Inang1ng } \\
\text { vall lever. } \\
\text { Tootwall } \\
\text { lever. }\end{array}$ & $21 / 4$ & $\begin{array}{l}40 \\
60\end{array}$ & & $\begin{array}{l}30 \\
9\end{array}$ & & & & 28 & & 2 & & Trace. & & & & & & & & & \\
\hline 951 & do. & & do. & do. & $\begin{array}{l}\text { Ianget ag } \\
\text { vall layor. } \\
\text { Pootivall } \\
\text { 1avor. }\end{array}$ & $\left\{\begin{array}{l}1 / 8 \\
1 / 64\end{array}\right.$ & $\begin{array}{l}40 \\
70\end{array}$ & & $\begin{array}{l}40 \\
9\end{array}$ & & & & $\begin{array}{l}17 \\
20\end{array}$ & & $\begin{array}{l}3 \\
1\end{array}$ & & Irace. & a & & & & & & & & \\
\hline 952 & do. & & do. & do. & $\begin{array}{l}\text { Ranglage } \\
\text { vall 1ayor. } \\
\text { Pootval1 } \\
\text { 1ayor. }\end{array}$ & $\begin{array}{l}3 / 8 \\
1 / 32\end{array}$ & $\begin{array}{l}40 \\
60\end{array}$ & & $\begin{array}{l}39 \\
19\end{array}$ & & & & 20 & & $\begin{array}{l}1 \\
1\end{array}$ & & & & & & & & & & & \\
\hline 953 & Horablende gaole & & do. & do. & $\begin{array}{l}\text { Heang1ng } \\
\text { val1 1avor. } \\
\text { Tootvall } \\
\text { Iaver. }\end{array}$ & $\begin{array}{l}3 / 8 \\
1 / 64\end{array}$ & $\begin{array}{l}45 \\
60\end{array}$ & & $\begin{array}{l}25 \\
5\end{array}$ & & & & $\begin{array}{l}28 \\
34\end{array}$ & & $\begin{array}{l}2 \\
1\end{array}$ & & trace. & & & & & & & & & \\
\hline 954 & do. & & do. & do. & 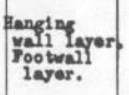 & $\begin{array}{l}1 / 8 \\
1 / 64\end{array}$ & $\begin{array}{l}40 \\
70\end{array}$ & & $\begin{array}{l}40 \\
9\end{array}$ & & & & $\begin{array}{l}17 \\
20\end{array}$ & & $\begin{array}{l}3 \\
1\end{array}$ & & Irace. & & & & 3 & $\theta$ & & & & \\
\hline
\end{tabular}




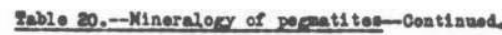

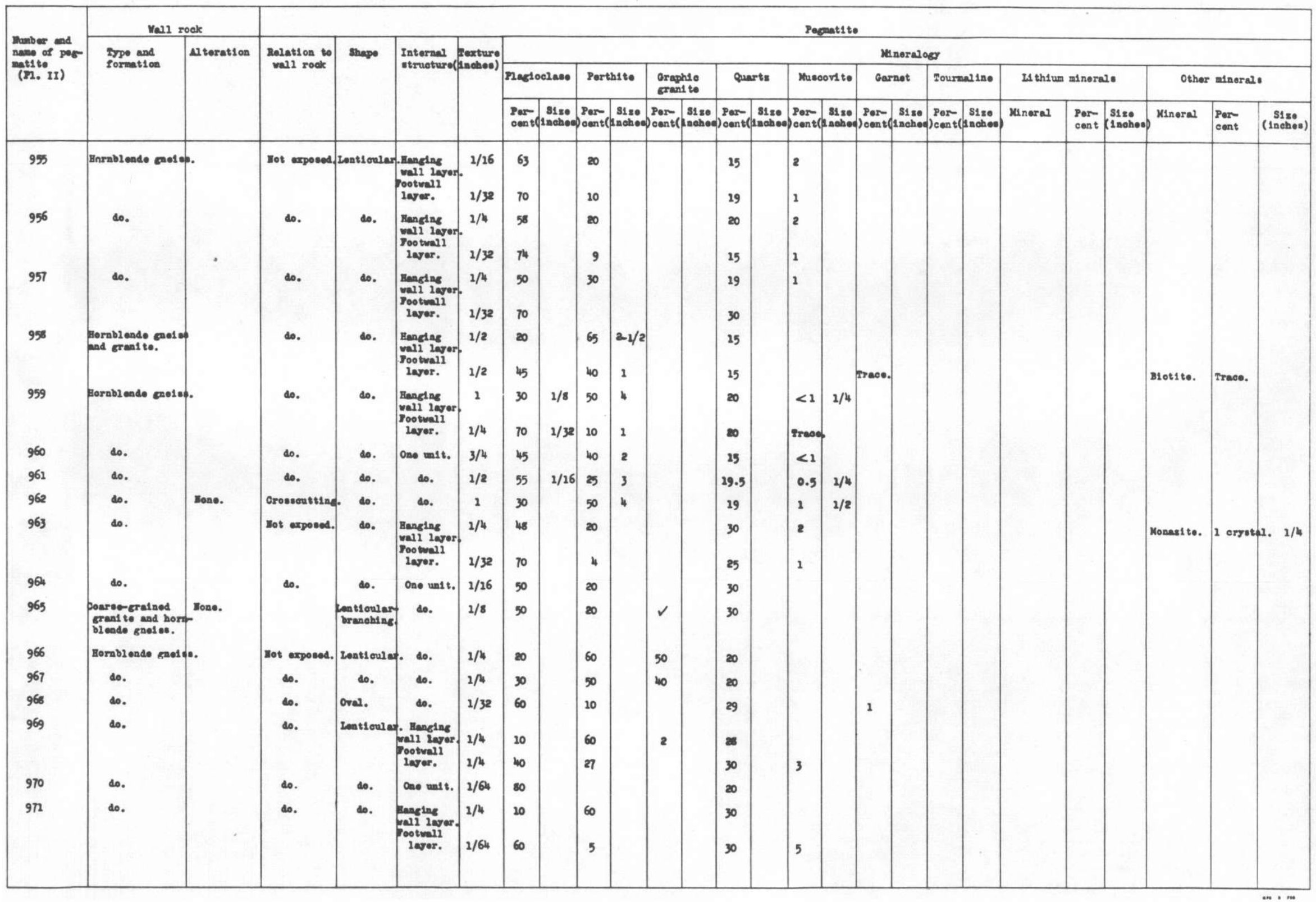


Fable 20,-Minerelopy of pereatitel-Cont1 nued.

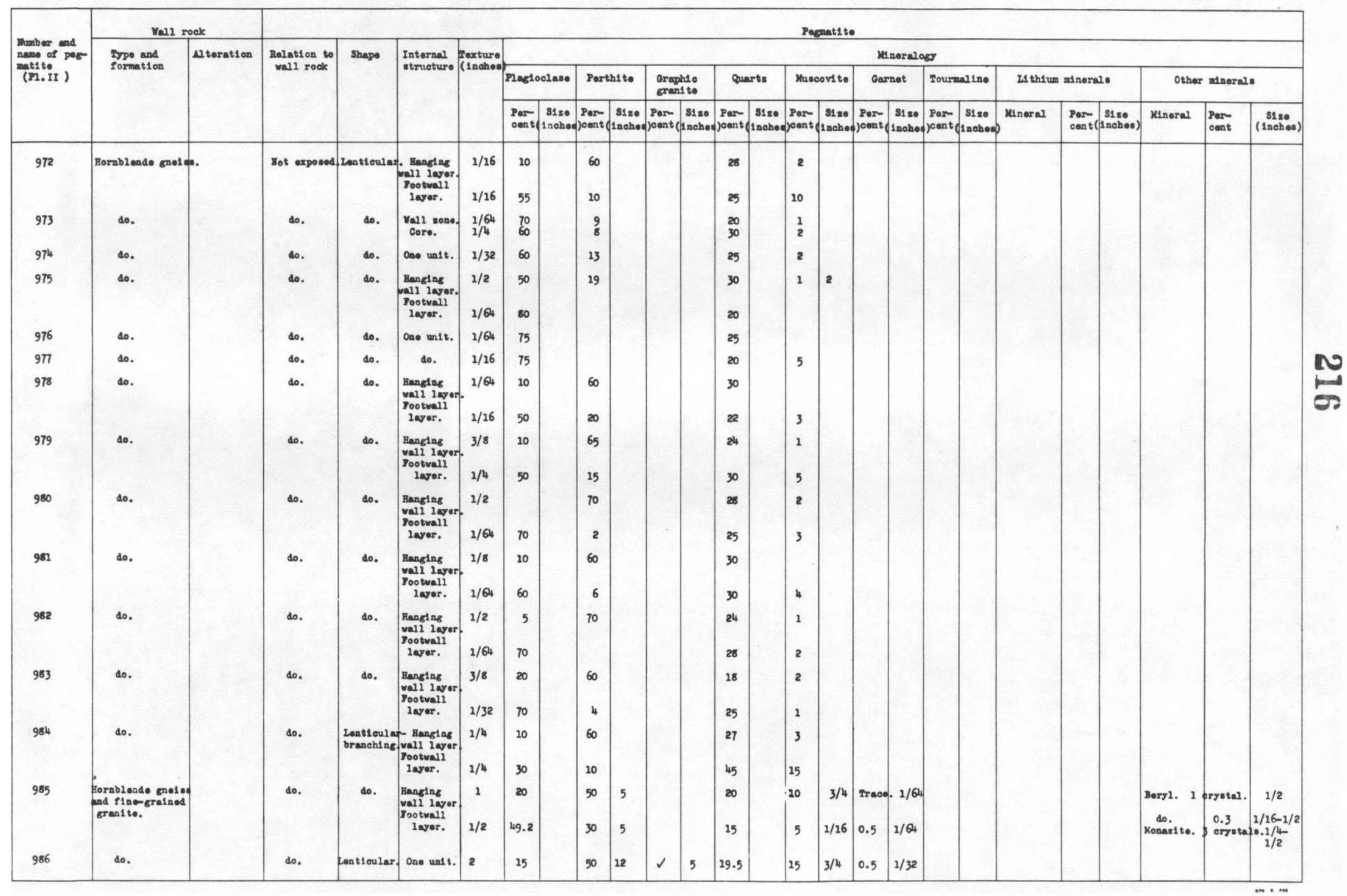


Feb10 20.-Minoralogy of pepentites - Con t1 nued.

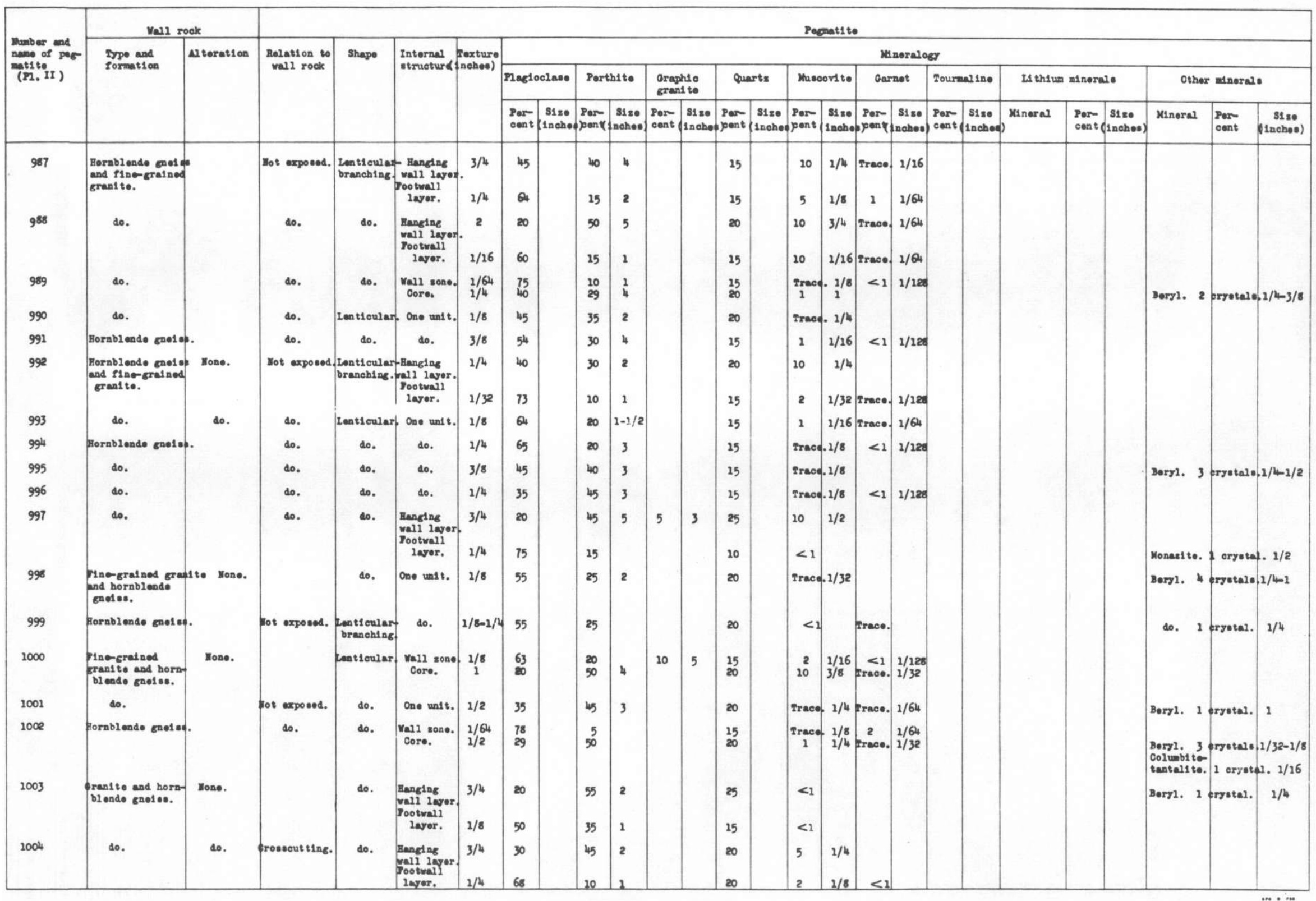


2ab10 20.-Minoralory of perentites-Continued.

\begin{tabular}{|c|c|c|c|c|c|c|c|c|c|c|c|c|c|c|c|c|c|c|c|c|c|c|c|c|c|c|}
\hline \multirow{4}{*}{$\begin{array}{l}\text { Munber ond } \\
\text { nene of por } \\
\text { matito } \\
\text { (II. II) }\end{array}$} & \multicolumn{2}{|c|}{ Vall roak } & \multicolumn{24}{|c|}{ Paonet1 to } \\
\hline & \multirow{3}{*}{$\begin{array}{l}\text { Trpe and } \\
\text { formation }\end{array}$} & \multirow[t]{3}{*}{ Altoration } & \multirow{3}{*}{$\begin{array}{l}\text { Rolation to } \\
\text { well rook }\end{array}$} & \multirow[t]{3}{*}{ Shape } & \multirow{3}{*}{$\begin{array}{l}\text { Internal } \\
\text { etruetureo }\end{array}$} & \multirow{3}{*}{$\mid \begin{array}{l}\text { Textures } \\
\text { Inohos) }\end{array}$} & \multicolumn{20}{|c|}{ Maneralogy } \\
\hline & & & & & & & \multicolumn{2}{|c|}{ Plagtociaso } & \multicolumn{2}{|c|}{ Parthito } & \multicolumn{2}{|c|}{$\begin{array}{l}\text { Graph10 } \\
\text { Erant to }\end{array}$} & \multicolumn{2}{|c|}{ Gants } & \multicolumn{2}{|c|}{ Musoorlto } & \multicolumn{2}{|c|}{ Garnot } & \multicolumn{2}{|c|}{ Tournaling } & \multicolumn{3}{|c|}{ IS th1um minerals } & \multicolumn{3}{|c|}{ Other nineral" } \\
\hline & & & & & & & $\begin{array}{l}\text { Parr } \\
\text { oont }\end{array}$ & $\begin{array}{l}\text { 81so } \\
\text { 1nchos }\end{array}$ & $\begin{array}{l}\text { Por- } \\
\text { Poent d: }\end{array}$ & $\begin{array}{c}\text { 81zo } \\
\text { 1nohods }\end{array}$ & $\begin{array}{l}\text { Por- } \\
\text { peent (2 }\end{array}$ & $\begin{array}{l}81 \text { so } \\
\text { (1neheos }\end{array}$ & Par- & $\begin{array}{c}8180 \\
1 \text { inehood) }\end{array}$ & $\begin{array}{l}\text { Por- } \\
\text { poent }\end{array}$ & $\begin{array}{c}81 \text { so } \\
\text { 1nchoof) }\end{array}$ & $\begin{array}{l}\text { Por- } \\
\text { )eent } 1\end{array}$ & $\begin{array}{l}\text { S1 so } \\
\text { lnohoof) }\end{array}$ & $\begin{array}{l}\text { Por } \\
\text { Peant }\end{array}$ & $\begin{array}{l}81 \text { sio } \\
\text { 1noboop }\end{array}$ & Xineral & contch & $\begin{array}{l}\text { S1: } \\
\text { Anoboses) }\end{array}$ & Kineral & Poor & $\begin{array}{c}81 \mathrm{se} \\
\text { (1 nobos) }\end{array}$ \\
\hline (Cont1nued) & $\begin{array}{l}\text { aran1te and hornt } \\
\text { blendo act os. }\end{array}$ & Mono. & Grossoutt1nes. & fLont1eular. & - Core. & 2 & & & 30 & & & & 70 & & & & $<1$ & & & & & ? & & Boryl. 5 & pryotalo. & $\mid 1 / 16-3 / 4$ \\
\hline 1005 & do. & do. & & $\begin{array}{l}\text { Lent1oular } \\
\text { breach1nge. }\end{array}$ & One unit. & $1 / 8-1 / 4$ & 65 & & 25 & & & & 20 & & $<1$ & & traceo. & & & & & & & do. 10 & oprotal. & $1 / 4$ \\
\hline 1006 & Horablendo gasipo & o. & Mot exposed. & do. & do. & $1 / 8$ & 58 & & 20 & 2 & & & 20 & & 2 & $1 / 8$ & & & & & & & & 4. 9 or & ipetale. 2 & $1 / 32-1 / 4$ \\
\hline 1007 & هo. & & Ao. & Leatis coulat. & do. & $1 / 8-1 / 4$ & 54 & & 20 & & & & 25 & & 1 & & Fraece. & & & & & & & & & \\
\hline 1008 & 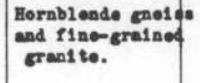 & & do. & $\begin{array}{l}\text { Lontioulat } \\
\text { branching. }\end{array}$ & do. & $|1 / 8=1 / 4|$ & 55 & & 15 & & & & 30 & & $<1$ & & Trace. & & & & & & & & & \\
\hline 1009 & @o. & Mono. & & Lonticular. & do. & $1 / 4-1 / 2$ & 47 & & 33 & & & & 20 & & Frace & & Erace. & & & & & & & Bergl. 2 & orgetale. & $.1 / 4-1 / 2$ \\
\hline 1010 & do. & & Iot exposed. & branchinge. & do. & $3 / 26$ & 55 & & 30 & 2 & & & 15 & & Irace. & $1 / 16$ & & & & & & & & & ergotale. & $.1 / 16-1 / 4$ \\
\hline 1011 & 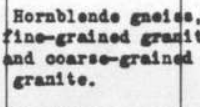 & $\begin{array}{l}\text { atono. } \\
\text { ito." }\end{array}$ & & do. & هo. & $1 / 4$ & 45 & & 35 & & & & 20 & & $<1$ & & Trace. & & & & & & & 4. 10 & gryotas. & $1 / 4$ \\
\hline 1012 & 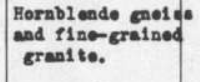 & & Iot exposed. & Leantiouladed. & do. & $1 / 4$ & 50 & & 30 & & & & $\approx$ & & $<1$ & & Trece. & & & & & & & do. 20 & protale. & $1 / 4$ \\
\hline 1013 & 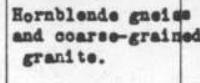 & Mono. & & $\begin{array}{l}\text { Lent1 oulas } \\
\text { branching. }\end{array}$ & do. & $1 / 4$ & 50 & & 29 & . & & & 20 & & 1 & & Frace. & & & & & & & & & \\
\hline 1014 & 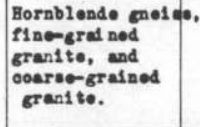 & •. & Hot exposed. & Loaticular. & do. & $1 / 8-1 / 4$ & 55 & & 25 & & & & 20 & & $<1$ & & Traoo. & & & & & & & Borgl. 2 & aryotale. & . $3 / 4$ \\
\hline 1015 & do. & do. & & do. & do. & $1 / 8-1 / 4$ & 60 & & 20 & & & & 20 & & $<1$ & & Traoe. & & & & & & & \&o. & aryotal a. & $.1 / 4-1 / 2$ \\
\hline 1016 & 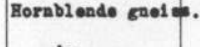 & & Iyot exposed. & do. & do. & $3 / 16$ & 53 & & 25 & 3 & & & 20 & & 2 & $1 / 8$ & Frace. & $1 / 18$ & & & & & & هo. & oryotal. & $1 / 8$ \\
\hline 1017 & do. & & do. & $\begin{array}{l}\text { Lont1 oular- } \\
\text { branching. }\end{array}$ & do. & $1 / 8$ & 57.5 & & 20 & 2 & & & 20 & & 2 & $1 / 8$ & 0.5 & $1 / 64$ & & & & & & & & \\
\hline 1018 & do. & & \&o. & Lont1cular. & do. & $1 / 8$ & 45 & & 30 & 3 & & & 20 & & 5 & $1 / 4$ & 0.1 & $1 / 16$ & & & & & & & & \\
\hline 1019 & $\begin{array}{l}\text { Hornblende gnotes } \\
\text { nd f1nograined } \\
\text { cranite. }\end{array}$ & & do. & Lonticularer & do. & $1 / 8$ & 42 & & 30 & 2 & 20 & 3 & 15 & & 8 & $1 / 8$ & Trace. & $1 / 64$ & & & & & & & & \\
\hline 1020 & do. & Hoano. & & Lenticular. & do. & $1 / 4$ & 30 & & 40 & 3 & 30 & 3 & 20 & & 10 & & & & & & & & & & & \\
\hline 1021 & do. & & Hot expoeed. & do. & do. & $1 / 8$ & 50 & & 25 & 3 & 10 & & 20 & & 5 & $1 / 8$ & Trace. & $1 / 32$ & & & & & & & & \\
\hline 1022 & Hornblende gnelop. & & do. & do. & $\begin{array}{l}\text { Vall sone. } \\
\text { Core. }\end{array}$ & $\int_{2}^{1 / 16}$ & $\begin{array}{l}50 \\
10\end{array}$ & $1 / 32$ & $\begin{array}{l}20 \\
49\end{array}$ & 3 & & & $\begin{array}{l}28 \\
30\end{array}$ & & $\stackrel{2}{1}$ & & & & & & & & & B1otito. & Irace. & \\
\hline 2023 & do. & & do. & do. & $\begin{array}{l}\text { Val1 sone. } \\
\text { Coro. }\end{array}$ & $\mid \begin{array}{l}1 / 2 \\
1-1 / 2-3 \mid\end{array}$ & 60 & & $\begin{array}{l}19 \\
50\end{array}$ & 3 & & & $\begin{array}{l}20 \\
50\end{array}$ & & 1 & & & & & & & . & & & & \\
\hline
\end{tabular}


Tab10 20.--Mineraloes of pepatit ter-Cont1 nued.

\begin{tabular}{|c|c|c|c|c|c|c|c|c|c|c|c|c|c|c|c|c|c|c|c|c|c|c|c|c|c|c|}
\hline \multirow{4}{*}{$\begin{array}{l}\text { Mumber and } \\
\text { noneo of poo } \\
\text { matit to } \\
\text { (PI. II) }\end{array}$} & \multicolumn{2}{|c|}{ Wall rock } & \multicolumn{24}{|c|}{ Ponat 1 to } \\
\hline & \multirow{3}{*}{$\begin{array}{l}\text { Type and } \\
\text { formation }\end{array}$} & \multirow[t]{3}{*}{ N1teration } & \multirow{3}{*}{$\begin{array}{l}\text { Rolati on to } \\
\text { vall rook }\end{array}$} & \multirow{3}{*}{ Shape } & \multirow{3}{*}{$\begin{array}{l}\text { Internal } \\
\text { strueture }(1\end{array}$} & \multirow{3}{*}{$\left|\begin{array}{l}\text { Texture } \\
\text { (1nchos) }\end{array}\right|$} & \multicolumn{20}{|c|}{ Meneralogy } \\
\hline & & & & & & & \multicolumn{2}{|c|}{ Piagloclase } & \multicolumn{2}{|c|}{ Perth1te } & \multicolumn{2}{|c|}{$\begin{array}{l}\text { Graph10 } \\
\text { gran1 to }\end{array}$} & \multicolumn{2}{|c|}{ Quarts } & \multicolumn{2}{|c|}{ Muscovit to } & \multicolumn{2}{|c|}{ Garnot } & \multicolumn{2}{|c|}{ Tournal ino } & \multicolumn{3}{|c|}{ Lit th1um mineral. } & \multicolumn{3}{|c|}{ Other mineral. } \\
\hline & & & & & & & $\begin{array}{l}\text { Per- } \\
\text { cont }\end{array}$ & S1zo & $\begin{array}{l}\text { Porr } \\
\text { cent }(1\end{array}$ & $\begin{array}{c}\text { s1zo } \\
\text { (1nehoed) }\end{array}$ & $\begin{array}{l}\text { Per- S } \\
\text { )eent (in }\end{array}$ & $\begin{array}{l}\text { S1ze } \\
\text { neheos) }\end{array}$ & $\begin{array}{l}\text { Per- } \\
\text { jeente: }\end{array}$ & \begin{tabular}{|c|} 
S1zo \\
(1nchoos)
\end{tabular} & $\begin{array}{l}\text { Per- } \\
\text { a) centcl } 1\end{array}$ & $\begin{array}{c}\text { S1 ze } \\
\text { 1nohoef) }\end{array}$ & $\begin{array}{l}\text { Per- } \\
\text { ) cont } 12\end{array}$ & 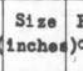 & $\begin{array}{l}\text { Per- } \\
\text { eent }(1\end{array}$ & \begin{tabular}{|l|} 
S1zo \\
inchoses
\end{tabular} & Mineral & $\begin{array}{l}\text { Por- } \\
\text { cent }(1\end{array}$ & $\begin{array}{l}\text { S1zo } \\
\text { 1nchoos) }\end{array}$ & 1) Kineral & $\begin{array}{l}\text { Por- } \\
\text { cent }\end{array}$ & $\begin{array}{c}\text { S1 1 } 0 \\
\text { (1nchoos) }\end{array}$ \\
\hline 1024 & Hornblende gne1 aep. & & Mot exposed. & Lenticular. & $\begin{array}{c}\text { Mall sone. } \\
\text { Coro. }\end{array}$ & $\mid \begin{array}{c}1 / 2 \\
3 / 4-21 / 2\end{array}$ & $2 \begin{array}{l}40 \\
220\end{array}$ & & $\begin{array}{l}28 \\
55\end{array}$ & $2-1 / 2$ & & & $\begin{array}{l}30 \\
25\end{array}$ & & 2 & & & & & & & & & & & \\
\hline 1025 & do. & & do. & do. & $\begin{array}{c}\text { Mall sone. } \\
\text { Core. }\end{array}$ & $\begin{array}{l}1 / 8 \\
1 / 8\end{array}$ & $\begin{array}{l}55 \\
30\end{array}$ & & $\begin{array}{l}10 \\
37\end{array}$ & & & & $\begin{array}{l}30 \\
30\end{array}$ & & $5_{3}^{5}$ & & & & & & & & & & & \\
\hline 1026 & $\begin{array}{l}\text { Fino-gral nod } \\
\text { grant to and horn } \\
\text { blondo gnol hos. }\end{array}$ & Mono. & & do. & $\begin{array}{c}\text { Vall sone. } \\
\text { Coro. }\end{array}$ & $\frac{3 / 8}{2}$ & 45 & & 20 & 5 & 15 & & $\begin{array}{l}20 \\
80\end{array}$ & & 10 & $3 / 8 \mathrm{R}$ & racece. & $1 / 32$ & & & & & & & 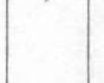 & \\
\hline 1027 & do. & do. & & do. & $\begin{array}{c}\text { Yal1 sono. } \\
\text { Coro. }\end{array}$ & $1 / 16$ & $\begin{array}{l}60 \\
10\end{array}$ & & $\begin{array}{l}20 \\
35\end{array}$ & 3 & & & $\begin{array}{l}15 \\
45\end{array}$ & & 10 & $\begin{array}{l}1 / 2 \\
3 / 4\end{array}$ & Trace. & $1 / 16$ & & & & & & Boryl. 2 & eryotalo.1 & $0.1 / 4-3 / 8$ \\
\hline 1028 & 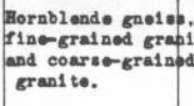 & ito do. & & $\begin{array}{l}\text { Lan t1culas-y- } \\
\text { branohinge }\end{array}$ & $\begin{array}{l}\text { Vall sono. } \\
\text { Coro. }\end{array}$ & $1 / 8$ & $\begin{array}{l}63 \\
15\end{array}$ & & $\begin{array}{l}10 \\
30\end{array}$ & $\frac{1}{4}$ & & & $\begin{array}{l}15 \\
50\end{array}$ & & $\begin{array}{l}5 \\
5\end{array}$ & $\begin{array}{c}1 / 8 \\
1\end{array}$ & 2 & $1 / 64$ & & & & & & Borg1. 1 & eryotal. & $3 / 8$ \\
\hline 1029 & 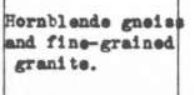 & do. & & do. & One unit. & $1 / 2$ & 40 & & 30 & 4 & & & 20 & & 10 & $1 / 2=x$ & Irace. & $1 / 16$ & & & & & & & & \\
\hline 1030 & do. & do. & & do. & do. & $3 / 4$ & 35 & & 35 & 5 & & & 20 & & 10 & $1 / 27$ & Trace. & $1 / 16$ & & & & & & & & \\
\hline 1031 & do. & & Ilot exposed. & Lent1cular. & do. & $1 / 8$ & 49 & & 30 & 3 & & & 20 & & Trace. & $.1 / 16$ & 1 & $1 / 04$ & & & & & & Beryl. 1 = & eryotal. & $3 / 16$ \\
\hline 1032 & do. & & do. & do. & do. & $1 / 4$ & 53 & & 25 & 4 & & & 20 & & 2 & $1 / 2 \quad I x$ & Irace. & $1 / 16$ & & & & & & do. 1 . & eryetal. & $3 / 16$ \\
\hline 1033 & Hornblende grelas. & & do. & do. & do. & $3 / 8$ & 49 & & 25 & 4 & & & 20 & & 5 & $1 / 4$ & 1 & $1 / 64$ & & & & & & do. 2 & eryetale. & $.1 / 16-1 / 8$ \\
\hline 1034 & do. & & do. & $\begin{array}{l}\text { Lont1 cular } \\
\text { branching. }\end{array}$ & do. & $3 / 16$ & 39.5 & & 30 & 3 & & & 20 & & 10 & $1 / 4$ & 0.5 & $1 / 64$ & & & & & & do. 1 & eryotal. & $3 / 16$ \\
\hline 1035 & $\begin{array}{l}\text { Bornblende gaelab } \\
\text { and f1no-gralnod } \\
\text { grant te. }\end{array}$ & & do. & Lenticular. & do. & $1 / 16$ & 61 & & 20 & 3 & & & 15 & & 2 & $1 / 8$ & 2 & $1 / 64$ & & & & & & $\begin{array}{l}\text { columbit to- } \\
\text { tantall to. }\end{array}$ & 1 cryotal & al. $3 / 8$ \\
\hline 1036 & do. & & do. & do. & do. & $1 / 4$ & 43.5 & & 25 & & & & 20 & & 10 & $1 / 2$ & 0.5 & $1 / 128$ & & & & & & $\begin{array}{l}\text { Cloavoland- } \\
\text { 1 to. } \\
\text { B1otito. } \\
\text { Columbito- } \\
\text { tantalito. } \\
\text { Beryl. } 2 \text {. }\end{array}$ & $\begin{array}{c}1 \\
\text { Trace. } \\
1 \text { cryotal } \\
\text { crystale.1 }\end{array}$ & $\begin{array}{c}3 / 8 \\
1 / 16-1 / 8\end{array}$ \\
\hline 1037 & do. & & do. & do. & do. & $3 / 8$ & 34.5 & & 35 & & & & 20 & & 10 & $1 / 8$ & 0.53 & $1 / 128$ & & & & & & & & \\
\hline 1038 & $\begin{array}{l}\text { lornblende gaol on } \\
\text { fino-grainod gran } \\
\text { nd coorsograingd } \\
\text { gran1to. }\end{array}$ & $\begin{array}{l}\text { Mono. } \\
\text { nite. }\end{array}$ & & $\begin{array}{l}\text { Lont1cular } \\
\text { branch1ng. }\end{array}$ & do. & $1 / 2$ & 40 & & 30 & 3 & & & 20 & & 10 & $3 / 4 \mathrm{rx}$ & Frace. & $1 / 16$ & & & & & & & & \\
\hline 1039 & $\begin{array}{l}\text { Pormblende gaol ad } \\
\text { and fline-grained } \\
\text { granite. }\end{array}$ & & lot exposed. & Lenticular. & . do. & $1 / 8$ & 60 & & 15 & 3 & & & 20 & & 5 & \begin{tabular}{l|l}
$1 / 4$ & 7
\end{tabular} & Trace. & $1 / 128$ & & & & & & $\begin{array}{l}\text { Bory1. } \\
\text { B1ot1t o. }\end{array}$ & $\begin{array}{l}2 \text { eryotal } \\
\text { rrace. }\end{array}$ & a. $\begin{array}{l}3 / 8 \\
1 / 4\end{array}$ \\
\hline 1040 & $\begin{array}{l}\text { Hornblondo gnelse } \\
\text { fino-gral nod grang } \\
\text { and coarsograined } \\
\text { gran1 to. }\end{array}$ & aito, Mono. & & $\begin{array}{l}\text { fonticular } \\
\text { branching. }\end{array}$ & $\begin{array}{l}\text { Rangling } \\
\text { val1 laveot. } \\
\text { Pootval1 } \\
\text { laver. }\end{array}$ & $=.^{1 / 4}$ & $\begin{array}{l}40 \\
78\end{array}$ & & $\begin{array}{l}40 \\
5\end{array}$ & $\begin{array}{l}4 \\
1 / 2\end{array}$ & & & $\begin{array}{l}15 \\
15\end{array}$ & & $\begin{array}{l}5 \\
\text { Irace. }\end{array}$ & $\begin{array}{l}1 / 4 \mathrm{kx} \\
1 / 16\end{array}$ & 2 & $\begin{array}{c}1 / 16 \\
1 / 128\end{array}$ & & & & & & Borgl. 1 o & oryotal. & $3 / 8$ \\
\hline
\end{tabular}




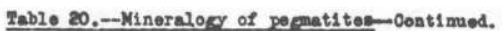

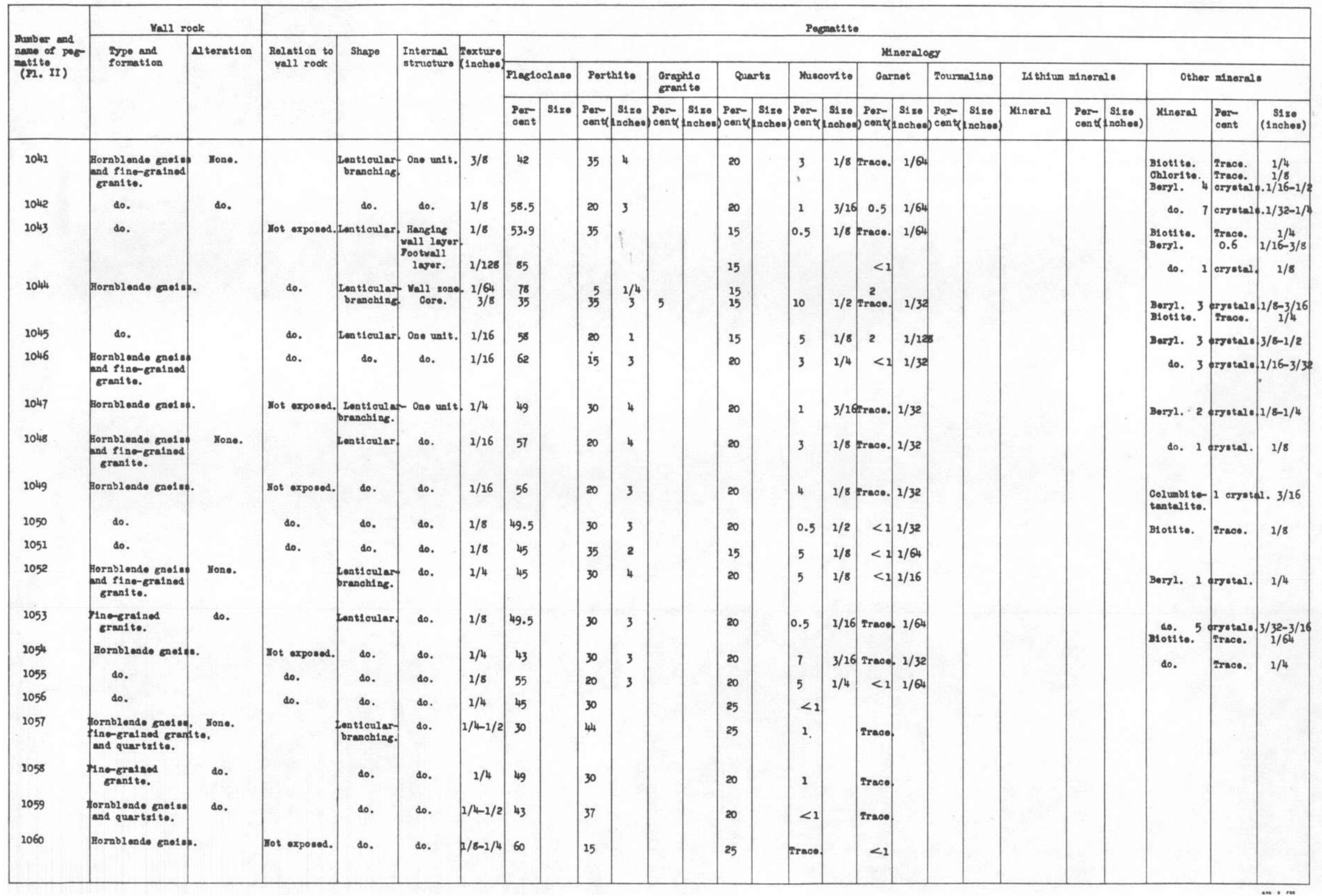


Tablo 20.--Mineralory of pepat1 tog--Cont1 auded.

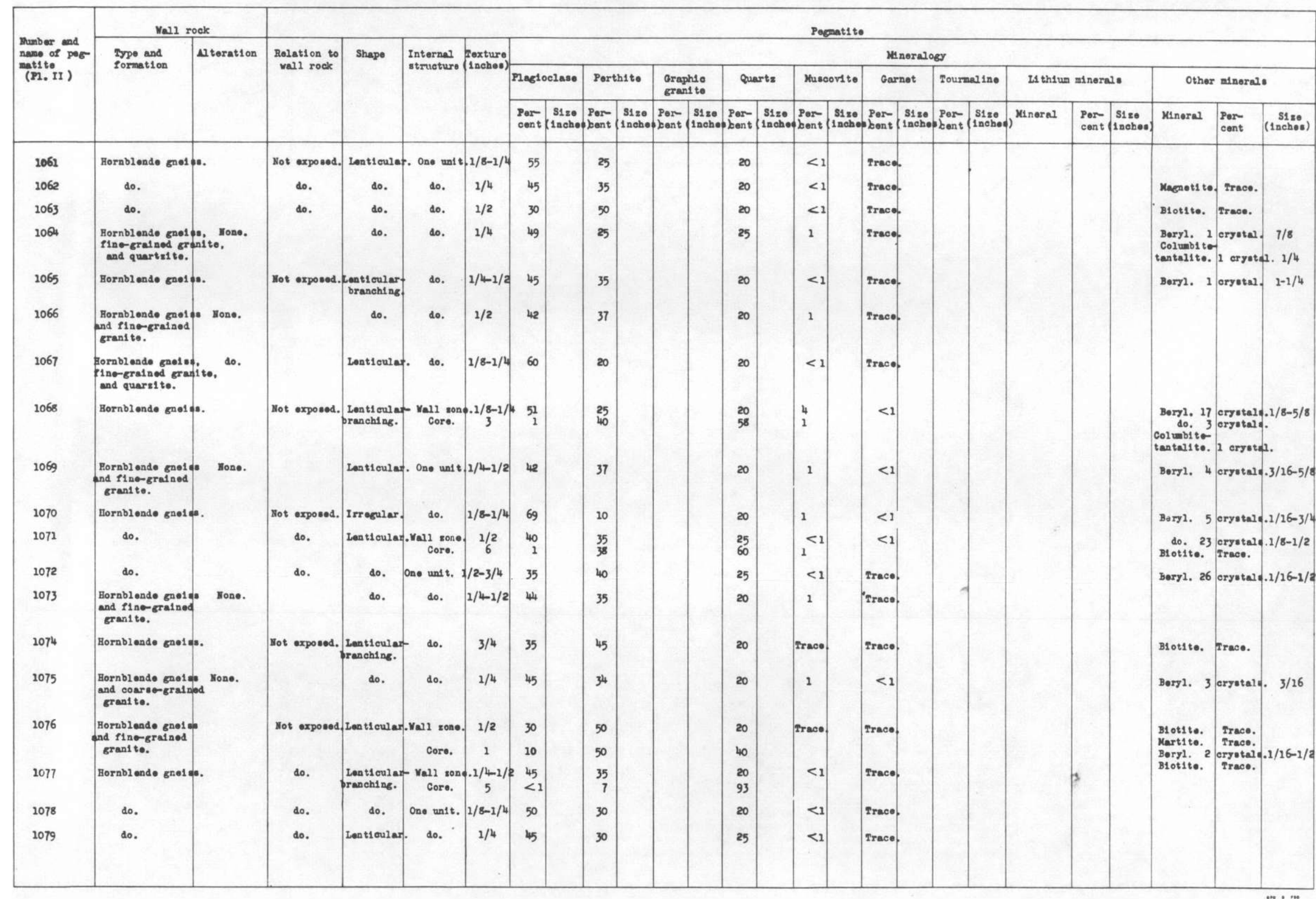


Feb10 20,-Mineralory of pereetitor-Gont1nuod.

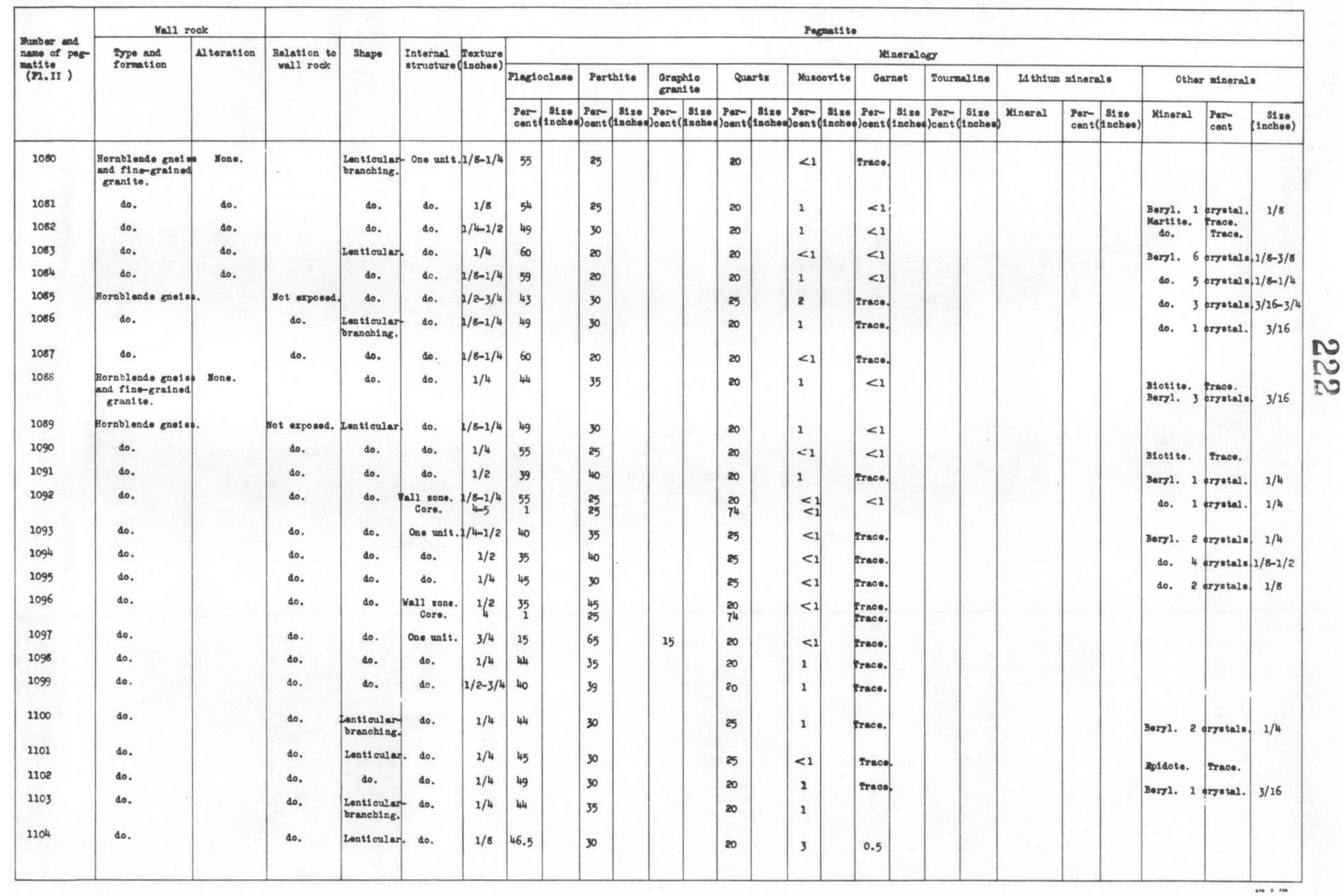




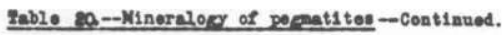

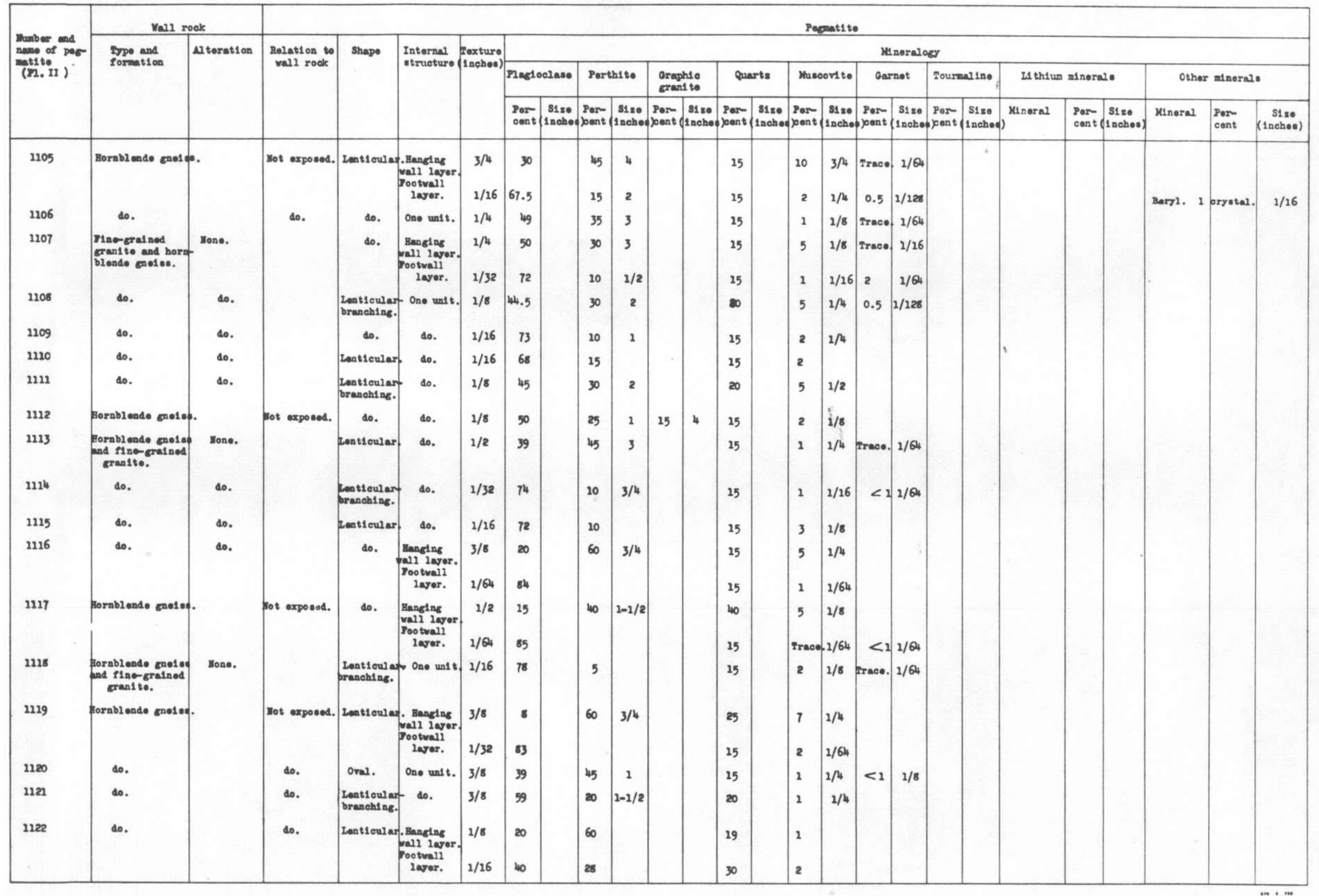


Tab1e 20,--Minoralery of pereatit tef--Continued.

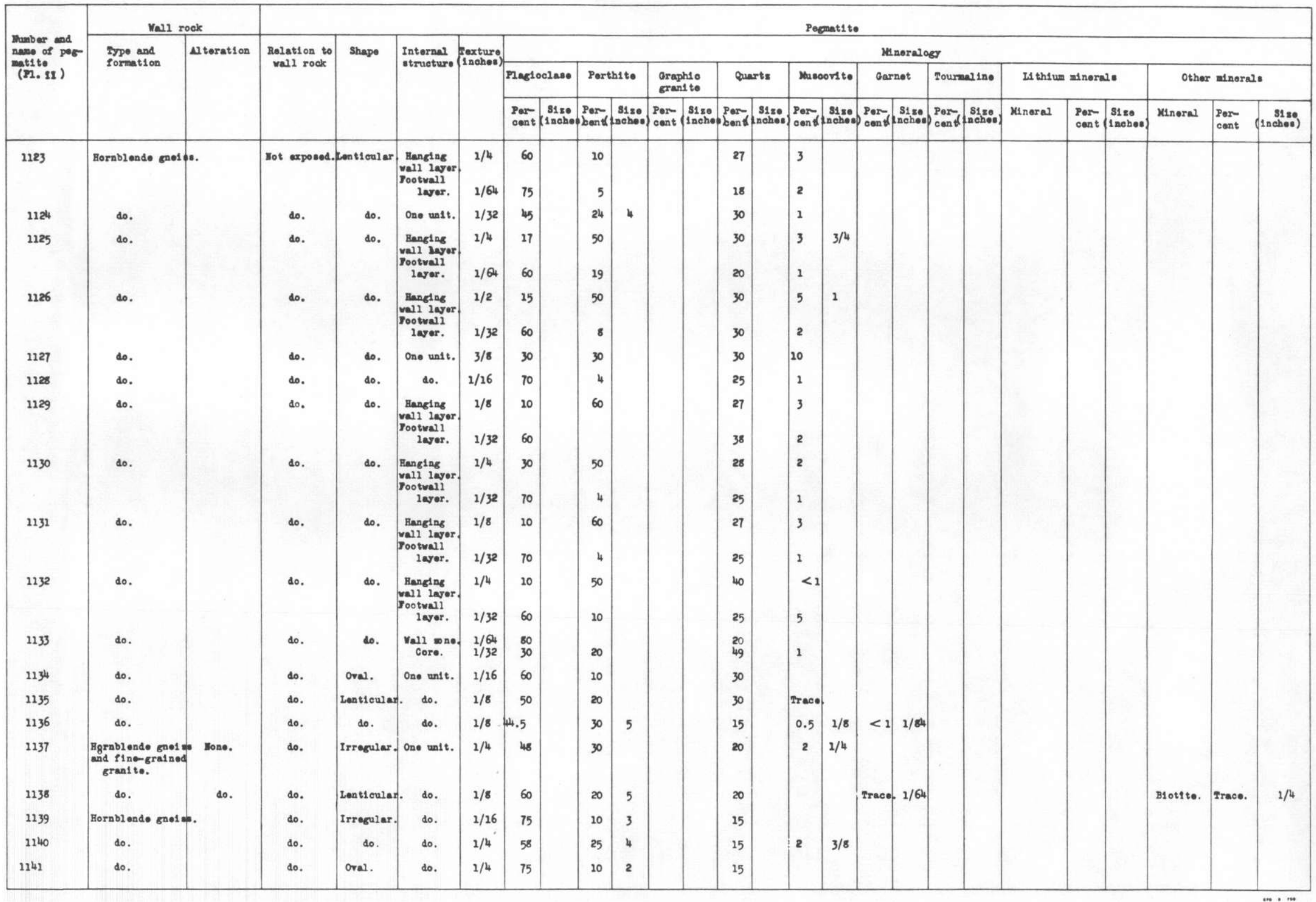




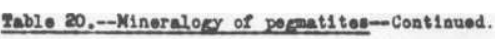

\begin{tabular}{|c|c|c|c|c|c|c|c|c|c|c|c|c|c|c|c|c|c|c|c|c|c|c|c|c|c|c|}
\hline \multirow{4}{*}{$\begin{array}{l}\text { Mumber and } \\
\text { nove of pio } \\
\text { matit to } \\
\text { (II.II) }\end{array}$} & \multicolumn{2}{|c|}{ Wall rook } & \multicolumn{24}{|c|}{ Peonet1 to } \\
\hline & \multirow{3}{*}{$\begin{array}{l}\text { Type and } \\
\text { formation }\end{array}$} & \multirow[t]{3}{*}{ N-1eration } & \multirow{3}{*}{$\begin{array}{l}\text { Rolation to } \\
\text { wall rooke }\end{array}$} & \multirow[t]{3}{*}{ Shape } & \multirow{3}{*}{$\begin{array}{l}\text { Internal } \\
\text { strueturo }\end{array}$} & \multirow{3}{*}{$\begin{array}{l}\text { Soxture } \\
\text { 1nchoos) }\end{array}$} & \multicolumn{20}{|c|}{ Mnoralogy } \\
\hline & & & & & & & \multicolumn{2}{|c|}{ Maglociaso } & \multicolumn{2}{|c|}{ Porth1te } & \multicolumn{2}{|c|}{$\begin{array}{l}\text { Graph10 } \\
\text { gran1 to }\end{array}$} & \multicolumn{2}{|c|}{ guerts } & \multicolumn{2}{|c|}{ Musoovit to } & \multicolumn{2}{|c|}{ Garnot } & \multicolumn{2}{|c|}{ Tourmal ino } & \multicolumn{3}{|c|}{ IS thium minorale } & \multicolumn{3}{|c|}{ Othor minerals. } \\
\hline & & & & & & & $\begin{array}{l}\text { Porr } \\
\text { oont }\end{array}$ & $\left.\begin{array}{c}5180 \\
\text { (1nohod) }\end{array}\right)$ & $\begin{array}{l}\text { Per- } \\
\text { Deent }\end{array}$ & $\begin{array}{l}\text { s1zo } \\
\text { 1nohodx }\end{array}$ & $\begin{array}{l}\text { Por } \\
\text { Deant }\end{array}$ & $\begin{array}{l}\text { s1 so } \\
\text { lnchoot) }\end{array}$ & $\begin{array}{l}\text { Per- } \\
\text { beent }\end{array}$ & $\begin{array}{l}\text { S1so } \\
\text { 1nehoof }\end{array}$ & $\begin{array}{l}\text { Por } \\
\text { beont }\end{array}$ & 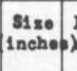 & $\begin{array}{l}\text { Por- } \\
\text { beont }\end{array}$ & 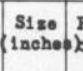 & \begin{tabular}{l|} 
Por \\
Eeant
\end{tabular} & 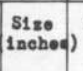 & 1) & $\begin{array}{l}\text { Por- } \\
\text { cont } 1 \text { I }\end{array}$ & \begin{tabular}{|l|} 
S1180 \\
1nchoos:
\end{tabular} & Kinoral & $\begin{array}{l}\text { Por } \\
\text { cent }\end{array}$ & $\begin{array}{c}5120 \\
(1 \text { cohoos })\end{array}$ \\
\hline 1142 & Bornblende gne1 de. & •. & Mot exposed. & Lenticulas. & . Ono unit. & $1 / 2$ & 50 & & 35 & 2 & & & 15 & & & & & & & & & & & & & \\
\hline 1143 & do. & & do. & oval. & do. 2 & $1-1 / 2$ & 45 & & 33 & & 15 & 8 & 20 & & & & & & & & & & & & & \\
\hline 2144 & do. & & do. & Irrogular. & do. & $1 / 4$ & 75 & & 10 & 2 & & & 15 & & 5 & $1 / 4$ & & & & & & & & & & \\
\hline 1145 & do. & & هo. & branchlare. & هo. & $1 / 4$ & 50 & & 25 & & 15 & 6 & 15 & & 10 & $1 / 4$ & & & & & & & & & & \\
\hline 1146 & do. & & do. & Leatioulan. & do. & $1 / 8$ & 50 & & 20 & 3 & 10 & 5 & 20 & & 10 & $1 / 4$ & & & & & & & & & & \\
\hline 1147 & do. & & do. & $\begin{array}{l}\text { Lenticulart- } \\
\text { branching. }\end{array}$ & do. & $1 / 4$ & 56 & & 25 & & 15 & 6 & 15 & & 3 & $1 / 8$ & 1 & $1 / 128$ & & & & & & & & $z$ \\
\hline 1148 & do. & & do. & do. & $\begin{array}{c}\text { Vall sone. } \\
\text { Core. }\end{array}$ & $\begin{array}{l}1 / 8 \\
3 / 4\end{array}$ & $\begin{array}{l}58.5 \\
10\end{array}$ & & 25 & $1^{2} / 2$ & & & $\begin{array}{l}15 \\
30\end{array}$ & & ${ }_{55}^{1}$ & $\begin{array}{c}1 / 8 \\
2\end{array}$ & 0.5 & $1 / 64$ & & & & & & & & \\
\hline 1149 & هo. & & do. & Lont1oular. & One unit. & $1 / 16$ & 72 & & 10 & 2 & & & 15 & & 3 & $1 / 4$ & & & & & & & & & & \\
\hline 1150 & do. & & do. & do. & $\begin{array}{l}\text { Vall sone. } \\
\text { Core. }\end{array}$ & $1 / 4$ & $\begin{array}{l}40 \\
10\end{array}$ & & $\begin{array}{l}30 \\
30\end{array}$ & $\begin{array}{l}3 \\
6\end{array}$ & & & $\begin{array}{l}20 \\
55\end{array}$ & & $\begin{array}{r}10 \\
5\end{array}$ & $\begin{array}{c}1 / 4 \\
1\end{array}$ & & & & & & & & Borg1. 2 & eryotale & $\int_{3-1 / 4}^{1-1 / 2-}$ \\
\hline 1151 & $\begin{array}{l}\text { Coareo-gral ned } \\
\text { gran1 to and } \\
\text { hornbl onde gneil as. }\end{array}$ & Mono. & & do. & One unit. & $1 / 8$ & 45 & & 35 & 3 & & & 15 & & 5 & $1 / 4 \mathrm{~T}$ & Trace. & $1 / 128$ & & & & & & & & \\
\hline 1152 & do. & do. & & đo. & $\begin{array}{l}\text { Banging } \\
\text { rall layer. } \\
\text { Tootwall } \\
\text { layor. }\end{array}$ & $\begin{array}{l}1 / 8 \\
1 / 64\end{array}$ & 40 & & $\begin{array}{l}40 \\
84\end{array}$ & 3 & & & $\begin{array}{l}15 \\
15\end{array}$ & & 5 & $1 / 4$ & 12 & $1 / 128$ & & & & & & & & \\
\hline 1153 & Hornblende gnelas. & & Not expoced & $\begin{array}{l}\text { Lenticular-: } \\
\text { branching. }\end{array}$ & $\begin{array}{l}\text {-Hangling } \\
\text { vall Lavor. } \\
\text { rootvall } \\
\text { lavor. }\end{array}$ & $\begin{array}{l}1 / 8 \\
1 / 64\end{array}$ & 40 & & 40 & 1 & & & $\begin{array}{l}15 \\
15\end{array}$ & & 5 & $3 / 8 \mathrm{~T}$ & Trace. & $\begin{array}{l}1 / 128 \\
1 / 128\end{array}$ & & & & & & & & \\
\hline 1154 & $\begin{array}{l}\text { Pino-grained } \\
\text { granl to and hornt } \\
\text { Diendo gnoles. }\end{array}$ & Mono. & & Lent1 oular. & $\begin{array}{l}\text { Hanging } \\
\text { vall layor } \\
\text { Pootwall } \\
\text { layer. }\end{array}$ & $\begin{array}{c}1 / 8 \\
1 / 64\end{array}$ & $\begin{array}{l}40 \\
80\end{array}$ & & $\begin{array}{c}43.5 \\
5\end{array}$ & $\begin{array}{c}1-1 / 2 \\
1 / 2\end{array}$ & & & $\begin{array}{l}15 \\
15\end{array}$ & & 1 & 1/2 & 0.5 & $\begin{array}{l}1 / 128 \\
1 / 128\end{array}$ & & & & & & & & \\
\hline 2155 & Hornblende gaelob. & & Yot exposed. & Dontioular & $\begin{array}{l}\text { Manging } \\
\text { vall 1evor. } \\
\text { Yolutwall } \\
\text { 1ayor. }\end{array}$ & $\begin{array}{c}3 / 8 \\
1 / 64\end{array}$ & $\begin{array}{l}25 \\
79\end{array}$ & & $\begin{array}{l}45 \\
5\end{array}$ & $\begin{array}{c}2 \\
1 / 4\end{array}$ & & & $\begin{array}{l}20 \\
15\end{array}$ & & 10 & $3 / 4$ & 1 & $1 / 128$ & & & & & & & & $=$ \\
\hline 1156 & do. & & do. & Lent1 evlar & $\begin{array}{l}\text { Mangling } \\
\text { vall } 1 \text { ayor. } \\
\text { 7ootvall } \\
\text { layor. }\end{array}$ & $\begin{array}{l}1 / 16 \\
1 / 64\end{array}$ & $\begin{array}{r}48.5 \\
84\end{array}$ & & 35 & 2 & 25 & 5 & $\begin{array}{l}15 \\
15\end{array}$ & & 1 & $1 / 4$ & $\begin{array}{cc}0.5 \\
1\end{array}$ & $\begin{array}{l}1 / 128 \\
1 / 128\end{array}$ & & & & & & 0 & & \\
\hline 1157 & do. & & do. & $\begin{array}{l}\text { Lenti oulant } \\
\text { branching. }\end{array}$ & One unit. & $1 / 2$ & 15 & & 50 & & 40 & 5 & 20 & & 15 & $1 / 4$ & $<1$ & $2 / 32$ & & & & & & & & \\
\hline 1158 & do. & & do. & Lont1cules. & . do. & $1 / 4$ & 55 & & 20 & 2 & & & 25 & & & & & & & & & & & & & \\
\hline 1159 & do. & & do. & do. & do. & $1 / 8$ & 65 & & 15 & 3 & & & 20 & & Traoed. & $1 / 16$ & & & & & & & & & & \\
\hline 1160 & do. & & do. & $\begin{array}{l}\text { Cont1 cular- } \\
\text { branching. }\end{array}$ & do. & $1 / 8$ & 59 & & 25 & 3 & & & 15 & & 1 & $1 / 8=$ & Irace. & $1 / 8$ & & & & & & & & \\
\hline
\end{tabular}


Feb10 20, -Nineralory of pepat1 ton-Cont1 mod.

\begin{tabular}{|c|c|c|c|c|c|c|c|c|c|c|c|c|c|c|c|c|c|c|c|c|c|c|c|c|c|c|}
\hline \multirow{4}{*}{$\begin{array}{l}\text { Mumbor and } \\
\text { noveo of peo } \\
\text { matit to } \\
\text { (PI.II) }\end{array}$} & \multicolumn{2}{|c|}{ Mell rock } & \multicolumn{24}{|c|}{ Pagmat 1 to } \\
\hline & \multirow{3}{*}{$\begin{array}{l}\text { Type and } \\
\text { format } 1 \text { ion }\end{array}$} & \multirow[t]{3}{*}{ Llteration } & \multirow{3}{*}{$\begin{array}{l}\text { Rolation to } \\
\text { vall rock }\end{array}$} & \multirow[t]{3}{*}{ Shape } & \multirow{3}{*}{$\begin{array}{l}\text { Internal } \\
\text { strueturo } 1\end{array}$} & \multirow{3}{*}{$\begin{array}{l}\text { Texture } \\
(1 \text { 1nchoo })\end{array}$} & \multicolumn{20}{|c|}{ Weneralogy } \\
\hline & & & & & & & \multicolumn{2}{|c|}{ P1agloclaso } & \multicolumn{2}{|c|}{ Perth1te } & \multicolumn{2}{|c|}{$\begin{array}{l}\text { Graph10 } \\
\text { gran1 to }\end{array}$} & \multicolumn{2}{|c|}{ Quartz } & \multicolumn{2}{|c|}{ Musoorlt to } & \multicolumn{2}{|c|}{ Garnot } & \multicolumn{2}{|c|}{ Tournaline } & \multicolumn{3}{|c|}{ IS th1um minerals } & \multicolumn{3}{|c|}{ Other mineral. } \\
\hline & & & & & & & $\begin{array}{l}\text { Per- } \\
\text { cont }\end{array}$ & $\begin{array}{c}\text { S1ze } \\
\text { 1nehoed) }\end{array}$ & $\begin{array}{l}\text { Por- } \\
\text { )eant d1 }\end{array}$ & 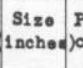 & $\begin{array}{l}\text { Per- } \\
\text { cent (1) }\end{array}$ & \begin{tabular}{l|l}
$\mathbf{S 1 z 0}$ & $P$ \\
1nohoof $)_{0}$
\end{tabular} & $\begin{array}{l}\text { Per- } \\
\text { cent }\end{array}$ & $\begin{array}{l}\text { S1zo } \\
\text { 1nchood) }\end{array}$ & $\begin{array}{l}\text { Per- } \\
\text { Xeont }(1-\end{array}$ & $\begin{array}{l}31 \text { so } \\
\text { inchoo } x\end{array}$ & $\begin{array}{l}\text { Por- } \\
\text { yeont }\end{array}$ & $\begin{array}{l}\text { S1 se } \\
\text { 1nehoop } x\end{array}$ & $\begin{array}{l}\text { Per- } \\
\text { cent }\end{array}$ & $\begin{array}{c}\text { s1ze } \\
\text { (1nehood) }\end{array}$ & Minoral & $\begin{array}{l}\text { Por- } \\
\text { cont }\end{array}$ & $\begin{array}{l}\text { S1se } \\
\text { (1nohoed) }\end{array}$ & Xinoral & $\begin{array}{l}\text { Por- } \\
\text { eent }\end{array}$ & $\begin{array}{c}\text { S1so } \\
\text { (1nchot) }\end{array}$ \\
\hline 1161 & Hornbl ende gnelos. & & Not exposod. & Lantioular. & One unit. & $1 / 4$ & 65 & & 10 & 4 & & & 25 & & & & & & & & & & & & & \\
\hline 1162 & do. & & do. & do. & do. & $3 / 8$ & 60 & & 10 & $1-1 / 2$ & & & 30 & & & & & & & & & & & & & \\
\hline 1163 & do. & & do. & do. & do. & $1 / 8$ & 70 & & 15 & 1 & & & 15 & & & & Trace. & $-1 / 64$ & & & & & & & & \\
\hline 110 & do. & & do. & $\begin{array}{l}\text { Lent1 oulart: } \\
\text { brenching }\end{array}$ & $\begin{array}{l}\text { Kanging } \\
\text { vall sono. } \\
\text { rootval1 } \\
\text { laver. }\end{array}$ & $\begin{array}{l}1 / 2 \\
1 / 64\end{array}$ & 30 & & 10 & $3 / 4$ & & & 20 & & Traco. 1 & $1 / 4$ & trace. 3 & 1/128 & & & & & & & & \\
\hline 1165 & do. & & do. & Lentioules." & $\begin{array}{l}\text { Mall sone. } \\
\text { Corn. }\end{array}$ & ${ }_{3}^{1 / 16}$ & $\begin{array}{l}60 \\
15\end{array}$ & & $\begin{array}{l}20 \\
38\end{array}$ & 2 & & & $\begin{array}{l}15 \\
45\end{array}$ & & $\begin{array}{l}5 \\
2\end{array}$ & $1 / 16$ & & & & & & & & & & \\
\hline 1166 & $\begin{array}{l}\text { Hornblonde, gnolp, } \\
\text { and granl te. }\end{array}$ & Mono. & do. & do. & Ono unit. & $1 / 8$ & 62 & & 20 & 2 & & & 15 & & 3 & $1 / 47$ & Trace. & $1 / 128$ & & & & & & & & \\
\hline 1167 & $\begin{array}{l}\text { Pino-gral nod } \\
\text { grant to and horn- } \\
\text { blonde gneloo. }\end{array}$ & do. & & do. & do. & $1 / 8$ & 50 & & 25 & 3 & & & 20 & & 5 & $1 / 4$ & & & & & & & & & & \\
\hline 1168 & do. & do. & & do. & do. & $1 / 16$ & 69 & & 10 & 1 & & & 20 & & 1 & $1 / 16$ & & & & & & & & & & \\
\hline 1169 & do. & do. & & $\begin{array}{l}\text { Lont1 cular- } \\
\text { branch1ng. }\end{array}$ & $\begin{array}{l}\text { - Vall zono. } \\
\text { Core. }\end{array}$ & ${ }_{3}^{1 / 4}$ & 53 & & $\begin{array}{l}25 \\
10\end{array}$ & $\frac{1}{4}$ & 15 & 5 & $\begin{array}{l}20 \\
80\end{array}$ & & $\frac{2}{10}$ & $\begin{array}{l}2 / 8 \\
3 / 4\end{array}$ & & & & & & & & & & \\
\hline 1170 & Rornblende gaelas. & & Sot exposed. & do. 0 & One unit. & $1 / 8$ & 50 & & 20 & 3 & & & 20 & & 10 & $1 / 4$ & & & & & & & & & & \\
\hline 1171 & $\begin{array}{l}\text { Fornblonde gnel as } \\
\text { and finnograined } \\
\text { gran1to. }\end{array}$ & None. & & Lent1 cular. & do. & $1 / 2$ & 30 & & 50 & 8 & & & 15 & & 5 & $3 / 8$ & $<1$ & $1 / 64$ & & & & & & & & \\
\hline 1172 & do. & do. & & Lont1oular & $\begin{array}{l}\text { Manging } \\
\text { vall laver. } \\
\text { jootwall } \\
\text { laver. } \\
\text { core. }\end{array}$ & $\begin{array}{l}1 / 4 \\
1 / 64 \\
3\end{array}$ & $\begin{array}{l}35 \\
75\end{array}$ & & $\begin{array}{l}40 \\
45\end{array}$ & 5 & & & $\begin{array}{l}15 \\
15 \\
45\end{array}$ & & $\begin{array}{l}10 \\
10 \\
10\end{array}$ & $\begin{array}{l}1 / 4 \\
1 / 64 \\
3 / 4\end{array}$ & $\begin{array}{l}<1 \\
\text { Trace. }\end{array}$ & $1 / 04$ & & & & & & Bary1. 1 & eryetal. & 1 \\
\hline 1173 & Hornblende gneles. & & Not exposed. & Lentioular. & One unit. & \begin{tabular}{l|l}
$1 / 8$ & 6
\end{tabular} & 69.5 & & 15 & 2 & & & 15 & & 0.51 & $1 / 4$ & $<1$ & $1 / 32$ & & & & & & & & \\
\hline 1174 & do. & & do. & $\begin{array}{l}\text { Lont1oulan-y } \\
\text { branch1ng. }\end{array}$ & $\begin{array}{l}\text { Yall zone. } \\
\text { Core. }\end{array}$ & $\begin{array}{c}1 / 8 \\
2\end{array}$ & $\begin{array}{r}60 \\
7\end{array}$ & & $\begin{array}{l}20 \\
50\end{array}$ & & & & $\begin{array}{l}20 \\
43\end{array}$ & & $\begin{array}{l}<1 \\
<1\end{array}$ & & trace. & & & & & & & Boryl. 8 & deryotale. & $1 / 4-1$ \\
\hline 1175 & do. & & do. & Len t1 cular. & One unit.t/ & $1 / 4-1 / 2$ & 54 & & 25 & & & & 20 & & 1 & & Trace. & & & & & & & & & \\
\hline 1176 & do. & & do. & do. & do. $2 /$ & $1 / 4-1 / 2$ & 44 & & 35 & & & & 20 & & 1 & & & & & & & & & & & \\
\hline 1177 & do. & & do. & Irrogular. W & $\begin{array}{l}\text { Veall sone. } \\
\text { Core. }\end{array}$ & $1 / 2$ & $\begin{aligned} 53 \\
1\end{aligned}$ & & $\begin{array}{l}25 \\
30\end{array}$ & & & & $\begin{array}{l}20 \\
66\end{array}$ & & $\frac{2}{3}$ & & $<1$ & & & & & & & & & \\
\hline 1178 & do. & & do. & do. & $\begin{array}{l}\text { Vall sono. } \\
\text { Core. }\end{array}$ & $1 / 2$ & ${ }_{<1}^{35}$ & & $\begin{array}{l}41 \\
15\end{array}$ & & & & $\begin{array}{l}20 \\
85\end{array}$ & & 4 & & $<1$ & & & & & & & & & \\
\hline 1180 & do. & & do. & $\begin{array}{c}\text { do. } \\
\text { Ienticular. }\end{array}$ & $\begin{array}{l}\text { One unit. } \\
\text { Practure } \\
\text { P1111ng. } \\
\text { One unlt. }\end{array}$ & $\begin{array}{c}1 / 2 \\
3 \\
1 / 8-1 / 4\end{array}$ & $\begin{array}{r}40 \\
2 \\
49\end{array}$ & & $\begin{array}{l}40 \\
58 \\
20\end{array}$ & & 10 & & $\begin{array}{l}19 \\
40 \\
30\end{array}$ & & $\begin{array}{l}1 \\
<1 \\
1\end{array}$ & & $<1$ & & & & & & & Boryl. 8 & cryotale. & $.1 / 4-1 / 2$ \\
\hline 1181 & 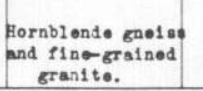 & Yone. & & $\begin{array}{l}\text { Iont1 culart } \\
\text { branchíng. }\end{array}$ & do & $2 / 8-1 / 4$ & 45 & & 33 & & & & 20 & & 2 & & Trace. & & & & & & & & & \\
\hline
\end{tabular}


Teb10 20,--Mineralogy of pematit tos --Continued.

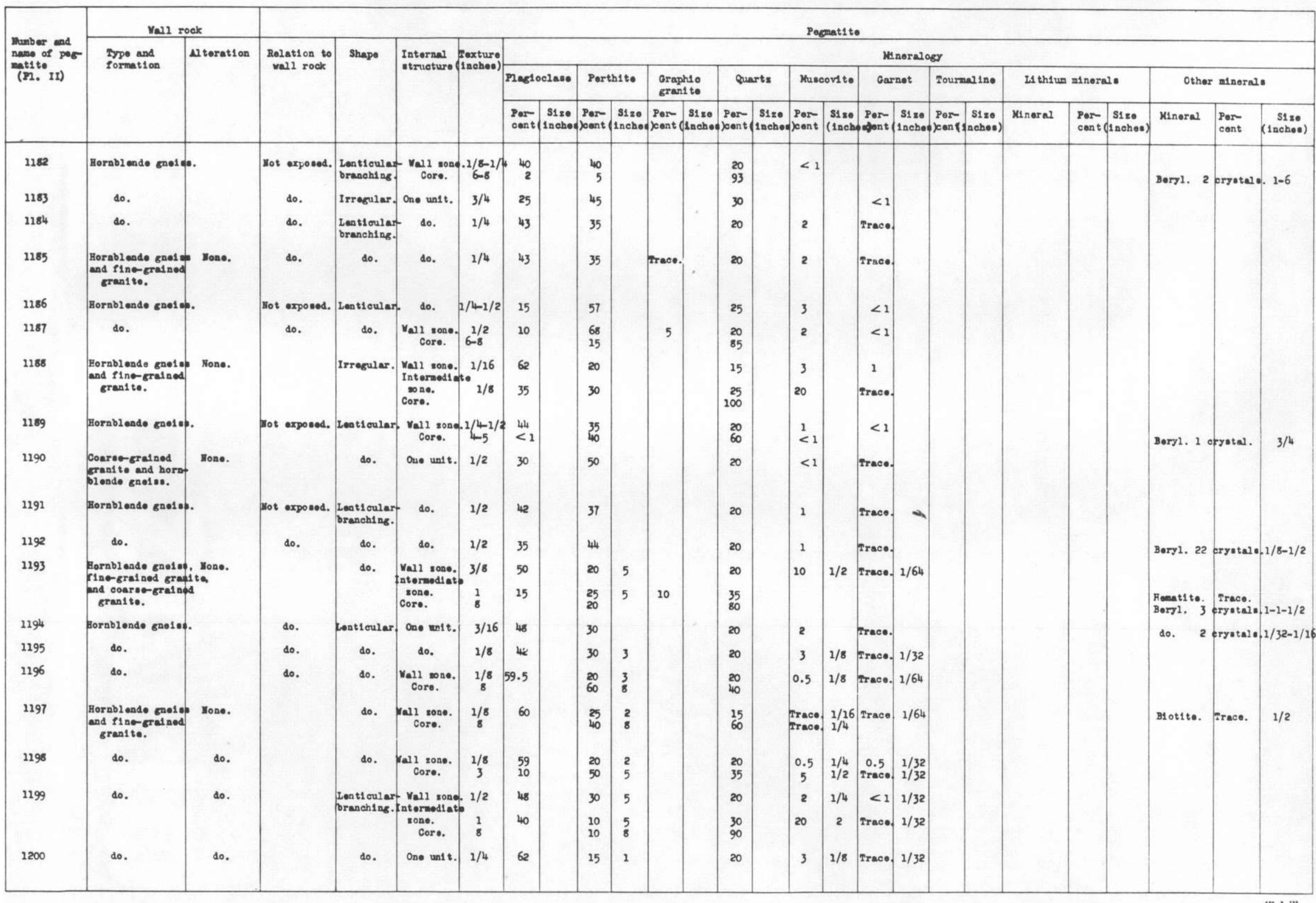


Feb10 20,-Minerelore of peent1 ter-Cont1 nued.

\begin{tabular}{|c|c|c|c|c|c|c|c|c|c|c|c|c|c|c|c|c|c|c|c|c|c|c|c|c|c|c|}
\hline \multirow{4}{*}{ 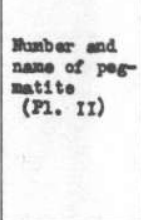 } & \multicolumn{2}{|c|}{ Yell rook } & \multicolumn{24}{|c|}{ Popentito } \\
\hline & \multirow{3}{*}{$\begin{array}{l}\text { Eype and } \\
\text { formation }\end{array}$} & \multirow[t]{3}{*}{ N toration } & \multirow{3}{*}{$\begin{array}{l}\text { Rolation to } \\
\text { wall rook }\end{array}$} & \multirow[t]{3}{*}{ Shape } & \multirow{3}{*}{$\mid \begin{array}{l}\text { Internal } \\
\text { otrueturo }\end{array}$} & \multirow{3}{*}{$\begin{array}{l}\text { Coxture } \\
\text { (1nohoo: }\end{array}$} & \multicolumn{20}{|c|}{ Wharaloer } \\
\hline & & & & & & & \multicolumn{2}{|c|}{ magloolase } & \multicolumn{2}{|c|}{ Porthite } & \multicolumn{2}{|c|}{$\begin{array}{l}\text { Graphse } \\
\text { Eranit to }\end{array}$} & \multicolumn{2}{|c|}{ Quarts } & \multicolumn{2}{|c|}{ Nusoorito } & \multicolumn{2}{|c|}{ Garnot } & \multicolumn{2}{|c|}{ Tournalino } & \multicolumn{3}{|c|}{ LA thium minorale } & \multicolumn{3}{|c|}{ Other minerale } \\
\hline & & & & & & & $\begin{array}{l}\text { Por- } \\
\text { Cont }\end{array}$ & $\begin{array}{l}8180 \\
1 \text { 1nehoo }\end{array}$ & $\begin{array}{l}\text { Por } \\
\text { doent }\end{array}$ & $\begin{array}{l}\text { S1: } \\
\text { Inoheo }\end{array}$ & $\begin{array}{l}\text { Por- } \\
\text { Jeont de }\end{array}$ & $\begin{array}{l}81 \mathbf{s 0} \\
\text { 1neheof }\end{array}$ & $\begin{array}{l}\text { Par- } \\
\text { Soont }\end{array}$ & $\begin{array}{c}3180 \\
1 \text { (1mahood }\end{array}$ & Por & $\begin{array}{l}\text { sisso } \\
\text { 1nohoo }\end{array}$ & Per- & $\begin{array}{l}81 \text { s } \\
\text { 1mohoo }\end{array}$ & $\begin{array}{l}\text { Par- } \\
\text { Cent }\end{array}$ & $\begin{array}{l}8180 \\
\text { 1nched) }\end{array}$ & Winaral & $\underset{\cos t}{\operatorname{Par} t}$ & $\begin{array}{l}81 \Sigma 0 \\
\text { (1nehed) }\end{array}$ & Ninoral & $\begin{array}{l}\text { Porr } \\
\text { oont }\end{array}$ & (1nobes) \\
\hline 1201 & Hornblende ene1 & & Not exposed. & Irragular. & One unit. & $3 / 8$ & 39 & & 40 & 4 & & & 20 & & 1 & $1 / 4$ & $<1$ & $2 / 04$ & & & & & & Boryl. 1 of & tyatal. & $\begin{array}{l}1 / 2 \\
1 / 4\end{array}$ \\
\hline 1202 & do. & & do. & Lent1oular. & $\begin{array}{l}\text { Mall zone. } \\
\text { Coro. }\end{array}$ & $\frac{1 / 4}{5}$ & $\begin{array}{l}50 \\
5\end{array}$ & & $\begin{array}{l}30 \\
35\end{array}$ & $2-1 / 2$ & & & 20 & & Praoos. & $1 / 4$ & Ireoo. & $1 / 6$ & & & & & & Borri. 4 of & trace. & $1 / 1 / 26-1 / 2$ \\
\hline 1203 & do. & & do. & do. & One unit. & $1 / 4$ & 40 & & 35 & 1 & & & 25 & & Prace. & $1 / 4$ & trace. & $1 / 64$ & & & & & & & & \\
\hline 1204 & do. & & do. & do. & do. & $1 / 16$ & 56.5 & & 20 & 3 & & & $\infty$ & & 3 & $1 / 8$ & 0.5 & $1 / 0$ & & & & & & Magenet 1 to. & traoe. & $1 / 4$ \\
\hline 1205 & do. & & هo. & do. & do. & $1 / 16$ & 55 & & 20 & $3 / 4$ & & & 20 & & 5 & $1 / 8$ & $<1$ & & & & & & & & & \\
\hline 1206 & هo. & & do. & $\begin{array}{l}\text { Lont1 cular } \\
\text { branoht ag. }\end{array}$ & $\begin{array}{l}\text { Vall sone. } \\
\text { Enternodiato }\end{array}$ & $1 / 4$ & 50 & & 25 & 3 & & & 20 & & 5 & $1 / 8$ & $<1$ & $1 / 2$ & & & & & & & & \\
\hline & & & & & $\begin{array}{l}\text { sono. } \\
\text { Core. }\end{array}$ & ${ }^{1 / 4}$ & 48 & & $\begin{array}{l}10 \\
40\end{array}$ & 5 & & & $\underset{60}{20}$ & & 20 & 1 & 2 & $1 / 4$ & & & & & & & & \\
\hline 1207 & do. & & do. & Lentioular. & one unit. & $3 / 16$ & 40 & & 30 & 5 & & & 80 & & 20 & $1 / 4$ & $<1$ & $1 / 64$ & & & & & & & & \\
\hline 1208 & $\begin{array}{l}\text { Rornblende gnoi ad } \\
\text { ned fine-gralned } \\
\text { granito. }\end{array}$ & Mono. & & هo. & 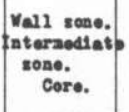 & $3 / 8$ & $\begin{array}{r}44.5 \\
25 \\
20\end{array}$ & & $\begin{array}{l}30 . \\
10 \\
40\end{array}$ & $\begin{array}{l}5 \\
3 \\
8\end{array}$ & & & $\begin{array}{l}20 \\
35 \\
35\end{array}$ & & $\begin{array}{r}5 \\
30 \\
5\end{array}$ & $\begin{array}{l}1 / 8 \\
1 / 4\end{array}$ & 0.5 & $1 / 32$ & & & & & & & & \\
\hline 1209 & Bornbl onde gnel oed & & pot exposod. & do. & $\begin{array}{c}\text { Vall sone. } \\
\text { Core. }\end{array}$ & $1 / 8$ & 45 & & 25 & 3 & & & $\begin{array}{r}80 \\
100\end{array}$ & & 10 & $1 / 4=$ & Irace. & $1 / 32$ & & & & & & & & \\
\hline 1210 & do. & & ه.. & $\begin{array}{l}\text { Zantioulary } \\
\text { oranching. }\end{array}$ & ono unit. & $1 / 4$ & 53 & & 25 & 4 & & & 20 & & 2 & $1 / 4=$ & Trace. & $1 / 16$ & & & & & & & & \\
\hline 1211 & do. & & do. & Len t1 cular. & $\begin{array}{l}\text { Vall sono.t } \\
\text { Core. }\end{array}$ & $\lim _{6-8} / 1 / 2$ & $\begin{array}{r}15 \\
2\end{array}$ & & $\begin{array}{l}59 \\
30\end{array}$ & & & & 25 & & $1<1$ & & $<1$ & & & & & & & & & \\
\hline 1212 & do. & & do. & do. & $\begin{array}{c}\text { Vell sone. } \\
\text { Core. }\end{array}$ & $1 / 2$ & 30 & & 40 & 5 & & & $\begin{array}{r}20 \\
100\end{array}$ & & 10 & $1 / 2=$ & Prace. & $1 / 32$ & & & & & & & & \\
\hline 1213 & $\begin{array}{l}\text { Bornblende gnoled and } \\
\text { ond flnogralnod } \\
\text { granlto. }\end{array}$ & Mone. & & so. & One unit. & $1 / 4$ & 60 & & .25 & & 15 & 5 & 15 & & & & & & & & & & & B1ot1te. & Trace. & $1 / 4$ \\
\hline 12214 & Bornblende gnelece. & & Pot expoesd. & do. & do. & $3 / 8$ & 45 & & 40 & & $\approx$ & & 15 & & & & & & & & & & & Chlor1te. & Irace. & $1 / 4$ \\
\hline 1215 & do. & & do. & do. & do. & $3 / 8$ & 40 & & 35 & 4 & & & 25 & & & & & & & & & & & Macnotit to. & Trace. & $1 / 16$ \\
\hline 1216 & 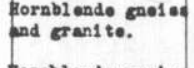 & & do. & do. & do. & $3 / 8$ & 45 & & 30 & & 3 & & 24.5 & & & & 0.5 & $1 / 64$ & & & & & & mentito. & Trace. & \\
\hline 1217 & Fornblende enes eec. & & do. & do. & $\begin{array}{c}\text { Vall wono. } \\
\text { Oore. }\end{array}$ & $\begin{array}{l}1 / 16 \\
1 / 2\end{array}$ & $\begin{array}{l}75 \\
45\end{array}$ & & 30 & 3 & & & $\begin{array}{l}25 \\
25\end{array}$ & & & & & & & & & & & Magnotite. & Irace. & $1 / 16$ \\
\hline 1218 & do. & & do. & do. & One unit. & $1 / 4$ & 40 & & 40 & & 10 & & 20 & & & & & & & & & & & Martite. & Trace. & \\
\hline 1219 & do. & & do. & do. & $\begin{array}{c}\text { vall sone. } \\
\text { core. }\end{array}$ & $1 / 2$ & 15 & & $\begin{array}{l}60 \\
2\end{array}$ & & 10 & & $\begin{array}{l}25 \\
98\end{array}$ & & & & & & & & & & & B1otito. & $\underset{\text { Traco. }}{<1}$ & \\
\hline 1220 & do. & & do. & $\begin{array}{l}\text { Sentieulas } \\
\text { pranching. }\end{array}$ & Ono un1t. & $2-3$ & 15 & & 65 & & & & 20 & & & & & & & & & & & Macrot1 to. & Trace. & \\
\hline 1221 & do. & & do. & pont1eular. & do. & $/ 4-1 / 2$ & 35 & & 40 & & & & 25 & & & & $<1$ & & & & & & & Mart1 to. & prace. & \\
\hline
\end{tabular}


Tab10 20.-Mineralogy of pemet1 tol-Cont1 nued.

\begin{tabular}{|c|c|c|c|c|c|c|c|c|c|c|c|c|c|c|c|c|c|c|c|c|c|c|c|c|c|c|}
\hline \multirow{4}{*}{$\begin{array}{l}\text { Mumber and } \\
\text { nane of peg } \\
\text { mat1 te } \\
\text { (PI. II) }\end{array}$} & \multicolumn{2}{|c|}{ Mall rock } & \multirow{4}{*}{$\begin{array}{l}\text { Relation to } \\
\text { vall rock }\end{array}$} & \multicolumn{23}{|c|}{ Pogmat 1 to } \\
\hline & \multirow{3}{*}{$\begin{array}{l}\text { Type and } \\
\text { formation }\end{array}$} & \multirow[t]{3}{*}{ Llteration } & & \multirow[t]{3}{*}{ Shape } & \multirow{3}{*}{$\begin{array}{l}\text { Internal } \\
\text { strueture of }\end{array}$} & \multirow{3}{*}{$\begin{array}{l}\text { Toxture } \\
\text { (1nchos) }\end{array}$} & \multicolumn{20}{|c|}{ Mtneralogy } \\
\hline & & & & & & & \multicolumn{2}{|c|}{ Plagloclase } & \multicolumn{2}{|c|}{ Porth1te } & \multicolumn{2}{|c|}{$\begin{array}{l}\text { Graph10 } \\
\text { gran1 to }\end{array}$} & \multicolumn{2}{|c|}{ Quartz } & \multicolumn{2}{|c|}{ Muscovit to } & \multicolumn{2}{|c|}{ Garnot } & \multicolumn{2}{|c|}{ Tournal ine } & \multicolumn{3}{|c|}{ II th1um mineral. } & \multicolumn{3}{|c|}{ Other mineral, } \\
\hline & & & & & & & $\begin{array}{l}\text { Par- } \\
\text { conts }\end{array}$ & $\begin{array}{c}51 z 0 \\
(1 \text { cohos) }\end{array}$ & $\begin{array}{l}\text { Por- } \\
\text { )eont (1 }\end{array}$ & $\begin{array}{l}\text { S1zo } \\
\text { 1nchoe. }\end{array}$ & $\begin{array}{l}\text { Port } \\
\text { deoent (1 }\end{array}$ & $\begin{array}{l}\text { S1zo } \\
\text { 1noheof }\end{array}$ & $\begin{array}{l}\text { Per- } \\
\text { deent }\end{array}$ & 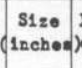 & $\begin{array}{l}\text { Per } \\
\text { deent }(1\end{array}$ & $\begin{array}{c}5120 \\
1 \text { 1ncheid }\end{array}$ & $\begin{array}{l}\text { Per- } \\
\text { cont }(1\end{array}$ & $\begin{array}{c}\text { S1zo } \\
\text { 1noheot }\end{array}$ & $\begin{array}{l}\text { Per- } \\
\text { deant } 1\end{array}$ & $\begin{array}{l}\text { S1zo } \\
\text { 1nchoes) }\end{array}$ & Mineral & $\begin{array}{l}\text { Por } \\
\text { cont }\end{array}$ & 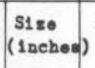 & Ninoral & $\begin{array}{l}\text { Por } \\
\text { cont }\end{array}$ & $\begin{array}{c}\text { S1se } \\
\text { (1nches) }\end{array}$ \\
\hline 1222 & Quarts monzonit to & None. & & $\begin{array}{l}\text { Ionticular- } \\
\text { branching. }\end{array}$ & One unit. & $1 / 8$ & 60 & & 20 & & & & 20 & & arace. & & Trace. & & & & & & & Magnoti to. & Trace. & \\
\hline 1223 & do. & & & do. & do. & $1 / 4$ & 40 & & 40 & v & & & 20 & & & & $<1$ & & & & & & & do. & $<1$ & \\
\hline 1224 & do. & & & do. & do. & $1 / 4$ & 55 & & 25 & & & & 20 & & rrace. & & Trace. & & & & & & & do. & trace. & \\
\hline 1225 & do. & & & Ient1cular. & do. & $3 / 4$ & 20 & & 55 & s. & 10 & & 25 & & & & Trace. & & & & & & & $\begin{array}{l}\text { Mart1to. } \\
\text { B1ot1te. }\end{array}$ & Trace. & \\
\hline 1226 & do. & Mone. & & $\begin{array}{l}\text { Lenticulart } \\
\text { branching. }\end{array}$ & $\begin{array}{c}\text { Wall sone. } \\
\text { Core. }\end{array}$ & $3 / 4-1$ & 10 & & 70 & ' & 15 & & $\begin{array}{r}20 \\
100\end{array}$ & & & & Trace. & & & & & & & $\begin{array}{l}\text { Kartito. } \\
\text { B1ot1 to. }\end{array}$ & $\begin{array}{l}\text { Trace. } \\
\text { Trace. }\end{array}$ & \\
\hline 1227 & do. & & & Ient 1 cular. & One unit. & $3 / 4$ & 25 & & 50 & & 20 & & 25 & & & & & & & & & & & Martite. & Trace. & \\
\hline 1228 & do. & & & $\begin{array}{l}\text { Lont1 culart } \\
\text { branching. }\end{array}$ & do. & $2 / 2-3 / 4$ & 25 & & 55 & & & & 20 & & & & Trace. & & & & & & & $\begin{array}{l}\text { do. } \\
\text { B1otite. }\end{array}$ & $\begin{array}{l}\text { Trace. } \\
\text { Trace. }\end{array}$ & \\
\hline 1229 & $\begin{array}{l}\text { Ruartz monzon1 to } \\
\text { and horrnblende } \\
\text { gne1 ss. }\end{array}$ & None. & & do. & do. & $1 / 4-1 / 2$ & 20 & & 55 & & & & 25 & & & & $<1$ & & & & & & & Meenetite. & $<1$ & \\
\hline 1930 & Ruartz monzonit te. & & & do. & do. & $3 / 4$ & 50 & & 25 & & & & 25 & & & & & & & & & & & $\begin{array}{l}\text { do. } \\
\text { B1otite. }\end{array}$ & $\begin{array}{r}<1 \\
\text { Trace. }\end{array}$ & \\
\hline 1231 & 10. & Mone. & & Irregular. & do. & $1 / 4-1 / 2$ & 35 & & 45 & & & & 20 & & $<1$ & & Trace. & & & & & & & Kagnet 1 te. & $\begin{array}{l}\text { Trace. } \\
\text { Trace. }\end{array}$ & \\
\hline 1232 & Hornblende g geises. & & Hot exposed. & $\begin{array}{l}\text { Lent1 cular } \\
\text { brenching. }\end{array}$ & do. & $1 / 8-1 / 4$ & 50 & & 30 & & & & 20 & & & & Erace. & & & & & & & do. & $\begin{array}{l}\text { Trace. } \\
\text { Trace. }\end{array}$ & \\
\hline 1233 & Ruartz monzonite. & & & Lenticular. & do. 2 & $1 / 4-1 / 2$ & 30 & & 55 & & & & 15 & & $<1$ & $a$ & $<1$ & & & & & & & Kartite. & $<1$ & \\
\hline 1234 & do. & None. & & Irragular. " & $\begin{array}{l}\text { Wall zone. } \\
\text { Core. }\end{array}$ & $1 / 2$ & 15 & & 60 & & & & $\begin{array}{l}25 \\
100\end{array}$ & & & & $<1$ & & & & & & & $\begin{array}{l}\text { do. } \\
\text { Columbito- } \\
\text { tantal1to. }\end{array}$ & $\mid \begin{array}{c}<1 \\
10 \text { cryota }\end{array}$ & ale. \\
\hline 1235 & do. & do. & & do. & One unit. & $1 / 4$ & 20 & & 55 & & & & 25 & & & & & & & & & & & Mart1t o. & $<1$ & \\
\hline 1236 & Bornb1 ende gne1er. & & Hot exposed. & Lont1cular. & do. & $1 / 8$ & 60 & & 15 & & & & 25 & & & & $<1$ & & & & & & & $\begin{array}{l}\text { Megnotite. } \\
\text { B10t1 te. }\end{array}$ & Trace. & \\
\hline 1237 & do. & & do. & do. & do. & $1 / 32$ & 88 & & 5 & $1 / 2$ & & & 15 & & & & & & & & & & & do. & 2 & $1 / 16$ \\
\hline 1238 & do. & & do. & Irregular. $W_{0}$ & $\begin{array}{l}\text { Mall zono. } \\
\text { Core. }\end{array}$ & $1 / 32$ & $\begin{array}{l}80 \\
10\end{array}$ & & 30 & 1 & & & $\begin{array}{l}15 \\
60\end{array}$ & & Trace. & & Trace. & $3 / 8 \mathrm{~F}$ & Irace. 2 & $2-1 / 2$ & & & & $\begin{array}{l}\text { do. } \\
\text { do. } \\
\text { Beryi. } 3 \text { e } \\
\text { semarakt to }\end{array}$ & $\begin{array}{l}\text { Trace. } \\
\text { Frace: } \\
\text { crryetaide. } 3 \\
2 \text { cryotal }\end{array}$ & $\begin{array}{c}1 / 64 \\
1 / 16 \\
3 / 4-1-1 / 2 \\
1.1 / 8\end{array}$ \\
\hline 1239 & do. & & do. & do. & One unit. & $1 / 64$ & 78 & & 5 & 5 & & & 15 & & & & & & & & & & & B1ot1 to. & 2 & $1 / 64$ \\
\hline 1240 & do. & & do. & do. & do. & $1 / 32$ & 75 & & 10 & & & & 15 & & & & & & & & & & & $\begin{array}{l}\text { do. } \\
\text { columb1 to- } \\
\text { tantal1to. }\end{array}$ & $\begin{array}{c}<1 \\
1 \text { eryatal }\end{array}$ & $\begin{array}{r}1 / 32 \\
1.1 / 8\end{array}$ \\
\hline 1241 & do. & & do. & foat1 cular. & do. & $1 / 2$ & 30 & & 55 & & 35 & 3 & 15 & & & & & & Frace. & $1 / 8$ & & & & B1otite. & $<1$ & $1 / 32$ \\
\hline 1242 & do. & & do. & trrogular. & $\begin{array}{c}\text { Wall rone. } \\
\text { Core. }\end{array}$ & $1 / 32$ & $\begin{array}{l}50 \\
60\end{array}$ & & 30 & & & & $\begin{array}{l}20 \\
40\end{array}$ & & & & & & & & & & & $\begin{array}{l}\text { do. } \\
\text { samar akite. }\end{array}$ & $\begin{array}{l}\text { Trace. } \\
2 \text { eryotal }\end{array}$ & $\begin{array}{l}1 / 16 \\
\text { a. } 1 / 8\end{array}$ \\
\hline
\end{tabular}


Tab10 20.-Mineralogy of peenatites-Cont1 nued.

\begin{tabular}{|c|c|c|c|c|c|c|c|c|c|c|c|c|c|c|c|c|c|c|c|c|c|c|c|c|c|c|}
\hline \multirow{4}{*}{$\begin{array}{l}\text { Mumber and } \\
\text { nonve of peg- } \\
\text { matit to } \\
\text { (PI. II) }\end{array}$} & \multicolumn{2}{|c|}{ Wall rock } & \multicolumn{24}{|c|}{ Pouat 1 to } \\
\hline & \multirow{3}{*}{$\begin{array}{l}\text { Typo and } \\
\text { formation }\end{array}$} & \multirow[t]{3}{*}{ Nleration } & \multirow{3}{*}{$\begin{array}{l}\text { Relation to } \\
\text { vall rock }\end{array}$} & \multirow[t]{3}{*}{ Shape } & \multirow{3}{*}{$\begin{array}{l}\text { Internal } \\
\text { structure }\end{array}$} & \multirow{3}{*}{$\begin{array}{l}\text { Moxture } \\
\text { (1nchoo })\end{array}$} & \multicolumn{20}{|c|}{ Mineralogy } \\
\hline & & & & & & & \multicolumn{2}{|c|}{ Plagloclase } & \multicolumn{2}{|c|}{ Porth1te } & \multicolumn{2}{|c|}{$\begin{array}{l}\text { Graph10 } \\
\text { gran1 to }\end{array}$} & \multicolumn{2}{|c|}{ Quartz } & \multicolumn{2}{|c|}{ Muscovd to } & \multicolumn{2}{|c|}{ Garnet } & \multicolumn{2}{|c|}{ Tournalino } & \multicolumn{3}{|c|}{ Li thiun mineral. } & \multicolumn{3}{|c|}{ Other mineral. } \\
\hline & & & & & & & $\begin{array}{l}\text { Por- } \\
\text { cont }\end{array}$ & $\begin{array}{c}\text { s1ze } \\
\text { 1nchos) }\end{array}$ & $\begin{array}{l}\text { Perr } \\
\text { )eont }(1\end{array}$ & 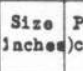 & $\begin{array}{l}\text { Pert } \\
\text { )eent (11: }\end{array}$ & $\begin{array}{l}5120 \\
\text { inche d) }\end{array}$ & Per & \begin{tabular}{|l|} 
S1ze \\
1 1ncheos)
\end{tabular} & $\begin{array}{l}\text { Per } \\
\text { a)cent (12 }\end{array}$ & 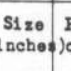 & $\begin{array}{l}\text { Per- } \\
\text { )eont (1 }\end{array}$ & 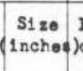 & $\begin{array}{l}\text { Por } \\
\text { Peent }(1\end{array}$ & $\begin{array}{l}\text { Size } \\
\text { inchoes) }\end{array}$ & Minoral & $\begin{array}{l}\text { Por } \\
\text { cent } d_{1}\end{array}$ & \begin{tabular}{|l|} 
S1zo \\
1 1nchoos
\end{tabular} & Kineral & \begin{tabular}{l|} 
Por \\
cont
\end{tabular} & 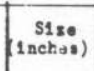 \\
\hline 1243 & Fornblende gnel aes. & & Not exposed. & Irrogular. & $\begin{array}{c}\text { Vall sone. } \\
\text { Core. }\end{array}$ & $1 / 16$ & 75 & & 5 & & & & $\begin{array}{r}20 \\
100\end{array}$ & & & & & & Trace. & $1 / 8$ & & & & B1ot1 te. & Trace. & \\
\hline 1244 & do. & & do. & $\begin{array}{l}\text { Lenticular-s } \\
\text { branch1ng. }\end{array}$ & $\begin{array}{l}\text {-South and. } \\
\text { Morth and. } \\
\text { Core. }\end{array}$ & $\begin{array}{l}1 / 2 \\
1 / 64 \\
2-1 / 2\end{array}$ & $\begin{array}{l}60 \\
84 \\
60\end{array}$ & & 20 & 3 & & & $\begin{array}{l}20 \\
15 \\
40\end{array}$ & & & & Trace. & $1 / 64$ & & & & & & Magnetito. & $\begin{array}{c}\text { Trace. } \\
1\end{array}$ & $\begin{array}{l}1 / 4 \\
1 / 64\end{array}$ \\
\hline 1245 & do. & & do. & Lenticular. & One unit. & $1 / 64$ & 84 & & & & & & 15 & & & & & & & & & & & B1ot1te. & 1 & $1 / 32$ \\
\hline 1246 & do. & & do. & do. & do. & $1 / 8$ & 70 & & 15 & & 5 & 3 & 15 & & & & $<1$ & $1 / 04$ & & & & & & & & \\
\hline 1247 & do. & & do. & Irragular. & do. & $1 / 16$ & 80 & & 5 & 1 & & & 15 & & & & & & & & & & & $\begin{array}{l}\text { Biot1to. } \\
\text { Mart1 to. }\end{array}$ & race. & $\begin{array}{l}1 / 8 \\
1 / 16\end{array}$ \\
\hline 1248 & do. & & do. & do. & $\begin{array}{c}\text { Vall zone. } \\
\text { Core. }\end{array}$ & $1 / 8$ & 65 & & 20 & & 10 & 8 & $\begin{array}{r}15 \\
100\end{array}$ & & Frace. 1 & $1 / 64$ & $<1$ & $1 / 16$ & & & & & & Blot1te. & race. & $1 / 2$ \\
\hline 1249 & do. & & do. & Lent1cular. & One unit. & $1 / 4$ & 70 & & 15 & 6 & & & 15 & & Frace. & $1 / 4 \mathrm{Tx}$ & Trace. & $1 / 64$ & & & & & & & & \\
\hline 1250 & do. & & do. & do. & do. & $1 / 16$ & 75 & & 15 & & 5 & 5 & 10 & & Prace. 1 & $1 / 16$ & $<1$ & $1 / 64$ & & & & & & & & \\
\hline 1251 & do. & & do. & de. & do. & $1 / 16$ & 80 & & 5 & $1 / 2$ & & & 15 & & & & $<1$ & $1 / 64$ & & & & & & B1ot1 te. & $<1$ & $1 / 32$ \\
\hline 1252 & do. & & do. & do. & do. & $1 / 32$ & 75 & & 10 & 3 & & & 25 & & & & $<1$ & $1 / 64$ & & & & & & & & \\
\hline 1253 & do. & & do. & do. & $\begin{array}{l}\text { Vall zono. } \\
\text { tntermodilato } \\
\text { sone. } \\
\text { Core. }\end{array}$ & $\begin{array}{l}1 / 16 \\
1\end{array}$ & $\begin{array}{l}75 \\
30\end{array}$ & & $\begin{array}{l}10 \\
50 \\
25\end{array}$ & 3 & 5 & 3 & $\begin{array}{l}15 \\
20 \\
75\end{array}$ & & trace. 1 & $1 / 8$ & Trace. & $1 / 16$ & & & & & & $\begin{array}{c}\text { B1ot1to. } \\
\text { do. }\end{array}$ & $\begin{array}{l}\text { Trace. } \\
\text { Traco. }\end{array}$ & $\begin{array}{c}1 / 2 \\
2\end{array}$ \\
\hline 1254 & $\begin{array}{l}\text { Coarso-grainod } \\
\text { granits and horn- } \\
\text { blondo gnoles. }\end{array}$ & Mono. & & do. & One unit. & $1 / 16$ & 75 & & 10 & 2 & & & 15 & & & & & & & & & & & Magnet1 to. & irace. & $\begin{array}{l}1 / 32 \\
1 / 32\end{array}$ \\
\hline 1255 & Hornblende gnelse. & & Not exposed. & do. & do. & $1 / 8$ & 55 & & 30 & 3 & & & 15 & & rraco. 1 & $1 / 16 x_{x}$ & Trace. & $1 / 64$ & & & & & & & & \\
\hline 1256 & do. & & do. & do. & do. & $1 / 4$ & 55 & & 30 & & $x$ & 5 & 15 & & & & $<1$ & $1 / 04$ & & & & & & Mart1 to. & $<1$ & $1 / 64$ \\
\hline 1257 & $\begin{array}{l}\text { goarso-gralnod } \\
\text { granito and horn- } \\
\text { blondo gnol oo. }\end{array}$ & Mone. & & oral. & do. & $1 / 8$ & 65 & & 20 & & 10 & 5 & 15 & & rrace. 1 & $1 / 16$ & & & & & & & & Brot1te. & arace. & $1 / 16$ \\
\hline 1258 & do. & do. & & Irragular. & do. & $1 / 16$ & 70 & & 15 & 1 & & & 15 & & frace. 1 & $1 / 16$ & $<1$ & $1 / 64$ & & & & & & & & \\
\hline 1259 & do. & do. & & do. & do. & $1 / 8$ & 55 & & 30 & & 20 & 5 & 15 & & $\begin{array}{lll}1 & 1\end{array}$ & $1 / 8 \quad 2 x$ & Trace. & $1 / 04$ & & & & & & & & \\
\hline 1260 & do. & do. & & $\begin{array}{l}\text { contleulart } \\
\text { branch1ng. }\end{array}$ & do. & $1 / 16$ & 70 & & 15 & 3 & & & 15 & & & & $<1$ & $1 / 32$ & & & & & & & & \\
\hline 1261 & do. & do. & & Irregular. & do. & $1 / 8$ & 65 & & 20 & & 10 & 5 & 15 & & frace. 1 & $1 / 8$ Tr & rrace. & $1 / 32$ & & & & & & & & \\
\hline 1262 & Fornblende gnelas. & & fiot expsead. & Lenticular. & $\begin{array}{l}\text { Mall zone. } \\
\text { Core. }\end{array}$ & $\begin{array}{l}1 / 8 \\
1-1 / 2\end{array}$ & $\begin{array}{l}70 \\
75\end{array}$ & & $\begin{array}{r}15 \\
5\end{array}$ & $\begin{array}{l}1 \\
2\end{array}$ & & & $\begin{array}{l}15 \\
20\end{array}$ & & $\begin{array}{l}\text { fraco. } \\
\text { frace. } \\
1\end{array}$ & $\begin{array}{l}1 / 32 \\
1 / 16=x\end{array}$ & race. & $\begin{array}{c}1 / 64 \\
1 / 32\end{array}$ & & & & & & & & \\
\hline 1263 & do. & & do. & do. & One unit. & $1 / 8$ & 70 & & 10 & $1-1 / 2$ & & & 20 & & & & $<1$ & $1 / 64$ & & & & & & & & \\
\hline 1264 & do. & & do. & $\begin{array}{l}\text { Lont1 cular- } \\
\text { pranching. }\end{array}$ & do. & $1 / 8$ & 50 & & 30 & 3 & & & 20 & & & & $<1$ & $1 / 16$ & & & & & & & & \\
\hline 1265 & do. & & do. & Lentieular. & do. & $1 / 8$ & 50 & & 30 & 5 & 5 & & 20 & & & & $<1$ & $1 / 64$ & & & & & & B1ot1to. & Trace. & $3 / 8$ \\
\hline
\end{tabular}




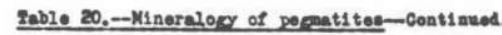

\begin{tabular}{|c|c|c|c|c|c|c|c|c|c|c|c|c|c|c|c|c|c|c|c|c|c|c|c|c|c|c|}
\hline \multirow{4}{*}{$\begin{array}{l}\text { Mumber and } \\
\text { nevo of por } \\
\text { natit to } \\
\text { (II) II) }\end{array}$} & \multicolumn{2}{|c|}{ Mall rook } & \multirow{4}{*}{$\begin{array}{l}\text { Rolation to } \\
\text { vall rookk }\end{array}$} & \multicolumn{23}{|c|}{ Pegnat1 to } \\
\hline & \multirow{3}{*}{$\begin{array}{l}\text { Typo and } \\
\text { formation }\end{array}$} & \multirow[t]{3}{*}{ Nteration } & & \multirow[t]{3}{*}{ Shape } & \multirow{3}{*}{$\begin{array}{l}\text { Interneal } \\
\text { atrueture of }\end{array}$} & \multirow{3}{*}{ Texture } & \multicolumn{20}{|c|}{ Meneralogy } \\
\hline & & & & & & & \multicolumn{2}{|c|}{ Plaglociaso } & \multicolumn{2}{|c|}{ Porth1to } & \multicolumn{2}{|c|}{$\begin{array}{l}\text { Graph10 } \\
\text { gran1 to }\end{array}$} & \multicolumn{2}{|c|}{ Quarts: } & \multicolumn{2}{|c|}{ Musoord to } & \multicolumn{2}{|c|}{ Garnot } & \multicolumn{2}{|c|}{ Tournalino } & \multicolumn{3}{|c|}{ IL th4um minorale } & \multicolumn{3}{|c|}{ Other mineral. } \\
\hline & & & & & & & $\begin{array}{l}\text { Por- } \\
\text { oont }\end{array}$ & $\begin{array}{l}\text { 81zo. } \\
\text { 1nohe. }\end{array}$ & Por- & $\begin{array}{c}\text { S1zo } \\
\text { inchood }\end{array}$ & $\begin{array}{l}\text { Per- } \\
\text { Peont }(1\end{array}$ & $\begin{array}{l}31 \text { zoe } \\
\text { 1neheod }\end{array}$ & Par- & S1zo: & Por, & $\begin{array}{l}\text { s1 so } \\
\text { 1noho. }\end{array}$ & Por- & 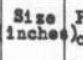 & $\begin{array}{l}\text { Perr } \\
\text { cent }\end{array}$ & 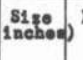 & Minaral & $\underset{\cos t(1}{\text { Por }}$ & $\begin{array}{l}\text { s1so } \\
\text { 1nchos) }\end{array}$ & Kinoral & $\begin{array}{l}\text { Per- } \\
\text { eent }\end{array}$ & (1 s1seto: \\
\hline 1266 & $\begin{array}{l}\text { Tino-gral nod } \\
\text { gran1 to and horo } \\
\text { blendo gnot so. }\end{array}$ & Mone. & & Lenti oular. & . One unt t. & $1 / 8$ & 62 & & 20 & 2 & & & 15 & & 3 & $1 / 4$ & Traoe. & $1 / 12$ & & & & & & & & \\
\hline 1267 & 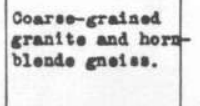 & Ao. & & do. & $\begin{array}{l}\text { Mall sone. } \\
\text { Intormeding. } \\
\text { sone. } \\
\text { Coro. }\end{array}$ & $\int_{1-1 / 2}^{3}$ & $\begin{array}{l}33 \\
30\end{array}$ & & $\begin{array}{l}50 \\
20 \\
15\end{array}$ & 8 & 30 & 3 & $\begin{array}{l}15 \\
30 \\
85\end{array}$ & & 20 & $\begin{array}{c}1 / 4 \\
3\end{array}$ & Treece. & $1 / 16$ & & & & & & & & \\
\hline 1268 & Hornblende gael ge. & & Mot exposed. I & Irregular. & One unt. & $1 / 4$ & 45 & & 40 & & 30 & 5 & 15 & & & & & & & & & & & $\begin{array}{l}\text { M1 otite. } \\
\text { Magnetito. }\end{array}$ & $\begin{array}{r}<1 \\
\text { Traos. }\end{array}$ & $\begin{array}{l}1 / 4 \\
1 / 8\end{array}$ \\
\hline 1269 & $\begin{array}{l}\text { Rornblende gno1 } \\
\text { and granl to. }\end{array}$ & Mone. & Crosscut t1 ng. & do. & do. & $1 / 8$ & 60 & & 15 & 3 & & & $\approx$ & & & & $<1$ & $1 / 32$ & & & & & & do. & $<1$ & $1 / 8$ \\
\hline 1270 & Hornblende gne1 oos. & & Hot exposed. I & Lent1 cular. & do. & $1 / 4$ & 35 & & 50 & & & & 15 & & $<1$ & & $<1$ & & & & & & & & & \\
\hline 1271 & do. & & do. & Irregular. & do. & $3 / 4$ & 49 & & 30 & & & & 20 & & $<1$ & & Trace. & & & & & & & & & \\
\hline 1272 & do. & & do. & Lontioular. & do. & $1 / 4$ & 63 & & 15 & & & & 20 & & 2 & & $<1$ & & & & & & & & & \\
\hline 1273 & do. & & do. do. & $\begin{array}{l}\text { Lent1 oulart- } \\
\text { branching. }\end{array}$ & do. & $3 / 4$ & 49 & & 30 & & & & 20 & & 1 & & Trace. & & & & - & & & & & \\
\hline 1274 & do. & & do. & do. & do. & $1 / 4-1 / 2$ & 58 & & 20 & & & & 20 & & 2 & & $<1$ & & Irace. & & & & & Mertito. & Frace. & \\
\hline 1275 & do. & & do. & do. & do. & $1 / 8-1 / 4$ & 65 & & 15 & & & & 20 & & $<1$ & & $<1$ & & & & & & & & & \\
\hline 1276 & do. & & do. & Lentioular. & do. & $2 / 8-1 / 4$ & 65 & & 25 & & & & 20 & & $<1$ & & $<1$ & & & & & & & & & \\
\hline 1277 & do. & & do. & do. & do. & $1 / 4$ & 54 & & 25 & . & & & 20 & & $<1$ & & $<1$ & & traco. & & & & & $\begin{array}{l}\text { Martite. } \\
\text { B10t1to. }\end{array}$ & Trace. & \\
\hline 2278 & do. & & do. & $\begin{array}{l}\text { Lont1 oulart } \\
\text { branoh1ng. }\end{array}$ & do. & $1 / 4$ & 45 & & 35 & & & & 20 & & trace. & & Trace. & & Trace. & & & & & Martito. & $<1$ & \\
\hline 1279 & $\begin{array}{l}\text { Forablonde gnoles } \\
\text { and flnoograin ned } \\
\text { gran1to. }\end{array}$ & Mono. & 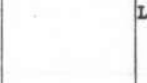 & Lenticular. & do. & $\mid 2 / 8-1 / 4$ & 90 & & 5 & & & & 5 & & & & & & & & & & & Brotito. & $<1$ & \\
\hline 1280 & $\begin{array}{l}\text { Mornblonde gnolob } \\
\text { and quarts mon- } \\
\text { sonite. }\end{array}$ & do. & $i$ & do. & do. & $1 / 4-1 / 2$ & 40 & & 35 & & & & 25 & & $<1$ & & Irace. & & & & & & & & & \\
\hline 1281 & do. & do. & $?$ & Irrogular. & do. & $\mid 1 / 2-3 / 4$ & 35 & & 40 & & & & 25 & & & & Trace. & & & & & & & Mart1 to. & $<1$ & \\
\hline 1282 & 4o. & do. & $\cdots$, & Lont 1oular. & do. & $1 / 2$ & 15 & & 65 & & 5 & & 20 & & & & Trace. & & & & & & & $\begin{array}{l}\text { B1ot1 to. } \\
\text { Magnotito. }\end{array}$ & $\begin{array}{l}<1 \\
<1\end{array}$ & \\
\hline 1283 & do. & do. & & Irrogular. & do. & $1 / 4$ & 35 & . & 45 & & 5 & & 20 & & Traeo. & & Trace. & & & & & & & do. & treses. & \\
\hline 1284 & Forn b1 end o gne1 an. & & Yot exposed. & Lanticular. & do. 1 & $12-24$ & 20 & & 60 & & 70 & & 20 & & & . & & & & & & & & $\begin{array}{l}\text { Brotite. } \\
\text { Magnotite. }\end{array}$ & $\underset{\text { Traco. }}{<1}$ & \\
\hline 1285 & $\begin{array}{l}\text { Pornblonde gno1son } \\
\text { end quarts mon- } \\
\text { zonite. }\end{array}$ & None. & & $\begin{array}{l}\text { Lent1 culart } \\
\text { oraneh1ng. }\end{array}$ & $\begin{array}{c}\text { Yall zone. } \\
\text { Core. }\end{array}$ & $8-12$ & 30 & & 15 & & 60 & & 20 & & $<1$ & & Trace. & & - & & & & & 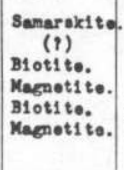 & $\begin{array}{c}\text { Trace. } \\
<1 \\
<1 \\
\text { Trace. } \\
\text { Trace. }\end{array}$ & \\
\hline
\end{tabular}


Fable 20.--Mineralogy of pematiter-Con t1nued.

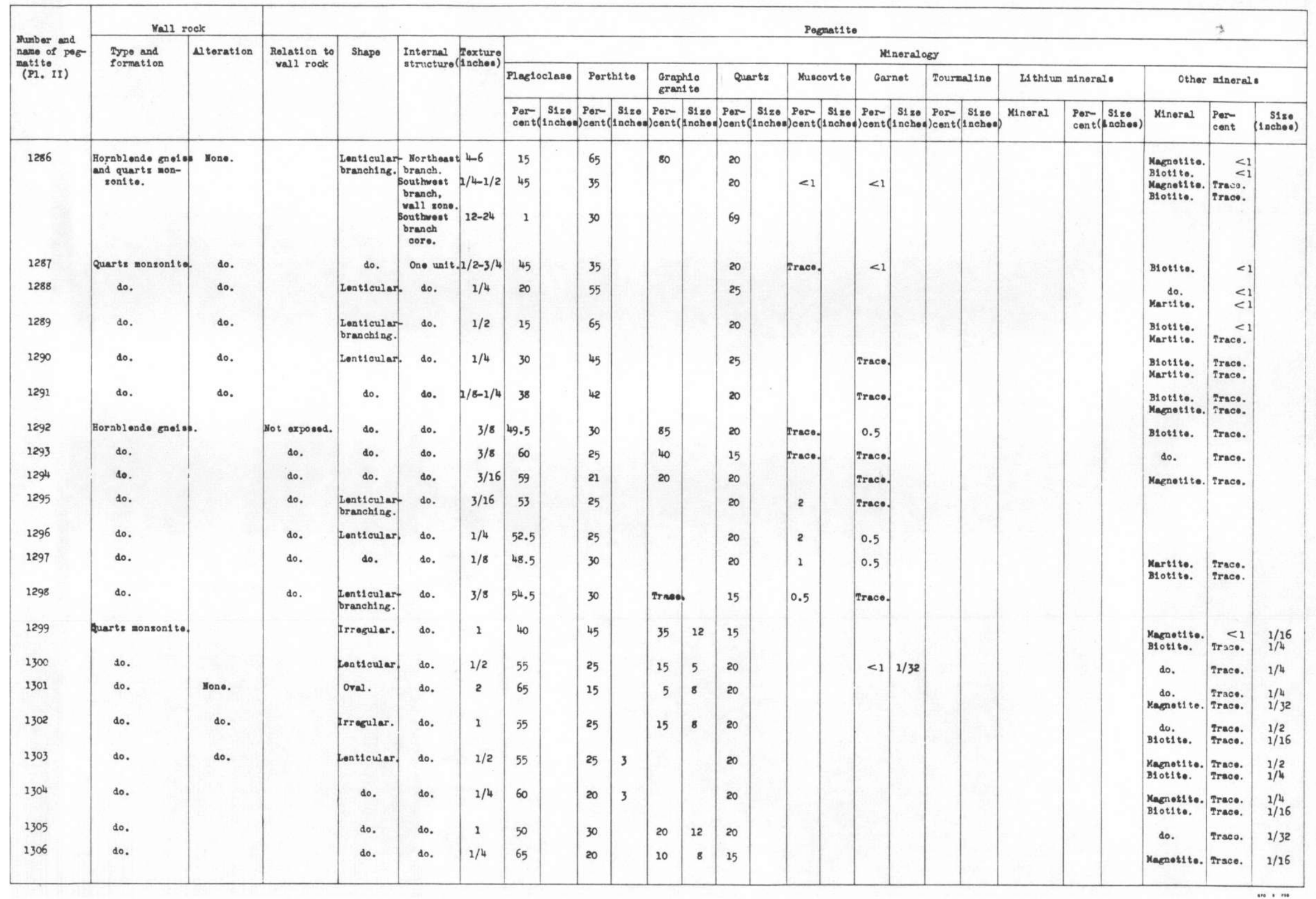


Feb10 20,-Ninerelore of pemat1 ter-cont1nued.

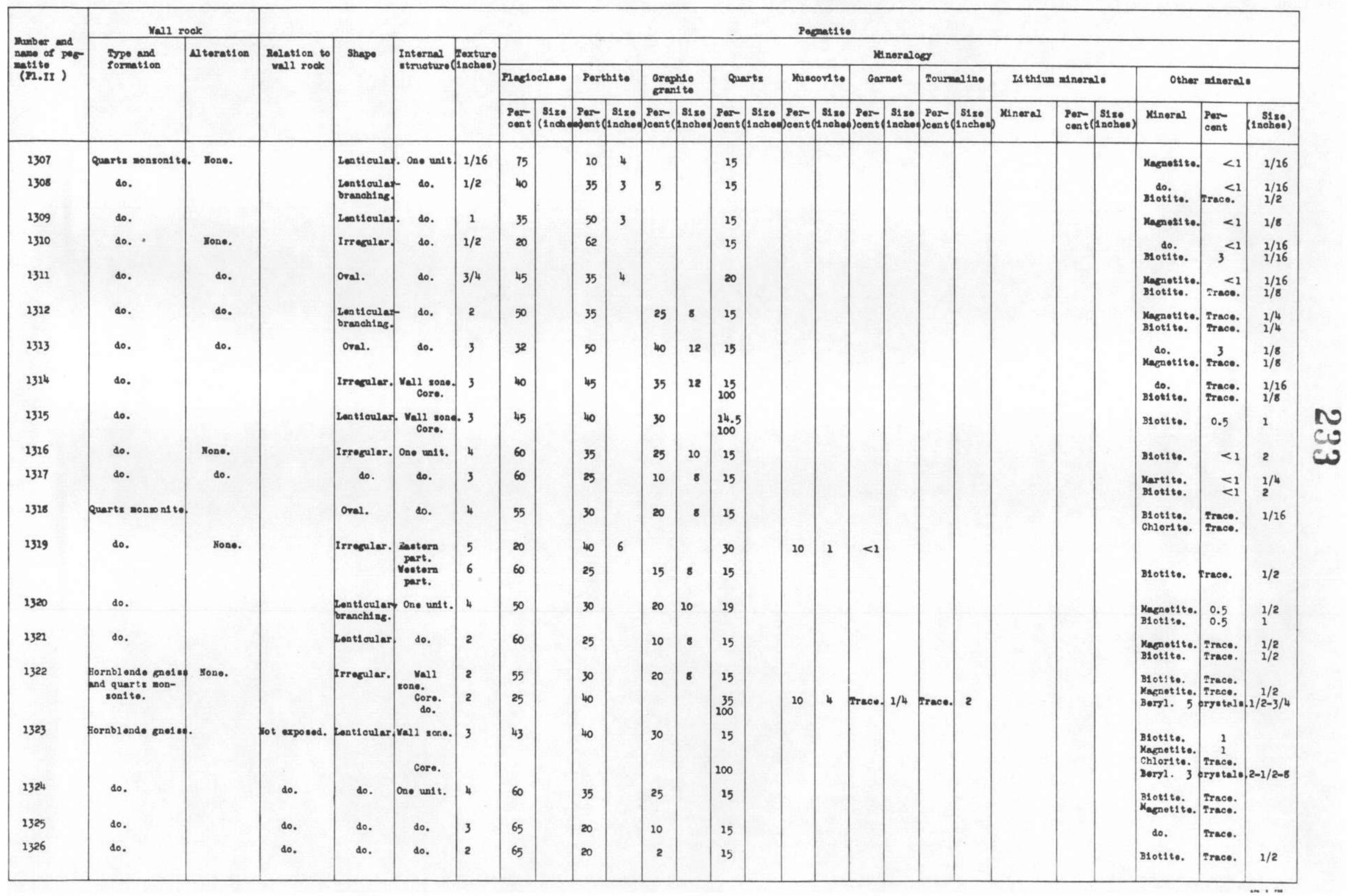


Table 20--Mineralogy of pepat1 tes --Cont1nuod.

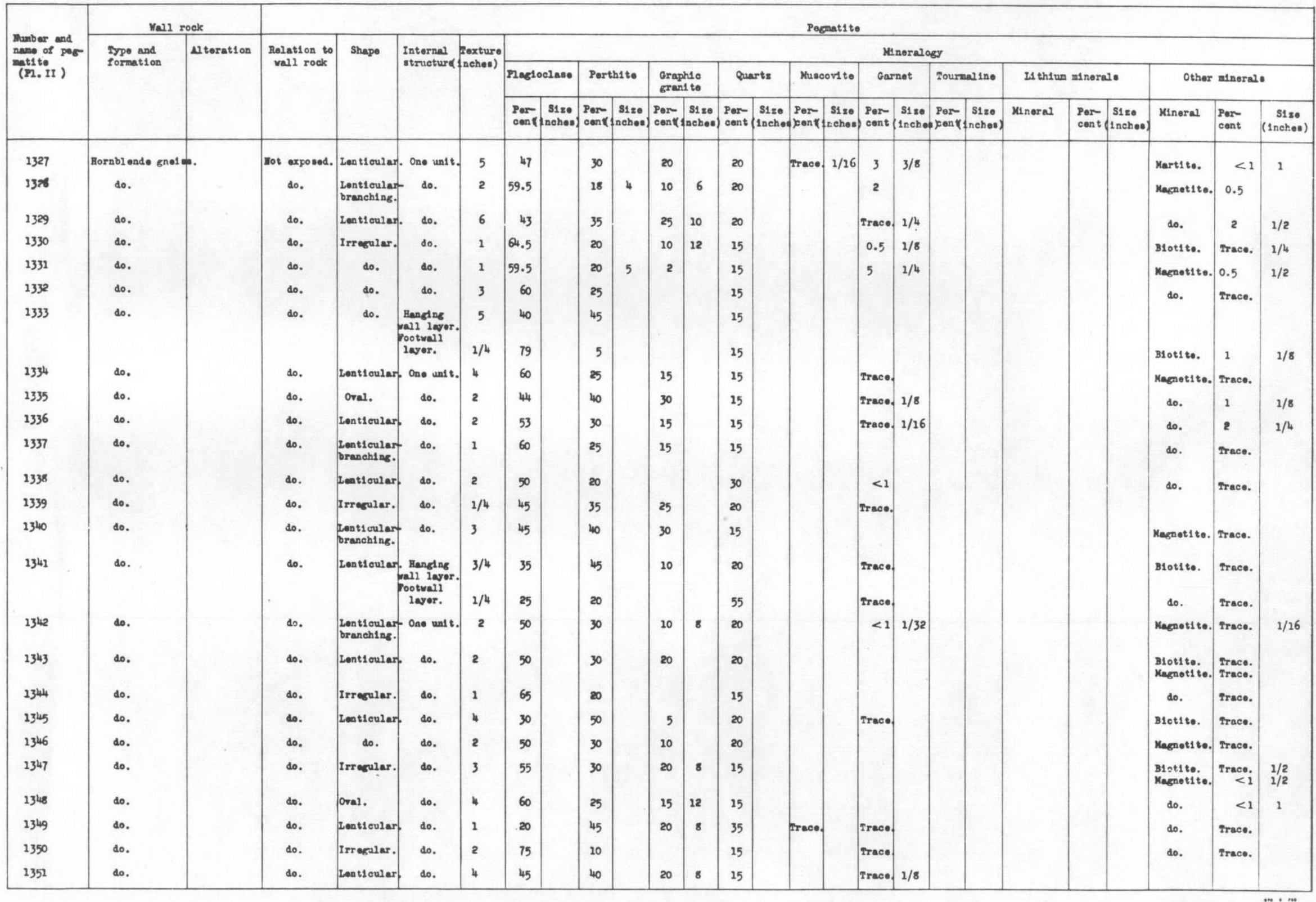


Foble aQ-Mineralocy of pepeatitos-Continued.

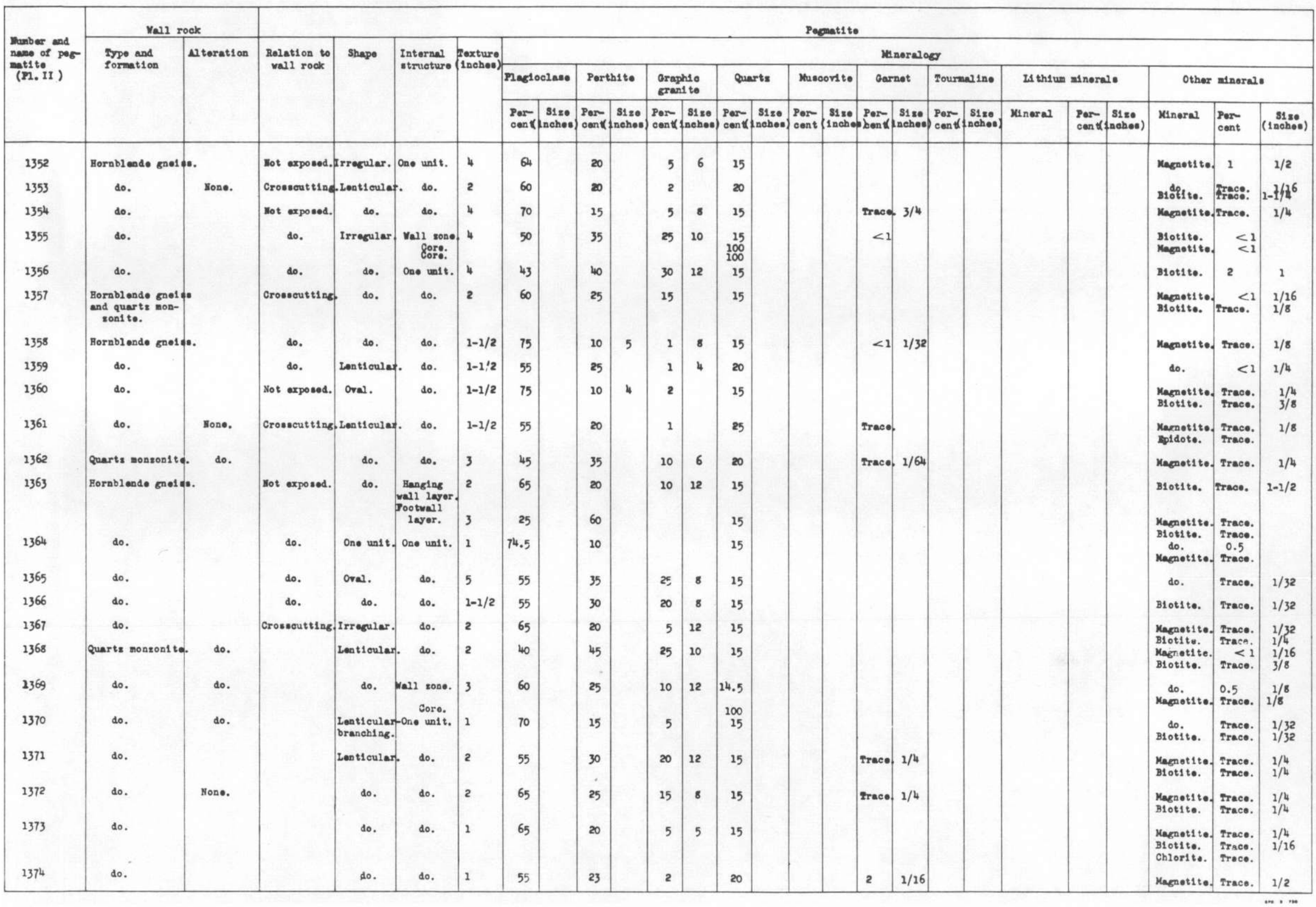


Iab10. --Minoralocy of pepeat1 tos

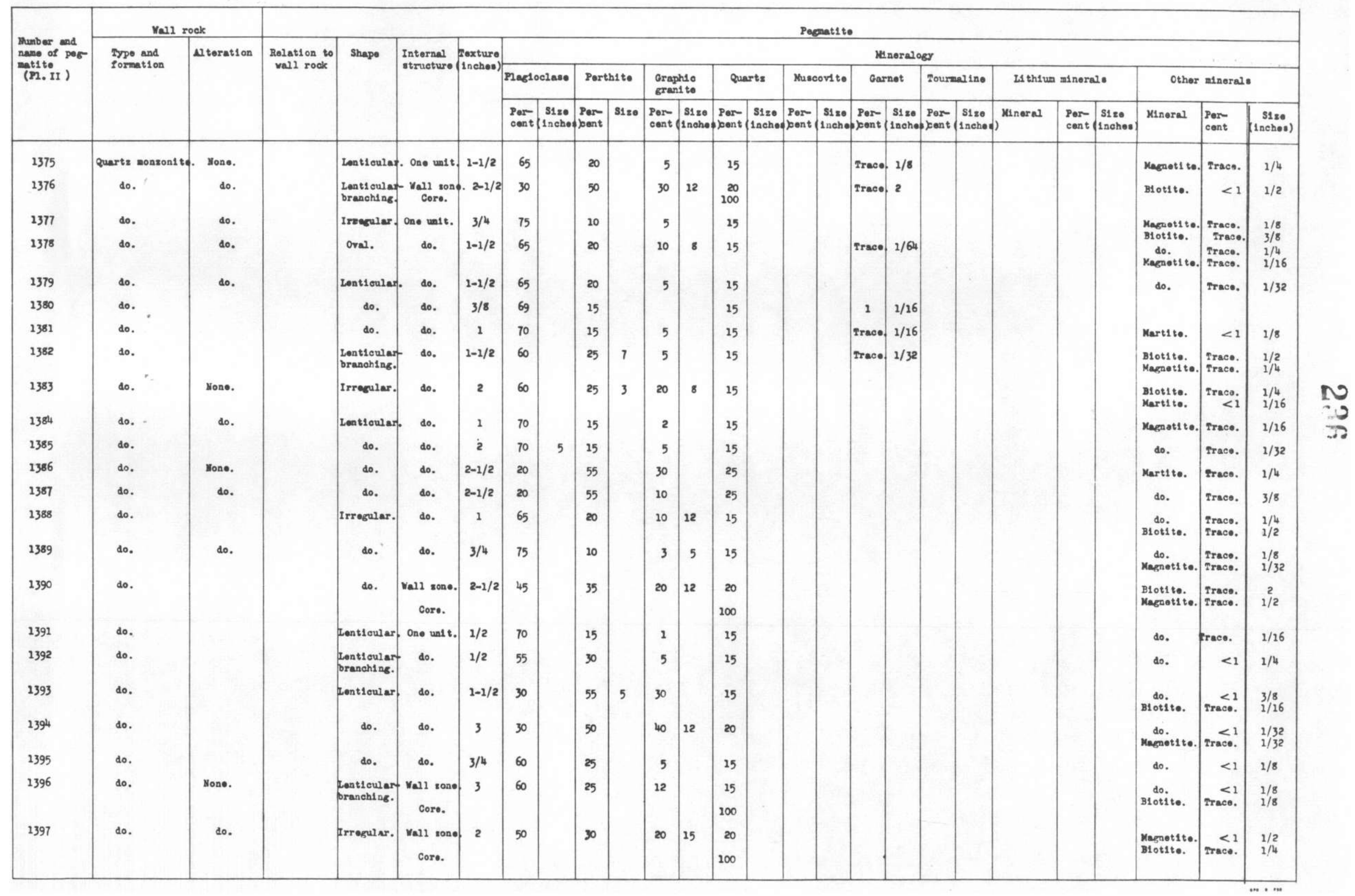


Tab10 20,--Mineralogy of peeat1 tos--Cont1nued.

\begin{tabular}{|c|c|c|c|c|c|c|c|c|c|c|c|c|c|c|c|c|c|c|c|c|c|c|c|c|c|c|}
\hline \multirow{4}{*}{$\begin{array}{l}\text { Mhumber and } \\
\text { name of pog } \\
\text { matit to } \\
\text { (PI. II) }\end{array}$} & \multicolumn{2}{|c|}{ Nall rock } & \multirow{4}{*}{$\begin{array}{l}\text { Rolation to } \\
\text { vall rock }\end{array}$} & \multicolumn{23}{|c|}{ Pograt 1 to } \\
\hline & \multirow{3}{*}{$\begin{array}{l}\text { Type and } \\
\text { formation }\end{array}$} & \multirow[t]{3}{*}{ Nlteration } & & \multirow[t]{3}{*}{ Shape } & \multirow{3}{*}{$\begin{array}{l}\text { Internal } \\
\text { structure }\end{array}$} & \multirow{3}{*}{$\begin{array}{l}\text { Sexture } \\
\text { 1nchos: }\end{array}$} & \multicolumn{20}{|c|}{ Neneralogy } \\
\hline & & & & & & & \multicolumn{2}{|c|}{ Plagioclase } & \multicolumn{2}{|c|}{ Perth1te } & \multicolumn{2}{|c|}{$\begin{array}{l}\text { Graphse } \\
\text { gran1 to }\end{array}$} & \multicolumn{2}{|c|}{ Quartz } & \multicolumn{2}{|c|}{ Muscovit to } & \multicolumn{2}{|c|}{ Garnet } & \multicolumn{2}{|c|}{ Tourmal tho } & \multicolumn{3}{|c|}{ Is thium mineral. } & \multicolumn{3}{|c|}{ Other minerals } \\
\hline & & & & & & & $\begin{array}{l}\text { Par- } \\
\text { cent }\end{array}$ & $\begin{array}{l}\text { S1zo } \\
\text { (nehood) }\end{array}$ & $\begin{array}{l}\text { Per- } \\
\text { cont }\end{array}$ & $\begin{array}{l}\text { S1ze } \\
\text { 1nchoof }\end{array}$ & $\begin{array}{l}\text { Per- } \\
\text { cent } \\
(1\end{array}$ & $\begin{array}{l}\text { S1ze } \\
\text { 1ncheof }\end{array}$ & $\begin{array}{l}\text { Por } \\
\text { ) cent }\end{array}$ & $\begin{array}{l}\text { S1zo } \\
\text { 1nohody }\end{array}$ & \begin{tabular}{l|l} 
Per & s \\
cent & 1n
\end{tabular} & $\begin{array}{l}\text { S1so } \\
\text { inchog } x\end{array}$ & $\begin{array}{l}\text { Per- } \\
\text { )eont (1 }\end{array}$ & 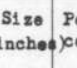 & $\begin{array}{l}\text { Por } \\
\text { cent }\end{array}$ & $\begin{array}{l}\text { S1ze } \\
\text { 1ncheos) }\end{array}$ & )$^{\text {Mineral }}$ & $\begin{array}{l}\text { Por- } \\
\text { cent } d_{1}\end{array}$ & $\begin{array}{c}\text { S1zo } \\
\text { (1noheos) }\end{array}$ & Kinaral & $\begin{array}{l}\text { Per } \\
\text { cent }\end{array}$ & $\begin{array}{c}51 \text { ses } \\
\text { (1 1 nchou })\end{array}$ \\
\hline 1398 & Quarts monsonite. & . Bone. & & Oval. & One unit. & $1 / 32$ & 10 & & 72 & & & & 15 & & & & & & & & & & & B1ot1 to. & 3 & $1 / 32$ \\
\hline 1399 & do. & do. & & Irragular. & do. & $1 / 32$ & 20 & & 65 & & & & 15 & & & & & & & & & & & $\begin{array}{l}\text { Magnetit to. } \\
\text { B1 ot1 to. }\end{array}$ & $\underset{\text { mace. }}{<1}$ & $\begin{array}{l}1 / 16 \\
1 / 16\end{array}$ \\
\hline 1400 & do. & do. & & do. & do. & $3 / 4$ & 70 & & 15 & & 10 & 12 & 15 & & & & & & & & & & & Magnotito. & Trace. & $1 / 32$ \\
\hline 1401 & do. & do. & & do. & do. & $1 / 8$ & 75 & & 10 & & & & 15 & & & & & & & & & & & do. & Trace. & $1 / 16$ \\
\hline $\begin{array}{l}1402 \\
\text { Tr10 \10. } 1\end{array}$ & do. & do. & & do. & $\begin{array}{l}\text { Vall ono. } \\
\text { Interzodiate }\end{array}$ & - $1 / 4$ & 50 & & 25 & 1 & 10 & 12 & 15 & & & & & & & & & & & $\begin{array}{l}\text { Biot1 to. } \\
\text { Magnet1 to. }\end{array}$ & $\begin{array}{l}\text { Trace. } \\
\text { Trace. }\end{array}$ & $\begin{array}{l}1 / 16 \\
1 / 8\end{array}$ \\
\hline & & & & & $\begin{array}{l}\text { sone. } \\
\text { do. } \\
\text { Core. }\end{array}$ & $\begin{array}{l}6 \\
1\end{array}$ & $\begin{array}{l}34 \\
25\end{array}$ & $\begin{array}{l}2 \\
3\end{array}$ & 30 & 18 & & & $\begin{array}{r}35 \\
60 \\
100\end{array}$ & & 25 & 1 & $\begin{array}{c}0.5 \\
<1\end{array}$ & \begin{tabular}{l|l}
$1 / 2$ & $\operatorname{Tr}$ \\
$1 / 2$ &
\end{tabular} & aco. & 2 & & & & $\begin{array}{l}\text { B1ot1te. } \\
\text { Beryl. } 6=\end{array}$ & $\begin{array}{c}0.5 \\
\text { cryotale. }\end{array}$ & $1 / 2-8$ \\
\hline 1403 & do. & do. & & $\begin{array}{l}\text { Lent1 oular- } \\
\text { branch1ng. }\end{array}$ & One unit. & $.1 / 4$ & 55 & & 25 & & & & 20 & & & & & & & & & & & Magnoti to. & Trace. & $1 / 16$ \\
\hline 1404 & do. & & & Irragalar. & $\begin{array}{c}\text { Val1 zone. } \\
\text { Core. }\end{array}$ & $\begin{array}{l}1 / 32 \\
1 / 2\end{array}$ & $\begin{array}{l}60 \\
45\end{array}$ & & $\begin{array}{l}20 \\
40\end{array}$ & & & & $\begin{array}{l}20 \\
15\end{array}$ & & & & & & & & & & & $\begin{array}{l}\text { do. } \\
\text { do. }\end{array}$ & Trace. & $\begin{array}{l}1 / 16 \\
1 / 8\end{array}$ \\
\hline 1405 & do. & & & do. & Ono unit. & $1 / 2$ & 45 & & 15 & 2 & & & 40 & & & & & & & & & & & do. & $\begin{array}{l}\text { Trace. } \\
\text { Trace. }\end{array}$ & $\begin{array}{l}1 / 16 \\
1 / 32\end{array}$ \\
\hline 1406 & do. & & & Oral. & $\begin{array}{c}\text { vall sono. } \\
\text { Core. }\end{array}$ & $\begin{array}{l}1 / 64 \\
1 / 4\end{array}$ & $\begin{array}{r}79 \\
55\end{array}$ & & 30 & & & & $\begin{array}{l}15 \\
15\end{array}$ & & racoe. 1 & $1 / 64$ & & & & & & & & $\begin{array}{l}\text { do. } \\
\text { do. }\end{array}$ & $\underset{\text { Trace. }}{1}$ & $\begin{array}{l}1 / 64 \\
1 / 8\end{array}$ \\
\hline 1407 & do. & Mone. & & $\begin{array}{l}\text { Lont1cular- } \\
\text { branohing. }\end{array}$ & $\begin{array}{l}\text { Mall sone. } \\
\text { Coro. }\end{array}$ & $\begin{array}{l}1 / 32 \\
1 / 4\end{array}$ & $\begin{array}{r}79.5 \\
55\end{array}$ & & 30 & 2 & & & $\begin{array}{l}15 \\
15\end{array}$ & & Frace. & & & & & & & & & $\begin{array}{l}\text { do. } \\
\text { do. }\end{array}$ & $\begin{array}{c}0.5 \\
\text { Trace. }\end{array}$ & \\
\hline 1408 & do. & do. & & Irregular. & Ono un1t. & $3 / 8$ & 65 & & 15 & & & & 20 & & & & & & & & & & & Magnet1 to. & $<1$ & $1 / 16$ \\
\hline 1409 & do. & & & do. & do. & $1 / 2$ & 55 & & 30 & 1 & & & 15 & & & & & & & & & & & $\begin{array}{l}\text { B1ot1 te. } \\
\text { Magnatite. }\end{array}$ & $\begin{array}{r}\text { Trace: } \\
<1\end{array}$ & $\begin{array}{l}1 / 16 \\
1 / 4\end{array}$ \\
\hline 1410 & do. & Mone. & & Lent1 cular. & do. & $1 / 8$ & 70 & & 15 & 2 & 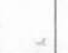 & & 15 & & & & & & & & & & & B1otite. & $<1$ & $1 / 8$ \\
\hline 1411 & do. & do. & & do. & do. & $1 / 2$ & 65 & & 75 & 2 & & & 20 & & & & & & & & & & & $\begin{array}{l}\text { B1ot1 to. } \\
\text { Magrotit to. }\end{array}$ & Trace. & $\begin{array}{l}1 / 8 \\
1 / 8\end{array}$ \\
\hline 1412 & do. & do. & & Irrogular. & do. & 2 & 30 & & 50 & & 40 & 8 & 20 & & & & & & & & & & & B1otito. & Trace. & $1 / 4$ \\
\hline 1413 & do. & do. & & Lont1 cular. & do. & $3 / 4$ & 35 & & 50 & & 40 & 5 & 15 & & & & & & & & & & & Magnet1 te. & Trace. & $1 / 4$ \\
\hline $\begin{array}{l}1414 \\
\text { Snoveboe }\end{array}$ & do. & do. & & Irrogular. & $\begin{array}{c}\text { vall soase. } \\
\text { Gore. }\end{array}$ & 3 & 30 & & 50 & & 40 & & $\begin{array}{r}20 \\
100\end{array}$ & & & & & & & & & & & $\begin{array}{c}\text { do. } \\
\text { B1otite. }\end{array}$ & Trac9. & $\begin{array}{l}1 / 4 \\
1 / 2\end{array}$ \\
\hline 1415 & do. & do. & & do. & One unit. & 3 & 30 & & 50 & & 40 & 8 & 20 & & & & & & & & & & & $\begin{array}{l}\text { Karnet1 te. } \\
\text { B1ot1te. }\end{array}$ & $\begin{array}{l}\text { Trace. } \\
\text { Trace. }\end{array}$ & $\begin{array}{l}1 / 8 \\
1 / 2\end{array}$ \\
\hline 1416 & do. & do. & & Lant1oular. & do. & 1 & 55 & & 15 & & 5 & & 30 & & & & & & & & & & & Magnotito. & Trace. & $1 / 16$ \\
\hline 1417 & do. & do. & & Irregular. & do. & $1 / 2$ & 30 & & 20 & 3 & & & 50 & & & & & & & & & & & do. & Trace. & $1 / 16$ \\
\hline 1418 & do. & do. & & do. & so. & $1 / 4$ & 10 & & 65 & & & & 25 & & & & & & & & & & & $\begin{array}{l}\text { Martit te. } \\
\text { B1ot1 te. }\end{array}$ & $\begin{array}{l}\text { Trace. } \\
\text { Trace. }\end{array}$ & \\
\hline 1419 & do. & do. & & $\begin{array}{c}\text { Lont1eular. } \\
\text { Core. }\end{array}$ & Vall sone. & $3 / 4$ & 35 & & 45 & & 5 & & $\begin{array}{r}20 \\
200 \\
\end{array}$ & & & & & & & & & & & Mart1 te. & Trace. & \\
\hline
\end{tabular}


Feb10 20,-Minoralogy of pepeat1 tos--Cont1 nuod.

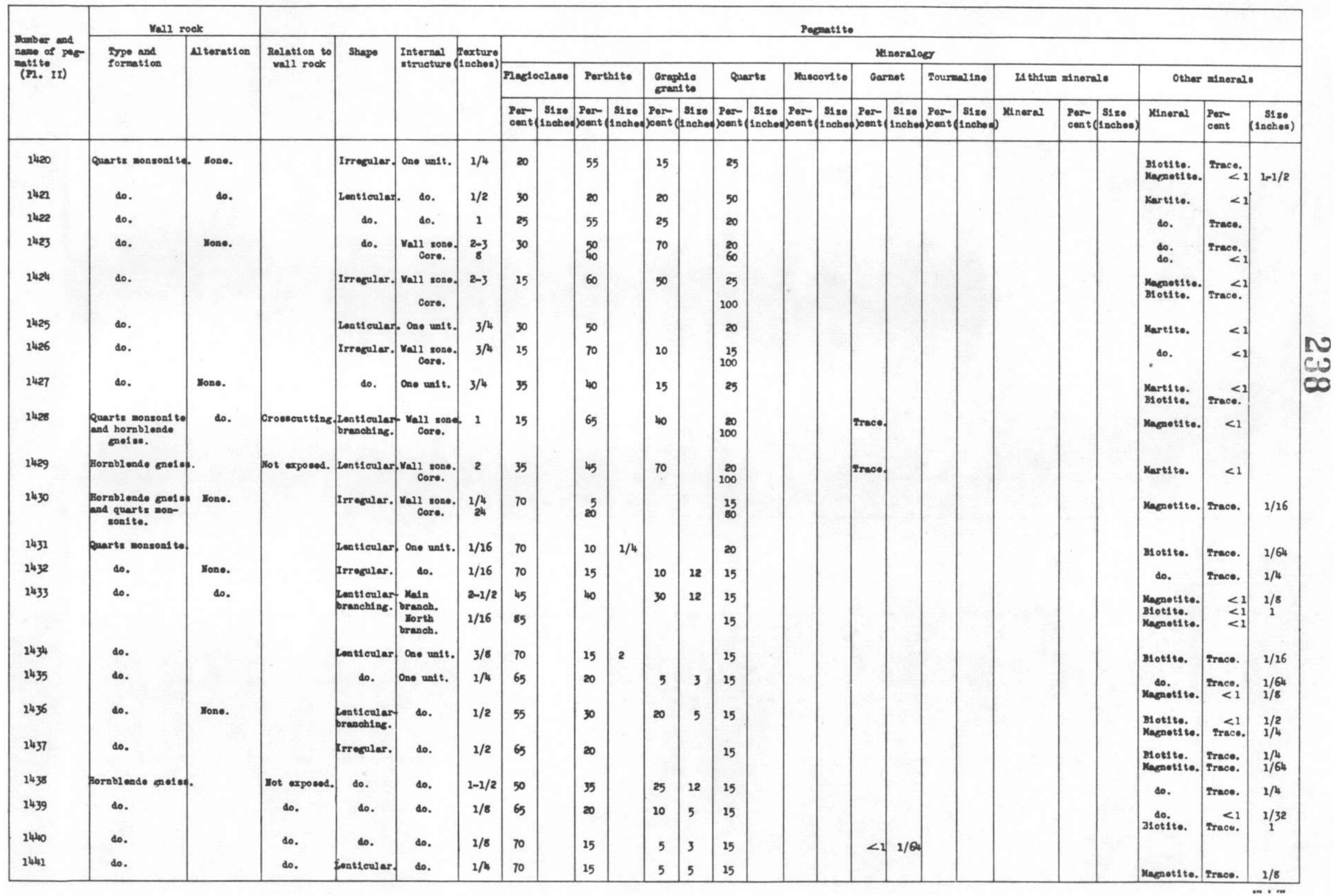


Tab1e 20,--Mineralogy of peenat1 top-Cont1nued.

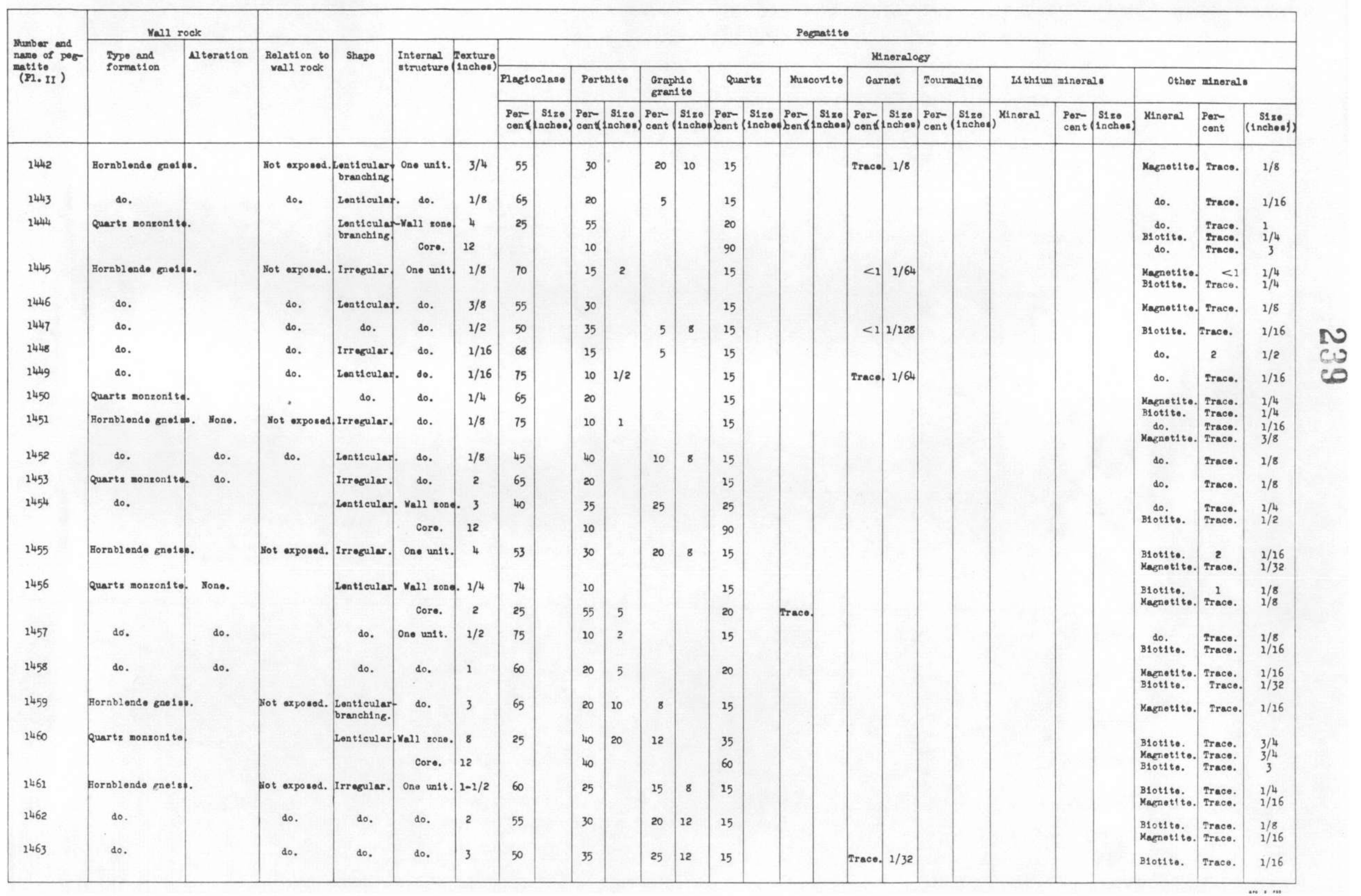


Tab10 20,-Minoralogy of peratitoe-Continued.

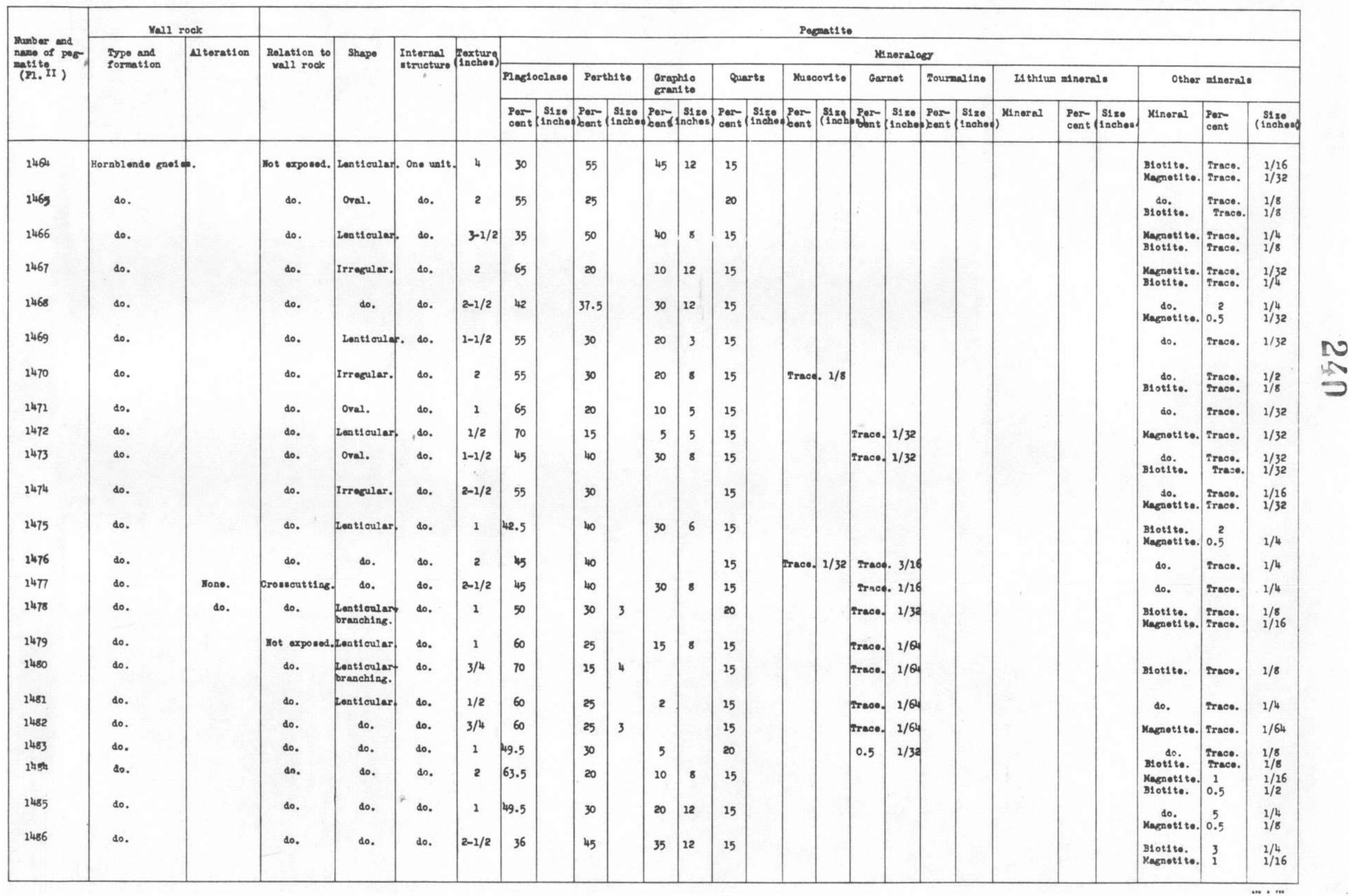


zable zo-Minorelory of perentiter-Con tinvod.

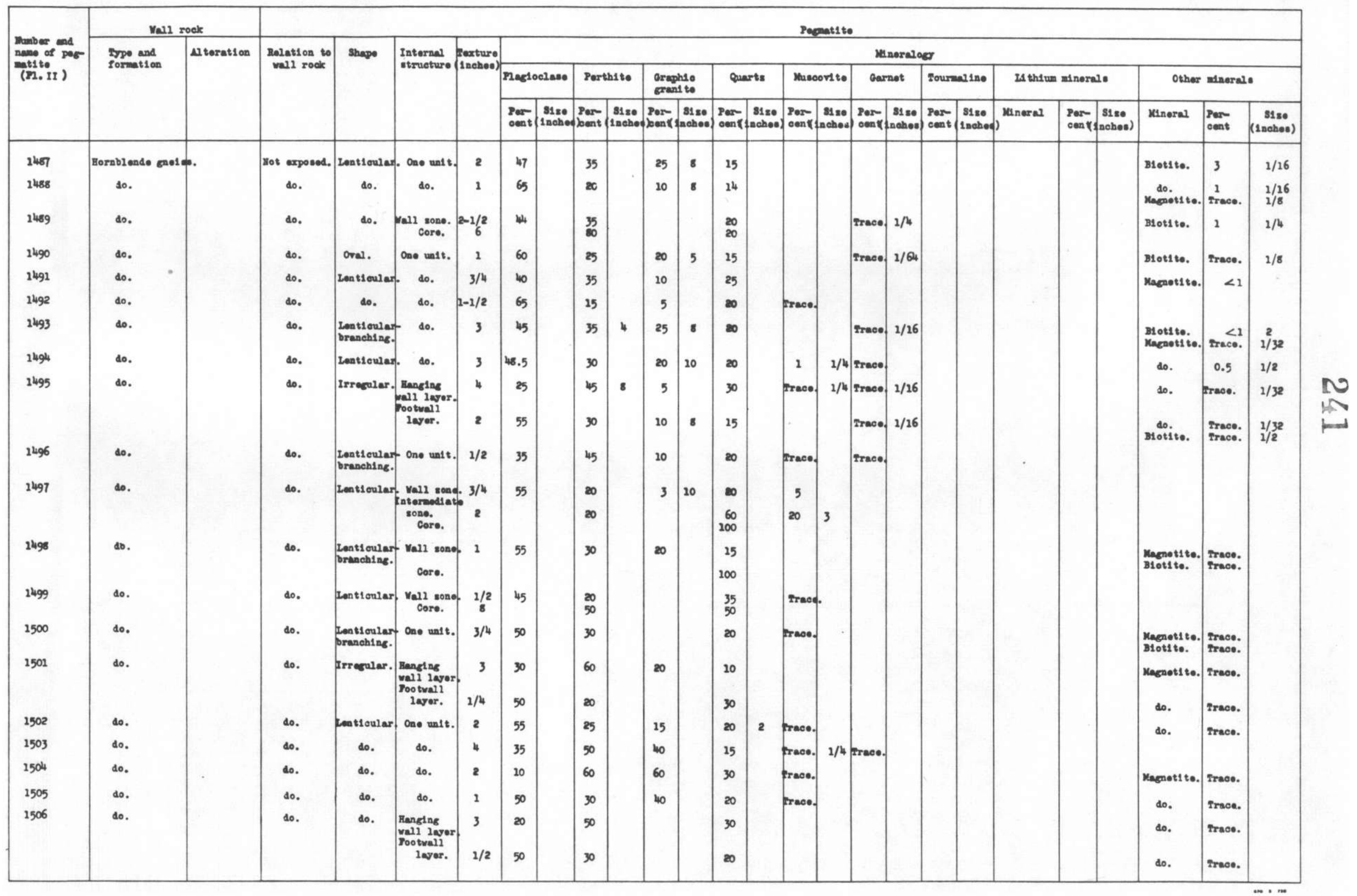


Fab10 20.--Mineraloey of pepat1 tos-Cont1 nued.

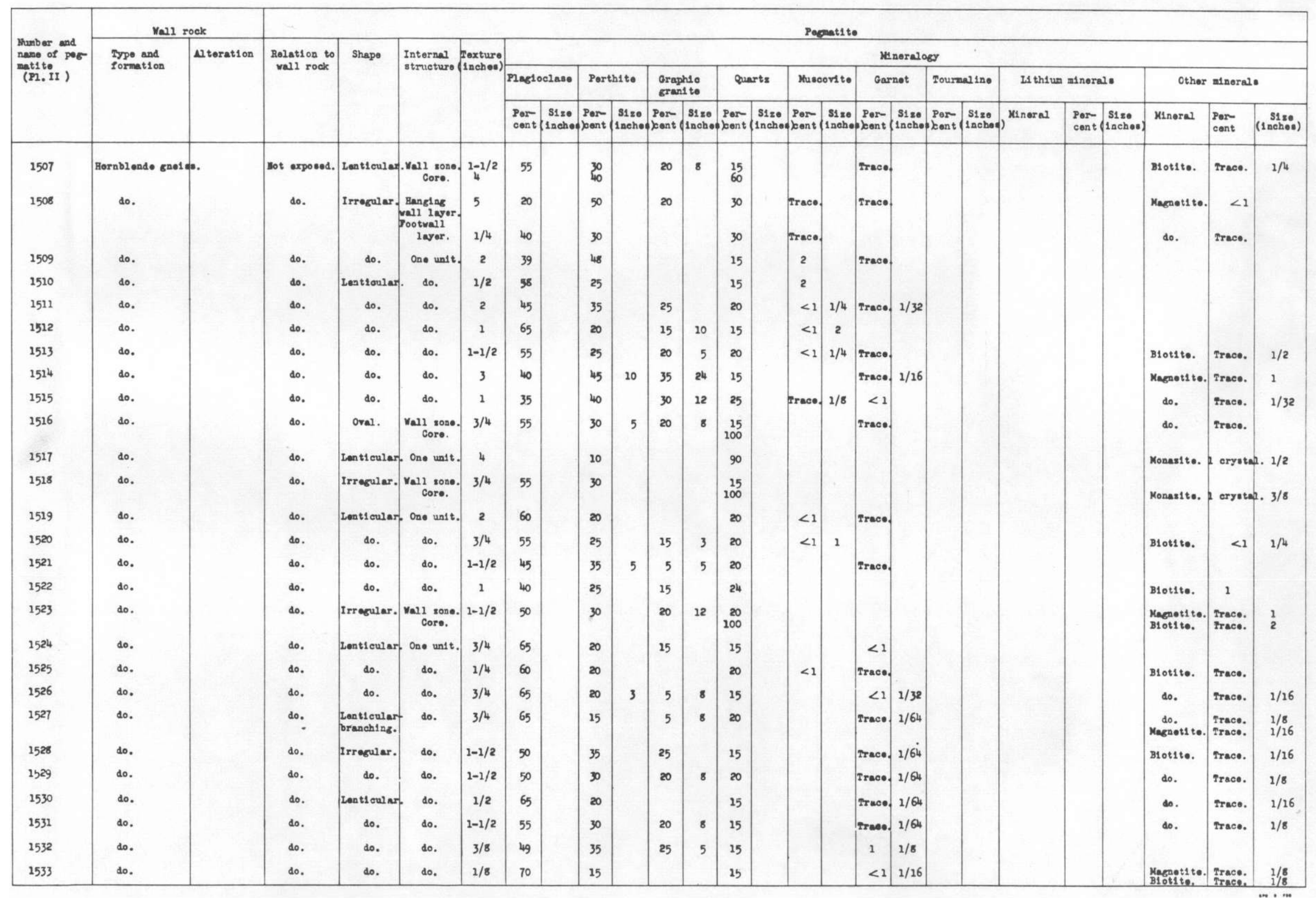


Tab10 20.--Kineralogy of pepeat1 tof-Cont1 nood.

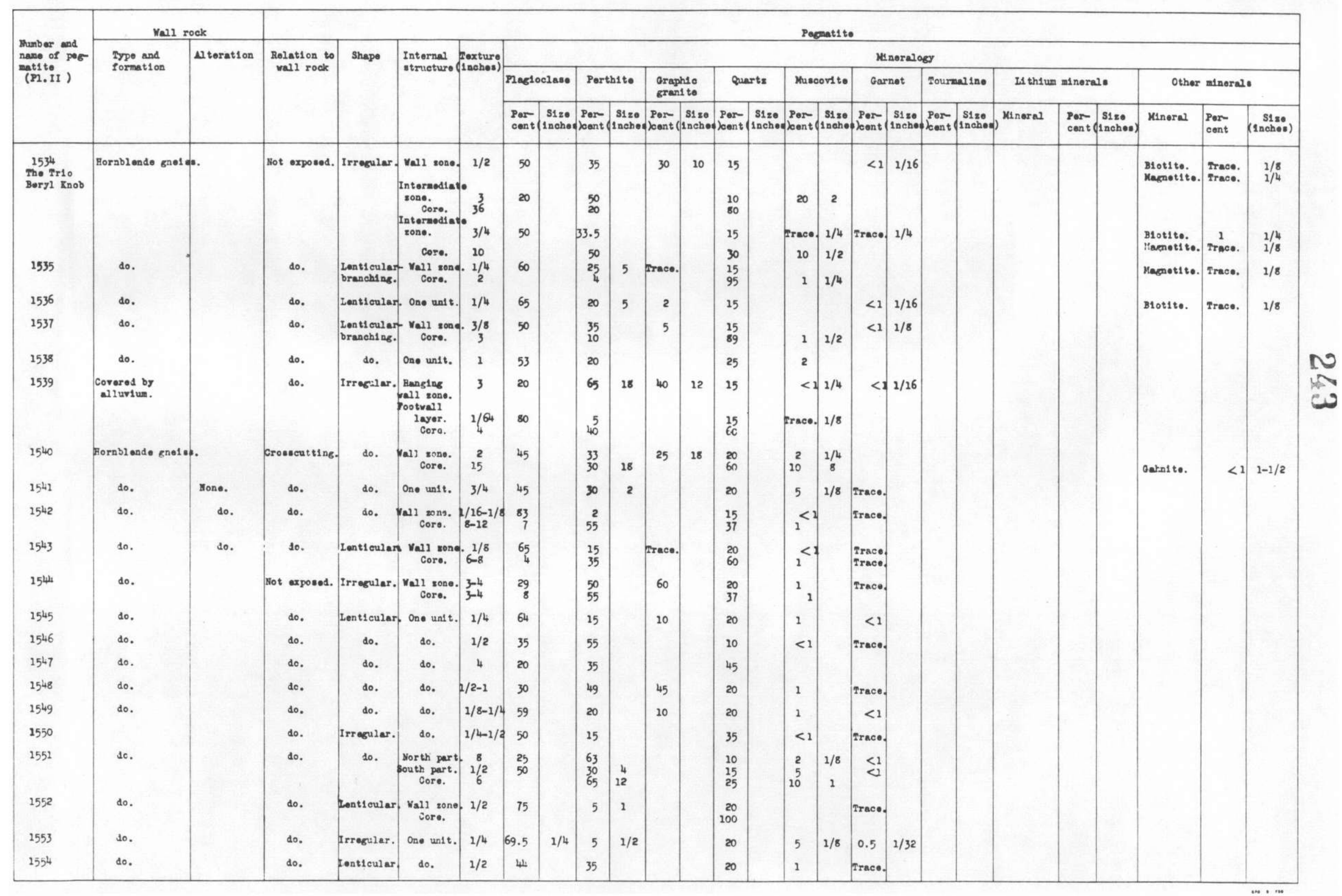


Teb10 20.--Mineraloery of pepat1 tof-Cont1 nued.

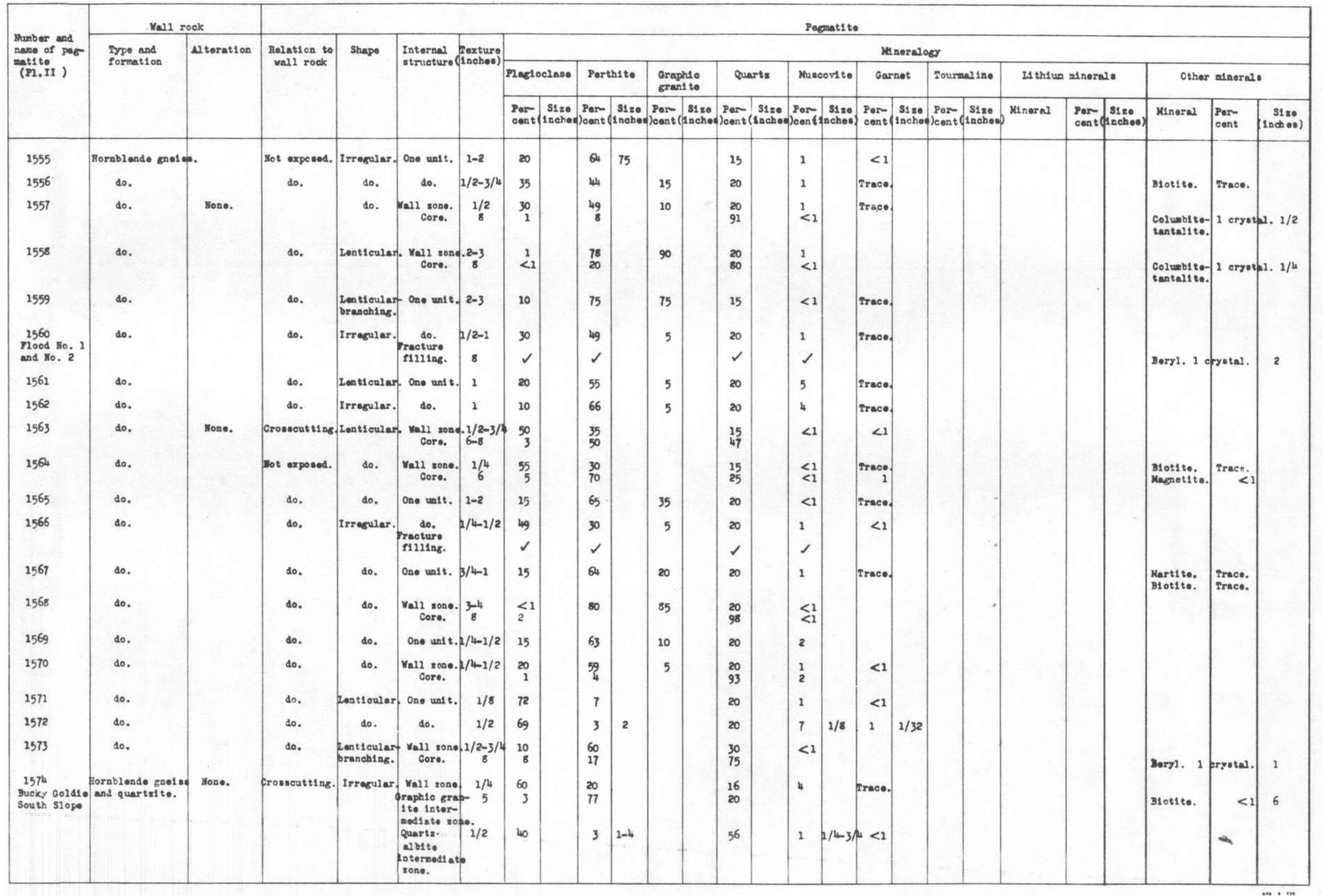


Fable za-Mineralory of pereat1 tes--Cont1 inued.

\begin{tabular}{|c|c|c|c|c|c|c|c|c|c|c|c|c|c|c|c|c|c|c|c|c|c|c|c|c|c|c|}
\hline \multirow{4}{*}{$\begin{array}{l}\text { Mumber and } \\
\text { nemeo of peg } \\
\text { matit to } \\
\text { (PI.II) }\end{array}$} & \multicolumn{2}{|c|}{ Meall rook } & \multicolumn{24}{|c|}{ Peomat 1 to } \\
\hline & \multirow{3}{*}{$\begin{array}{l}\text { Type and } \\
\text { formation }\end{array}$} & \multirow{3}{*}{ Niteration } & \multirow{3}{*}{$\begin{array}{l}\text { Rolation to } \\
\text { val1 rock }\end{array}$} & \multirow[t]{3}{*}{ Shape } & \multirow{3}{*}{$\begin{array}{l}\text { Internal } \\
\text { strueturo of }\end{array}$} & \multirow{3}{*}{$\begin{array}{l}\text { Cexture } \\
\text { (1nchoos) }\end{array}$} & \multicolumn{20}{|c|}{ Neneralogy } \\
\hline & & & & & & & \multicolumn{2}{|c|}{ Plagiociase } & \multicolumn{2}{|c|}{ Porthito } & \multicolumn{2}{|c|}{$\begin{array}{l}\text { Graphse } \\
\text { Gran1 to }\end{array}$} & \multicolumn{2}{|c|}{ Quarts } & \multicolumn{2}{|c|}{ Muscord to } & \multicolumn{2}{|c|}{ Garnot } & \multicolumn{2}{|c|}{ Tournal ine } & \multicolumn{3}{|c|}{ Li thium minerale } & \multicolumn{3}{|c|}{ Other minerals. } \\
\hline & & & & & & & $\begin{array}{l}\text { Por- } \\
\text { cont }\end{array}$ & $\begin{array}{c}5180 \\
1 \text { incto of }\end{array}$ & $\begin{array}{l}\text { Per- } \\
\text { Doent }(1\end{array}$ & $\begin{array}{l}\text { S1so } \\
\text { 1nehoog) }\end{array}$ & $\begin{array}{l}\text { Por- } \\
\text { jeont (1 }\end{array}$ & $\begin{array}{l}3130 \\
\text { inct on }\end{array}$ & $\begin{array}{l}\text { Par- } \\
\text { Jeent }\end{array}$ & $\begin{array}{c}\text { S1zo } \\
\text { 1nchoos) }\end{array}$ & $\begin{array}{l}\text { Por } \\
\text { poent }\end{array}$ & $\begin{array}{l}\text { S1 se } \\
\text { 1nohoed }\end{array}$ & $\begin{array}{l}\text { Por- } \\
\text { joont }\end{array}$ & $\begin{array}{l}\text { S1zo } \\
\text { 1ncheo }\end{array}$ & $\begin{array}{l}\text { Per } \\
\text { ) } \operatorname{cont} \text { (d }\end{array}$ & \begin{tabular}{|l|} 
S1:00 \\
(1nehood
\end{tabular} & Kinoral & $\begin{array}{l}\text { Por } \\
\text { cont } c_{1}\end{array}$ & \begin{tabular}{|l|} 
S1se \\
(1nch os $)$
\end{tabular} & Kineral & $\begin{array}{l}\text { Per- } \\
\text { cent }\end{array}$ & $\begin{array}{r}\text { S1so } \\
\text { (1nchoe) }\end{array}$ \\
\hline $\begin{array}{l}\text { 1574 } \\
\text { Buokg Gold1: } \\
\text { South s1 ope- } \\
\text { Cont1nuod. }\end{array}$ & $\begin{array}{l}\text { Rornblonde gnoldo } \\
\text { and quartsit to. }\end{array}$ & Iono. & Crosscutting. & Irrogular & 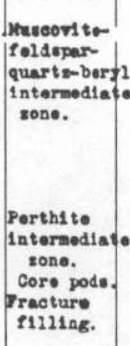 & $0^{60}$ & $<1$ & & 93 & 60 & & & $\begin{array}{r}7 \\
100 \\
50\end{array}$ & & $<1$ & & 6 & & & & & & & 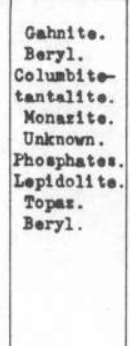 & $\begin{array}{c}8.9 \\
.11 \\
.003 \\
.003 \\
\text { Traco. } \\
\text { Trace. } \\
<1 \\
<1\end{array}$ & $\begin{array}{l}1 / 8-1 \\
1 / 2-6 \\
2 / 4-3 / 4 \\
1 / 2-4 \\
1 / 64-1 / 8 \\
1-3\end{array}$ \\
\hline 1575 & Jornblende gnei & & Mot exposed. & oral. & One unit. & 4 & & & 2 & & & & 98 & & & & & & & & & & & & & \\
\hline $\begin{array}{l}1576 \\
\text { Camp Robbor }\end{array}$ & do. & & do. & do. & $\begin{array}{c}\text { Mall sone. } \\
\text { Core. }\end{array}$ & 1 & 15 & & 60 & & 15 & & $\begin{array}{r}25 \\
100\end{array}$ & & & & Trace. & & & & & & & & & \\
\hline 1577 & do. & & do. & Irrogular. & One unit. 1 & $1-1-1 / 2$ & 35 & & 45 & & 20 & & 20 & & $<1$ & & Trace. & & & & & & & & & \\
\hline 1578 & do. & & do. & do. & do. & $3 / 4$ & 35 & & 49 & & 20 & & 15 & & 1 & & Trace. & & & & & & & & & \\
\hline 1579 & do. & & do. & do. & do. & $1-2$ & 15 & & 65 & & 80 & & 20 & & & & Trace. & & & & & & & Martito. & oryetal & 4. \\
\hline 1580 & do. & & do. & do. & do. & $2-3$ & 15 & & 70 & & 80 & & 15 & & $<1$ & & Trace. & & & & & & & & & \\
\hline 1581 & 10. & & do. & so. & do. & 2 & 35 & & 50 & & 50 & & 15 & & $<1$ & & Trace. & & & & & & & & & \\
\hline 1582 & do. & & do. & so. & do. & $1 / 2$ & 40 & & 40 & & 5 & & 20 & & $<1$ & & Trace. & & & & & & & & & \\
\hline 1583 & do. & & do. & Lenticular. & do. & $1 / 4$ & 30 & & 45 & & & & 25 & & $<1$ & & $<1$ & & & & & & & & & \\
\hline 1584 & do. & & do. & do. & do. & $2 / 2-3 / 4$ & 25 & & 55 & & 35 & & 20 & & $<1$ & & $<1$ & & & & & & & & & \\
\hline 1585 & do. & & do. & Irregular. & do. & $2 / 4-1 / 2$ & 5 & & 75 & & 75 & & 20 & & $<1$ & & Traeo & & & & & & & & & \\
\hline 1586 & do. & & do. & do. & do. & $3 / 4-1$ & 30 & & 53 & & 10 & & 25 & & 2 & & Trace. & & & & & & & & & \\
\hline 1587 & do. & & do. & Zont1oular. & to. & $3-4$ & 15 & & 65 & & 70 & & 20 & & $<1$ & & & & & & & & & & & \\
\hline 1588 & do. & & do. & do. & do. & 1 & 40 & & 40 & & 20 & & 20 & & $<1$ & & Trace. & & & & & & & & & \\
\hline 1589 & $\begin{array}{l}\text { Hornbl andeg gnol oo } \\
\text { and quartsite. }\end{array}$ & & & Irrogular. & do. & $1 / 4-1 / 2$ & 21 & & 59 & & 5 & & 20 & & 1 & & $<1$ & & & & & & & Magnet1 to. & Trace. & \\
\hline $\begin{array}{l}1590 \\
\text { windv Knob }\end{array}$ & Rornblende gnelose. & & Fot exposed. & do. & $\begin{array}{l}\text { Vall sono. } \\
\text { fnternoditat } \\
\text { sono: } \\
\text { Core. }\end{array}$ & $\begin{array}{l}1 / 4 \\
6\end{array}$ & $\begin{array}{l}65 \\
15\end{array}$ & & $\begin{array}{l}20 \\
69\end{array}$ & 18 & & & $\begin{array}{r}15 \\
10 \\
100\end{array}$ & & 3 & $1-1 / 2$ & $\begin{array}{l}<1 \\
3\end{array}$ & $1 / 2$ & & & & & & do. & Trace. & \\
\hline 1591 & do. & & do. & Lenticular. & $\begin{array}{l}\text { vall zono } \\
\text { coro. }\end{array}$ & ${ }_{4}^{1 / 2}$ & $\begin{array}{l}70 \\
10\end{array}$ & & $\begin{array}{l}15 \\
60\end{array}$ & & & & $\begin{array}{l}15 \\
29\end{array}$ & & $i_{1}^{<1}$ & & $\begin{array}{l}\text { Trace. } \\
\text { Trseco. }\end{array}$ & & & & & & & & & \\
\hline 1592 & do. & sone. & & $\begin{array}{l}\text { Lent1cular } \\
\text { branching. }\end{array}$ & One unit. & $1 / 2$ & 50 & & 30 & 5 & & & 20 & & & & $<1$ & $1 / 16$ & & & & & & Magnet1 to. & Trace. & $1 / 8$ \\
\hline 1593 & do. & & pot expesos. & oval. & do. & $1 / 2$ & 40 & & 40 & & 10 & & 2 & & $<1$ & & Trace. & & & & & & & & & \\
\hline
\end{tabular}


Tab10 20-Mineralopy of peopat1 tos-Cont1 nued.

\begin{tabular}{|c|c|c|c|c|c|c|c|c|c|c|c|c|c|c|c|c|c|c|c|c|c|c|c|c|c|}
\hline \multirow{4}{*}{$\begin{array}{l}\text { Mumbor and } \\
\text { neve of peg } \\
\text { matite } \\
\text { (PI. II) }\end{array}$} & \multicolumn{2}{|c|}{ Mall rook } & \multirow{4}{*}{$\begin{array}{l}\text { Relation to } \\
\text { vall rook }\end{array}$} & \multirow{4}{*}{ Shape } & \multicolumn{21}{|c|}{ Pogratite } \\
\hline & \multirow{3}{*}{$\begin{array}{l}\text { Type and } \\
\text { format1 on }\end{array}$} & \multirow[t]{3}{*}{ Ll teration } & & & Internal & gexture & \multicolumn{19}{|c|}{ Mineralogy } \\
\hline & & & & & & & P1ag1oc1aso & \multicolumn{2}{|c|}{ Perthite } & \multicolumn{2}{|c|}{$\begin{array}{l}\text { Graph10 } \\
\text { gran1 to }\end{array}$} & \multicolumn{2}{|c|}{ Quartz } & \multicolumn{2}{|c|}{ Muscovit to } & \multicolumn{2}{|c|}{ Garnet } & \multicolumn{2}{|c|}{ Tourmalino } & \multicolumn{3}{|c|}{ L1 thiun mineral. } & \multicolumn{3}{|c|}{ Other minerals } \\
\hline & & & & & & & $\begin{array}{l}\text { Per } 51 z 0 \\
\text { cont(/n nehos) }\end{array}$ & $\begin{array}{l}\text { Per- } \\
\text { cent }\end{array}$ & $\begin{array}{l}\text { S1zo } \\
\text { 1nchoo }\end{array}$ & $\begin{array}{l}\text { Per- } \\
\text { peont }\end{array}$ & $\begin{array}{l}\text { S1ze } \\
\text { inchoo }\end{array}$ & $\begin{array}{l}\text { Per- } \\
\text { benter. }\end{array}$ & $\begin{array}{c}\text { s1ze } \\
\text { incheos) }\end{array}$ & $\begin{array}{l}\text { Perr } \\
\text { cont (. }\end{array}$ & $\begin{array}{l}\text { S1 ze } \\
\text { inchoos) }\end{array}$ & $\begin{array}{l}\text { Per- } \\
\text { Bentar }\end{array}$ & $\begin{array}{l}\text { S1 zo } \\
\text { Incheos) }\end{array}$ & $\begin{array}{l}\text { Por- } \\
\text { cent }\end{array}$ & $\begin{array}{l}\text { S1ze } \\
\text { (inchoof) }\end{array}$ & Minernal & $\begin{array}{l}\text { Por- } \\
\text { cont }\end{array}$ & $\begin{array}{l}S_{11 z e} \\
\text { (1netos) }\end{array}$ & Mineral & $\begin{array}{l}\text { Porr } \\
\text { cont }\end{array}$ & $\begin{array}{c}\text { S1ze } \\
\text { (1ncheo) }\end{array}$ \\
\hline 1594 & Hornbleade gnolos. & & Mot exposed. & Lont1cular. & One unit. & $1 / 2-3 / 4$ & 35 & 45 & & 15 & & 20 & & Trace. & & Trace. & & & & & & & & & \\
\hline 1595 & do. & & & Irrogular. & $\begin{array}{c}\text { Wall rono. } \\
\text { Core. }\end{array}$ & 1 & 25 & 55 & & 65 & & $\begin{array}{r}20 \\
100\end{array}$ & & $<1$ & & Trace. & & & & & & & Mart1to. & Trace. & \\
\hline 1596 & do. & & Not exposod. & Lent1 oular. & One unit. & 8 & 25 & 54 & & 30 & & 20 & & 1 & & Trace: & & & & & & & Mart1to. & Traco. & \\
\hline 1597 & do. & & do. & do. & do. & $1 / 8$ & 65 & 15 & & & & 20 & & & & $<1$ & & & & & & & & & \\
\hline 2598 & do. & Bono. & & do. & do. & $1 / 8$ & 25 & 55 & & & & 20 & & Trace. & & $<1$ & & & & & & & & & \\
\hline 1599 & do. & do. & Crosecut t1ng. & do. & do. & $1 / 16$ & 70 & 15 & & & & 15 & & & & $<1$ & & & & & & & & & \\
\hline 1600 & do. & & Not exposed. 1 & Irrogular. & do. & $1-1 / 2$ & 45 & 40 & & 30 & & 15 & & & & & & & & & & & Marnotilo. & Trace. & $1 / 32$ \\
\hline 1601 & do. & & do. & Lenticuiar. & do. & $1 / 4$ & 75 & 10 & & 5 & 8 & 15 & & & & & & & & & & & Magnet: to. & Trase. & $1 / 8$ \\
\hline 1602 & do. & & do. & $\begin{array}{l}\text { Lonticular- } \\
\text { branching. }\end{array}$ & do. & $1 / 8$ & 70 & 15 & & 5 & 3 & 15 & & & & & & & & & & & do. & Trace. & $1 / 16$ \\
\hline 1603 & do. & & do. & Lentioular. & do. & $1 / 8$ & 58 & 25 & & & & 15 & & & & 2 & $1 / 32$ & & & & & & & & \\
\hline 1604 & do. & & do. & do. & do. & $1 / 8$ & 75 & 10 & & & & 15 & & & & $<1$ & $1 / 16$ & & & & & & & & \\
\hline 1605 & do. & None. & Crosscutting. & do. & do. & $1 / 8$ & 55 & 30 & & 5 & & 15 & & & & $<1$ & $1 / 64$ & & & & & & & & \\
\hline 1606 & do. & & Iot exposed. & so. & do. & $1 / 8$ & 50 & 30 & & & & 20 & & & & $<1$ & $1 / 16$ & & & & & & & & \\
\hline 1607 & so. & & do. & do. & do. & $1 / 2$ & 35 & 50 & & & & 15 & & & & $<1$ & $1 / 32$ & & & & & & & & \\
\hline 1608 & do. & & do. & do. & do. & $1 / 8$ & 75 & 10 & & & & 15 & & & & Trace. & $1 / 32$ & & & & & & & & \\
\hline 1609 & do. . & & do. & do. & do. & $3 / 4$ & 15 & 25 & & 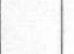 & & 60 & & Trace. & & $<1$ & & & & & & & B1ot1to. & Trace. & \\
\hline 1610 & do. & & do. & Irragular. & $\begin{array}{l}\text { Well sone. } \\
\text { Core pode. }\end{array}$ & .46 & 35 & 55 & & 50 & & $\begin{array}{r}20 \\
100\end{array}$ & & $<1$ & & $<1$ & & & & & & & do. & Trace. & \\
\hline 1611 & do. & & do. & Lent1 cular. & $\begin{array}{l}\text { Mall zono. } \\
\text { Core. }\end{array}$ & $\cdot 3-4$ & 20 & $\begin{array}{r}50 \\
3\end{array}$ & & 40 & & $\begin{array}{l}30 \\
97\end{array}$ & & Trace. & & & & & & & & & & & \\
\hline 1612 & do. & & do. & $\begin{array}{l}\text { Lentic- } \\
\text { ular- } \\
\text { branching. }\end{array}$ & $\begin{array}{l}\text { Mall zone. } \\
\text { core. }\end{array}$ & $2-3$ & 20 & 55 & & & & $\begin{array}{l}25 \\
99\end{array}$ & & $<1$ & & & & & & & & & Mart1 to. & Trace. & \\
\hline 1613 & $\begin{array}{l}\text { Hornbl onde gned sep } \\
\text { und quartzi1 to. }\end{array}$ & & do. & do. & One unit. & $3-4$ & 30 & 45 & & 30 & & 25 & & trace. & & Trace. & & & & & & & & & \\
\hline 1614 & do. & & do. & Lon t1 cular. & do. & $1-2$ & 50 & 30 & & 5 & & 20 & & arace. & & Trace. & & & & & & & & & \\
\hline 1615 & guartzito. & & do. & do. & do. & $1-2$ & 40 & 40 & & 5 & & 20 & & $<1$ & & Trace. & & & & & & & & & \\
\hline 1616 & Fornb1 onde ganesos. & & do. & do. & do. & $1 / 4$ & 50 & 25 & & & & 25 & & & & $<1$ & & & & & & & Magnotite. & $<1$ & \\
\hline 1617 & do. & & do. & Irrogular. & do. & $3 / 4$ & 20 & 60 & & 15 & & 20 & & & & Trace. & & & & & & & $\begin{array}{l}\text { B1 ot1 te. } \\
\text { Magnotite. }\end{array}$ & Trace. & \\
\hline 1618 & $\begin{array}{l}\text { puarts-b1 ot1 to- } \\
\text { sch1 ot. }\end{array}$ & Mono. & crossout ting. & do. & do. & $2-3$ & 20 & 55 & & 55 & & 25 & & & & Trace. & & & & & & & Martite. & $<1$ & \\
\hline 1619 & 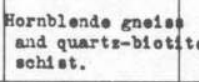 & & pot exposed. & do. & do. & $4-6$ & 15 & 60 & & 55 & & 25 & & & & & & & & & & & & $\begin{array}{l}\text { Trace. } \\
\text { Trace. }\end{array}$ & \\
\hline
\end{tabular}


Fable 20.--Mineralory of pepet1 teg-Cont1 nuod.

\begin{tabular}{|c|c|c|c|c|c|c|c|c|c|c|c|c|c|c|c|c|c|c|c|c|c|c|c|c|c|c|}
\hline \multirow{4}{*}{$\begin{array}{l}\text { Mumbor and } \\
\text { nano of poo } \\
\text { matit to } \\
\text { (P1. II) }\end{array}$} & \multicolumn{2}{|c|}{ reall rock } & \multicolumn{24}{|c|}{ Pegmat1 to } \\
\hline & \multirow{3}{*}{$\begin{array}{l}\text { 2ype and } \\
\text { formation }\end{array}$} & \multirow[t]{3}{*}{ N teration } & \multirow{3}{*}{$\begin{array}{l}\text { Rolation to } \\
\text { vall' rook }\end{array}$} & \multirow[t]{3}{*}{ Shape } & \multirow{3}{*}{$\begin{array}{l}\text { Internal } \\
\text { strueture (1) }\end{array}$} & \multirow{3}{*}{ Texture } & \multicolumn{20}{|c|}{ Heneralogy } \\
\hline & & & & & & & \multicolumn{2}{|c|}{ Plaglociaso } & \multicolumn{2}{|c|}{ Porth1te } & \multicolumn{2}{|c|}{$\begin{array}{l}\text { Graph10 } \\
\text { gran1 to }\end{array}$} & \multicolumn{2}{|c|}{ Quarts } & \multicolumn{2}{|c|}{ Muscort to } & \multicolumn{2}{|c|}{ Garnot } & \multicolumn{2}{|c|}{ Tournalino } & \multicolumn{3}{|c|}{ Li thium minerale } & \multicolumn{3}{|c|}{ Other mineral. } \\
\hline & & & & & & & $\begin{array}{l}\text { Por- } \\
\text { cont } t\end{array}$ & $\begin{array}{l}\text { S1zo } \\
\text { (1nchen }\end{array}$ & Per & $\begin{array}{c}\text { s1zo } \\
\text { (1nehos) }\end{array}$ & $\begin{array}{l}\text { Per } \\
\text { Pent! } 1\end{array}$ & $\begin{array}{l}51 \text { ze } \\
\text { 1nchea }\end{array}$ & d) Pear- & $\begin{array}{l}\text { s1zo: } \\
\text { (1nchood }\end{array}$ & Per- & \begin{tabular}{|l|} 
sise \\
11 ncho. \\
\end{tabular} & Por- & 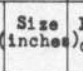 & 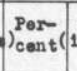 & \begin{tabular}{|l|} 
S128 \\
1nchoop
\end{tabular} & Nineral & $\begin{array}{l}\text { Per- } \\
\text { cont }(12\end{array}$ & $\begin{array}{l}\begin{array}{c}\text { S180 } \\
\text { incheos) }\end{array} \\
\end{array}$ & Kineral & $\begin{array}{l}\text { Por- } \\
\text { cent }\end{array}$ & 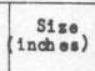 \\
\hline 1620 & Covered. & & Sot exposed. & Lon t1 cular. & one unit. & $1 / 4-1 / 2$ & 50 & & 30 & & & & 20 & & & & $<1$ & & & & & & & $\begin{array}{l}\text { Blotito. } \\
\text { Martito. }\end{array}$ & $\begin{array}{l}\text { Trace. } \\
\text { Frace. }\end{array}$ & \\
\hline 1621 & Hornblende gaol on. & & do. & do. & do. & $1 / 4-1 / 2$ & 45 & & 35 & & & & 20 & & & & & $\mathrm{O}_{\mathrm{y}}$ to & & & & & & B1otite. & $<1$ & \\
\hline 1622 & do. & & do. & do. & do. & $1 / 4-1 / 2$ & 35 & & 45 & & & & 20 & & & & Trace. & & Trace. & & & & & do. & $<1$ & \\
\hline 1623 & do. & & do. & $\begin{array}{l}\text { Ionticular } \\
\text { iranching. }\end{array}$ & co. & 1 & 15 & & 50 & & & & 35 & & & & $<1$ & & & & & & & do. & Tracel & \\
\hline 1624 & do. & & do. & Irrogular. & do. & 2 & 1 & & 33 & & & & 65 & & 1 & & $<1$ & & & & & & & do. & Trace. & \\
\hline 1625 & do. & & do. & Iontioular. & do. & $1-2$ & 15 & & 60 & & & & 25 & & & & $<1$ & & & & & & & & & \\
\hline 1626 & do. & & Crosscuts1ng. & do. & do. & $3 / 4$ & 30 & & 45 & & & & 25 & & $<1$ & & $<1$ & & & & & $\cdot$ & & B1otite. & Trace. & \\
\hline 2627 & do. & Mono. & & Irragular. & do. & $1-1 / 2$ & ${ }^{1} 55$ & & 7 & & & & 35 & & 3 & & & & Traco. & & Lop1dol1 to. & Trace. & & & & \\
\hline 1628 & do. & & Sot exposod. & Iont1oular. & do. & $1 / 4-1 / 2$ & 35 & & 45 & & & & 20 & & trace. & & $<1$ & & & & & & & & & \\
\hline 1629 & do. & & do. & $\begin{array}{l}\text { Lonticular } \\
\text { branching. }\end{array}$ & $\begin{array}{c}\text { Mall sone. } \\
\text { core. }\end{array}$ & $\begin{array}{c}1 / 2 \\
12\end{array}$ & 40 & & $\begin{array}{l}40 \\
10\end{array}$ & & & & $\begin{array}{l}20 \\
90\end{array}$ & & Prace. & & & & & & & & & $\begin{array}{l}\text { Brot1 to. } \\
\text { Yagnet1ito. }\end{array}$ & $\begin{array}{l}\text { Trace. } \\
\text { Trace. }\end{array}$ & \\
\hline 1630 & do. & Yone. & & do. & $\begin{array}{c}\text { Yall sono. } \\
\text { core. }\end{array}$ & $\begin{array}{c}1 / 4 \\
3-6\end{array}$ & $\begin{array}{r}20 \\
1\end{array}$ & & $\begin{array}{r}55 \\
5\end{array}$ & & & & $\begin{array}{l}25 \\
94\end{array}$ & & $<1$ & & $\begin{array}{r}<1 \\
\text { Trace. }\end{array}$ & & & & & & & $\begin{array}{l}\text { Mapnotit to. } \\
\text { Yonazit to. }\end{array}$ & $\begin{array}{l}\text { Traco. } \\
1 \text { cr: } ; \text { ata }\end{array}$ & tal. \\
\hline 1631 & Tonalito. & do. & & do. & $\begin{array}{c}\text { Yall sone. } \\
\text { core. }\end{array}$ & $3-4$ & $\stackrel{25}{<1}$ & & $\begin{array}{r}50 \\
7\end{array}$ & & & & $\begin{array}{l}25 \\
93\end{array}$ & & & & $<1$ & & & & & & & & & \\
\hline 1632 & do. & do. & & Irrogular. & $\begin{array}{c}\text { Wall zone. } \\
\text { core. }\end{array}$ & $\begin{array}{l}1 / 8 \\
3\end{array}$ & 30 & & $\begin{array}{r}40 \\
5\end{array}$ & & 1 & & $\begin{array}{l}30 \\
95\end{array}$ & & & & Trace. & & & & & & & $\begin{array}{l}\text { B1ot1 te. } \\
\text { Martite. }\end{array}$ & $\begin{array}{l}\text { Trace. } \\
\text { Trace. }\end{array}$ & \\
\hline 1633 & to. & do. & & do. & One unit. 2 & $2 / 2-3 / 4$ & 25 & & 50 & & & & 25 & & & & Trace. & & & & & & & B1otite. & Trace. & \\
\hline 1634 & Fornblende gne1 ap. & & Sot exposed. & Lont1eular. & $\begin{array}{l}\text {. Mall sone. } \\
\text { core. }\end{array}$ & $\frac{3-4}{1}$ & 15 & & $\begin{array}{c}65 \\
\text { traco. }\end{array}$ & & 40 & & $\begin{array}{r}20 \\
100\end{array}$ & & Trace. & & & & & & & & & & & \\
\hline 1635 & do. & & so. & Oral. & One unit. & $1 / 4$ & 25 & & 50 & & & & 25 & & & & Trace. & & & & & & & $\begin{array}{l}\text { M1otite. } \\
\text { Martite. }\end{array}$ & $\begin{array}{l}\text { Trace. } \\
\text { Trace. }\end{array}$ & \\
\hline 1636 & do. & & to. & Ient1 oular. & do. & $1 / 8$ & 35 & & 44 & & & & 30 & & & & & & & & & & & $\begin{array}{l}\text { B1otite. } \\
\text { Martito. }\end{array}$ & $1<1$ & \\
\hline 1537 & do. & & so. & do. & do. & $1 / 2$ & 15 & & 60 & & & & 25 & & & & & & & & & & & Biotste. & $<1$ & \\
\hline 1638 & Covered. & & do. & Irrogular. & $\begin{array}{c}\text { Vall zone. } \\
\text { Core. }\end{array}$ & $\begin{array}{l}2 \\
1\end{array}$ & 20 & & 55 & & 60 & & $\begin{array}{c}25 \\
100\end{array}$ & & & & & & & & & & & $\begin{array}{l}\text { Ma:tite. } \\
\text { Botitio. } \\
\text { Kartite. }\end{array}$ & $\begin{array}{l}<1 \\
\text { Traze. } \\
\text { Trace. }\end{array}$ & \\
\hline 1639 & Bornblende gnelob & None. & & Lenticular. & One unit. & $1 / 2$ & 40 & & 35 & & & & 25 & & $<1$ & & $<1$ & & & & & & & B1ot1 te. & Trace. & \\
\hline 1640 & ds. & co. & & do. & do. & 1 & 40 & & 30 & & & & 30 & & $<1$ & & $<1$ & & & & & & & & & \\
\hline 1641 & do. & do. & & do. & do. & $3 / 4$ & 15 & & 65 & & & & 20 & & $<1$ & & $<1$ & & & & & & & & & \\
\hline 1642 & do. & & $\begin{array}{c}\text { sot exposed. } \\
\text { do. }\end{array}$ & $\begin{array}{c}\text { Irregular. } \\
\text { do. }\end{array}$ & $\begin{array}{c}\text { Vall zone. } \\
\text { core. } \\
\text { One unit. }\end{array}$ & $\begin{array}{c}1 / 2-3 / 4 \\
1 / 2\end{array}$ & $\begin{array}{l}35 \\
20\end{array}$ & & $\begin{array}{l}40 \\
55\end{array}$ & & 5 & & $\begin{array}{r}25 \\
100 \\
25\end{array}$ & & rrace. & & $\begin{array}{l}<1 \\
<1\end{array}$ & & & & & & & B1ot1te. & $<1$ & $U_{F}$ to 2 \\
\hline
\end{tabular}


Table 20.--Mineralory of pemat1 tos--Cont1nued.

\begin{tabular}{|c|c|c|c|c|c|c|c|c|c|c|c|c|c|c|c|c|c|c|c|c|c|c|c|c|c|c|}
\hline \multirow{4}{*}{$\begin{array}{l}\text { Mumbor and } \\
\text { neve of peo } \\
\text { metite to } \\
\text { (PI.II) }\end{array}$} & \multicolumn{2}{|c|}{ Kall rook } & \multicolumn{24}{|c|}{ Pegmat1 to } \\
\hline & \multirow{3}{*}{$\begin{array}{l}\text { Type and } \\
\text { formation }\end{array}$} & \multirow[t]{3}{*}{ L teration } & \multirow{3}{*}{$\begin{array}{l}\text { Relation to } \\
\text { vall roak }\end{array}$} & \multirow[t]{3}{*}{ Shape } & \multirow{3}{*}{$\begin{array}{l}\text { Internal } \\
\text { atrueturo of }\end{array}$} & \multirow{3}{*}{$\begin{array}{l}\text { Toxture } \\
(1 \text { nohoses) }\end{array}$} & \multicolumn{20}{|c|}{ Wheralogy } \\
\hline & & & & & & & \multicolumn{2}{|c|}{ Plagloclase } & \multicolumn{2}{|c|}{ Porth1te } & \multicolumn{2}{|c|}{$\begin{array}{l}\text { Graphse } \\
\text { gran1 to }\end{array}$} & \multicolumn{2}{|c|}{ Quarts: } & \multicolumn{2}{|c|}{ Muscovl to } & \multicolumn{2}{|c|}{ Garnot } & \multicolumn{2}{|c|}{ Tournalino } & \multicolumn{3}{|c|}{ L1 thlun mineral. } & \multicolumn{3}{|c|}{ Other mineral. } \\
\hline & & & & & & & $\begin{array}{l}\text { Par- } \\
\text { cont }\end{array}$ & $\begin{array}{c}51 z 0 \\
1 \text { 1nehes }\end{array}$ & $\begin{array}{l}\text { Por- } \\
\text { Poont }\end{array}$ & $\begin{array}{c}\text { S1zo } \\
1 \text { nchood }\end{array}$ & $\begin{array}{l}\text { Per- } \\
x \operatorname{cont}(1\end{array}$ & $\begin{array}{c}\text { s1zo } \\
\text { (1ncheos) }\end{array}$ & $\begin{array}{l}\text { Par- } \\
\text { jeent }\end{array}$ & $\left(\begin{array}{c}\text { S1zo } \\
\text { (1neheas) }\end{array}\right.$ & $\begin{array}{l}\text { Per } \\
\text { yent }\end{array}$ & $\begin{array}{l}\text { S1:0 } \\
\text { unchoo; }\end{array}$ & $\begin{array}{l}\text { Per- } \\
\text { peont }\end{array}$ & $\begin{array}{l}\text { S1 zo } \\
\text { 1neho, }\end{array}$ & $\begin{array}{l}\text { Per } \\
\text { teent }(1\end{array}$ & \begin{tabular}{|l|}
$\begin{array}{c}\text { S1ze } \\
\text { 1nchoes) }\end{array}$ \\
\end{tabular} & )$^{\text {Mineral }}$ & $\begin{array}{l}\text { Por- } \\
\text { cont }(1\end{array}$ & $\begin{array}{l}51 z \theta \\
\text { (1nchos) }\end{array}$ & Minoral & $\begin{array}{l}\text { Por- } \\
\text { cent }\end{array}$ & $\begin{array}{c}5120 \\
\text { (1ncheo) }\end{array}$ \\
\hline 1644 & Hornblende gne1os. & 8. & Sot exposed. & Lenticules & f. One unit. & $1 / 4$ & 20 & & 55 & & & & 25 & & Trace. & & $<1$ & & & & & & & B1ot1 te. & $<1$ & \\
\hline 1645 & do. & & do. & do. & do. 1 & $1 / 8-1 / 4$ & 35 & & 35 & & & & 30 & & & & $<1$ & & & & & & & do. & $<1$ & \\
\hline 1646 & do. & & crosecutting. & s. do. & do. & $1-2$ & 25 & & 50 & & & & 35 & & & & $<1$ & & & & & & & do. & $<1$ & \\
\hline 1647 & do. & & do. & $\begin{array}{l}\text { Lonticular } \\
\text { branch1ng. }\end{array}$ & do. & $1 / 4-1 / 2$ & 35 & & 40 & & & & 25 & & Trace. & & $<1$ & & & & & & & do. & Trace. & \\
\hline 1648 & $\begin{array}{l}\text { Pornblende gnolos } \\
\text { and quartzite. }\end{array}$ & Sone. & & do. & do. & $1 / 4-1 / 2$ & 30 & & 35 & & & & 35 & & Trace. & & $<1$ & & & & & & & B1ot1to. & Trace. & \\
\hline 1649 & Hornblende enel oe. & & Mot exposed. & Cont1 cular. & do. & $1 / 4-1 / 2$ & 15 & & 55 & & & & 30 & & & & $<1$ & & & & & & & do. & irace. & \\
\hline 1650 & do. & & do. & do. & do. & $1 / 2$ & 40 & & 40 & & & & 20 & & & & rrace. & & & & & & & do. & Trace. & \\
\hline 1651 & do. & & do. & trregular. & do. & $1 / 4$ & 35 & & 40 & & & & 25 & & & & Trace. & & & & & & & do. & Trace. & \\
\hline 1652 & do. & & do. & $\begin{array}{l}\text { onti cular- } \\
\text { branching. }\end{array}$ & do. & $1 / 2$ & 30 & & 50 & & 5 & & 20 & & & & trace. & & & & & & & do. & Trace. & \\
\hline 1653 & do. & & do. & Lent1cular. & do. & $2-3$ & 20 & & 65 & & 10 & & 15 & & & & & & & & & & & Magnotito. & $<1$ & \\
\hline 1654 & do. & & do. & do. & do. & $<1 / 8$ & 19 & & 55 & & & & 25 & & & & & & & & & & & B1ot1to. & 1 & \\
\hline 1655 & do. & & do. & $\begin{array}{l}\text { font1 cular- } \\
\text { branching. }\end{array}$ & do. ? & $1 / 8-1 / 4$ & 40 & & 39 & & & & 20 & & & & & & & & & & & do. & 1 & \\
\hline 1656 & do. & & do. & do. & $\begin{array}{c}\text { Mall zone. } \\
\text { core. }\end{array}$ & 6-8 & 25 & & 55 & & 50 & & $\begin{array}{r}20 \\
100\end{array}$ & & $<1$ & & & & & & & & & do. & $<1$ & \\
\hline 1657 & do. & & do. & Irragular. & One unit. & 1 & 20 & & 55 & & 30 & & 25 & & & & & & & & & & & $\begin{array}{l}\text { B1ot1te. } \\
\text { Martite. }\end{array}$ & $\begin{array}{l}<1 \\
<1\end{array}$ & \\
\hline 1658 & do. & & do. & Oval. & do. & $1-2$ & 10 & & 70 & & 10 & & 20 & & & & & & & & & & & $\begin{array}{l}\text { 31ot1 to. } \\
\text { Magnet1 to. }\end{array}$ & $\begin{array}{l}<1 \\
<1\end{array}$ & \\
\hline 1659 & do. & Mono. & & $\begin{array}{l}\text { Lenticular- } \\
\text { branching. }\end{array}$ & $\begin{array}{c}\text { Wall sone. } \\
\text { Core. }\end{array}$ & $0.1-2$ & 30 & & $\begin{array}{l}45 \\
15\end{array}$ & & 30 & & $\begin{array}{l}25 \\
85\end{array}$ & & & & & & & & & & & $\begin{array}{l}\text { B1otite. } \\
\text { Marti te. }\end{array}$ & $\begin{array}{l}<1 \\
<1\end{array}$ & \\
\hline 1660 & do. & & Pot expoeed. & Irrogular. & One unit. & $2=3$ & 15 & & 60 & & 75 & & 25 & & & & & & & & & & & $\begin{array}{l}\text { B1ot1 to. } \\
\text { Martite. }\end{array}$ & $\begin{array}{l}<1 \\
<1\end{array}$ & \\
\hline 1661 & Ruartz monzonite. & Sore. & & do. & $\begin{array}{c}\text { Vall zone. } \\
\text { Core. }\end{array}$ & 4 & 10 & & 70 & & & & $\begin{array}{r}20 \\
100\end{array}$ & & & & & & & & & & & Brotite. & $\begin{array}{l}<1 \\
<1\end{array}$ & \\
\hline 1662 & do. & do. & & do. & one unit. & $2-3$ & 40 & & 40 & & 15 & & 20 & & & & & & & & & & & $\begin{array}{l}\text { B1ot1 to. } \\
\text { Martito. }\end{array}$ & $\begin{array}{l}<1 \\
<1\end{array}$ & \\
\hline 1663 & do. & do. & & do. & do. & 1 & 20 & & 25 & & & & 55 & & & & & & & & & & & B1otite. & Trace. & \\
\hline 1664 & do. & & & Cont Ioular. & do. & $1 / 4$ & 30 & & 50 & & & & 20 & & & & & & & & & & & Martits. & $<1$ & \\
\hline 1665 & 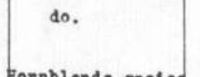 & & & do. & so. & $1 / 8$ & 20 & & 55 & & & & 25 & & & & & & & & & & & $\begin{array}{l}\text { B1ot1te. } \\
\text { Mart1 to. }\end{array}$ & $\begin{array}{l}<1 \\
<1\end{array}$ & \\
\hline 1666 & Fornblende gneles. & 1. Sone. & & Irragular. & $\begin{array}{c}\text { Yall zone. } \\
\text { Coro. }\end{array}$ & $1 / 2$ & 20 & & 50 & & 15 & & $\begin{array}{r}30 \\
100\end{array}$ & & & & & & & & & & & $\begin{array}{l}\text { Botitite. } \\
\text { Martt te: } \\
\text { Bery1. } 1\end{array}$ & $\begin{array}{r}<1 \\
<1 \\
<\text { eryotwa. }\end{array}$ & \\
\hline
\end{tabular}


Teb10 20,--Mineralogy of peratitos--Cont1 nued.

\begin{tabular}{|c|c|c|c|c|c|c|c|c|c|c|c|c|c|c|c|c|c|c|c|c|c|c|c|c|c|c|}
\hline \multirow{4}{*}{$\begin{array}{l}\text { Mumber and } \\
\text { nave of pog } \\
\text { matite } \\
\text { (PI.II) }\end{array}$} & \multicolumn{2}{|c|}{ Weall rock } & \multicolumn{24}{|c|}{ Pomat 1te } \\
\hline & \multirow{3}{*}{$\begin{array}{l}\text { Type and } \\
\text { format 1on }\end{array}$} & \multirow{3}{*}{ N1teration } & \multirow{3}{*}{$\begin{array}{l}\text { Relation to } \\
\text { vall rock }\end{array}$} & \multirow[t]{3}{*}{ Shape } & \multirow{3}{*}{$\begin{array}{l}\text { Internal } \\
\text { structure of }\end{array}$} & \multirow{3}{*}{$\begin{array}{l}\text { Texture } \\
\text { (1nches) }\end{array}$} & \multicolumn{20}{|c|}{ Heneralogy } \\
\hline & & & & & & & \multicolumn{2}{|c|}{ Plaglociaso } & \multicolumn{2}{|c|}{ Porth1 te } & \multicolumn{2}{|c|}{$\begin{array}{l}\text { Graphs: } \\
\text { gran1 to }\end{array}$} & \multicolumn{2}{|c|}{ Quartz } & \multicolumn{2}{|c|}{ Nuscovis to } & \multicolumn{2}{|c|}{ Garnot } & \multicolumn{2}{|c|}{ Tournelino } & \multicolumn{3}{|c|}{ L1 thium mineral. } & \multicolumn{3}{|c|}{ Other minerals } \\
\hline & & & & & & & $\begin{array}{l}\text { Par- } \\
\text { cont }\end{array}$ & $\begin{array}{l}\mathbf{S 1 z \theta} \\
\text { 1nchoo }\end{array}$ & $\begin{array}{l}\text { Por- } \\
\text { foent }\end{array}$ & $\begin{array}{c}\text { S1zo } \\
\text { (1nehod) }\end{array}$ & $\begin{array}{l}\text { Per- } \\
\text { )eent (1) }\end{array}$ & $\begin{array}{l}\text { S1zo } \\
\text { 1nchoof }\end{array}$ & $\begin{array}{l}\text { Par- } \\
\text { deent }\end{array}$ & $\begin{array}{l}\text { S1zo } \\
\text { 1nchoo }\end{array}$ & $\begin{array}{l}\text { Per- } \\
\text { doent }\end{array}$ & 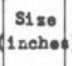 & $\begin{array}{l}\text { Por- } \\
\text { d)eont }\end{array}$ & $\begin{array}{c}\text { S1so } \\
\text { (1ncheot }\end{array}$ & $\begin{array}{l}\text { Per } \\
\text { cent }\end{array}$ & \begin{tabular}{|c|} 
S1ze \\
1 1nchoos
\end{tabular} & Mineral & $\begin{array}{l}\text { Por } \\
\text { cont } \mathrm{C}\end{array}$ & $\begin{array}{c}\text { S1zo } \\
\text { (1nchoot) }\end{array}$ & Kinoral & $\begin{array}{l}\text { Porr } \\
\text { cent }\end{array}$ & $\begin{array}{c}\text { S1:00 } \\
\text { (10chos) }\end{array}$ \\
\hline 1667 & Quartz monzonf to. & - & & Irregular. & One unit. & $1 / 8$ & 10 & & 55 & & & & 35 & & & & & & & & & & & $\begin{array}{l}\text { 31et1 te. } \\
\text { Kartite. }\end{array}$ & irace. & \\
\hline 1668 & do. & & & $\begin{array}{l}\text { Innt1 culart } \\
\text { branching. }\end{array}$ & do. & $1 / 16$ & 72 & & 2 & & & & 25 & & & & & & & & & & & B1otite. & 1 & \\
\hline 1669 & do. & Nono. & & Irregular. & do. & $3 / L-1$ & 2 & & 78 & & 5 & & 20 & & & & & & & & & & & Magnotito. & $\underset{\text { Trace. }}{<1}$ & \\
\hline 1670 & do. & & & Lent1 oular. & do. & 46 & 20 & & 80 & & 85 & & 20 & & & & & & & & & & & do. & Trace. & \\
\hline 1671 & Hornblende gnel op. & & Not exposed. & do. & do. & $1 / 8$ & 55 & & 20 & & & & 25 & & & & & & & & & & & $\begin{array}{l}\text { B1ot1 to. } \\
\text { Martito. }\end{array}$ & $<1$ & ' \\
\hline 1672 & do. & & do. & do. & de. & $2-3$ & 30 & & 45 & & 25 & & 25 & & & & & & & & & & & do. & Trace. & \\
\hline 1673 & do. & & do. & Irragular. & do. & $1 / 8-1 / 4$ & 50 & & 25 & & & & 25 & & & & Trace. & & & & & & & Nagnet1 to. & Trace. & \\
\hline 1674 & do. & & do. & $\begin{array}{l}\text { Lonticular. } \\
\text { branchlng. }\end{array}$ & do. & $1 / 4$ & 30 & & 40 & & & & 30 & & $<1$ & & $<1$ & & & & & & & & & \\
\hline 1675 & do. & None. & & Irrogular. & One unit. & $1 / 2$ & 5 & & 70 & & & & 25 & & & & $<1$ & & & & & & & B1 ot1 to. & Trace. & \\
\hline 1676 & do. & do. & crosscutting. & do. & do. p & $1 / 8-1 / 4$ & 60 & & 15 & & & & 25 & & & & Trace. & & & & & & & do. & $<1$ & \\
\hline 1677 & dn. & & Not exposed. & do. & do. & $1 / 8-1 / 4$ & 35 & & 40 & & & & 25 & & & & Trace. & & & & & & & do. & Trace. & $\because$ \\
\hline 1678 & do. & & do. & Ient1 cular. & do. & $1 / 8$ & 64 & & 10 & & & & 25 & & & & & & & & & & & do. & ${ }^{1}<1$ & \\
\hline 1679 & & & do. & do. & do. & $1 / 8-1 / 4$ & 65 & & 15 & & & & 25 & & & & & & & & & & & do. & Trace. & \\
\hline 1680 & do. & & do. & do. & do. & $1 / 4$ & 50 & & 30 & & & & 20 & & & & & & & & & & & Magneti to. & Trace. & \\
\hline 1681 & do. & & do. & Irregular. & do. & $1 / 4$ & 35 & & 40 & & & & 25 & & & & & & & & & & & $\begin{array}{l}\text { do. } \\
\text { Botsto. }\end{array}$ & $\begin{array}{l}<1 \\
<1\end{array}$ & \\
\hline 1682 & Rzartz monzonite. & Sono. & & do. & do. & $3 / 4$ & 20 & & 55 & & & & 25 & & & & & & & & & & & Marnotite. & $<1$ & \\
\hline 1683 & Fiornblende gnel es & & Not exposed. & do. & do. & $1 / 8$ & 60 & & 15 & & & & 25 & & & & & & & & & & & $\begin{array}{l}\text { B1 ot1 te. } \\
\text { Magnotite. }\end{array}$ & Fraco. & , \\
\hline 1684 & do. & & do. & do. & do. & $1 / 2-3 / 4$ & 15 & & 55 & & & & 30 & & frace. & & $<1$ & & & & & & & B1ot1te. & $<1$ & \\
\hline 1685 & do. & & do. & Lenticular. & do & $1 / 4-1 / 2$ & 3 & & 61 & & & & 35 & & $<1$ & & 1 & & & & & & & & & \\
\hline 1636 & do. & & do. & to. & do. & $1 / 4-1 / 2$ & 10 & & 60 & & & & 30 & & & & $<1$ & & & & & & & B1 ot1 to. & $<$ & \\
\hline 1687 & dc. & & do. & 1o. & do. & $1 / 2$ & 10 & & 55 & & & & 35 & & & & $<1$ & & & & & & & do. & $<1$ & \\
\hline 1688 & do. & & do. & do. & do. & $1 / 4-1 / 2$ & 7 & & 63 & & & & 30 & & & & $<1$ & & & & & & & & & \\
\hline 1689 & do. & & do. & do. & do. & $1 / 4-1 / 2$ & 5 & & 60 & & & & 35 & & & & $<1$ & & & & & & & & & \\
\hline $\begin{array}{l}1690 \\
\text { Iazy Das }\end{array}$ & do. & & do. & do. & de. & $1 / 4$ & 40 & & 35 & & & & 25 & & $<1$ & & $<1$ & & . & & & & & Biot!te. & Traco. & \\
\hline 1691 & do. & & do. & do. & do. & $1 / 4-1 / 2$ & 20 & & 55 & & & & 25 & & & & $<1$ & & & & & & & do. & Trace. & \\
\hline 1692 & do. & & do. & Irregular. & do. & $1 / 4$ & 12 & & 63 & & & & 25 & & & & $<1$ & & & & & & & do. & $<1$ & \\
\hline
\end{tabular}


Feb10 20.-Minoralory of peentitea-continuod.

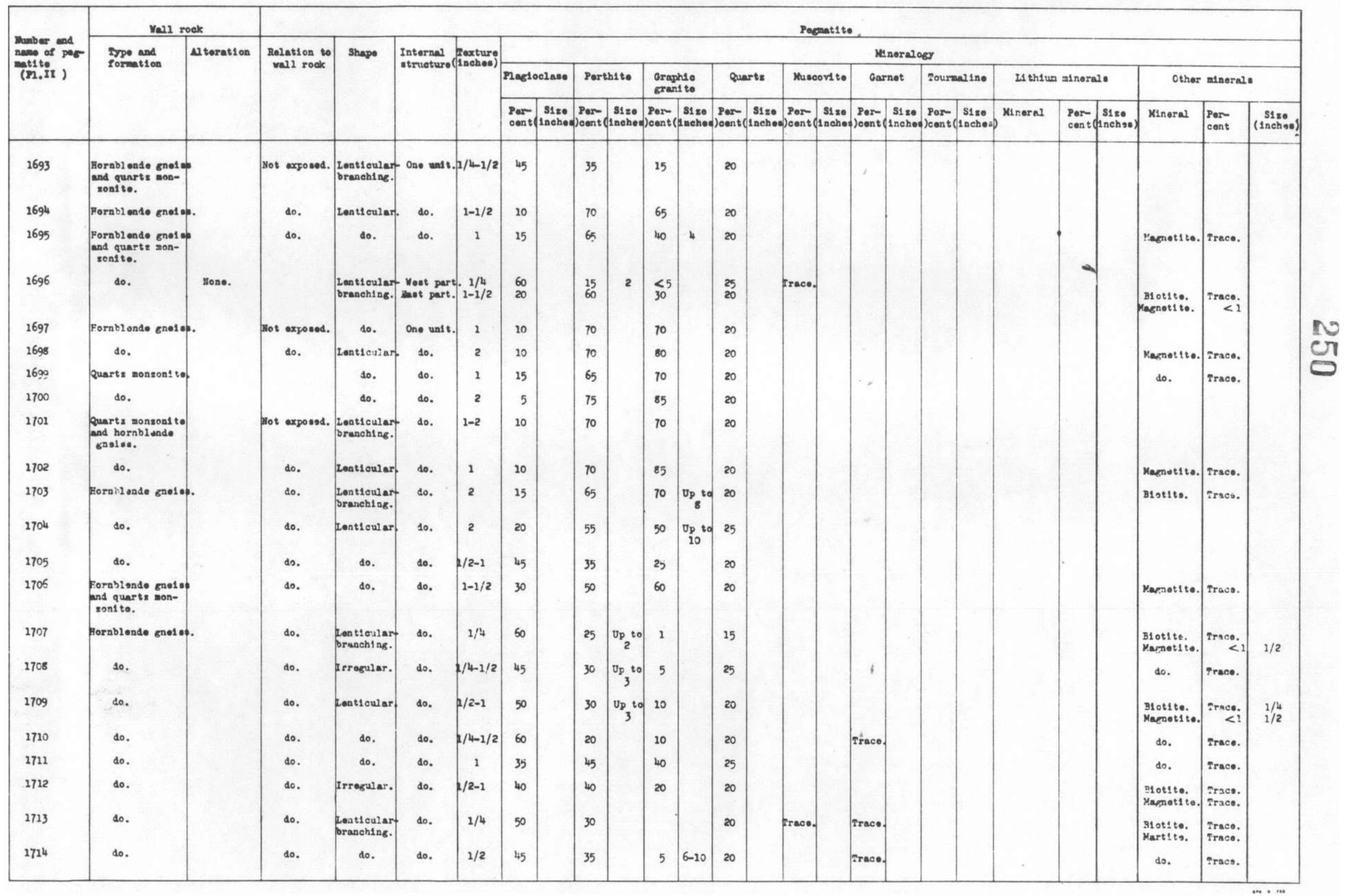


Fable 20,-Minoralory of pepatites-Cont1 uned.

\begin{tabular}{|c|c|c|c|c|c|c|c|c|c|c|c|c|c|c|c|c|c|c|c|c|c|c|c|c|c|c|}
\hline \multirow{4}{*}{$\begin{array}{l}\text { Munber and } \\
\text { nave of peo } \\
\text { metitito } \\
\text { (II. II) }\end{array}$} & \multicolumn{2}{|c|}{ Voll rook } & \multicolumn{24}{|c|}{ Pegatite } \\
\hline & \multirow{3}{*}{$\begin{array}{l}\text { Type and } \\
\text { Sormat } 1 \text { ion }\end{array}$} & \multirow[t]{3}{*}{ Nlteration } & \multirow{3}{*}{$\begin{array}{l}\text { Rolation to } \\
\text { vall rook }\end{array}$} & \multirow[t]{3}{*}{ Shape } & \multirow{3}{*}{$\begin{array}{l}\text { Internal } \\
\text { strueture }\end{array}$} & \multirow{3}{*}{$\begin{array}{l}\text { Coxture } \\
\text { (1nchoos) }\end{array}$} & \multicolumn{20}{|c|}{ Weneralogy } \\
\hline & & & & & & & \multicolumn{2}{|c|}{ Plagloclase } & \multicolumn{2}{|c|}{ Porthite } & \multicolumn{2}{|c|}{$\begin{array}{l}\text { Graph10 } \\
\text { gran1 to }\end{array}$} & \multicolumn{2}{|c|}{ Querts } & \multicolumn{2}{|c|}{ Muscovit to } & \multicolumn{2}{|c|}{ Garnet } & \multicolumn{2}{|c|}{ Tournalino } & \multicolumn{3}{|c|}{ L1 th1un minoral. } & \multicolumn{3}{|c|}{ Other minerals. } \\
\hline & & & & & & & $\begin{array}{l}\text { Par } \\
\text { cont }\end{array}$ & $\left.\begin{array}{c}31 z 0 \\
\text { 1neho: }\end{array}\right)$ & $\begin{array}{l}\text { Porr } \\
\text { Poent }\end{array}$ & $\begin{array}{c}\text { S1zo } \\
\text { 1nchod) }\end{array}$ & $\begin{array}{l}\text { Por } \\
\text { Peont (1 }\end{array}$ & $\begin{array}{l}\text { S1zo } \\
\text { 1nehes) }\end{array}$ & $\begin{array}{l}\text { Par } \\
\text { Doent }\end{array}$ & $\begin{array}{c}\text { sizo: } \\
\text { (1nchea) }\end{array}$ & $\begin{array}{l}\text { Por- } \\
\text { Joent } 1\end{array}$ & $\begin{array}{l}\text { s1 so } \\
\text { 11cheo: }\end{array}$ & Por- & $\begin{array}{l}\text { S1zo } \\
\text { (1nches: }\end{array}$ & $\begin{array}{l}\text { Par- } \\
\text { ()eont }\end{array}$ & 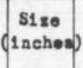 & Minoral & $\begin{array}{l}\text { Por- } \\
\operatorname{con} t\end{array}$ & \begin{tabular}{|l|}
5180 \\
$(1$ sehoad)
\end{tabular} & Nineral & $\begin{array}{l}\text { Perr } \\
\text { cont }\end{array}$ & $\begin{array}{c}\text { S1so } \\
\text { (1nekeos) }\end{array}$ \\
\hline 1715 & Rorablende gaelo & & Mot exposed. & Len t1 cular. & . One unit t. & $1 / 4$ & 60 & $\begin{array}{c}1 / 16- \\
1 / 8\end{array}$ & 20 & $1 / 2-2$ & & & 20 & & & & Trace. & & & & & & & & & \\
\hline 1716 & do. & & do. & do. & do. & $1 / 4$ & 60 & & 20 & $1 / 2-1$ & & & 20 & & & & Trace. & & & & & & & & & \\
\hline 1717 & هo. & & do. & $\begin{array}{l}\text { Lonticular- } \\
\text { branch1ng. }\end{array}$ & do. & 1 & 35 & $1 / 8$ & 45 & $1-3$ & 20 & & 20 & $1 / 8-1 / 4$ & & & & & & & & & & Magneti to. & $<1$ & $1 / 4$ \\
\hline 1718 & do. & & do. & do. & do. & 1 & 50 & & 30 & $2 / 2-3$ & 30 & & 20 & & & & & & & & & & & do. & $<1$ & $<1 / 2$ \\
\hline 1719 & do. & & do. & Irrogular. & do. & $1 / 4$ & 60 & $1 / 8$ & 20 & $2 / 2$ & & & 10 & $1 / 4-1$ & & & & & & & & & & & & \\
\hline 1720 & $\begin{array}{l}\text { Bornblende gne1 ap } \\
\text { and quarts mon- } \\
\text { sont to. }\end{array}$ & Mono. & & e. & $\begin{array}{l}\text { Morthoeant } \\
\text { ond South- } \\
\text { coat onde. } \\
\text { pontral } \\
\text { part. }\end{array}$ & $\begin{array}{c}1 \\
1 / 4-1 / 2\end{array}$ & 35 & & 79 & & 10 & & 20 & & & & Irace. & & & & & & & Marti to. & $<1$ & $1 / 2$ \\
\hline 1721 & Ruarts monzon1 to & do. & & Lenticular. & One unit. & $1 / 2-1$ & 20 & $\begin{array}{l}1 / 16- \\
1 / 8\end{array}$ & 60 & $1 / 2-3$ & 30 & $1-3$ & 20 & $2 / 8-1 / 4$ & Traco & $0.1 / 8=$ & Trace. & $1 / 8$ & & & & & & $\begin{array}{l}\text { Mesnotite. } \\
\text { Blot 1to. }\end{array}$ & Traso. & ${ }_{1}^{1 / 4-1 / 2}$ \\
\hline 1722 & $\begin{array}{l}\text { lornblende gnoteo } \\
\text { and quarrts mon- } \\
\text { zen1to. }\end{array}$ & do. & & $\begin{array}{l}\text { Lonticular } \\
\text { Oranching. }\end{array}$ & do. & 2 & 30 & & 50 & & 20 & & 20 & & & & Trace. & & & & & & & nagnot 1te. & Trace; & $3 / 4$ \\
\hline 1723 & do. & & & do. & do. & 2 & 5 & & 75 & & 40 & & 20 & & & & $<1$ & & & & & & & $\begin{array}{l}\text { B1ot1te. } \\
\text { Hartite. }\end{array}$ & $\begin{array}{r}\text { rrace. } \\
<i\end{array}$ & \\
\hline 1724 & Hornblende grol eof. & & pot axposed. & Lentioular. & do. & 3 & 30 & & 50 & & 30 & & 20 & & & & Trace. & $1 / 32$ & & & & & & Narnots to. & Trace. & $1 / 8$ \\
\hline 1725 & do. & & do. & do. & do. & $3 / 4$ & 60 & & 25 & & 10 & 6 & 15 & & & & & & & & & & & do.. & Trace. & $1 / 32$ \\
\hline 1726 & do. & & do. & do. & do. & $1 / 4$ & 50 & & 30 & 3 & & & 20 & & & & $<1$ & $1 / 16$ & & & & & & do. & $<1$ & $1 / 32-1 / 4$ \\
\hline 1727 & do. & & do. & do. & do. & $3 / 4$ & 35 & & 45 & & 10 & 5 & 20 & & & & trace. & $1 / 16$ & & & & & & & & \\
\hline 1728 & do. & & do. & Irrogular. & do. & 4 & 39 & & 50 & 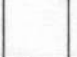 & 60 & 10 & 20 & & & & & & & & & & & Biotito. & Trace. & $1 / 16$ \\
\hline 1729 & 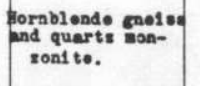 & & do. & Rent1 oul ar & do. & $1 / 2$ & 45 & & 35 & 3 & & & 20 & & & & & & & & & & & Magetito. & $\begin{array}{l}\text { Trace. } \\
\text { Trace. }\end{array}$ & $\begin{array}{l}1 / 8 \\
1 / 32\end{array}$ \\
\hline 1730 & do. & & do. & do. & do. & 3 & 30 & & 55 & & 40 & 6 & 15 & & & & & & & & & & & $\begin{array}{l}\text { B1ot! to. } \\
\text { ragnotito. }\end{array}$ & $\begin{array}{l}\text { Trace. } \\
\text { Traco: }\end{array}$ & $\begin{array}{l}1 / 8 \\
1 / 32\end{array}$ \\
\hline 1731 & fornblende gneled. & & do. & do. & do. & $1 / 4$ & 49.5 & & 30 & 3 & & & 20 & & & & 0.5 & $1 / 16$ & & & & & & Biotite. & Trace. & $\begin{array}{l}1 / 4 \\
1 / 32\end{array}$ \\
\hline 1732 & $\begin{array}{l}\text { fornblende gno1 se } \\
\text { and quarts moo- } \\
\text { sonito. }\end{array}$ & & do. & do. & do. & $1 / 2$ & 65 & $1 / 8$ & 20 & & 20 & 4 & 15 & & & & & & & & & & & B1 otito. & Trace. & $1 / 8$ \\
\hline 1733 & do. & & do. & or tionchinger. & do. & $1 / 4$ & 45 & & 35 & & 20 & 4 & 20 & & & & & & & & & & & Magnot1 te. & Trace. & $1 / 16$ \\
\hline 1734 & Hornblen & & do. & do. & do. & 6 & 10 & & 70 & & 85 & & 20 & & Irace. & & & & & & & & & $\begin{array}{l}\text { B1ot1 to. } \\
\text { Martite. } \\
\text { Somaraki to }\end{array}$ & (r) $\begin{array}{l}<1 \\
3\end{array}$ & oryetale. \\
\hline 1735 & 耳orablende gnelece. & & do. & do. & do. & $1 / 2$ & 55 & $1 / 32$ & 30 & 4 & & & 15 & & & & & & & & & & & Magnet1 to. & Trace. & $1 / 16$ \\
\hline
\end{tabular}


Fab10 20.--Minoralory of perent1 teg-Cont1 nused.

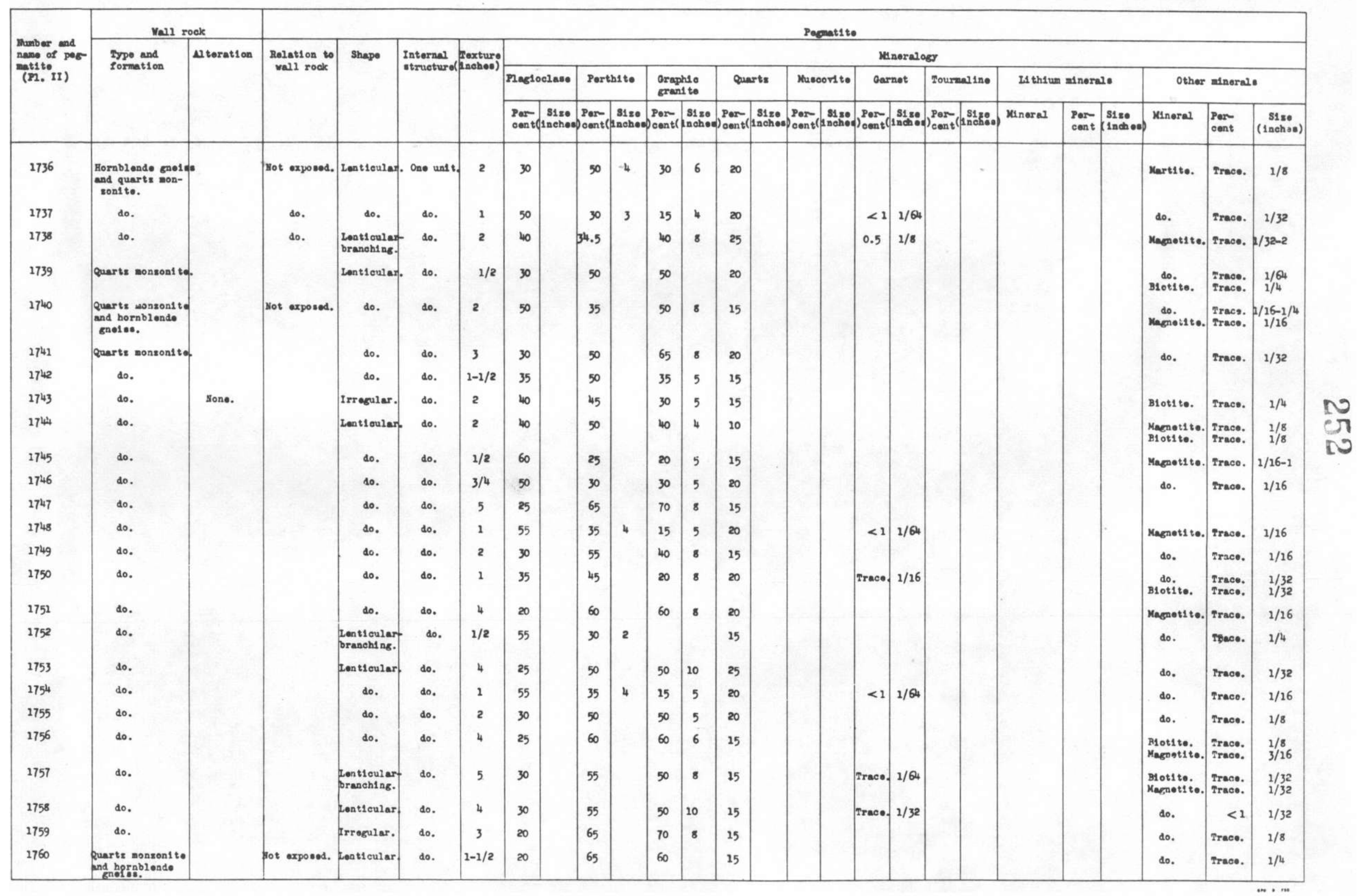


Ieb1020.-Minoraloery of peratit tos-Continued.

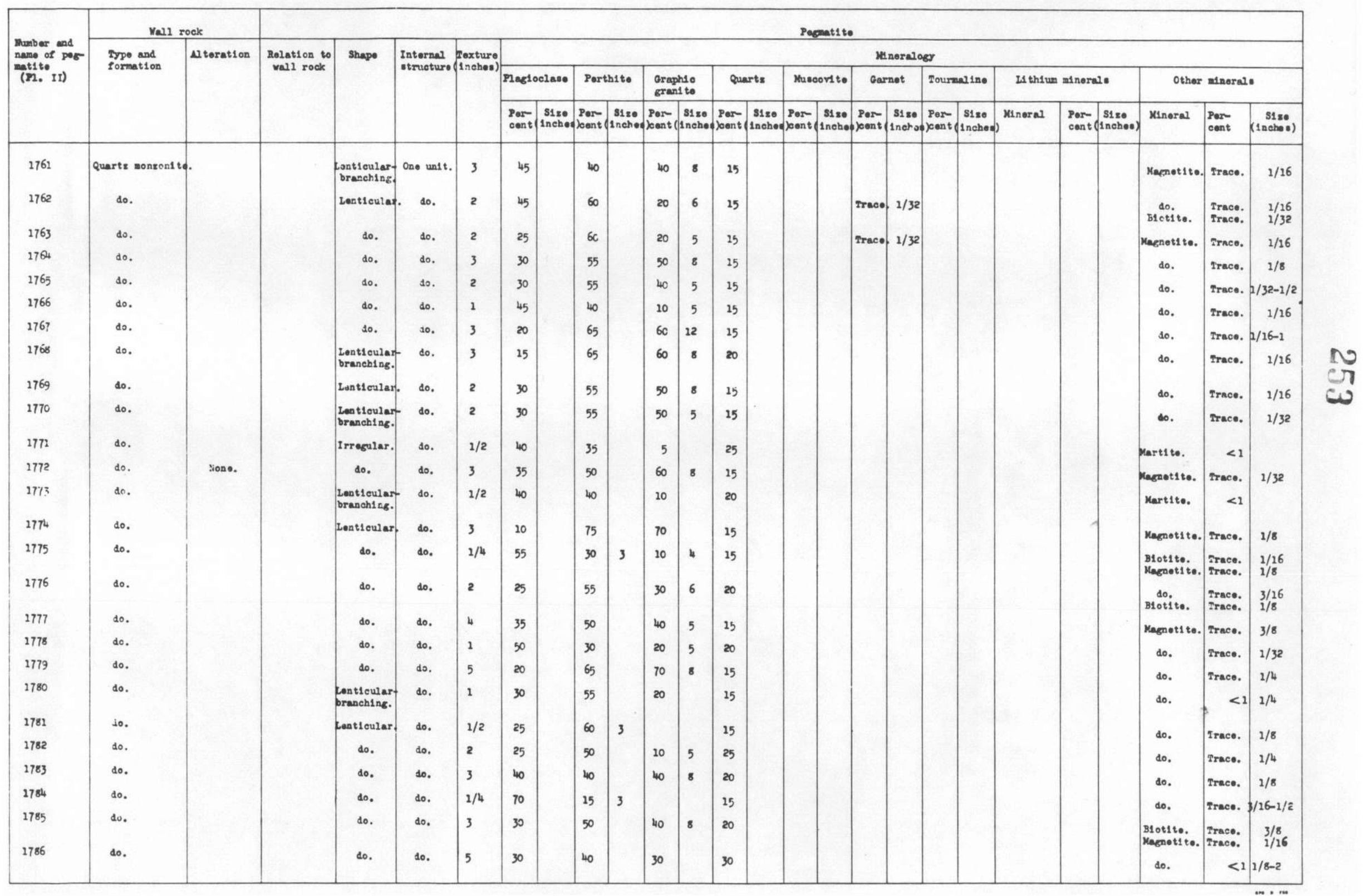


Teb10 20.--Minoralory of perat1 teo-Cont1nued.

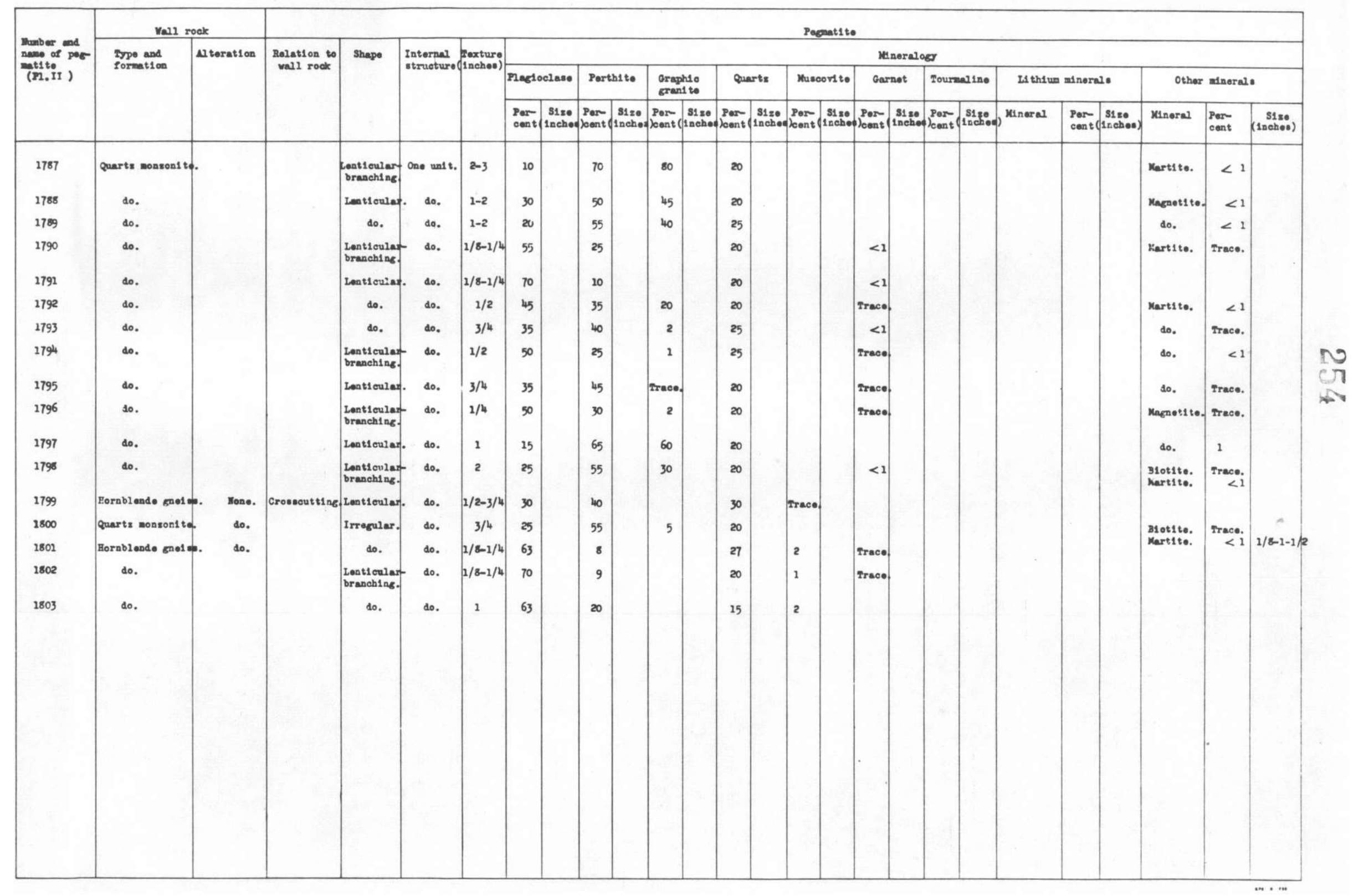




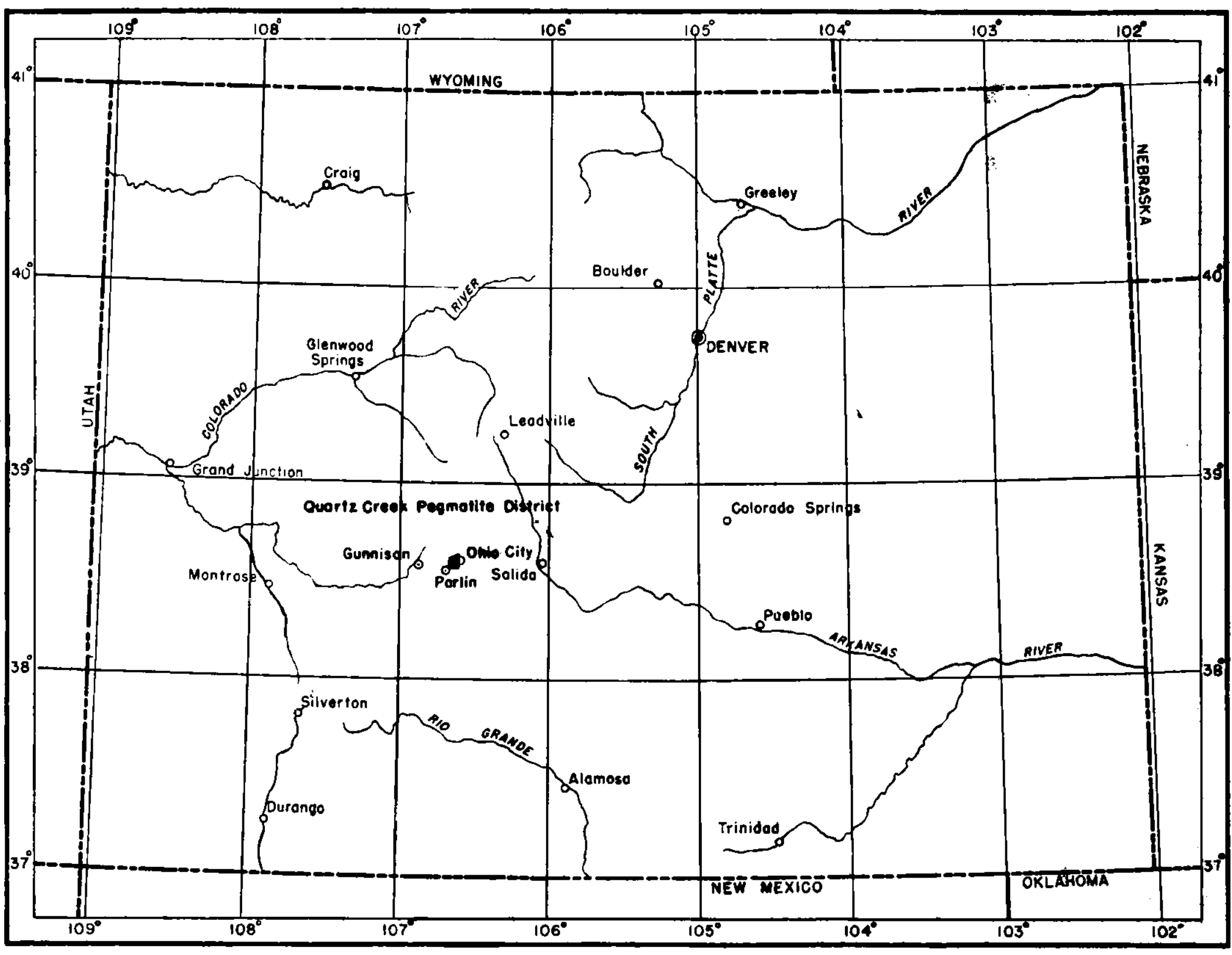

or

FIGURE I.

INDEX MAR QUARTZ CREEK PEGMATITE DISTRICT, COLORADO 


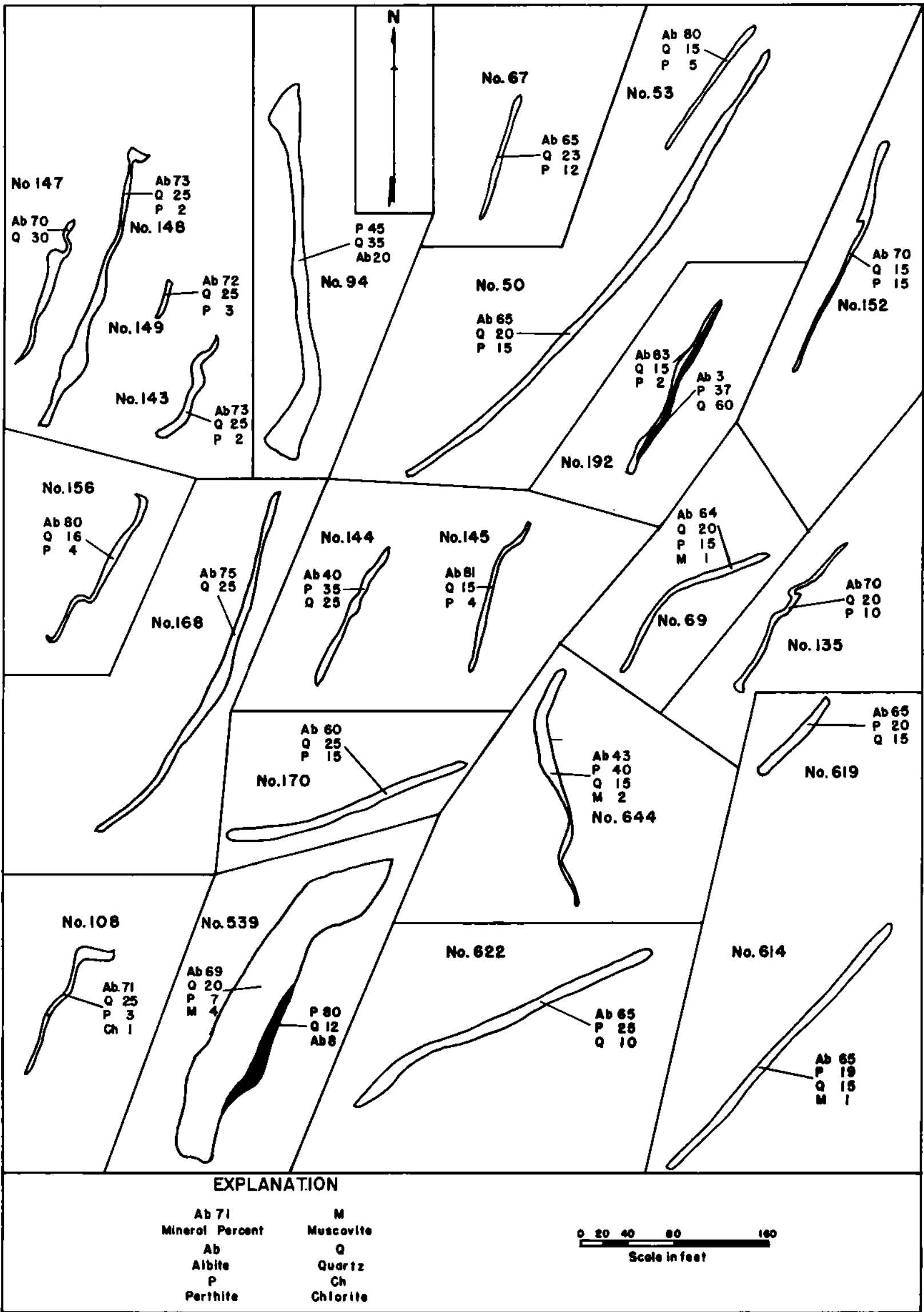

FIGURE 2. LENTICULAR PEGMATITES, QUARTZ CREEK PEGMATITE DISTRIGT 


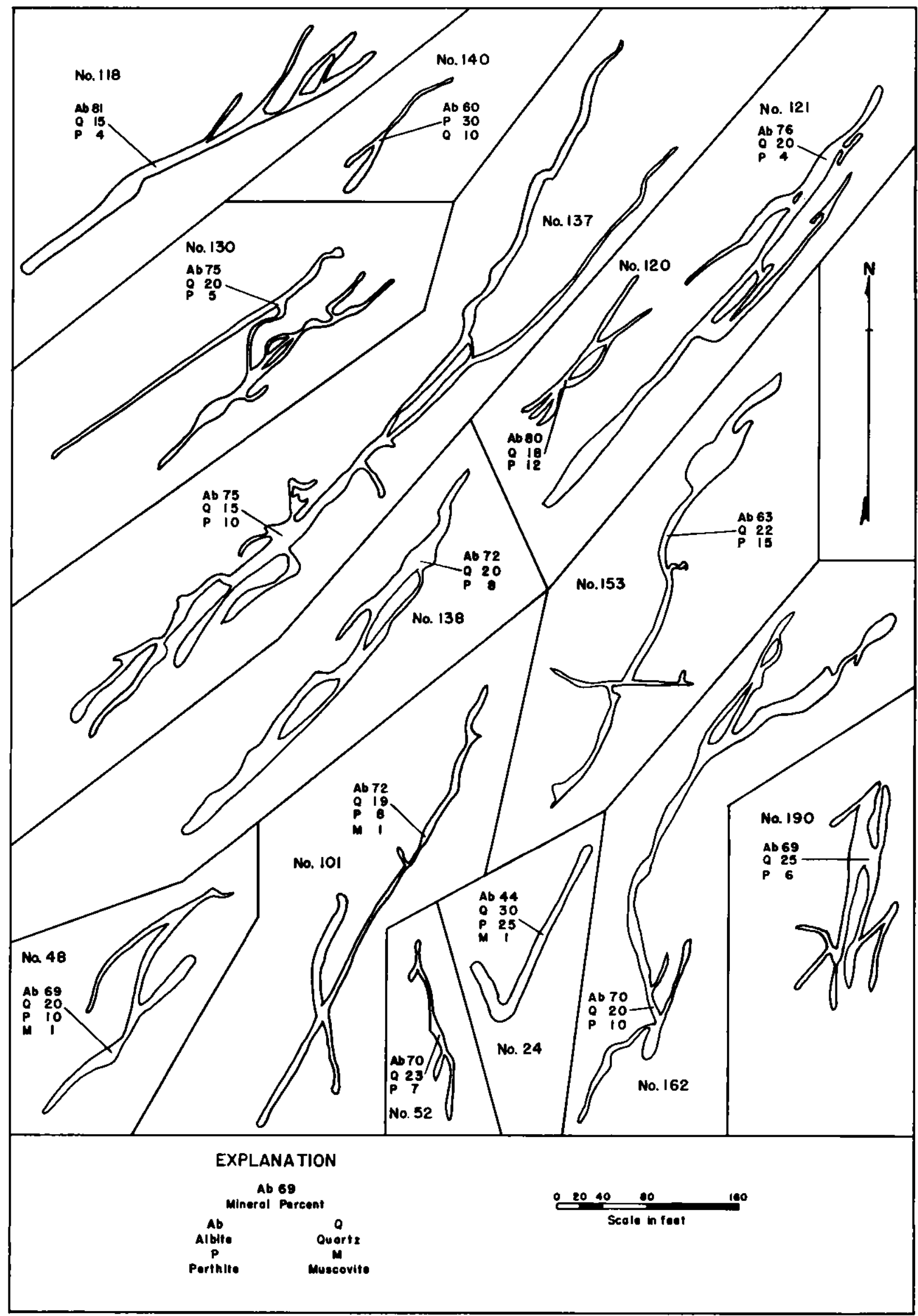

FIGURE 3. LENTICULAR AND BRANCHING PEGMATITES, QUARTZ CREEK PEGMATITE DISTRICT 


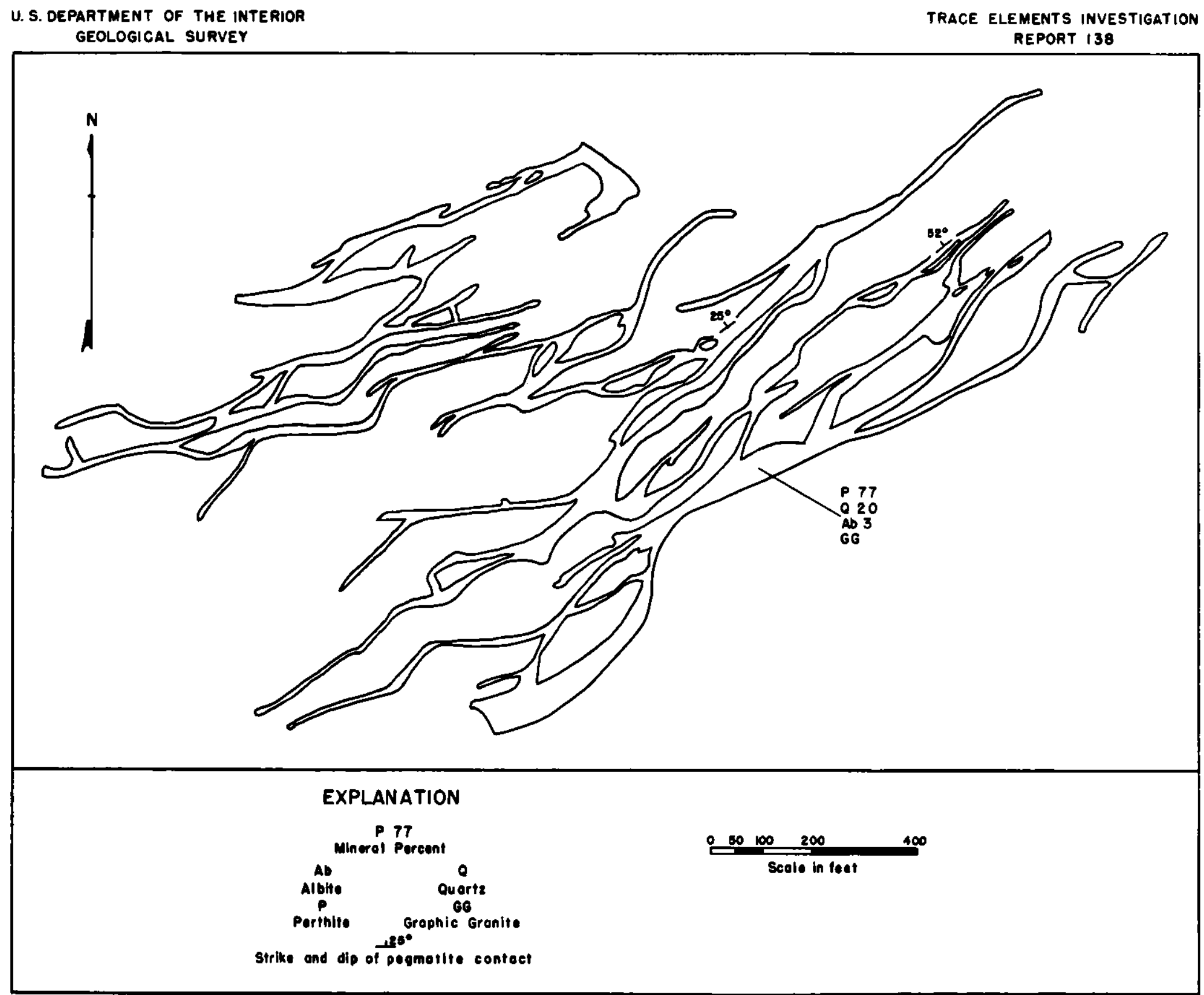

N

FIGURE 4. SHAPE OF PEGMATITE NO. 1294, QUARTZ CREEK PEGMATITE DISTRICT 
U.S. DEPARTMENT OF THE INTERIOR

2.59 GEOLOGICAL SURVEY

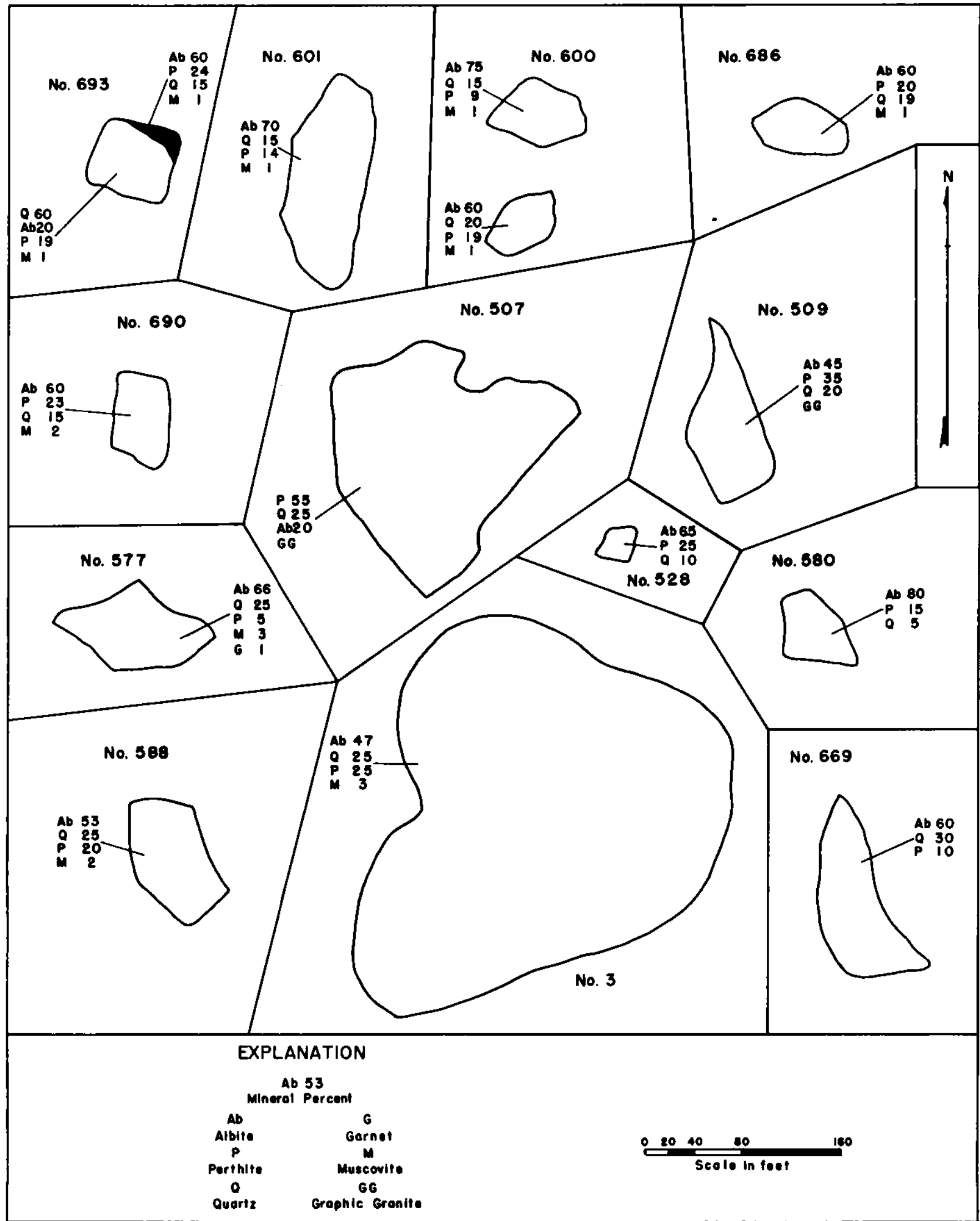

FIGURE 5. OVAL PEGMATITES, QUARTZ CREEK PEGMATITE DISTRICT 


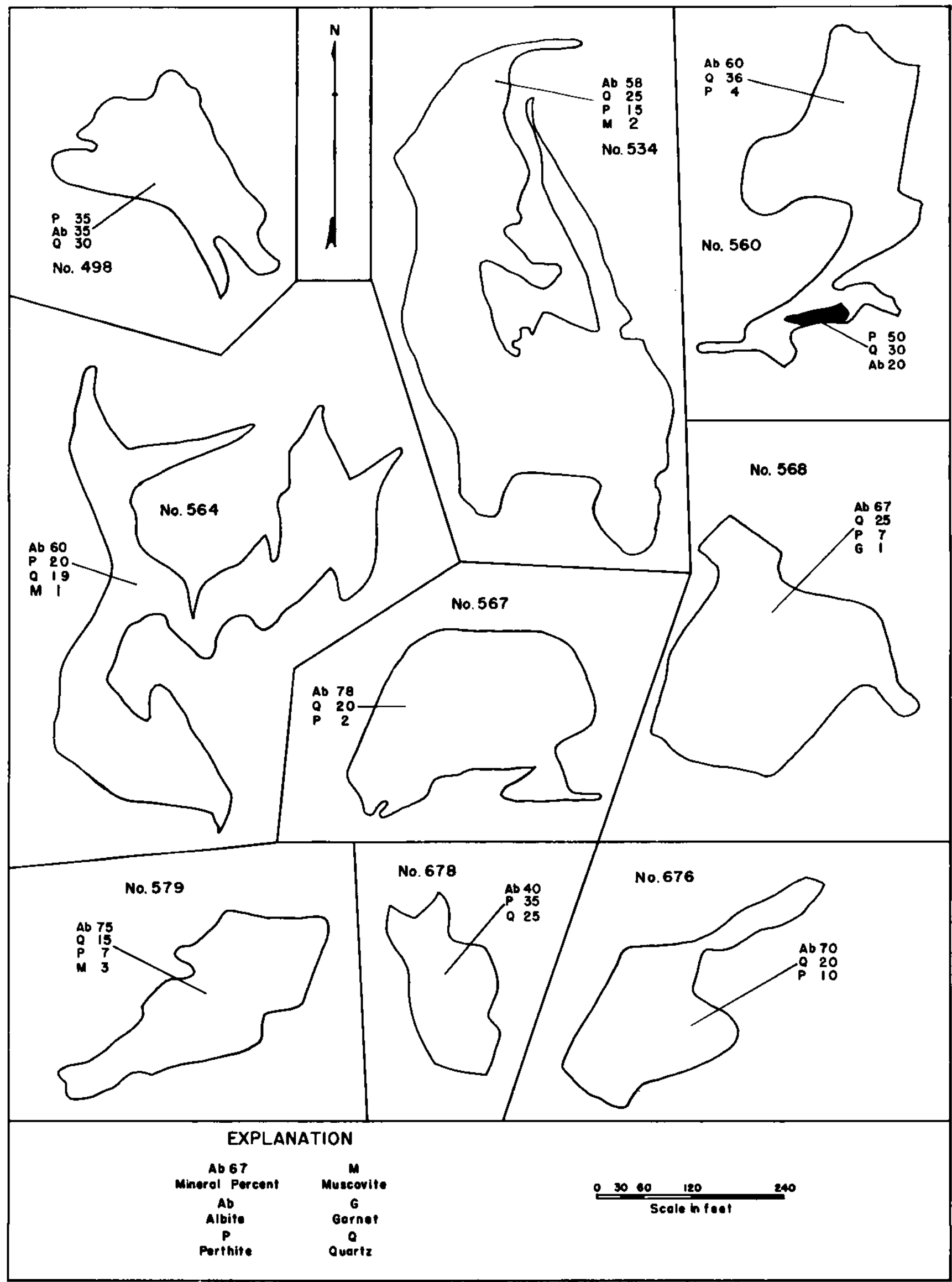

FIGURE 6. IRREGULAR PEGMATITES, QUARTZ CREEK PEGMATITE DISTRICT 

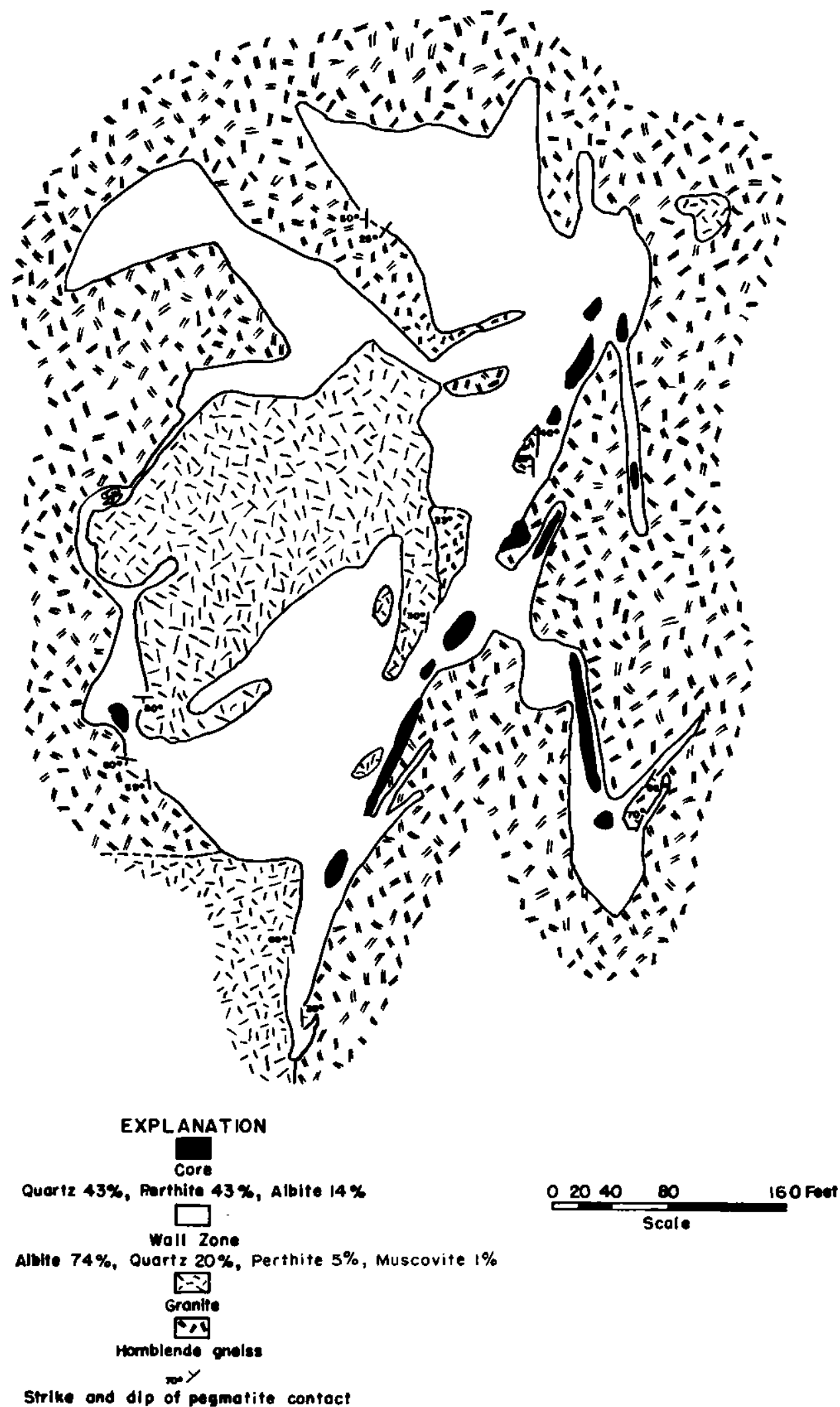

Strike and dip of pegmatite confoct 
U. S. DEPARTMENT OF THE INTERIOR GEOLOGICAL SURVEY
TRACE ELEMENTS INVESTIGATION REPORT I38

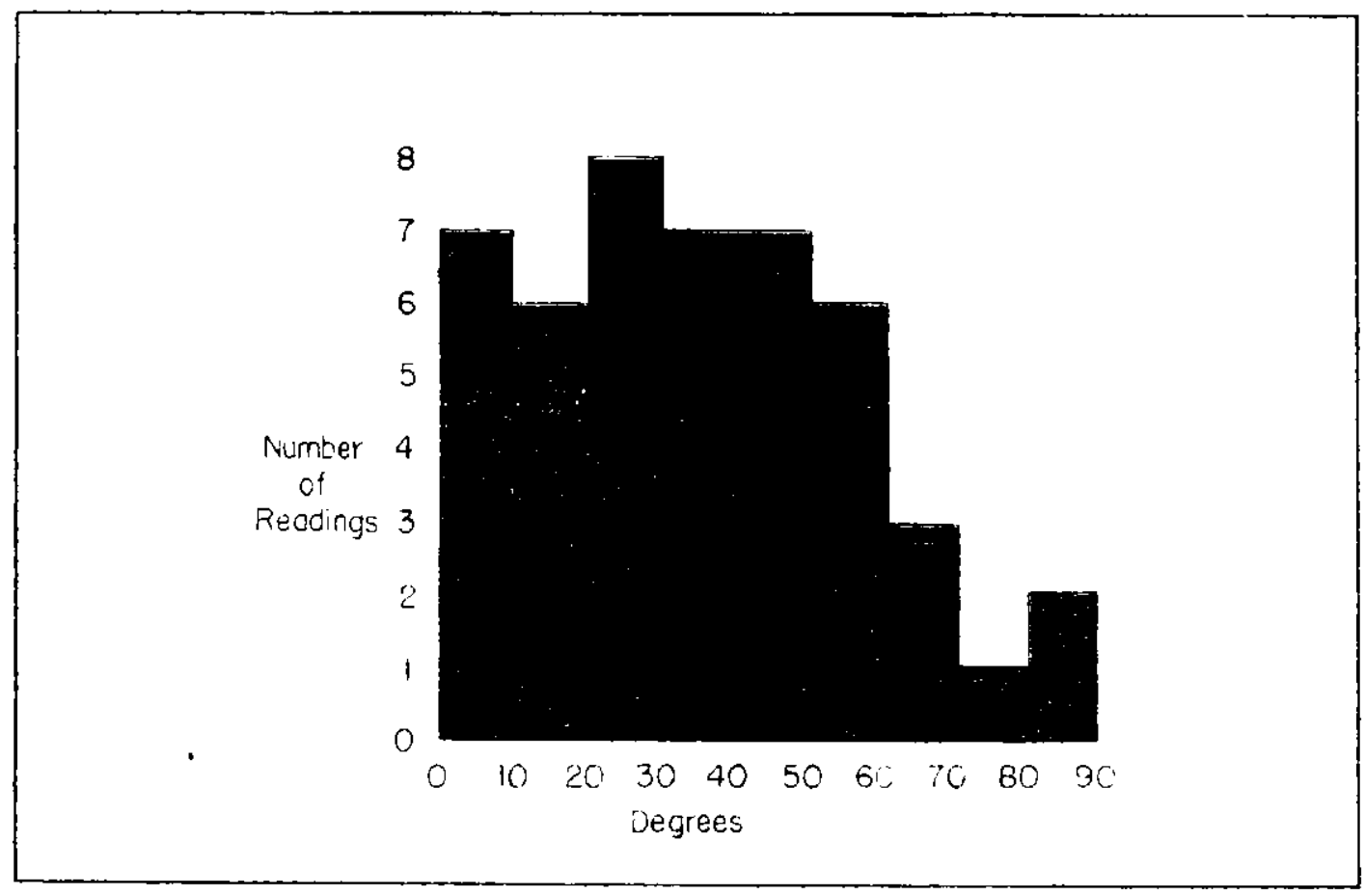

FIGURE 8. ANGLE BETWEEN PEGMATITE CONTACTS AND FOLIATION OF COUNTRY ROCK 


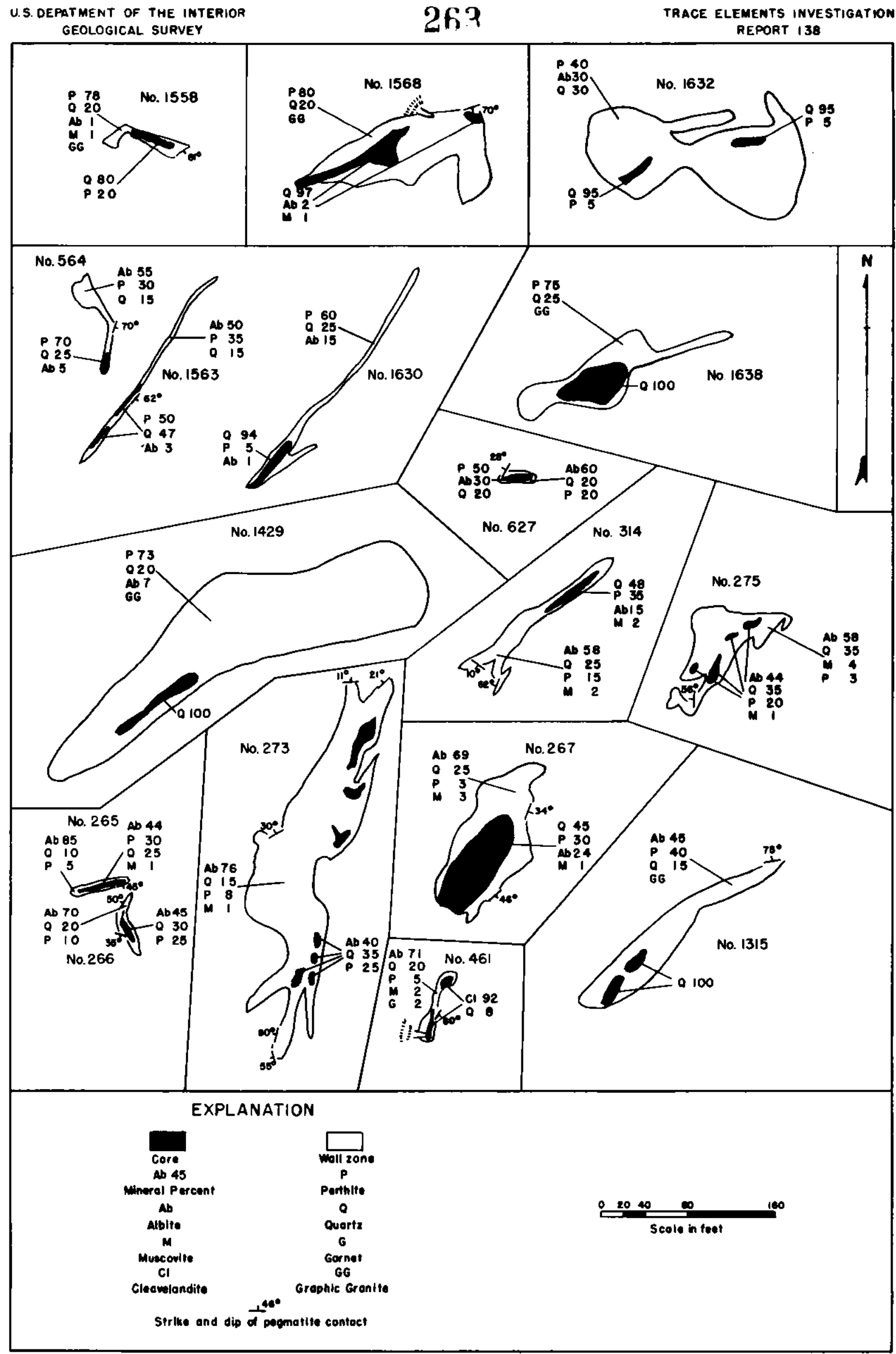

FIGURE 10. ZONED PEGMATITES, QUARTZ CREEK PEGMATITE DISTRICT 


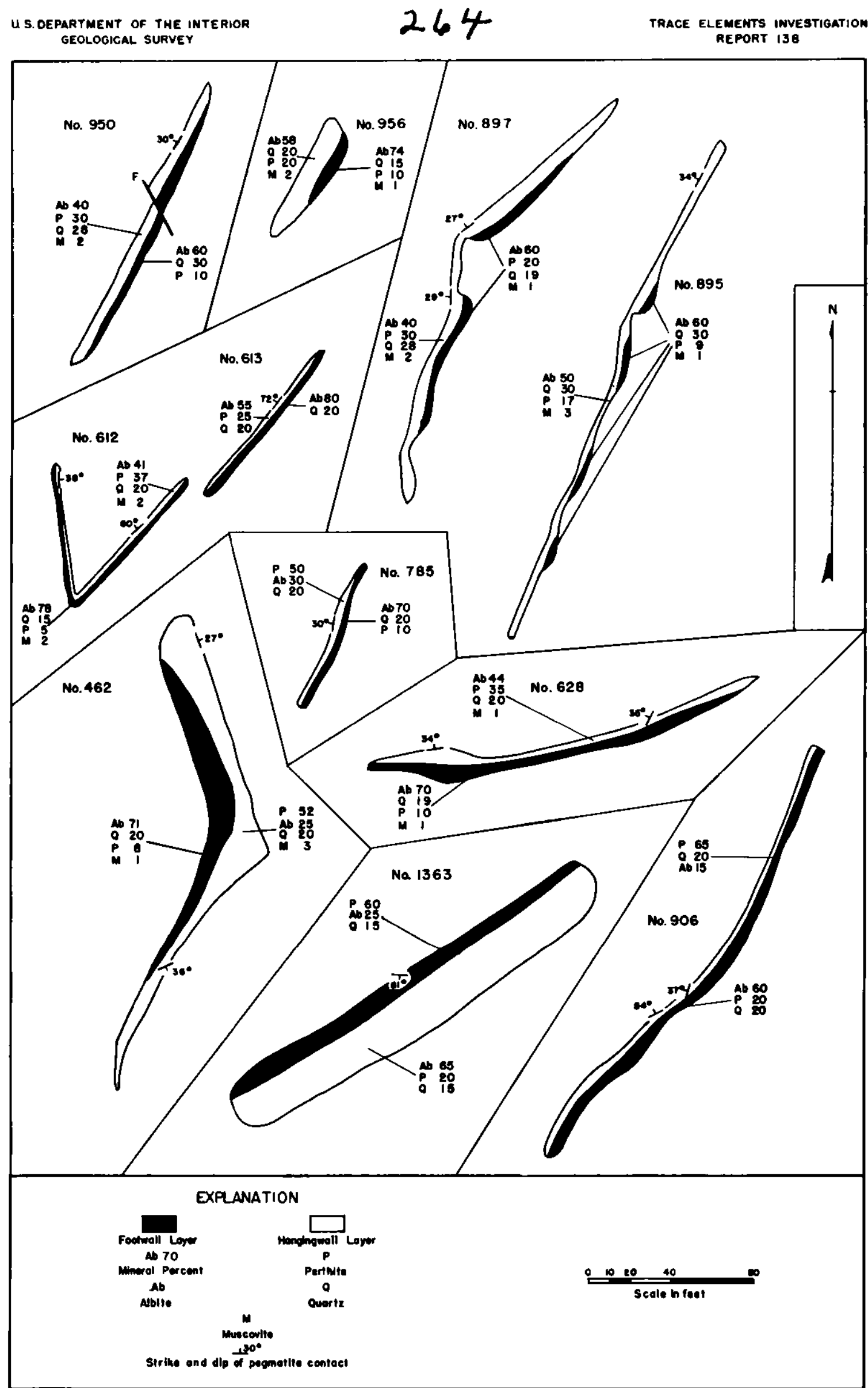

FIGURE 1 I. LAYERED PEgMATITES, QUARTZ CREEK PEgMATITE DISTRICT 


\section{$\therefore 5$}

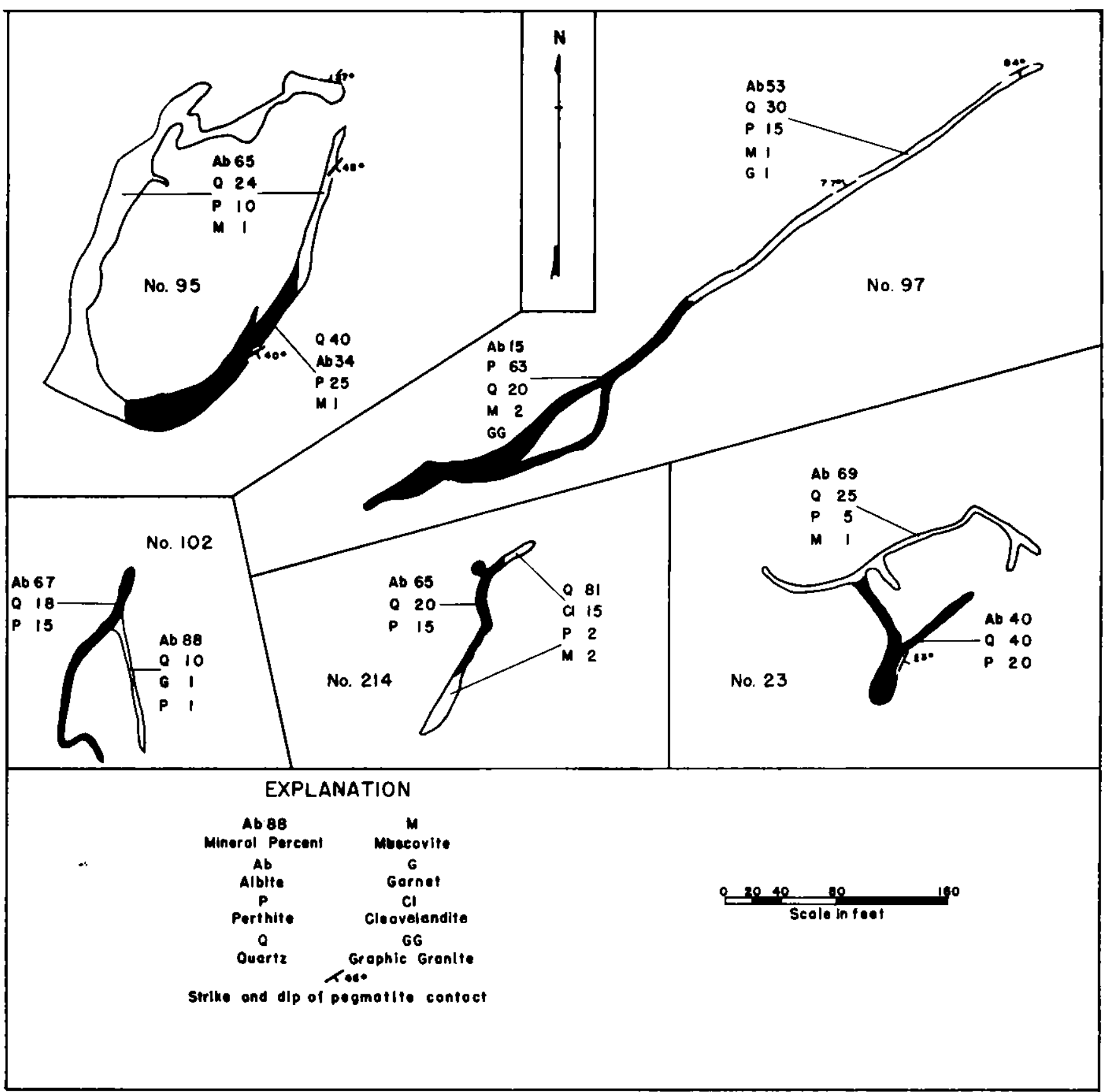

FIGURE 12. PEGMATITES SHOWING VARIATION IN COMPOSITION ALONG STRIKE QUARTZ CREEK PEGMATITE DISTRICT 


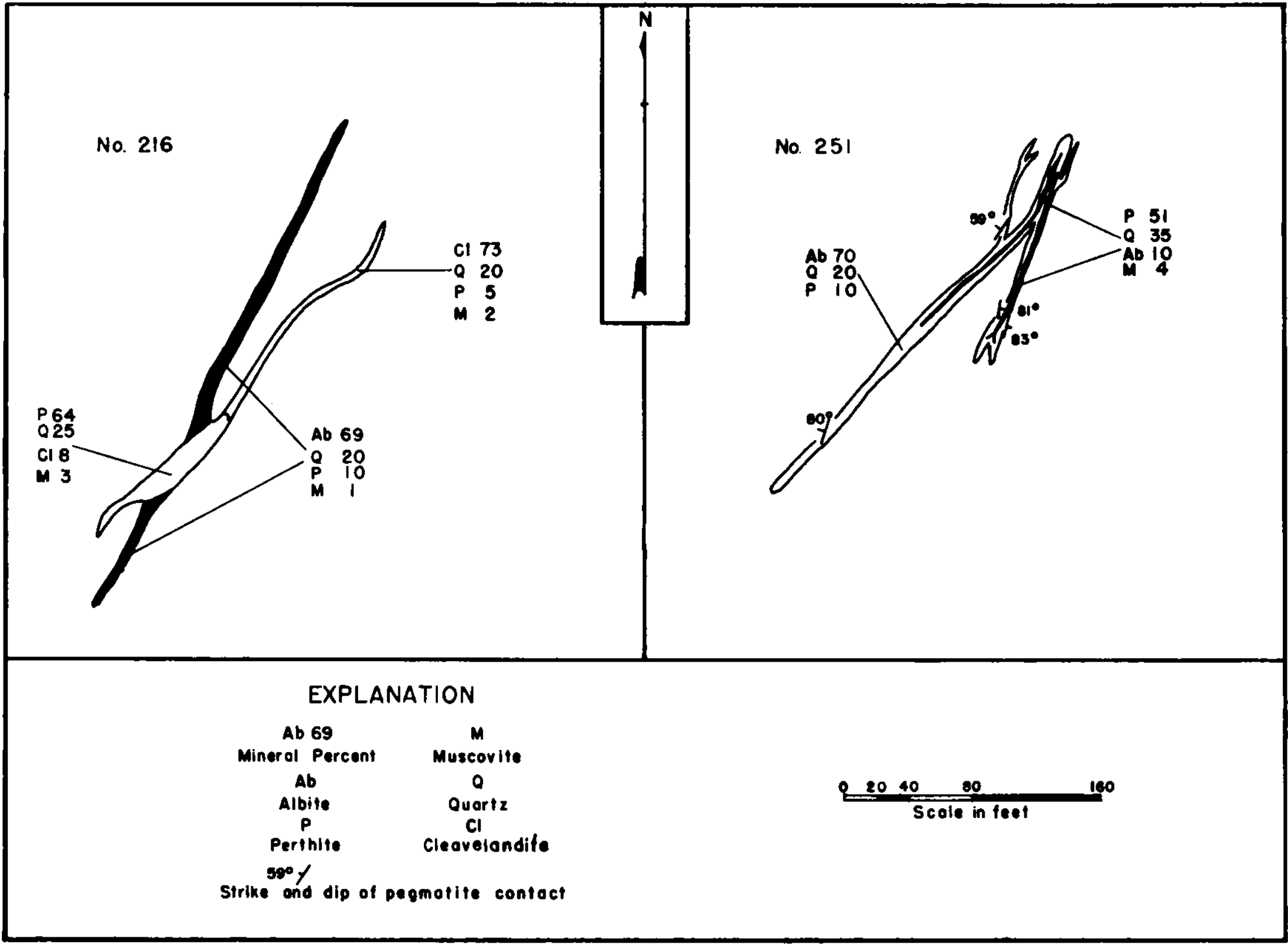


U. S. DEPARTMENT OF THE INTERIOR GEOLOGICAL SURVEY

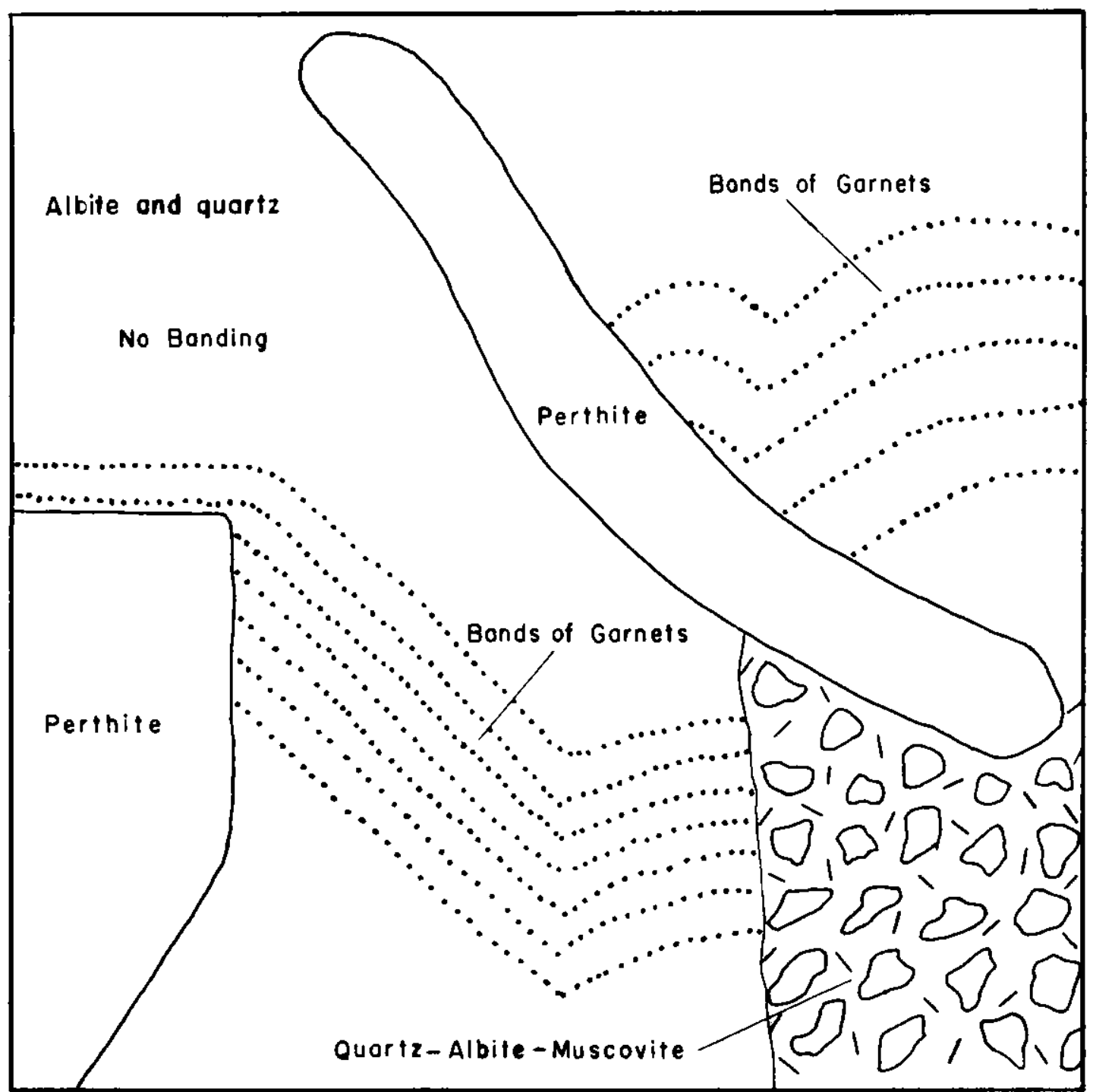

FIGURE 14. RELATION OF BANDING TO CRYSTALS OR NON-BANDED MINERAL AGGREGATES, PEGMATITE NO. 70 


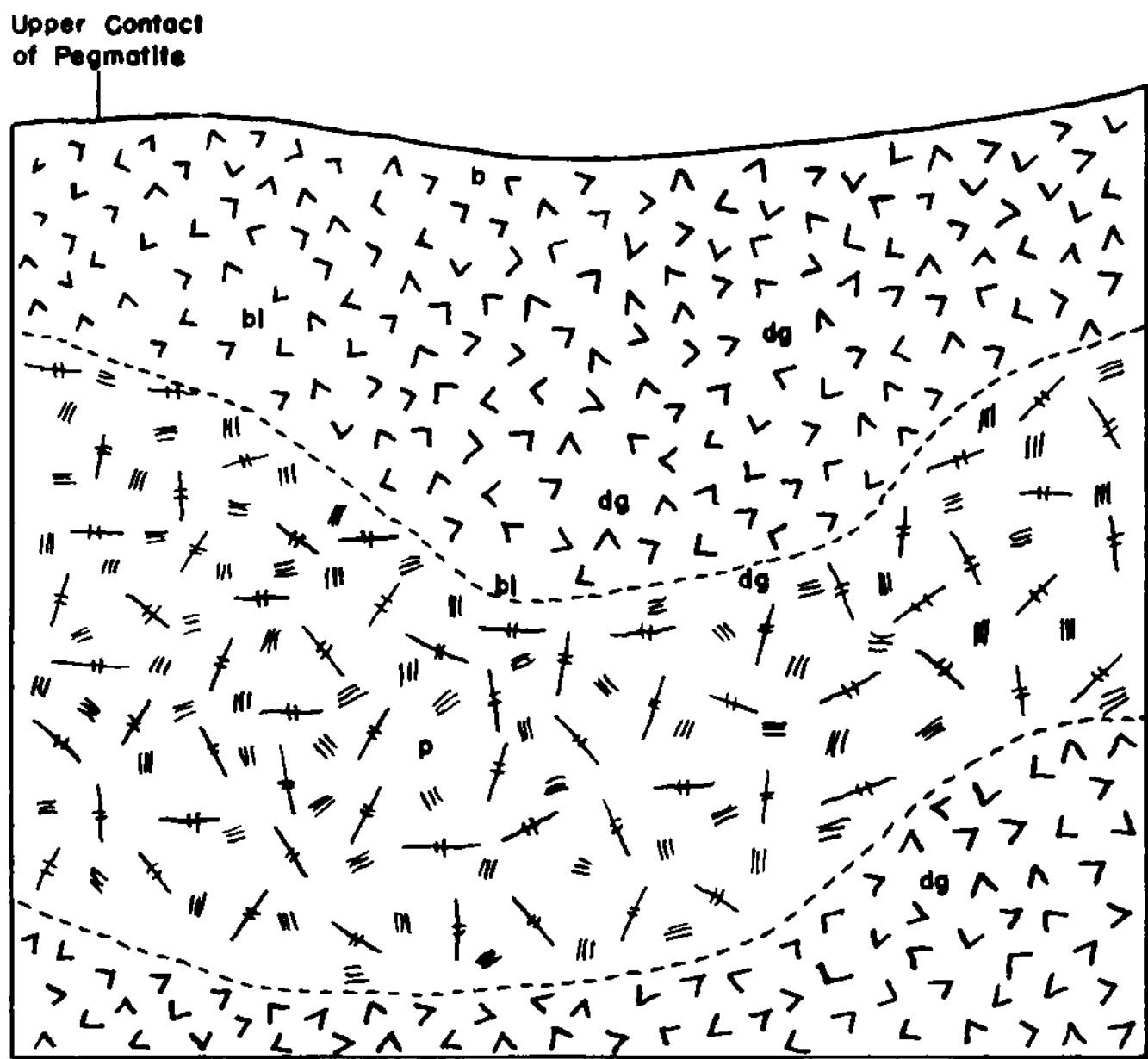

Base of Pit

EXPLANATION

\section{${ }^{4}>\mathrm{N}<$}

Albite-Quert2 Pegmotite (Containing Albito (64\%)

Cuortz (30\%), Muscovife (4\%), Tourmallme (R\%land gornet $(k \mid \%)$ )

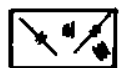

Cleovelandite-Quartz-Lepidolite Pegmatite Contoining cleovelandite (54\%), Quartz (25\%) epidollte (20\%), Muscovite $(x)$, Topoz $(<\mid \%)$, and Tourmaline $(k \mid \%))$

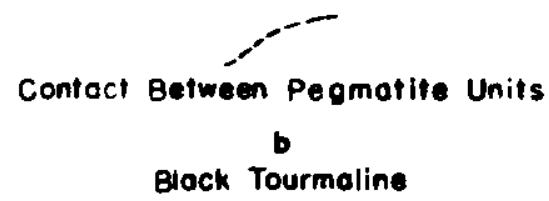

do

Dork Green Tourmaline

bl

Blue Tourmalim

p

Pink Tourmaline

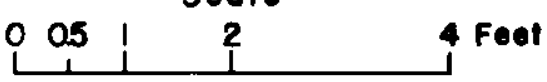

FIGURE 15. DISTRIBUTION OF TOURMALINE, FACE OF CUT IN PEgMATITE NO 453 


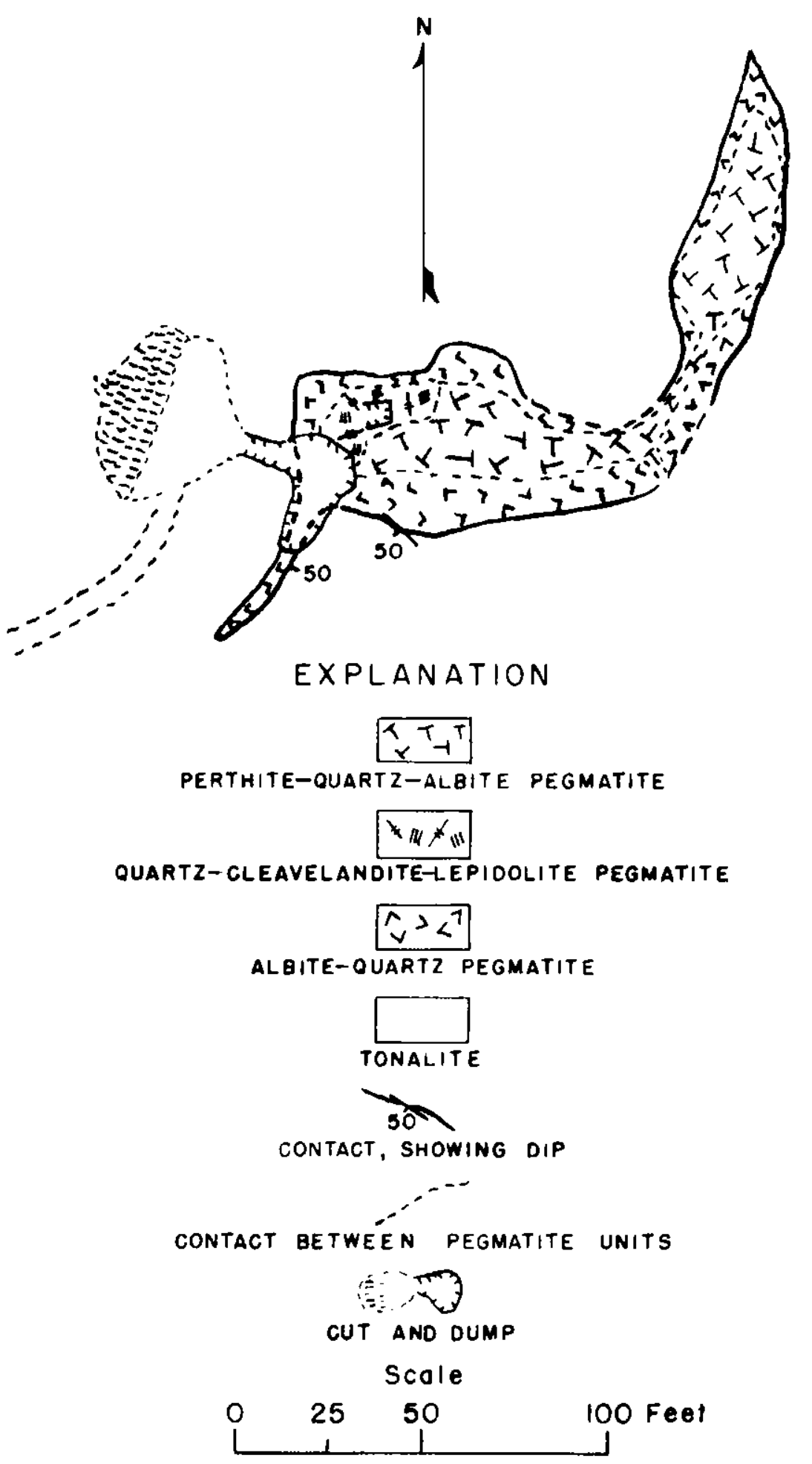

Geology by J.B. Honley and R. Miller Sept. 1943 Revised by M.H. Stootz Sept. 1949

FIGURE 23. GEOLOGIC MAP, BROWN DERBY NO. 5 (NO.535) PEGMATITE 


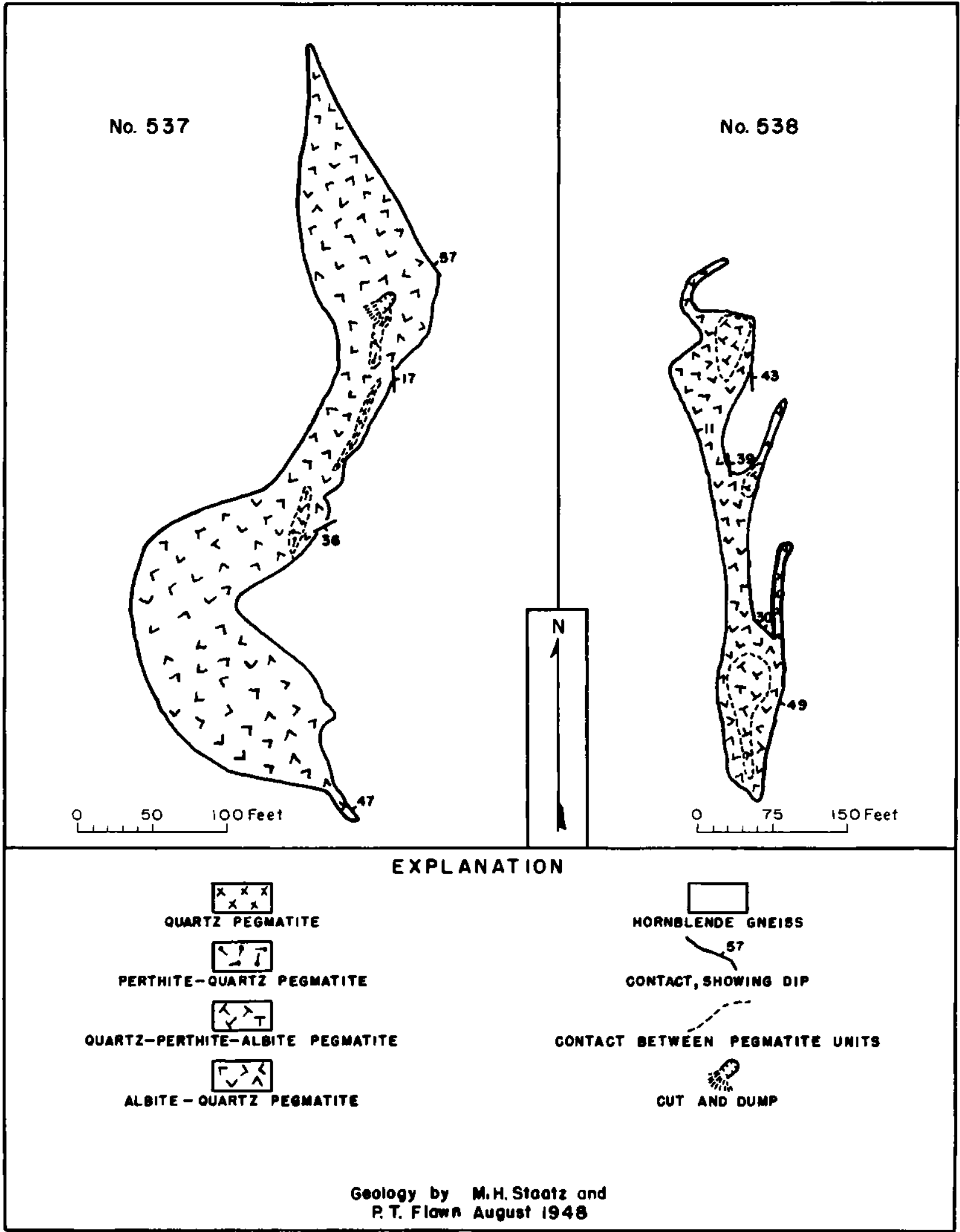

FIGURE 24. GEOLOGIC MAP OF PEGMATITES NO. 537 AND NO. 538 
NO. 560
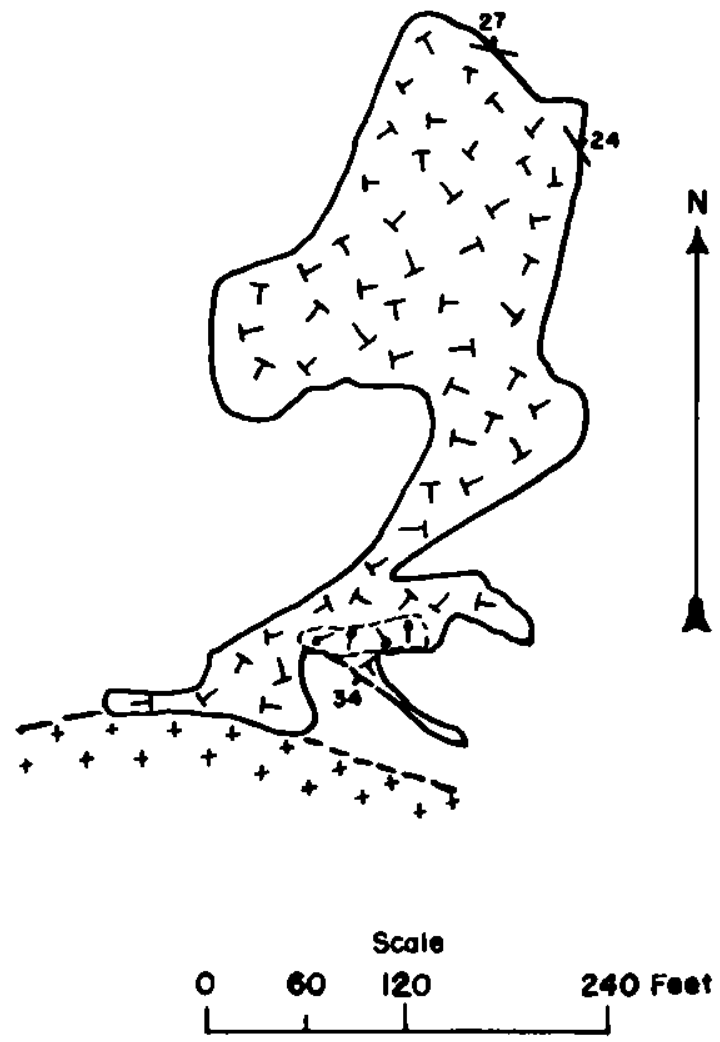

NO. $\mathbf{5 9 0}$

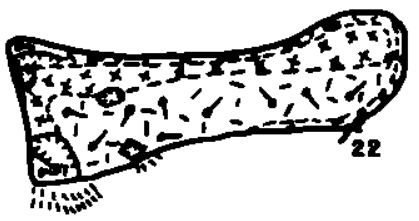

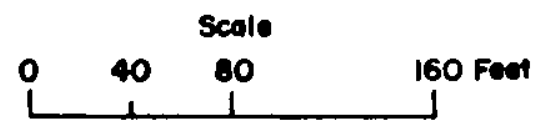

EXPLANATION

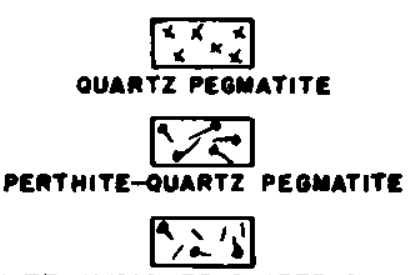

1a

PERTMITE-AMSconte-QUARTZ PEOMATITE

$\mathbf{R}^{\mathrm{K}} \mathrm{\lambda}$

AL BITE-oUARTZPERTHITE PEGMATITE

$$
\frac{+4+}{\cos t}
$$

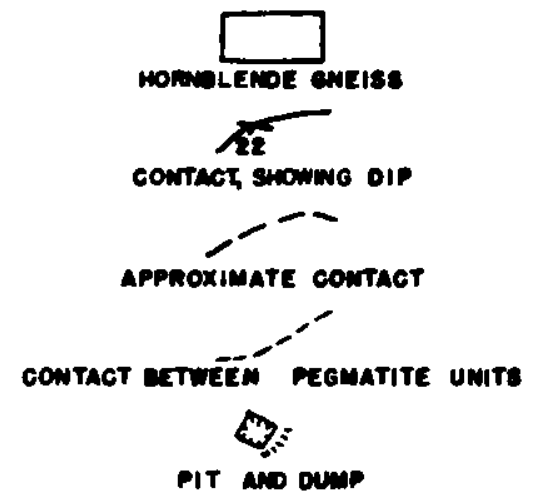

Geology by M.H. Stadz and

P. T.Flawn August 1948

FIGURE 25. GEOLOGIC MAPS OF PEGMATITE 560 AND BERYL AND RARE MINERALS LODE (NO 590) 


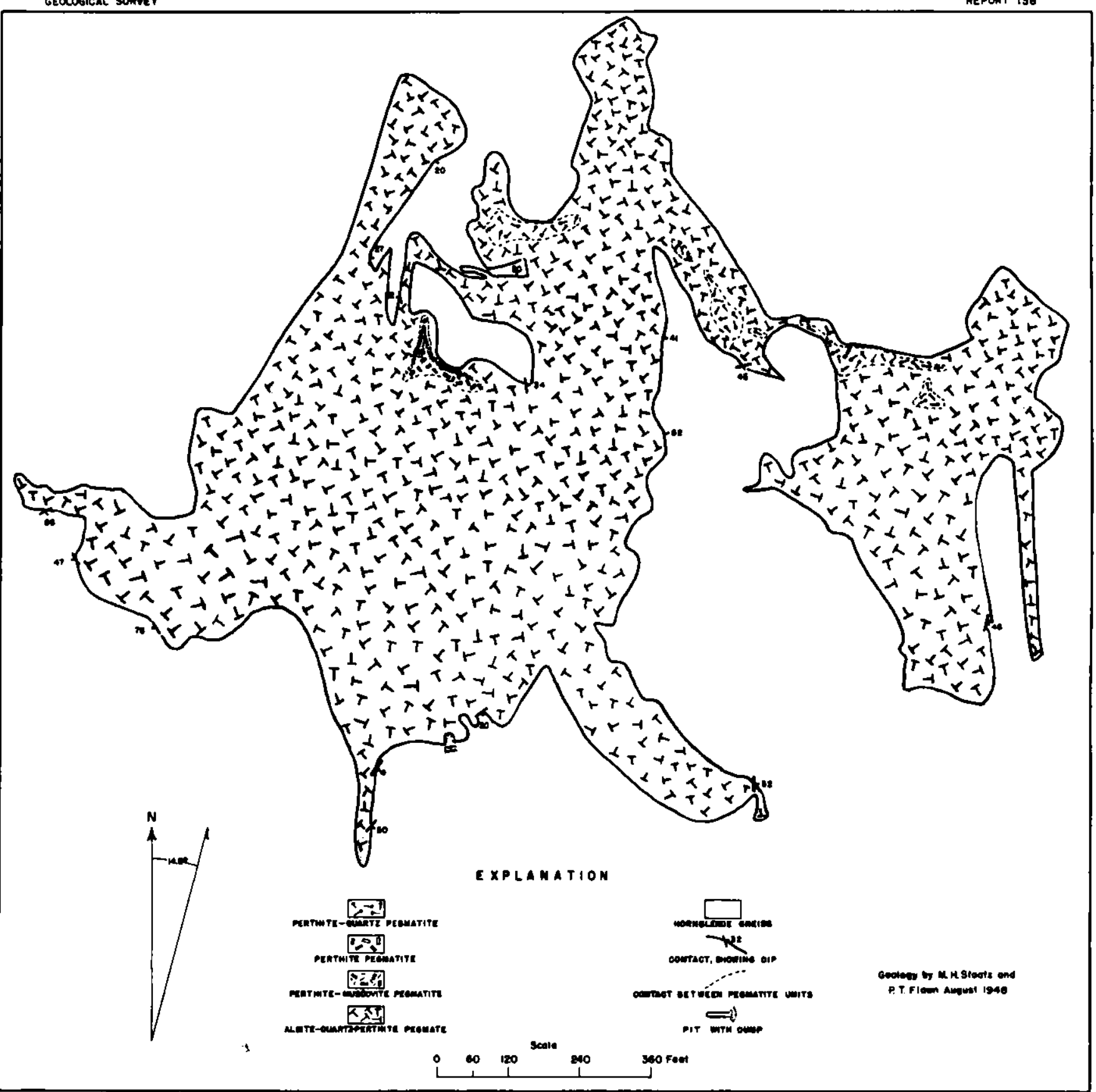

FIGURE 26. GEOLOGIC MAP, BUCKHORN (NO. 659) PEGMATITE 


\section{OFFICIAI UST ONLY}

273

\section{USGS - IIII Report 138 - Part II \\ GROLOGY - MITLRRALOGY}

Distribution (Serieg A)

No. of copies

American Cyanamid Company , Watertown...................... I

Argonne National Laboratory, ........................... I

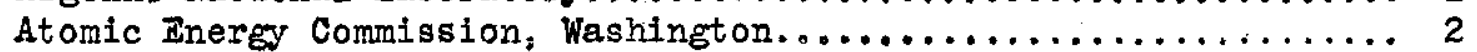

Carbide and Carbon themicals Company, $Y-12$ Area, ............... I

Colorado Raw Materials Office (T. W. Oster) .................. I

Division of Raw Materials, Denver......................... 1

Division of Raw Materials, New York,....................... 6

Division of Raw Materials, Salt Lake,City................... I

Division of Raw Materials, Washington...................... 3

Dow Chemical Company, Pittsburgh....................... 1

Technical Informetion Service, Oak Ridge.................. 6

U. S. Geological Survey:

Minere1 Deposits Branch, Washington.................. 2

Geocienjistry and Petrolozy Branch, Washington, ................. I

Gobhysics Branch, Washingtoin,.......................... I

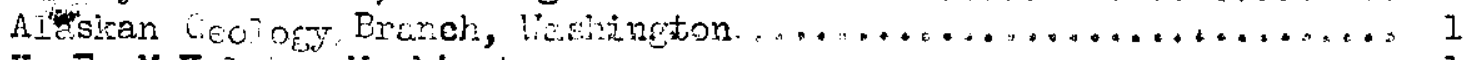

V. $\mathbb{Z}$. McKelvey, Washington, ........................ 1

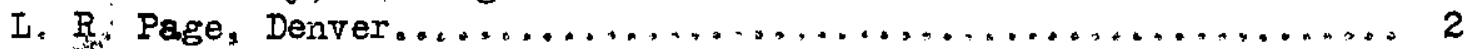

R. $P$, Fischer, Grand Junction. ......................... 1

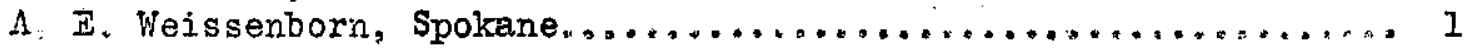

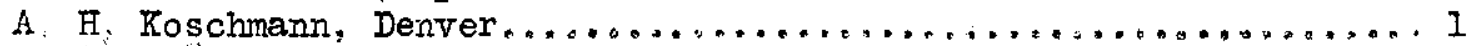

E. H. Barley, San Francisco........................... 1

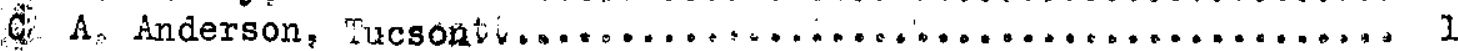

David Gallagher, Joplin............................... 1

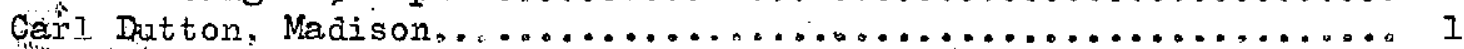

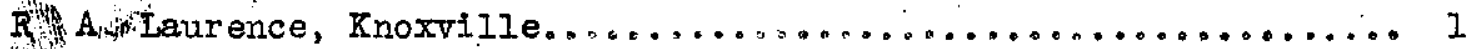

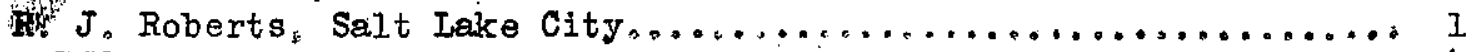

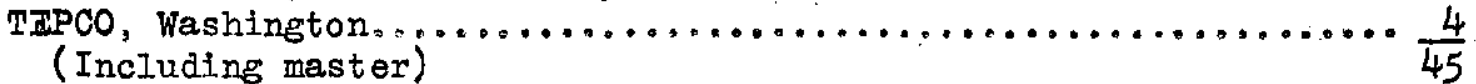




\section{OFFICIAL USE ONLY}

274

$$
\text { USGS - TEI Report } 138 \text { - Part II }
$$

CONTENTS

Method of calculating pegmatite mineral resources . . . . . . 275

Resources ...................... 277

\section{TABIङS}

Table 21. Beryl-bearing pegmatites with less than two square inches of exposed beryl ........... 278

22. Pegmatite mineral resources ........... 281 


\section{OEICIAL USD ONLY}

275

METHOD OF CALCULATING PRGMATITS MINERAL RASOURCIS

The resources of beryl, potassium feldspar, scrap mica, lepidolite, spodumene, amblygonite, columbite-tantalite, microlite, monazite, and topaz have been calculated on the basis of arbilfolyt-off points. These points were necessary to separate those pegmatites containing small quantities of industrial minerals from those deposits that have possibilities of becoming commercial deposits in the future.

Most of the beryl-bearing pegmatites contain only one or two small crystals of beryl. Beryl-bearing pegmatites that contain less than two square inches of exposed beryl are listed in table 21. This table gives the number of beryl crystals observed and their size range for each pegmatite. Pegmatites with an exposure of nore than two square inches of beryl are Iisted in table 22, vith the potential beryl resources of each unit.

The perthite and muscovite, which would help pay for mining the beryl, are calculated in each unit that contains over two square inches of beryl.

Potassiun feldspar is found in a large proportion of the pegmatites. This mineral has a low unit price and, therefore, must be mined in large quantities by inexpensive methods in order to make a profit. To add to the cost of mining is the relatively high transportation costs. A narrow geuge railroad passes through Parlin but the cost of reloading at Salida to a standard geuge car makes it cheaper to truck the 58 miles directly to Salida, The usual method of separating the feldspar from the remainder of the pegmatite is by hand cobbing. In recent years, however, sereral mills have been erected. The closest mill to the Quartz Creek district is the mill of the Consolideted Feldspar Company at Parkdale, Colo: A 
separation is made between hand cobbing and milling feldspar with specifications for each. To be able to hano cob feldspar, the pegmatite must be sufficiently large to give sample tonnages, have crystals large enough to be easily hand cobbed, and be of sufficiently high tenor so as to profitably handle the rock. Iimits on these three items are set low enough to anticipate a considerable improvement in minine: cheaper transportation, and a rise in the unit value, The resources of both hand cobbing and milling potash feldspar are given in table 22. The requirements for hand cobbing potash feldspar pegmatites are as follows: a maximum width of the pegmatite unit in excess of 40 feet and a minimum length of from 200 to 300 feet depending on the width; an average grain size of the potassium feldspar in excess of 12 inches; and the tenor of the rock to exceed 25 percent potassium feldspar All pegmatites falling under this category also have beryl reserves in the Quartz Creek district.

In milling practice prain size is of little importance, and the feldspar resources of the graphic granite pegmatites are all calculated under this classification. By far the greater feldspar resources in the Quartz Creek district fall under this heading as graphic granite pegmatites ar the more common throughout the area. Potash feldspar-bearing pegmatites must meet the following requirements to be considered as milling pegmatites: a maximum widh of 40 feet and a length of at least 300 feet, and have a tenor in excess of 1.5 pexcent potassium feldispar.

No sheet mica is found in this district and there are only three pegmatite units which have screp mica in excess of 15 percent. These all contain beryl. Scrap mica reserves are figured therefore, as byproducts of

\section{OFTICIAL USE ONLY}


beryubearing pegmetites.

The Quartzoreak district is noted for its rarer minerals. Many of these occur in small pods or as one or two crystals. Because of the interest these pegmatites have caused in the past, all pegmatites which contain lepidolite, spodumene, amblygonite, microlite, columbitetantalite, monazite, or topaz are included in table 22.

\section{PESOURCHS}

A section on reserves in Part I gives the district wide totals of the various economic minerals. Table 22 in Part II gives the resertes broken down to the various properties. Though the reserves of some properties can be published in Part I, the failure to get permission to publish on all properties does not permit a complete listing of properties that is given here, Some pegmatites have only one mineral of economic interest; such as feldspar, but many heve several minerals, Reserves are calculated for various units on 134 pegmetites. Only 53 of the total pegratites on which reserves were calculated were of one unit 35 of these were feldspar-rich. 
OFFICIAL UST ONII

278

Table 21.-Beryl-bearing pogmatites with less than two square inchos of exposed beryl

\begin{tabular}{|c|c|c|c|c|c|}
\hline $\begin{array}{l}\text { Pegmatite } \\
\text { Ho. }\end{array}$ & $\begin{array}{c}\text { No. of } \\
\text { crustals }\end{array}$ & $\begin{array}{l}\text { Sige range } \\
\text { In inches }\end{array}$ & $\begin{array}{l}\text { Pegmat ito } \\
\text { Non. }\end{array}$ & $\begin{array}{c}\text { Ioo of } \\
\text { cryotals }\end{array}$ & $\begin{array}{l}\text { Size fengo } \\
\text { in inches }\end{array}$ \\
\hline 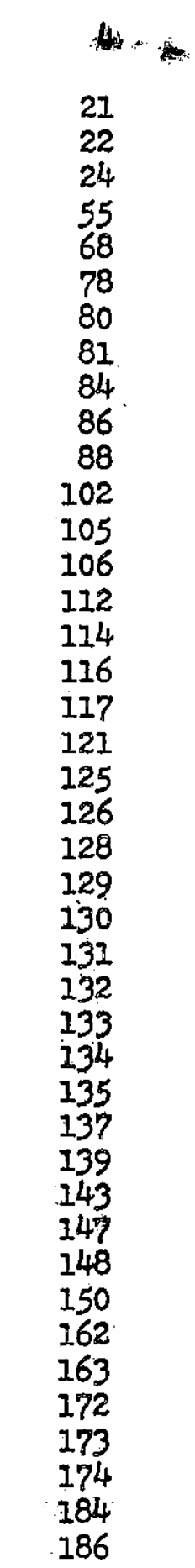 & $\begin{array}{r}1 \\
1 \\
1 \\
1 \\
2 \\
2 \\
2 \\
1 \\
2 \\
2 \\
1 \\
2 \\
4 \\
2 \\
13 \\
2 \\
2 \\
3 \\
5 \\
1 \\
1 \\
2 \\
1 \\
3 \\
2 \\
2 \\
2 \\
2 \\
1 \\
4 \\
1 \\
1 \\
3 \\
1 \\
2 \\
8 \\
1 \\
3 \\
5 \\
1 \\
2 \\
1\end{array}$ & $\begin{array}{c}1 / 8 \text { by } 1 / 4 \\
\text { to by } 3 \\
1 / 4 \\
4 \\
1 / 2 \\
1-1 / 2 \\
1 / 4 \text { to } 2 \\
1 / 8 \\
1 / 8 \\
1 / 8 \\
1 / 8 \\
1 / 4 \\
1 / 4 \\
1 / 2 \\
1 / 8 \text { to } 1 / 4 \\
1 / 8 \text { to } 1 / 4 \\
1 / 8 \\
1 / 4 \text { to } 3 / 4 \\
1 / 8 \text { to } 1 / 4 \\
1 / 8 \text { to } 1 / 2 \\
5 / 8 \\
1 / 8 \\
1 / 8 \\
1 / 8 \\
1 / 8 \\
1 / 8 \\
3 / 4 \\
1 / 4 \\
1 / 4 \\
1 / 8 \\
1 / 4 \\
1 / 2 \\
3 / 16 \\
1 / 8 \text { to } 1 / 4 \\
1 / 8 \\
1 / 4 \\
1 / 8 \text { to } 1 / 4 \\
1 / 8 \\
1 / 8 \text { to } 1 / 4 \\
1 / 8 \text { to } 1 / 4 \\
1 / 16 \\
1 / 16 \\
1 / 8 \\
1 / 8\end{array}$ & $\begin{array}{l}188 \\
190 \\
196 \\
197 \\
198 \\
201 \\
223 \\
226 \\
230 \\
231 \\
233 \\
237 \\
238 \\
239 \\
240 \\
244 \\
245 \\
259 \\
279 \\
281 \\
283 \\
290 \\
299 \\
300 \\
301 \\
302 \\
305 \\
308 \\
311 \\
316 \\
325 \\
330 \\
336 \\
338 \\
342 \\
347 \\
348 \\
356 \\
360 \\
363 \\
364 \\
365 \\
366 \\
367\end{array}$ & 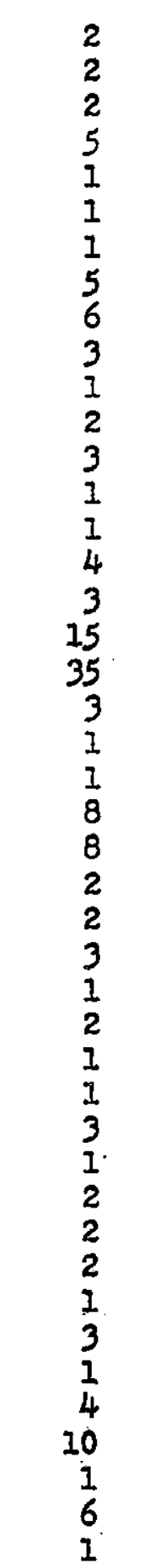 & $\begin{array}{c}1 / 8 \\
1 / 8 \\
1 / 16 \text { to } 3 / 4 \\
1 / 4 \\
1 / 4 \\
1 / 2 \\
1 / 4 \\
1 / 8 \text { to } 1 / 2 \\
1 / 8 \text { to } 1 / 2 \\
11 / 4 \\
1 / 4 \\
3 / 8 \\
1 / 4 \\
1 / 4 \\
1 / 2 \\
1 / 8 \text { to } 1 / 4 \\
1 / 2 \text { to } 1-1 / 4 \\
1 / 8 \text { to } 1 / 2 \\
1 / 8 \text { to } 3 / 8 \\
1 / 8 \text { to } 1 / 4 \\
1 / 4 \\
1-1 / 2 \\
1 / 16 \text { to } 1 / 4 \\
1 / 4 \\
1 / 2 \\
1 / 2 \text { to } 1 \\
1 / 16 \\
16 \\
1 / 4 \\
3 / 4 \\
1 / 2 \\
1 / 2 \\
1 / 8 \\
1 / 4 \\
1 / 4 \\
1 / 16 \\
1 / 4 \\
1 / 8 \text { to } 1 / 4 \\
1 / 2 \\
1 / 2 \\
1 / 8 \text { to } 1 / 4 \\
1 / 4 \\
1 / 8 \text { to } 1 \\
1 / 4 \\
1 / 4 \\
1 / 4\end{array}$ \\
\hline
\end{tabular}


Table 2l.-Beryl-bearing pegmatites with less than two square inches of exposed beryl-Coptinued

\begin{tabular}{|c|c|c|c|c|c|}
\hline $\begin{array}{l}\text { Pegmatite } \\
\mathrm{No}_{3}\end{array}$ & $\begin{array}{l}\text { No. of } \\
\text { crystals }\end{array}$ & $\begin{array}{l}\text { Size range } \\
\text { In inches }\end{array}$ & 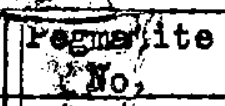 & $\begin{array}{l}\text { No. of } \\
\text { crystals }\end{array}$ & $\begin{array}{l}\text { Size range } \\
\text { in inches }\end{array}$ \\
\hline $\begin{array}{l}377 \\
378 \\
379 \\
382 \\
384 \\
390 \\
413 \\
416 \\
418 \\
420 \\
425 \\
428 \\
431 \\
433 \\
1135 \\
436 \\
437 \\
438 \\
439 \\
440 \\
457 \\
463 \\
477 \\
483 \\
547 \\
543 \\
351 \\
589 \\
598 \\
602 \\
643 \\
728 \\
778 \\
905 \\
908 \\
936 \\
985 \\
989 \\
995 \\
998 \\
999 \\
1007 \\
1002 \\
\end{array}$ & 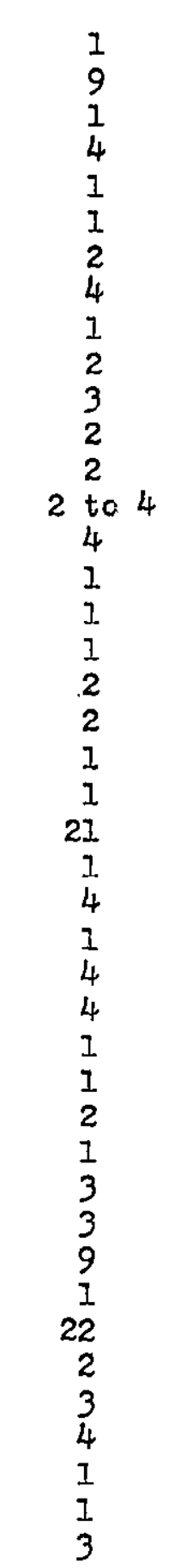 & 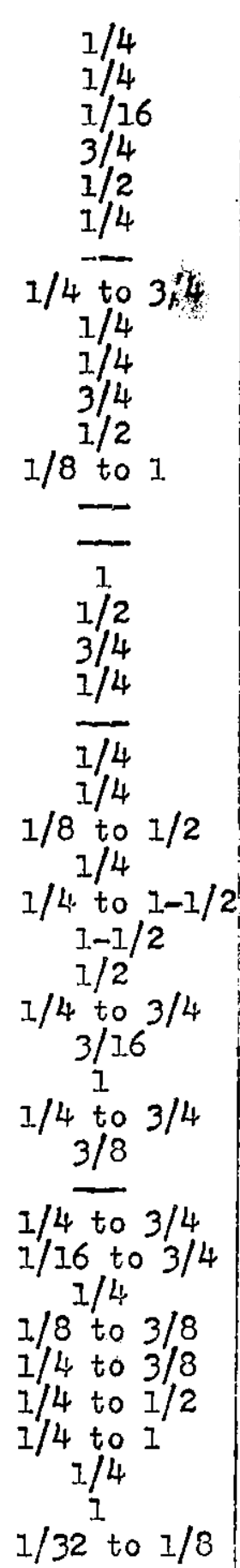 & $\begin{array}{l}1003 \\
1004 \\
1005 \\
1006 \\
1009 \\
1010 \\
1011 \\
1012 \\
1014 \\
1015 \\
1016 \\
1027 \\
1028 \\
1031 \\
1032 \\
1033 \\
1034 \\
1036 \\
1039 \\
1040 \\
1041 \\
1042 \\
1043 \\
1044 \\
1045 \\
1046 \\
1047 \\
1048 \\
1052 \\
1053 \\
1064 \\
1065 \\
1068 \\
1069 \\
1070 \\
1071 \\
1072 \\
1075 \\
1076 \\
1031 \\
1083 \\
1084 \\
1085\end{array}$ & $\begin{array}{r}1 \\
5 \\
1 \\
9 \\
2 \\
6 \\
1 \\
2 \\
2 \\
5 \\
1 \\
2 \\
1 \\
1 \\
1 \\
2 \\
1 \\
2 \\
1 \\
1 \\
4 \\
7 \\
11 \\
3 \\
3 \\
3 \\
2 \\
1 \\
1 \\
5 \\
1 \\
1 \\
20 \\
4 \\
5 \\
23 \\
26 \\
3 \\
2 \\
1 \\
6 \\
5 \\
3\end{array}$ & $\begin{array}{c}1 / 4 \\
1 / 16 \text { to } 3 / 4 \\
1 / 4 \\
1 / 32 \text { to } 1 / 4 \\
1 / 4 \text { to } 1 / 2 \\
1 / 16 \text { to } 1 / 4 \\
1 / 4 \\
1 / 4 \\
3 / 4 \\
1 / 4 \text { to } 1 / 2 \\
1 / 8 \\
1 / 4 \text { to } 3 / 8 \\
3 / 8 \\
3 / 16 \\
3 / 16 \\
1 / 16 \text { to } 1 / 8 \\
3 / 16 \\
1 / 16 \text { to } 1 / 8 \\
3 / 8 \\
3 / 8 \\
1 / 16 \text { to } 1 / 2 \\
1 / 32 \text { to } 1 / 4 \\
1 / 16 \text { to } 3 / 8 \\
1 / 8 \text { to } 3 / 16 \\
3 / 8 \text { to } 1 / 2 \\
1 / 16 \text { to } 3 / 32 \\
1 / 8 \text { to } 1 / 4 \\
1 / 8 \\
1 / 4 \\
3 / 32 \text { to } 3 / 16 \\
7 / 8 \\
1-1 / 4 \\
1 / 8 \text { to } 5 / 8 \\
3 / 16 \text { to } 5 / 8 \\
1 / 16 \text { to } 3 / 4 \\
1 / 8 \text { to } 1 / 2 \\
1 / 16 \text { to } 1 / 2 \\
3 / 16 \\
1 / 16 \text { to } 1 / 2 \\
1 / 8 \\
1 / 8 \text { to } 3 / 8 \\
1 / 8 \text { to } 1 / 4 \\
3 / 16 \text { to } 3 / 4\end{array}$ \\
\hline
\end{tabular}


Table 21.-Beryl-bearing pegmatites with less then two square inches of exposed beryl-Continued.

\begin{tabular}{|c|c|c|c|c|c|}
\hline $\begin{array}{l}\text { Pegnatite } \\
\text { IIo, }\end{array}$ & $\begin{array}{c}\text { ITo. of } \\
\text { crysteis }\end{array}$ & $\begin{array}{l}\text { Size range } \\
\text { in inches }\end{array}$ & $\begin{array}{c}\text { Pegnetite } \\
\mathrm{NO}_{3}\end{array}$ & $\begin{array}{c}\text { Io. of } \\
\text { crysteIs }\end{array}$ & $\begin{array}{l}\text { Size renge } \\
\text { in inches }\end{array}$ \\
\hline 1086 & I & $3 / 16$ & 1174 & 8 & $1 / 4$ to 1 \\
\hline 1088 & 3 & $3 / 16$ & 1179 & 8 & $1 / 4$ to $1 / 2$ \\
\hline 1091 & 1 & $1 / 4$ & 1189 & 1 & $3 / 4$ \\
\hline 1.092 & 1 & $1 / 4$ & 1192 & 22 & $1 / 8$ to $1 / 2$ \\
\hline 1093 & 2 & $1 / 4$ & 1794 & 2 & $1 / 32$ to $1 / 16$ \\
\hline 1094 & 4 & $1 / 8$ to $I / 2$ & 1201 & 1 & $.7 / 2$ \\
\hline 1095 & 2 & $1 / 8$ & 1202 & 4 & $5 / 16$ to $1 / 2$ \\
\hline 1100 & 2 & $1 / 4$ & 1238 & 3 & $3 / 4$ to $1 / 2$ \\
\hline 1102 & 1 & $3 / 16$ & 1322 & 5 & $1 / 2$ to $3 / 4$ \\
\hline 1105 & 1 & $1 / 16$ & 1560 & 1 & $1-1 / 2$ \\
\hline 1172 & 1 & 1 & 1573 & $I$ & 1 \\
\hline
\end{tabular}


$\frac{\text { Tab10 22, }- \text { Peomat1 to nineral reaources }}{\text { 1n hort tono) }}$

\begin{tabular}{|c|c|c|c|c|c|c|c|c|c|c|c|c|c|c|c|c|c|c|c|c|c|c|c|c|c|c|}
\hline \multirow[b]{2}{*}{$\begin{array}{l}\text { Tumber and } \\
\text { nome of por } \\
\text { matit to } \\
\text { (PI. II ) }\end{array}$} & \multirow[b]{2}{*}{$\underset{\substack{\text { Internal } \\
\text { otrue ture }}}{ }$} & \multicolumn{5}{|c|}{ S1zo and shape of deponst } & \multicolumn{4}{|c|}{ Berg1 } & \multicolumn{4}{|c|}{ Toldoper } & \multicolumn{8}{|c|}{ Mesea } & \multicolumn{4}{|c|}{ Othor mineral. } \\
\hline & & Shape & $\begin{array}{l}\text { Average } \\
\text { langth } \\
\text { (foot) }\end{array}$ & $\begin{array}{l}\text { Arerage } \\
\text { thicke- } \\
\text { noses } \\
\text { (foet) }\end{array}$ & Dopth & Tons & Parr & $\begin{array}{c}\text { Oompo- } \\
\text { o1tion } \\
\text { (Porcont } \\
\text { BoO) }\end{array}$ & Tons & $\begin{array}{l}\text { Per- } \\
\text { cent } \\
\text { cobb- } \\
\text { ablo }\end{array}$ & $\begin{array}{l}\text { Per- } \\
\text { cont }\end{array}$ & $\begin{array}{l}\text { Compo- } \\
\text { at tion }\end{array}$ & Tons & $\begin{array}{l}\text { Perr } \\
\text { cent } \\
\text { cobbo- } \\
\text { ab10 }\end{array}$ & $\begin{array}{l}\text { Per- } \\
\text { cent } \\
\text { conude } \\
\text { oheot } \\
\text { and } \\
\text { punoh }\end{array}$ & $\begin{array}{l}\text { Porn } \\
\text { cent } \\
\text { honoet } \\
\text { and } \\
\text { punch } \\
\text { 1n } \\
\text { crude. }\end{array}$ & $\begin{array}{l}\text { size } \\
\text { of } \\
\text { sheot } \\
\text { and } \\
\text { punch }\end{array}$ & $\begin{array}{l}\text { Quality } \\
\text { of } \\
\text { shoet } \\
\text { and } \\
\text { punch }\end{array}$ & $\begin{array}{l}\text { Tons } \\
\text { oheot } \\
\text { and } \\
\text { punch }\end{array} \mid$ & $\begin{array}{c}\text { Total } \\
\text { tone } \\
\text { of } \\
\text { ocrap }\end{array}$ & $\begin{array}{c}\text { Total } \\
\text { tona } \\
\text { of } \\
\text { micas }\end{array}$ & $\begin{array}{l}\text { Per- } \\
\text { cont } \\
\text { cobb- } \\
\text { ablo }\end{array}$ & Mineral & $\begin{array}{l}\text { Per- } \\
\text { cont }\end{array}$ & $\begin{array}{l}\text { Compo- } \\
\text { sition }\end{array}$ & Fona \\
\hline 21 & Ono unit. & Lenticular. & .155 & 9 & & & & & & & & & & & & & & & & & & & $\begin{array}{c}\text { Columbito- } \\
\text { tantalito. }\end{array}$ & 13 & & \\
\hline 23 & $\begin{array}{l}\text { lorth brand } \\
\text { core. }\end{array}$ & do. & 265 & 2 to 4 & 25 & 1080 & 0.03 & 13.1 & 0.32 & 95 & 55 & & 590 & 100 & 0 & 0 & & & 0 & 20 & 20 & 50 & $\begin{array}{l}\text { Monazi to. } \\
\text { colunbito- } \\
\text { tantal1 to. }\end{array}$ & $\begin{array}{l}13 \\
15\end{array}$ & & \\
\hline 64 & $\begin{array}{l}\text { Yoot branos } \\
\text { core. }\end{array}$ & do. & 50 & 1 to 3 & & & & & & & & & & & & & & & & & & & $\begin{array}{l}\text { Yonaxite. } \\
\text { polumbito- } \\
\text { tantalite. }\end{array}$ & $\begin{array}{l}1 \\
13\end{array}$ & & \\
\hline 136 & One un1t. & Irregular & 195 & 20 & 25 & 7160 & p.002 & 13.2 & 0.14 & 30 & 8 & & 570 & 0 & & & & & & & & & & & & \\
\hline 205 & core. & Ienticulas. & 150 & , & & & & & & & & & & & & & & & & & & & $\begin{array}{l}\text { oolumbit to- } \\
\text { tental1te. }\end{array}$ & $1_{2}$ & & \\
\hline$\underset{\text { Opportun1 ty }}{213}$ & vall zone. & do. & 165 & 10 & 25 & 3580 & 0.08 & 13.0 & 2.8 & 95 & 12 & & 430 & 50 & & & & & & & & & 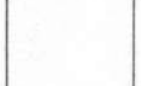 & & & \\
\hline $\begin{array}{l}215 \\
\text { Opportun1 ts } \\
\text { \$o. } 1\end{array}$ & ontral unit & $\begin{array}{l}\text { Lont1euld } \\
\text { branching. }\end{array}$ & $r-250$ & 14 & 25 & 7500 & 0.1 & 13.3 & 7.0 & 90 & 8.0 & & 600 & 50 & 0 & 0 & & & 0 & 150 & 150 & 0 & 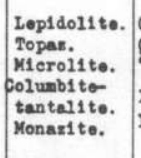 & $\begin{array}{l}0.5 \\
\beta_{i}^{1} \\
1_{6} \\
1_{4}\end{array}$ & & $\begin{array}{l}35 \\
7.0 \\
0.4\end{array}$ \\
\hline $\begin{array}{c}\text { ns } \\
\text { Opportun1 ty } \\
\text { No. } 1\end{array}$ & $\begin{array}{l}\text { South- } \\
\text { contral } \\
\text { unit. }\end{array}$ & Irragular. & 90 & 27 & 25 & 5170 & & & & & 60 & & 3100 & 75 & & & & & & & & & & & & \\
\hline $\begin{array}{l}216 \\
\text { Opportun1 ty } \\
\text { \$o. } 1\end{array}$ & $\begin{array}{l}\text { Mortheast } \\
\text { branch. }\end{array}$ & Lon t1 culary. & .167 & 7 & 25 & 2580 & 0.01 & 13.5 & 0.26 & 75 & 5 & & 130 & 50 & 0 & 0 & & & 0 & 50 & 50 & 5 & M1erolite. & 12 & & \\
\hline $\begin{array}{l}216 \\
\text { Opportun1 ty } \\
\mathbb{N o .} 1\end{array}$ & $\begin{array}{l}\text { Contral and } \\
\text { oouthwest- } \\
\text { orn branch. }\end{array}$ & do. & 106 & 12 & 25 & 2770 & 0.005 & 23.3 & 0.14 & 95 & 64 & & 1770 & 100 & 0 & 0 & & & 0 & 80 & 80 & 0 & & & & \\
\hline 245 & $\begin{array}{c}\text { South half } \\
\text { vall sone. }\end{array}$ & Irragular. & 1250 & 450 & & & & & & & & & & & & & & & & & & & $\begin{array}{l}\text { columbite- } \\
\text { tantallte. }\end{array}$ & 23 & & \\
\hline $\begin{array}{l}250 \\
\text { 20pportunits } \\
\text { Noo. } 24 \\
\text { and } 34\end{array}$ & Yall sone. & $\begin{array}{l}\text { Ient1culas- } \\
\text { branchlng. }\end{array}$ & -1310 & 35 & & & $1 / 2$ & 13.0 & & & & & & & & & & & & & & & Monazite. & 12 & & $\therefore$ \\
\hline $\begin{array}{l}250 \\
\text { Opportunity } \\
\text { Noo. 2A } \\
\text { and } 3 \mathbf{A}\end{array}$ & Core pode. & Ienticular. & 248 & 11 & 20 & 4870 & 0.02 & 13.1 & 1.0 & 100 & 30 & & 1460 & 80 & & & & & & & & & & & & \\
\hline 251 & core. & do. & 120 & 0.6 & 20 & 125 & 0.03 & 13.0 & 0.04 & 50 & 51 & & 64 & 80 & 0 & 0 & & & 0 & 5 & 5 & 10 & $\begin{array}{l}\text { columbito- } \\
\text { tantalite. } \\
\text { Monazite. }\end{array}$ & $\begin{array}{l}12 \\
15\end{array}$ & & \\
\hline 266 & do. & do. & 26 & 4 & & & & & & & & & & & & & & & & & & & $\begin{array}{c}\text { columbito } \\
\text { tantalite. }\end{array}$ & 11 & & \\
\hline 270 & do. & do. & 90 & 82 & 20 & 310 & 0.02 & 23.2 & 0.06 & 50 & 30 & & 90 & 60 & & & & & & & & & & & & \\
\hline 288 & do. & do. & 20 & 2 & 10 & 35 & 0.1 & 13.1 & 0.035 & 80 & & & & & & & & & & & & & & & & \\
\hline
\end{tabular}




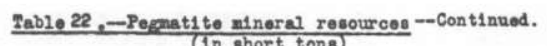

\begin{tabular}{|c|c|c|c|c|c|c|c|c|c|c|c|c|c|c|c|c|c|c|c|c|c|c|c|c|c|c|}
\hline \multirow[b]{2}{*}{$\begin{array}{l}\text { Mumber and } \\
\text { name of per } \\
\text { natito } \\
\text { (P1. II) }\end{array}$} & \multirow[b]{2}{*}{$\begin{array}{l}\text { Internal } \\
\text { otrueture }\end{array}$} & \multicolumn{5}{|c|}{ S1ze and ahape of dopoesit } & \multicolumn{4}{|c|}{ Bergl } & \multicolumn{4}{|c|}{ Taldopar } & \multicolumn{8}{|c|}{ Necea } & \multicolumn{4}{|c|}{ Other minerale } \\
\hline & & shape & \begin{tabular}{|c|} 
Average \\
length \\
(feot)
\end{tabular} & $\begin{array}{l}\text { Ararage } \\
\text { thlicks } \\
\text { neas } \\
\text { (foet) }\end{array}$ & $\left(\begin{array}{l}\text { Dopth } \\
(f o s t)\end{array}\right.$ & Tons & $\begin{array}{l}\text { Par } \\
\text { cont }\end{array}$ & $\begin{array}{l}\text { Oompo- } \\
\text { ofition } \\
(\text { Perceent } \\
\text { Boo) }\end{array}$ & Tons: & $\begin{array}{l}\text { Por- } \\
\text { oent } \\
\text { cosb- } \\
\text { ab10 }\end{array}$ & Pent & $\begin{array}{l}\text { Compo- } \\
\text { altion }\end{array}$ & Tons & $\begin{array}{l}\text { Per- } \\
\text { cent } \\
\text { cobb- } \\
\text { ablo }\end{array}$ & $\begin{array}{l}\text { Per- } \\
\text { cent } \\
\text { crude } \\
\text { oheot } \\
\text { and } \\
\text { punch }\end{array}$ & $\begin{array}{l}\text { Porr } \\
\text { cent } \\
\text { honeot } \\
\text { and } \\
\text { and } \\
\text { punh } \\
\text { 1n } \\
\text { orude }\end{array}$ & $\begin{array}{l}\text { s1so } \\
\text { of } \\
\text { sheot } \\
\text { and } \\
\text { punoh }\end{array}$ & $\begin{array}{l}\text { Quall ty } \\
\text { of } \\
\text { ahoet } \\
\text { and } \\
\text { punch }\end{array}$ & $\begin{array}{l}\text { Tons } \\
\text { sheot } \\
\text { and } \\
\text { punch }\end{array}$ & $\begin{array}{l}\text { Total } \\
\text { tons } \\
\text { of } \\
\text { sorap }\end{array}$ & $\begin{array}{c}\text { 2otal } \\
\text { tons } \\
\text { of } \\
\text { micas }\end{array}$ & $\begin{array}{l}\text { Por- } \\
\text { cont } \\
\text { cobbo } \\
\text { able }\end{array}$ & Mineral & $\begin{array}{l}\text { Per- } \\
\text { Cont }\end{array}$ & $\begin{array}{l}\text { Compo- } \\
\text { altion }\end{array}$ & Pons \\
\hline 289 & core. & Lent1oular. & 90 & 2 & 10 & 150 & 0.02 & 13.2 & 0.03 & 80 & 5 & & 7.5 & 60 & & & & & & & & & $\begin{array}{c}\text { Columbito- } \\
\text { tantall to. }\end{array}$ & $1_{1}$ & & \\
\hline 290 & do. & do. & $1-1 / 2$ & $1-1 / 2$ & & & & . & & & & & & & & & & & & & & & Monasi te. & ${ }^{1} 6$ & & \\
\hline 290 & do. & do. & 20 & , & & & & & & & & & & & & & & & & & & & $\begin{array}{c}\text { Col umbit to- } \\
\text { tantall to. }\end{array}$ & ${ }^{2}$ & & \\
\hline $\begin{array}{l}306 \\
\text { Opport un1 to } \\
\text { Ho. } 4\end{array}$ & Woot layer. & do. & 24 & 3 & 10 & 60 & & & & & & & & & 0 & 0 & & & 0 & 0.6 & 0.6 & 0 & $\begin{array}{l}\text { oppidolite. } \\
\text { Kisero11 te. }\end{array}$ & $1 \frac{5}{2}$ & & 3 \\
\hline 358 & One unit. & do. & 95 & 12 & 25 & 2480 & .002 & 13.1 & 0.05 & 0 & 20 & & 500 & 5 & & & & & & & & & & & & \\
\hline 359 & do. & do. & 257 & 14 & 25 & 7820 & 0.0008 & 13.1 & 0.06 & 50 & 20 & & 1560 & 5 & & & & & & & & & $\begin{array}{c}\text { Columbite- } \\
\text { tantall to. }\end{array}$ & 12 & & \\
\hline 385 & do. & do. & 79 & 6 & & & & & & & & & & & & & & & & & & & do. & $1_{2}$ & & \\
\hline 411 & core. & do. & 60 & 30 & 25 & 3920 & 0.9 & & 0.39 & 50 & 35 & & 1370 & 80 & 0 & 0 & & & 0 & 200 & 200 & 0 & & & & \\
\hline 417 & do. & Irregular. & 360 & 2 & 25 & 1920 & 0.2 & 23.3 & 3.8 & 60 & 45 & & 860 & 80 & 0 & 0 & & & 0 & 96 & 96 & 0 & & & & \\
\hline $\begin{array}{l}422 \\
\text { Ben-Keut } \\
\text { Mo. } 1\end{array}$ & do. & Lent1 cular. & 4. 6 & 5 & 25 & 65 & & & & & 81 & & $3_{52}$ & 80 & 0 & 0 & & & 0 & 9.8 & 0 & 0 & \begin{tabular}{|} 
Lopidolit to. \\
kicro11 to.
\end{tabular} & $\mid \begin{array}{c}2 \\
0.01\end{array}$ & & $\frac{1}{2} \cdot 33$ \\
\hline $\begin{array}{l}424 \\
\text { Basoooka }\end{array}$ & Vall zone. & do. & 228 & 10 & 25 & 4950 & & & & & 82 & & $3_{4060}$ & 70 & & & & & & & & & Lop1dol1 to. & 8 & & 396 \\
\hline $\begin{array}{l}424 \\
\text { Basooks }\end{array}$ & Core. & Oval. & 20 & 20 & 25 & 800 & & & & & 20 & & $3_{160}$ & 90 & & & & & & & & & $\begin{array}{l}\text { do. } \\
\text { M1crolite. } \\
\text { Spodumene. } \\
\text { Amblygonite. }\end{array}$ & . $\begin{array}{c}2 \\
1 \\
12 \\
6\end{array}$ & & $\begin{array}{l}16 \\
96 \\
45\end{array}$ \\
\hline 432 & $\begin{array}{l}\text { Pangling } \\
\text { rall layer. }\end{array}$ & Lent1 cular. & . 660 & 6 & 25 & 8300 & 0.05 & 13.2 & 4.2 & 30 & 30 & & 2490 & 60 & 0 & 0 & & & 0 & 330 & 330 & 0 & & & & \\
\hline 432 & $\begin{array}{l}\text { Poot vall } \\
\text { layor. }\end{array}$ & do. & & & & & $1_{2-4}$ & 13.4 & & & & & & & & & & & & & & & & & & \\
\hline 434 & Ono un1t. & do. & 32 & 7 & 20 & 390 & 0.1 & 13.4 & 0.4 & 100 & 8 & & 30 & 20 & 0 & 0 & & & 0 & 10 & 10 & 0 & & & & \\
\hline $\begin{array}{c}452 \\
\text { Brovn Dorbs } \\
\text { Dike Ito. } 1\end{array}$ & yost branch & do. & 20 & 0.5 & 8 & & & & & & & & & & & & & & & & & & $\begin{array}{c}\text { columbl to } \\
\text { tantalt to. } \\
\text { Konazi to. }\end{array}$ & $\begin{array}{l}1.4 \\
2.2\end{array}$ & & $\mid \begin{array}{l}2179 \\
{ }^{2} 282\end{array}$ \\
\hline 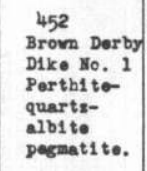 & $\begin{array}{l}\text { Ranging } \\
\text { vali lavor } \\
\end{array}$ & do. & 785 & 8 & 140 & 76,450 & 0.1 & & 76 & 95 & 40 & & 30,580 & 100 & 0 & 0 & & & 0 & 7,600 & 7,600 & 0 & & & & \\
\hline $\begin{array}{l}452 \\
\text { Brom Derby } \\
\text { D1ke No. } 1\end{array}$ & $\begin{array}{l}\text { Curved } \\
\text { 1opidolit to } \\
\text { laver. }\end{array}$ & do. & 190 & 2 & 140 & 4,630 & & & & & 44 & & $3_{2040}$ & 90 & & & & & & & & & $\begin{array}{l}\text { Lopidolit to. } \\
\text { Topaz. }\end{array}$ & $\begin{array}{c}15 \\
1\end{array}$ & & $\begin{array}{l}690 \\
46\end{array}$ \\
\hline $\begin{array}{l}452 \\
\text { Brovm Derby } \\
\text { Diko Ho. } 1\end{array}$ & $\begin{array}{l}\text { Lep1 dolit o } \\
\text { mi crolit to } \\
\text { pod. }\end{array}$ & do. & 50 & 6 & 10 & 260 & $1_{1}$ & & & & & & & & & & & & & & & & $\begin{array}{l}\text { Lopido11 to. } \\
\text { M1 crolite. } \\
\text { Topez. }\end{array}$ & $\begin{array}{c}40 \\
12^{.03}\end{array}$ & & $\frac{104}{257}$ \\
\hline
\end{tabular}

Trumber of oryotals obeerred.

oda aper. 
$\frac{\text { 2ab10 22, - Peopat1 to nineral resources--Cont1nued. }}{\text { (1n thort tono })}$

\begin{tabular}{|c|c|c|c|c|c|c|c|c|c|c|c|c|c|c|c|c|c|c|c|c|c|c|c|c|c|c|}
\hline \multirow[b]{2}{*}{$\begin{array}{l}\text { Rumber and } \\
\text { name of poo- } \\
\text { ant1 to } \\
\text { (P1. II) }\end{array}$} & \multirow[b]{2}{*}{$\begin{array}{l}\text { Internal } \\
\text { structure }\end{array}$} & \multicolumn{5}{|c|}{ S1ze and shape of doponst } & \multicolumn{4}{|c|}{ Beryl } & \multicolumn{4}{|c|}{ Toldapar } & \multicolumn{8}{|c|}{ Neon } & \multicolumn{4}{|c|}{ Other mineral. } \\
\hline & & Shape & $\begin{array}{c}\text { Average } \\
\text { length } \\
(\text { foot })\end{array}$ & $\begin{array}{l}\text { Average } \\
\text { thick- } \\
\text { nese } \\
\text { (feet) }\end{array}$ & $\mid \begin{array}{l}\text { Depth } \\
\text { (foot) }\end{array}$ & Tons & $\begin{array}{l}\text { Par } \\
\text { oent }\end{array}$ & $\begin{array}{l}\text { Compo- } \\
\text { altion 51 } \\
\text { (Porcent } \\
\text { Boo) }\end{array}$ & Tons & $\begin{array}{l}\text { Pex- } \\
\text { cant } \\
\text { cobb- } \\
\text { ab10 }\end{array}$ & Per- & $\begin{array}{l}\text { Compo- } \\
\text { a1tion }\end{array}$ & Tons & $\begin{array}{l}\text { Per- } \\
\text { cent } \\
\text { cobb- } \\
\text { ablo }\end{array}$ & \begin{tabular}{|l} 
Per- \\
cent \\
crude \\
sheot \\
and \\
punch \\
\end{tabular} & \begin{tabular}{|l|} 
Por- \\
cent \\
sheet \\
and \\
punch \\
1n \\
crude
\end{tabular} & $\begin{array}{l}\text { S1se } \\
\text { of } \\
\text { sheet } \\
\text { and } \\
\text { punch }\end{array}$ & $\begin{array}{l}\text { Qual1 ty } \\
\text { of } \\
\text { ohoet } \\
\text { and } \\
\text { punch }\end{array}$ & $\begin{array}{l}\text { Tone } \\
\text { aheot } \\
\text { and } \\
\text { punch }\end{array}$ & $\begin{array}{l}\text { Total } \\
\text { tone } \\
\text { of } \\
\text { sorap }\end{array}$ & $\begin{array}{l}\text { Total } \\
\text { tone } \\
\text { of } \\
\text { m1 oe }\end{array}$ & $\begin{array}{l}\text { Por- } \\
\text { cont } \\
\text { cobb- } \\
\text { ablo }\end{array}$ & Kineral & $\begin{array}{l}\text { Per- } \\
\text { cent }\end{array}$ & $\begin{array}{l}\text { Compo- } \\
\text { sition }\end{array}$ & Fono \\
\hline $\begin{array}{l}452 \\
\text { Brown Derby } \\
\text { Dike No. } 1\end{array}$ & $\begin{array}{l}\text { Quarte- } \\
\text { cloave- } \\
\text { landito- } \\
\text { lopidol1 to } \\
\text { topez layez. }\end{array}$ & $\begin{array}{l}\text { Lenticular } \\
=\end{array}$ & 4.319 & 2 & 140 & 7.770 & $1_{4}$ & & & & 25 & & 31940 & 90 & & & & & & & & & $\begin{array}{l}\text { Lep1 dol1 te. } \\
\text { Topax. }\end{array}$ & $\begin{array}{l}10 \\
10\end{array}$ & & 7777 \\
\hline $\begin{array}{l}453 \\
\text { Brovn/Derby } \\
\text { Dike \$to. } 2\end{array}$ & core. & do. & 180 & 1.5 & 240 & 5,640 & & & & & 53 & & 32990 & 70 & & & & & & & & & $\begin{array}{l}\text { Lopidolit to. } \\
\text { Topaz. } \\
\text { M1erolit te. }\end{array}$ & $\begin{array}{c}5 \\
1_{1}^{1} \\
11\end{array}$ & & $\begin{array}{r}280 \\
62\end{array}$ \\
\hline $\begin{array}{l}454 \\
\text { Brown Derby } \\
\text { D1ke No. } 3\end{array}$ & do. & do. & 108 & 1 & 150 & 2410 & 0.3 & & 4.2 & 95 & $\frac{1}{47}$ & & 3660 & $\begin{array}{c}100 \\
80\end{array}$ & 0 & 0 & & & 0 & 56 & 56 & co & $\begin{array}{l}\text { Lep1 dolite. } \\
\text { Columbl to- } \\
\text { tantallte. } \\
\text { k1eroll te. } \\
\text { Topas. }\end{array}$ & $\begin{array}{c}5 \\
12 \\
21 \\
24 \\
=1\end{array}$ & & 71 \\
\hline $\begin{array}{l}455 \\
\text { Brovn Deros } \\
\text { Dike Ho. } 4\end{array}$ & $\begin{array}{l}\text { Southern } \\
\text { part, } \\
\text { ooro. }\end{array}$ & do. & 342 & 8 & 25 & 5750 & 0.076 & 13.2 & 4.4 & 100 & 80 & & 4600 & 100 & & & & & & & & & & & & \\
\hline $\begin{array}{l}456 \\
\text { Brown Derbs } \\
\text { Dike No. } 5\end{array}$ & core. & do. & 50 & 1 & & & & & & & & & & & & & & & & & & & Mierolite. & $1_{1}$ & & \\
\hline $\begin{array}{l}457 \\
\text { Brovn Derbo } \\
\text { Dike Bo. } 6\end{array}$ & vall zone. & do. & 175 & 12 & 25 & 2600 & & & & & & & & & & & & & & & & & Lep1 dol1 te. & 3 & & 78 \\
\hline $\begin{array}{l}457 \\
\text { Brovn Derbor } \\
\text { Dike No. } 6\end{array}$ & core. & do. & 120 & 4 & 25 & 1040 & & & & & & & & & & & & & & & & & do. & 1 & & 10 \\
\hline $\begin{array}{l}458 \\
\text { Brown Derby } \\
\text { Dike Ito. } 7\end{array}$ & $\begin{array}{l}\text { Hang1ng } \\
\text { vall layou }\end{array}$ & do. & 95 & 5 & 25 & 1030 & .007 & 13.2 & 0.07 & 80 & 70 & & 720 & 70 & & & & & & & & & & & & \\
\hline $\begin{array}{l}459 \\
\text { Brovn Derby " } \\
\text { Dike Ilo. } 8\end{array}$ & Wall zone. I & $\begin{array}{l}\text { Lent1 cular } \\
\text { branchine. }\end{array}$ & -700 & 65 & 25 & 86,200 & .001 & 13.4 & 0.86 & 80 & 35 & & 30,200 & 85 & 0 & 0 & & & 0 & 2590 & 2590 & 10 & & & & \\
\hline $\begin{array}{l}459 \\
\text { Brown Dorby } \\
\text { D1ke tio. } 8\end{array}$ & Core pod. I & Len t1 cular. & 3 & 1 & 10 & 2.6 & & & & & 67 & & $3_{1.7}$ & 80 & 0 & 0 & & & 0 & 0.08 & 0.08 & 10 & $\begin{array}{l}\text { Lep1 do11 to. } \\
\text { Topaz. }\end{array}$ & ${ }_{10}^{2}$ & & $\begin{array}{l}0.05 \\
0.26\end{array}$ \\
\hline $\begin{array}{l}461 \\
\text { Brown Derby } \\
\text { Dike ko. } 10\end{array}$ & One un1t. I & $\begin{array}{l}\text { Lent1 culat } \\
\text { branching. }\end{array}$ & 560 & 20 & 25 & 54,900 & .0006 & 23.3 & 0.33 & 50 & 35 & & 19,200 & 50 & 0 & 0 & & & 0 & 550 & 550 & 0 & & & & \\
\hline 462 & core. & Lent1 culas. & 2. 40 & 3 & & & & & & & & & & & & & & & & & & & $\begin{array}{l}\text { Microlit te. } \\
\text { Lopidolite. }\end{array}$ & $\begin{array}{l}15 \\
<1\end{array}$ & & \\
\hline 497 & One unit. & Irregulaz. & 7. 876 & 65 & 50 & 236,000 & & & & & 65 & & ${ }^{4} 153,000$ & 10 & & & & & & & & & & & & \\
\hline 498 & do. & do. & 300 & 105 & 50 & 149,000 & & & & & 35 & & 452,000 & 20 & & & & & & & & & & & & \\
\hline 503 & do. & $\begin{array}{l}\text { Lent1cular } \\
\text { branch1ng. }\end{array}$ & -390 & 40 & 50 & 64,000 & & & & & 65 & & $4 / 1,600$ & 10 & 0 & 0 & & & 0 & 1920 & 1920 & 0 & & & & \\
\hline 505 & $\mathrm{Mat} n$ undt. $\mathrm{E}$ & Lenticular. & 2. 480 & 60 & 50 & 90,900 & & & & & 45 & & 40,900 & 10 & & & & & & & & & & & & \\
\hline 508 & do. & Irragular. & 1260 & -- & 50 & $1,360,000$ & & & & & 60 & f & 810,000 & 30 & & & & & & & & & & & & \\
\hline
\end{tabular}


Tab1e 22, - Pepatite ninerel reacurroes

\begin{tabular}{|c|c|c|c|c|c|c|c|c|c|c|c|c|c|c|c|c|c|c|c|c|c|c|c|c|c|c|}
\hline \multirow[b]{2}{*}{$\begin{array}{l}\text { Nhumber and } \\
\text { name of pog- } \\
\text { mat1 te } \\
\text { (P1. II) }\end{array}$} & \multirow[b]{2}{*}{$\begin{array}{l}\text { Internal } \\
\text { otructure }\end{array}$} & \multicolumn{5}{|c|}{ S1ze and shape of deposit } & \multicolumn{4}{|c|}{ Bery1 } & \multicolumn{4}{|c|}{ Teldepar } & \multicolumn{8}{|c|}{ Naca } & \multicolumn{4}{|c|}{ Othar minerale } \\
\hline & & shape & $\begin{array}{l}\text { Average } \\
\text { length } \\
(\text { feet })\end{array}$ & $\begin{array}{l}\text { Average } \\
\text { thicks- } \\
\text { ness } \\
(\text { f eet })\end{array}$ & Pepth & Tons & $\begin{array}{l}\text { Por- } \\
\text { cent }\end{array}$ & $\begin{array}{l}\text { Compo- } \\
\text { sition } 5 / \\
\text { (Percent } \\
\text { Be0) }\end{array}$ & Tons & $\begin{array}{l}\text { Per- } \\
\text { cont } \\
\text { cobb- } \\
\text { ablo }\end{array}$ & 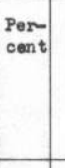 & $\begin{array}{l}\text { Compo- } \\
\text { a1 tion }\end{array}$ & Tons & $\begin{array}{l}\text { Par } \\
\text { cant } \\
\text { cobb- } \\
\text { ab10 }\end{array}$ & $\begin{array}{l}\text { Pern } \\
\text { cont } \\
\text { crude } \\
\text { sheet } \\
\text { and } \\
\text { punoh }\end{array}$ & $\begin{array}{l}\text { Per- } \\
\text { cont } \\
\text { ohoet } \\
\text { and } \\
\text { punch } \\
\text { 1n } \\
\text { crude }\end{array}$ & $\begin{array}{l}\text { S1:0 } \\
\text { of } \\
\text { sheot } \\
\text { and } \\
\text { punch }\end{array}$ & $\begin{array}{l}\text { Qual1 ty } \\
\text { of } \\
\text { sheet } \\
\text { and } \\
\text { punch }\end{array}$ & $\mid \begin{array}{l}\text { Fons } \\
\text { shoet } \\
\text { and } \\
\text { punch }\end{array}$ & $\begin{array}{c}\text { Total } \\
\text { tons } \\
\text { of } \\
\text { sorap }\end{array}$ & $\begin{array}{c}\text { Total } \\
\text { tons } \\
\text { of } \\
\text { mios }\end{array}$ & $\begin{array}{l}\text { Per- } \\
\text { cent } \\
\text { cosbo } \\
\text { ablo }\end{array}$ & Mineral & $\begin{array}{l}\text { Per- } \\
\text { cent }\end{array}$ & $\begin{array}{l}\text { Compor } \\
\text { sition }\end{array}$ & Fone \\
\hline 509 & Maln unt & Irrogular. & 600 & 60 & 50 & 158,000 & & & & & 30 & & 47,000 & 80 & & & & & & & & F & & & & \\
\hline 512 & One unit. & do. & 780 & 85 & 50 & 246,000 & & & & & 39 & & 496,000 & 5 & 0 & 0 & & & 0 & 2500 & 2500 & 0 & & & & \\
\hline 516 & do. $I$ & Lonticular. & 480 & 48 & 50 & 77.000 & & & & & 35 & & 427,000 & 10 & 0 & 0 & & & 0 & 770 & 770 & 0 & & & & \\
\hline 517 & Main unit. & do. & 300 & 45 & 50 & 56,000 & & & & & 25 & & 14,000 & 15 & & & & & & & & & & & & \\
\hline 534 & core. & do. & & & & & $1_{1}$ & & & & & & & & & & & & & & & & & & & \\
\hline $\begin{array}{l}535 \\
\text { Brom Darty } \\
\text { So. } 5\end{array}$ & Wall zone. & Irrogular. & 207 & $\cdots$ & 25 & 6200 & .01 & 13.3 & 0.62 & 30 & 10 & & 620 & 10 & & & & & & & & & Lopido11to. & Trace. & & \\
\hline $\begin{array}{l}535 \\
\text { Brown Derby } \\
\text { Ho. } 5\end{array}$ & $\begin{array}{c}\text { Intermediate } \\
\text { zone. }\end{array}$ & Lentioule & ar. 33 & 13 & 20 & 750 & 0.1 & 13.05 & 0.75 & 80 & $\begin{array}{l}4 \\
35\end{array}$ & & $33_{260}^{30}$ & $\begin{array}{l}90 \\
70\end{array}$ & 0 & 0 & & & 0 & 7.5 & 7.5 & 20 & $\begin{array}{l}\text { Lep1 dol1 te. } \\
\text { Topaz. } \\
\text { M1 crolite. } \\
\text { Columbi te- } \\
\text { tantall te. }\end{array}$ & $\begin{array}{c}5 \\
1_{13}^{<1} \\
1_{1}\end{array}$ & & 37 \\
\hline $\begin{array}{l}535 \\
\text { Broun Derby } \\
\text { No. } 5\end{array}$ & core. & Irregular. & 175 & 13 & 20 & 4,000 & .003 & & 0.12 & 100 & 39 & & 1560 & 95 & 0 & 0 & & & 0 & 40 & 40 & 10 & $\begin{array}{l}\text { Lopi dol1 te. } \\
\text { Columb1 to } \\
\text { tantal1 to. }\end{array}$ & $\begin{array}{l}7 \text { race. } \\
12\end{array}$ & & \\
\hline $\begin{array}{l}537 \\
\text { Brom Dorby } \\
\text { Xo. } 4\end{array}$ & do. & Cont1 cular. & 52 & 10 & 25 & 1125 & 0.31 & 13.4 & 3.4 & 65 & 66 & & 745 & 80 & 0 & 0 & & & 0 & 45 & 45 & 5 & & & & \\
\hline 538 & do. & Irregular. & 128 & 35 & 25 & 4360 & 0.95 & 13.4 & 42 & 75 & 32 & & 1400 & 80 & 0 & 0 & & & 0 & 131 & 131 & 0 & & & & \\
\hline 548 & $\begin{array}{l}\text { Hanging } \\
\text { rall laver. }\end{array}$ & Lant1cular & .125 & 7 & 25 & 1900 & .016 & 13.4 & 0.30 & 95 & 50 & & 950 & 30 & 0 & 0 & & & 0 & 38 & 38 & 0 & & & & \\
\hline 550 & One unit. & do. & 312 & 20 & & & & & & & & & & & & & & & & & & & Monazi te. & $1_{1}$ & & \\
\hline 557 & Wall zona. & do. & 1110 & 70 & 50 & 313.000 & & & & & 20 & & 62,600 & 0 & 0 & 0 & & & 0 & 3130 & 3130 & 0 & & & & \\
\hline 558 & Maln un1t. & $\begin{array}{l}\text { Lenticular } \\
\text { pranching. }\end{array}$ & -1044 & 75 & 50 & 707,000 & & & & & 20 & & 141,400 & 0 & 0 & 0 & & & 0 & 7070 & 7070 & 0 & & & & \\
\hline 560 & core pod. & Lenticular. & 74 & 20 & 15 & 2120 & 0.45 & 13.4 & 9.5 & 100 & 55 & & 1170 & 100 & & & & & & & & & & & & \\
\hline 564 & KaIn unit. & Irregular. & 600 & -- & 50 & 374,000 & & & & & 20 & & 74,800 & 0 & 0 & 0 & & & 0 & 3740 & 3740 & 0 & & & & \\
\hline 587 & Ono unit. & do. & 720 & 135 & 50 & 352,000 & & & & & 20 & & 70,400 & 0 & 0 & 0 & & & 0 & 3520 & 3520 & 0 & & & & \\
\hline $\begin{array}{l}590 \\
\text { Beryl and } \\
\text { Raro Minoral } \\
\text { Lodo }\end{array}$ & $40^{\text {ontermed at at }}$ & Lentioulp & ar.155 & 41 & 3 & 1450 & 0.1 & & 1.5 & 85 & 50 & & 725 & 100 & 0 & 0 & * & & 0 & 465 & 465 & 80 & $\begin{array}{c}\text { columbito } \\
\text { tantal1 to. }\end{array}$ & .002 & & ${ }^{2} 50$ \\
\hline 596 & Ono unit. & do. & 520 & 50 & 50 & 213.000 & & & & & 40 & & 45,200 & 50 & 0 & 0 & & & 0 & 1130 & 1130 & 0 & & & & \\
\hline $\begin{array}{l}604 \\
\text { mite spar } \\
\text { No. 1 }\end{array}$ & $\begin{array}{l}\text { fntermediato } \\
\text { sono. }\end{array}$ & do. & 90 & 6.5 & 25 & 1300 & 0.01 & & 0.13 & 65 & $\begin{array}{c}15 \\
50\end{array}$ & & $\begin{array}{l}194 \\
3950\end{array}$ & $\begin{array}{l}85 \\
50\end{array}$ & & & & & & & & & $\begin{array}{l}\text { Topas. } \\
\text { Iep1 doll te. } \\
\text { columbl to- } \\
\text { tantall te. } \\
\text { Mi croll te. }\end{array}$ & $\begin{array}{c}.003 \\
5 \\
.0003 \\
\text { Trace. }\end{array}$ & & $\begin{array}{l}278 \\
27.8 \\
2.3\end{array}$ \\
\hline $\begin{array}{l}604 \\
\text { Wh1 to spar } \\
\text { So. } 1\end{array}$ & Pod. & do. & 7 & 3.3 & 1 & 2 & & & & & & & & & & & & & & & & & $\begin{array}{l}\text { Lep1 dol1te. } \\
\text { M1 erolite. }\end{array}$ & \begin{tabular}{|l|}
90 \\
0.1
\end{tabular} & & $\frac{1}{4} \cdot 3^{3}$ \\
\hline
\end{tabular}


Tab10 22, - Pepatite nineral fesources --Continued.

\begin{tabular}{|c|c|c|c|c|c|c|c|c|c|c|c|c|c|c|c|c|c|c|c|c|c|c|c|c|c|c|}
\hline \multirow[b]{2}{*}{$\begin{array}{l}\text { Mumber and } \\
\text { name of poe } \\
\text { matit te } \\
\text { (P1. II) }\end{array}$} & \multirow[b]{2}{*}{$\begin{array}{l}\text { Internal } \\
\text { structure }\end{array}$} & \multicolumn{5}{|c|}{ S1ze and ahape of dopoest t } & \multicolumn{4}{|c|}{ Bery1 } & \multicolumn{4}{|c|}{ Joldopar } & \multicolumn{8}{|c|}{ Nea } & \multicolumn{4}{|c|}{ Other annerale } \\
\hline & & shape & $\begin{array}{c}\text { Average } \\
\text { 10ngth } \\
\text { (feot) }\end{array}$ & $\begin{array}{l}\text { Avarage } \\
\text { thicke } \\
\text { nesas } \\
\text { (foet) }\end{array}$ & $\begin{array}{l}\text { Depth } \\
\text { (foot) }\end{array}$ & Fone & $\begin{array}{l}\text { Por } \\
\text { oent }\end{array}$ & $\begin{array}{c}\text { Oompo- } \\
\text { s1tion } \\
\text { (Porcont } \\
\text { Boo) }\end{array}$ & Tone & $\begin{array}{l}\text { Per } \\
\text { oant } \\
\text { coobb- } \\
\text { ab10 }\end{array}$ & Pern & $\begin{array}{l}\text { Compo } \\
\text { o1 tion }\end{array}$ & Tons & $\begin{array}{l}\text { Par } \\
\text { oent } \\
\text { cobb- } \\
\text { ablo }\end{array}$ & \begin{tabular}{|c|}
$\begin{array}{c}\text { Per- } \\
\text { oont } \\
\text { carude } \\
\text { oreat } \\
\text { and } \\
\text { punah }\end{array}$ \\
\end{tabular} & $\begin{array}{l}\text { Porn } \\
\text { oent } \\
\text { ohoet } \\
\text { and } \\
\text { punoh } \\
\text { 1n } \\
\text { orude }\end{array}$ & $\begin{array}{l}\text { s1so } \\
\text { of } \\
\text { ofhoot } \\
\text { and } \\
\text { punch }\end{array}$ & $\begin{array}{l}\text { Qual1 ty } \\
\text { of } \\
\text { shoet } \\
\text { and } \\
\text { punoh }\end{array}$ & $\begin{array}{l}\text { Tone } \\
\text { oheot } \\
\text { and } \\
\text { punch }\end{array}$ & $\begin{array}{c}\text { gotal } \\
\text { tona } \\
\text { of } \\
\text { oorap }\end{array}$ & $\begin{array}{c}\text { Total } \\
\text { tona } \\
\text { of } \\
\text { mioa }\end{array}$ & $\begin{array}{l}\text { Per- } \\
\text { cont } \\
\text { cobb- } \\
\text { ablo }\end{array}$ & Kinoral & $\begin{array}{l}\text { Por- } \\
\text { cont }\end{array}$ & $\begin{array}{l}\text { Compo- } \\
\text { altion }\end{array}$ & Fone \\
\hline 605 & One un1t. I & Iant1 cular. & 100 & 3 & 25 & 720 & & 4 & & & 25 & & 180 & 25 & 0 & 0 & & & 0 & 7.2 & 7.2 & 0 & Lopidolite. & 2 & & 24.4 \\
\hline 607 & $\begin{array}{l}\text { Practure } \\
\text { f11111ng. }\end{array}$ & & Smal1. & & & & & . & & & 23 & & & 30 & & & & & & & & & do. & 2 & & \\
\hline 623 & Pod. & Zent1 coular. & 4. 14 & 4 & 15 & 73 & 0.6 & & 0.44 & 35 & 40 & & 29 & 30 & & & & & & & & & & & & \\
\hline $\begin{array}{l}636 \\
\text { Vhit to spar } \\
\text { so. } 2\end{array}$ & Vall sone. & Irrogular. & 130 & 4 & 25 & 2360 & & & & & & & & & & & & & & & & & Lop1doli te. & $<1$ & & \\
\hline $\begin{array}{l}636 \\
\text { vilte spar } \\
\text { Ito. } 2\end{array}$ & core. & Leatioular. & 235 & 24 & 25 & 9820 & $1_{2}$ & & & & $\begin{array}{l}45 \\
10\end{array}$ & & $\begin{array}{r}34400 \\
980\end{array}$ & $:$ & & & & & & & & & $\begin{array}{l}\text { do. } \\
\text { Mieroll te. }\end{array}$ & & & 980 \\
\hline 637 & do. & Irragular. & 147 & 45 & & & & & & & & & & & & & & & & & - & & 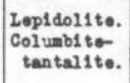 & Traco. & & \\
\hline 637 & $\begin{array}{c}\text { Fraeture } \\
\text { f1111ng. }\end{array}$ & Lent1 oular. & 55 & 6 & & & $a_{1}$ & & & & & 6 & & & & & & & & & & & $\begin{array}{l}\text { Lop1do11 to. } \\
\text { M1erol1 to. }\end{array}$ & Traco. & & \\
\hline $\begin{array}{l}659 \\
\text { Buocthorn }\end{array}$ & $\begin{array}{l}\text { Intermodiate } \\
\text { sone. }\end{array}$ & do. & 145 & - & 1.5 & 600 & 14 & $=$ & & 20 & 50 & & 300 & 100 & 0 & 0 & & & 0 & 240 & 240 & 95 & $\begin{array}{c}\text { Columb1 to- } \\
\text { tantalit to. } \\
\text { Monazite. }\end{array}$ & $\mid \begin{array}{l}14 \\
13\end{array}$ & & \\
\hline $\begin{array}{l}659 \\
\text { Buochorn }\end{array}$ & $\begin{array}{l}\text { Core. } \\
\text { Buckhorn } \\
\text { olatm. }\end{array}$ & do. & 145 & - & 5.5 & 2200 & 0.7 & & 15.4 & 98 & 91 & & 2000 & 100 & 0 & 0 & & & 0 & 22 & 22 & 0 & & & & \\
\hline ruourn & $\begin{array}{l}\text { Core pods, } \\
\text { r1dege. }\end{array}$ & irragular. & -- & - & 15 & 23.960 & .002 & & 0.50 & 70 & 53 & & 12,700 & 100 & 0 & 0 & & & 0 & 240 & 240 & 0 & & & & \\
\hline 661 & core. & Lent1 cular. & r. 10 & 1.5 & 10 & 13 & 8.5 & & 1.1 & 85 & 42 & & 5.5 & 95 & 0 & 0 & & & 0 & 1.3 & 1.3 & 0 & & & & \\
\hline 671 & Main unit t. & Irregular. & 690 & -- & 50 & 738,800 & & & & & 29 & & 4140,400 & 0 & 0 & 0 & & & 0 & 7400 & 7400 & 0 & & & & \\
\hline 697 & One unit. & Lenticular. & 350 & 50 & 25 & 36,500 & & & & & 54 & & 49.700 & 0 & 0 & 0 & & & 0 & 365 & 365 & 0 & & & & \\
\hline 783 & Vall sone. & Irragular. & 2300 & 70 & 50 & $1,380,000$ & & & & & 50 & & 4690,000 & 0 & & & & & & & & & & & & \\
\hline 783 & Core pod. & Cont1 oular. & 8 & 2 & 10 & 14 & 1.2 & & 0.17 & 100 & 65 & & 9.1 & 100 & 0 & 0 & & & 0 & 0.6 & 0.6 & 0 & & & & \\
\hline 790 & Ono unit. & do. & 640 & 55 & 25 & 55,200 & & & & & 65 & & 435.900 & 0 & & & & & & & & & & & & \\
\hline 826 & Vall sono. & do. & 24 & 14 & & & & & & & & & & & & & & & & & & & Monazi to. & & & \\
\hline 827 & Ono unit. & do. & 30 & 10 & & & & & & & & & & & & & & & & & & & do. & Frace. & & \\
\hline $\begin{array}{l}828 \\
837\end{array}$ & $\begin{array}{l}\text { do. } \\
\text { do. }\end{array}$ & $\begin{array}{c}\text { do. } \\
\text { Irrogular. }\end{array}$ & $\begin{array}{r}24 \\
360\end{array}$ & 4 & 50 & 254,000 & & & & & 65 & & 4165,000 & 0 & & & & & & & & & & & & \\
\hline $\begin{array}{c}\text { g47 } \\
\text { Black } \\
\text { Yonder }\end{array}$ & rall sone. & do. & 13,600 & - & 350 & $543,400,000$ & & & s & & 35 & & 4225,200, & .0000 & & & & , & & & & & & & & \\
\hline $\begin{array}{l}\text { 847 } \\
\text { Black } \\
\text { Yonder }\end{array}$ & $\begin{array}{l}\text { Intermediate } \\
\text { zone. }\end{array}$ & to Ient1 oul & 21 ar. 30 & 10 & 25 & 980 & 0.2 & 13.4 & 2.0 & 60 & 5 & & 49 & 50 & 0 & 0 & & & 0 & 49 & 49 & 40 & & & & \\
\hline
\end{tabular}




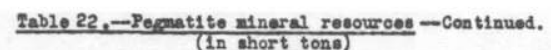

\begin{tabular}{|c|c|c|c|c|c|c|c|c|c|c|c|c|c|c|c|c|c|c|c|c|c|c|c|c|c|c|}
\hline \multirow[b]{2}{*}{$\begin{array}{l}\text { Mumber and } \\
\text { nante of por } \\
\text { matt1 to } \\
\text { (PI.II) }\end{array}$} & \multirow[b]{2}{*}{$\begin{array}{l}\text { Internal } \\
\text { strueture }\end{array}$} & \multicolumn{5}{|c|}{ S1zo and shepe of doposit } & \multicolumn{4}{|c|}{ Boryl } & \multicolumn{4}{|c|}{ Joldoper } & \multicolumn{8}{|c|}{ Hoa } & \multicolumn{4}{|c|}{ Other an neral. } \\
\hline & & Shape & $\begin{array}{l}\text { Average } \\
\text { langth } \\
\text { (feot) }\end{array}$ & $\begin{array}{l}\text { Arerage } \\
\text { thisckes } \\
\text { nease } \\
\text { (foet) }\end{array}$ & $\begin{array}{l}\text { Dopth } \\
\text { (foot) }\end{array}$ & Tone & $\begin{array}{l}\text { Par } \\
\text { cont }\end{array}$ & $\begin{array}{c}\text { Oompo } \\
\text { attion } \\
\text { (Percent } \\
\text { BeO) }\end{array}$ & Tono & $\begin{array}{l}\text { Per } \\
\text { cont } \\
\text { cobb- } \\
\text { ablo }\end{array}$ & Per- & $\begin{array}{l}\text { Compo- } \\
\text { o1 tion }\end{array}$ & Pons & $\begin{array}{l}\text { Par } \\
\text { cont } \\
\text { oobb- } \\
\text { ab10 }\end{array}$ & $\begin{array}{l}\text { Per- } \\
\text { cent } \\
\text { eanudo } \\
\text { ahoot } \\
\text { and } \\
\text { punoh }\end{array}$ & $\begin{array}{l}\text { Per- } \\
\text { oont } \\
\text { ohoet } \\
\text { and } \\
\text { punch } \\
\text { 1n } \\
\text { orvede }\end{array}$ & $\begin{array}{l}\text { s1ze } \\
\text { of } \\
\text { sheot } \\
\text { and } \\
\text { punch }\end{array}$ & $\begin{array}{l}\text { Qual1 ty } \\
\text { of } \\
\text { ohoet } \\
\text { and } \\
\text { punah }\end{array}$ & $\begin{array}{l}\text { Fons } \\
\text { oheot } \\
\text { and } \\
\text { punch }\end{array}$ & $\begin{array}{c}\text { Total } \\
\text { tona } \\
\text { of } \\
\text { ocrap }\end{array}$ & $\begin{array}{c}\text { Total } \\
\text { tona } \\
\text { of } \\
\text { mica }\end{array}$ & $\begin{array}{l}\text { Par- } \\
\text { cont } \\
\text { cobb- } \\
\text { ablo }\end{array}$ & Xineral & $\begin{array}{l}\text { Por- } \\
\text { oont }\end{array}$ & $\begin{array}{l}\text { Oompo- } \\
\text { a1tion }\end{array}$ & Pons \\
\hline $\begin{array}{l}\text { 847 } \\
\text { Black } \\
\text { Yonder }\end{array}$ & $\begin{array}{l}\text { Internodiat } \\
\text { sono. }\end{array}$ & o Lent1 cula & ar. 15 & 4 & 10 & 52 & & & & & & & & & 0 & 0 & & & 0 & 16 & 26 & 85 & $\begin{array}{l}\text { Monasite. } \\
\text { columblitio } \\
\text { tentalit to. }\end{array}$ & $\begin{array}{l}.007 \\
12\end{array}$ & & ${ }^{2} 93$ \\
\hline 852 & One unit. & Irragular. & 350 & 160 & 50 & 213.000 & & & & & 45 & & 495.850 & 10 & & & & & & & & & & & & \\
\hline 855 & do. & do. & 800 & - & 50 & 472,000 & & & & & 65 & & 4306,800 & 5 & & & & & & & & & & & & \\
\hline 860 & do. & do. & 364 & 90 & 50 & 115,400 & & & & & 50 & & 457.700 & 10 & & & & & & & & & & & & \\
\hline 963 & $\begin{array}{l}\text { langing } \\
\text { vell Iavor. }\end{array}$ & Latioular. & 165 & 4 & & & & & & & & & & & & & & & & & & & Monasi to. & $1_{1}$ & & \\
\hline 985 & do. & do. & 20 & 2 & & & & & & & & & & & & & & & & & & & هـ. & $1_{3}$ & & \\
\hline 997 & $\begin{array}{l}\text { Poot vall } \\
\text { lavor. }\end{array}$ & do. & 165 & 6 & & & & & & & & & & & & & & & & & & & do. & 11 & & \\
\hline 1002 & core. & do. & 20 & 1 & & & & ' & & & & & & & & & & & & & & & $\begin{array}{c}\text { Columbl to } \\
\text { tantal1 te. }\end{array}$ & 11 & & \\
\hline 1035 & Ono un1t. & do. & 22 & 2 & & & & & & & & & & & & & & & & & & & do. & $1_{1}$ & & \\
\hline 1036 & do. & do. & 100 & 12 & & & & & & & & & & & & & & & & & & & do. & 11 & & \\
\hline 1049 & do. & do. & 40 & 2 & & & & & & & & & & & & & & & & & & & do. & $1_{1}$ & & \\
\hline 1064 & do. & do. & 470 & 10 & & & & & & & & & & & & & & & & & & & do. & $1_{1}$ & & \\
\hline 1068 & Core. & do. & -- & 2 & & & & & & & & & & & & & & & & & & & do. & 21 & & \\
\hline 1140 & One unit. & Irragular. & 440 & 100 & 50 & 153.000 & & & & & 25 & & 38.250 & 5 & 0 & 0 & & & 0 & 3060 & 3060 & 0 & & & & \\
\hline 1142 & do. & font1 oular. & 520 & 120 & 50 & 266,000 & & & & & 35 & & 93.100 & 10 & & & & & & & & & & & & \\
\hline 1150 & Core. & do. & 3 & 1.5 & 3 & 1.2 & 2.8 & 13.4 & 0.03 & 100 & 30 & & 0.4 & 80 & 0 & 0 & & & 0 & 0.06 & 0.06 & 0 & & & & \\
\hline 1182 & do. & do. & 50 & 1 & 25 & 109 & 0.46 & & 0.50 & 100 & 5 & & 5.5 & 90 & & & & & & & & & & & & \\
\hline 1193 & do. & Oval. & 6 & 4 & 5 & 10 & 0.12 & 13.3 & 0.01 & 80 & 20 & & 2 & 90 & & & & & & & & & & & & \\
\hline 1234 & Mall zone.t & ent1 cular. & 176 & 14 & & & & & & & & & & & & & & & & & & & $\begin{array}{c}\text { columbite- } \\
\text { tantall to. }\end{array}$ & ${ }^{1} 10$ & & \\
\hline 1240 & One unit. & $\begin{array}{l}\text { anticular: } \\
\text { branching. }\end{array}$ & 50 & 11 & & & & & & & & & & & & & & & & & & & do. & 1 & & \\
\hline 1248 & Vall sono. & Irrogular. & 2335 & -- & 50 & $2,450,000$ & & 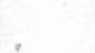 & & & 20 & & 4490,000 & 0 & & & & & & & & & & & & \\
\hline 1256 & One unit. & Lenticular. & 500 & 35 & 25 & 37.400 & & " & & & 30 & & 412,200 & 0 & 1 & & & & & & & & & & & \\
\hline 1269 & do. & Irragular. & 410 & 140 & 50 & 240,000 & & & & & 25 & & 60,000 & 0 & & & & & & & & & & & & \\
\hline 1316 & do. & do. & 360 & 65 & 50 & 108,500 & & & & & 35 & & 439,600 & 5 & & & & & & & & & & & & \\
\hline 1322 & Wall sone. & $\begin{array}{l}\text { Lont1cular - } \\
\text { oranch1ng. }\end{array}$ & -2780 & -- & 50 & $4,260,000$ & & & & & 30 & & $41,278,00$ & $\phi_{0}$ & & & & & & & & & & & & \\
\hline 1323 & core. & oral. & 15 & 15 & 10 & 196 & 0.2 & & 0.39 & 100 & & & & & & & & & & & & & & & & \\
\hline 1332 & One unst. & Irregular. & 568 & 65 & 50 & 252,000 & & & & & 25 & & 63,000 & 30 & & & & & & & & & & & & \\
\hline
\end{tabular}


$\frac{\text { Tab10 22-Pepmat1 ite ninerel resourcee }}{\text { 1n short tons) }}$

\begin{tabular}{|c|c|c|c|c|c|c|c|c|c|c|c|c|c|c|c|c|c|c|c|c|c|c|c|c|c|c|}
\hline \multirow[b]{2}{*}{$\begin{array}{l}\text { Mumber and } \\
\text { namb of per- } \\
\text { natite } \\
\text { (PI. II) }\end{array}$} & \multirow[b]{2}{*}{ Internal } & \multicolumn{5}{|c|}{ S1ze and shape of depoest t } & \multicolumn{4}{|c|}{ Berry 1} & \multicolumn{4}{|c|}{ Yoldepar } & \multicolumn{8}{|c|}{ Nasea } & \multicolumn{4}{|c|}{ Other minerals } \\
\hline & & shape & $\begin{array}{l}\text { Average } \\
\text { length } \\
\text { (feet) }\end{array}$ & \begin{tabular}{|l} 
Average \\
thicke- \\
neses \\
(feet)
\end{tabular} & Pepth & Tons & Par- & $\begin{array}{c}\text { Compo- } \\
\text { oftion } \\
\left(\begin{array}{c}\text { Percont } \\
B \infty 0)\end{array}\right.\end{array}$ & Tons & $\begin{array}{l}\text { Per- } \\
\text { cent } \\
\text { cobbb } \\
\text { able }\end{array}$ & $\begin{array}{l}\text { Per- } \\
\text { cent }\end{array}$ & $\begin{array}{l}\text { Compo- } \\
\text { a1tion }\end{array}$ & Tons & $\begin{array}{l}\text { Por } \\
\text { cont } \\
\text { cobb- } \\
\text { ab10 }\end{array}$ & $\begin{array}{l}\text { Pern } \\
\text { cont } \\
\text { crude } \\
\text { sheet } \\
\text { and } \\
\text { punoh }\end{array}$ & $\begin{array}{l}\text { Per- } \\
\text { eant } \\
\text { sheot } \\
\text { and } \\
\text { anuch } \\
\text { in } \\
\text { crude }\end{array}$ & $\begin{array}{l}\text { Size } \\
\text { of } \\
\text { sheot } \\
\text { and } \\
\text { punch }\end{array}$ & $\begin{array}{l}\text { Qual1 ty } \\
\text { of } \\
\text { shoet } \\
\text { and } \\
\text { punch }\end{array}$ & $\begin{array}{l}\text { Tons } \\
\text { sheet } \\
\text { and } \\
\text { punch }\end{array}$ & $\begin{array}{l}\text { Total } \\
\text { tons } \\
\text { of } \\
\text { sorap }\end{array}$ & $\begin{array}{c}\text { Total } \\
\text { tons } \\
\text { of } \\
\text { micos }\end{array}$ & $\begin{array}{l}\text { Per- } \\
\text { cont } \\
\text { cosb- } \\
\text { ablo }\end{array}$ & Mineral & \begin{tabular}{|l|} 
Por- \\
cont
\end{tabular} & $\begin{array}{l}\text { Compo- } \\
\text { a1tion }\end{array}$ & Pone \\
\hline 1341 & $\begin{array}{l}\text { Hanging } \\
\text { vall layer. }\end{array}$ & Lentioulary. & 580 & 20 & 50 & 52,700 & & & & & 45 & & 423.700 & 5 & & & & & & & & & & & & \\
\hline $13+12$ & $\begin{array}{l}\text { Poot vall } \\
\text { 1aver. }\end{array}$ & do. & 880 & 45 & 50 & 168.700 & & & & & 20 & & 433.700 & 0 & & & & & & & & & & & & \\
\hline 1347 & One un1t. I & Irrogular. & $=314$ & 38 & 25 & 39.000 & & & & & 30 & & 411,700 & 10 & & & & & & & & & & & & \\
\hline 1355 & vall zone. & do. 3 & 3.450 & -- & 90 & $7.826,000$ & & & & & 35 & & $42,739.000$ & 015 & & & & & & & & & & & & \\
\hline 1357 & One unit. & do. & 535 & 60 & 50 & 185,000 & & & & & 25 & & 446,200 & 0 & & & & & & & & & & & & \\
\hline $\begin{array}{c}1402 \\
\operatorname{Tx} 10 \text { \$10. } 1\end{array}$ & rall zone. & do. & 644 & - & 50 & 290,000 & & & & & 25 & & 42,500 & 0 & & & & & & & & & & & & \\
\hline $\begin{array}{l}1402 \\
\operatorname{Tr} 10 \text { ถ⿻. } 1\end{array}$ & $\begin{array}{l}\text { Intermodiate } \\
\text { zone. }\end{array}$ & - Leaticula & ar.96 & 5 & 20 & 860 & 0.91 & 13.2 & 7.3 & 95 & 30 & & 258 & 200 & & & & & . & & & & & & & \\
\hline 1426 & Mall sone. & oval. & 330 & 115 & 50 & 135.500 & & & & & 70 & & 94,900 & 5 & & & & & 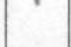 & & & & & & & \\
\hline 1428 & do. & $\begin{array}{l}\text { Tenticular } \\
\text { branchinge. }\end{array}$ & -1150 & - & 50 & 262,000 & & & & & 65 & & 470,000 & 0 & & & & & & & & & & & & \\
\hline 1429 & do. I & rrogular. & 385 & 76 & 50 & 109,000 & & & & & 45 & & 449,000 & 0 & & & & & & & & & & & & \\
\hline 2470 & One unit. & a. & 1,140 & - & 50 & 783.000 & & & & & 30 & & 4235,000 & 5 & & & & & & & & & & & & \\
\hline 1509 & do. & do. & 1,000 & - & 50 & $1,226,000$ & & & & & 48 & & 588,000 & 30 & 0 & 0 & & & 0 & 24,520 & 24,520 & 5 & & & & \\
\hline 1517 & do. & Cont1 oular. & . 34 & 12 & & & & & & & & & & & & & & & & & & & Monazite. & $1_{1}$ & & \\
\hline 1518 & do. & $\begin{array}{l}\text { Lent1 oular } \\
\text { branch1ne. }\end{array}$ & 362 & 20 & & & & & & & & & & & & & & & & & & & do. & $1_{1}$ & & \\
\hline 1523 & mall sone. & Irragular. & 600 & - & 50 & 379.000 & & & & & 30 & & 4113,700 & 5 & & & & & & & & & & & & \\
\hline The Tr10 & do. & do. & 2,800 & 760 & 100 & $2,287,000$ & & & & & 30 & & 4686,000 & 0 & & & & & & & & & & & & \\
\hline 1540 & do. & do. & 500 & 190 & 50 & 289,100 & & & & & 33 & & 495.400 & 5 & 0 & 0 & & & 0 & 5.780 & 5.780 & & & & & \\
\hline 1541 & do. & do. & 1,020 & 260 & 50 & $1,217,000$ & & & & & 30 & & 365.000 & 25 & 0 & 0 & & & 0 & 60.850 & 60,850 & 0 & & & & \\
\hline 1544 & do. & do. & 368 & 170 & 50 & 242,000 & & & & & 50 & & 4121,000 & 5 & 0 & 0 & & & 0 & 2,420 & 2,420 & 0 & & & & \\
\hline $\begin{array}{l}1557 \\
1558\end{array}$ & do. & $\begin{array}{l}\text { Lantioular. } \\
\text { do. }\end{array}$ & 24 & $\begin{array}{r}6 \\
1.5\end{array}$ & & & & & & & & & & & & & & & & & & & $\begin{array}{c}\text { Col minbi to } \\
\text { tantalito. } \\
\text { do. }\end{array}$ & $\begin{array}{l}1_{1} \\
1_{1}\end{array}$ & & \\
\hline 1566 & One unit. & trragular. & 384 & 75 & 50 & 131.300 & & & & & 30 & & 39.400 & 0 & 0 & 0 & & & 0 & 1,310 & 1,310 & 0 & & & & \\
\hline $\begin{array}{l}1574^{4} \\
\text { Bucky }\end{array}$ & $\begin{array}{l}\text { oraph10 } \\
\text { gran1 to. } \\
\text { Intormediat. } \\
\text { zone. }\end{array}$ & do. & 1.350 & 650 & 200 & $16,870,000$ & & & & & 80 & & $413,500,00$ & 000 & & & & & & & & & & & & \\
\hline $\begin{array}{l}1574 \\
\text { Bucky }\end{array}$ & $\begin{array}{c}\text { fuacovi to- } \\
\text { feldepar } \\
\text { quartz-bertz } \\
\text { 1ntermedi af } \\
\text { mone. }\end{array}$ & Oval. & 100 & 90 & 3 & 1,770 & 8.9 & 12.9 & 158 & 100 & 26 & & 460 & 100 & 0 & 0 & & & 0 & 708 & 708 & 100 & $\begin{array}{l}\text { Lep1dol1 te. } \\
\text { Topaz. } \\
\text { Columbi to- } \\
\text { tantal1 to. } \\
\text { Monasi te. }\end{array}$ & $\begin{array}{l}\text { Trace. } \\
\text { Trace } \\
0.11 \\
0.003\end{array}$ & & $\begin{array}{l}2.95 \\
0.05\end{array}$ \\
\hline
\end{tabular}




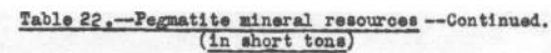

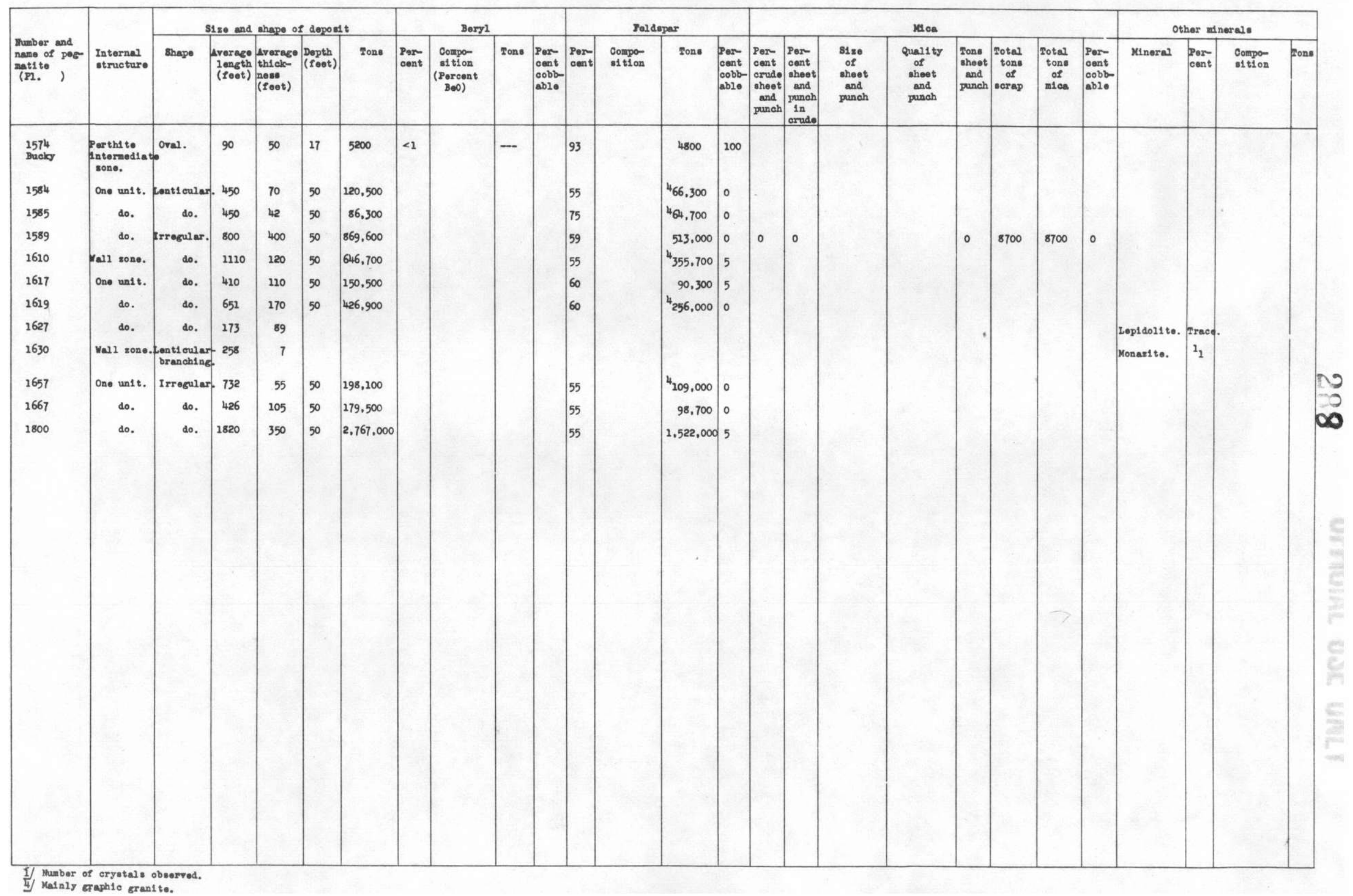




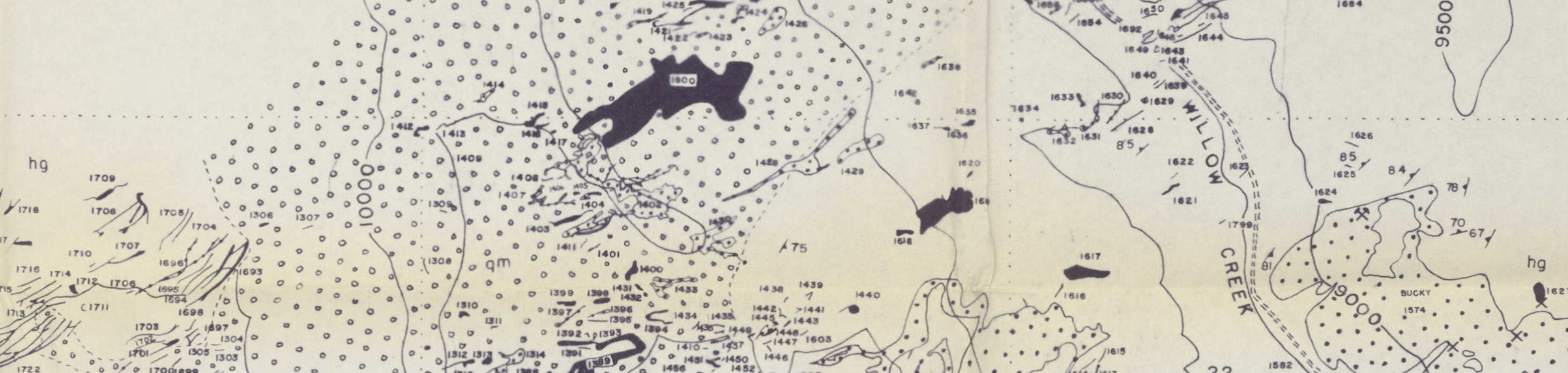

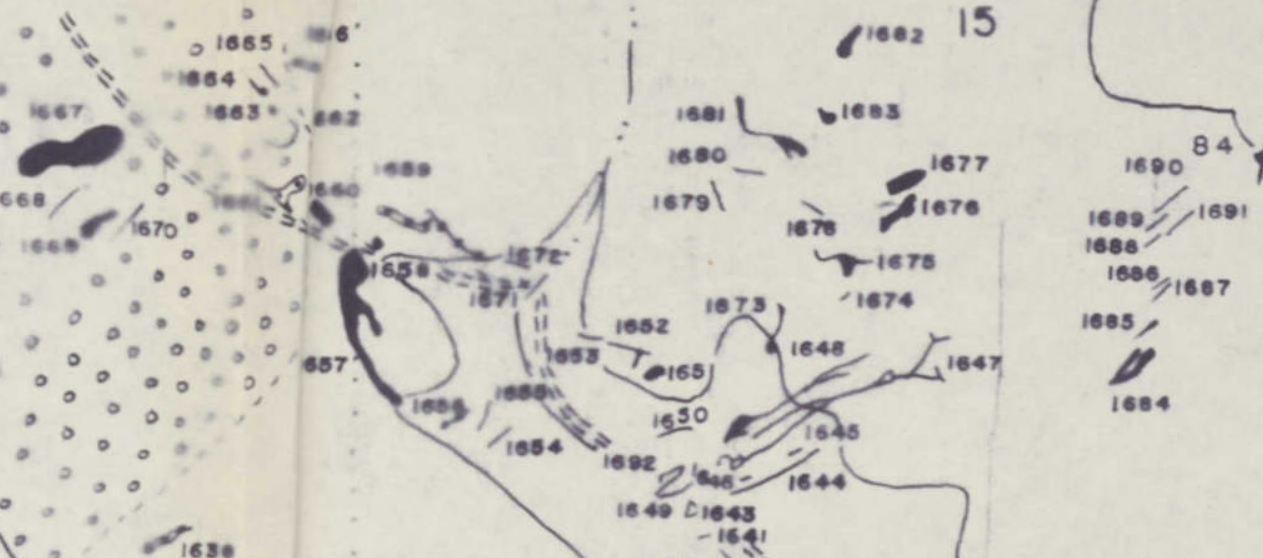
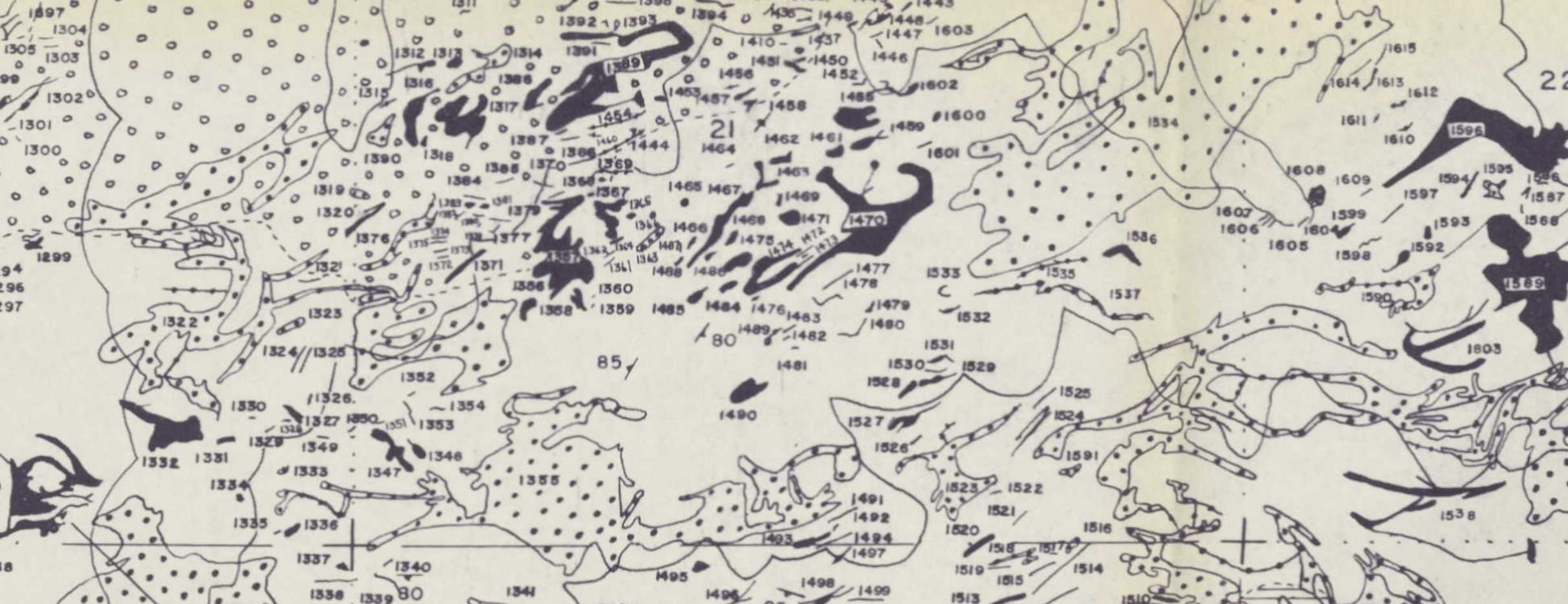

$x=$

(
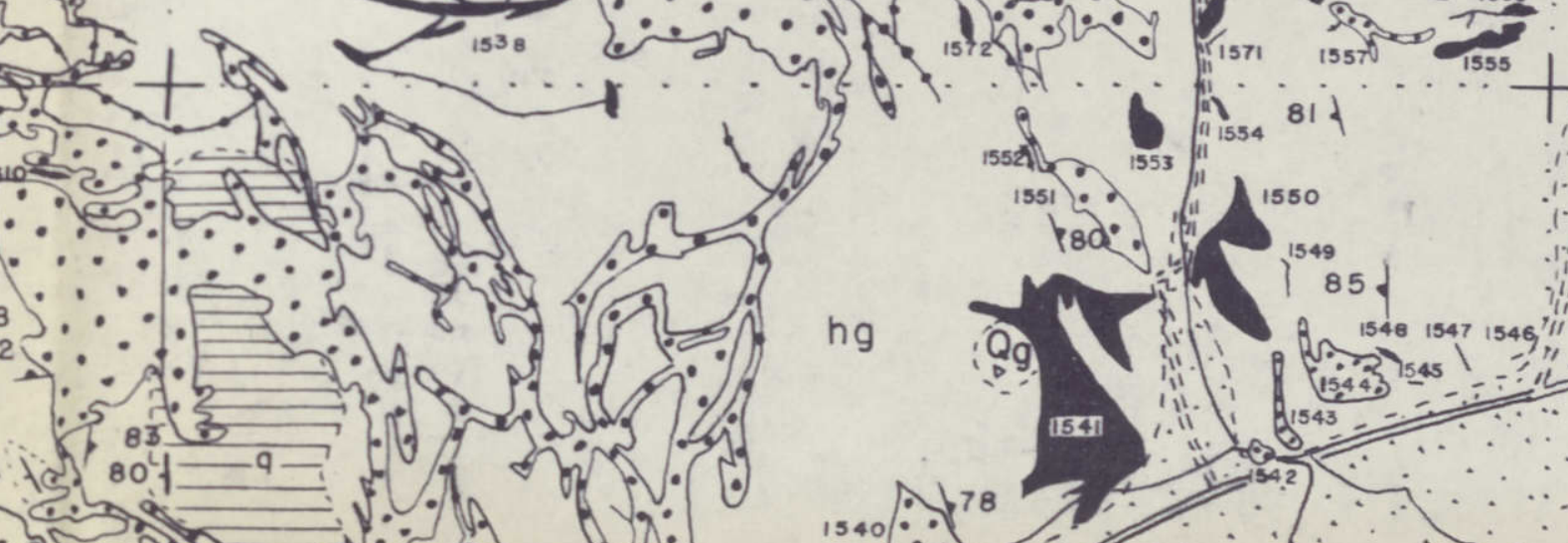

\section{(-1)}

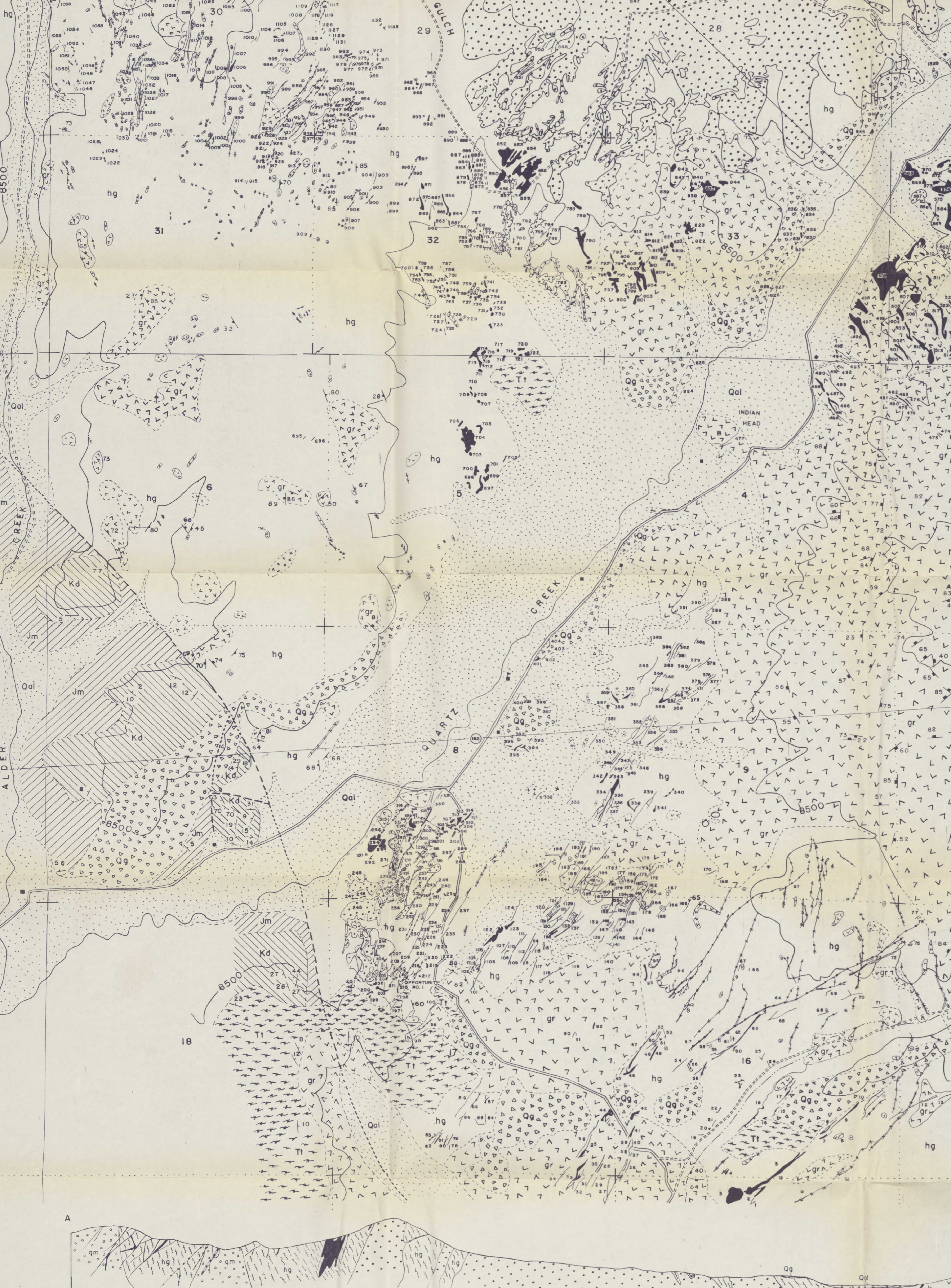

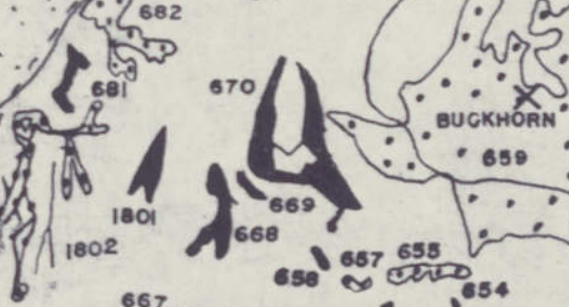

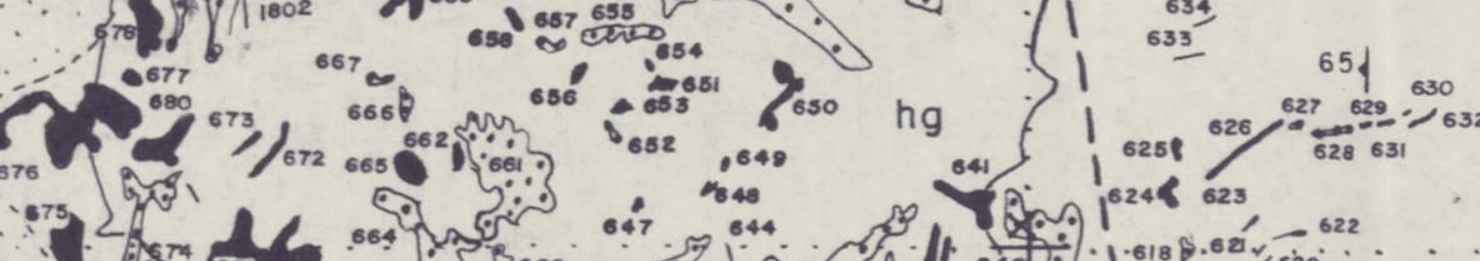

a d ond

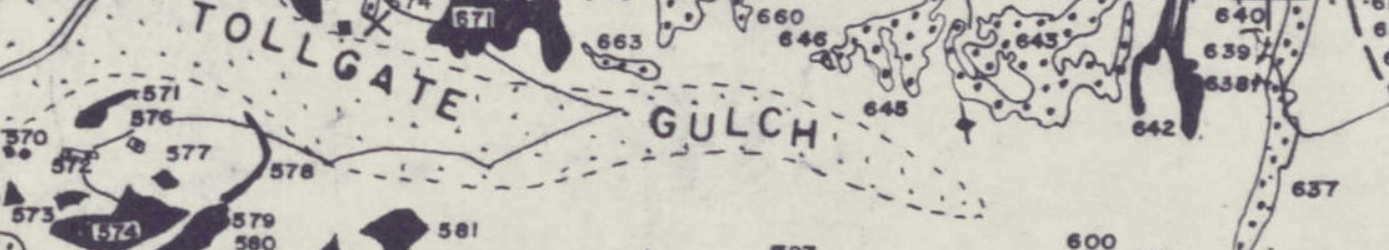
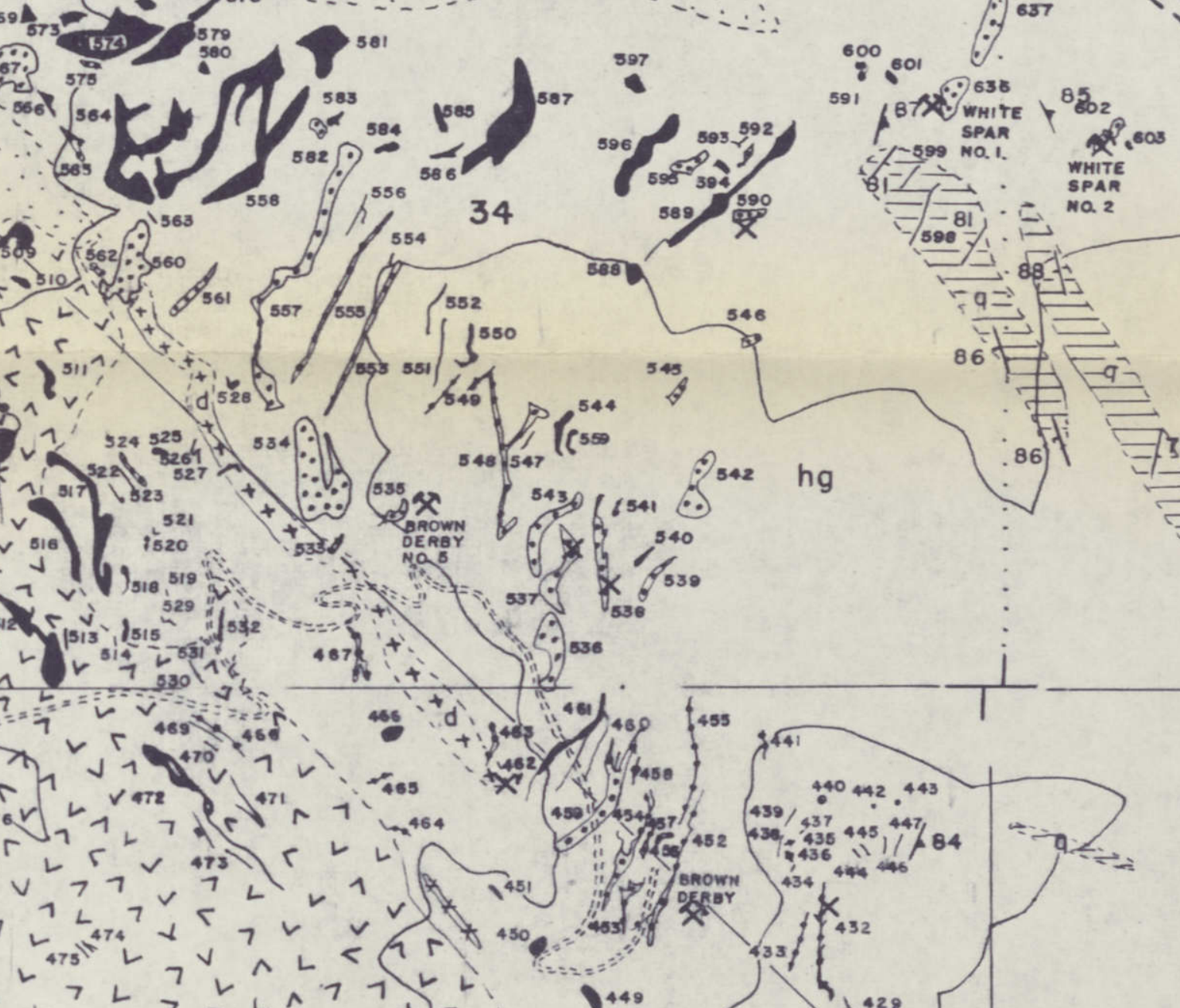



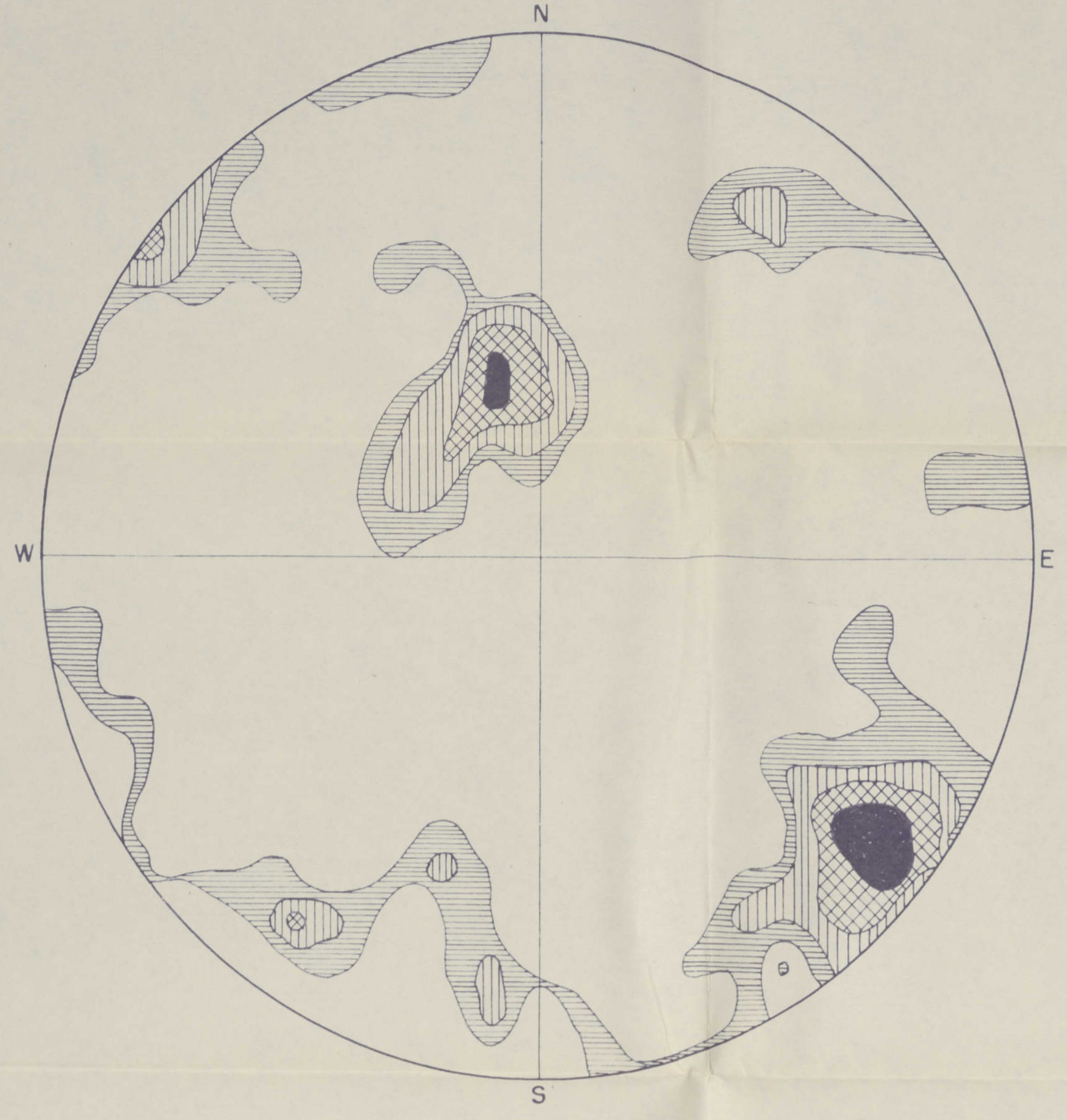

CONTOUR DIAGRAM OF 54 JOINTS AT LOCALITY A

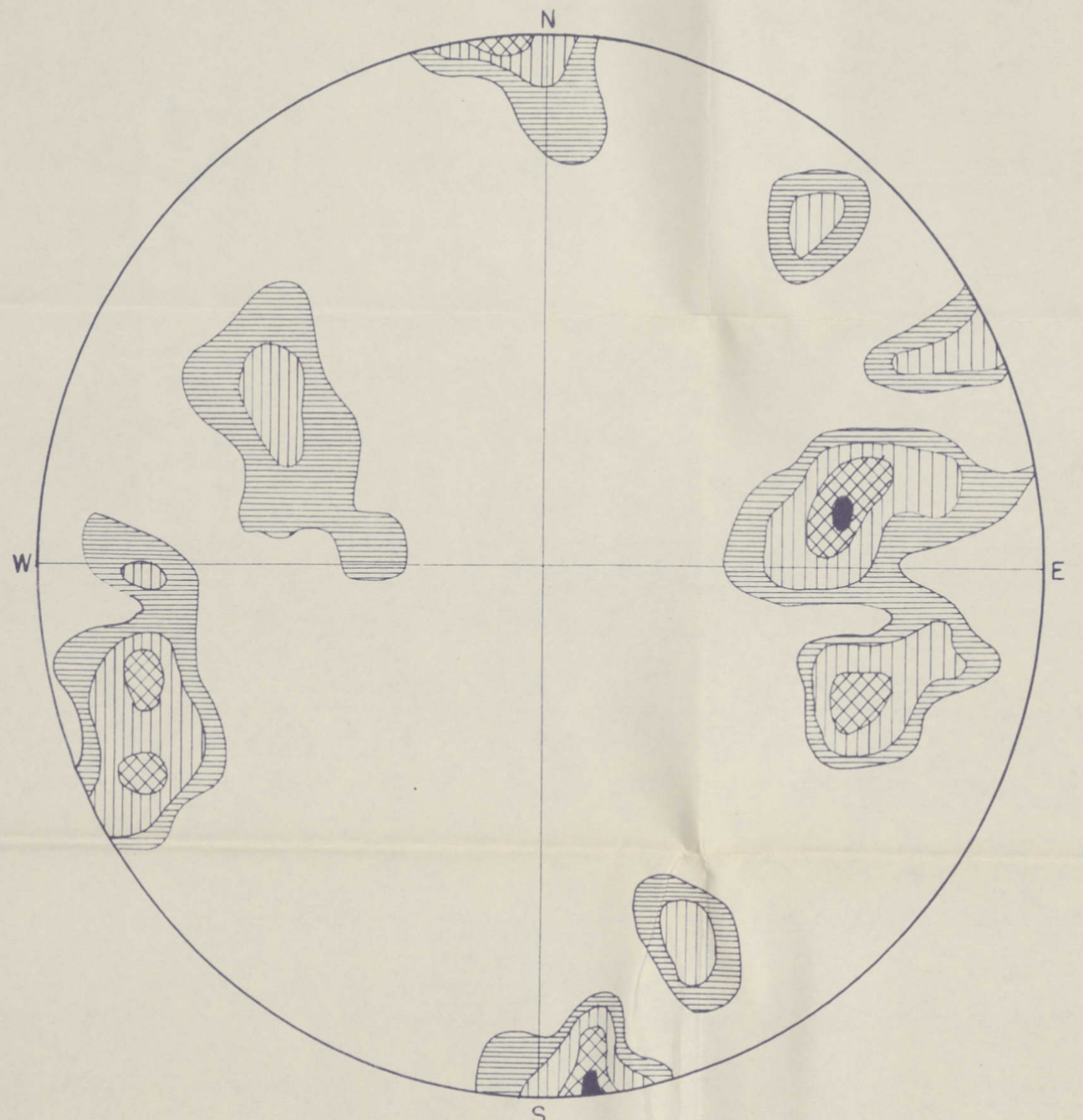

CONTOUR DIAGRAM OF 48 JOINTS AT LOCALITY

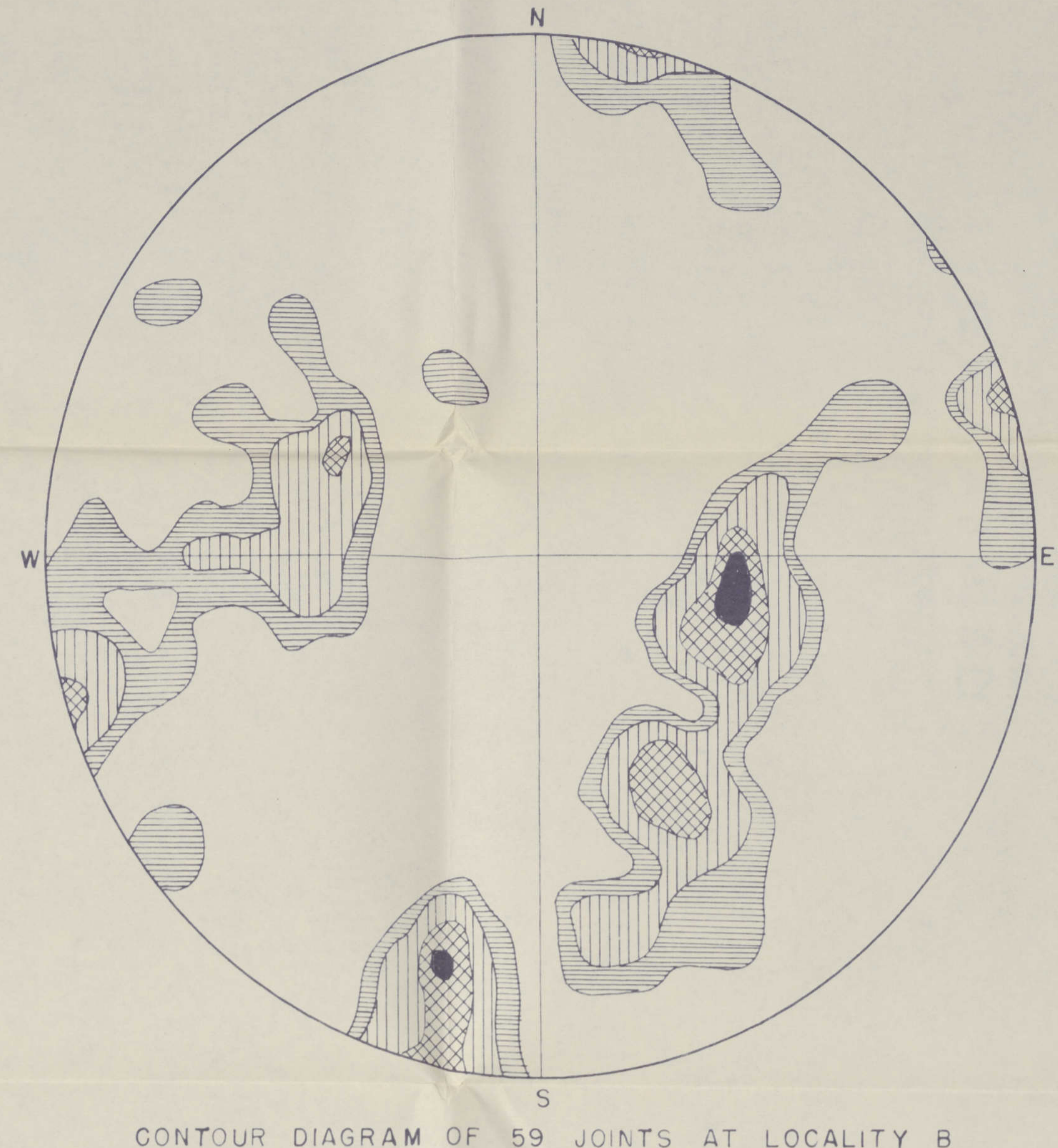

CONTOUR DIAGRAM OF 59 JOINTS AT LOCALITY B

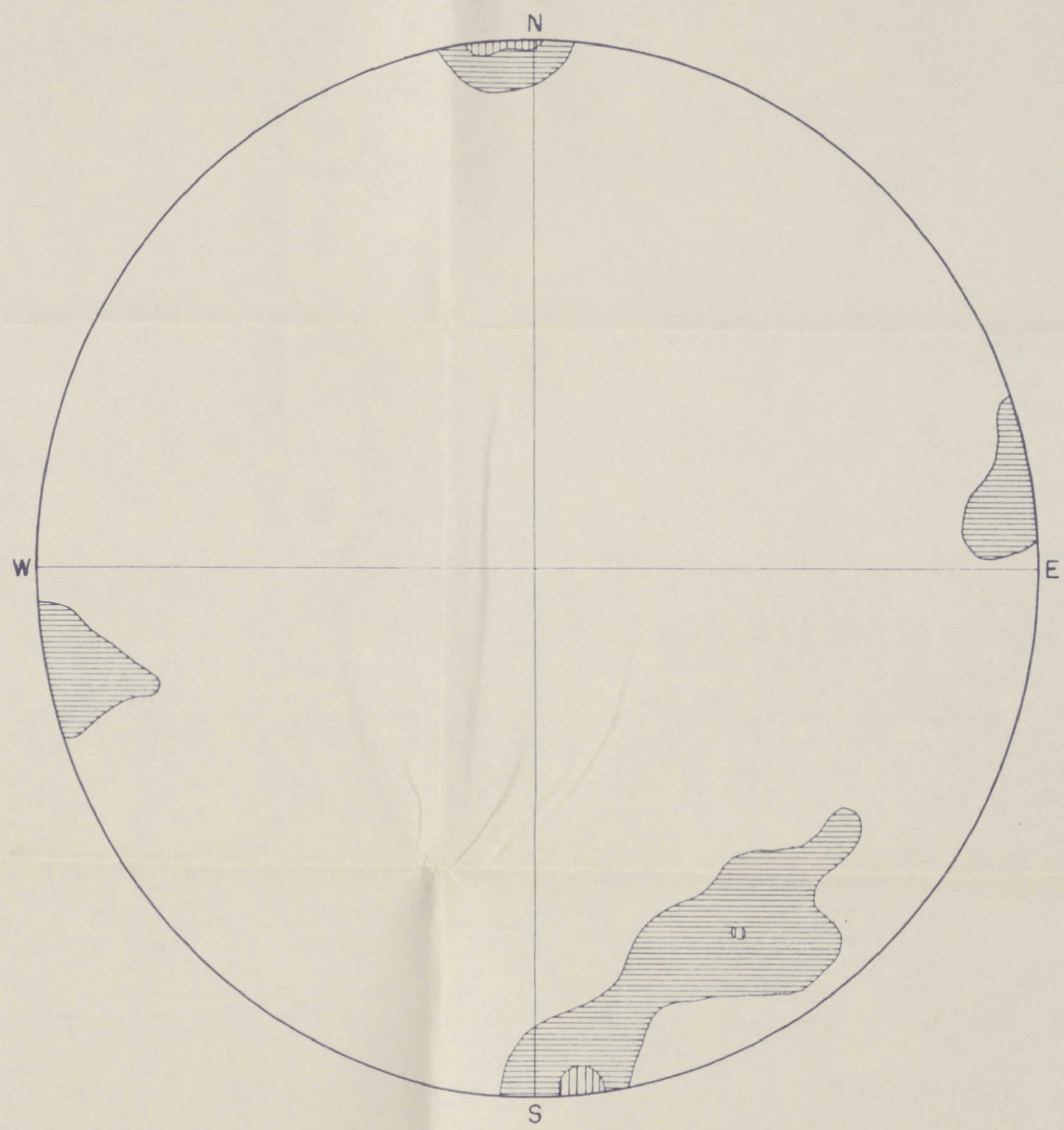

CONTOUR DIAGRAM OF 638 JOINTS FROM ENTIRE GRANITE AREA ON THE EAST SIDE OF QUARTZ CREEK

EXPLANATION

PERCENTAGE OF JOINTS MEASURED

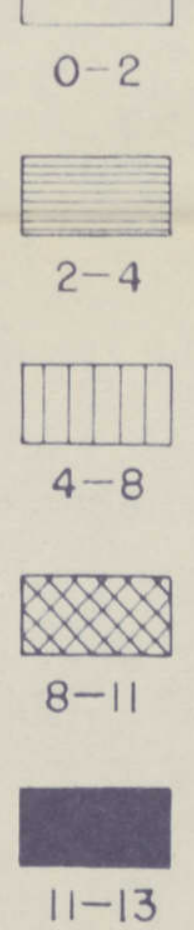

Localities $A, B$, and $C$ Shown on Plate 2 




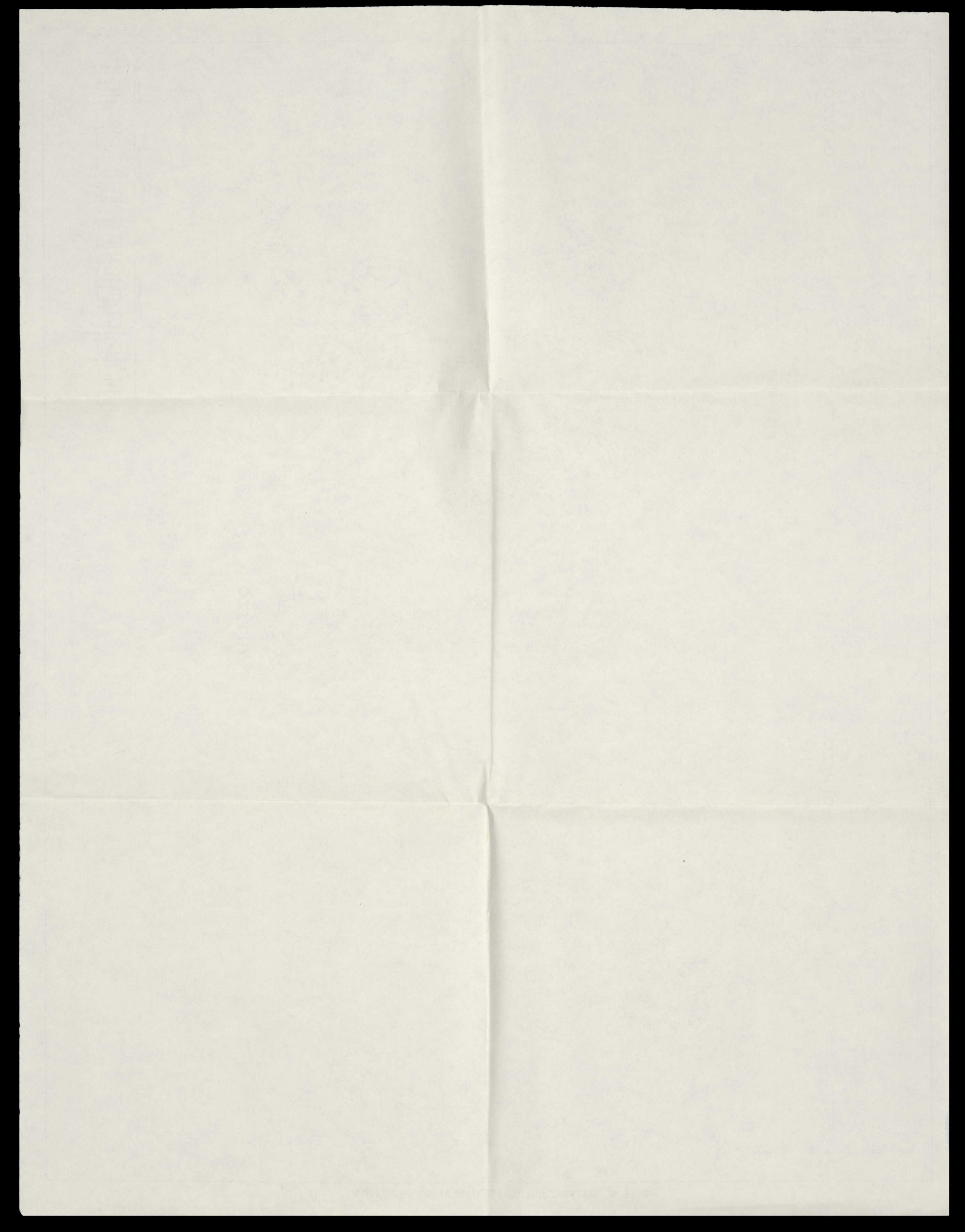




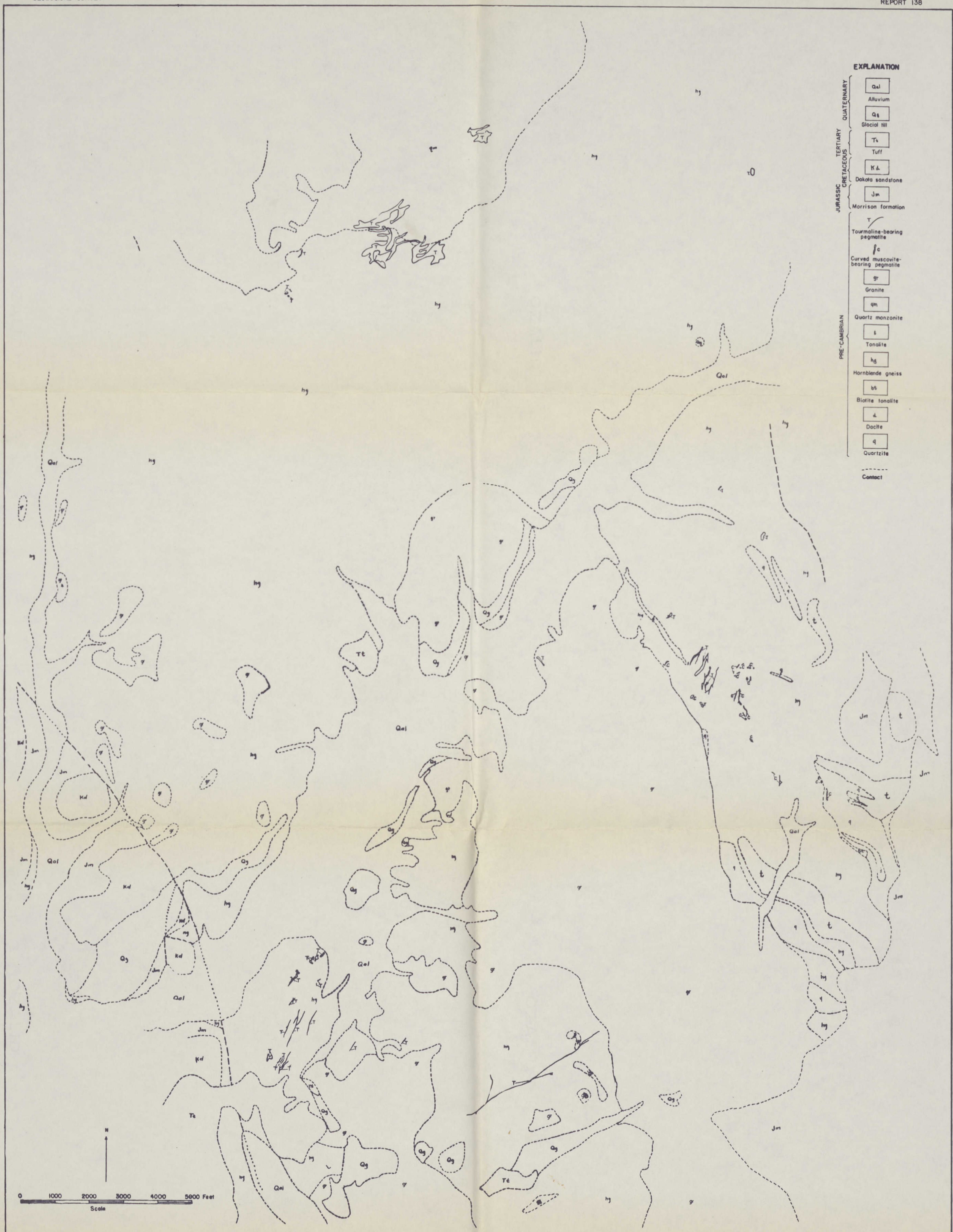




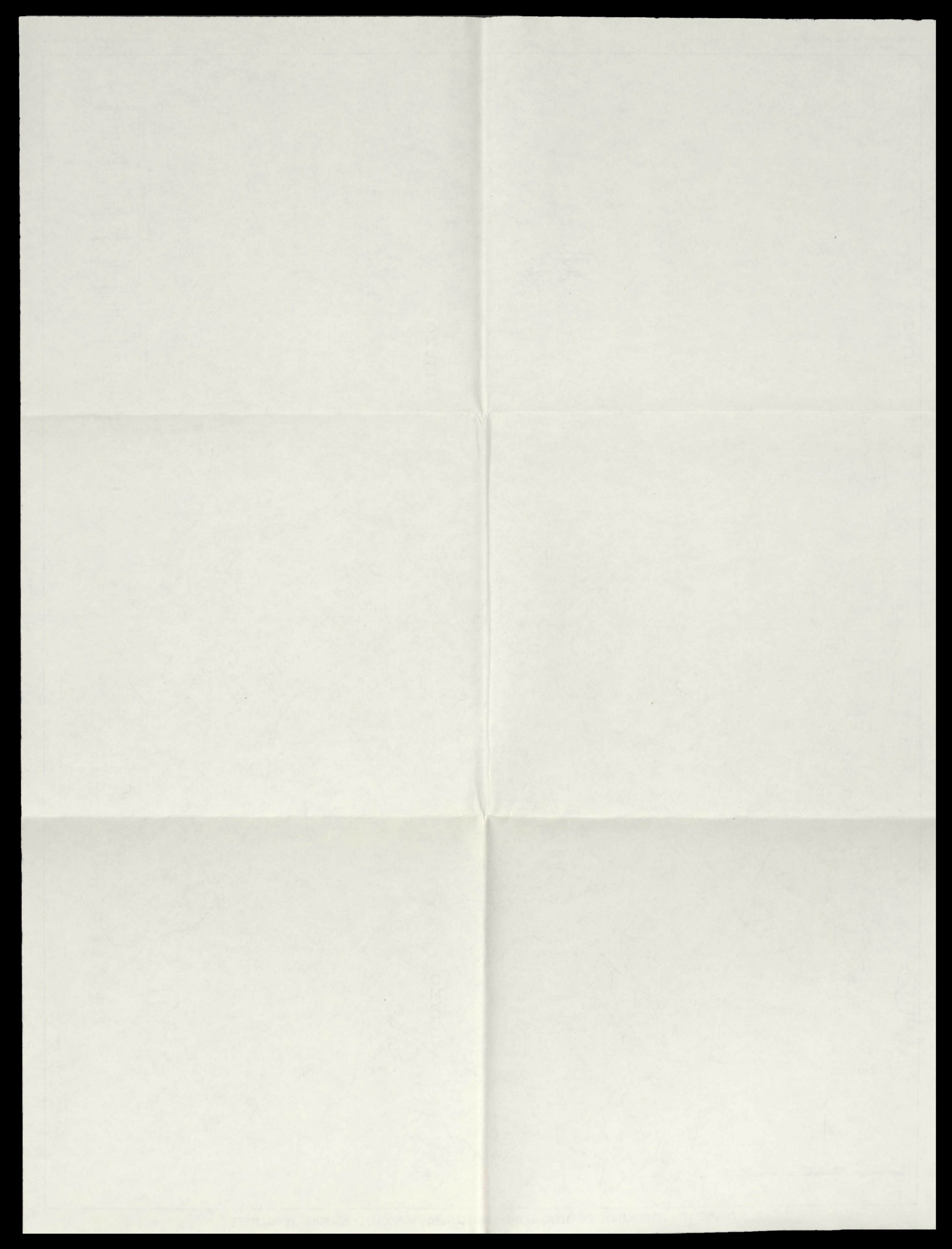


S. DEPARTMENT OF THE INTERIOr

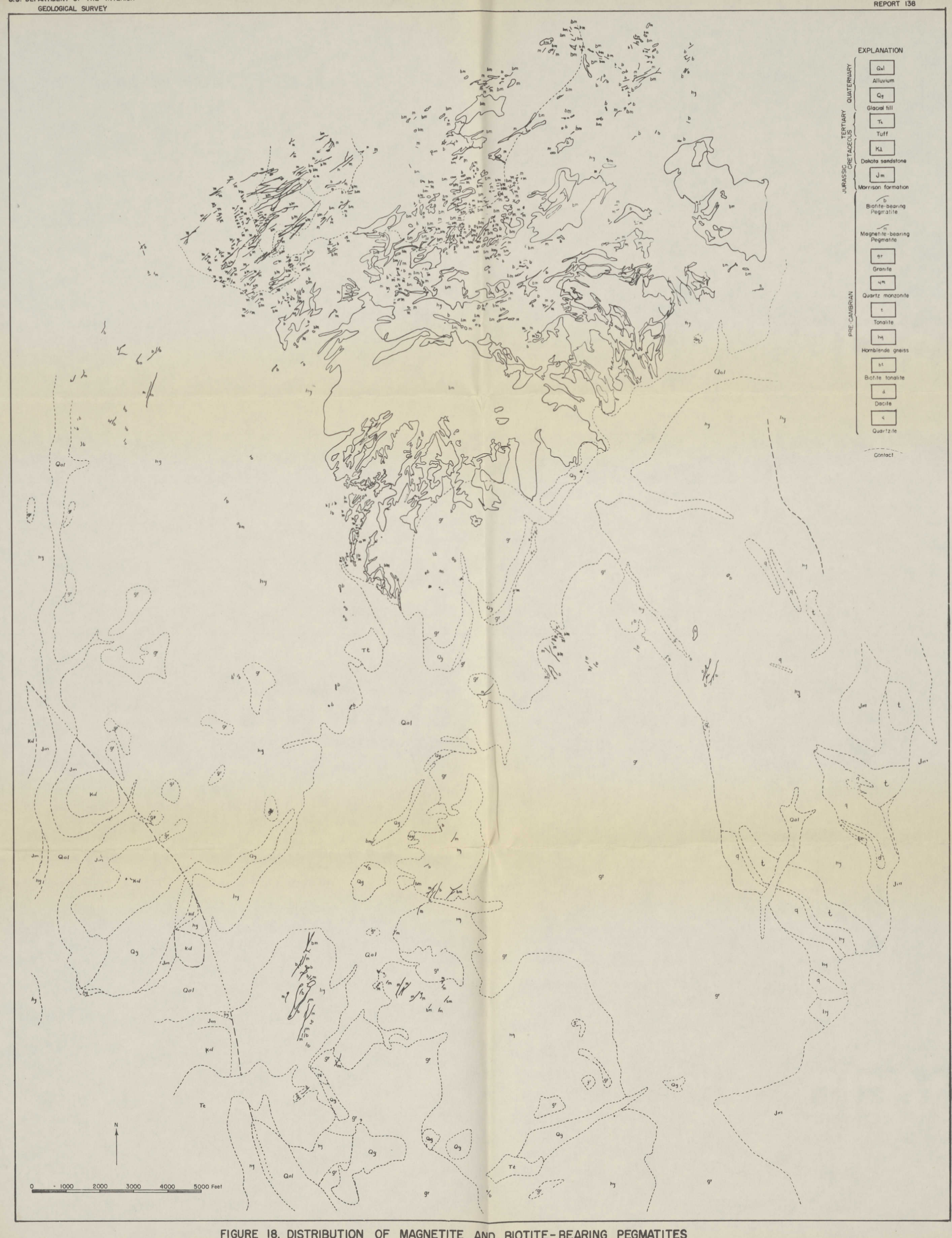

FIGURE 18. DISTRIBUTION OF MAGNETITE AND BIOTITE-BEARING PEGMATITES 



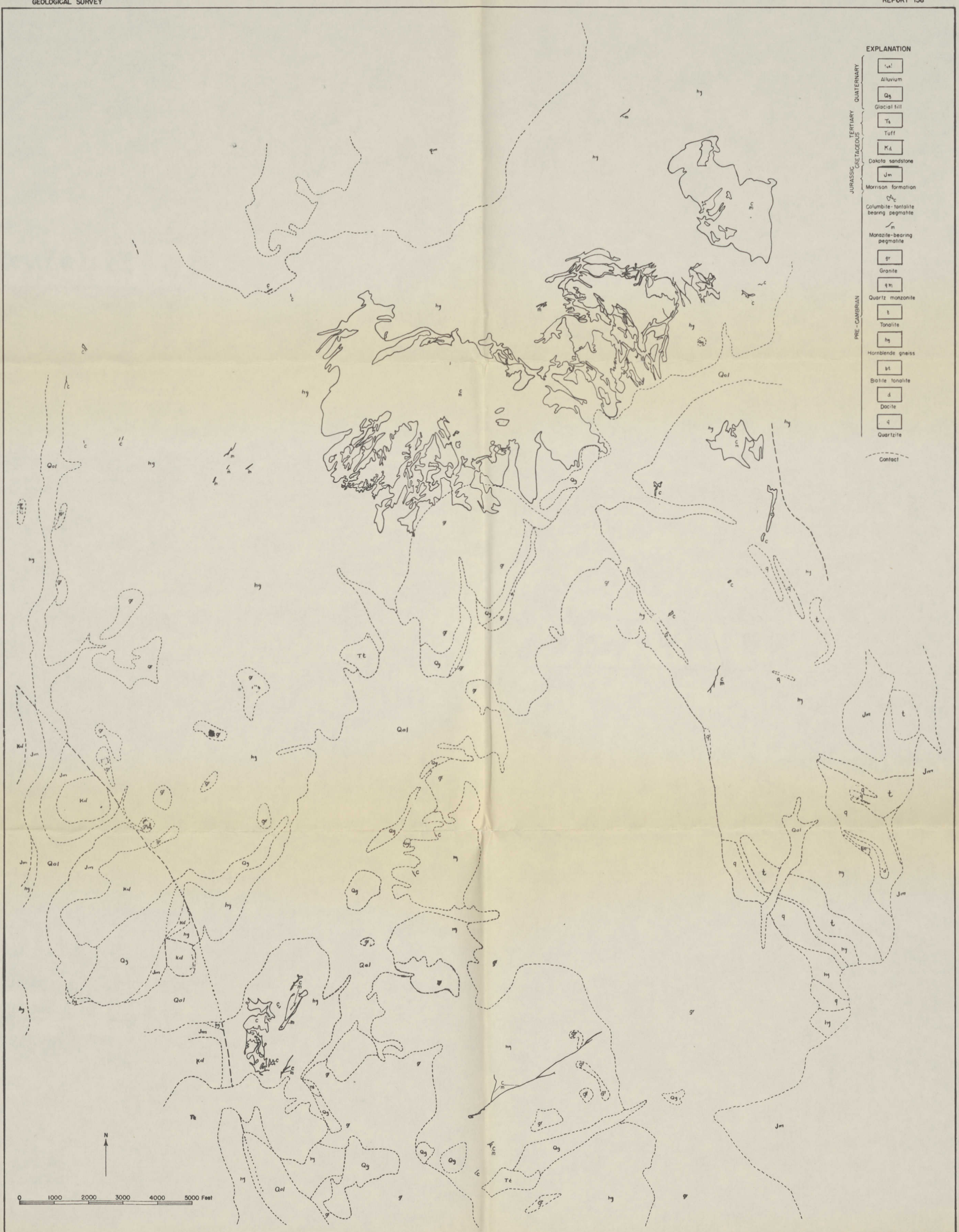




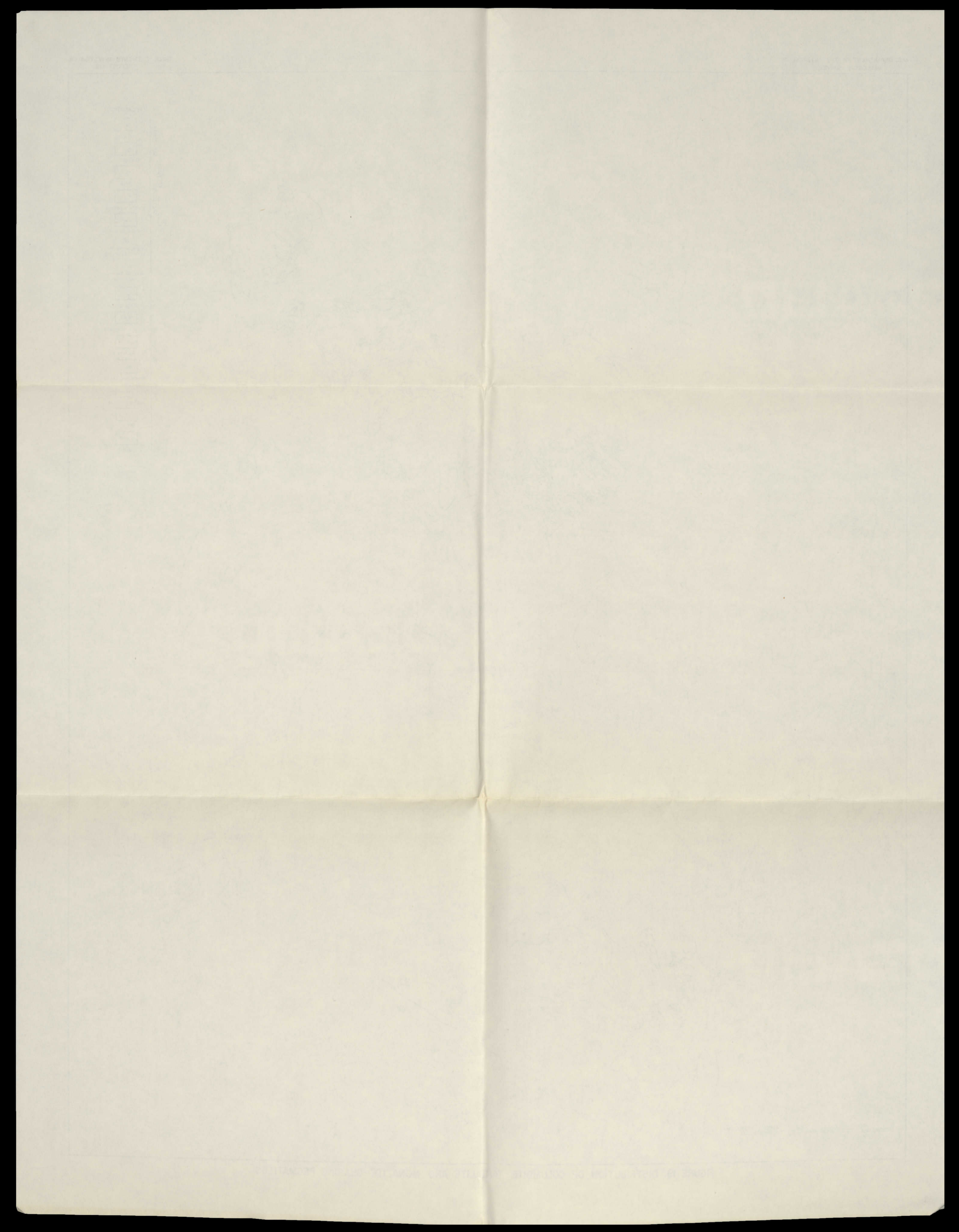




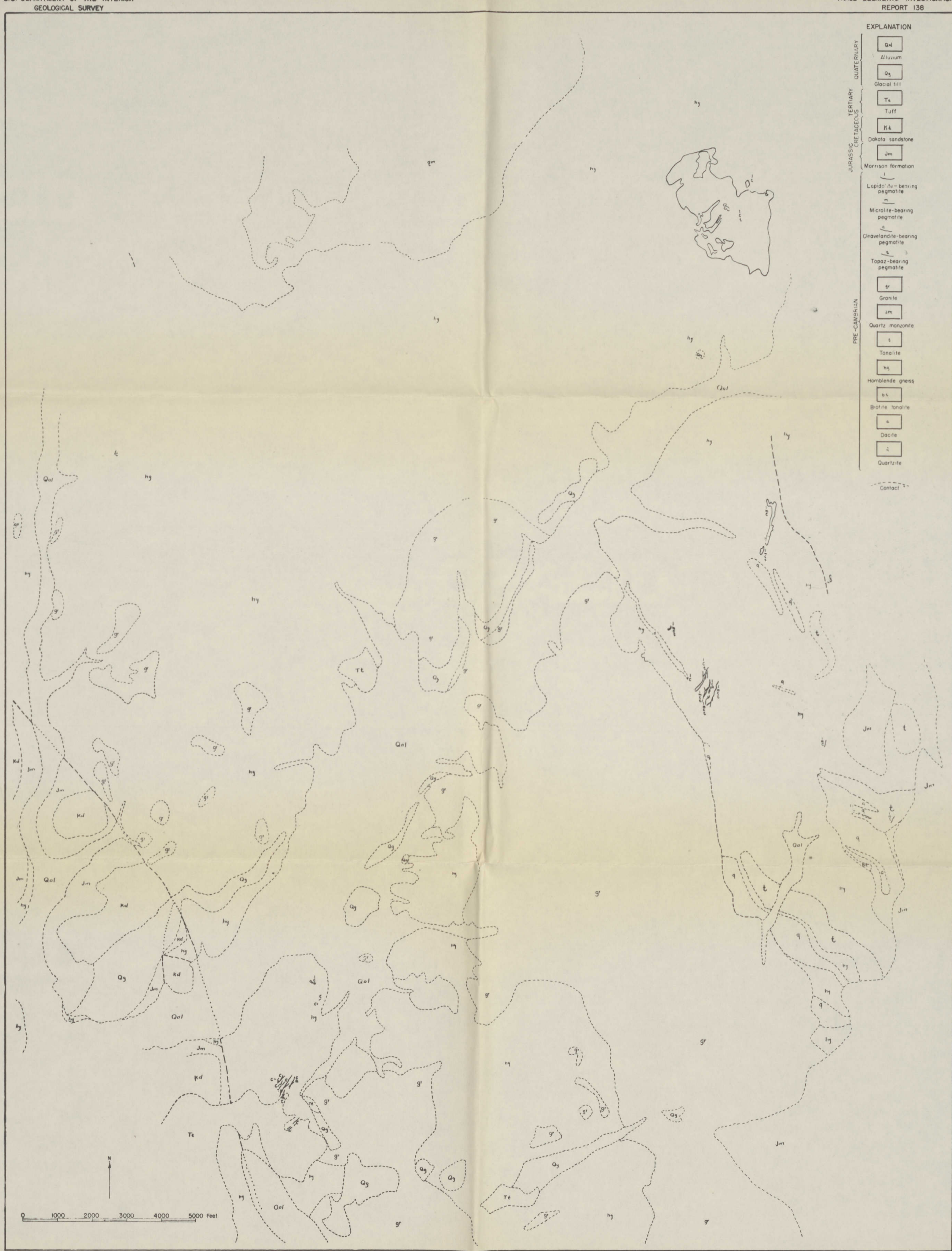

FIGURE 20. DISTRIBUTION OF LEPIDOLITE, CLEAVELANDITE, TOPAZ AND MICROLITE-BEARING PEGMATITES 



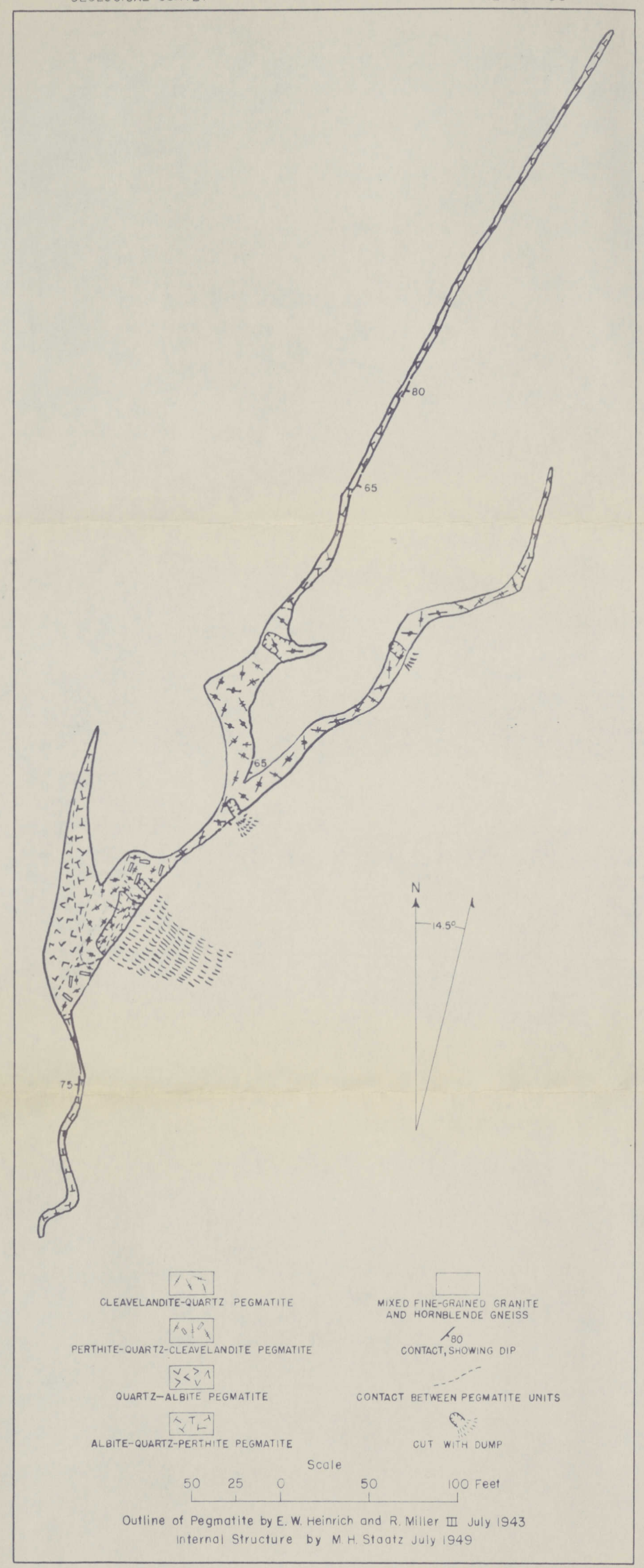

FIGURE 21. GEOLOGIC MAP, OPPORTUNITY NO.I (NO. 215) PEGMATITE 


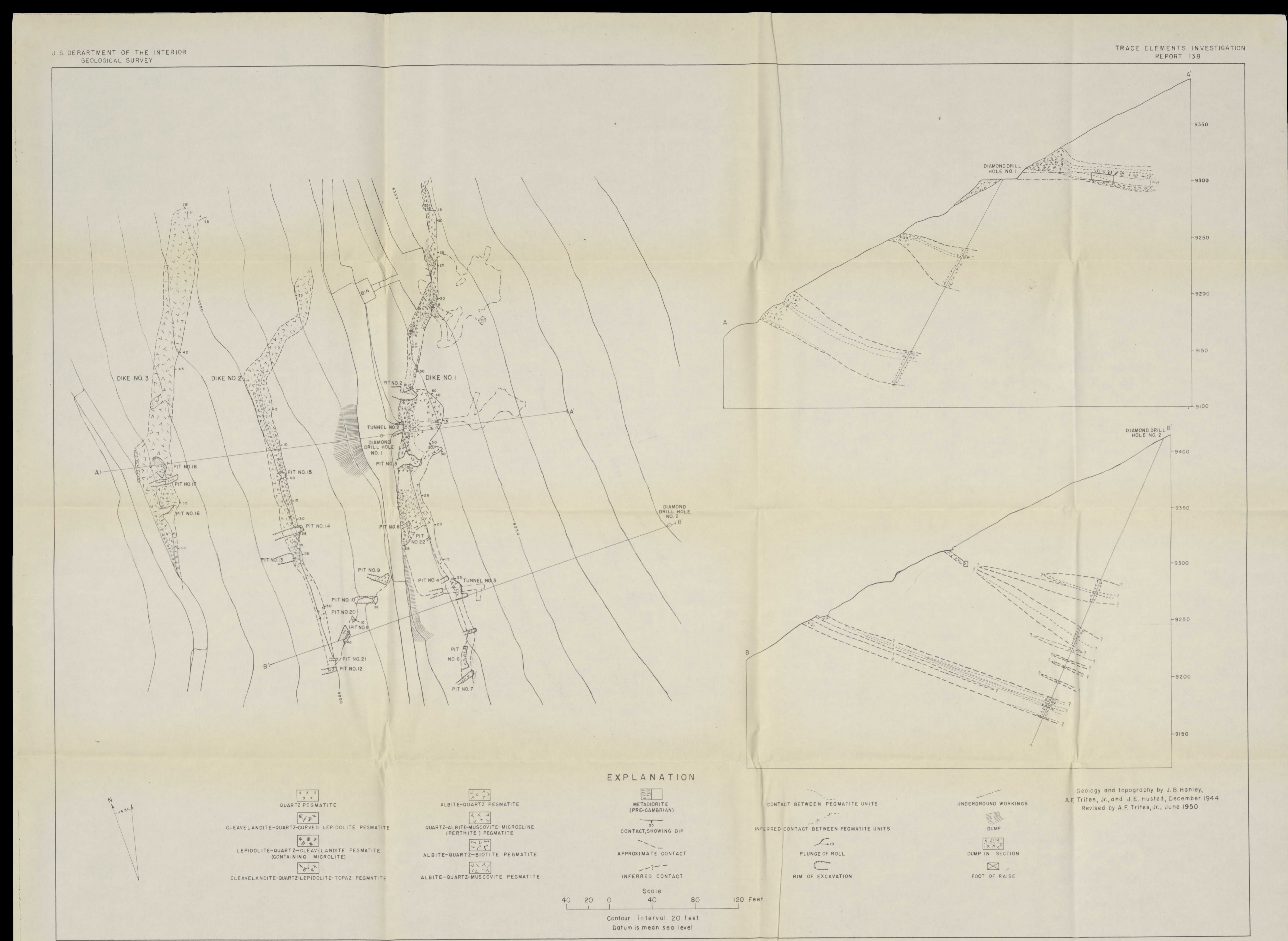

FIGURE 22. GEOLOGIC MAP AND SECTIONS OF BROWN DERBY MINE, SHOWING BUREAU OF MINES DIAMOND DRILLING 


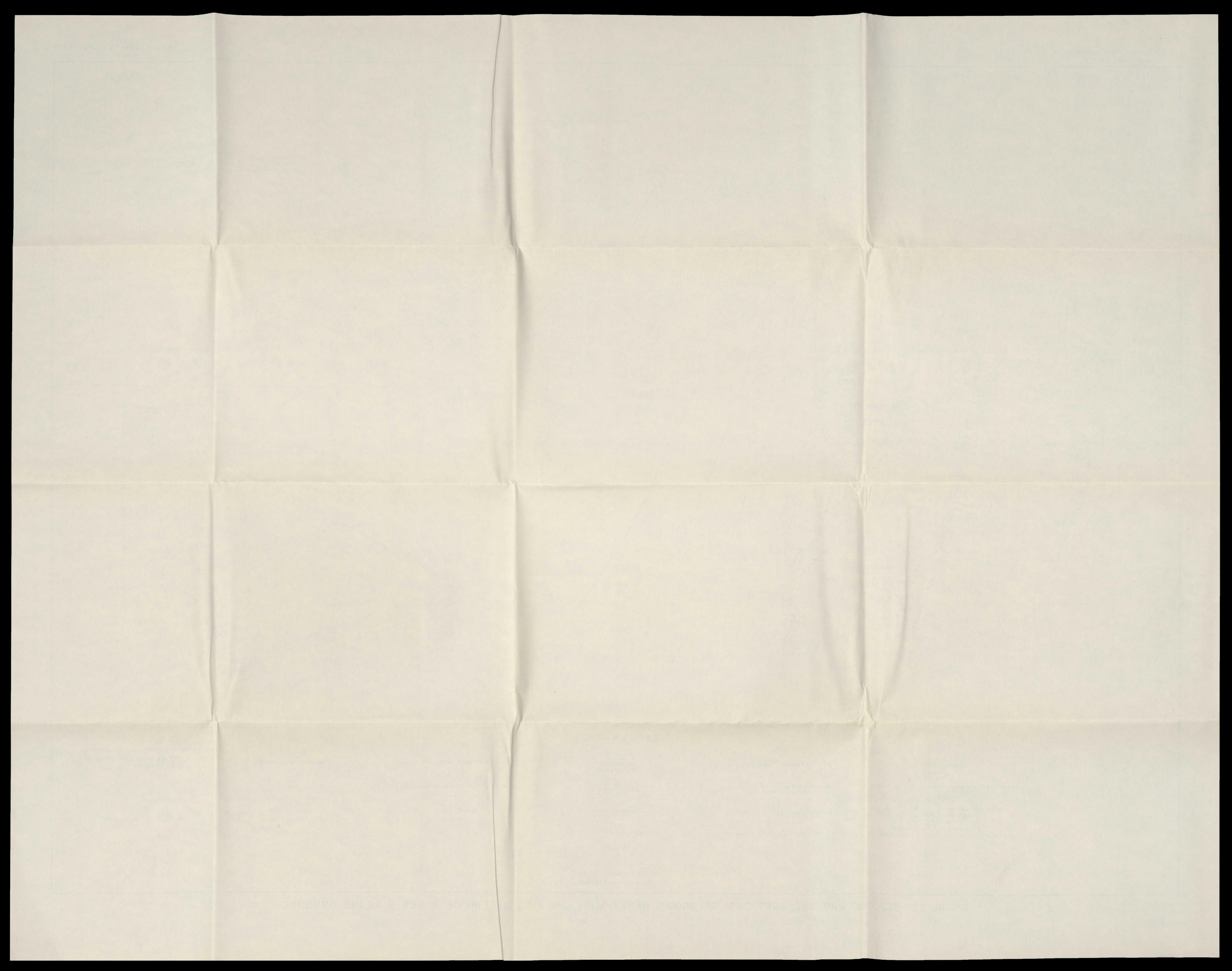




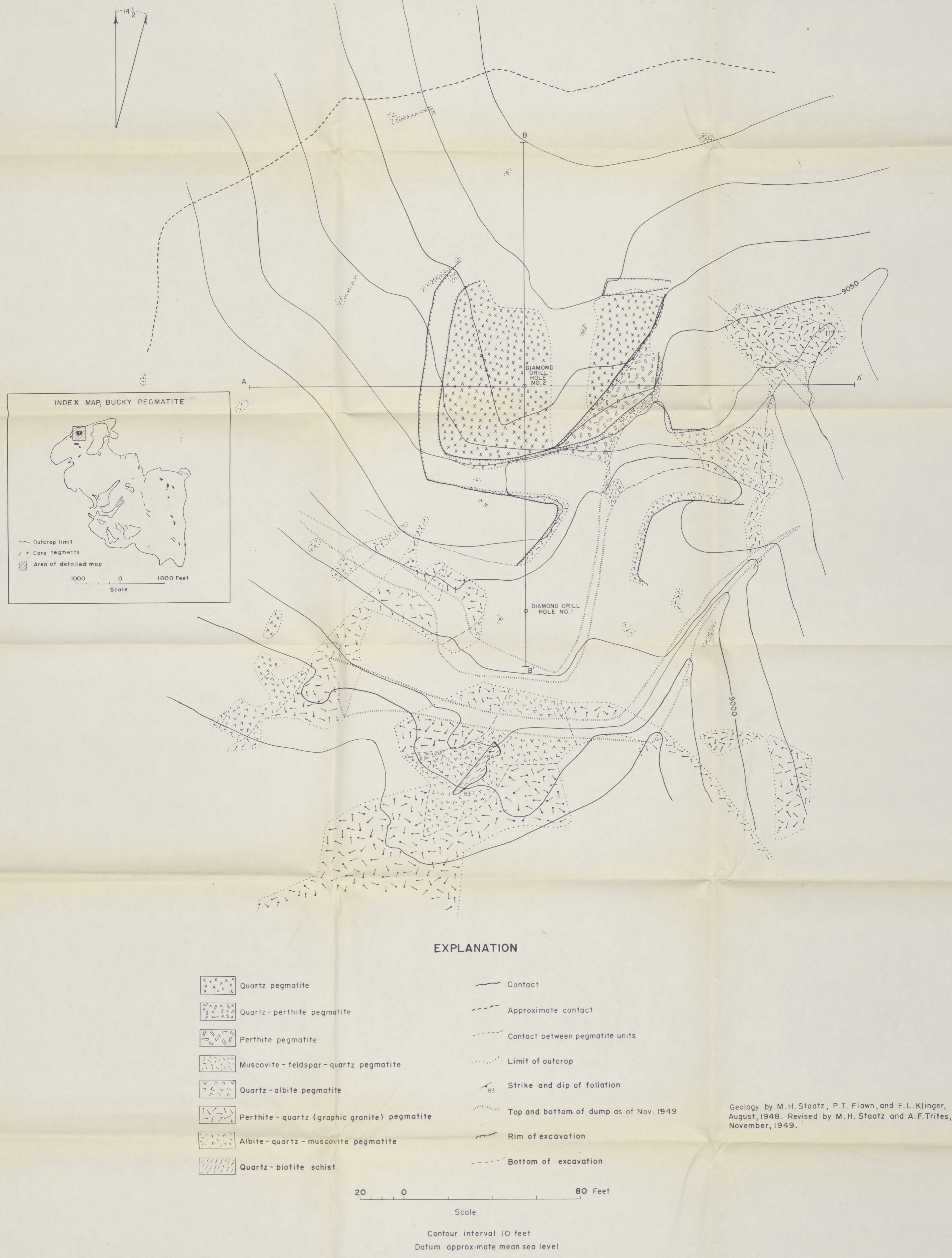




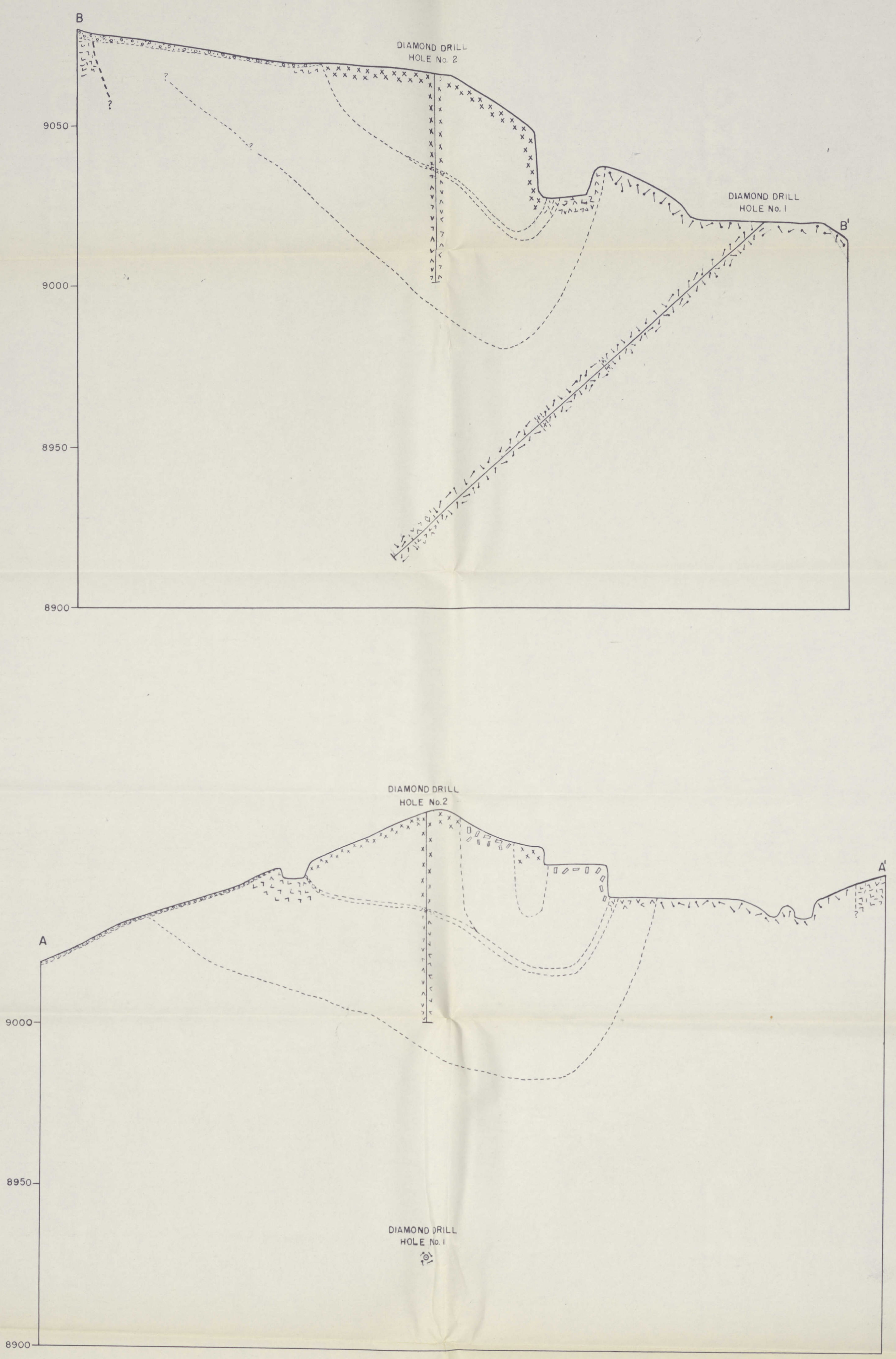

EXPLANATION
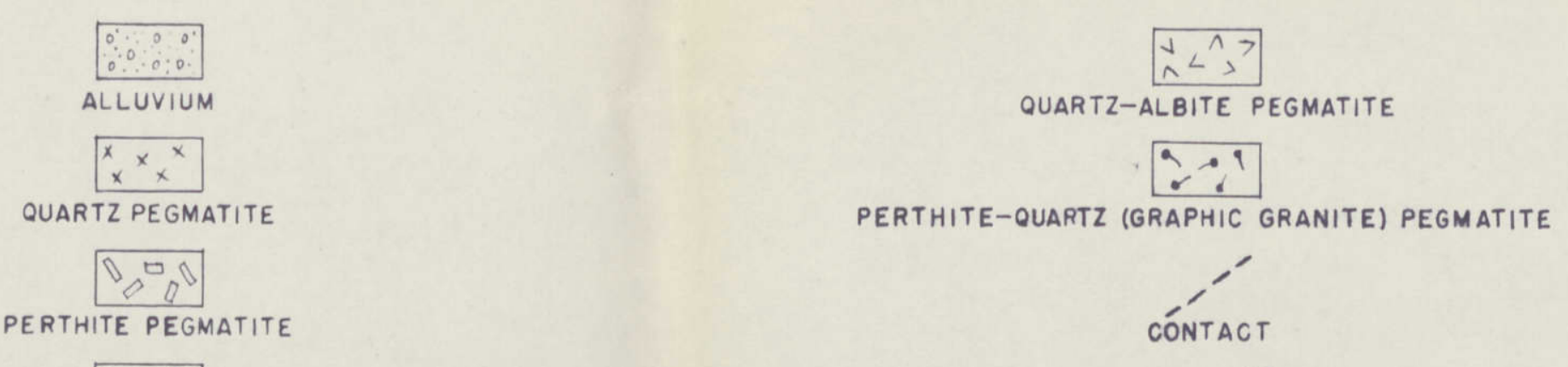

MUSCOVITE-FELOSPAR-QUARTZ PEGMATITE

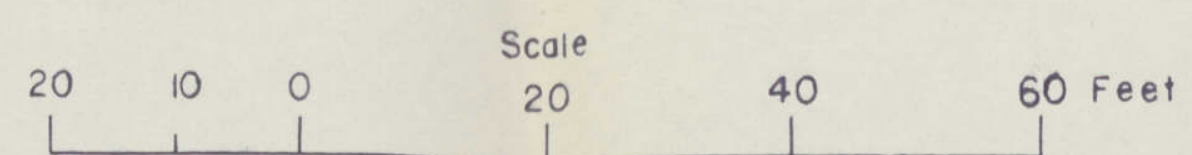




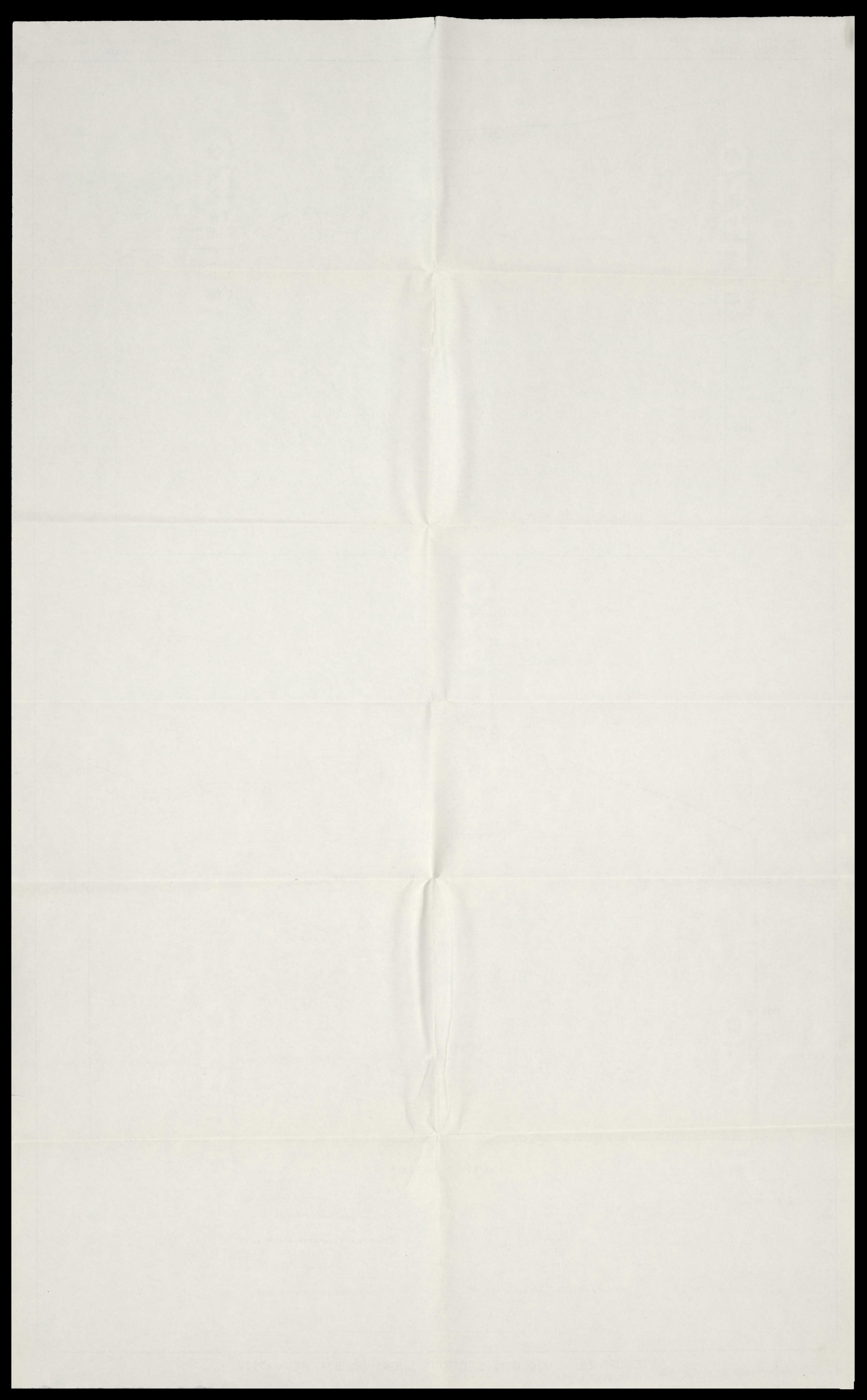



